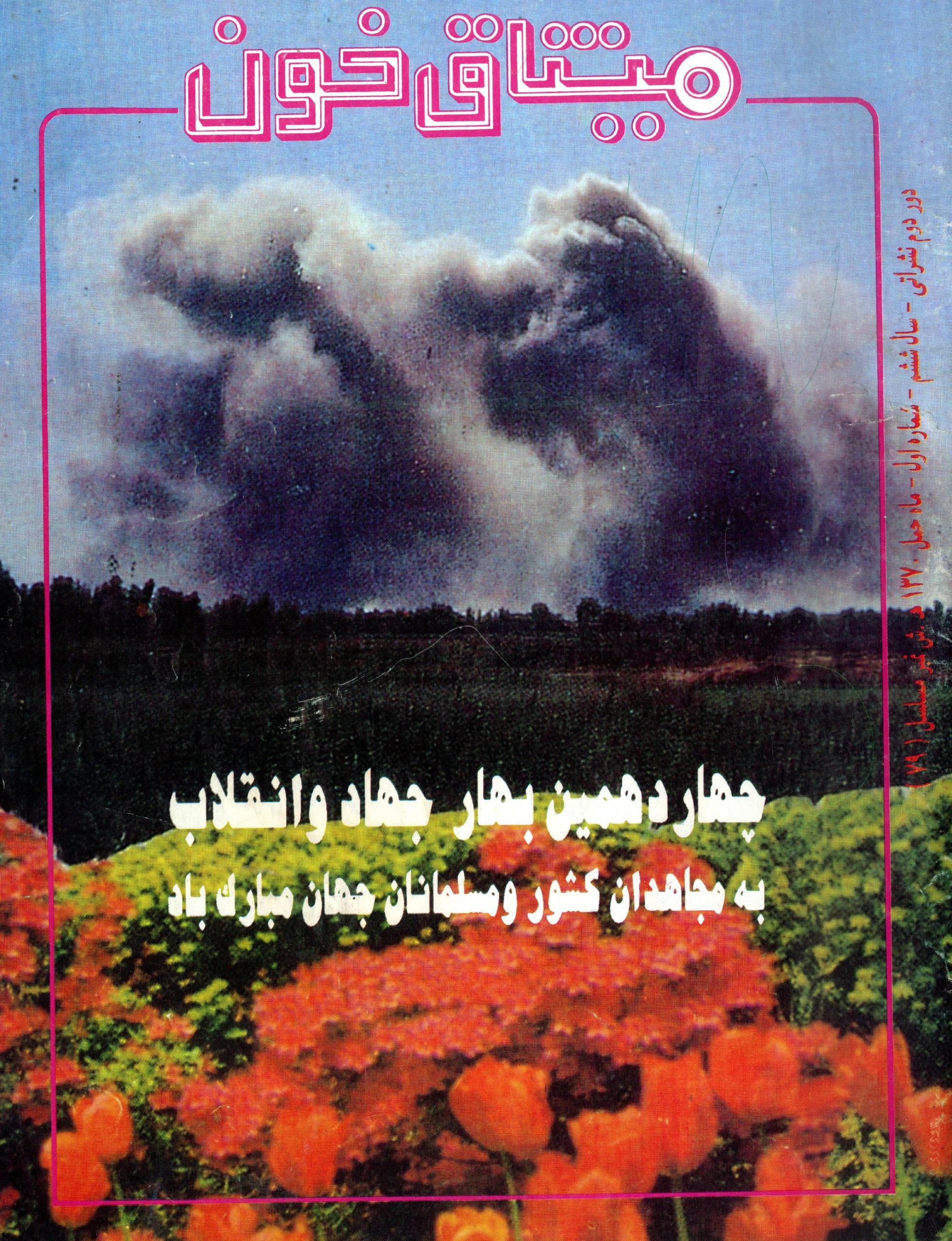




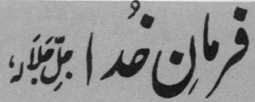

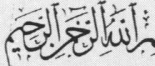

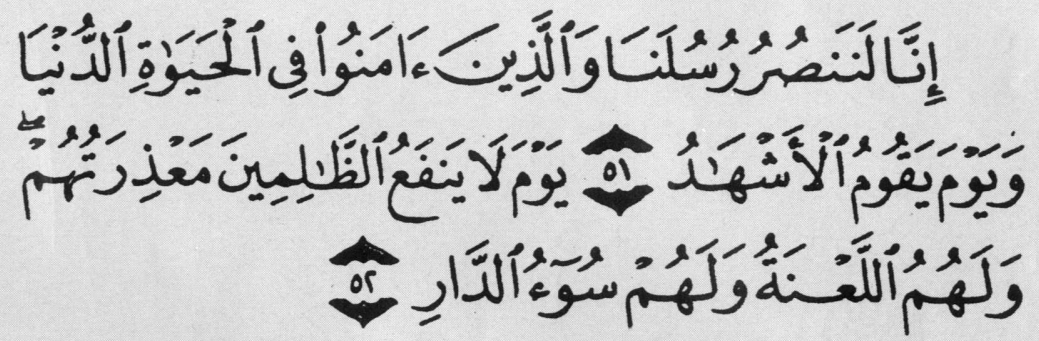

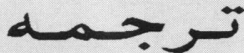

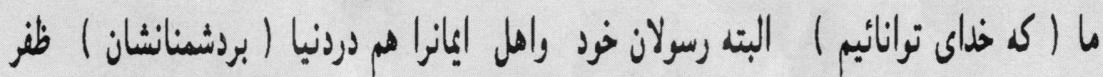

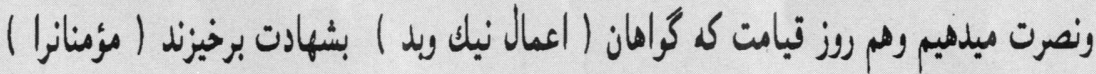

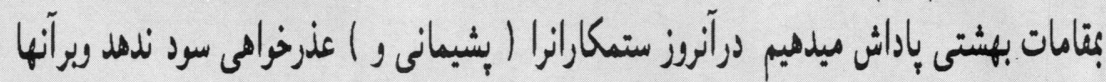

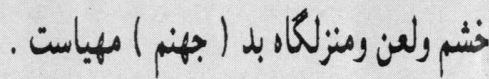

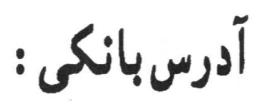

M.C.B. سلم كرش بنل AC/ NO 711 جارسله رود - بشارر - باكستان

TEL: 240481 Fax ( 0521$) 42410$

\section{آدرسمكاتباتى :}

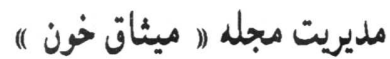

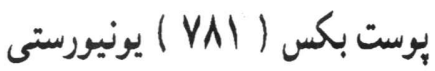

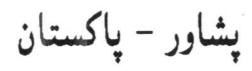
U.P.O.BOX \# 781 PESHAWAR - PAKISTAN

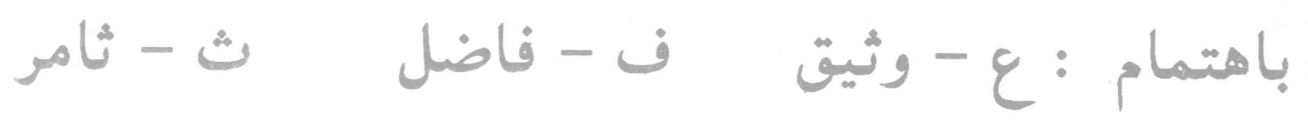

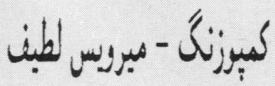


تنها ترور أزراذو

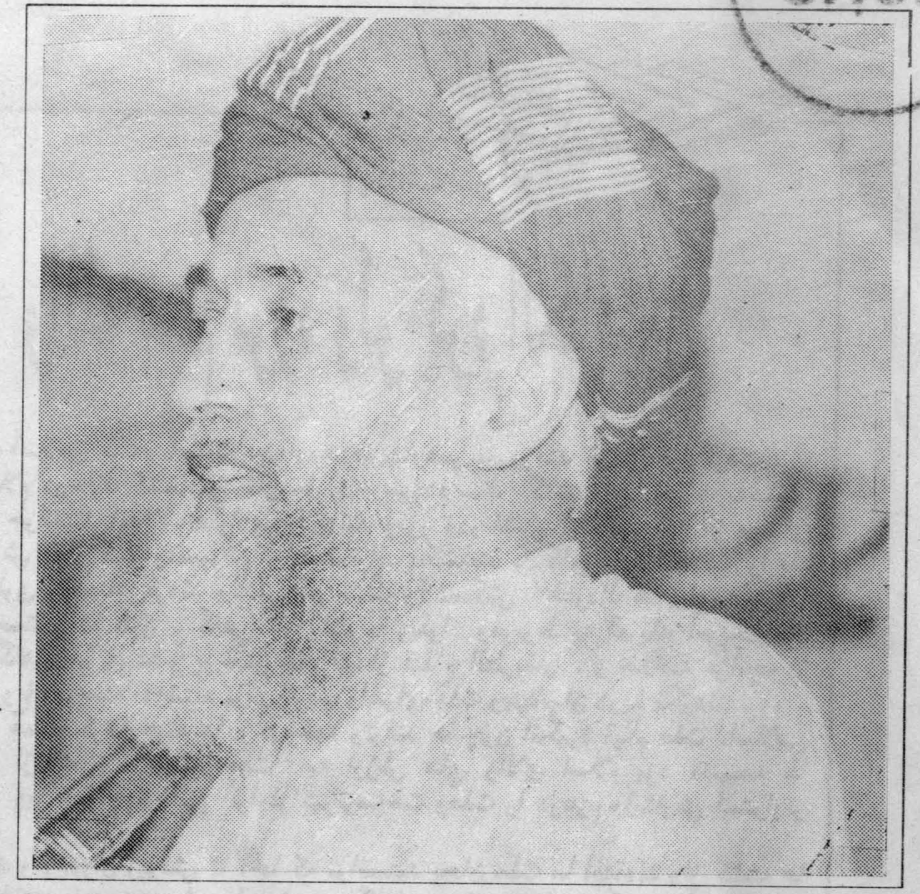

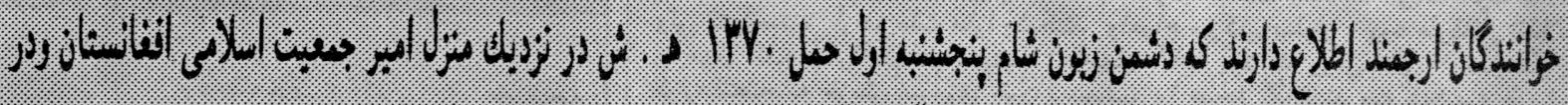

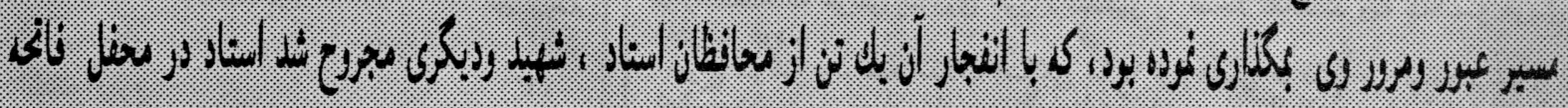
: is

(1). 111$)$

انـــال را ميخروانبه آيتى دريراير

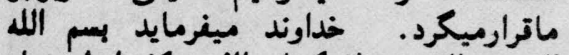

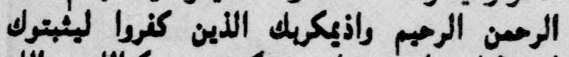

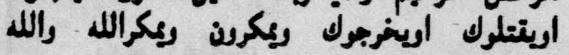

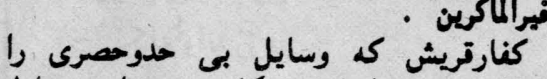
ديرباير دعوت اسلامى بكاريستئد واين وسايل

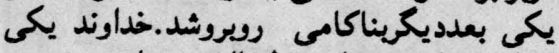

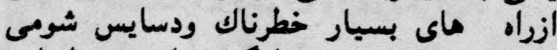
راكث مشركان جهار جلوكيرى ازيخش الشاعد

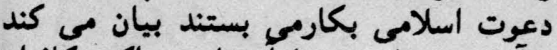

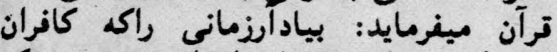

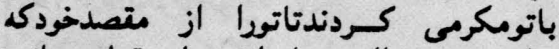

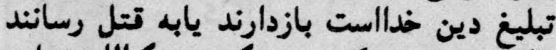

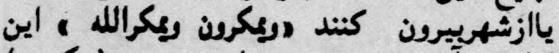
أولين وآخرين دسيسه شان نيست (يكروني

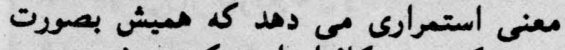

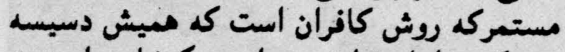

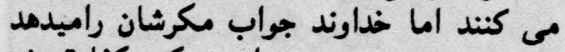
منسرين مينويسند بعدازين كا كنارتريش

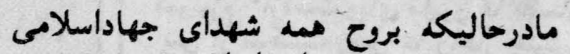

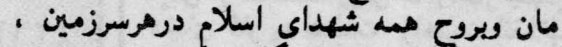

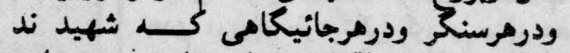

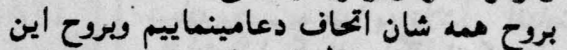

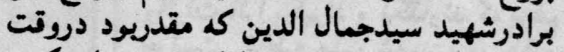

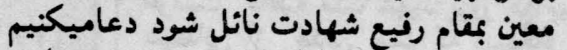

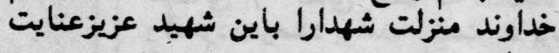

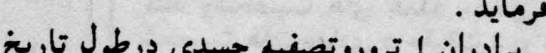
برادران ! تروروتصفيه جسدى درطول تاريخ

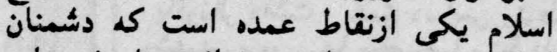

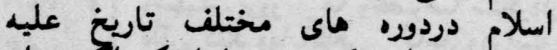

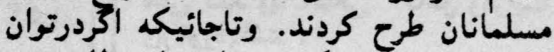

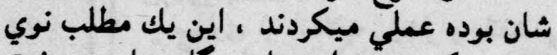

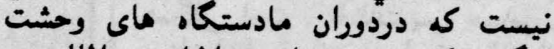

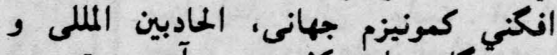

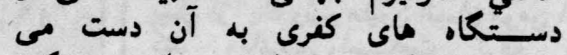

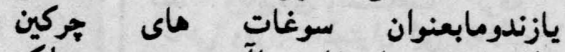

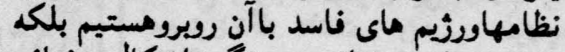

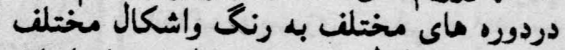

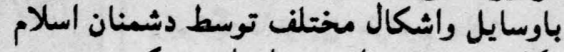
بكاربسته شده است مازمانى كه سورن

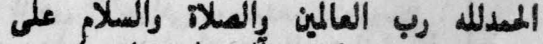

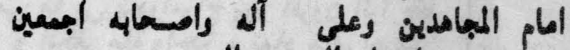

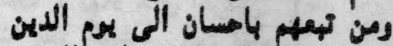

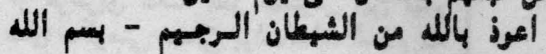

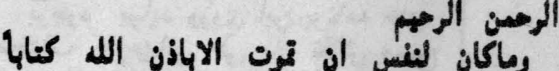

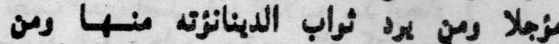

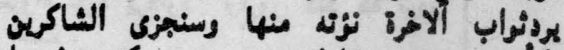

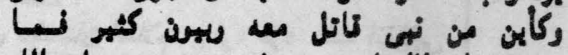

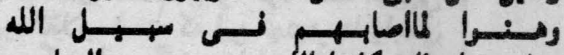

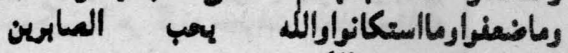

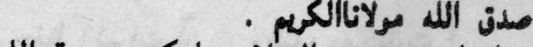

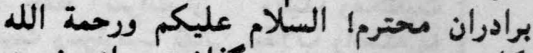

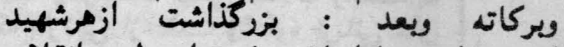

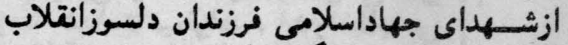

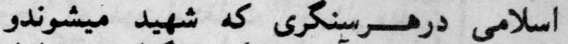

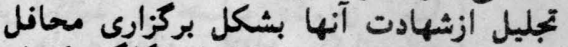

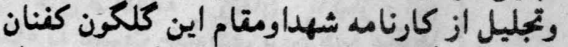

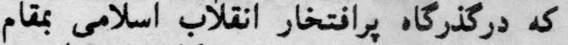

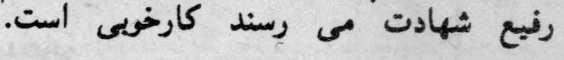

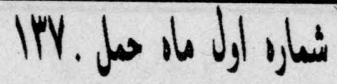




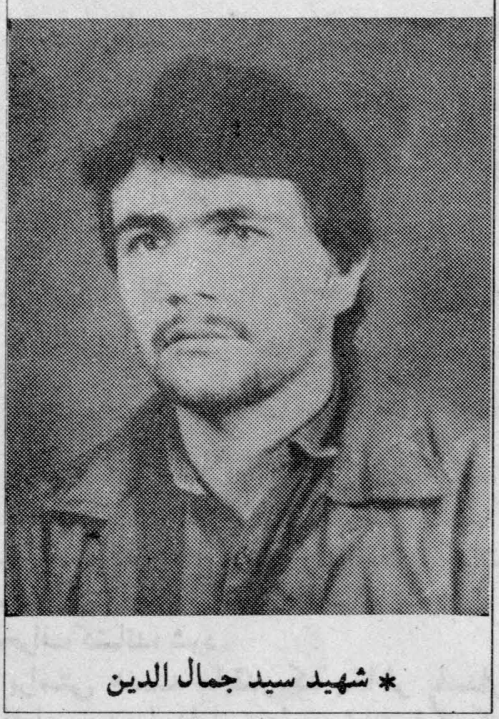

تعداداين دستكاه ها درمابين خودمسلمانها

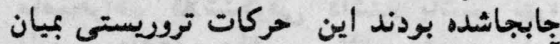

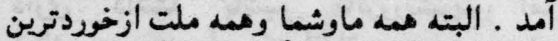

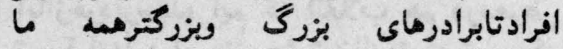

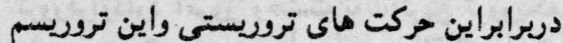

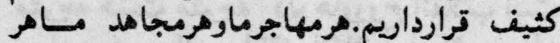

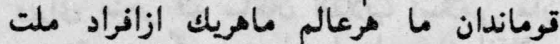
مسلمان ما كه درصف جهاد تران ترارداردوبشكل

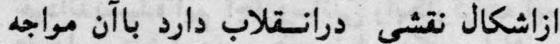

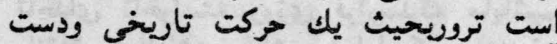

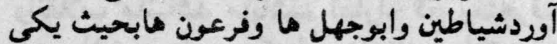

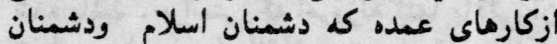

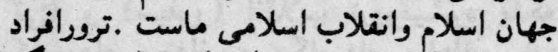

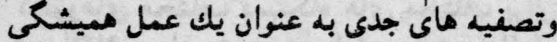

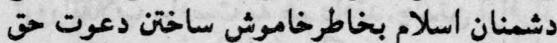

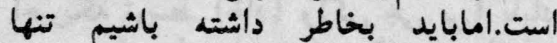
ترورانرادوترور شخصيت مايكانه هدف نيست نيست

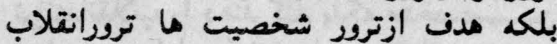

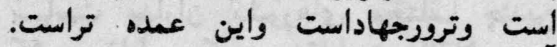
آنجيزيكه عمده واساسى است ترورداه وروات ورسم

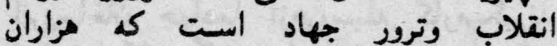

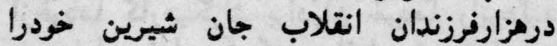

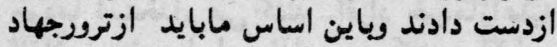

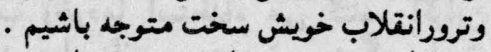

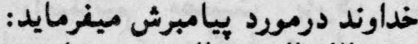

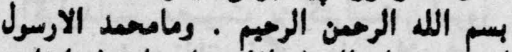

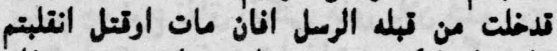

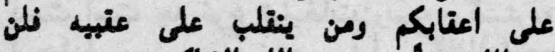

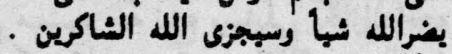

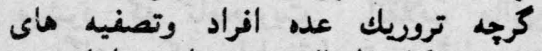

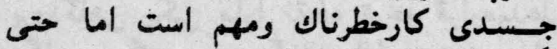

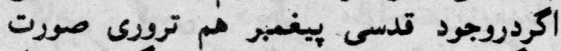

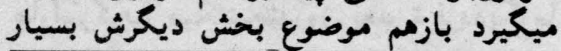

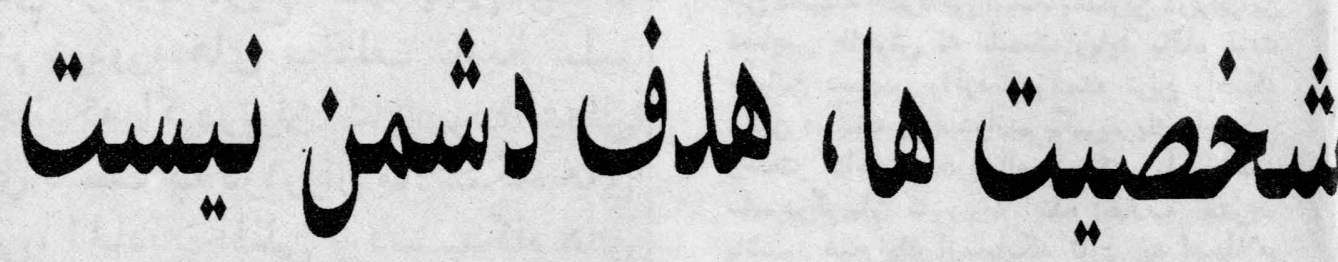

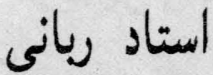

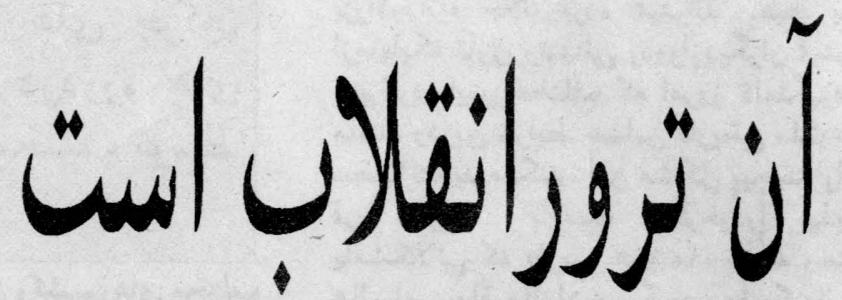

دشمنان كينه توزاسلام يِانى بخاطر قتل

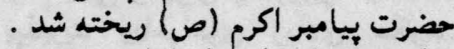
ابوجهل باتعدادى ازصناديد إصيد تريش بـ به مشوره

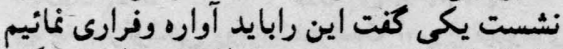

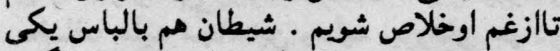

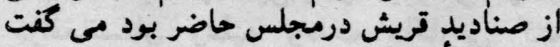

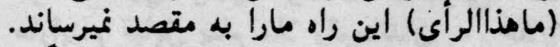

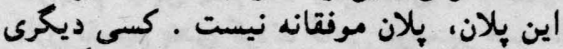

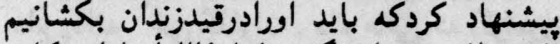

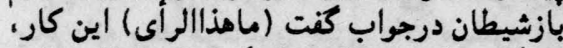

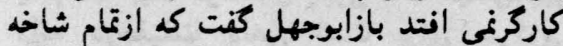

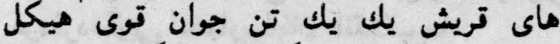

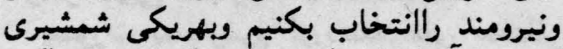

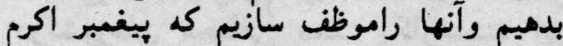

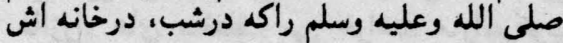

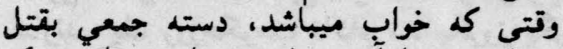

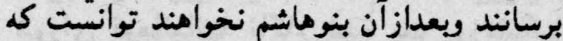

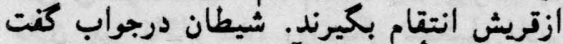

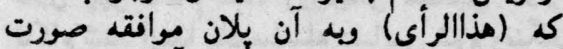

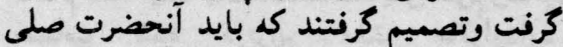

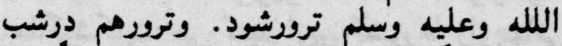

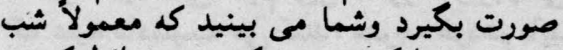

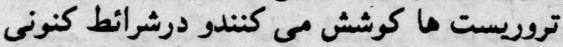

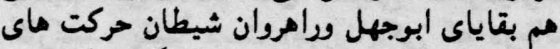

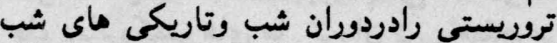

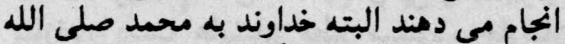

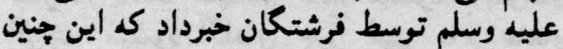

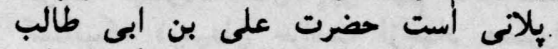

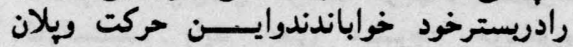

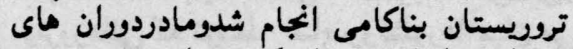

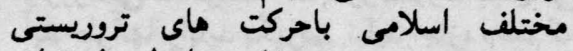

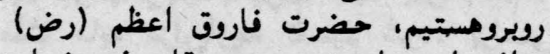

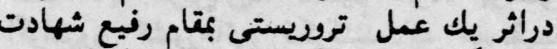

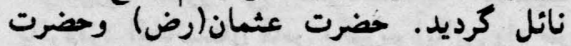

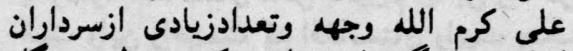

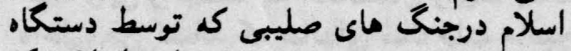

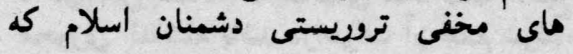

ديدند كه دعوت اسلامى هرروز اوج گيرى

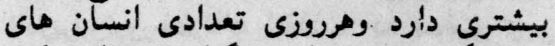

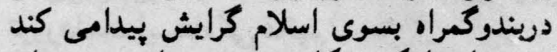

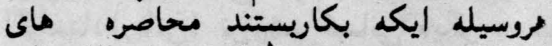

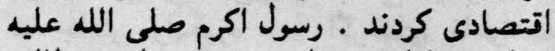

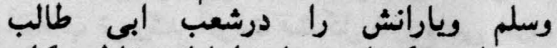

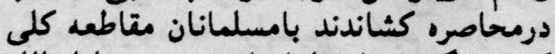

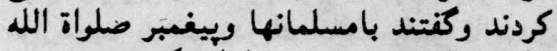

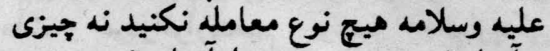

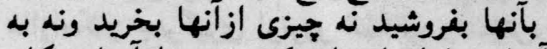
آنها معامله ازدواج كنيد بيد ونه ازآنها بنكاح ونها

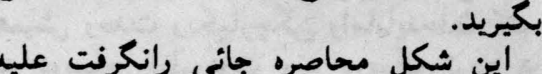

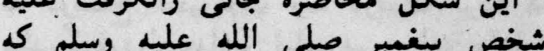

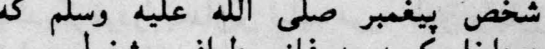

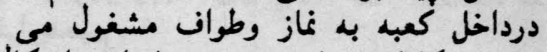

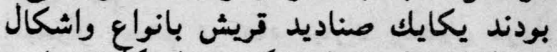

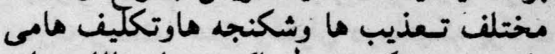

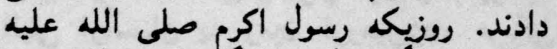

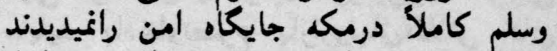
خواستند كه به طائف بروند ودرطائف هم امل ايل

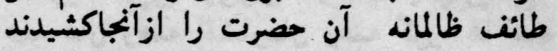

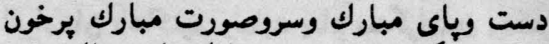

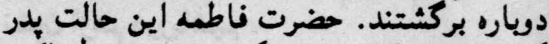

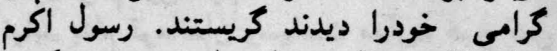

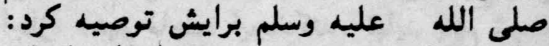

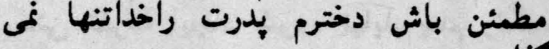
كذارد. اينها يك سلسله دسايس مسلسل بود بود

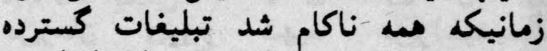

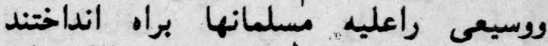
بعدازناكامى به رسول رليم الله صله بله الله عليه

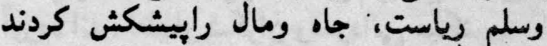
امارسول الله صلى الله عليه عليه وسلم درياسخ

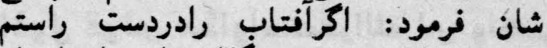

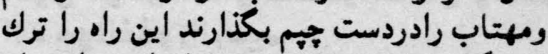

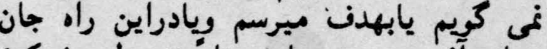
بجان آفرين مى سيارم بناء: توسط مشركين 
اين دسيسه خطرناكى است. بعدازين دربرابراين

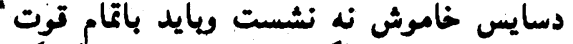

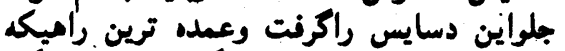

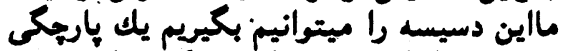

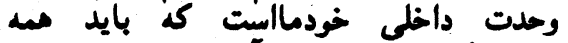

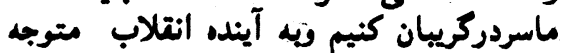

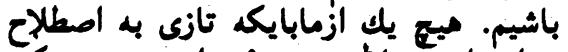

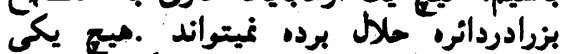
ازمابايكه تازى وتنهائى ودورازديكيكران فئميتواند

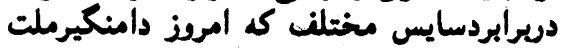

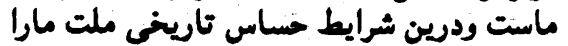

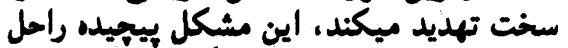

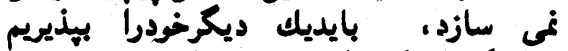

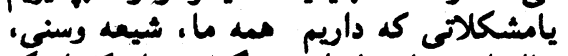

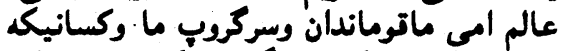

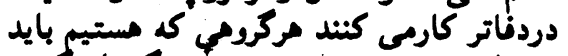

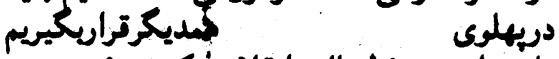
تادربرابرترورخطرناك انتلابز كله سخت ترين

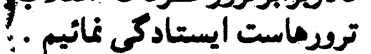

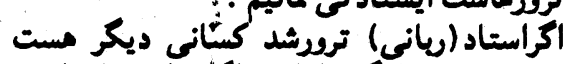

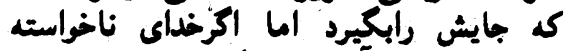

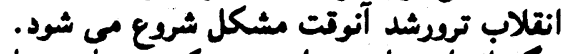

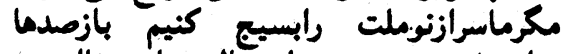

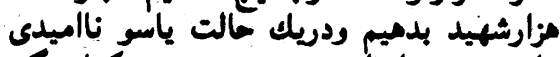

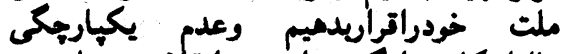

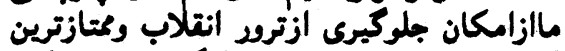

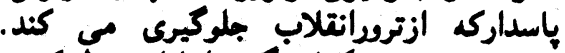

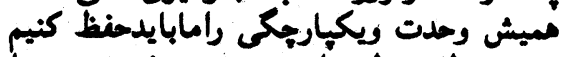

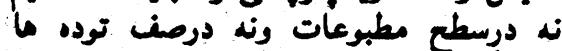

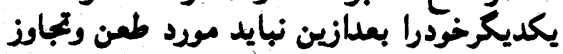

تراربدميم · تمغرو

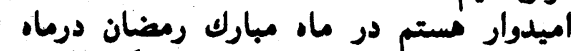

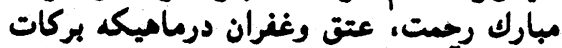

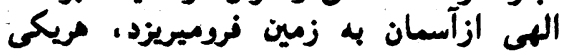

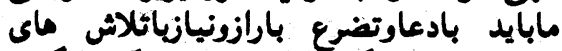

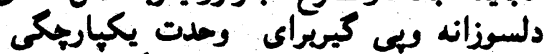

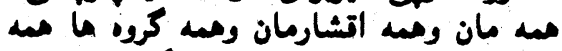

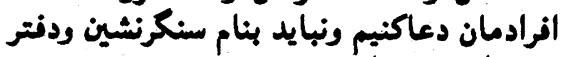

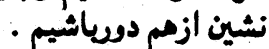

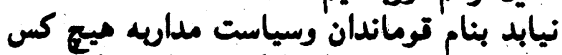

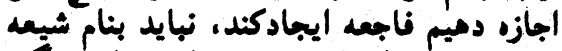

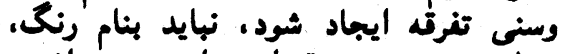

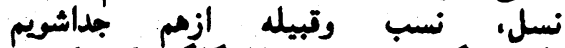

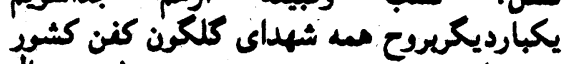

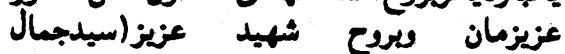

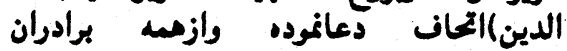

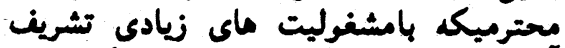
آورده أند، اظهار شكران وقدردانى ميكنم ماديث

اتول تولى هذاواستعغرالله لى ولكم انه مول الغنول رالرحيم هواليم

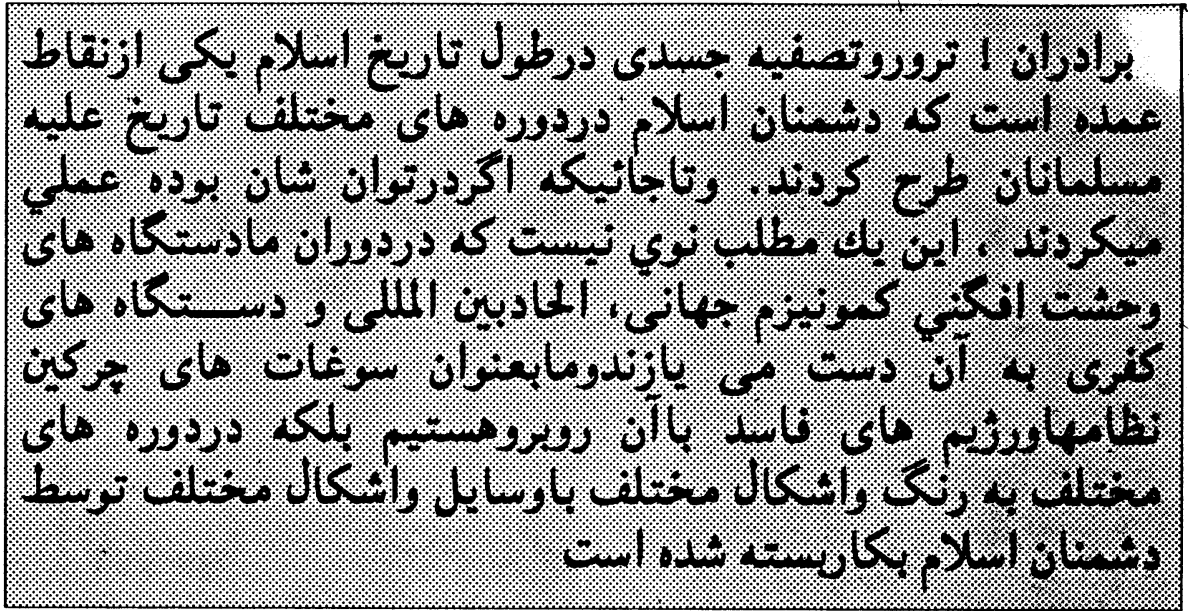

را.از زيان كانر و مسلمان وكثـــورماى مختلف

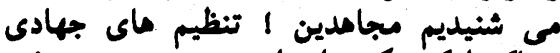

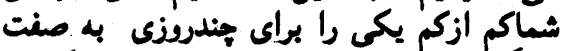

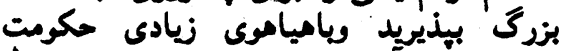

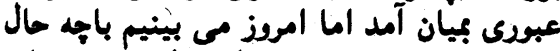

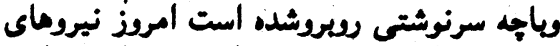

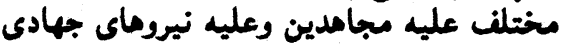

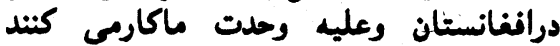

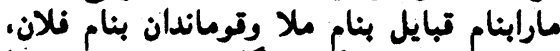

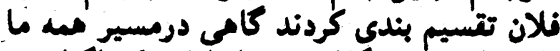

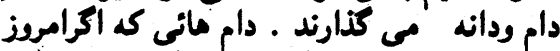

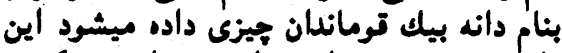

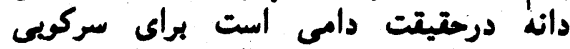

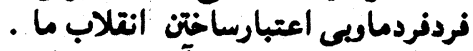

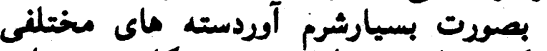

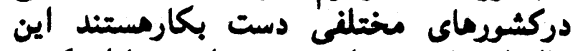

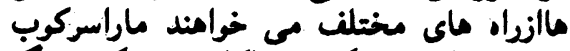

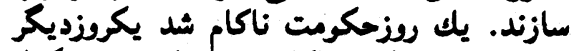

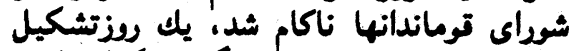

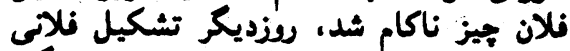

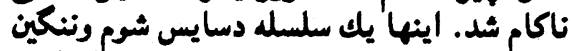

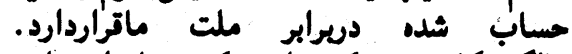

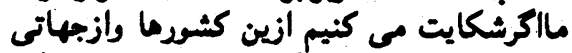

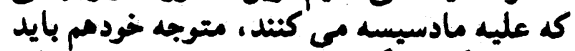

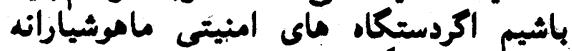

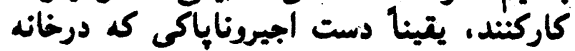

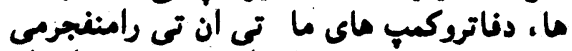

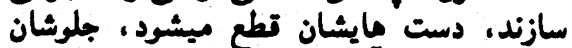

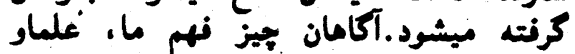

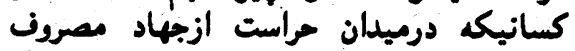

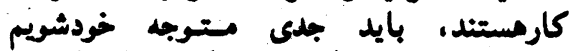

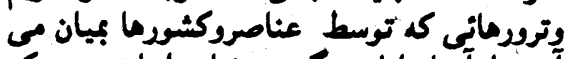

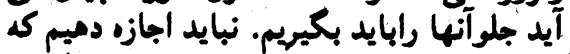

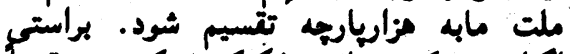

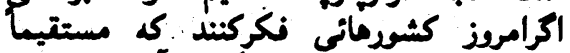

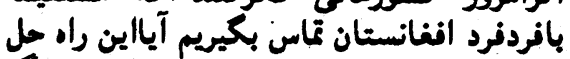

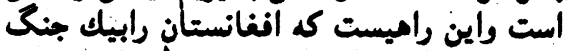

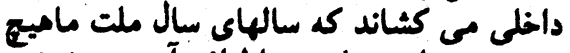
محودى نداشته باشد دراطراف آن جمع شونديج
مهم است كه راه اسلام و راه انتلاب كذاشتهته

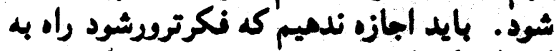

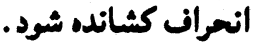

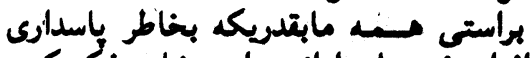

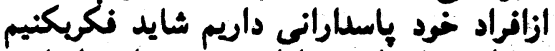

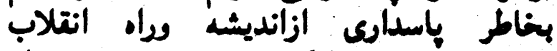

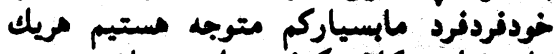

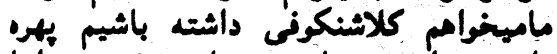

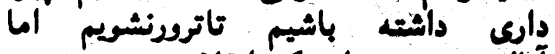

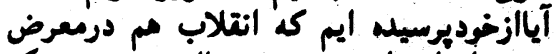

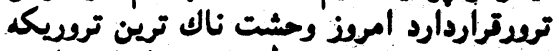

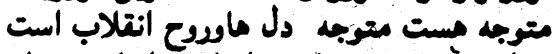

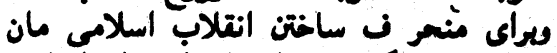

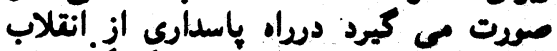

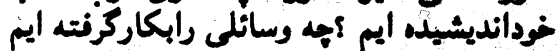

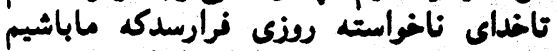

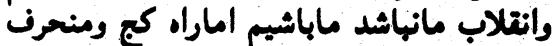

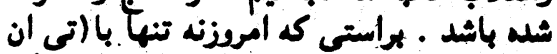

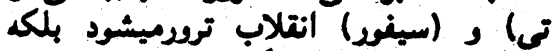

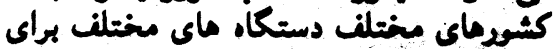

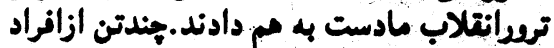

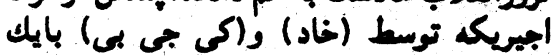

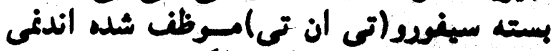

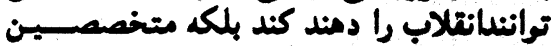

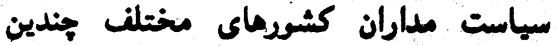

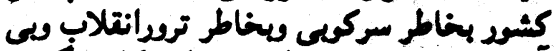

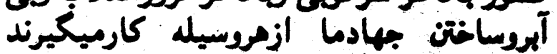

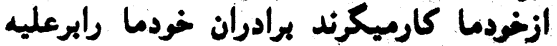

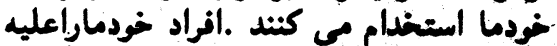

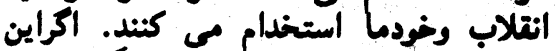

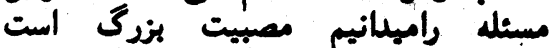

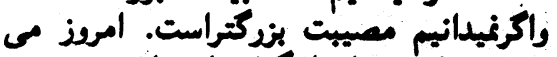

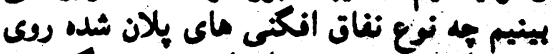

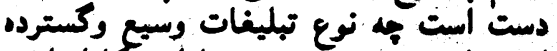

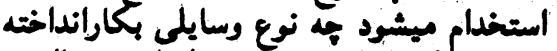

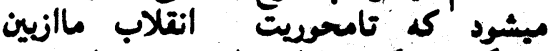

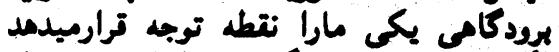

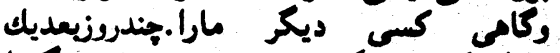
ماراسركوب ميكنندجندروز بعد ترفردديكرما 
تشله بودويه نصرت ويارى برودركار ايطان

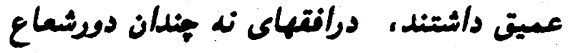

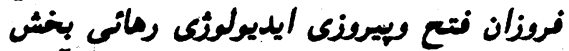

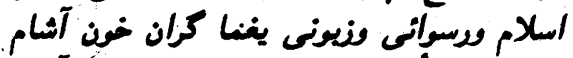

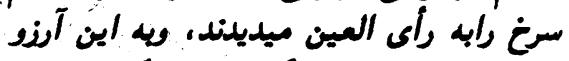

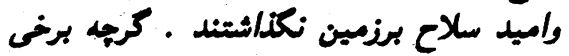

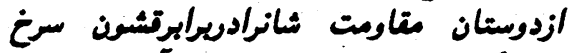
ويوانكى وجنون مس خواندند الما آنها بنام خدان

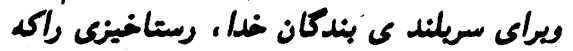

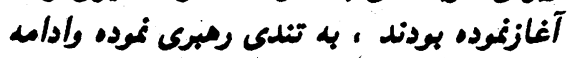

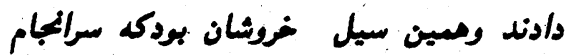

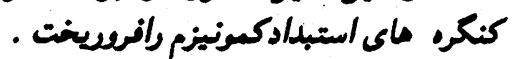

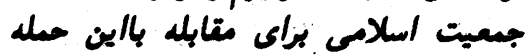

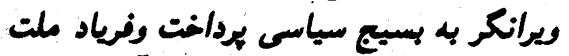

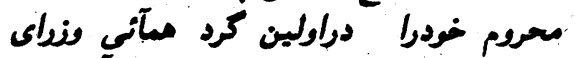

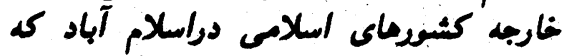

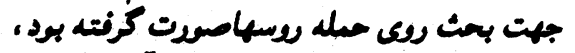

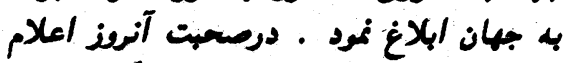

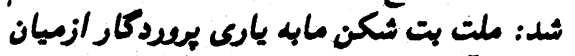

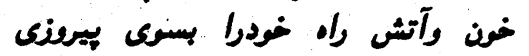

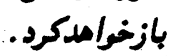

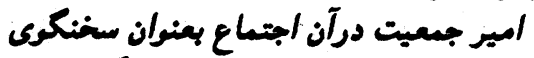

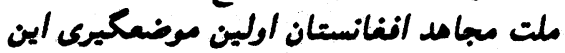

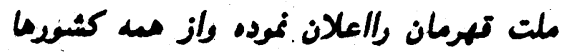

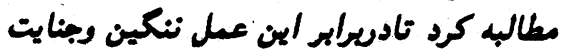

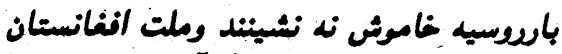

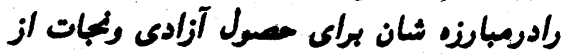

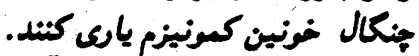

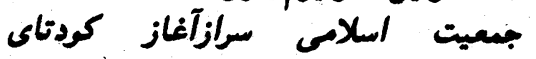

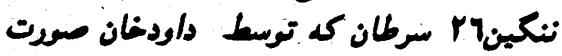

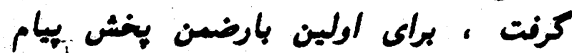

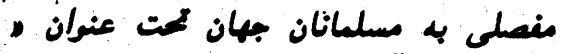

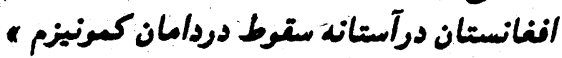

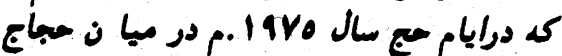

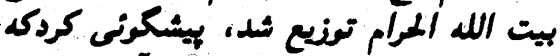

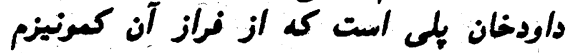

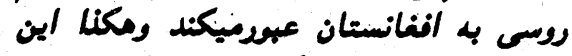

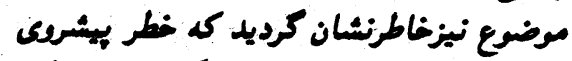

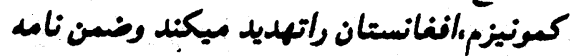

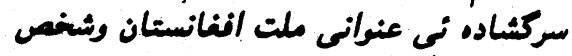

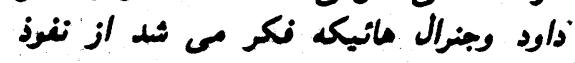

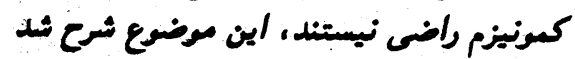

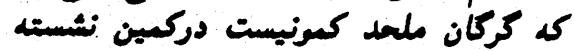

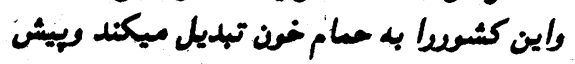

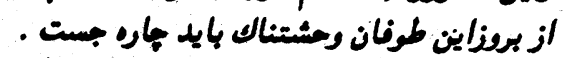

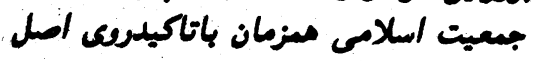

\begin{abstract}
بسم الله الرحهم الرحير
\end{abstract}

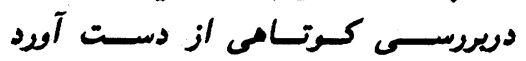

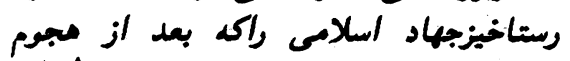

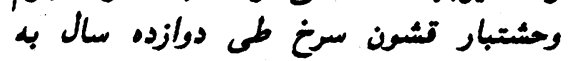

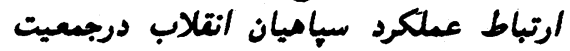

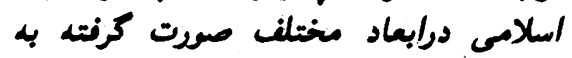
صودت ذيل ميتران نام برد: دوبعل سياسم:

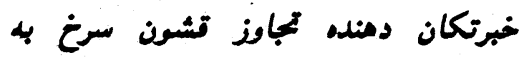

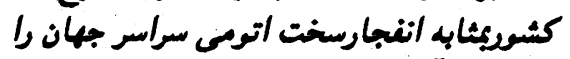

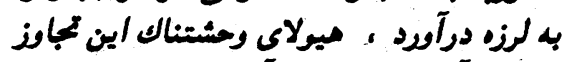

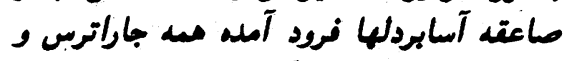

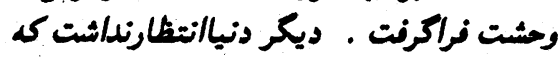

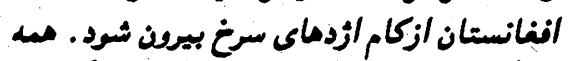

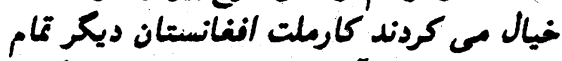

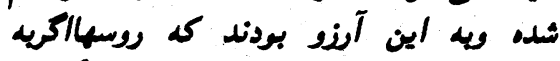

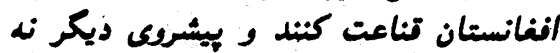

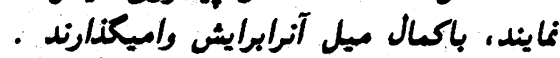

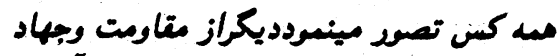

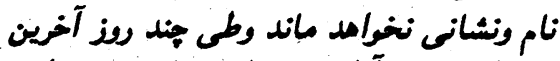

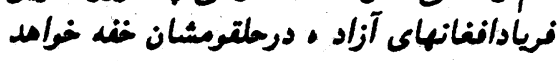

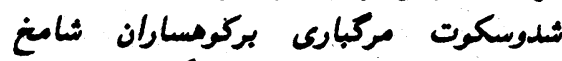

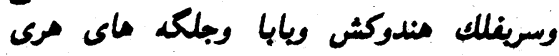

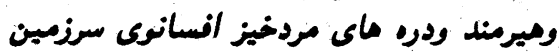

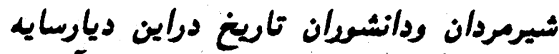

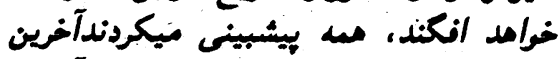

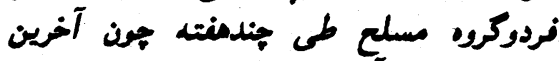

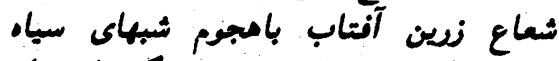

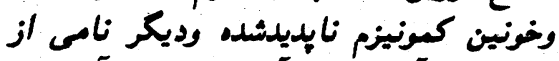

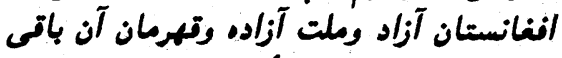

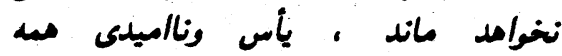

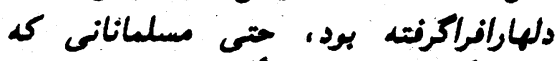

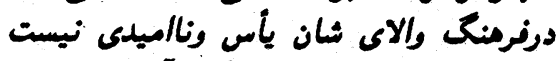

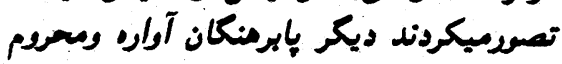

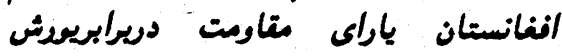

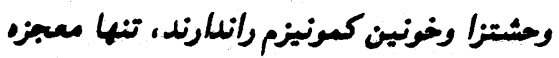

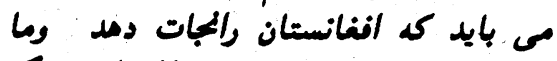

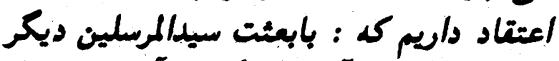

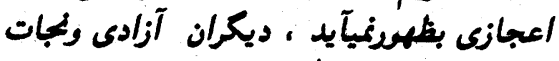

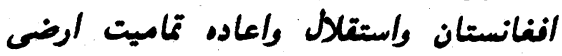

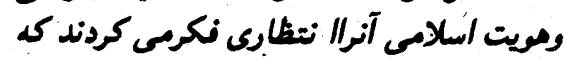

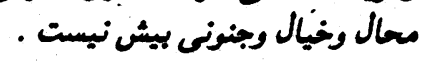

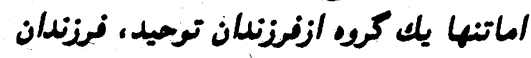

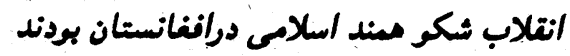

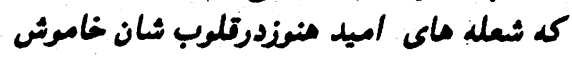
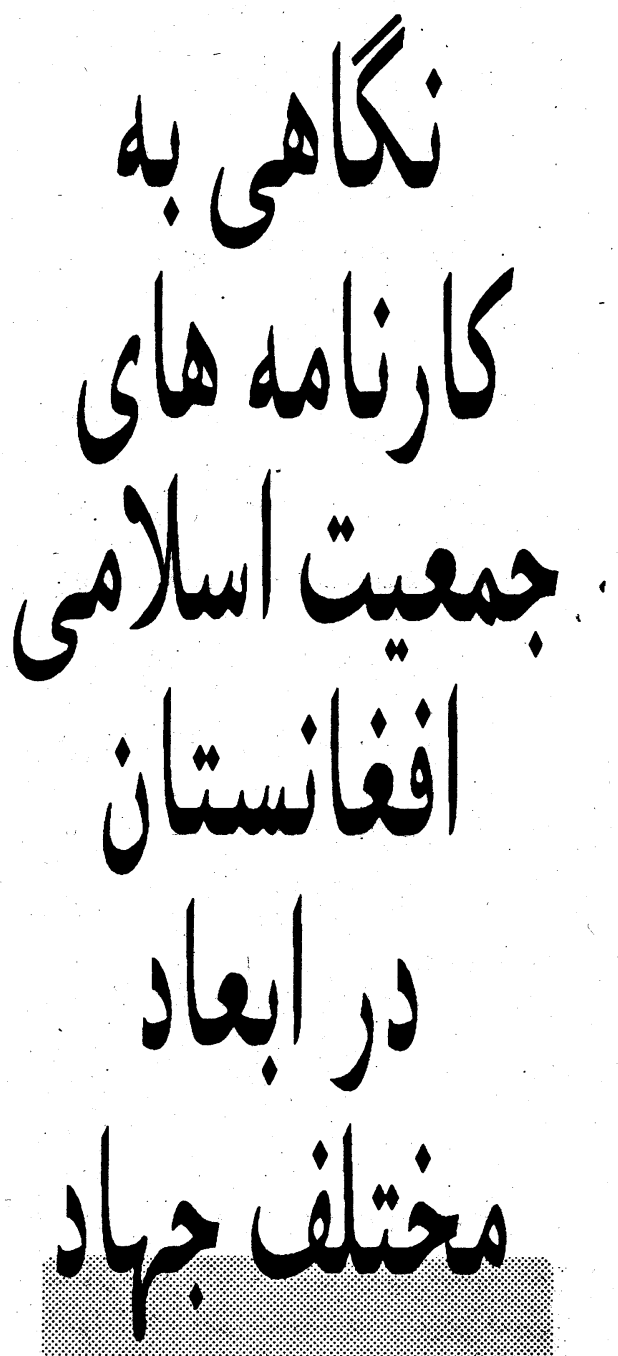

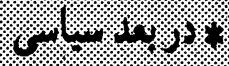

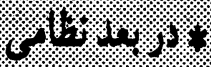

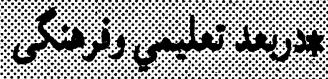

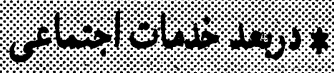

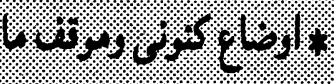




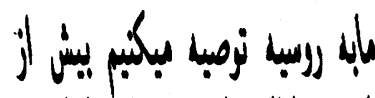

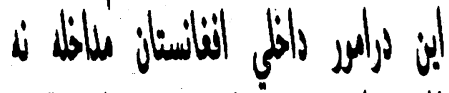

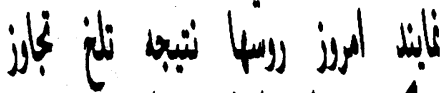

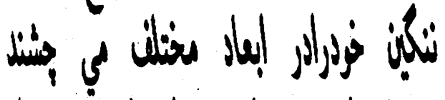

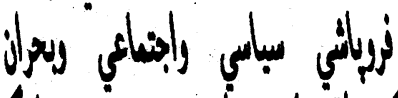

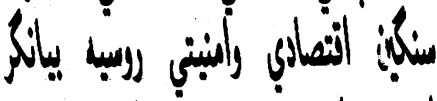

إني للكاسن .

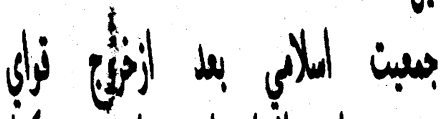

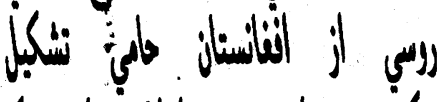

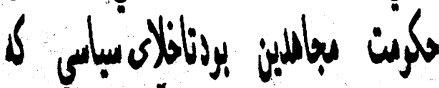

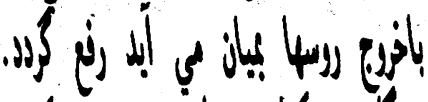

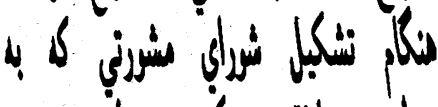

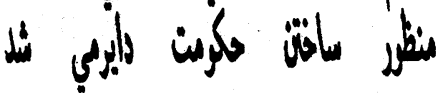

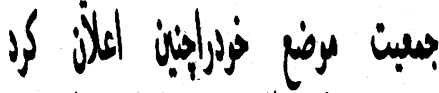

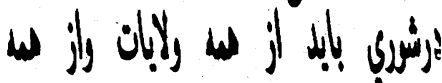

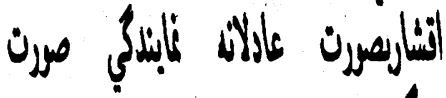

بيليرا.

افنغانستان سهم بكيرند وتنهاروسها مستند كد

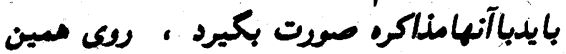

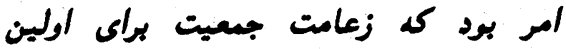

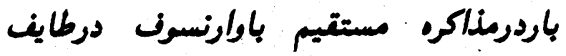

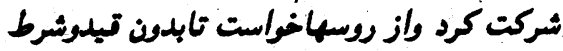

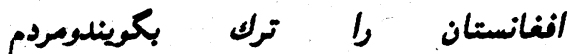

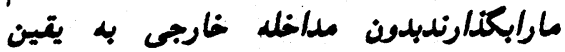

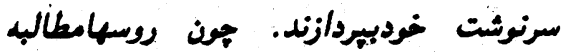

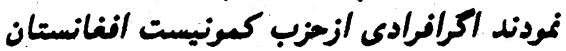

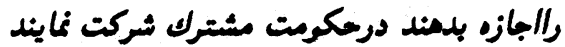

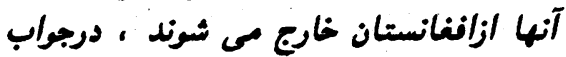

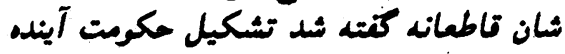

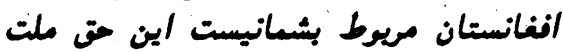

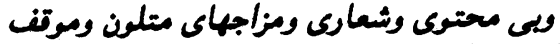
كيريلان غيرثابت وموسمى برميزئمودها. و روى اصل ثابت اسلامى ازسياست ثابت ومريت واقعبينانه

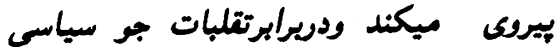
دجار نوسانهاى سياسى نشده ـ ـ باكثشروماى

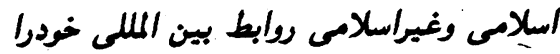

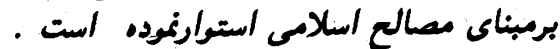

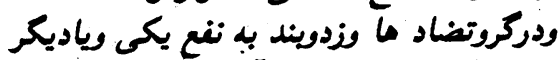

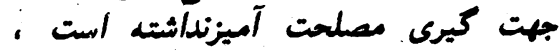

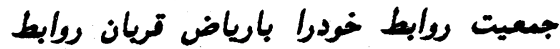

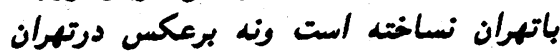

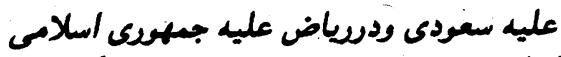
ايران ودرياكستان عليه مردوموضعكيرى

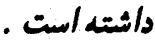

استتلاليت انتلاب وعلم وابستكى آن خط

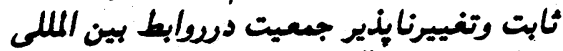

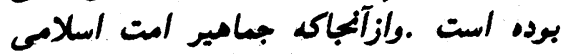

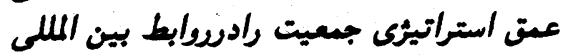

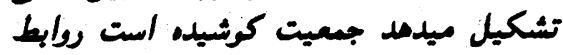
خويش رابا مسه جنبشهاى اسلامى وسازمانهاى

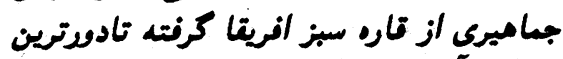
نقاط درآسيا ، امريكا وارويا تايم تنايد. درقضاياى بين المللى جهان اسلام الهام

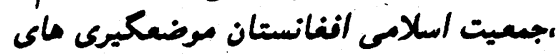
روشن وثابت داشتهد ويعكم قرآن وتعاليم والائي

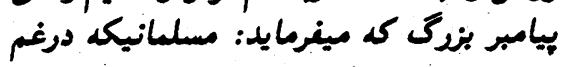

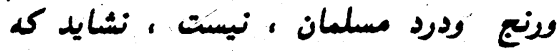
نامش رامسلمان نهد. وريراساس طبيعت ووران مبارزه وشركت

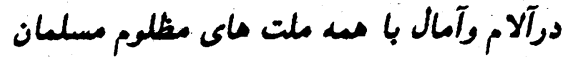

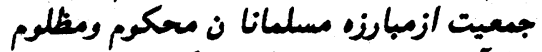
دراه آزادى شان قاطعانه ويكير دناع نمونه

بوناع از ملت محروم وآوارن ملسطبن، بشتيبانمى از ميام مردم زجرديده كشيمير،

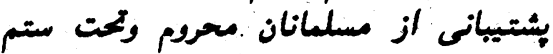
درنقاط مختلف جهان اهداف عمده بين المللف

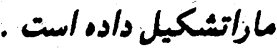

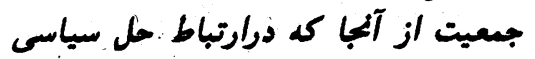
تضيه ، طرف اساسى روسهاراميداند مينئ فئس

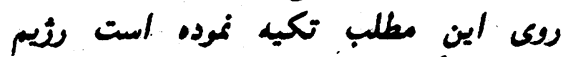

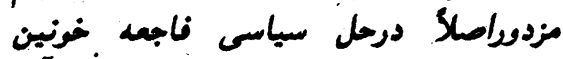

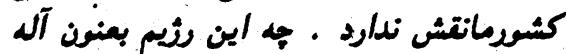

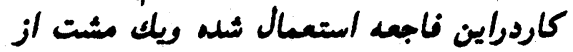
عناصر غداروخاين به دين، كثمورومردم شان شان حق ندارند كه درتعبين سرنوشيت آينده
خلل نابذير جهاد مسلح ببه فعاليت سياسى

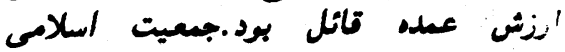

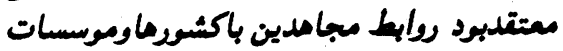

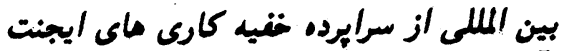

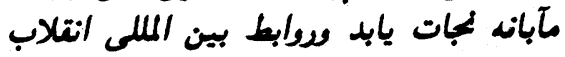

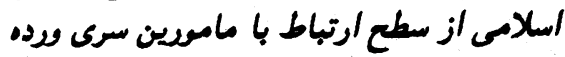

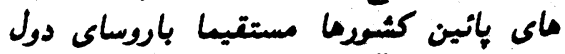

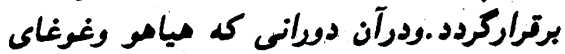

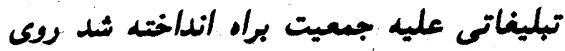

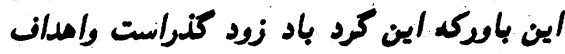

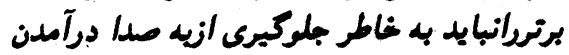

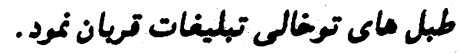

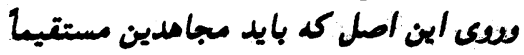

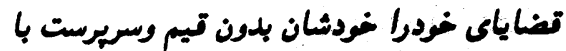

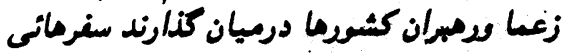

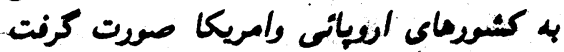

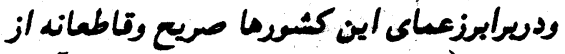

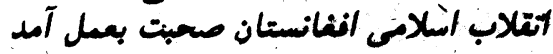

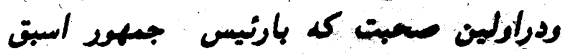

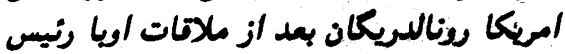

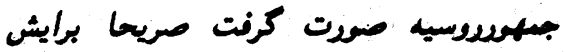

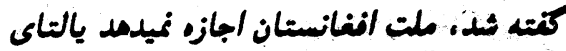

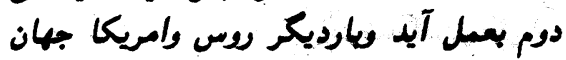

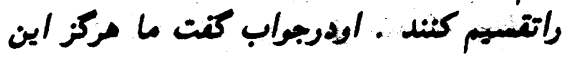
كنين كارى نمى كنيم وطى اين ديدارمادرامريكا

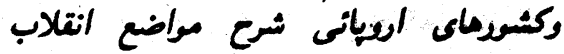

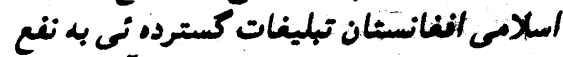
جهاد اسلامى وملث تهرمان مابعمل آمد.

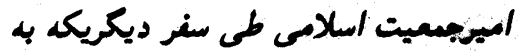

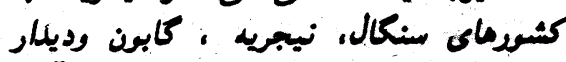

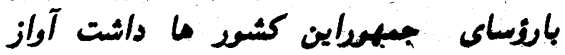
انتلاب اسلكامى را تالعاق افريثارسانيد.

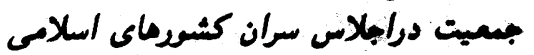

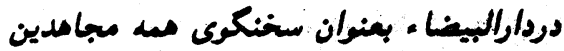

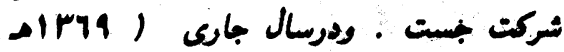

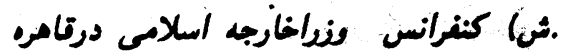

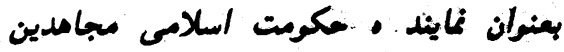

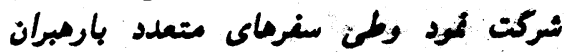

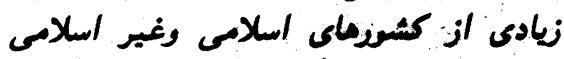

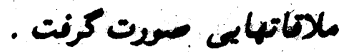
ودرعين مال درده ما اجتساع وكنغرانس

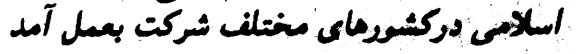

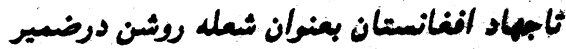
ملتهاى مسلسان منيشه فروزان باقئ ماند.

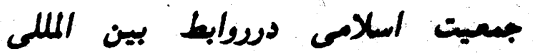
ومرضسكير ى سياسى خوداز حركتهاى تند 


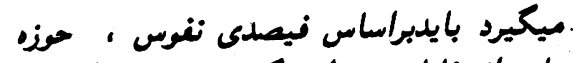

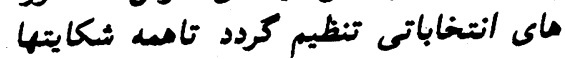

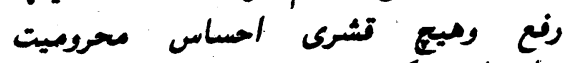
ونارضايتى نكند.

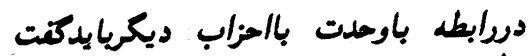

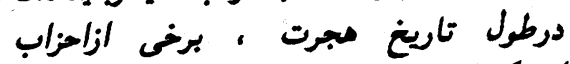

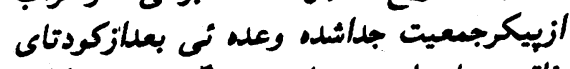

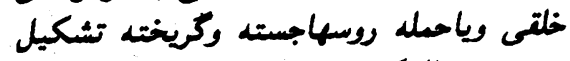

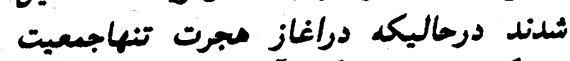

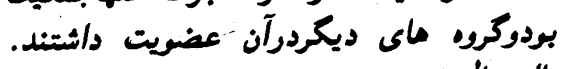

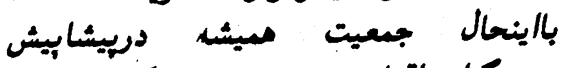

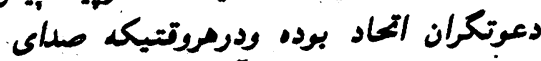

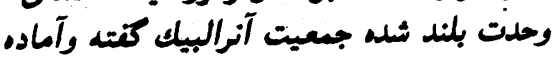
مزنوع كنشت بوده وتامنوز ورمسين مسيد مسيروران

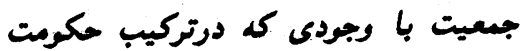

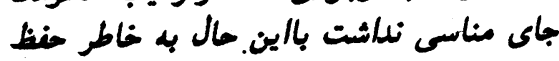

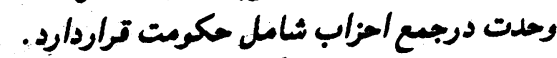

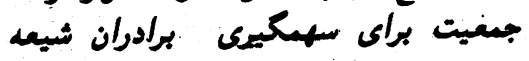

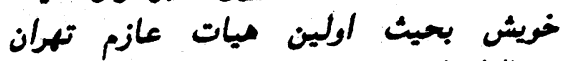

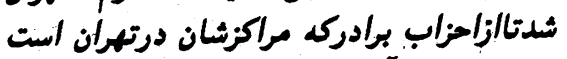

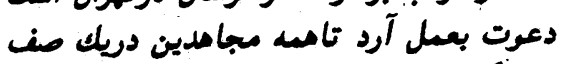

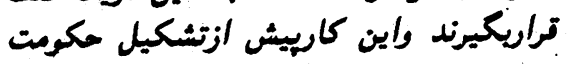

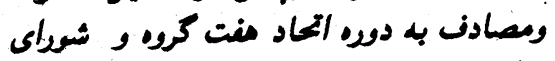
قيادى بود. منون مم جمعيت اصرارداردبرادران حزب

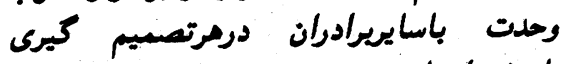
بايلشريك باشند.

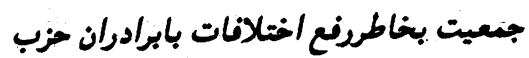

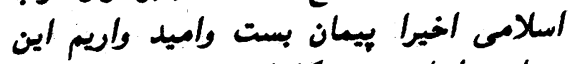

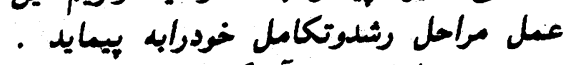

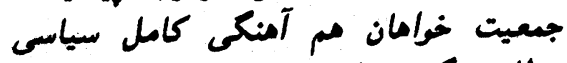

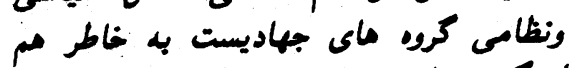

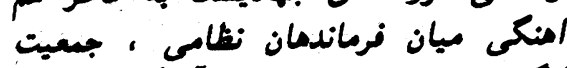

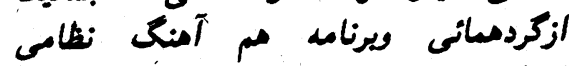

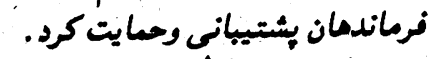

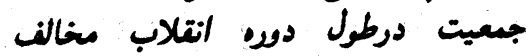

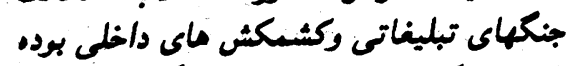

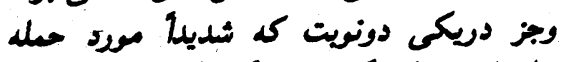

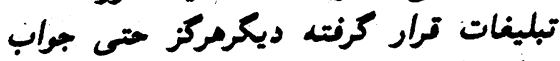

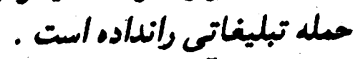

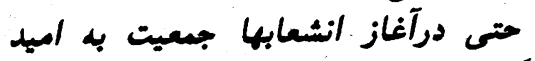

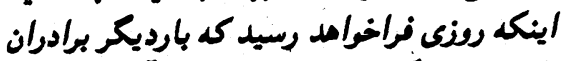

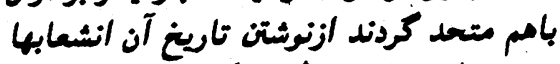

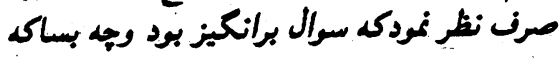

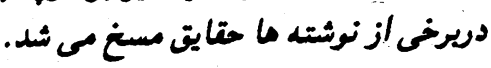

درتعيين نماينده ما جنين كارى رالنجام داد واز

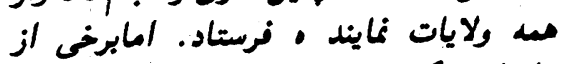
برادران ديخر جنين نكردند.

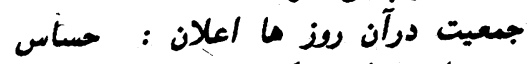

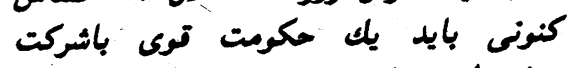
موئزتنظيم ماى قدئي

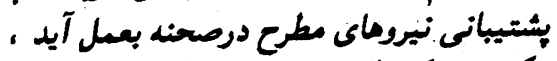

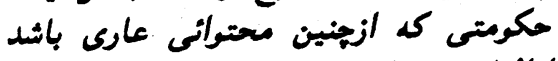

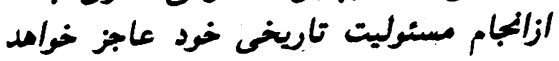
مسعيت اسلامى با آنكه تشكيل شوراى

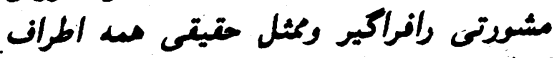

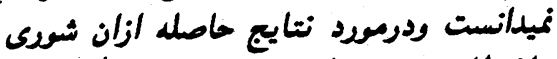

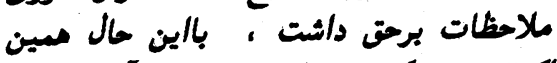

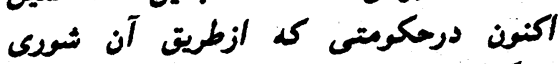

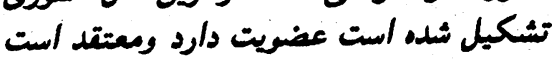

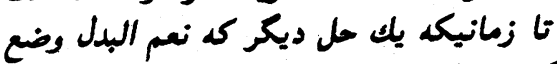

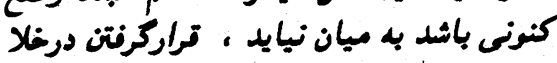

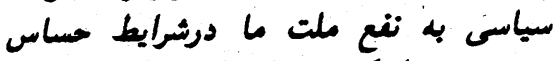
وسرنوشت ساز كنونى نيست ملت مات ورثرات

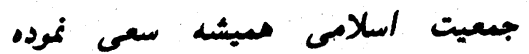

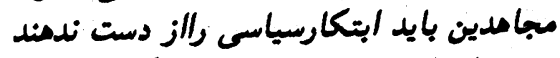

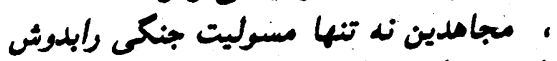

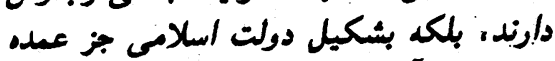

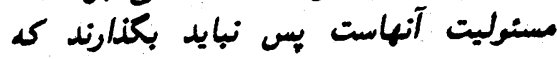

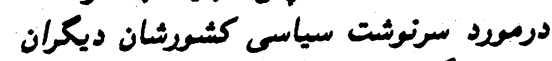
تصسيمبكيرند. روى اين فهم، جمعيت از انتخابات لويد

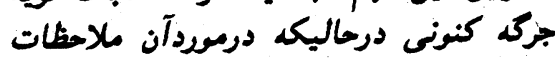

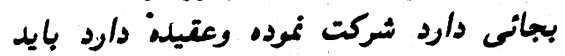

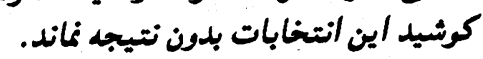

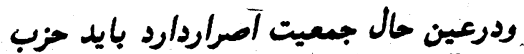

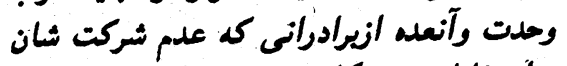

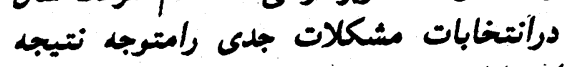

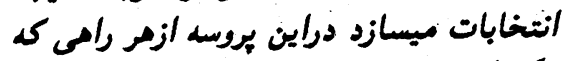
مكن است شركت جويند.

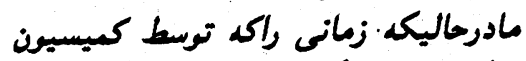

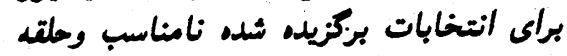

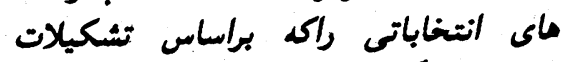

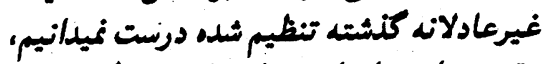

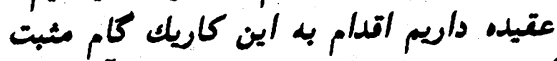

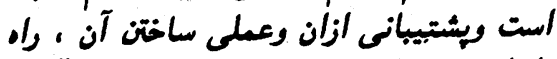

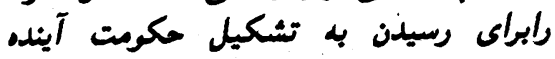
مسوارمى سازد . ماند ناكتئ نماندورانتخابات بعدى كه توسط حكومت انتقالى آينده درافنانستان بعدى صدرت صرسط
افغانستان است كه خودثان طوريكه مى ماند

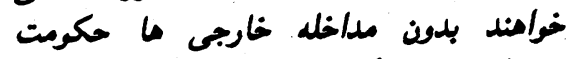

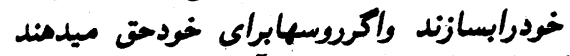

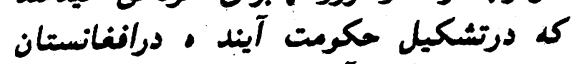

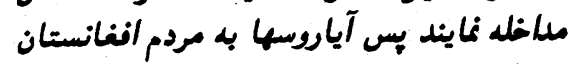

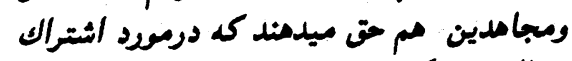

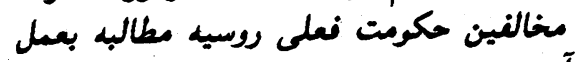

وقبل از ويداردرطايف ه، درآن حاليكه

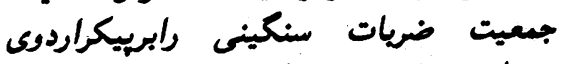

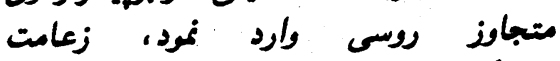
تجاوزكرومغروسوس راوادوار ساخت به شكست

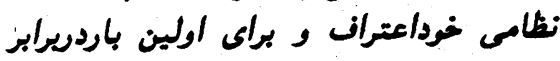

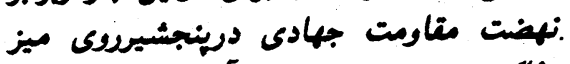

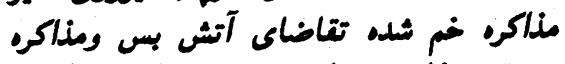

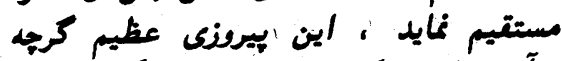

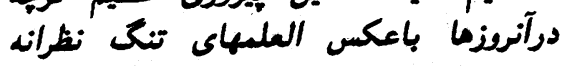

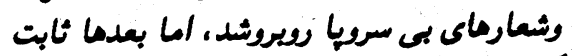

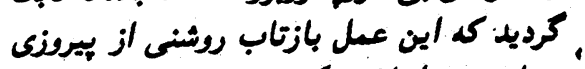

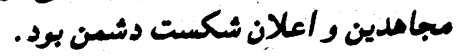

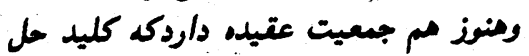

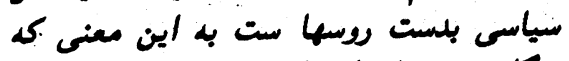

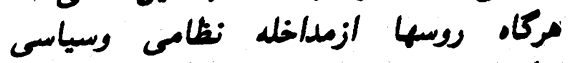
درافغانستان دست بردارند ديكرميع مشكل ورئل

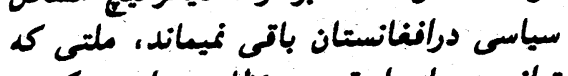

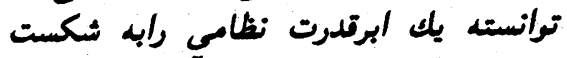

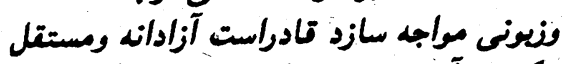

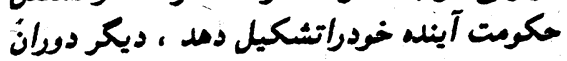

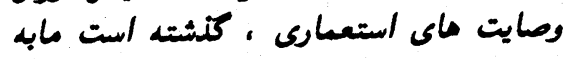

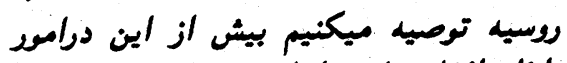

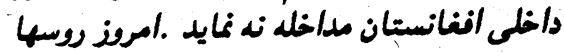

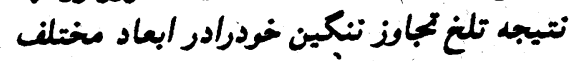

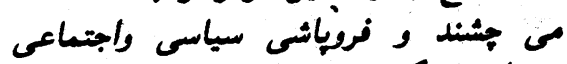
ويجران سنكين اتثصادى وامنيتى روسي وانيى بيانكر اين مدعاست . بعنين

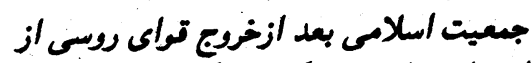

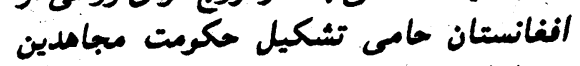

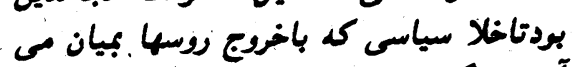
آيد رفع كردد.

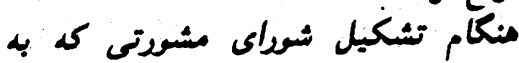

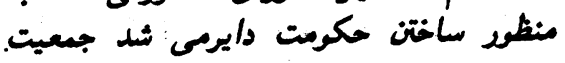

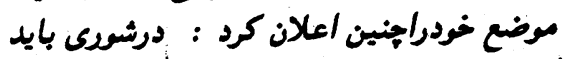

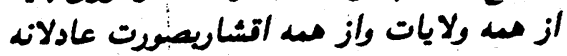
نما يندكى صهرت بكيرد.

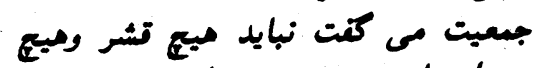

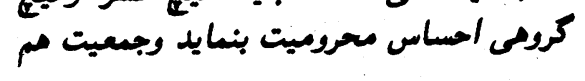




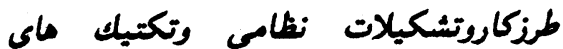

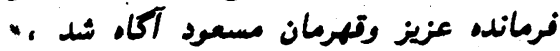

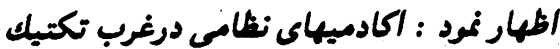

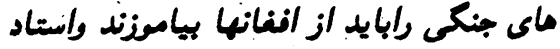

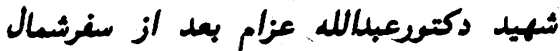

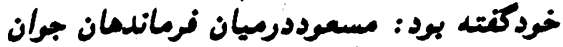

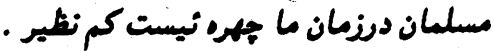

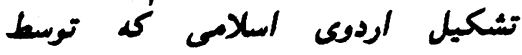

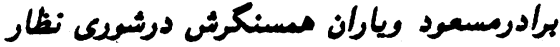

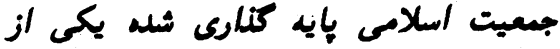

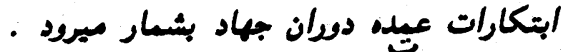

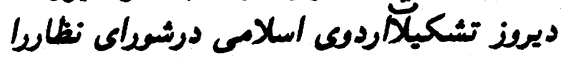

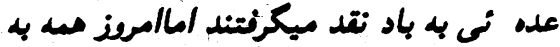

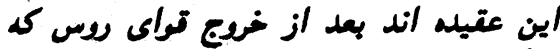

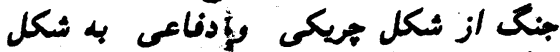

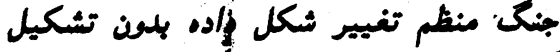

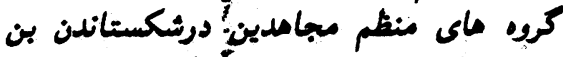

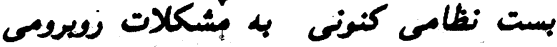

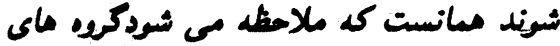

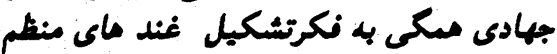

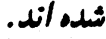
شنكرنشينان قهرمان جمعيت درطول قيام

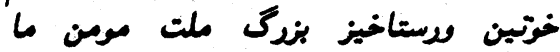

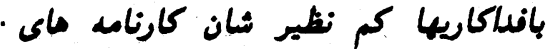

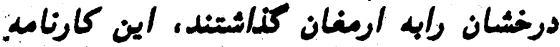

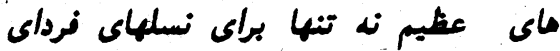

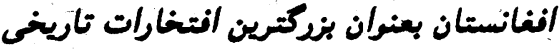

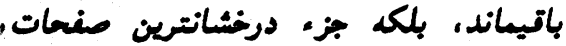
تاريخ مسلصانان راتشكيل ميدهد.

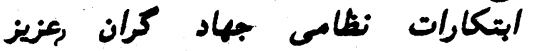

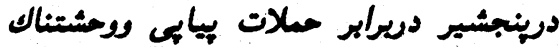
تشسون روسى وشكست مسلسل كاير آنها درمسه.

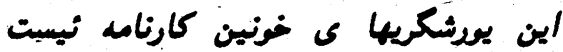

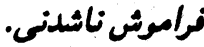
فتوحات تاريخى دوابرفرزندانتلاب درئسال

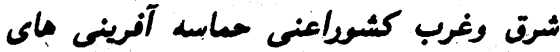

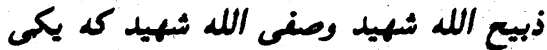

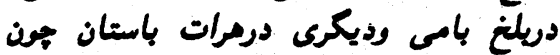
دواخترفروزان درغشيغ وديدند، ودرودوران حيات

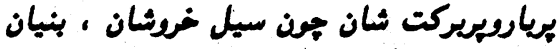

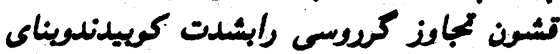

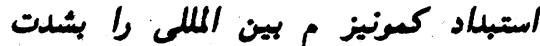

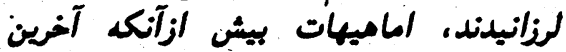

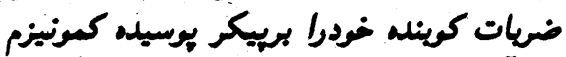

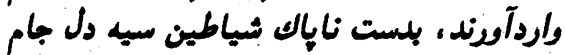

بهادت نوبشيدند.
46.

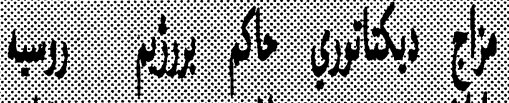

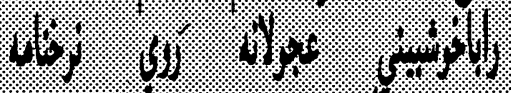

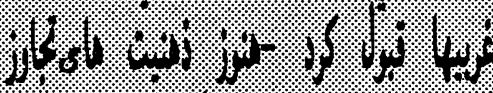

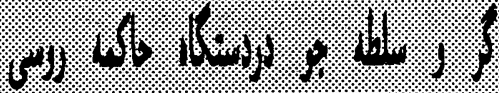

$\left\{\begin{array}{l}10 \\ 4\end{array}\right.$

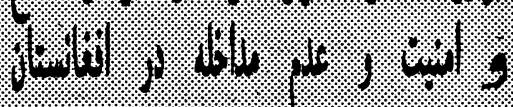

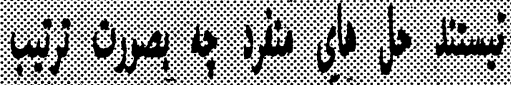
(4.7. (2):

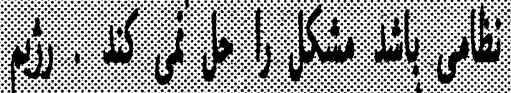

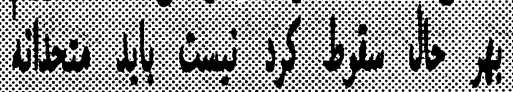
भi :

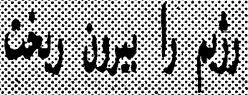

جمعيت بلدون خوف ومراس تالنجاكه متدويبود

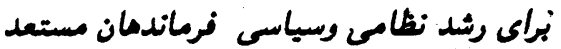

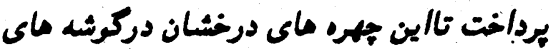

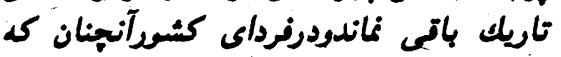

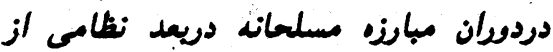

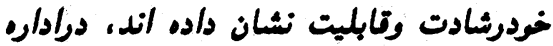

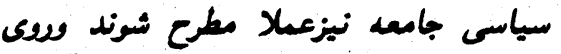

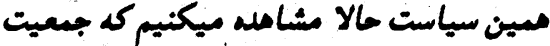

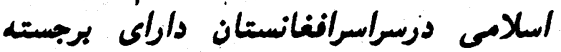
تمين فرماندمان وجبهات متتدرميباشد.

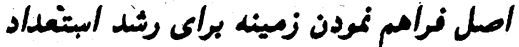

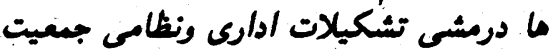

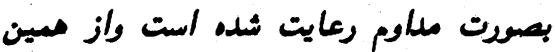
جاست كه ملاحظد ميثرد جهرو مارد ماى درخشان

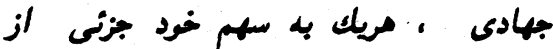
انتخارات ملت تهرمان وجهان اسلام بشرئ بشار ابتكارات عظيم اين اختران فروزان جهاد

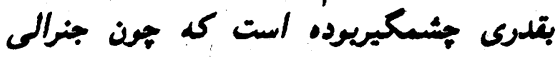

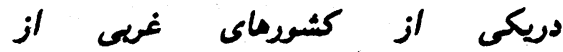

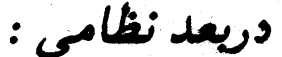

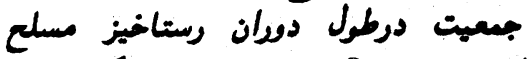

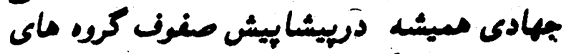

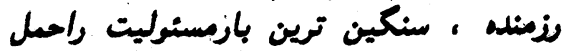
كرده است . بمعيت دوريعد نظامى باحمله روسها بسيج

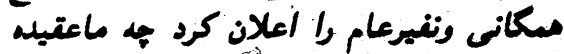

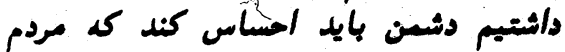

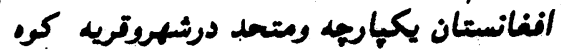

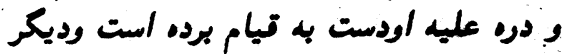

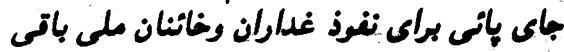

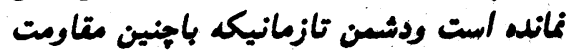

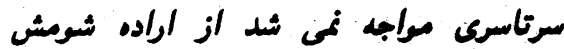

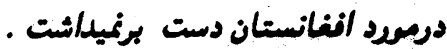

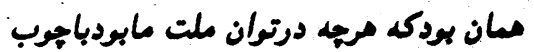

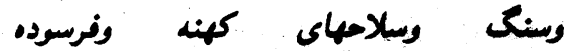

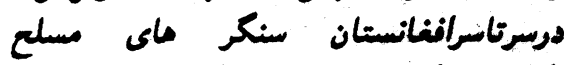

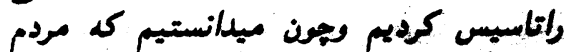

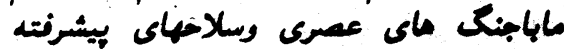
آشنائم تمارند يراى اولين بارئ ماردزتاريغ جهاديد

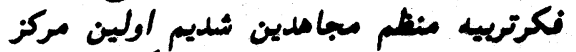

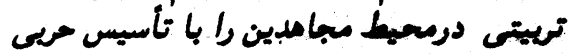

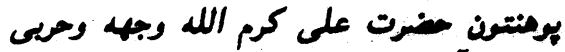

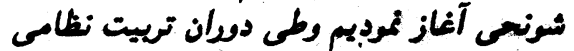

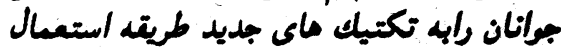

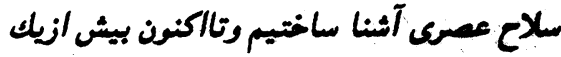

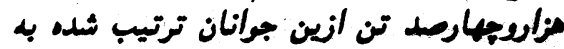
بهات جهادى فرستاديم كد تغيريرات مثبتى

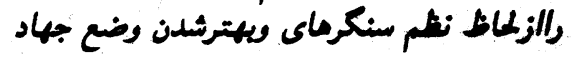

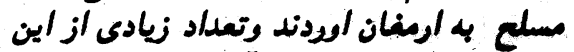

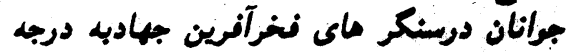
رفيع ثمبلدوت رسيدند.

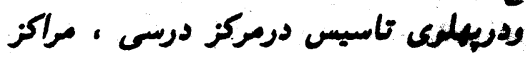

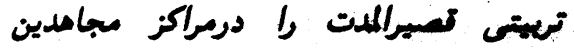

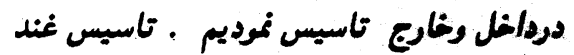

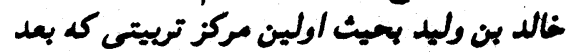

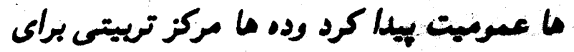

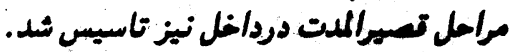

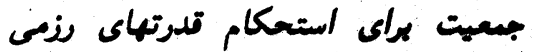

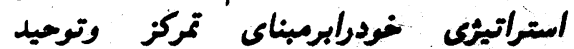

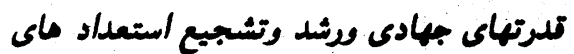

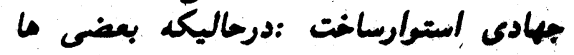

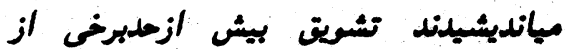

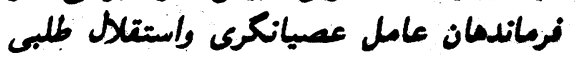

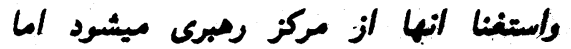


طورى ترتيب يافته كد شاكردان به مسايل

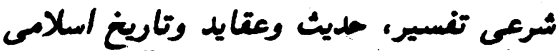
وجهان بينى اسلامس بايد اكاه بار آيند.

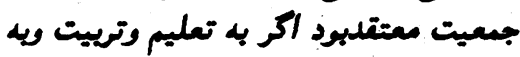

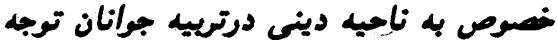
نكردو انتلاب اسلامس به بيراصي دريه كثيانده

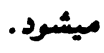

بمعيت دريخش هاى تمييتن به تاسيس

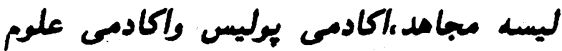

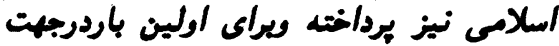

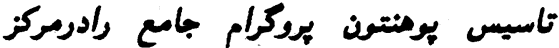

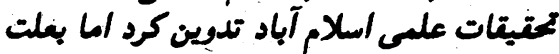

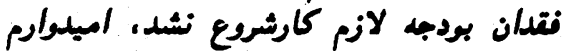

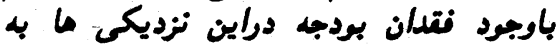

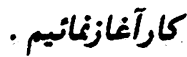

مدف جمعيت درتاسيس مدارئ مارس مختلف

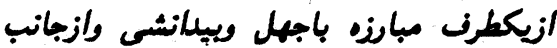

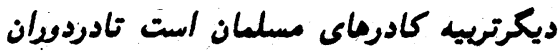
تاسيس دكرمت اسلامى درانغانستان بتواني

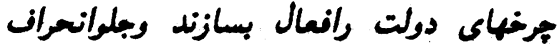

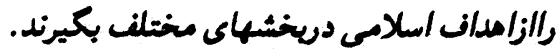

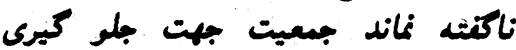

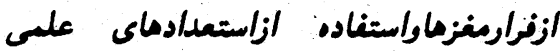

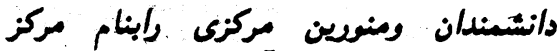

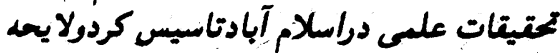
اي ترتيب شدكه دوبنشهاى مختلف استاديان

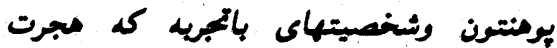

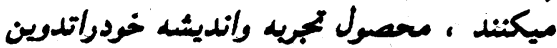

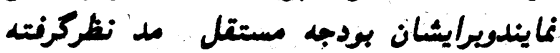

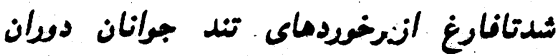

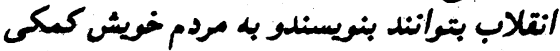

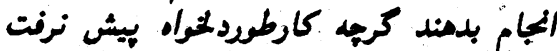

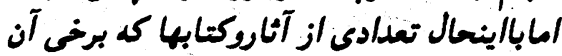
بجاب رسيله تاليف شدلد. جمعيت غزض كمبرد نلمبرداروعكاسى

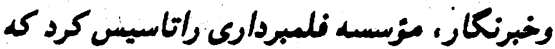

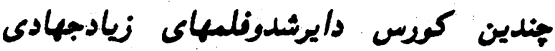

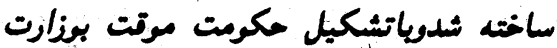
ارشادتعلت كرمت .

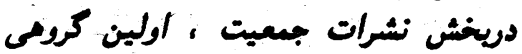

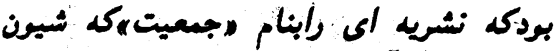

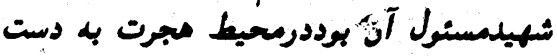
نوشته ونشرميشد.

جمعيث دردوران فعاليتهاى نشراتى خود

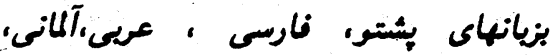
انكيسى ، روسى اردوودرمدت زمانى مم به

\section{دريعد تعليمى وفرمنكى :}

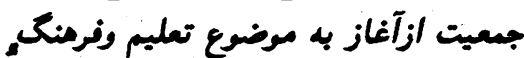

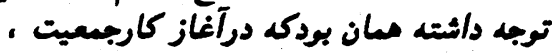

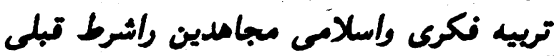

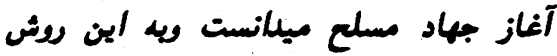

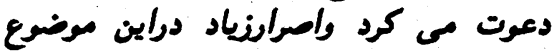

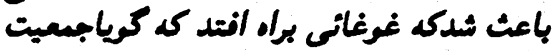

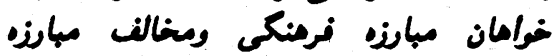

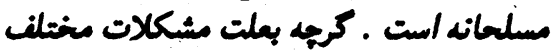

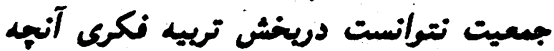

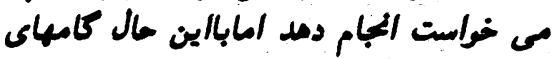
عمده نمى ورسطع كلم برداشته شيد.

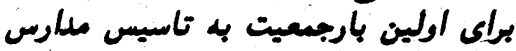

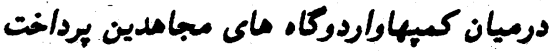

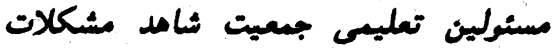

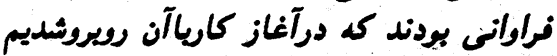

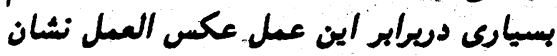

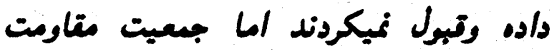

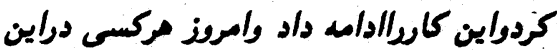

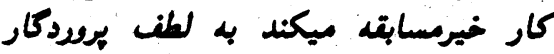

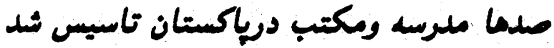
وده ما مزار شاكرد دوراين مدارس مشنغول دورس

وكمتر ين تعاديكه دريخش تهران به علت

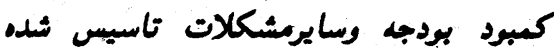

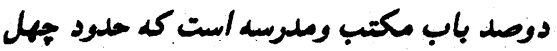
مزارشاكرد زيريوشش آن تراردارد.

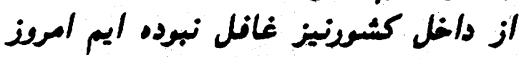

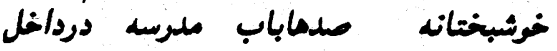
كشورثاسيس شده است.

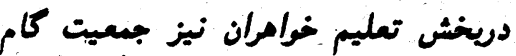

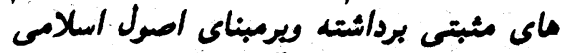

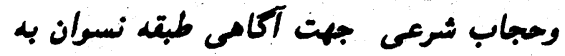

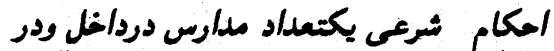

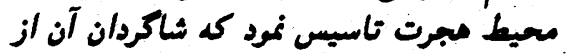

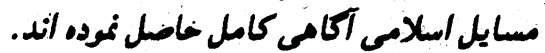

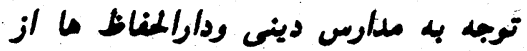

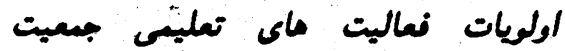

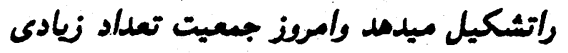

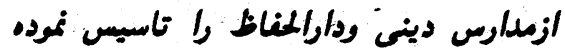

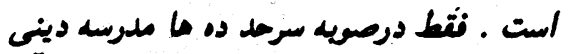

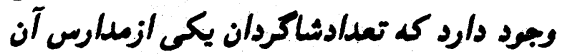

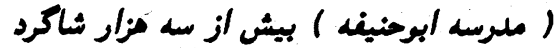

ناكته نماند درسايرمدارس نيزيروكام ما.
كارنامس هاى جشمكيرفرمانده ميشه

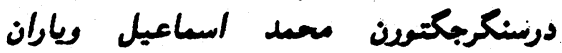

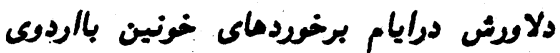

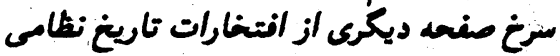
كشوراست . ابتكاركم نظير طازق شهيد دوردوروان

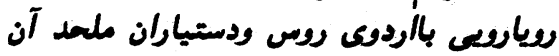

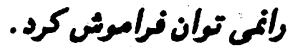

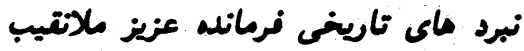

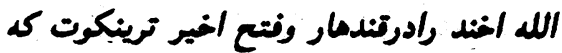

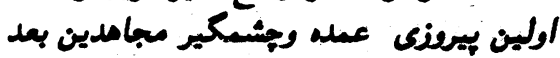

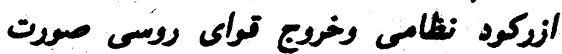

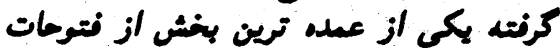

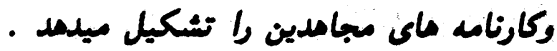

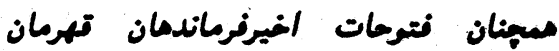

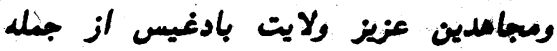

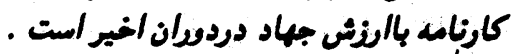

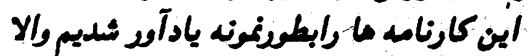

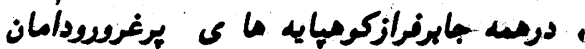

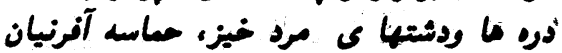

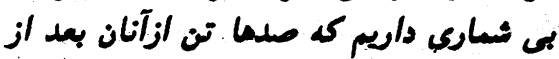

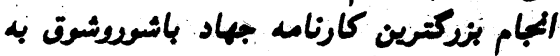

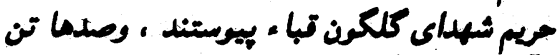

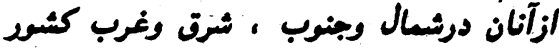

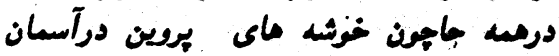

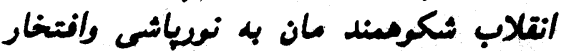

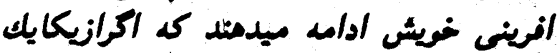
آنان نام يرم اين ودف باره صلمن كاغذخواهد ما واستان جاسه آفرينهاى سنكرنشينان

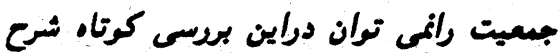

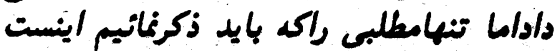

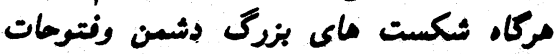

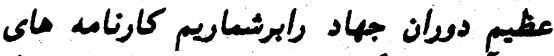

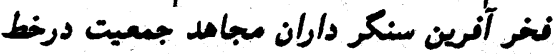

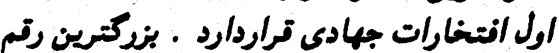

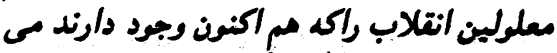

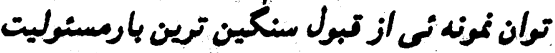

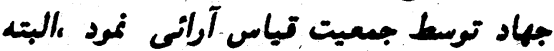

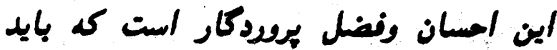

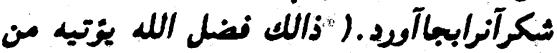

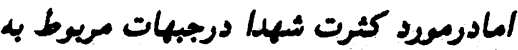

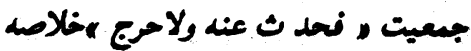

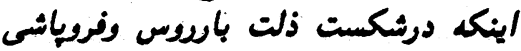
كمونيزم درجهان ، جمعيت نتش عبله د داشته 


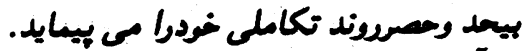

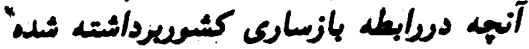

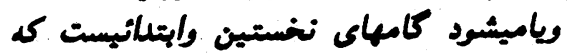

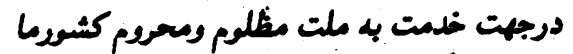

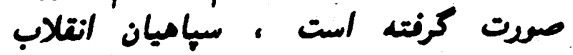

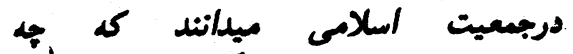

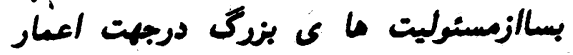

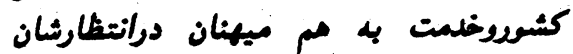

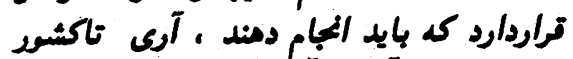

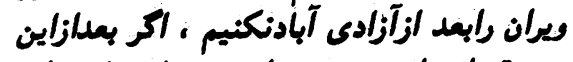

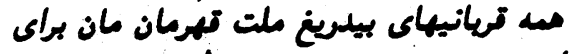

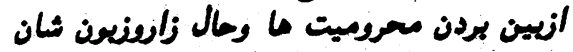

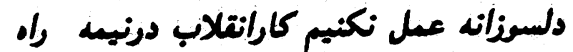

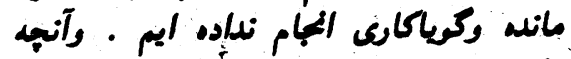

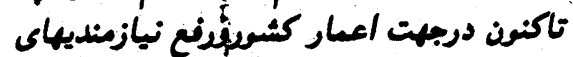

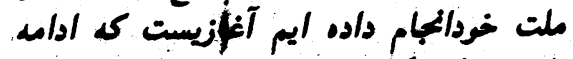

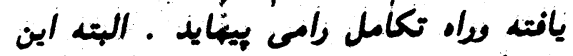

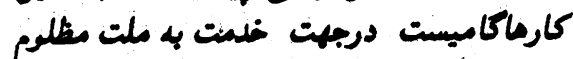

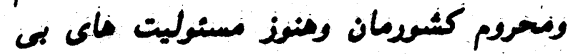

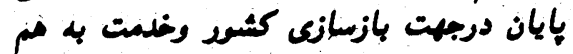

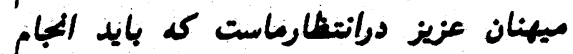

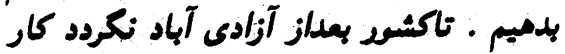

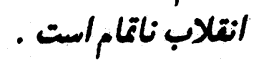

\section{اوضاع كنونه وموقف ما:}

بعد از خروج قواى لعس ازكشسياوجوديك

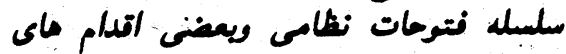

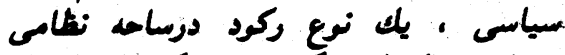

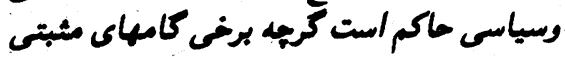

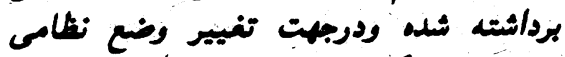

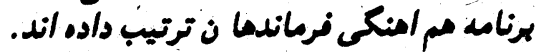

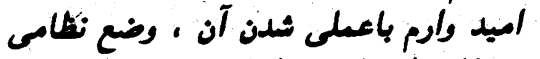

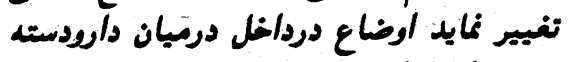

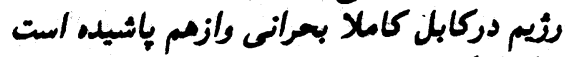

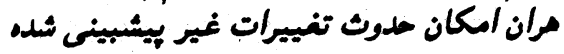

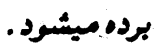

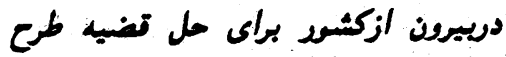

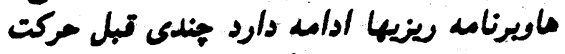

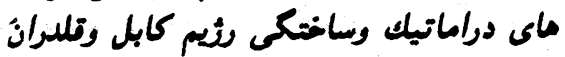

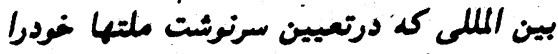

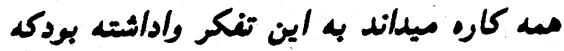

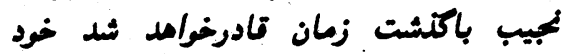

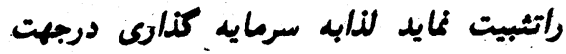

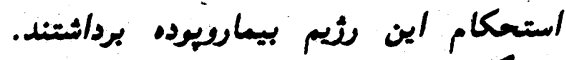

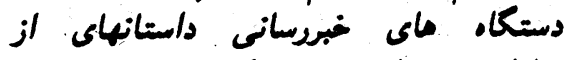
بهلوانيهاى نطامى و عملكردماى اداري
سالم اسلامى كامهاى موثرى برداشته اند.

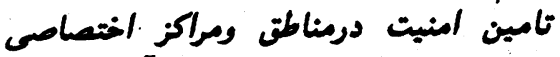

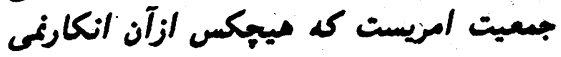

ونزد.

تاسيسن دارالايتامها اولين إتكاري بودئ

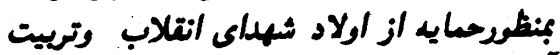

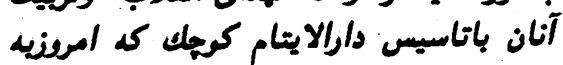

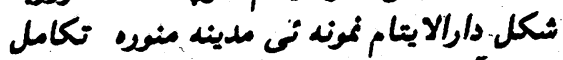

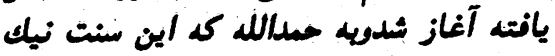

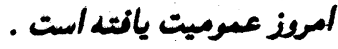

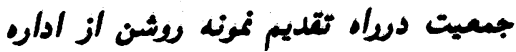

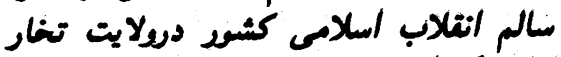

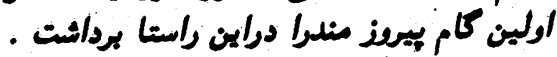

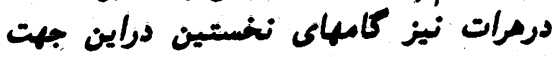

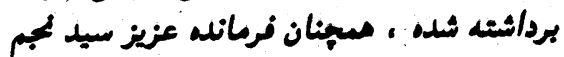

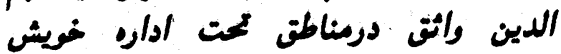

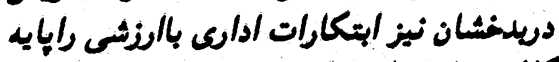

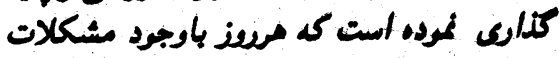

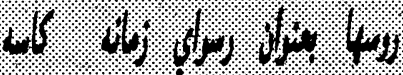

It

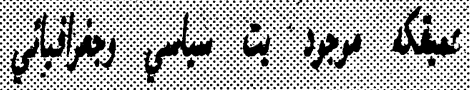
4. t.

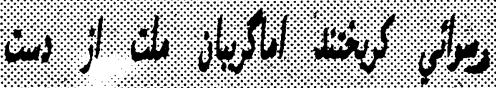

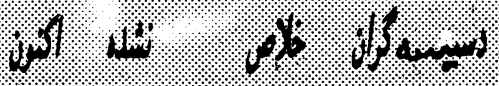

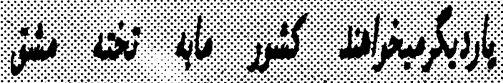

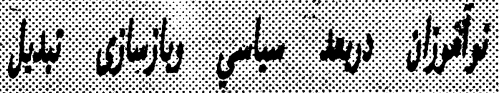
(3. 4 . .

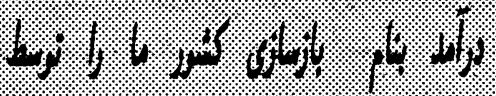

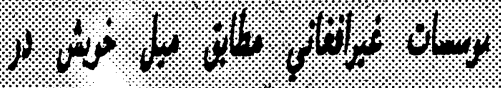

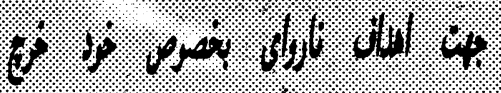
4.2

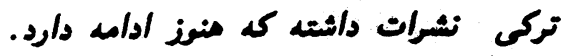

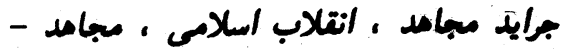

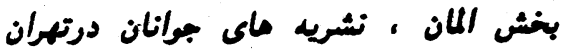

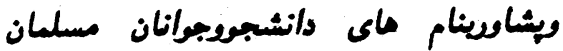
ومبله هاى المجامدون به عريس وميئاق خون به وانه

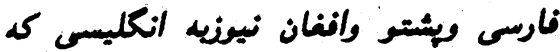

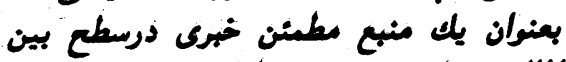

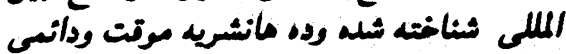

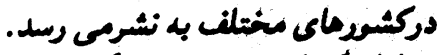

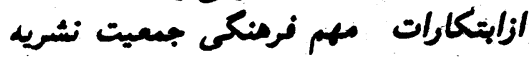

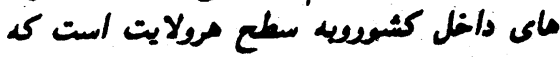

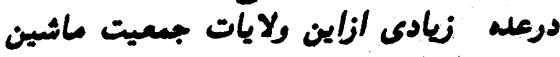

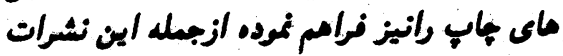

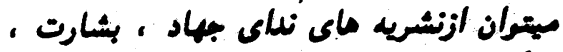

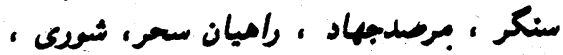

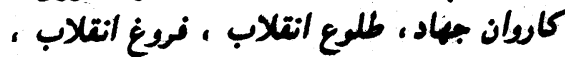

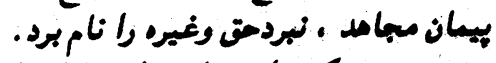

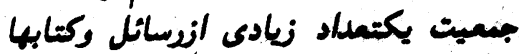

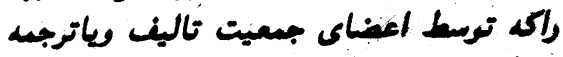

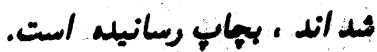

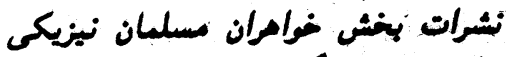

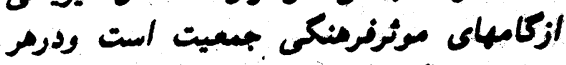

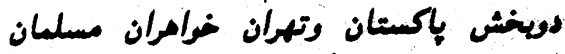

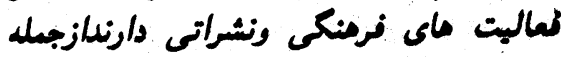

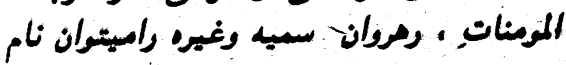
هرد درغضش فباليتهاى تميت بدنى بمعيت

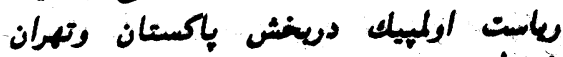

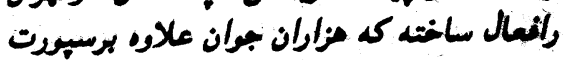

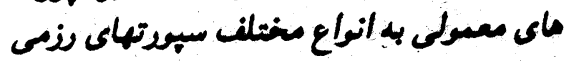

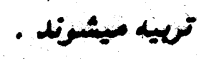

\section{دربعلخدمات اجتماعى :}

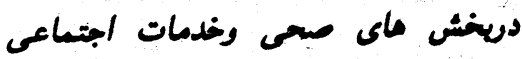

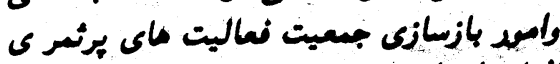

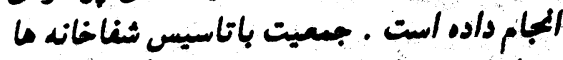

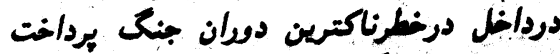

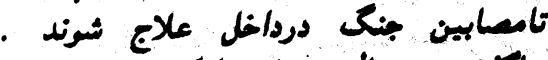

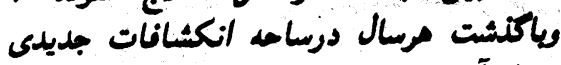

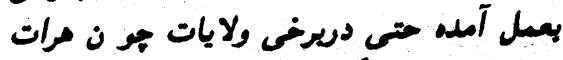

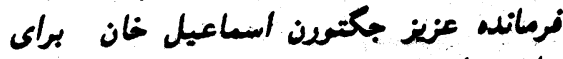

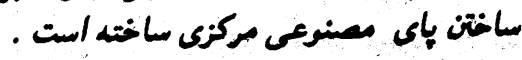

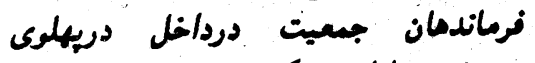

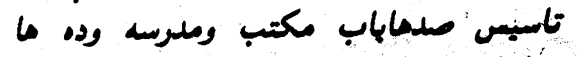

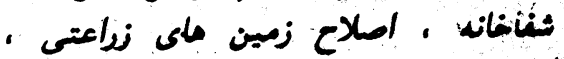

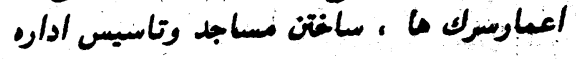


اكنون مان سلسله ادامه دارد . روزكارى در

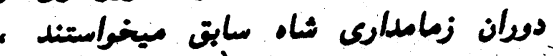

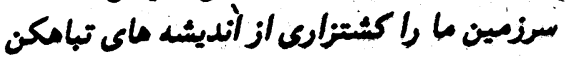

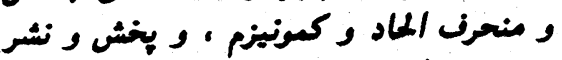

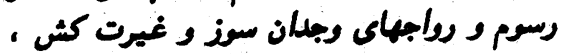

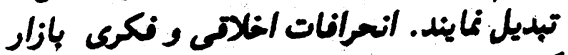

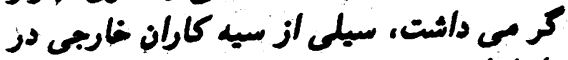

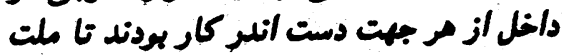

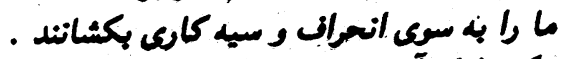

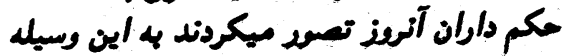

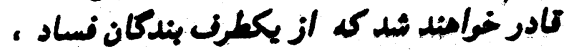

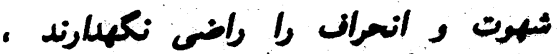

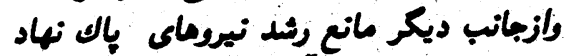

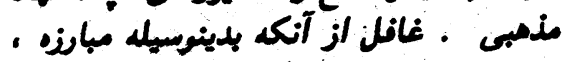

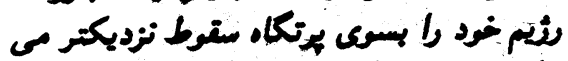

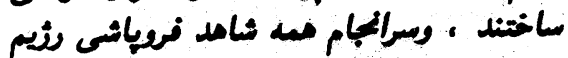
وآئ زمان كه كودتا كران كمونيست كليم

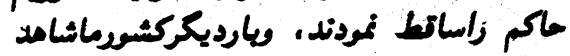

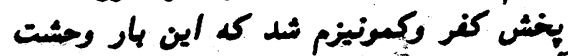

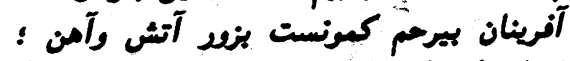

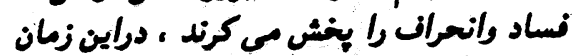

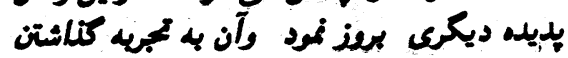

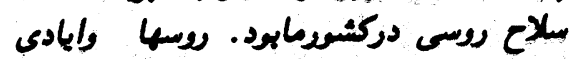

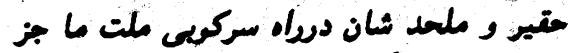

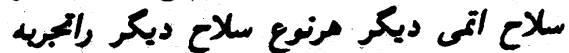

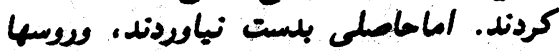

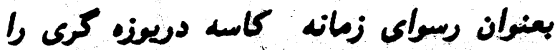

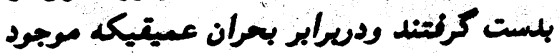

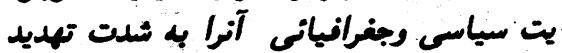
مى كند روسها به رسمراتمى كريختند الماكريبان

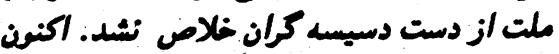

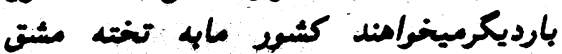

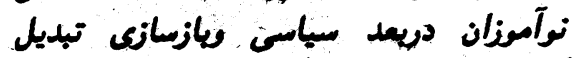

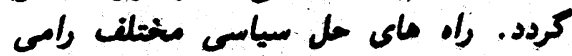

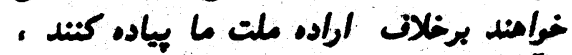

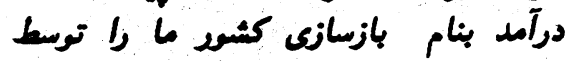

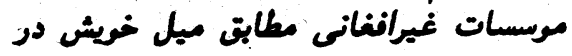

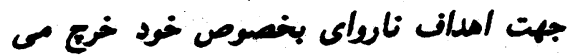

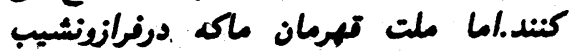

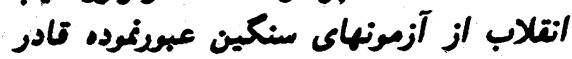

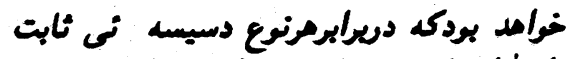

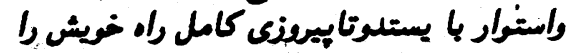

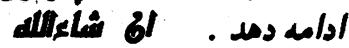

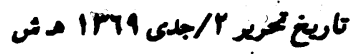

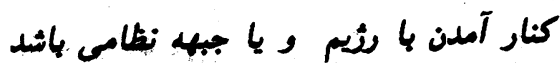

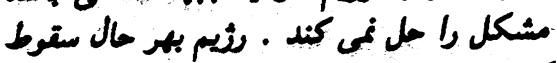

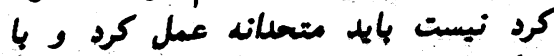

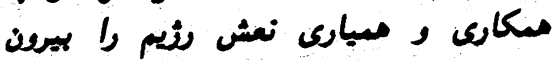

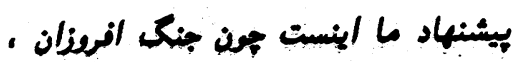

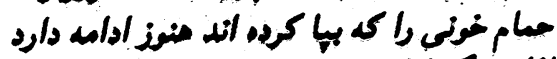

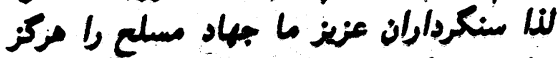

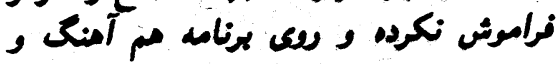

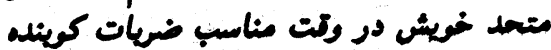

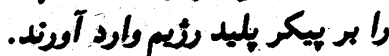

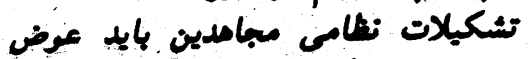

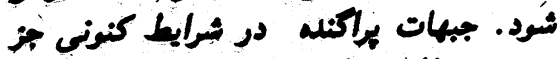

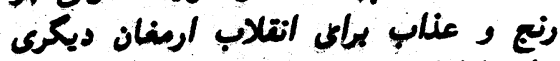

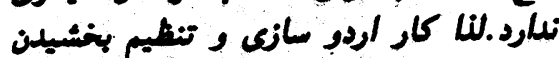

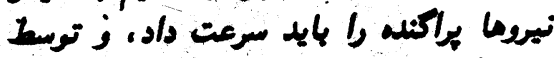

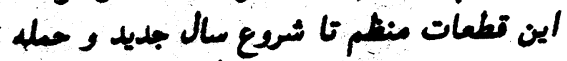

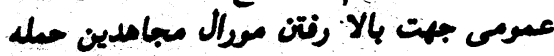

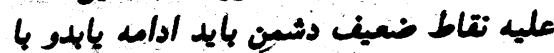

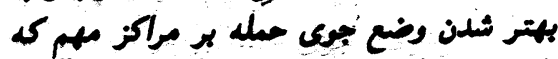

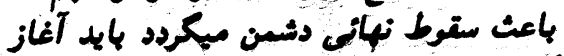
كرودو. از لحاث مياسى بايد وضع كنونم تغيير

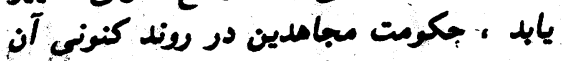

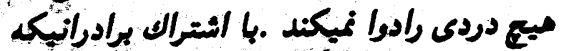

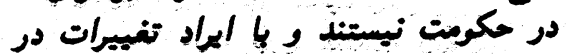

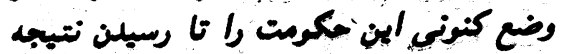

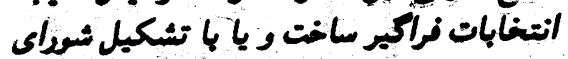

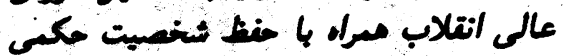

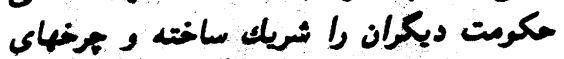

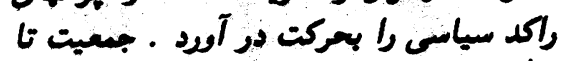

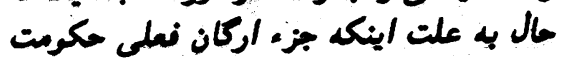

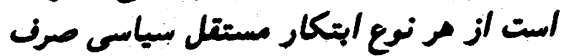

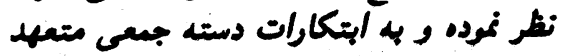

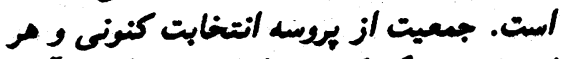

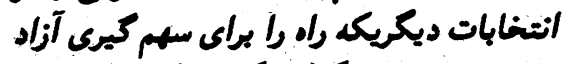

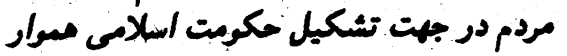
مس مازد حمايت مي كند.

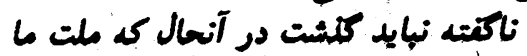

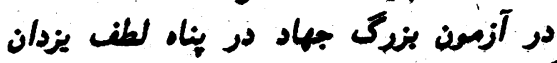

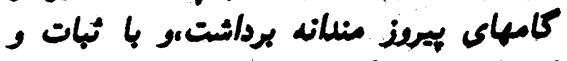

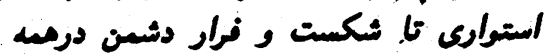

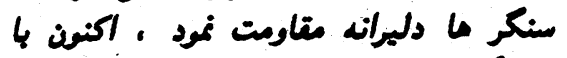

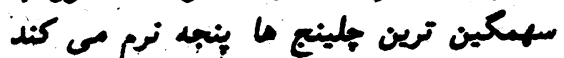

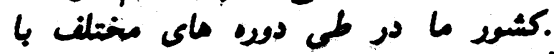

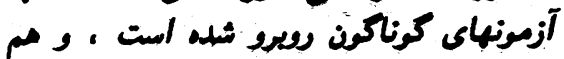

مكايت ميكرد ـ امابعد ما بشمبول روسها به ايه

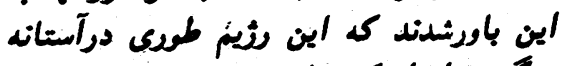

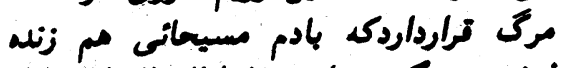

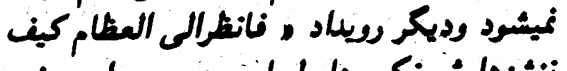

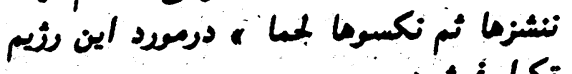
تكرار نميشرود.

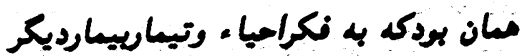

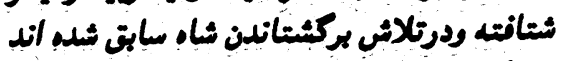

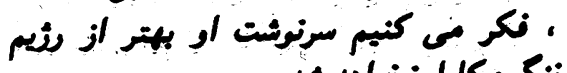

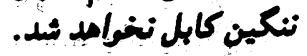

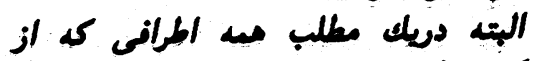

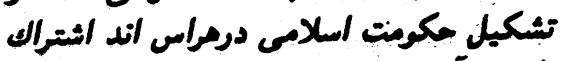

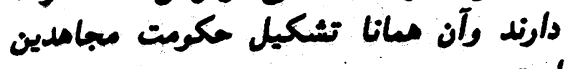
كيرمال اين مشكل بهرونيست ونبايد عامل

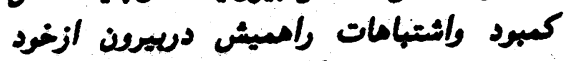

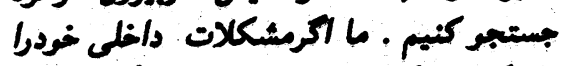

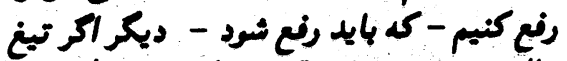

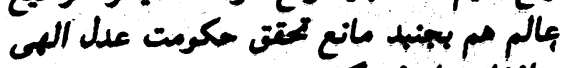
درانفانستان معى كربد.

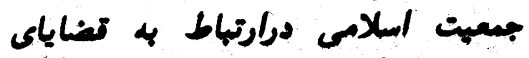

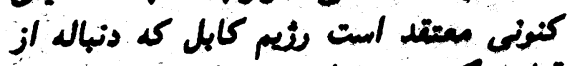

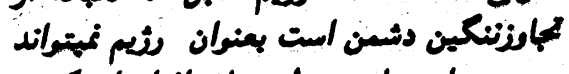

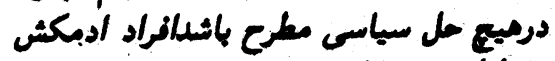

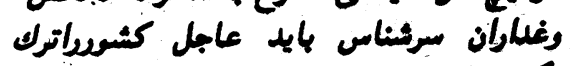

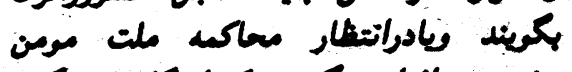

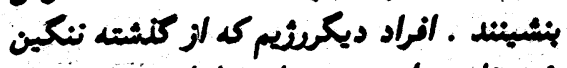

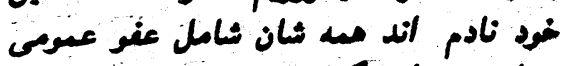

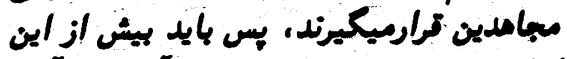

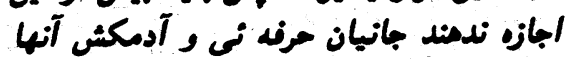

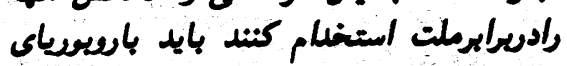

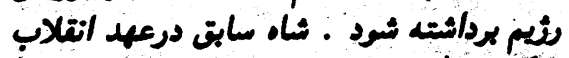

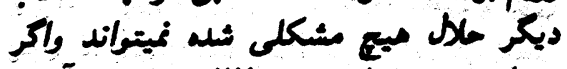

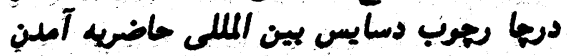

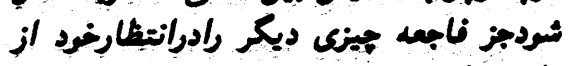

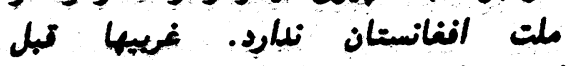

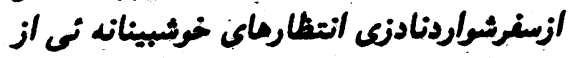

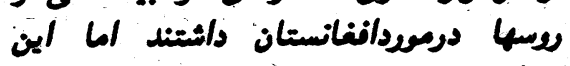

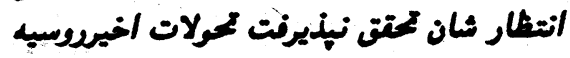

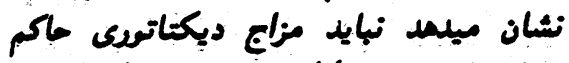

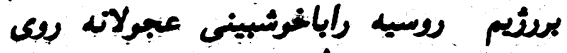

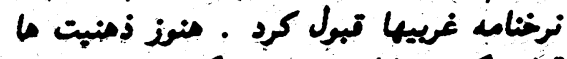

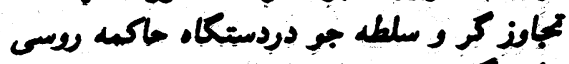

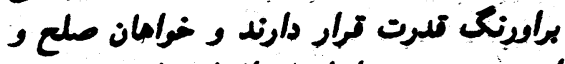

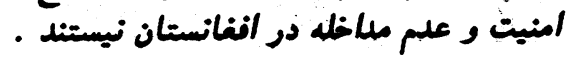

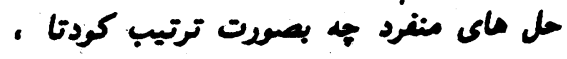




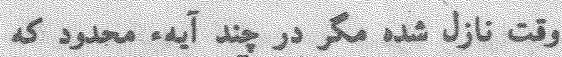

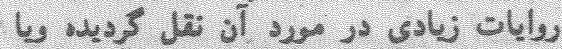

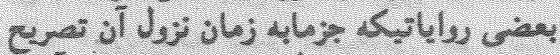

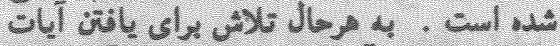

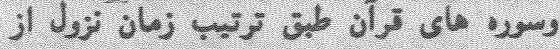

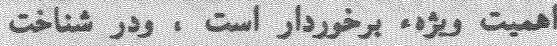

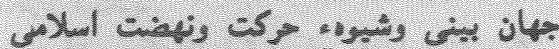

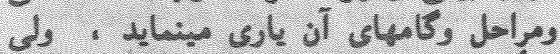

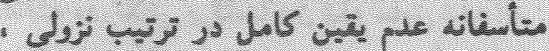

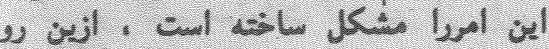

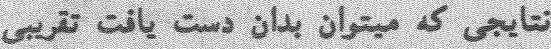

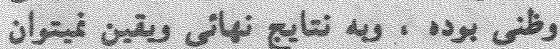

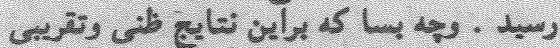

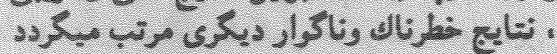

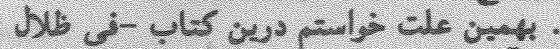

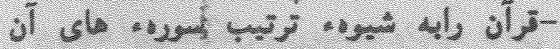

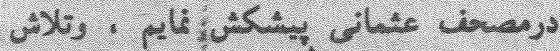

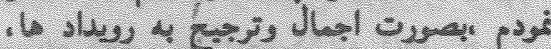

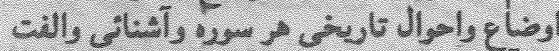

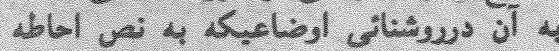

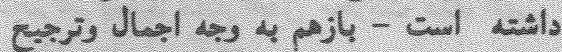

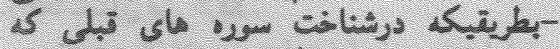

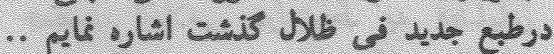

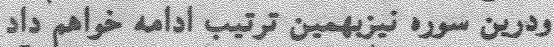

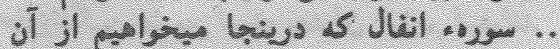

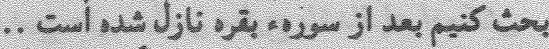

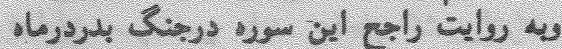

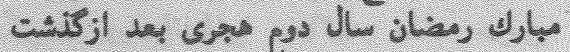

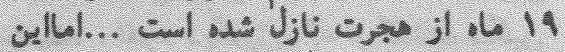

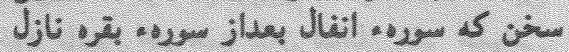

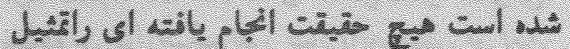

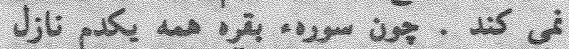

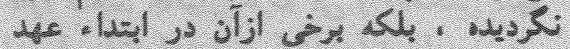

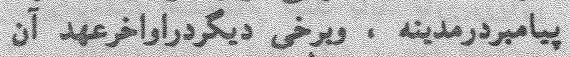

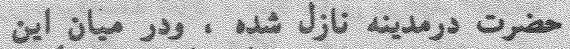

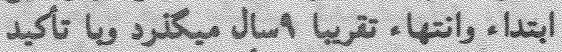

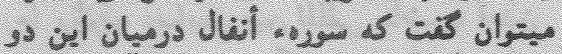

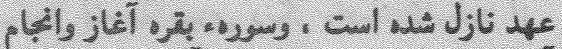

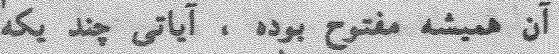

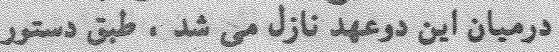

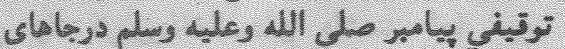

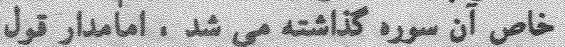

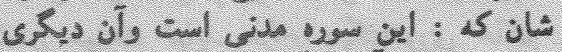

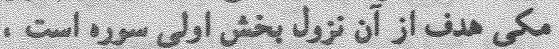

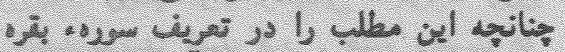

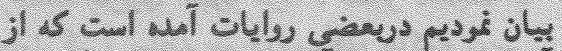

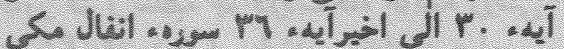
الت . وعبارت أزين آيات الست :

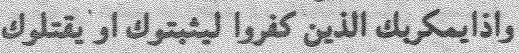
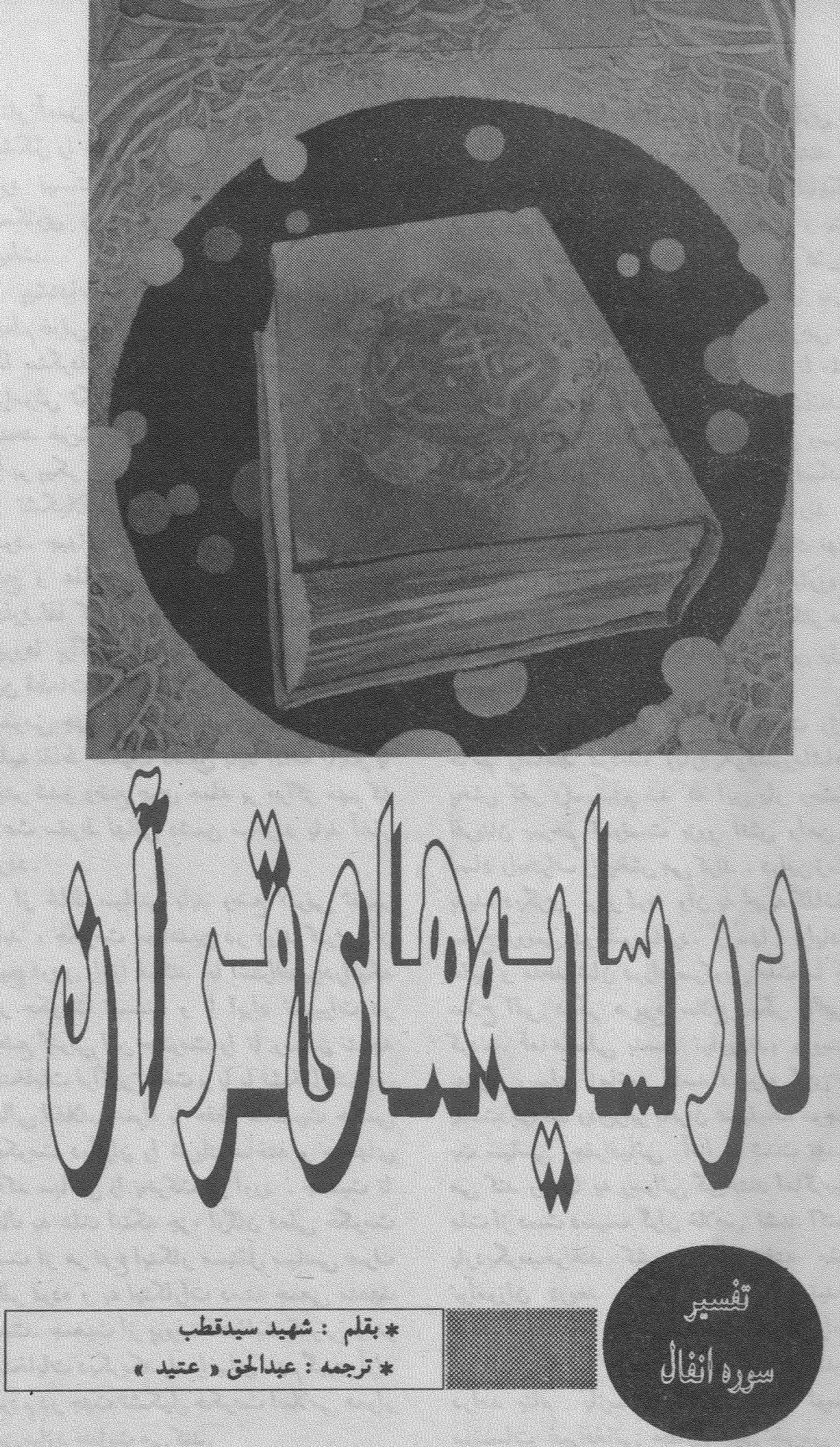

قرأن يطرد تطع ويتين الهان ندارد و تنها

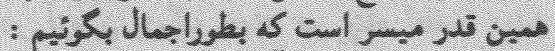

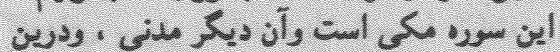

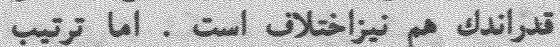

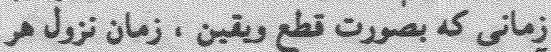

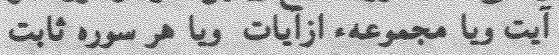

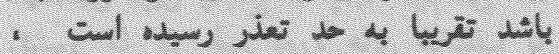
ونيتوان يطر تطع ويتين مك كرد كي درنلان
بلسير الله الرخهن الرحيبر

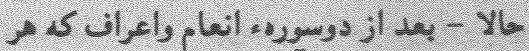

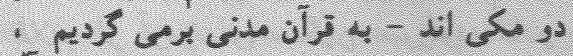

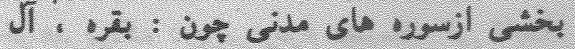

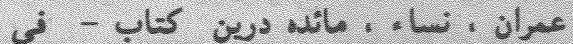

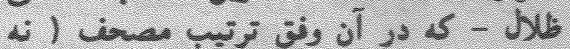

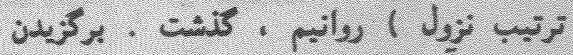

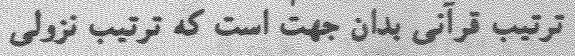




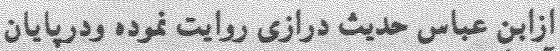
s ar or

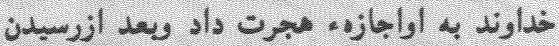

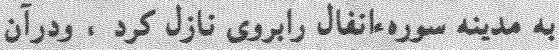

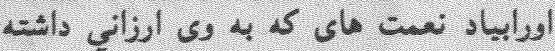

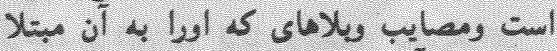

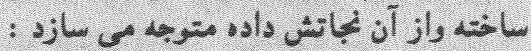

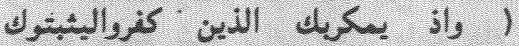

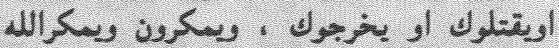
(is sul $>$ : wls

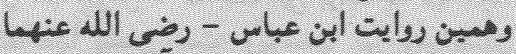

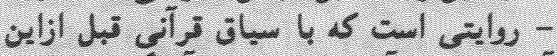

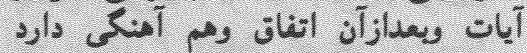

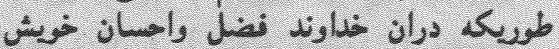

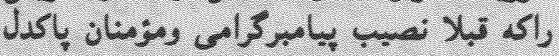

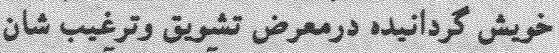

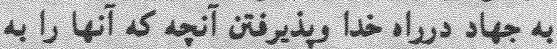

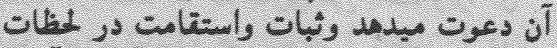

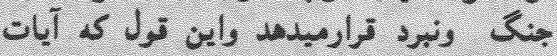

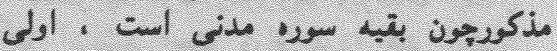

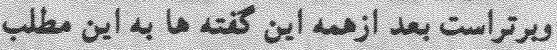

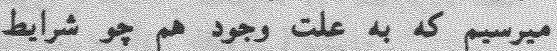

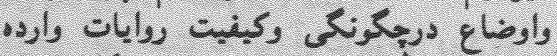

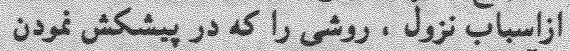

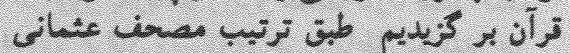

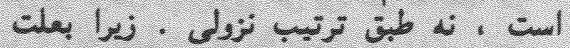

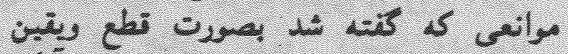
بمان

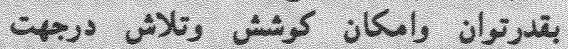

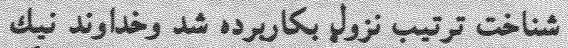

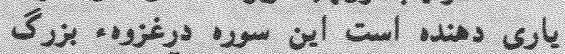

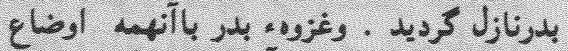

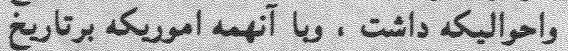

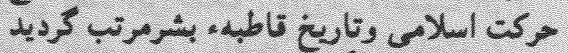

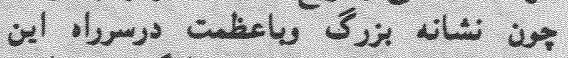

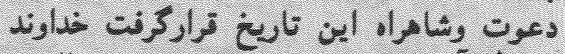

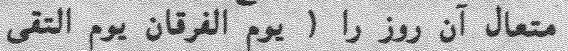

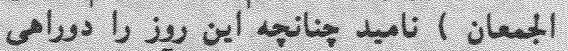
-

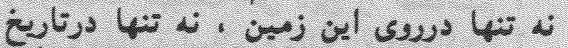

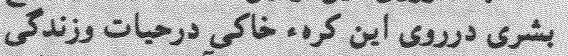

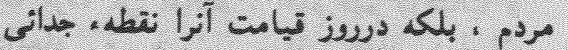

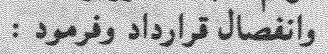

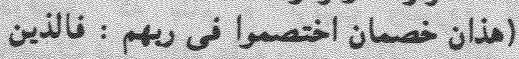

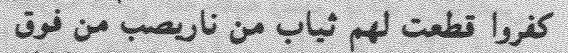

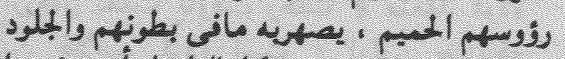

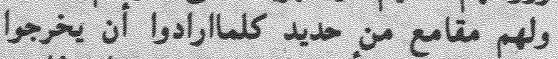

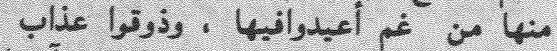

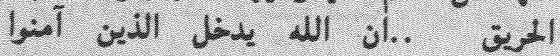

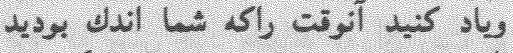

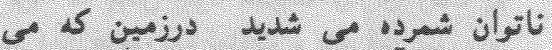

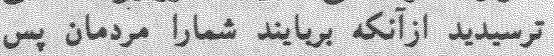

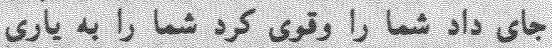

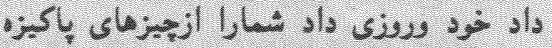

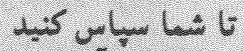

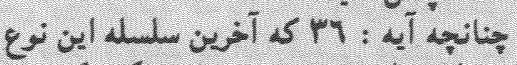

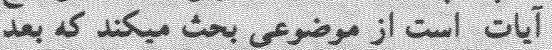

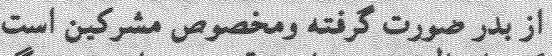

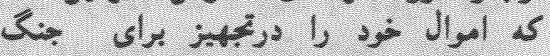

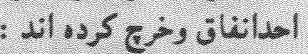

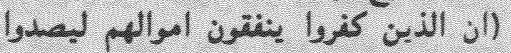
من

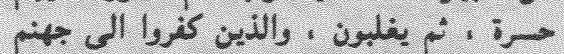
( is,

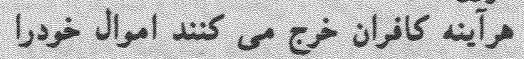

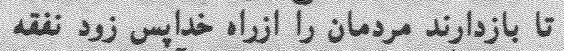
3دو

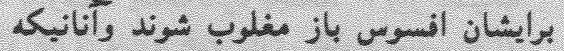

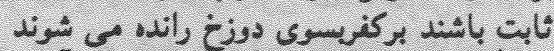

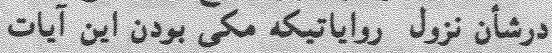

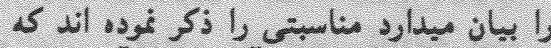

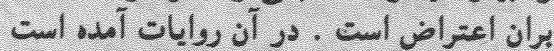

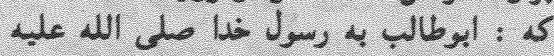

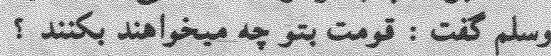

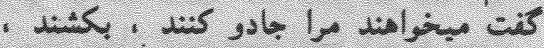

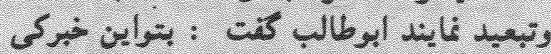

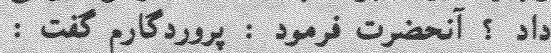

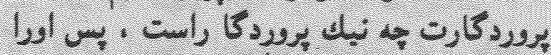

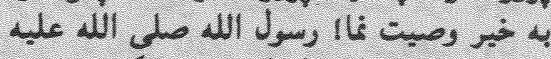

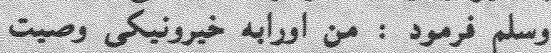
-

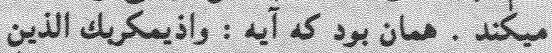

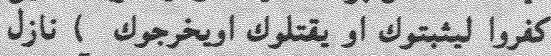

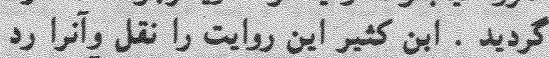

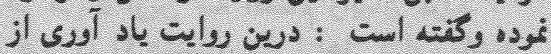

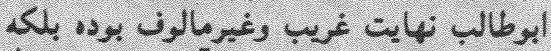

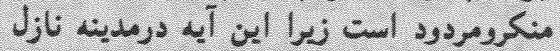

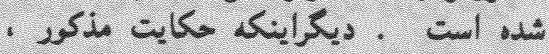


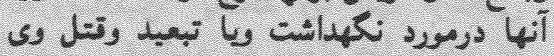

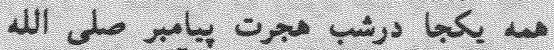

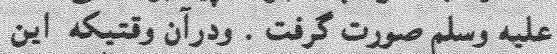

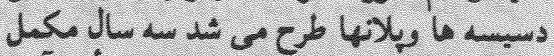

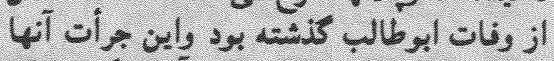

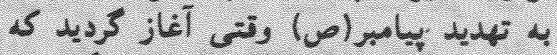

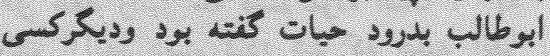

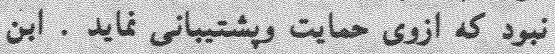

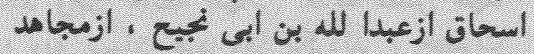

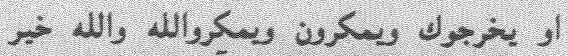

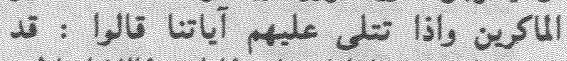

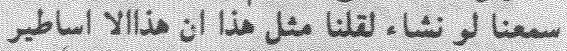

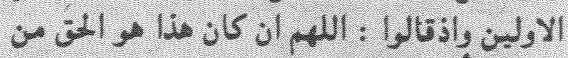

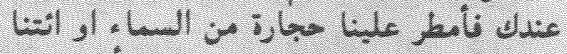

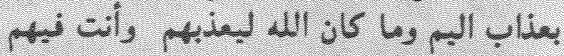

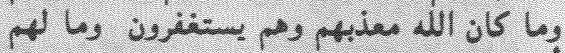

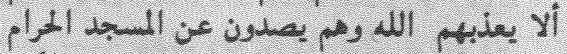

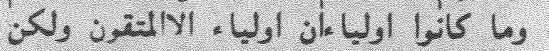

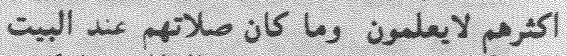

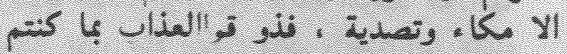

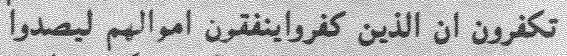
e

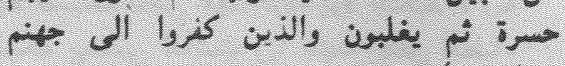

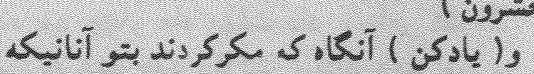

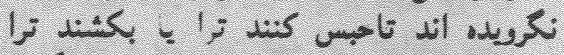

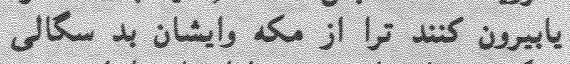

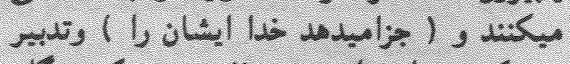

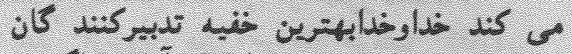

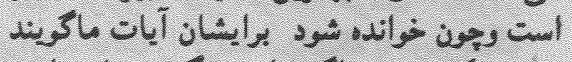

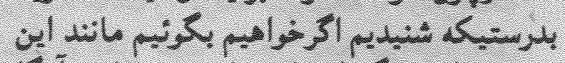

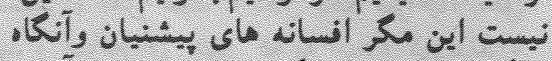

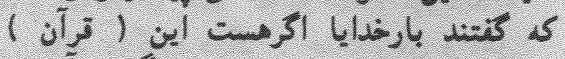

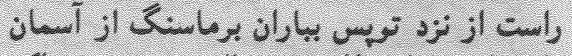

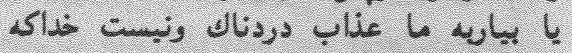

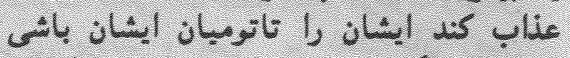

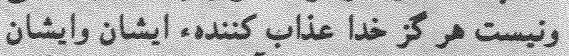

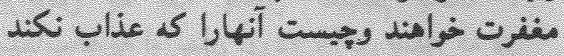

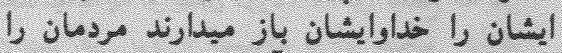

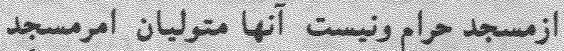

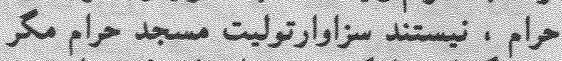

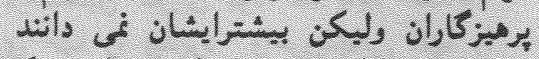

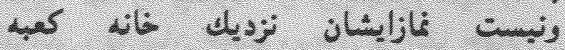

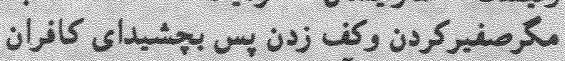
رات

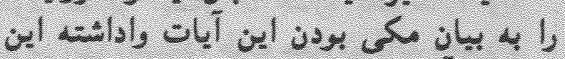

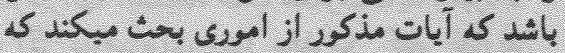

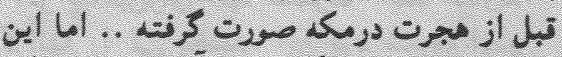

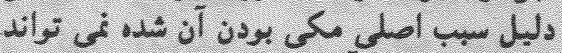

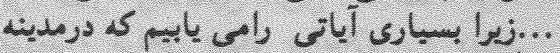

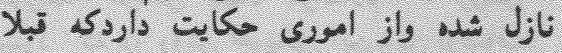

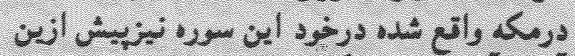

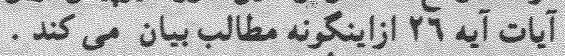

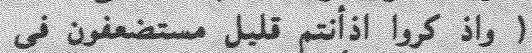

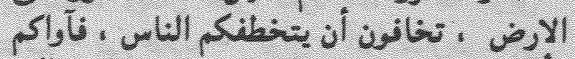

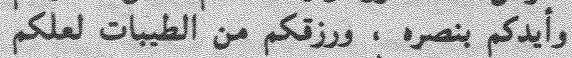
It : Jiell is 
رّول اكرم برعليه اين طاثنه جنكيد وبه آنها

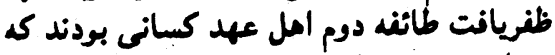

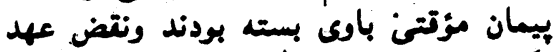

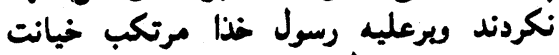

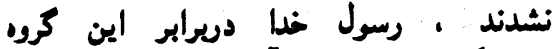
مامودكرديد كه عهد آنها رابه بايايان رساند

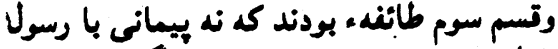

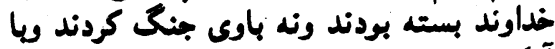
آنكه عهد مطلق بلدون تيدزمان ومكان بان داشتيند

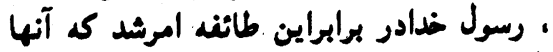

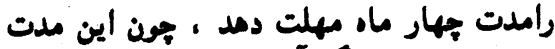

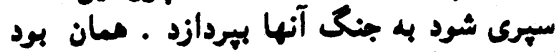

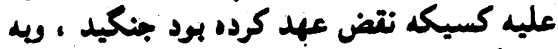

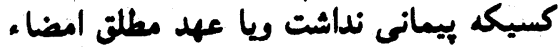

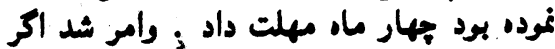

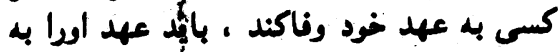

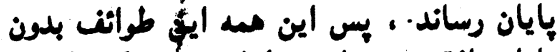

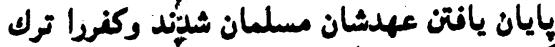

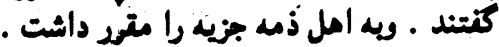

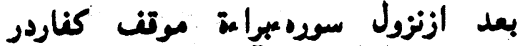

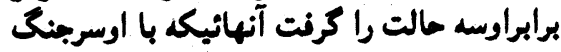

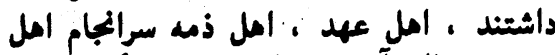

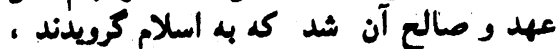

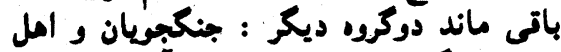

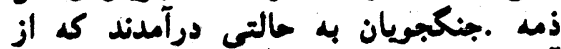

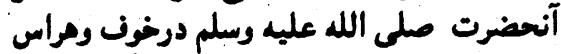

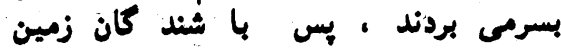

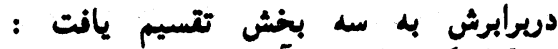

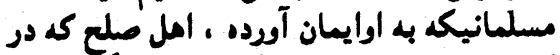

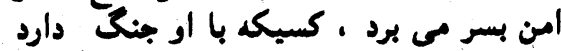

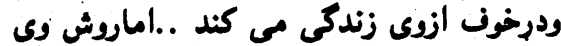

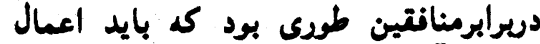

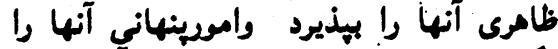

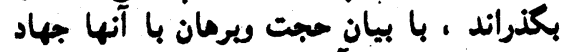

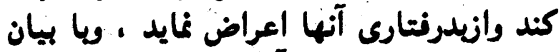

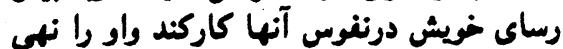

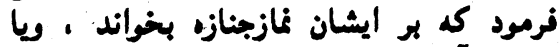

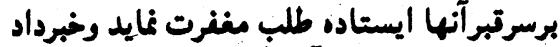

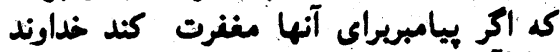

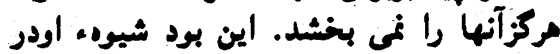

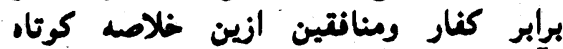

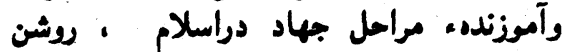

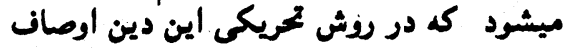

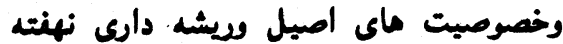

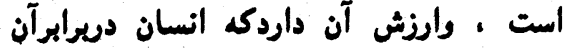

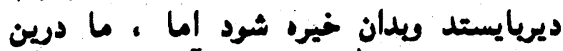

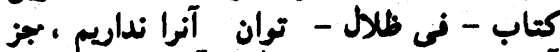

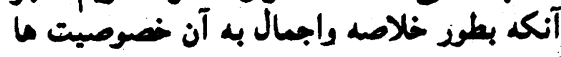

(ادامه دارد)

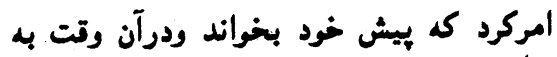

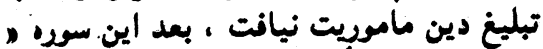

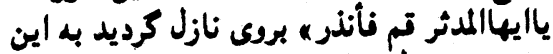

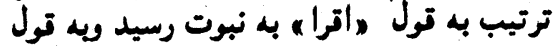

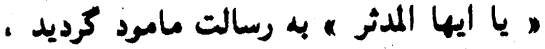

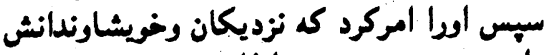

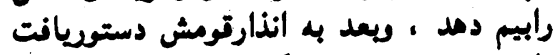

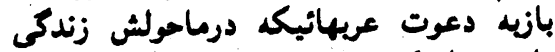

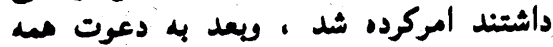

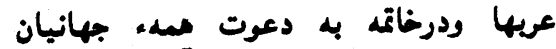

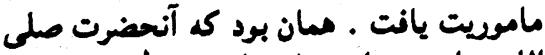

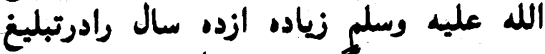

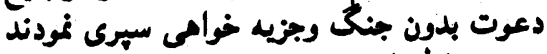

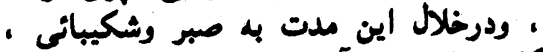

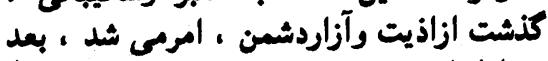

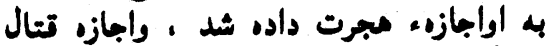

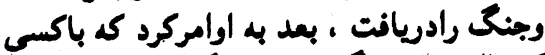

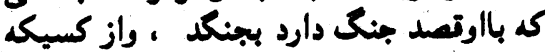

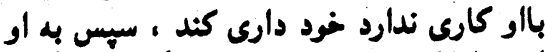

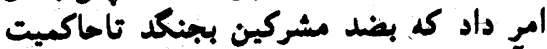

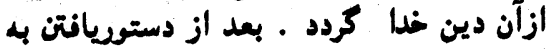

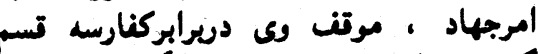

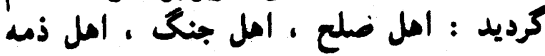

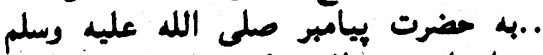

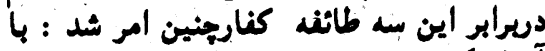

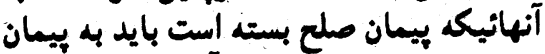

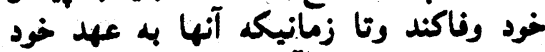

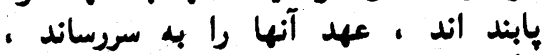

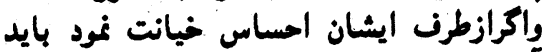

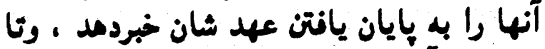

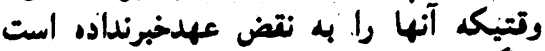

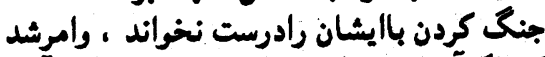

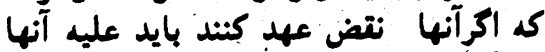

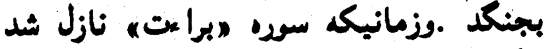

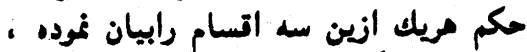

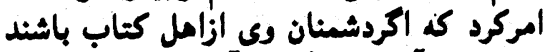

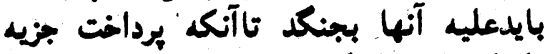

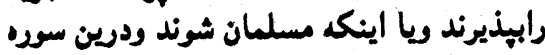

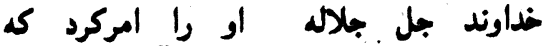

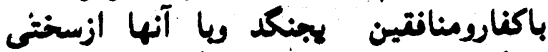

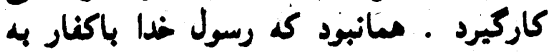

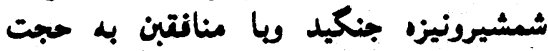

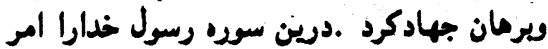

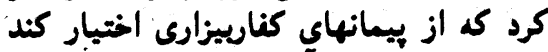

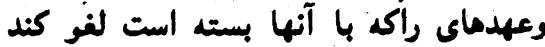

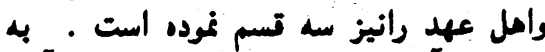

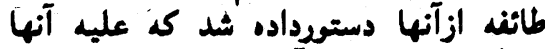

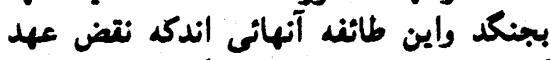

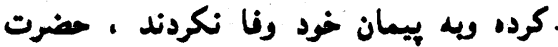

وعملوالشالالت بنات تجرى من تحتها الانهار

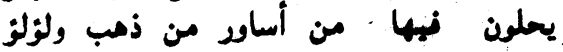

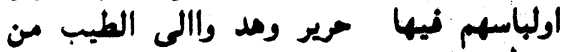

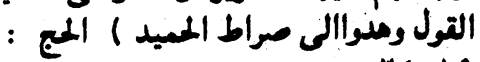
PE-19

تربعه : اين دو نريق دشمنان يكديكراند

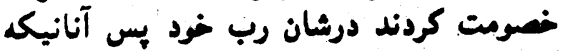

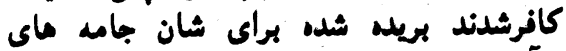

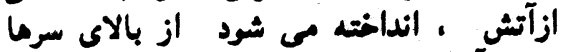
يشان آب جوش ، كداخته مى برايد به آنه آن آنهد

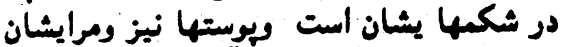

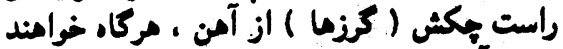

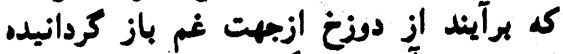

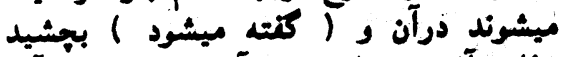

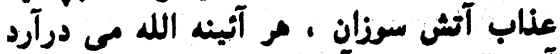

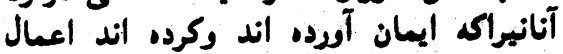

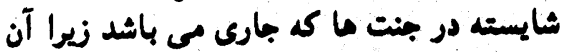

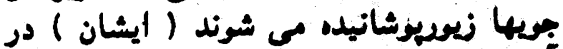

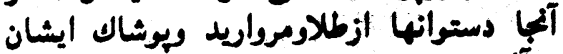

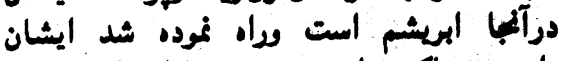

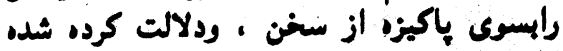

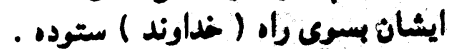

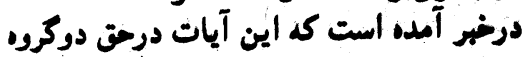

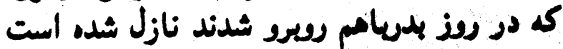

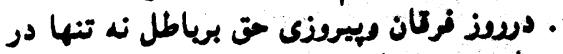

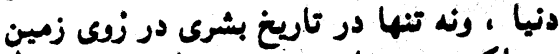

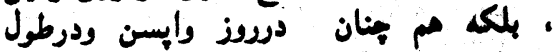

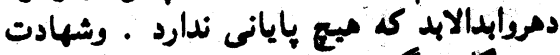

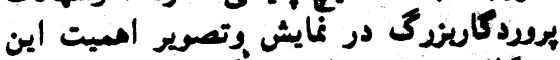

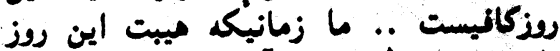

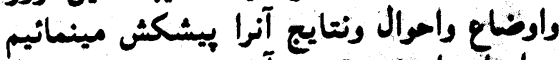

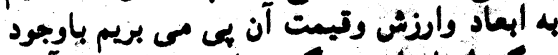

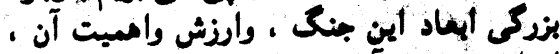

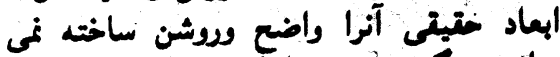

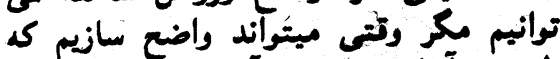

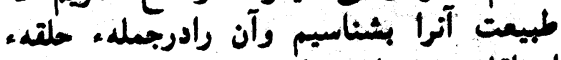

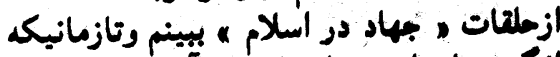

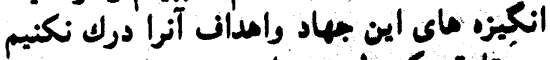

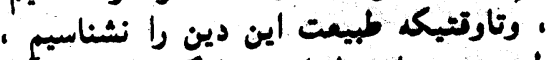

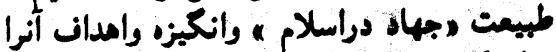

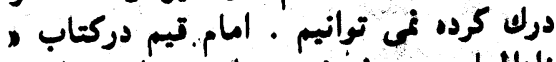

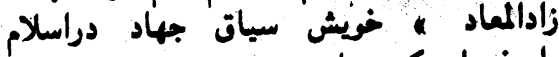

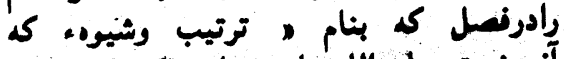

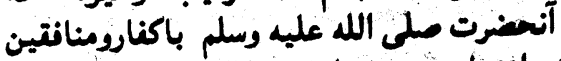

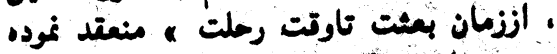

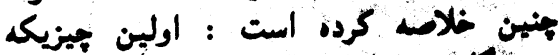

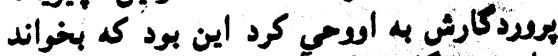

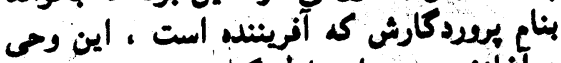

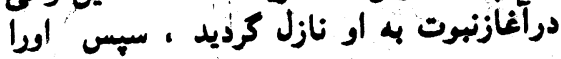


مرامود مشكل قبل مزمسه بادرميانى ميكند

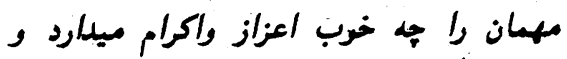

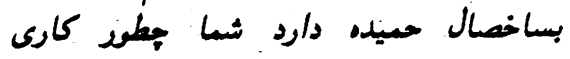
رامرتكب ميشريد كه باعث انزبار او كرديده

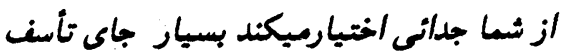

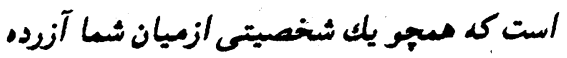

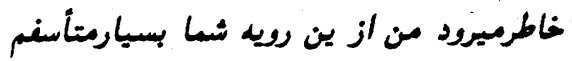

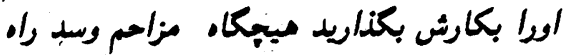

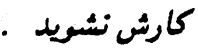

مردمان قريش سخنان اولا بنهو شئنيدند

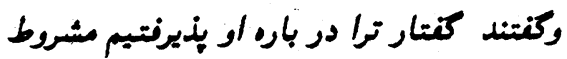

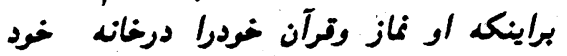

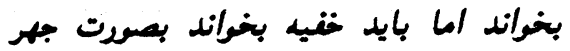

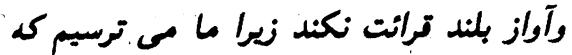

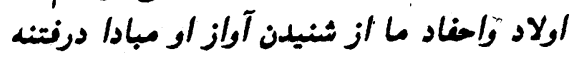

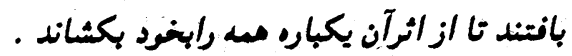

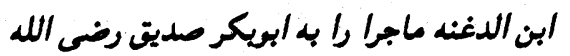

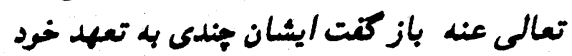

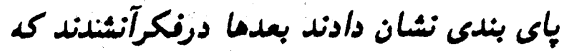

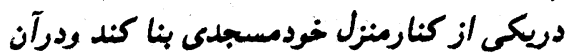

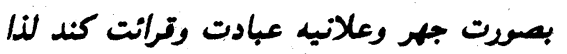

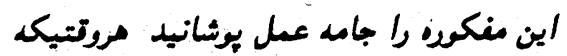

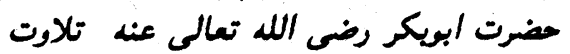

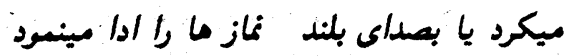

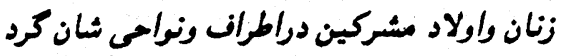

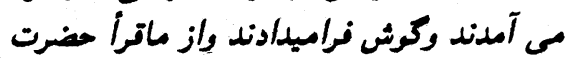

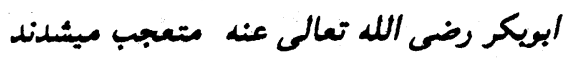

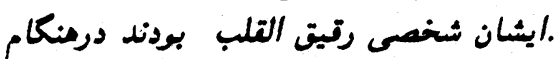

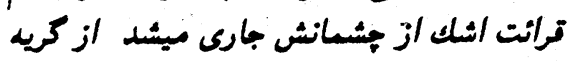

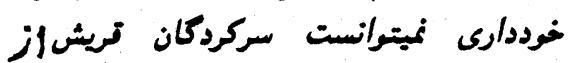

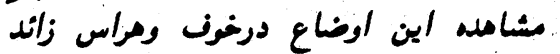

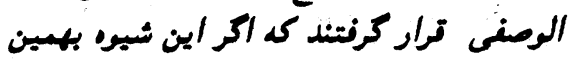

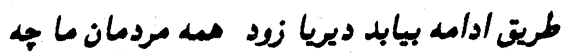

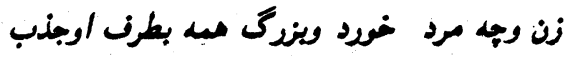

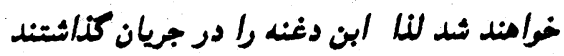

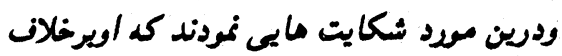

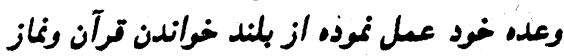

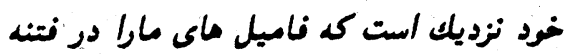

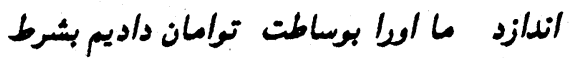

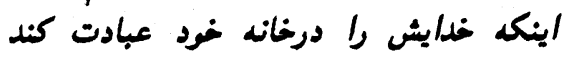

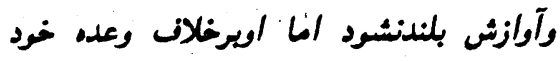

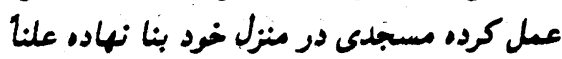

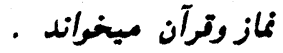

ام المؤمنين حضرت بع بع عايشه صديته

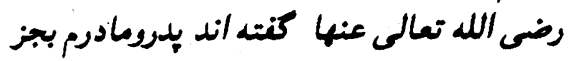

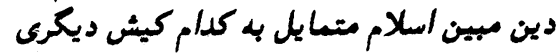
درآن رون كاريكه مسلسانان از دوست

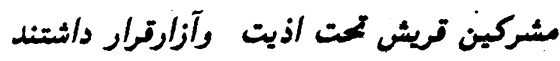

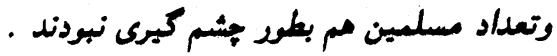

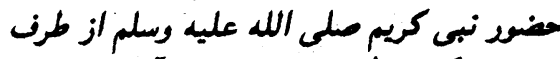

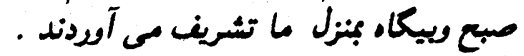

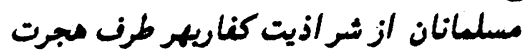

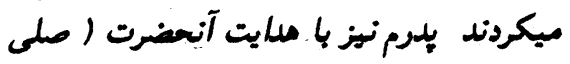

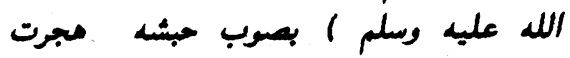

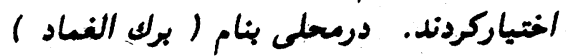

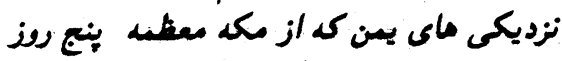

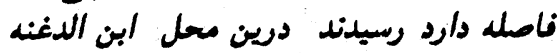

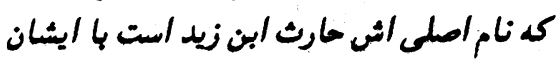

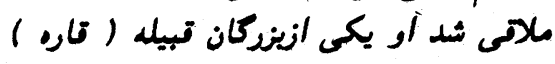

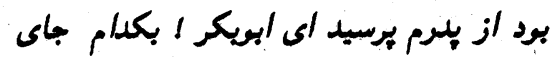

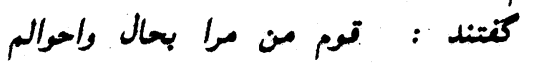

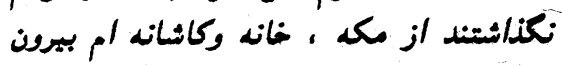

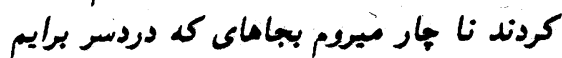

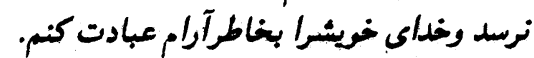

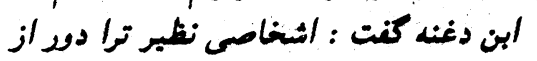

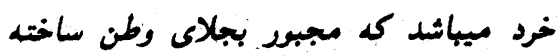
شود آنهس اوصافيكه تودارى جه كسمى مثلن

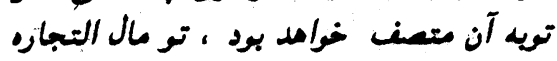

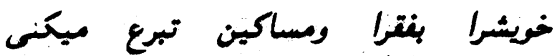
باوابستكان خوداز صله رحم كارميكيرى بحال

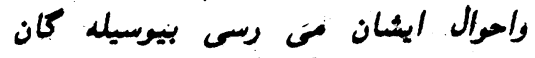

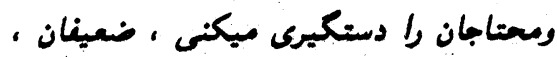

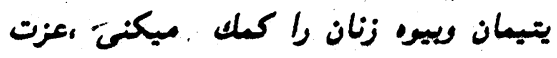

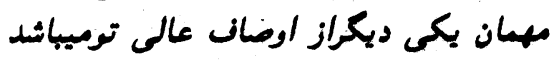

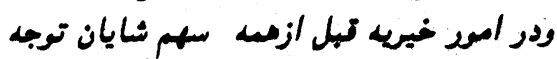
ميكيرى . مدر امرد تو انين عزم خردمنصرف شر من شنحا

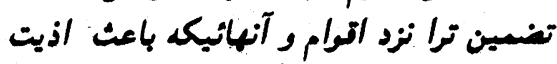

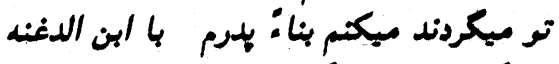

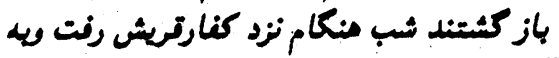
آنها كتث:

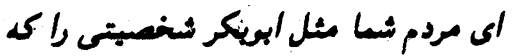

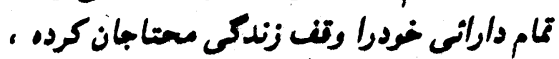

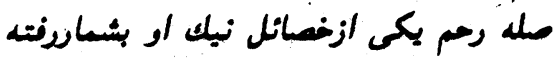
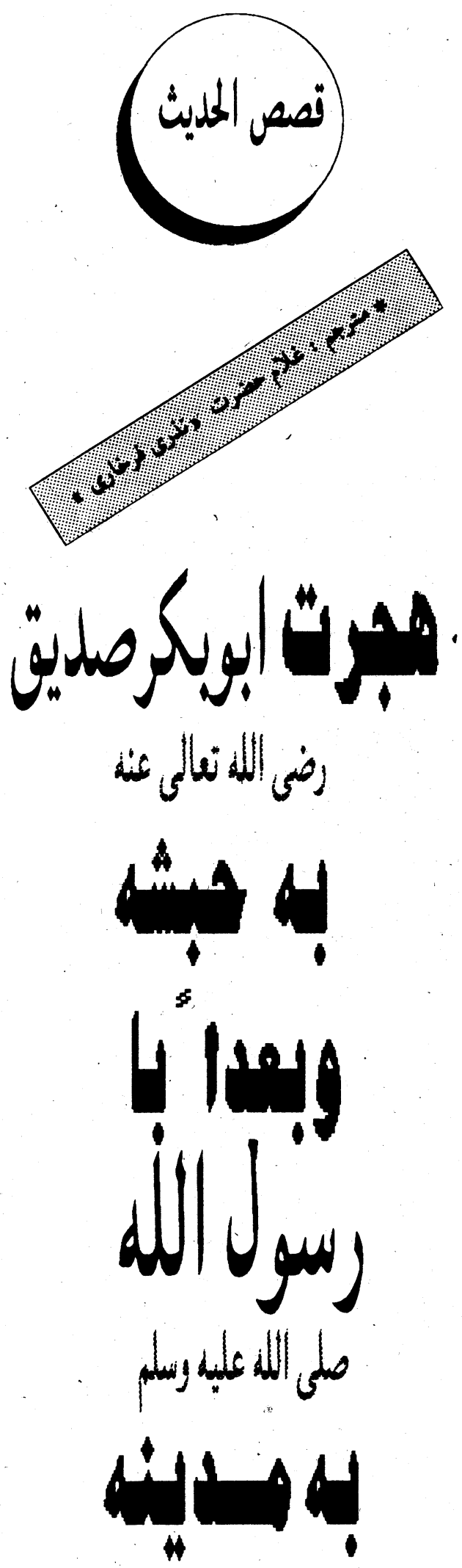

مبئزن مزن

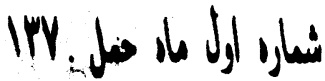


حضرت بع بع عائشه . رضى الله بعالى عنها

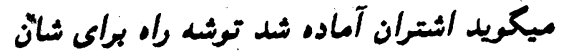

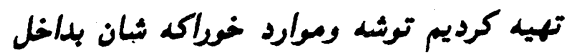

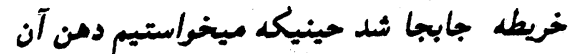

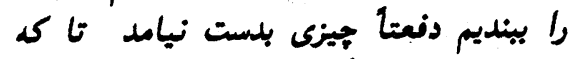

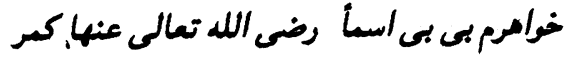

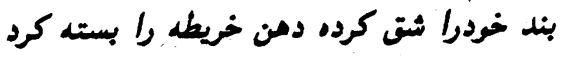

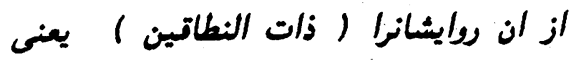

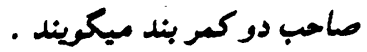

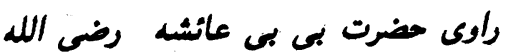

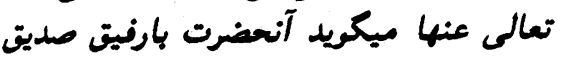

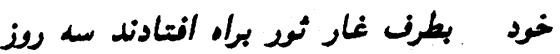

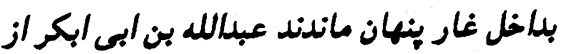

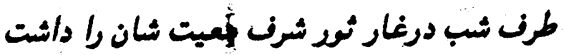

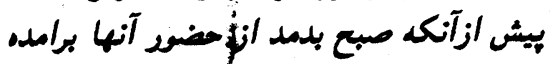

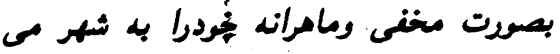

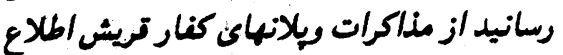

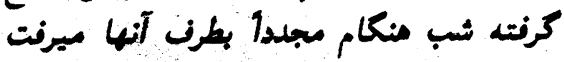

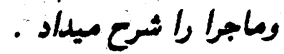
عامر بن مهيزه غلام آزاد كرده شهده حضرت ابريكر رضى الله تعالى عنه درتاريكهاى قبل فيل

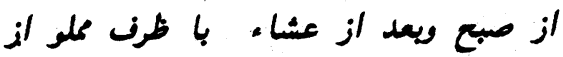

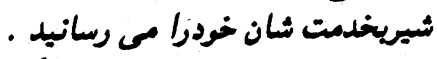

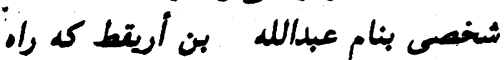

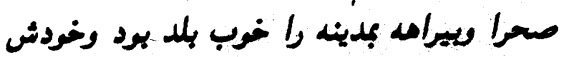

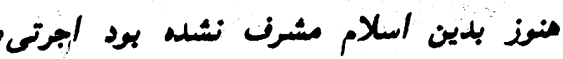
برايش تعبين كردند وتضسين اورا نمودندتا كه

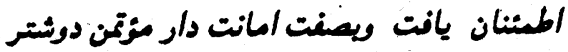

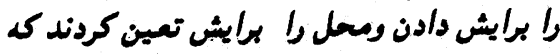

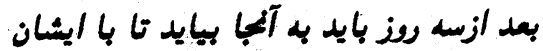
يكجا شرود ويراه بانتند . بايل

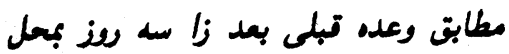

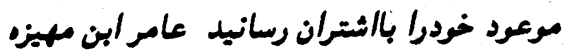

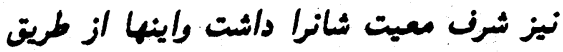

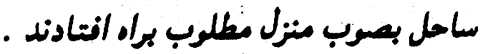

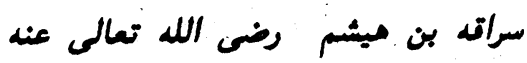

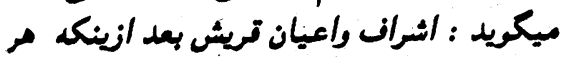
تدر جستجو وتنتيش وتلاثشى كردند تا تا اثرى

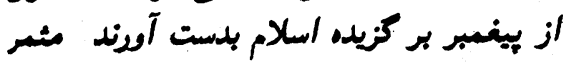

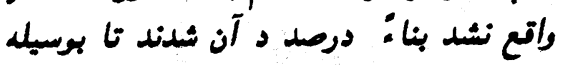

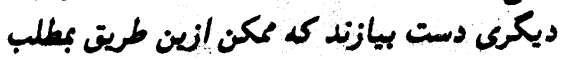

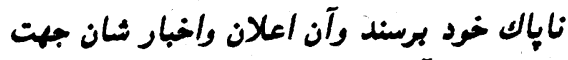
دستيابس آنجنانب درمقابل جايزه بس بران بردي

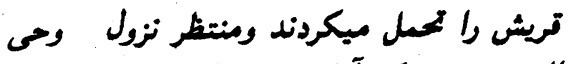

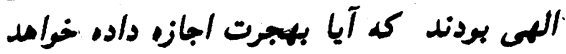

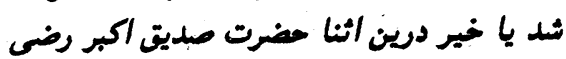

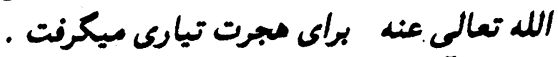
حضهد آنحضرت صلم الله عله عليه وسلم كنتيند

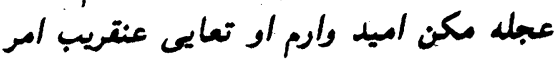

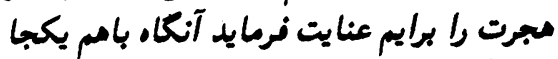

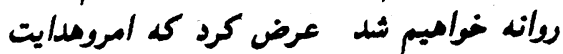

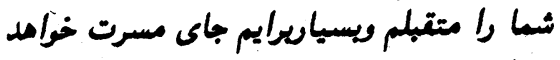

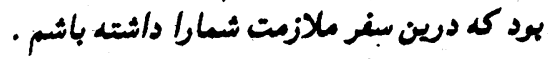
مضرت ابويكر صديت رضى الله تعالى عندي

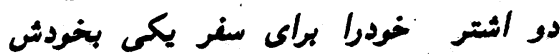

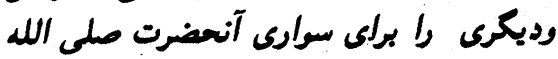

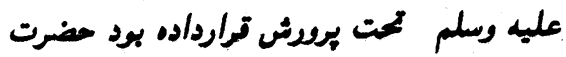

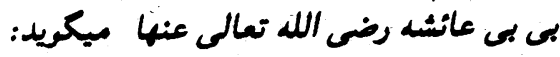

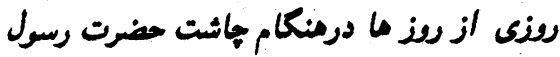

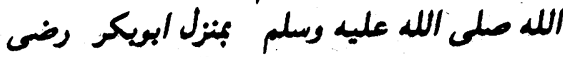

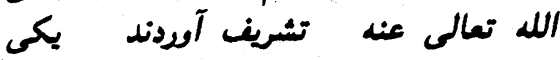

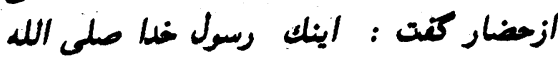

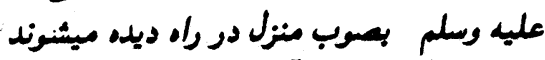

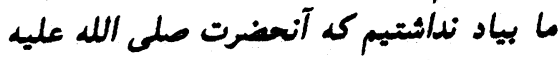

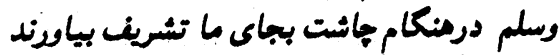

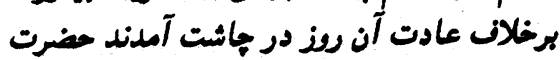

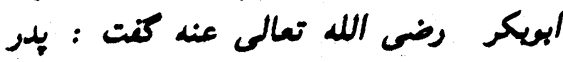

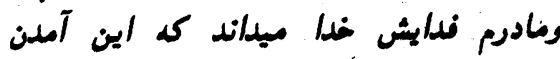

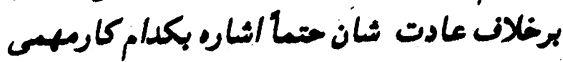
مياشد . معلاد

حين رسيدن بلد وازه اجازه ورود خواستنذ

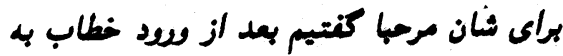

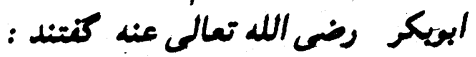

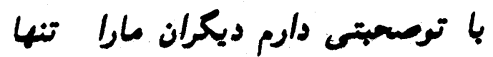

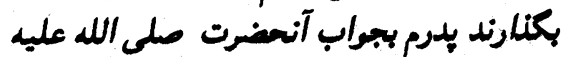

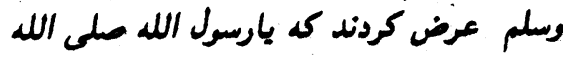

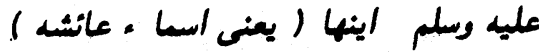

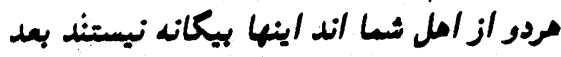

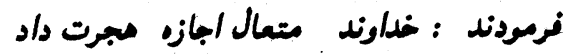

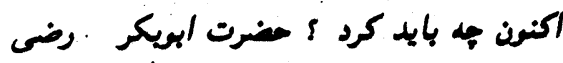

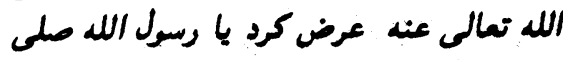
الله عليه وسلم اله تعاله

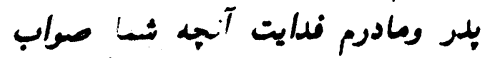

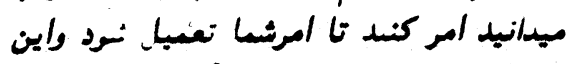
دو شتر براى سوارى ما وشسا آماده است ومريل تهريل

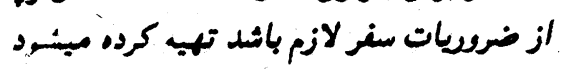

اين اعطال او ممكن سبب دكركونى اوضاع

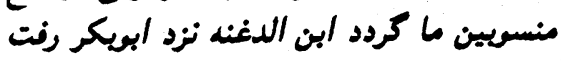

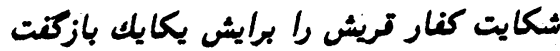

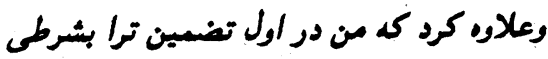

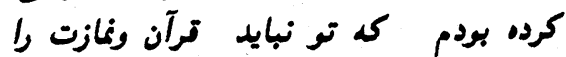

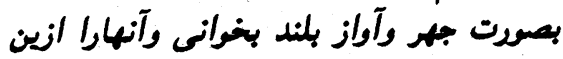

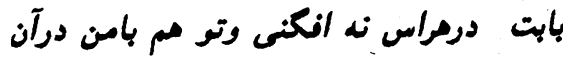

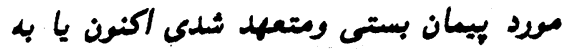

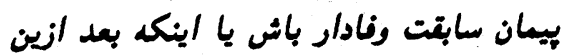

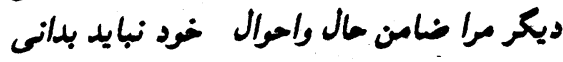

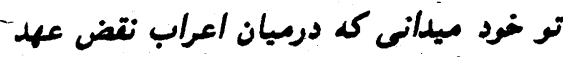

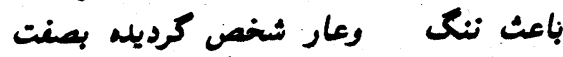

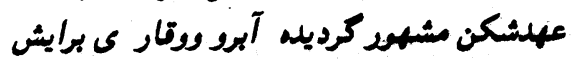
باقم نمياند . حضرت ابويكر رضى الله تعالم عند

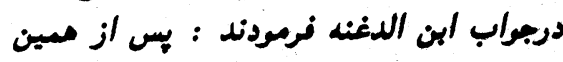

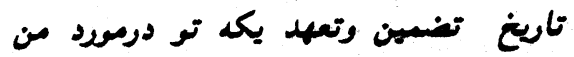

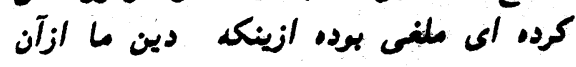

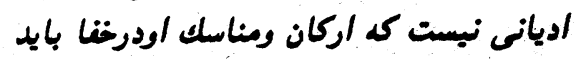

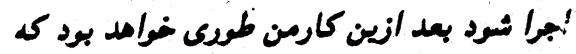

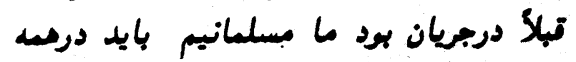

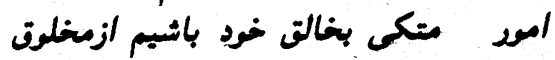

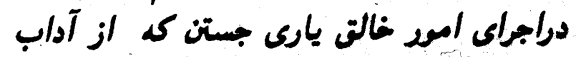

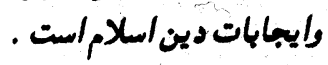

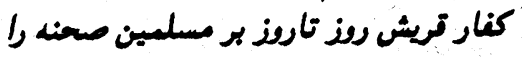

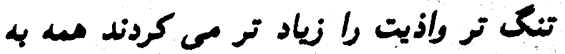

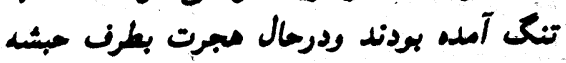
وملدينه ويله ميشيدند حضرت رسول اكرم صلى الله عليه وسلم

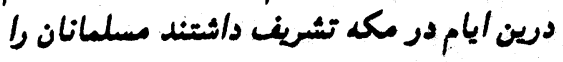

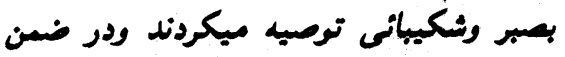

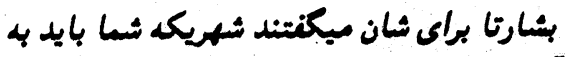

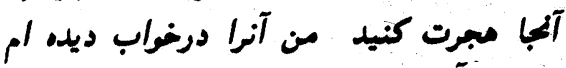

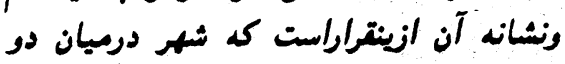

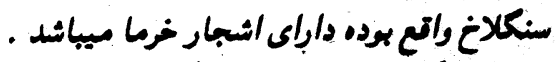
ورمنكاميكه حضرت رسول اكرم صلم الله

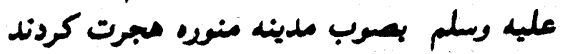

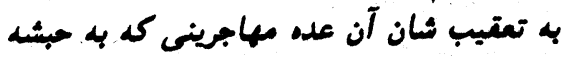

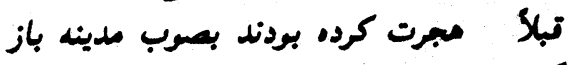

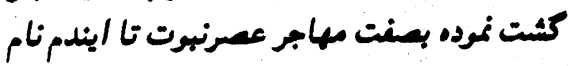

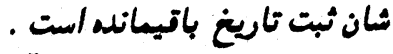

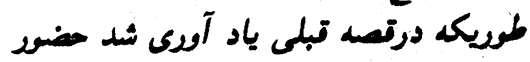

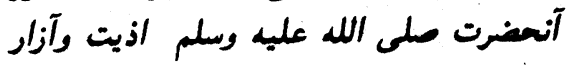


خود مشامده كرد فورا عرض كرد كه يا رسول الله

مرجه ميخواميد امركنيد من بخدمت الميلم

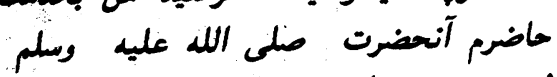

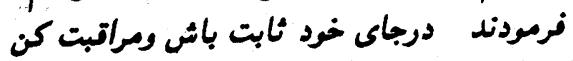
تا كسى بما ملحق نشود . فرودي

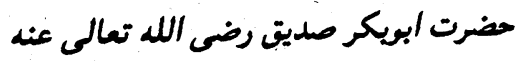

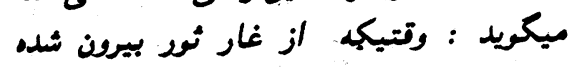

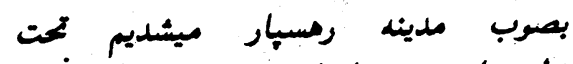

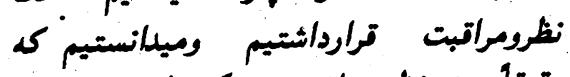

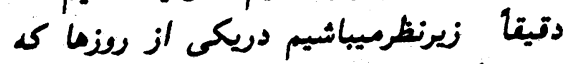

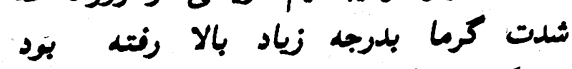
ومايكشب ويكروذ را سبرى كرده بوديم كرمان باد

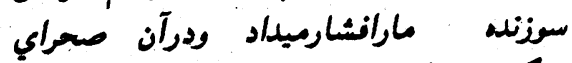
ريكستان طالب سايد شديم تا قدرى درآنيا

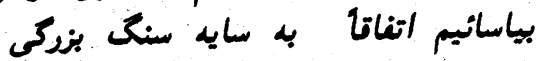

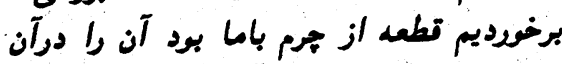

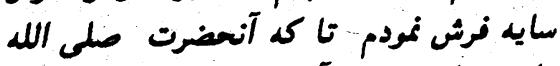

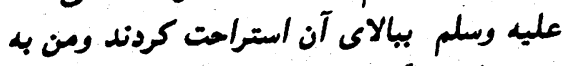

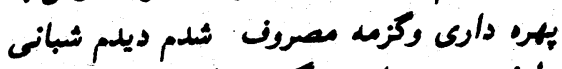

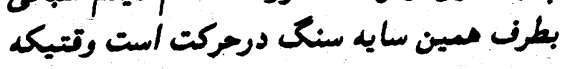

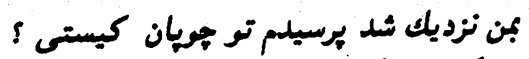

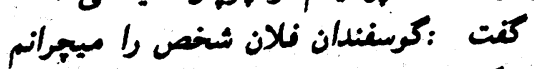

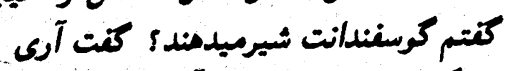

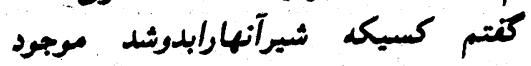

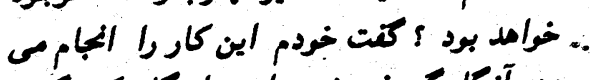

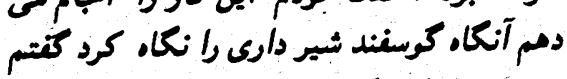

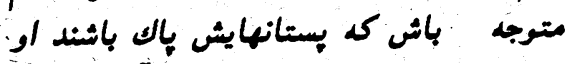

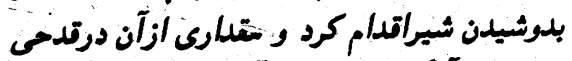

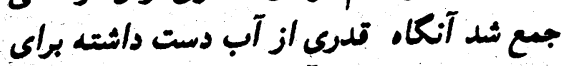

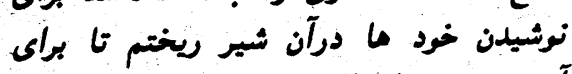

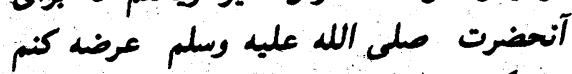

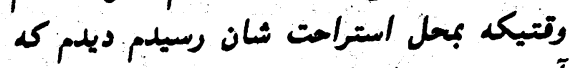

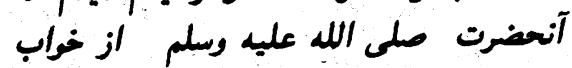
بيدار شده اند . . بهمت

عرض كردم كه يا رسول الله صلى الله عليه

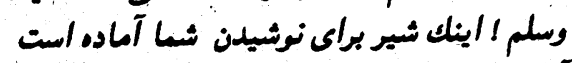

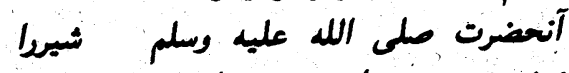

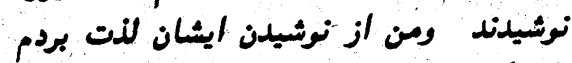

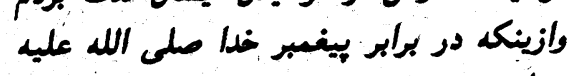

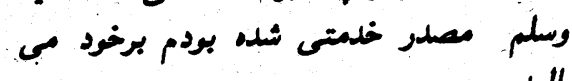
براه خود ييش ميرفتيم ناكاه زير رضى

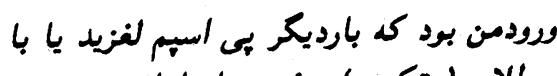

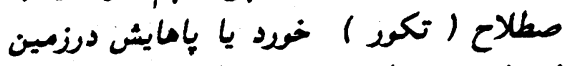

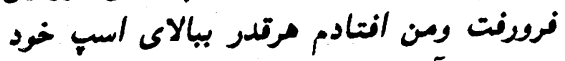

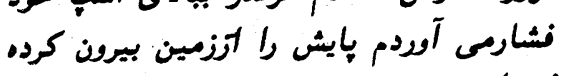

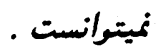

مبينكه نزديك به بيرون شدن بود ناكان

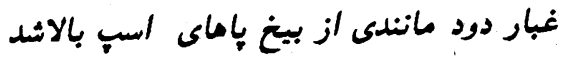

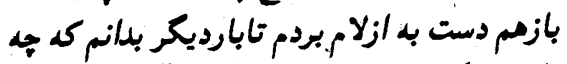

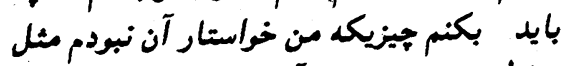

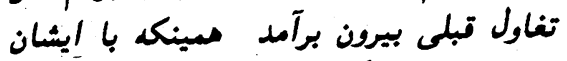

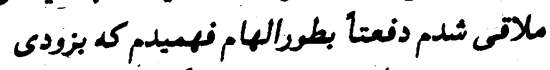

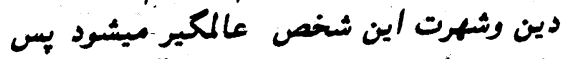

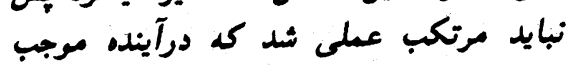

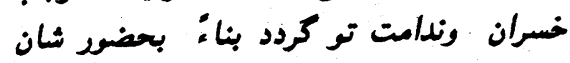

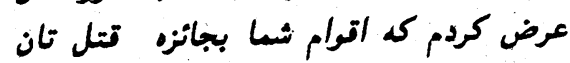

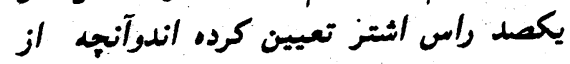

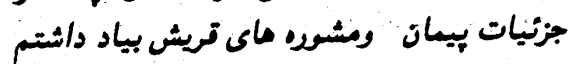

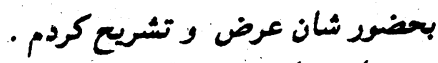

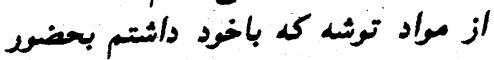

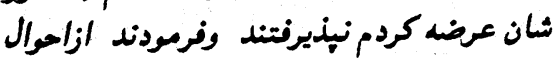

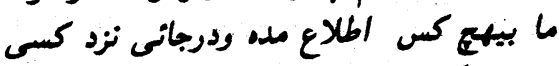

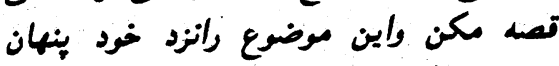

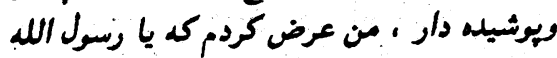

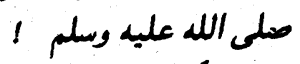
لطفا /مان نامه بمن مرحمت نماتيد آنحضرت الميل

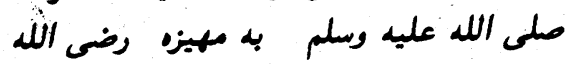
تعالى عنه امركردند كه نامه برايش بند بهديس

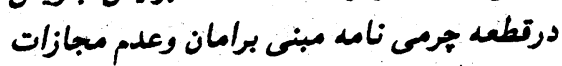

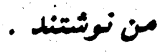

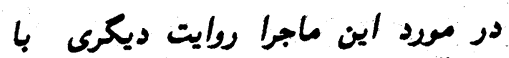

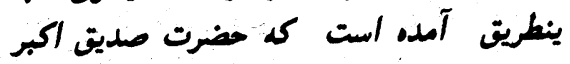

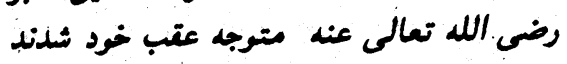

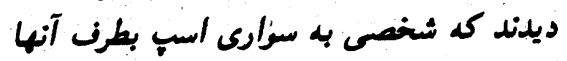

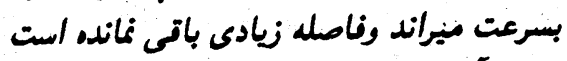

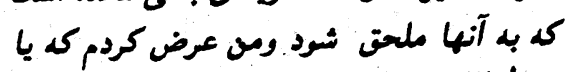

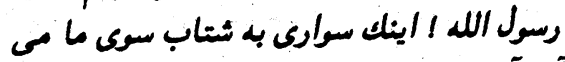

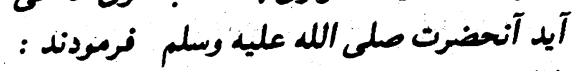

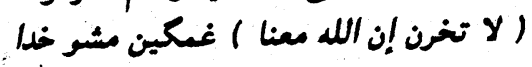
حضرت رسول اكرم طلف الله علين وسلم

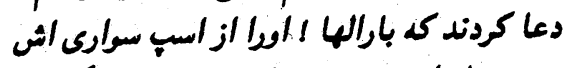

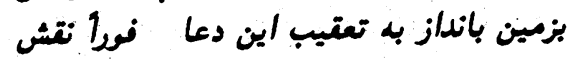
برزمين شد جون اين حادثه راغيرمترقبه بحال تعال
بود به اين معنى كد كتته بودند مركسيكد

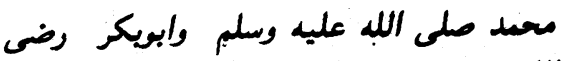

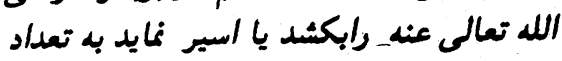

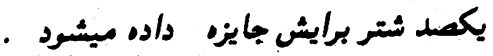

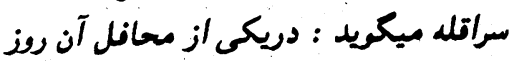

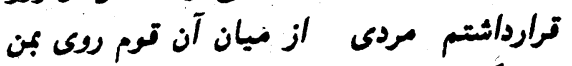

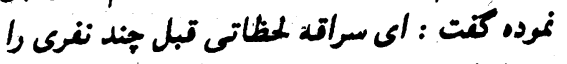

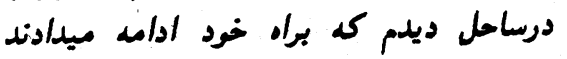

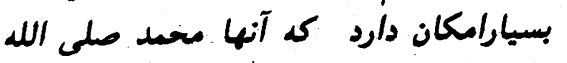

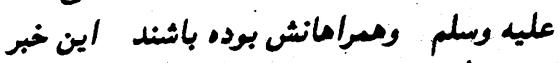

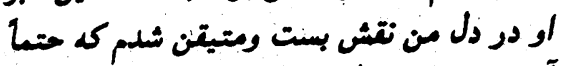

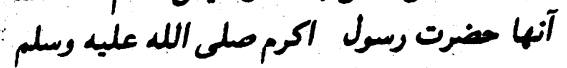

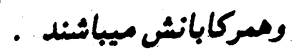

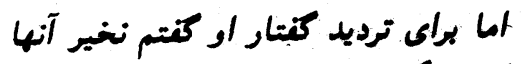

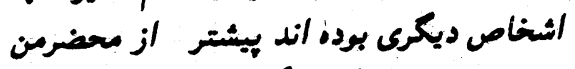

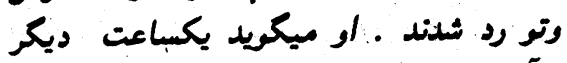

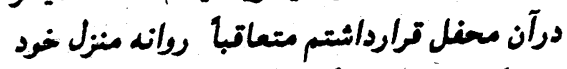

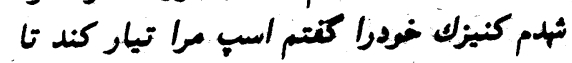

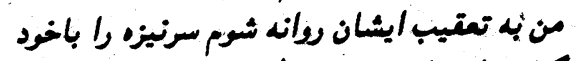

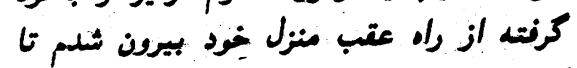

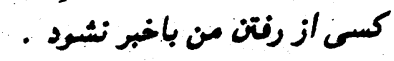

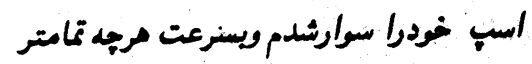

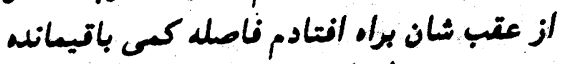

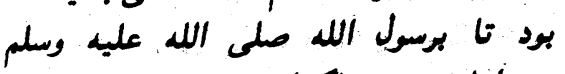

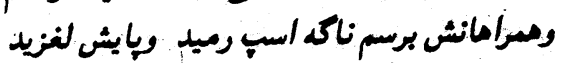

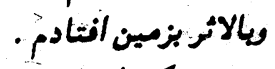

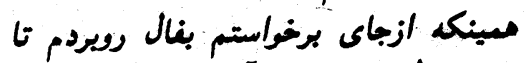

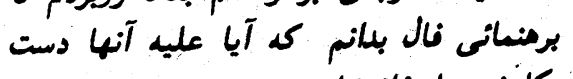
بكارشوميا بناد شان بان

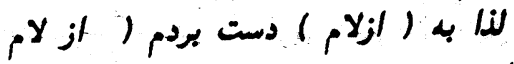

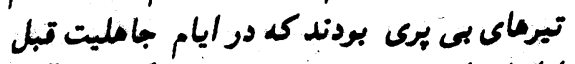

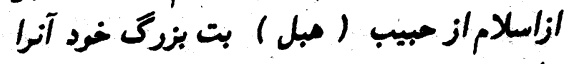

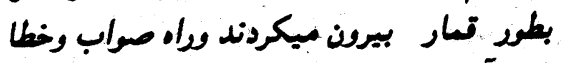

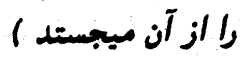
وريت نيرما / أمرنى ديف ) ) و ( ) نهانى

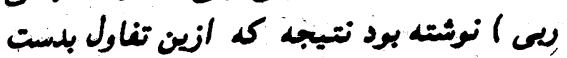

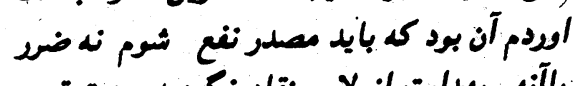

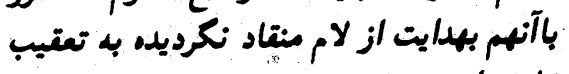

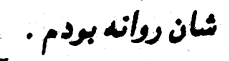
صلاى ترايت آنحضرت على الله عليد

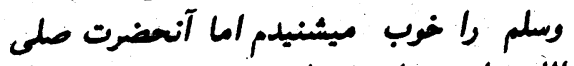

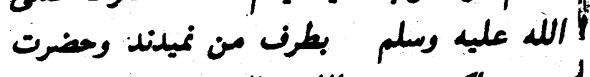

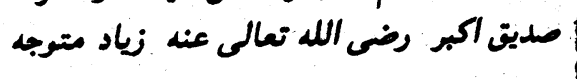


خ آنحضرت ايراد ميكرد وخودآنحضرت صلى الله

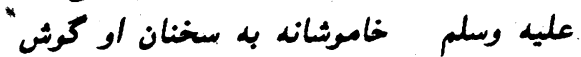

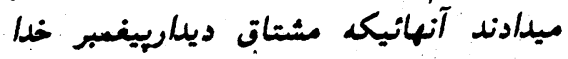

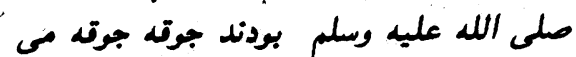

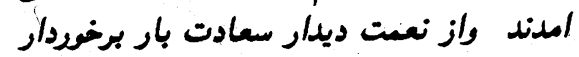

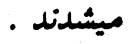

آنتاب رسيله بود ويبالاى آنحضرت

صلى الله عليه وسلم ميتابيد ابويكر رضم وبله

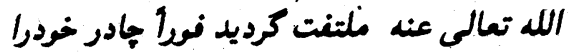

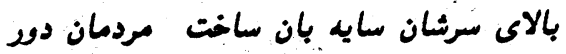

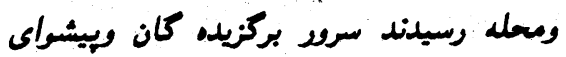

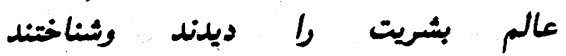

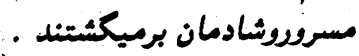

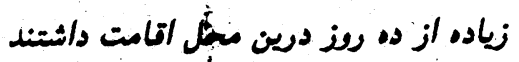

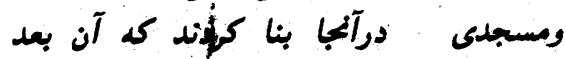

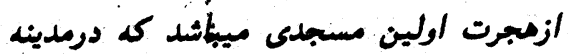

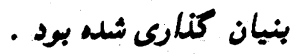
سهيلم رحة الله عليد كنته است كد آن

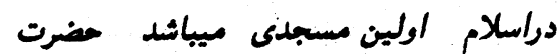

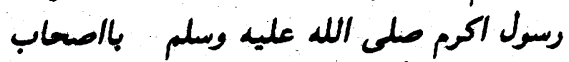

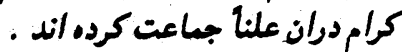

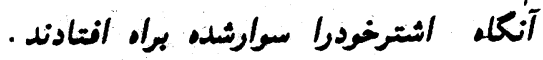

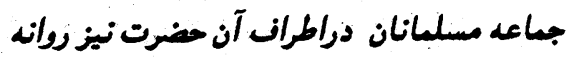

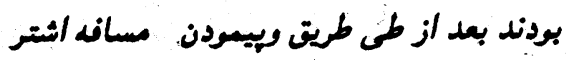

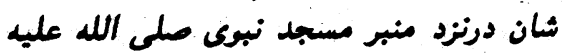

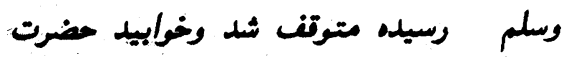

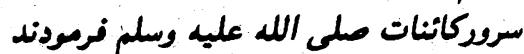

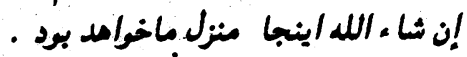

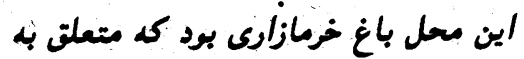

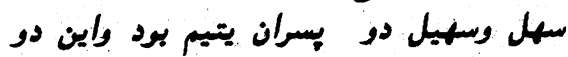

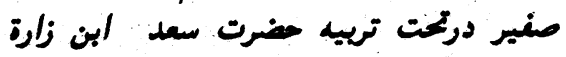

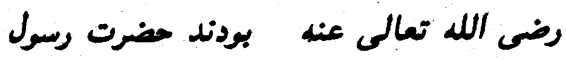

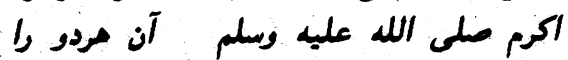

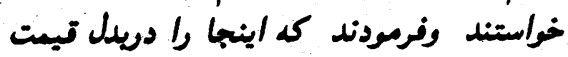

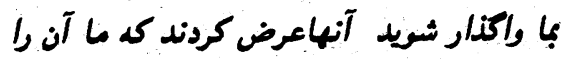

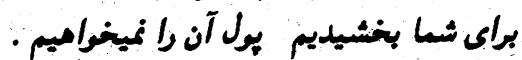
حضرت رمسل اكرم صلى الله عليه وسلم

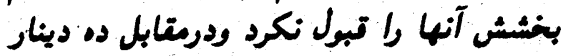

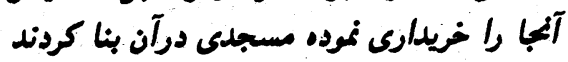

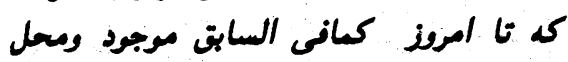

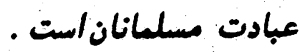

( بلد اول بنارى شريف )

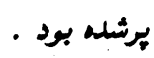
مدينكه موكب آن شهسوار يكتاى دوران

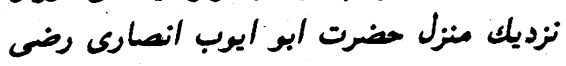

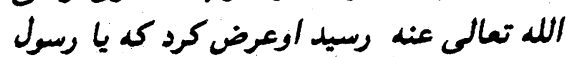

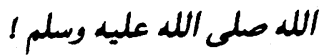
اين دورازه حويلى من است جه مئه ميثرد كه

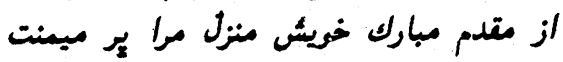
ومسعود سازيد . معدم مارك حضرت رسول اكرم صلى الله عليه وسلم

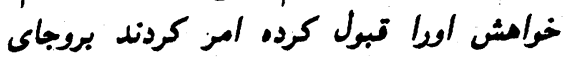

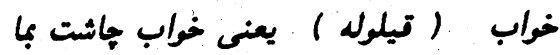

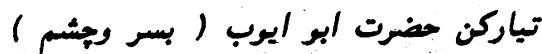
كتته وارد منزل خود كرديد ايدرب وميكنت تشريف وهيف

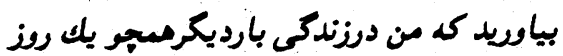

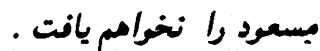
در روايت ديكرآمده است كه مسلمانان

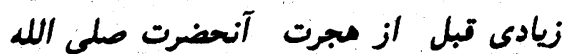

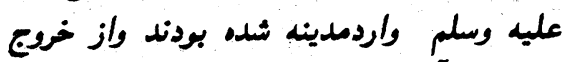
وعزيست آنحضرت صلى الله عليه وسلم ورديل

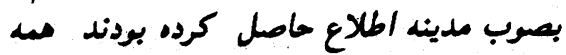

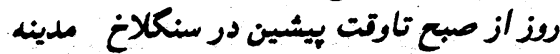

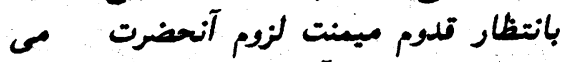

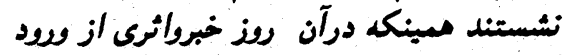

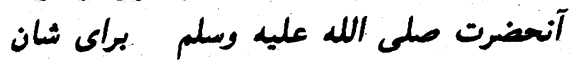

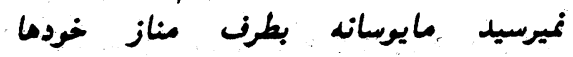
برميكشتند . بمريد

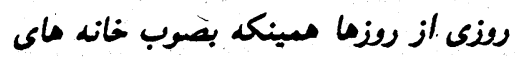
خود بركشند يكى از يهوديان مقيم مدينه بنا مينا

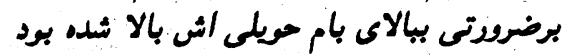

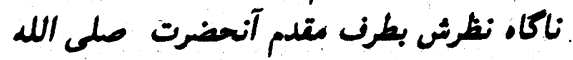

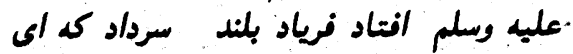

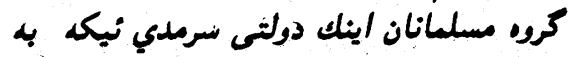
انتطلار آن بوديد با لباس مانى سفيد بطرف شرمان

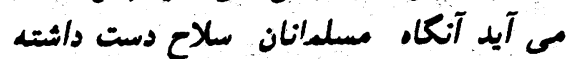

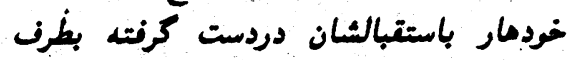

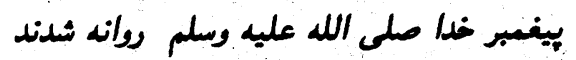

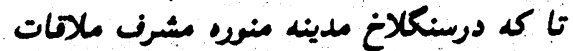

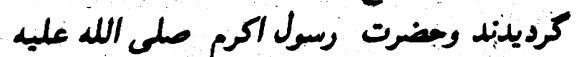

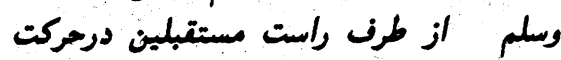

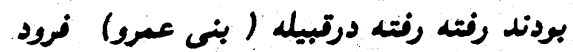

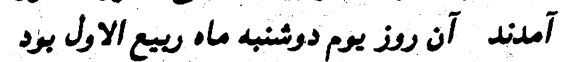
حضرت ابويكر صديت رضم الله تعالى عند

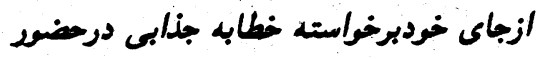

الله تعالى عنه با عده ازٍ تاجران مسلسانان كه

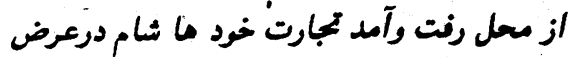

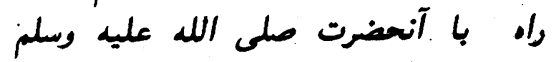

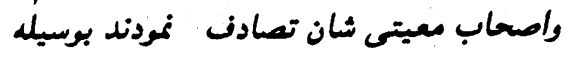

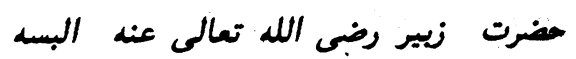
سغيد براى حضرت رسول اكرم صلى الله عليه وسلم وابويكر صديق رضم اللن تعالى عنه يوشانيده شد . يوانير

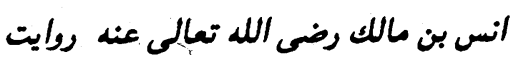

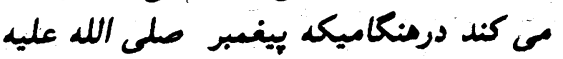

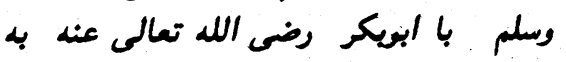

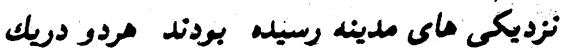

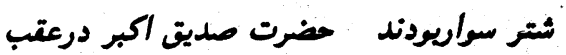

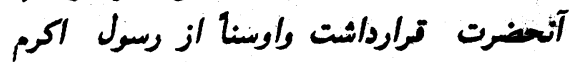

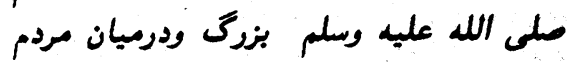

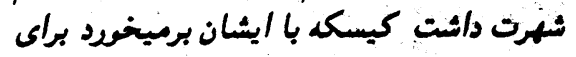

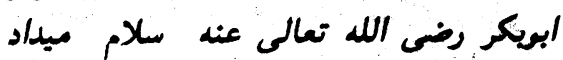

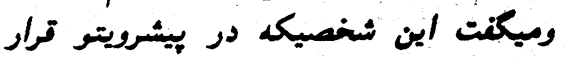
دارد جه كسم است إن درجواب مسجو اشخاص ميكنت :اين

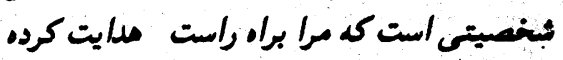
وطريت فنغ وفلاح دو جهانى را برايم نشان داده

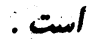
هذرت رسول اكرم صلى ألله عليه وسلم

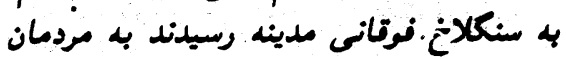

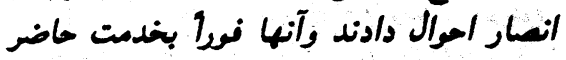

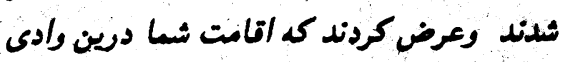

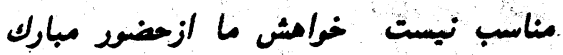

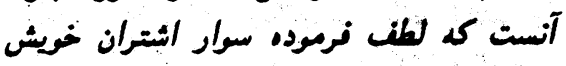

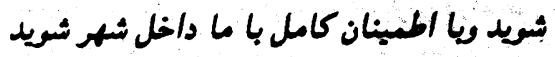
خرات رسمول اكرم صلى الله عليه وسلم

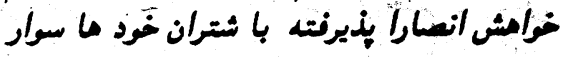

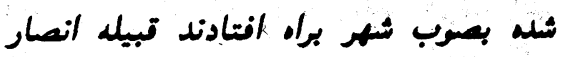
ورواليكه مبهز با سلاح خود ما بودند واطراف

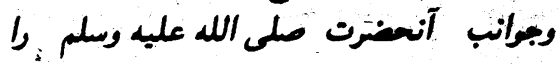
الهاط نموده بـ عزار واكرام فوق العاده ، روأنه

شهر شدند . شمرد

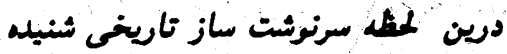

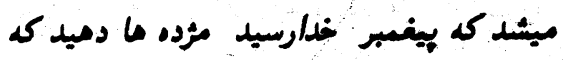

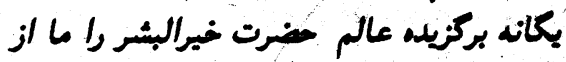

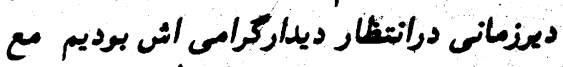

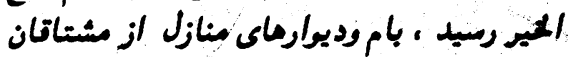
ديلارير انوار آنحضرت صلم الله عليه وسلم 
الشرايط نسبت به آن ديكر مى دانستند .

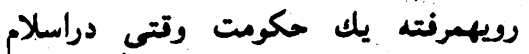

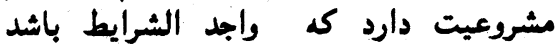

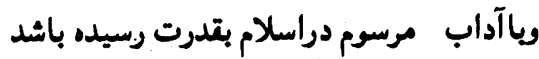

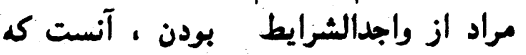
كانديداى زعامت مسلمين داراى اوصاف إنداف معين

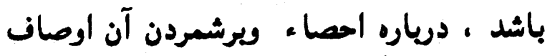

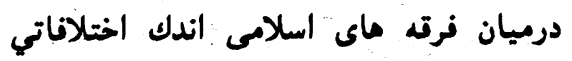

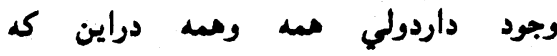

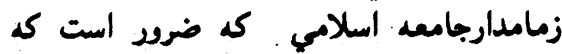

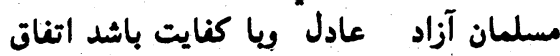
نظروجود دارد .

طريق به تدرت رسيدن مشروع درابلام

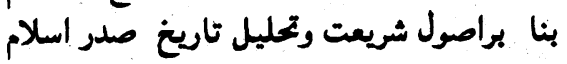

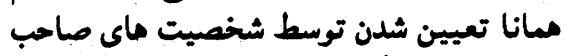

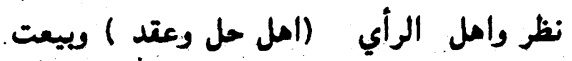

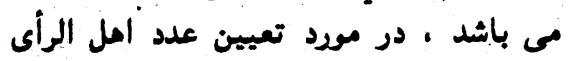

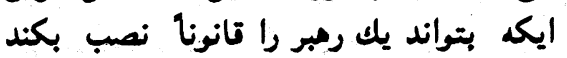
اختلاف نظر وجود دارد .

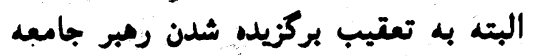

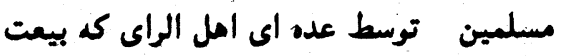

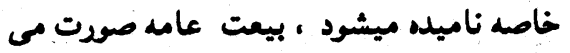

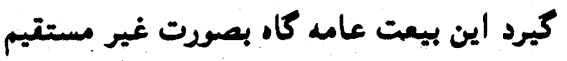
باواليان حكومت مركزى به اسم زئيس

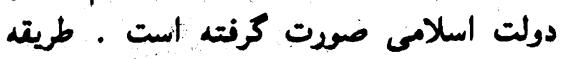

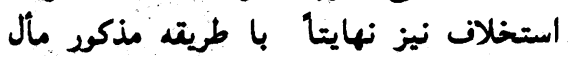

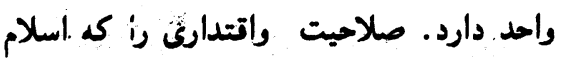

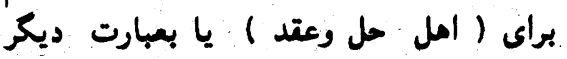

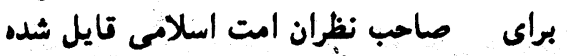

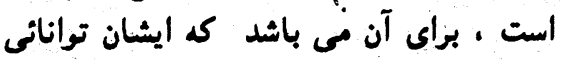
تشخيص فرد مستحق زعامت را دارا مى باند باشند . تئن

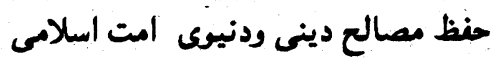

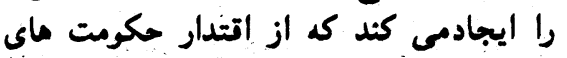

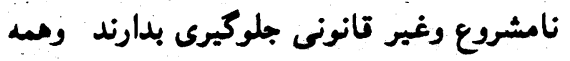

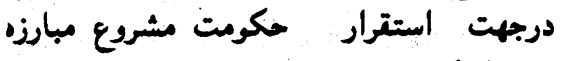
وجهاد بكنند . وروت

درين شكى نيست كه درعهد صدر اسلام

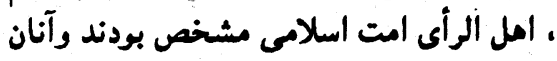

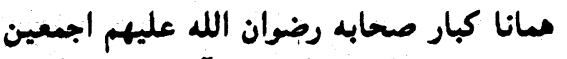

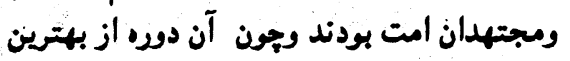

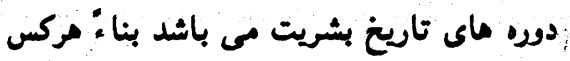

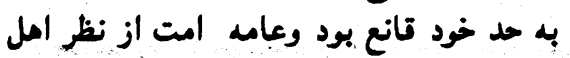
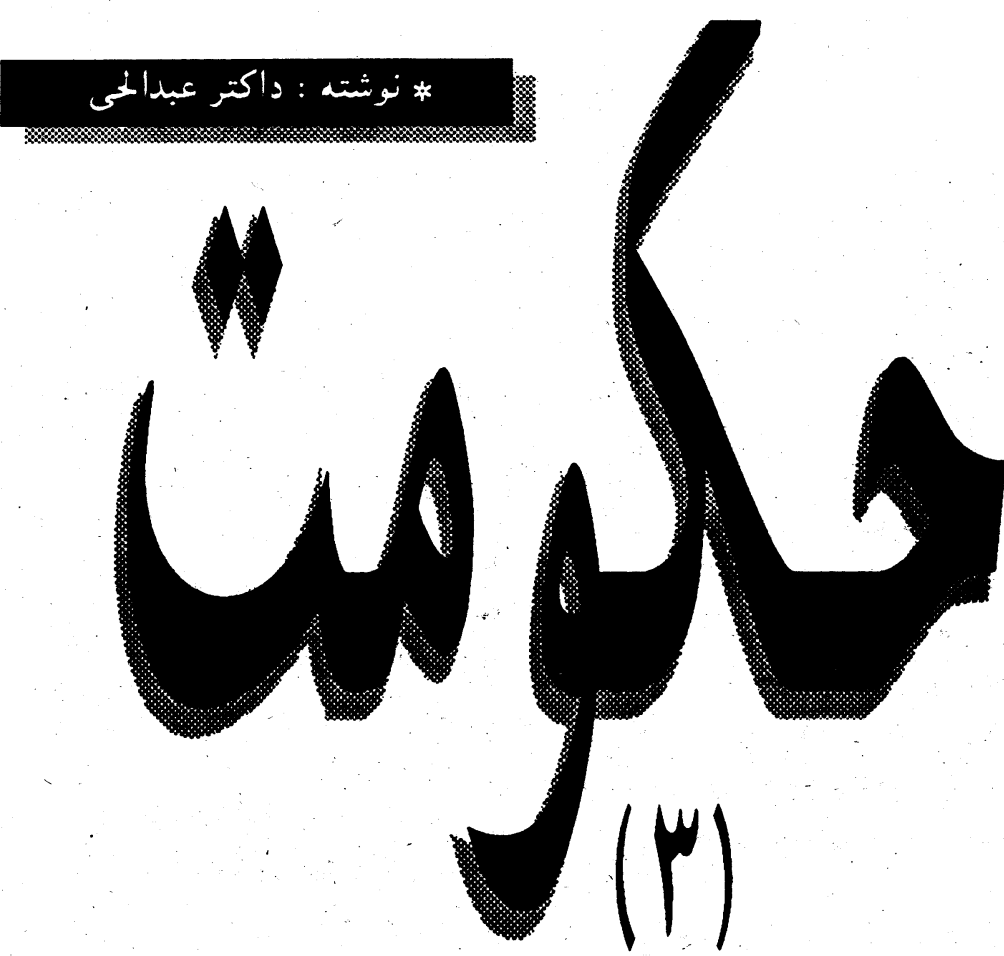

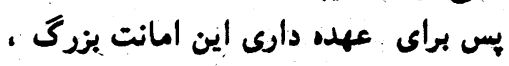

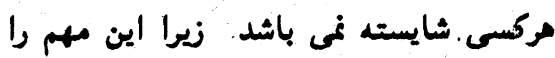

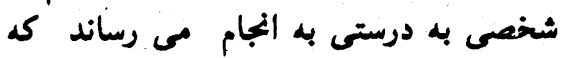

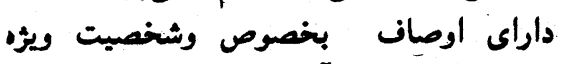

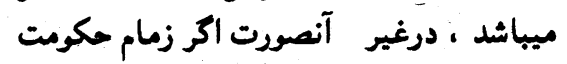

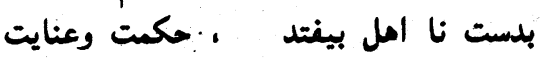

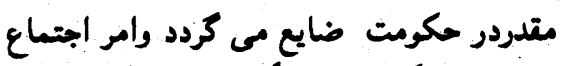

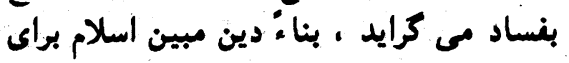

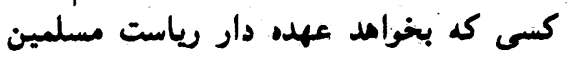

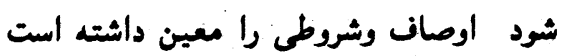

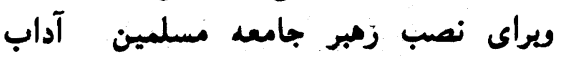
وطيقه اي دستور فرموده است ،عنايت شريعت واديت

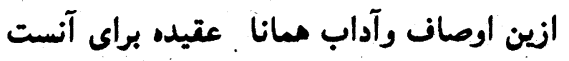

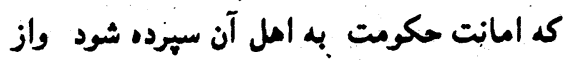

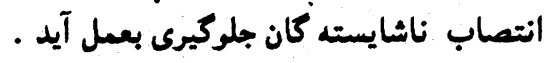
رعايت اوصاف لازم درشخصيت رئيس بانيس

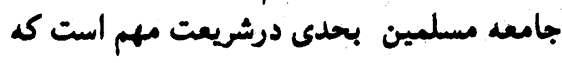

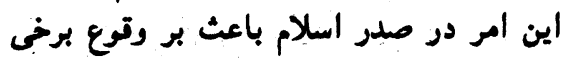

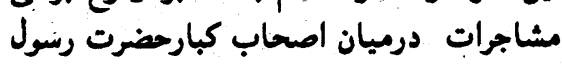

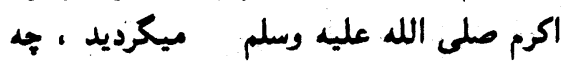
مريك از طرفين منازعه خودرا بيشتر واجيد وليد وليد

\section{\%.\%.}

مراد از مشروعيت ، تانونى بودن ميباشد ، مكرون

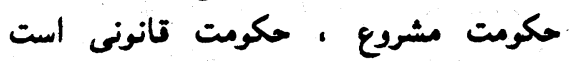
وبرخلاف ،هكومت نامشروع غير تانونى مى مى مانى باشد . باش مشروعيت ، يكى از موضوعات مهم علم

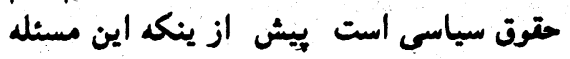

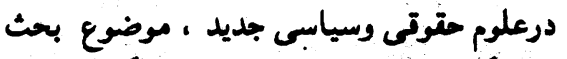

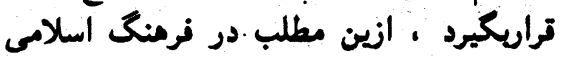

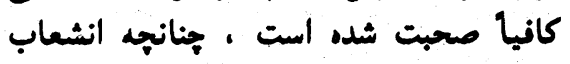

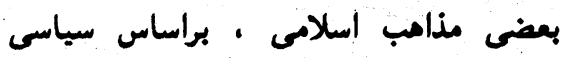

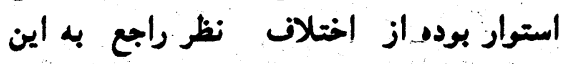

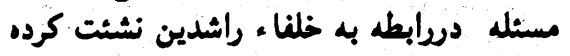
است.

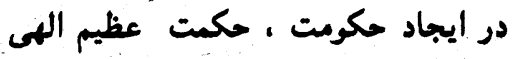

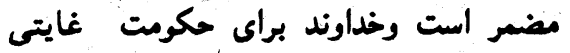

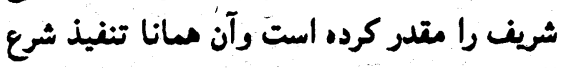

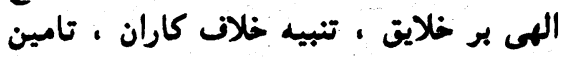

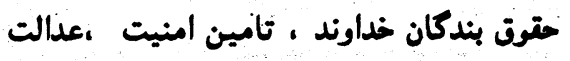


جانبه شده است ،مانا بى بهركى از كارتشكيلات ومنر سازباندمى درجه مطلوب حقا كه مهارت سازماندمى جز عمده منر

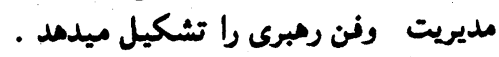

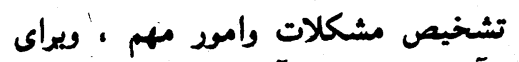

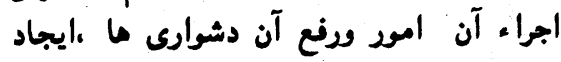

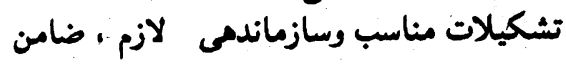

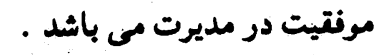

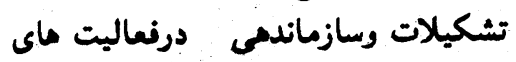

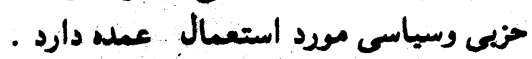
كاه يُهيده كى يك سازمان ادارى سياسى

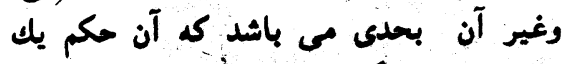

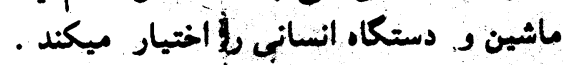

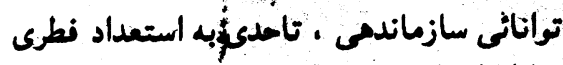

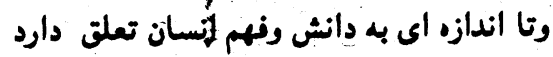

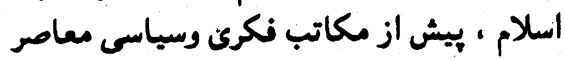

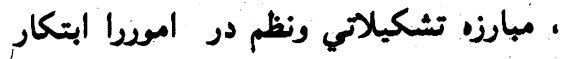

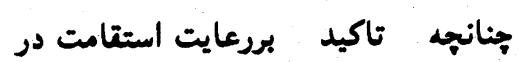

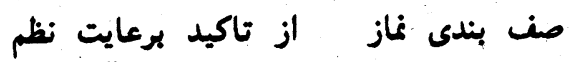

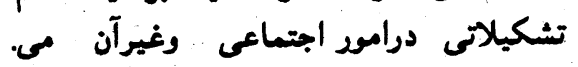
باشد .

حضرت رسول اكرم صلى الله عليه وسلم

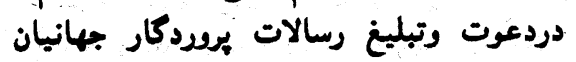

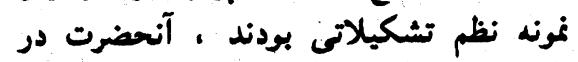

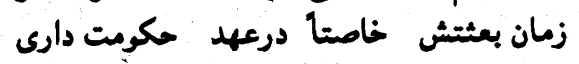

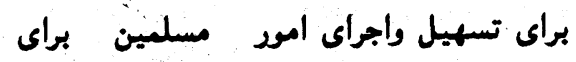

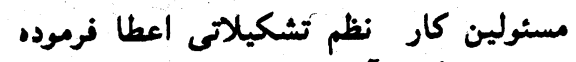

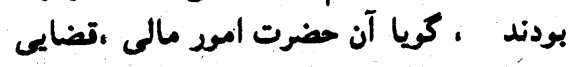

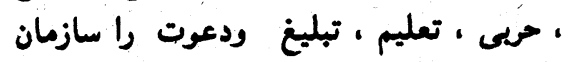
داده بودند . با كذشت زمان كه تلمرواسلامى وسيعتر

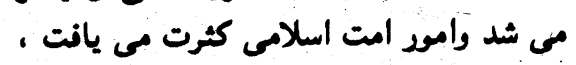

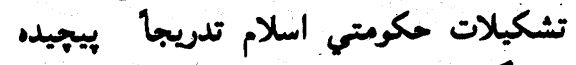

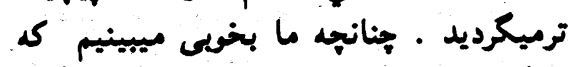

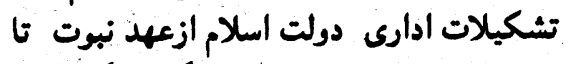

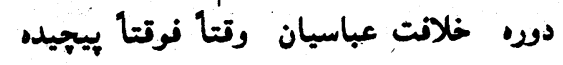

ترشده است .

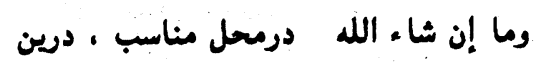

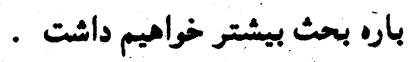

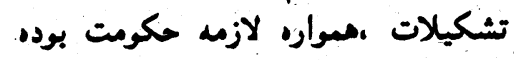
است ، در تديم عكومت ما ا 1 ز تشكيلات
* با كذبشت زماز كه تلمرواسلامى وسبتر مى شُل وامور امت اسلامى كثرت مى بانت ، تشكبلات حكومني اسلام

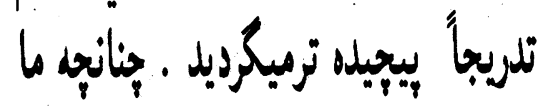
بخوبى ميبينبم كم تشكبلات الوارى دورلت اسلام ازعهل نبوت تا دوره خلافت

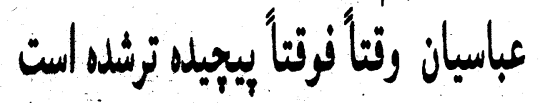

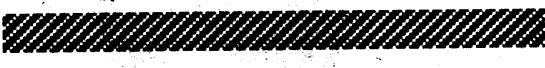
تشكيل بمعناى شكل دادن وسازماندمى است . تئريل تشكيل را ميتوان اينطور تعريف كرد :

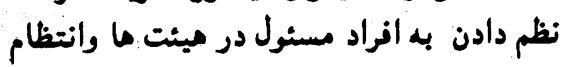

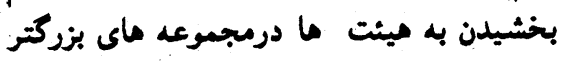

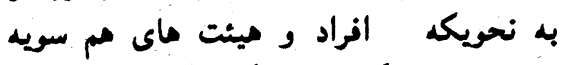

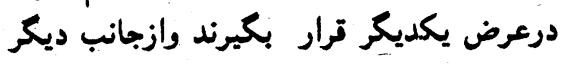

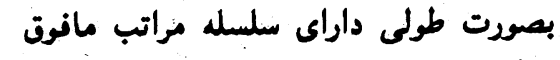

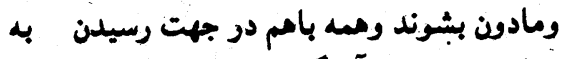

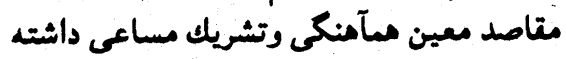
باشند . ماصد معر

در زمان ماضر كد زندكى اجتماعى انسان

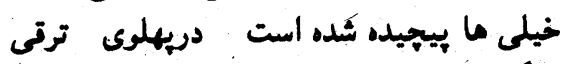

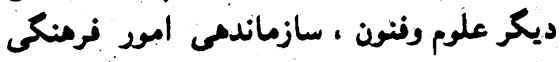

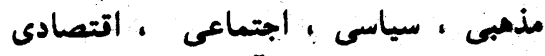
ومنرى بشكل متكامل · آن رواج يانته است .

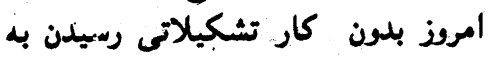

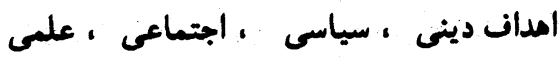

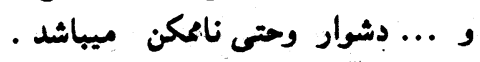

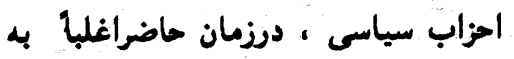

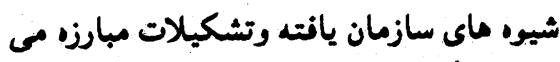

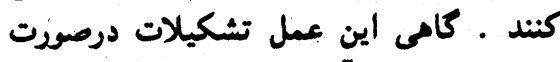

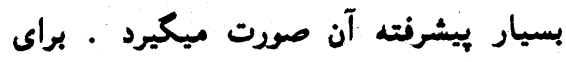

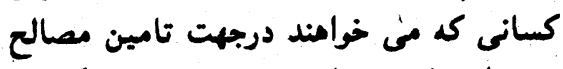

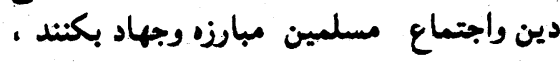

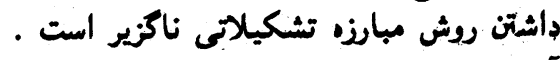

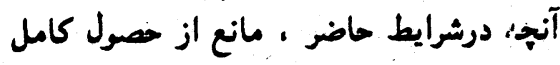

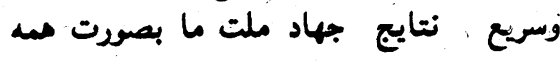

الراى خويش سر بيجى نمى كردند ،ازينرو

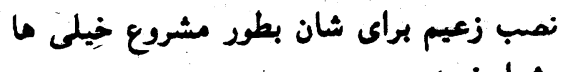
دشوار نبود .

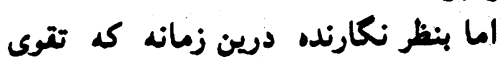

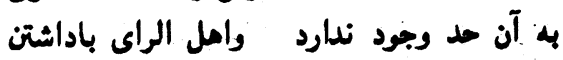

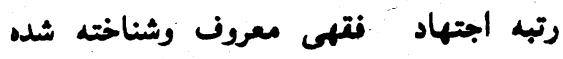

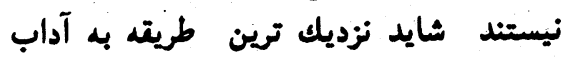

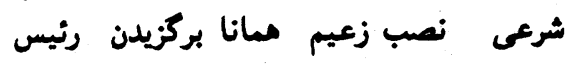

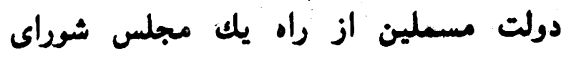

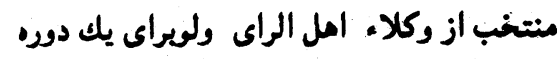

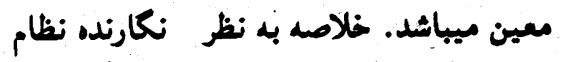

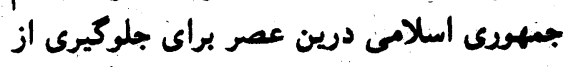

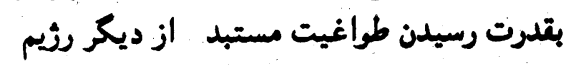
ما براى حفظ مصالح دين ودنياى مسلمانان

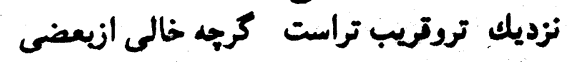
نقايص واشكالات نيست.

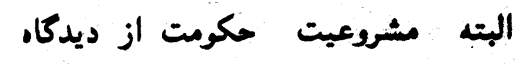

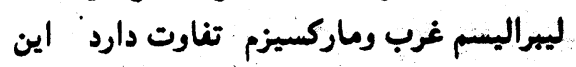

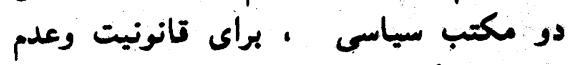
قانونيت حكومت معيارماى دارند مان ماندي

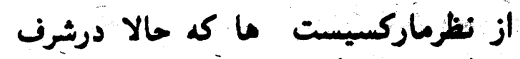

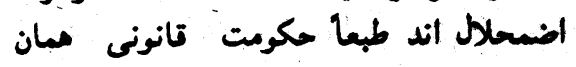

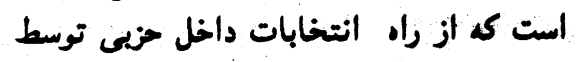

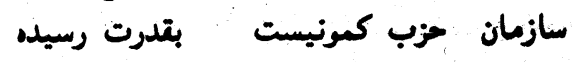
باشد زيرا ايشان حزب خودرا مان مايثده تمام عيار.

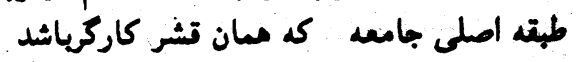

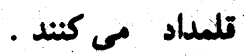

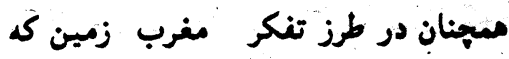

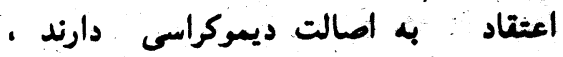

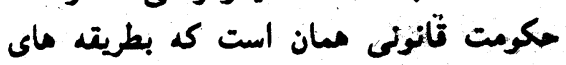

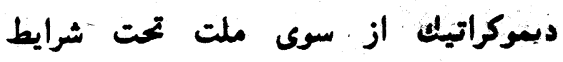

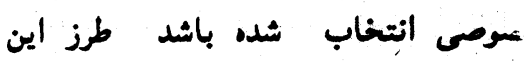

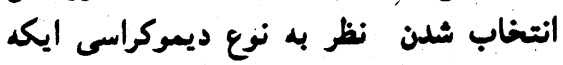

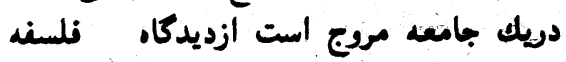

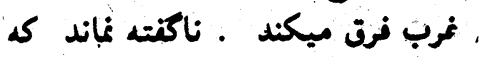

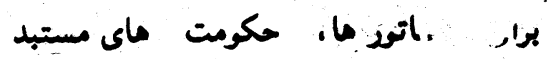

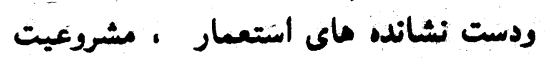

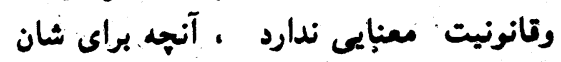

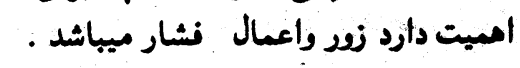

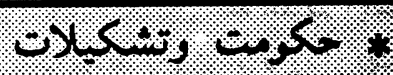




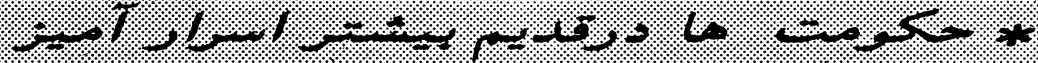
.

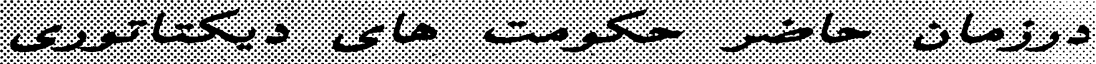

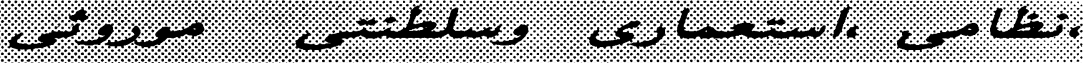
1.7.1.

حكومت باسياست رابطه محكم دارد • زيرا

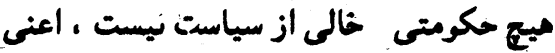

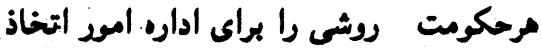

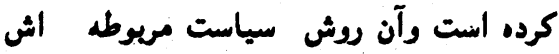

شده ميتراند كد يك مكومت فاقدي

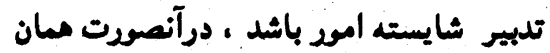

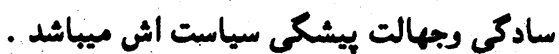

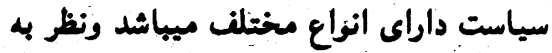

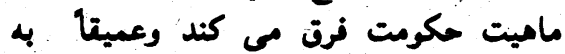

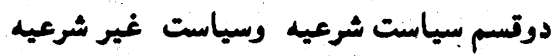
سياست شرعيه مان ، تدبيرامود برونق

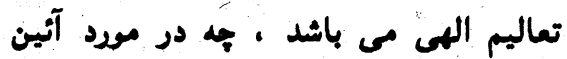

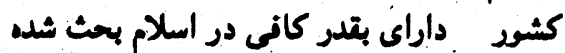

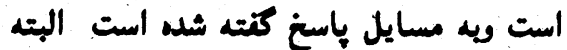

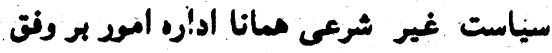

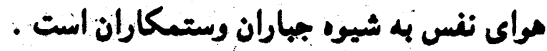

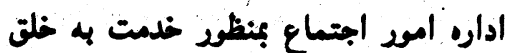

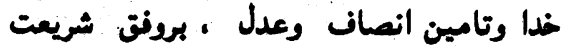

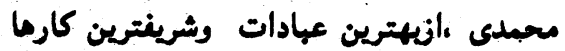

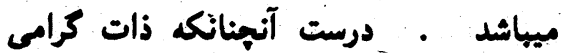

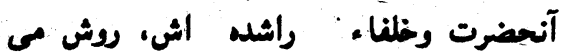

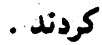
البت بيروى . از سياست ديكتاتوران

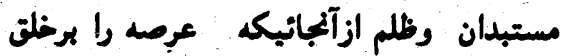

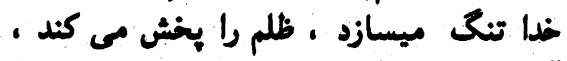

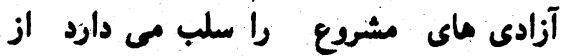

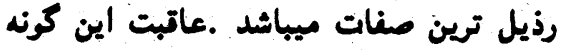
سياسث سنوط ورسوانى دردنيا وعذاب شئديد

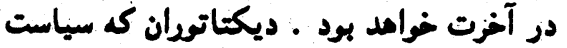

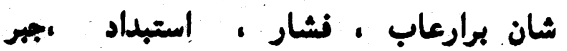

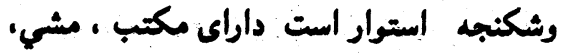

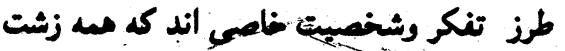

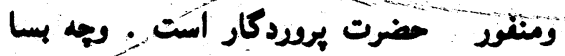

حالا هيثرفت ما ى تكنولوزى خاصتا اختراع

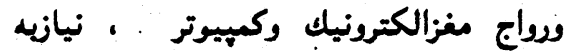
نغرات ويرسونل را تقليل بخشيده است .

سياست داراى منعانى منتلف ميباشد • سياست اصلك دردومعنى استعمال ميشود مغتئ

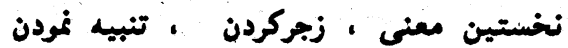

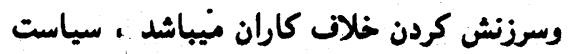

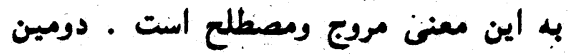

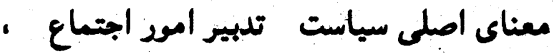

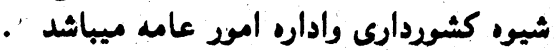

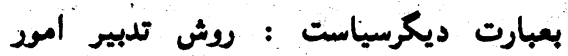

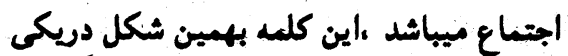

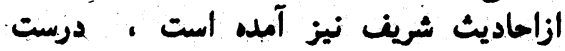
آنجاكه مى فرمايد : إن بنى إسرانيل كان تسوسهم الا بنياء او او كاقال رسول الله صله الله عليه وسلم .

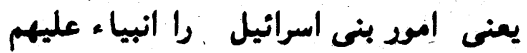

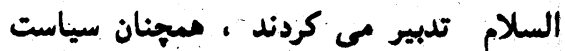

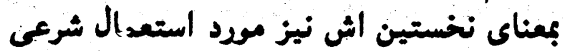
دارد .

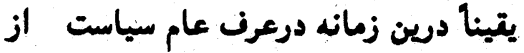

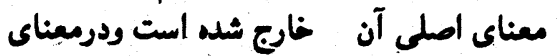

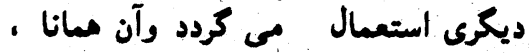

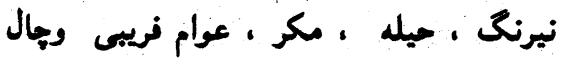

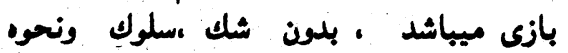

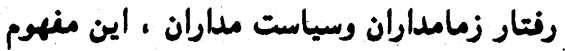

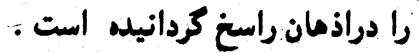

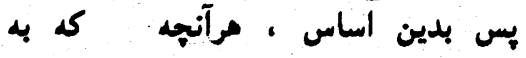

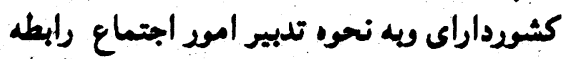
بكيرد ،سياسى كنته ميشود ، اعنى منسوب بله سياست
بسبط وساده اى برخودار بوده اند ؛ اما درزمان

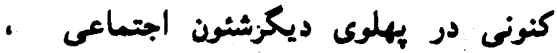

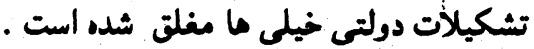

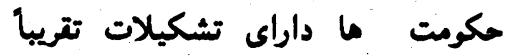

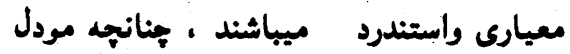

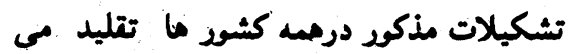

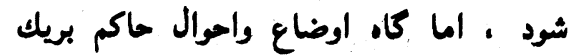

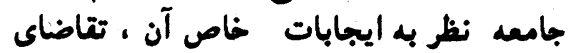

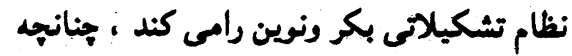

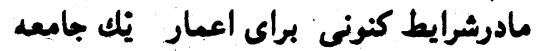

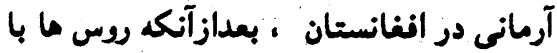

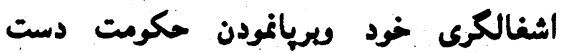

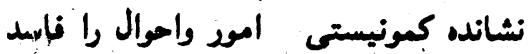

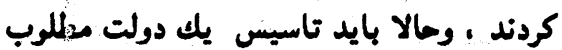

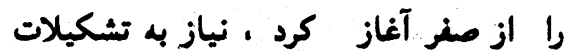

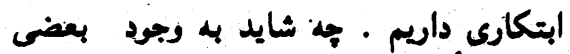

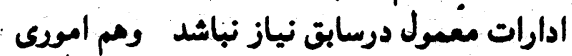

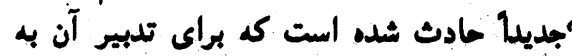

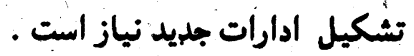

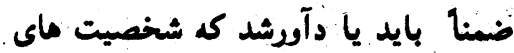

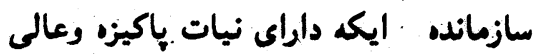

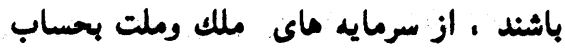

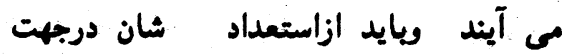

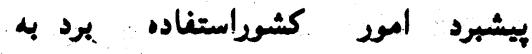
تشكيلات وسازماندهى معتول ، اكريا مديريت

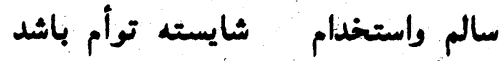

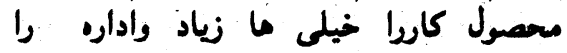

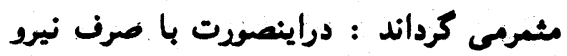

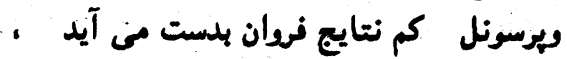

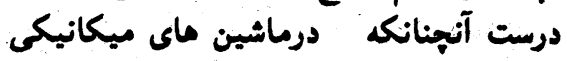

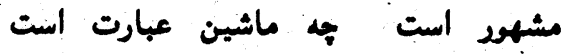

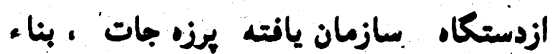

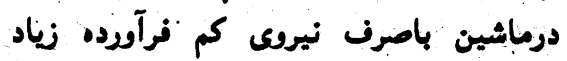

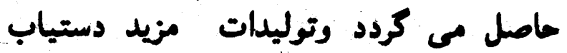

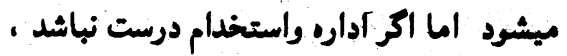

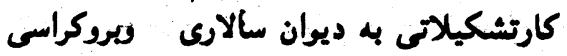

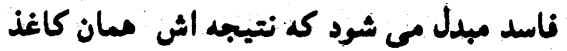

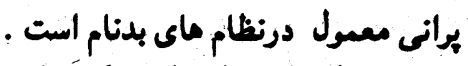

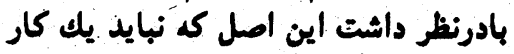

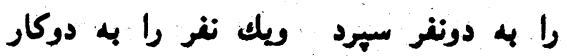

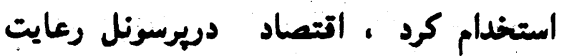

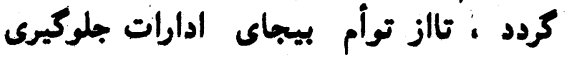

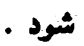




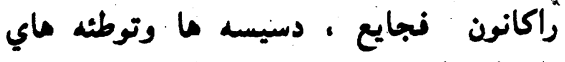

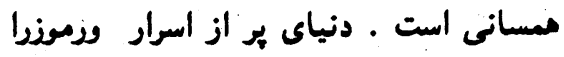

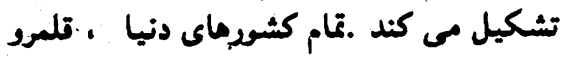

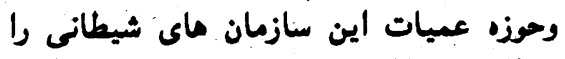

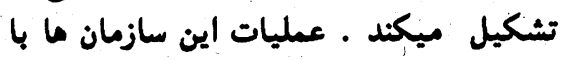

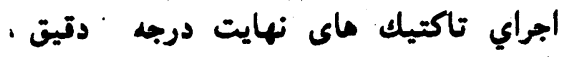

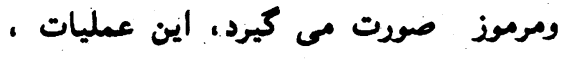

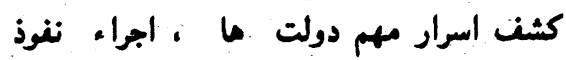

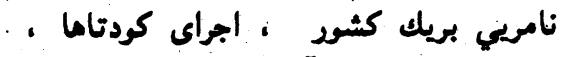

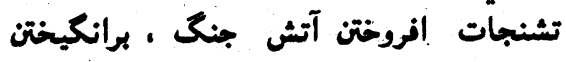

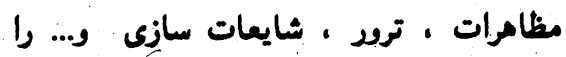

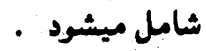

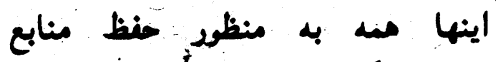

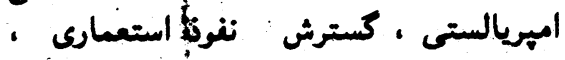
درمم شكستن رقبا وغيراينها طلئرت مى كيرد

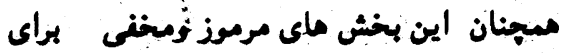

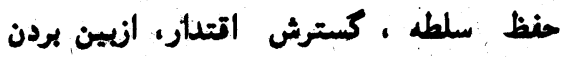

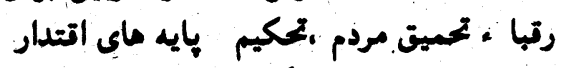

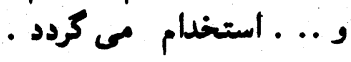

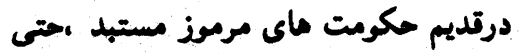

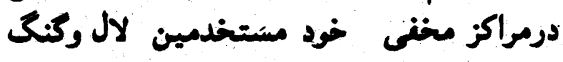

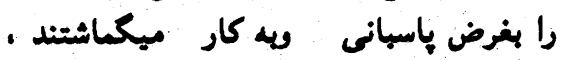

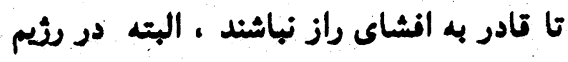

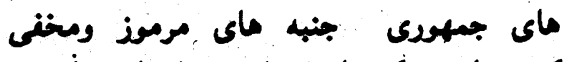

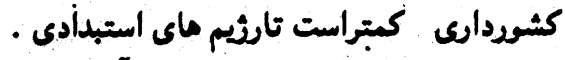

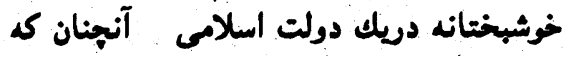

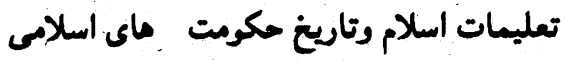

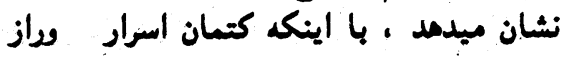

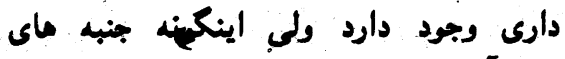

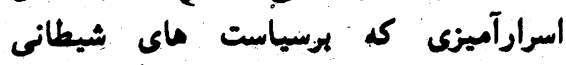

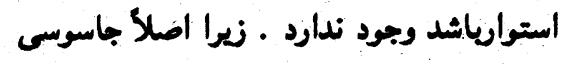

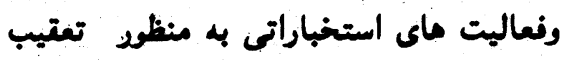

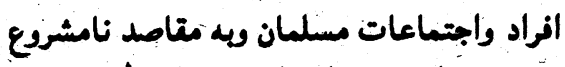

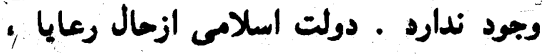

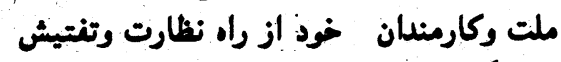

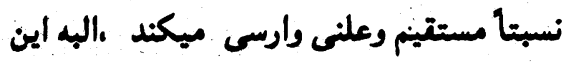

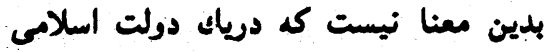

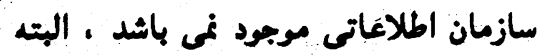

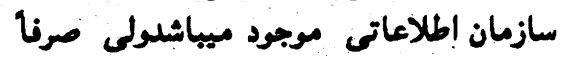

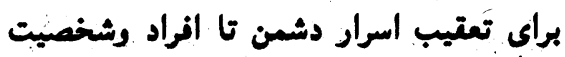

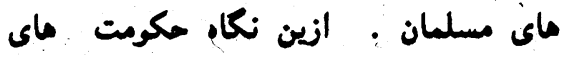
اسلامى از بساطت عجيبى برخوددار مى باشد ماند
استخبارات نظامى شان ميباشد .

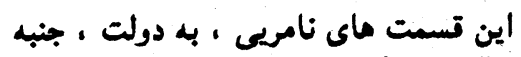

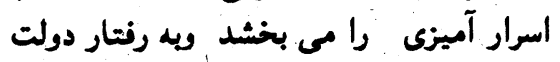

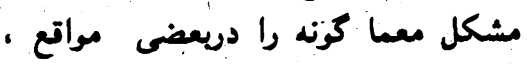

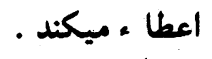

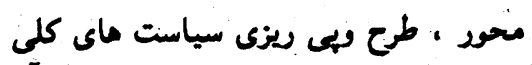

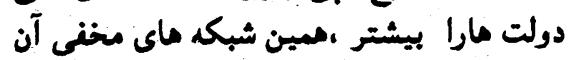

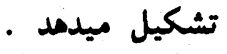
حكومت مات دورتديم بيثتر اسرار آميز

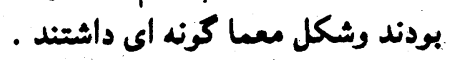
درزمان حاضر حكومت مائ ديكتاتورى

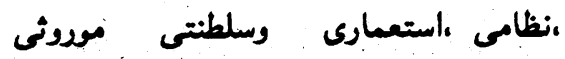

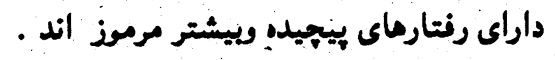
سازمان ماى اطلاعاتى رايج دردنيا نهاد

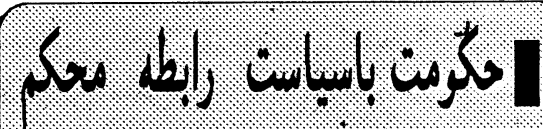

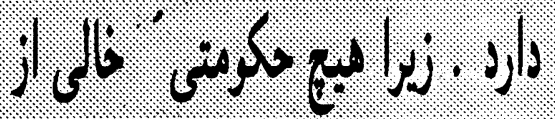

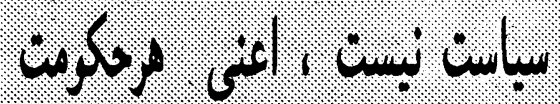
9)

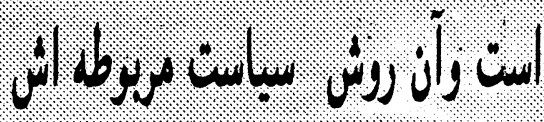
.106

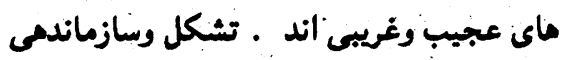

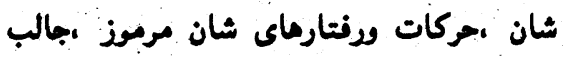

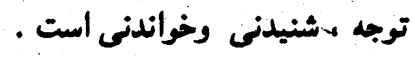

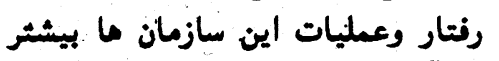

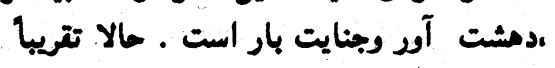

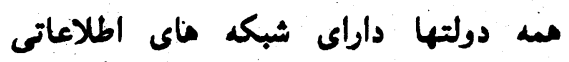

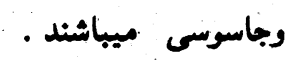
اما از مسه مرمبزتر خطرناكترواسرارآميز

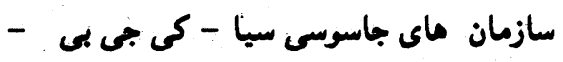

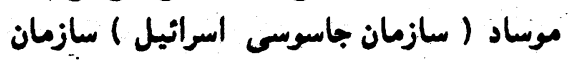

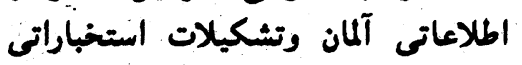
انكليس مم باشد ـ اين سازمانهاى جهنمى وتئلمات

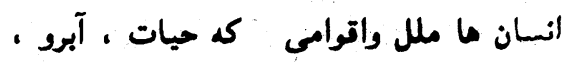

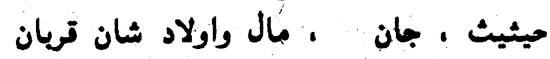

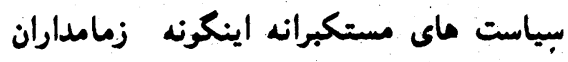

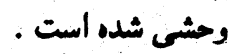

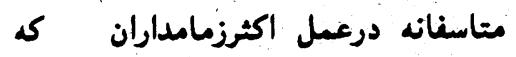

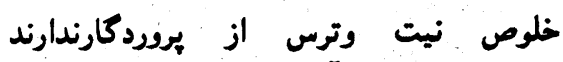

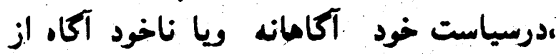

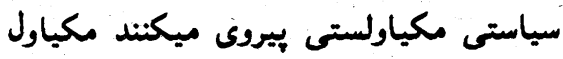

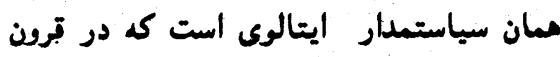

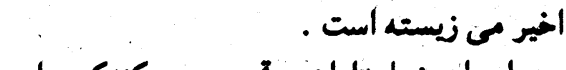

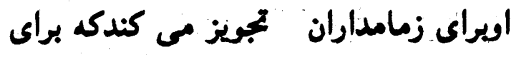

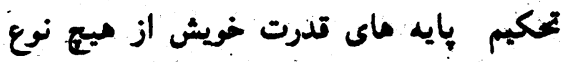

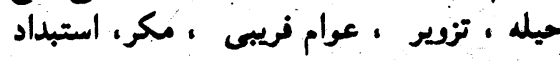

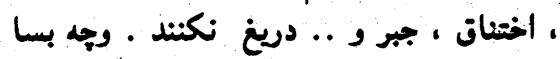

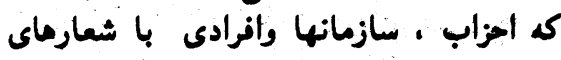

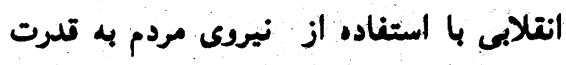

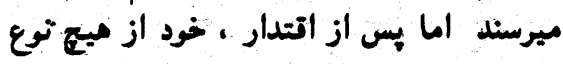

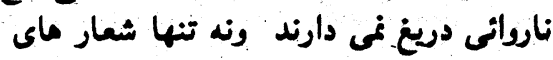

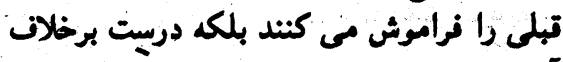

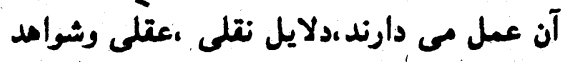

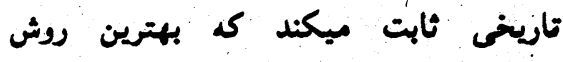

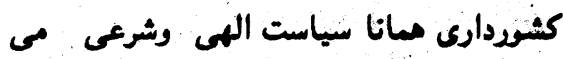
باشد .

\section{2.0.}

تشكيلات حكومت ما ورنتارشان : موان

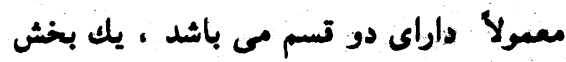

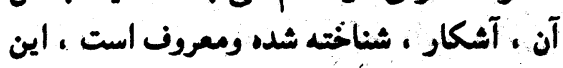

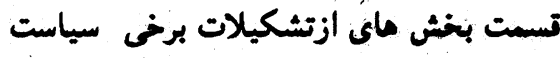

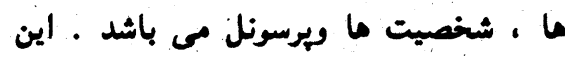

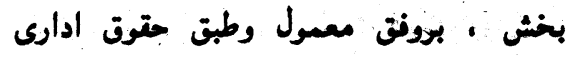

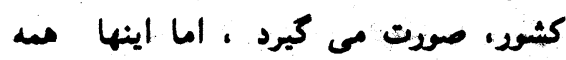

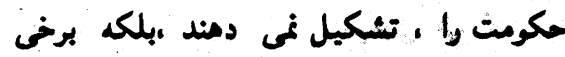

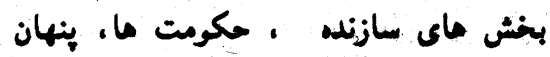

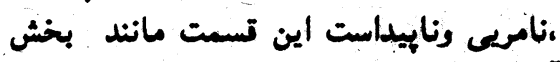

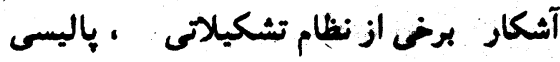

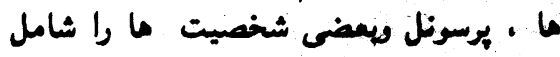
مبيnמد بخش تشكيلاتى ايكه ناميه است ،ماناتشكيلات بوليس مخفى ويا سازمان

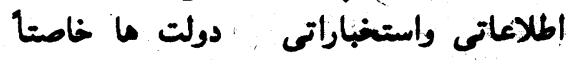




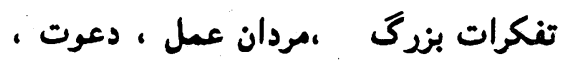

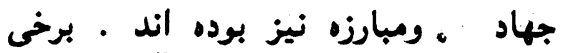

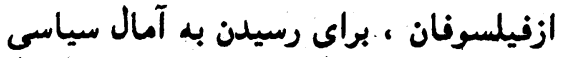

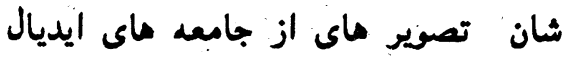
خودشان ران تقديم كردة اندان اندان اين جوائ ايديال

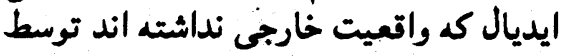

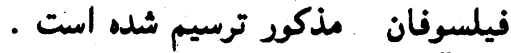

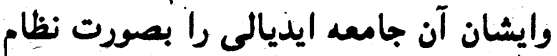

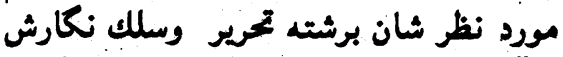

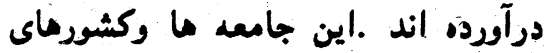

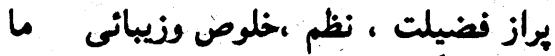

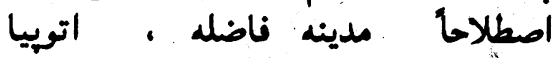

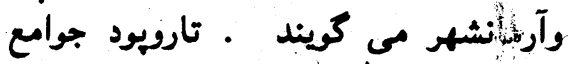

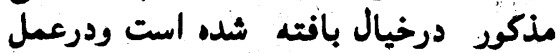

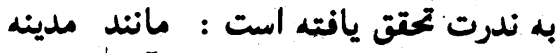
فاضلد افلاطون ،فارابى وآرمان شهر ماند

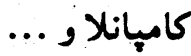

\section{جامعه بلون طبتات كمونيستى تئي}

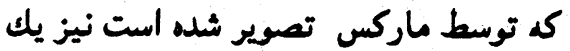

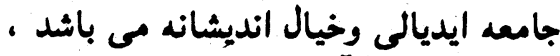

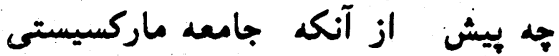

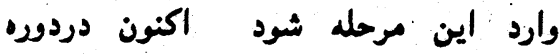

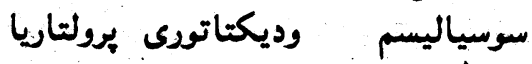

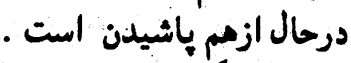

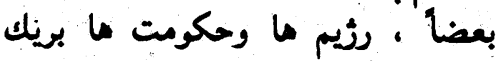

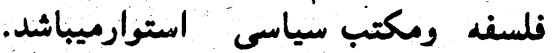

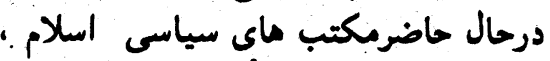

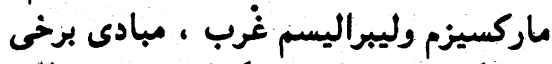

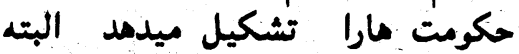

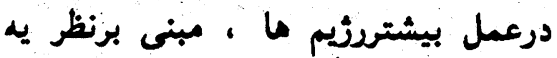

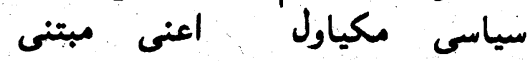

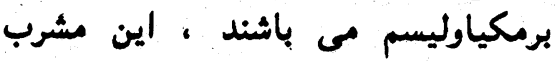

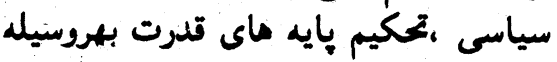

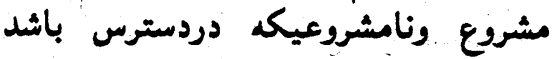

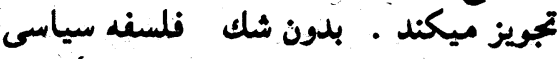
اسلام ، از بهترين انديشه ما ميباشد زئد زيرا

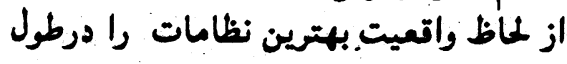

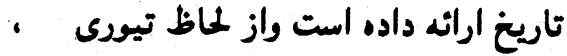

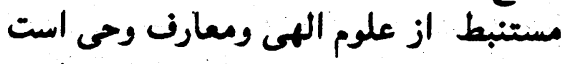

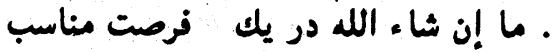

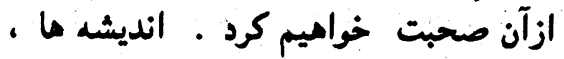

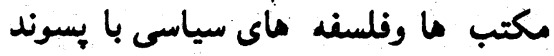

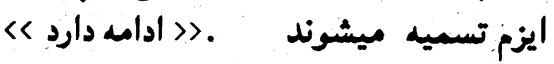

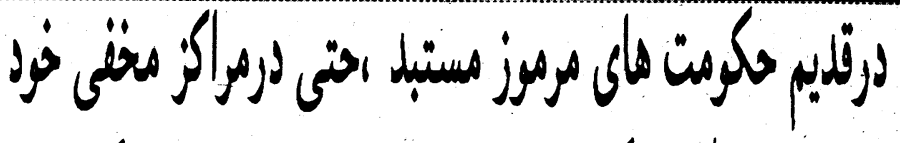

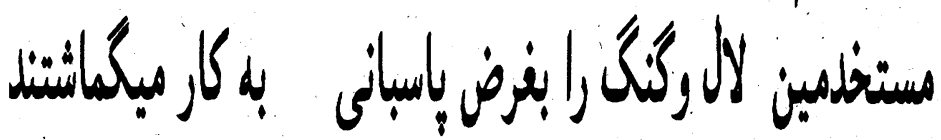

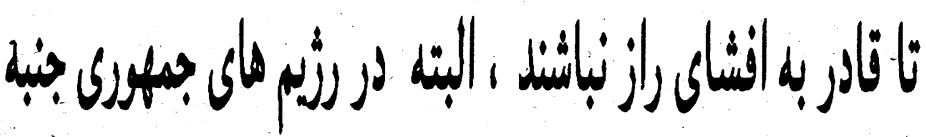

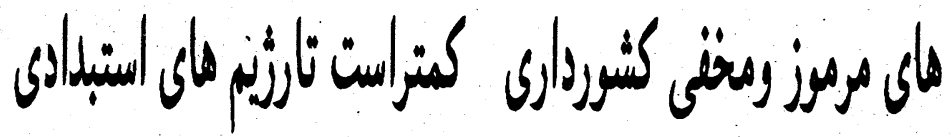

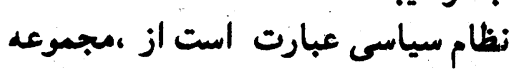

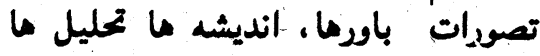

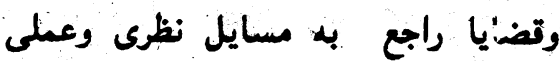

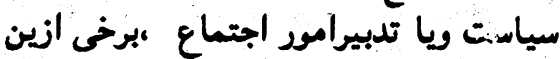

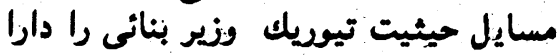

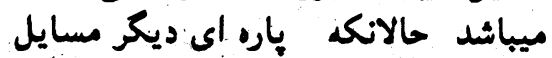

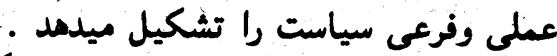

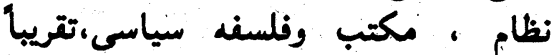

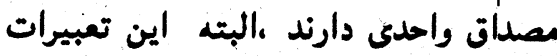

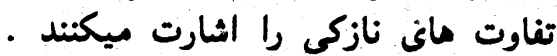

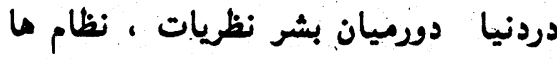

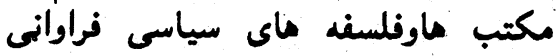

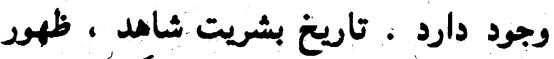

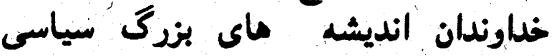

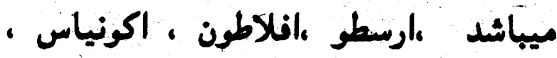

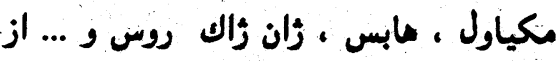

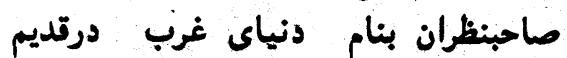

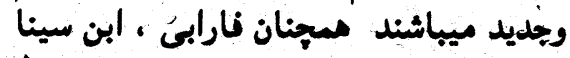

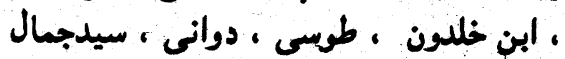

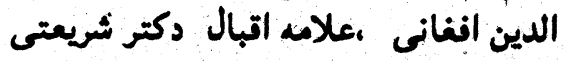

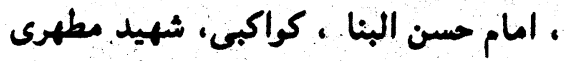

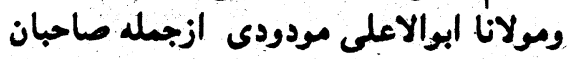

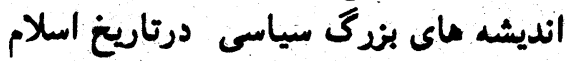

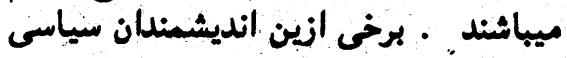

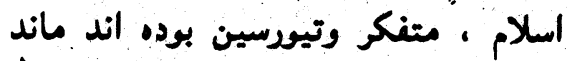

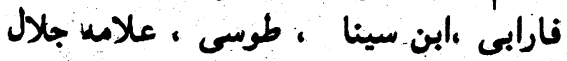

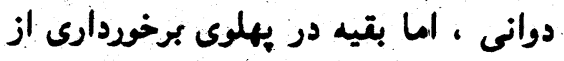

TH.

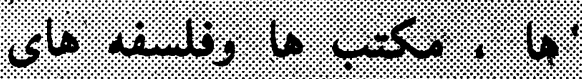
(.).

حكومت بحيث يك مظهر عملي

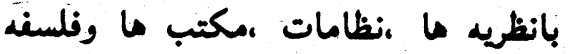

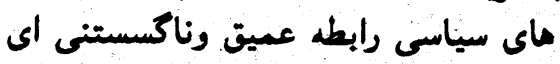

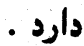

نظريه سياسى عبارت است از ، تصور

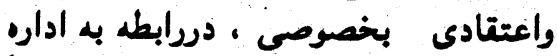

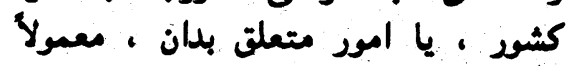

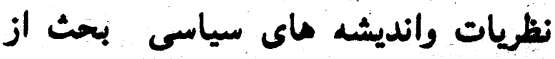

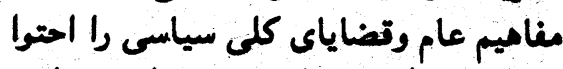

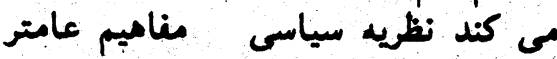

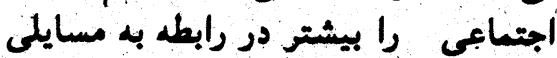

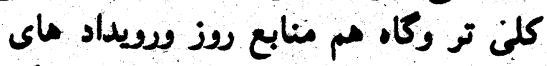

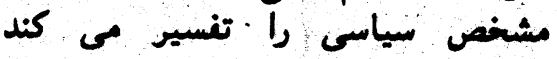

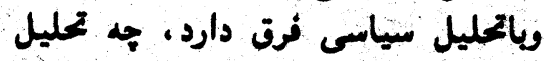

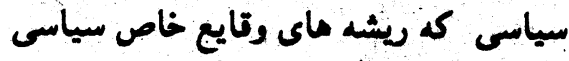

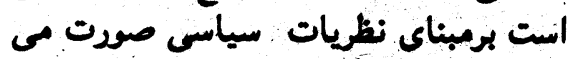

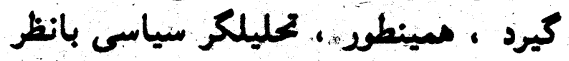

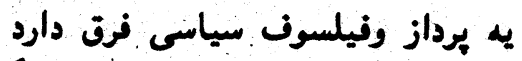
تحليل كر ، با استناد به نظريات فيل ديكران

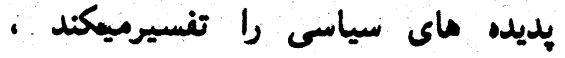

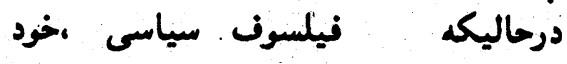


211.

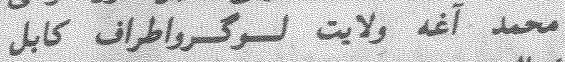

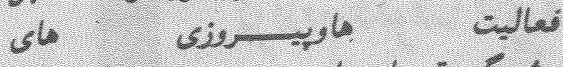

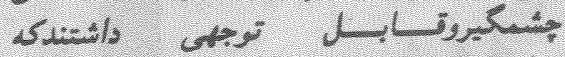

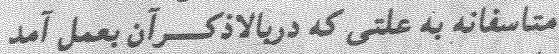

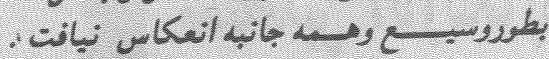

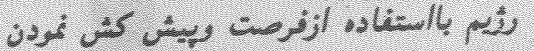

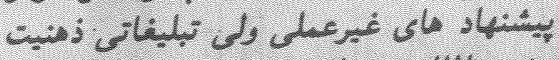

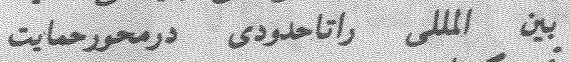
-146isis:

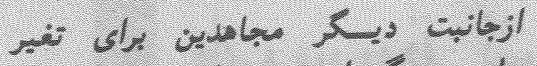

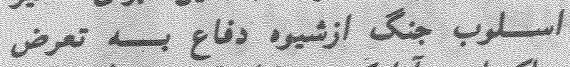
il

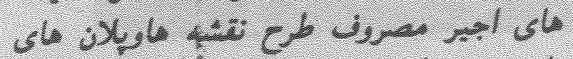

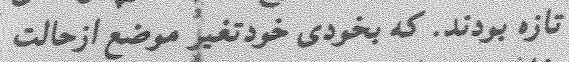

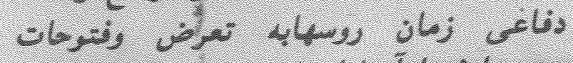
بالي $3,2=1$

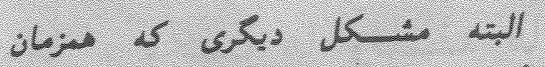

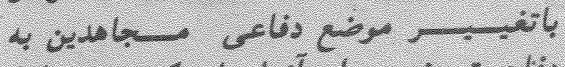
أنا

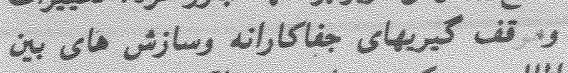

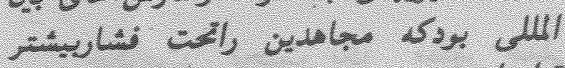
$.2,301,3$

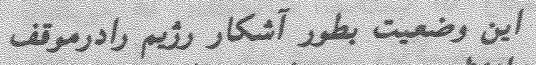

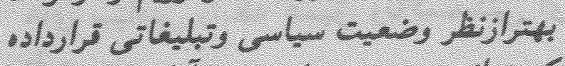

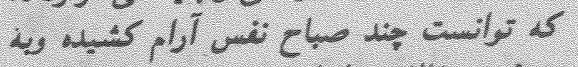
أن"

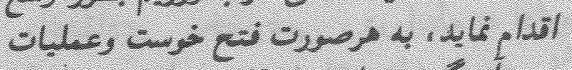

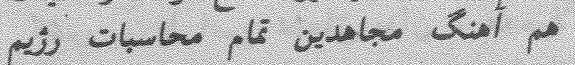

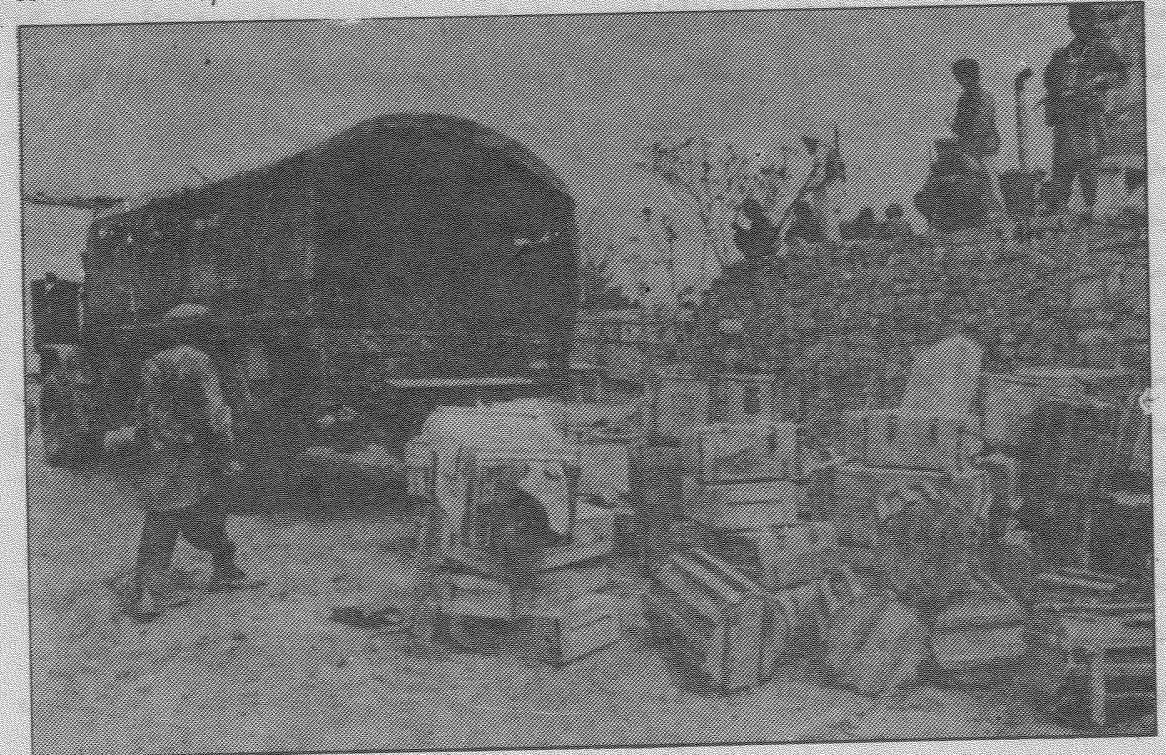

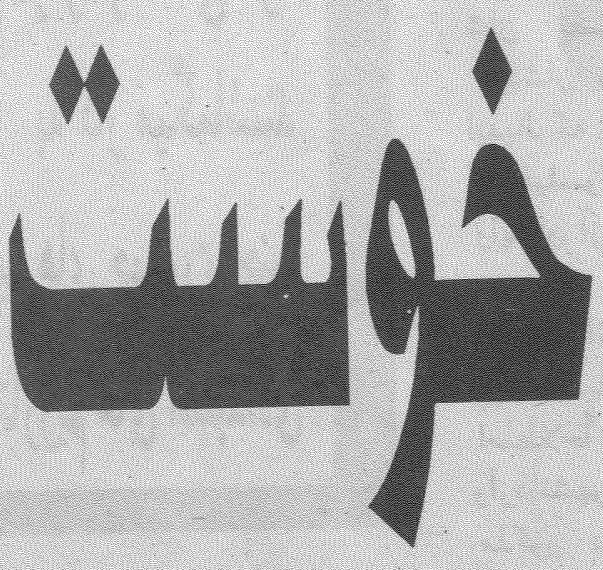
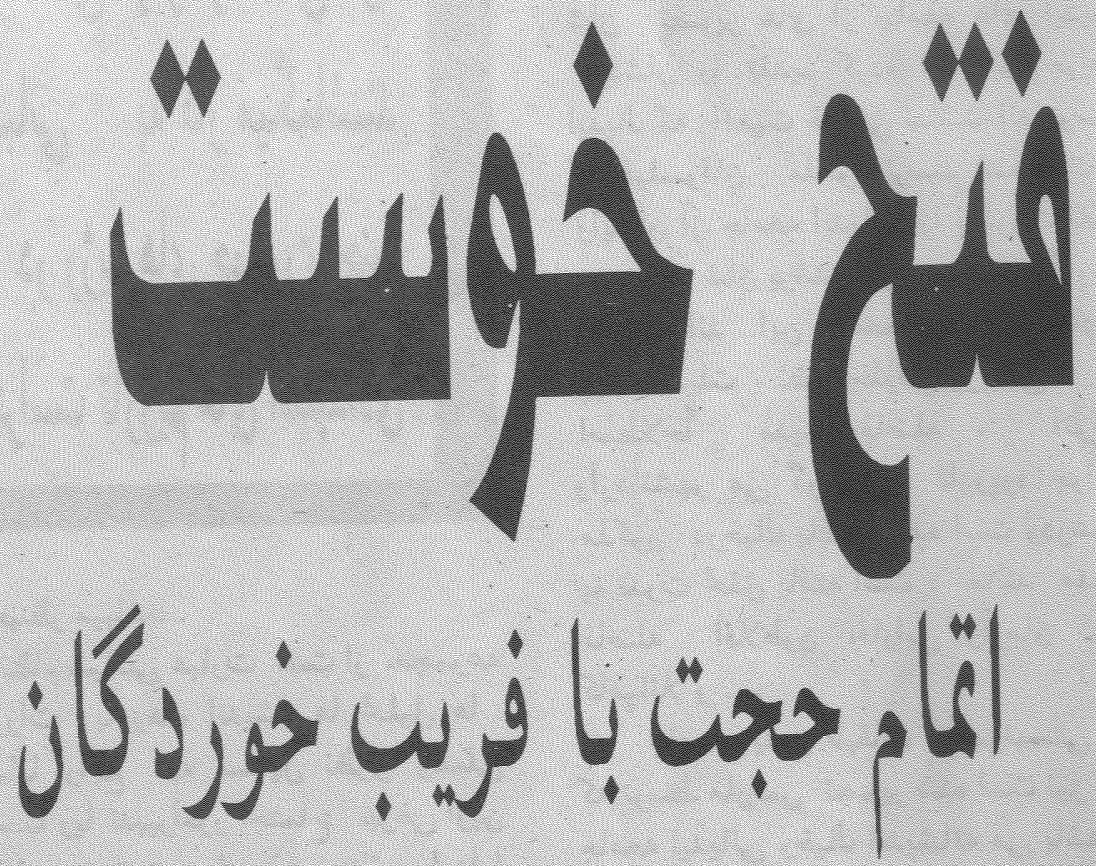

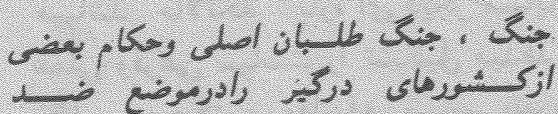

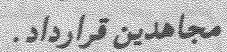

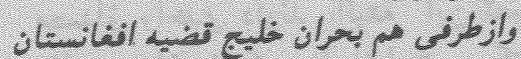

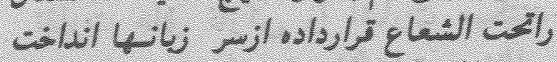

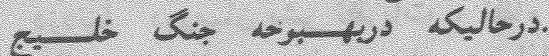

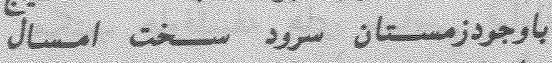

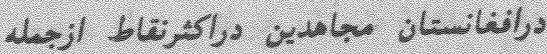

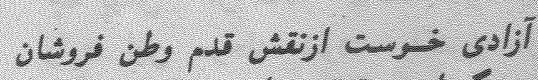

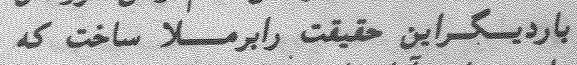

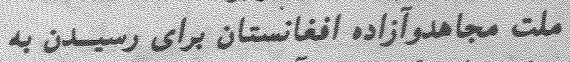

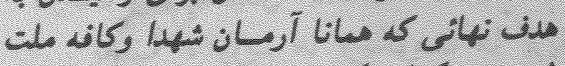
r.s.

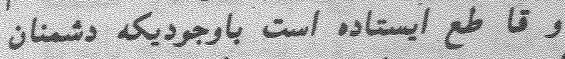

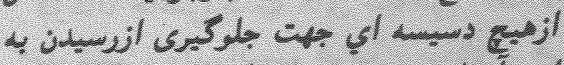

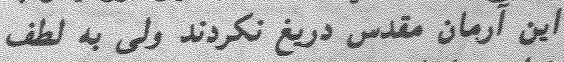

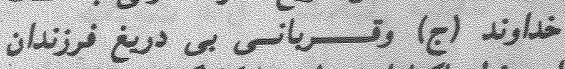

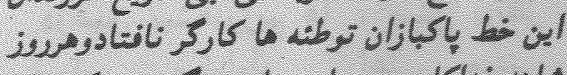

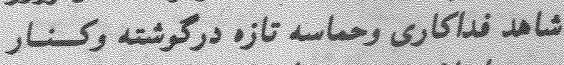

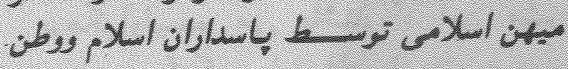

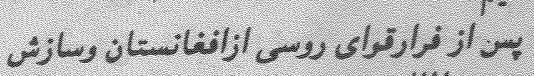

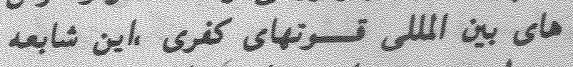

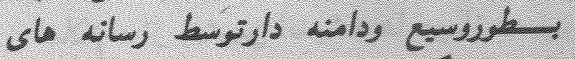

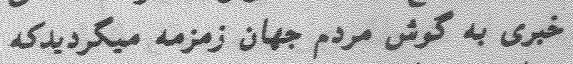

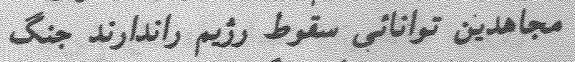

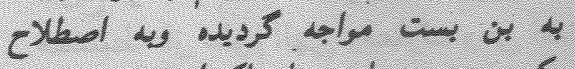

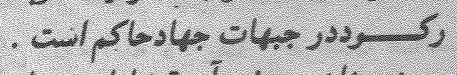

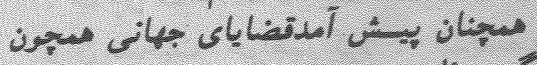

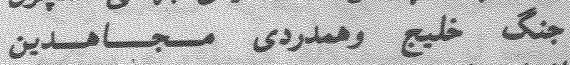

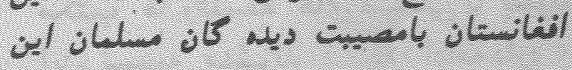




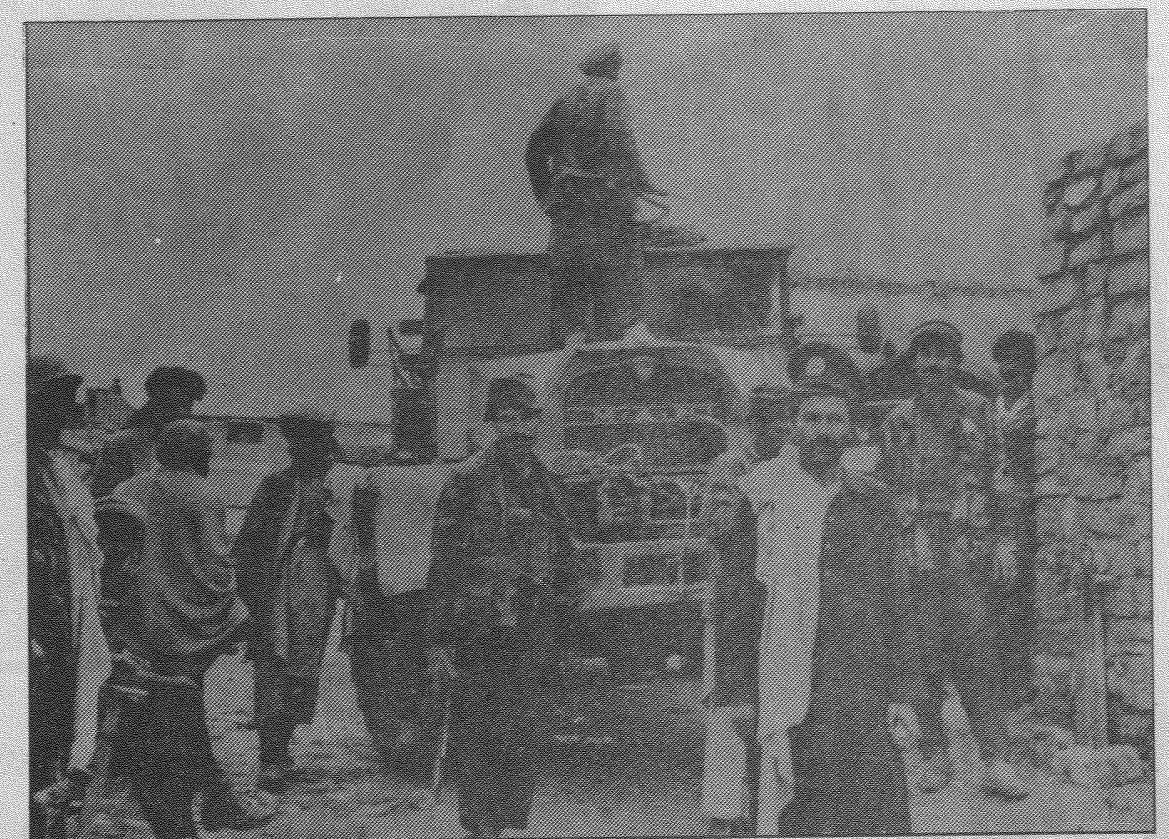

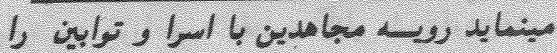
LiT ji .

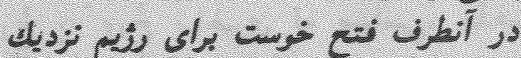
is als at is

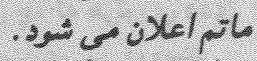

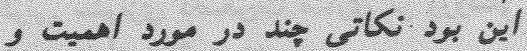
لا

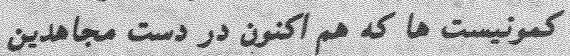

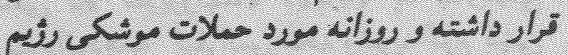

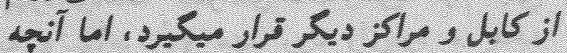

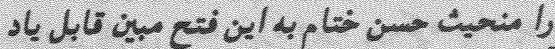

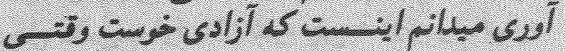

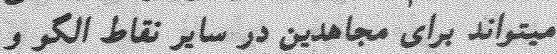

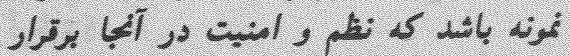

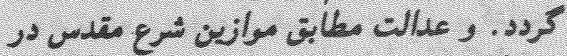

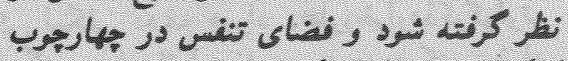

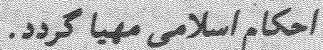

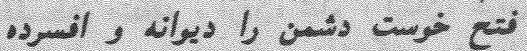

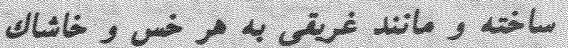

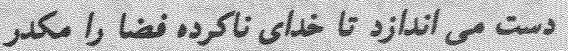

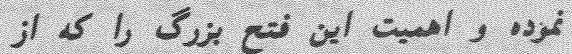

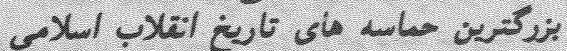

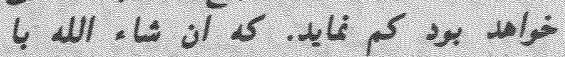

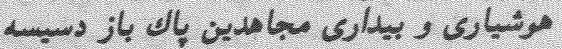

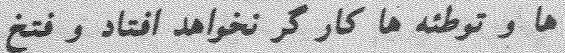

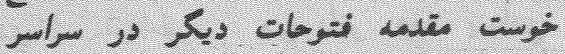

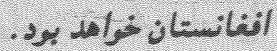

تصأ

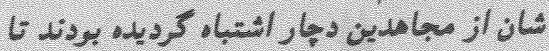

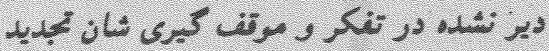

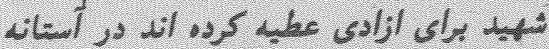

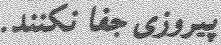

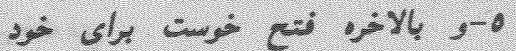

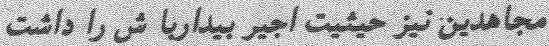

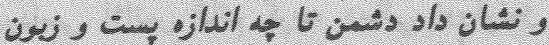

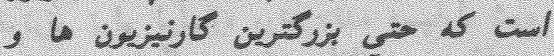

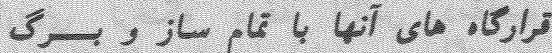

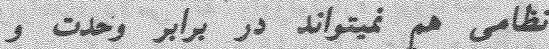

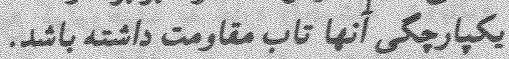

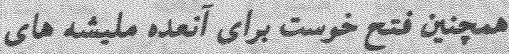

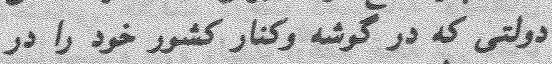

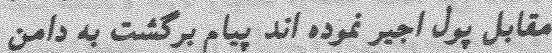

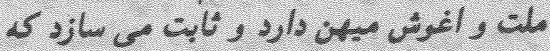

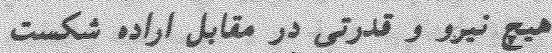

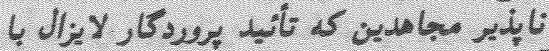

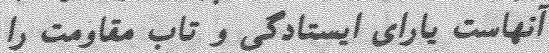

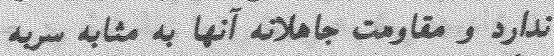

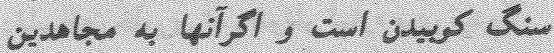

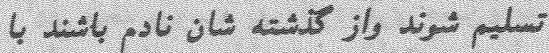

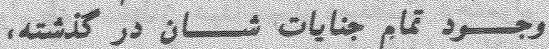

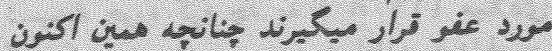

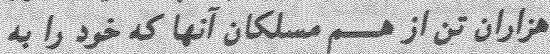

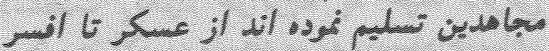

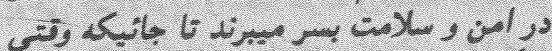
-6x Li L III on st il

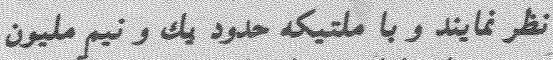

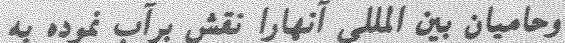

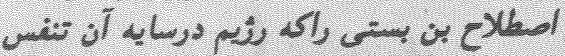

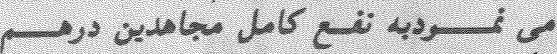

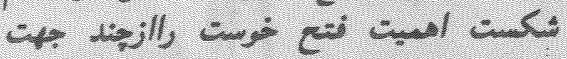
stols cososer al $=$

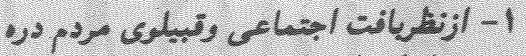
tis

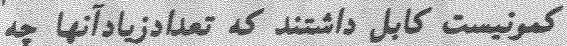

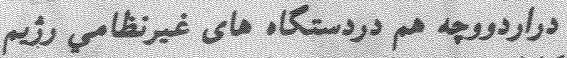

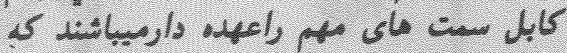

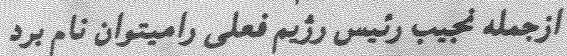

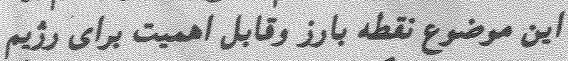
Jul

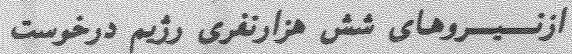

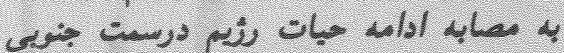

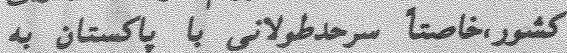
-30 - L

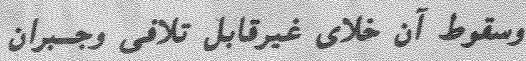

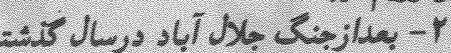

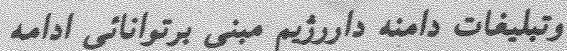

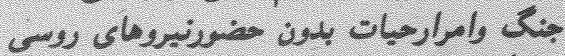

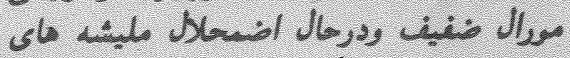

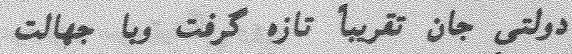
4 valu viligs

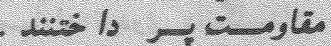

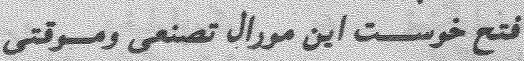

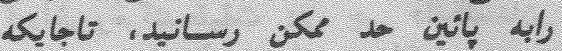

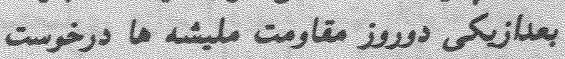
is al

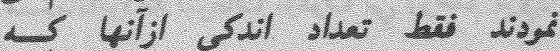

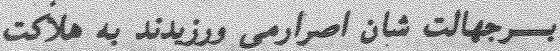

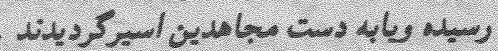

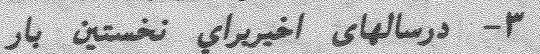

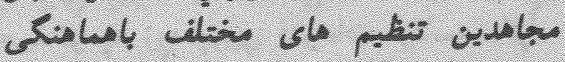

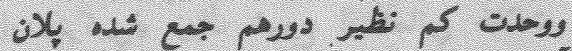

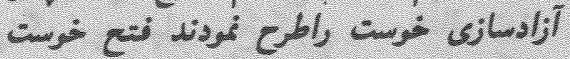

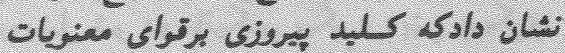

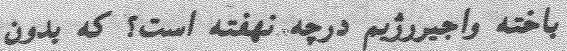

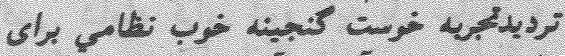

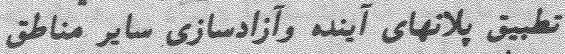

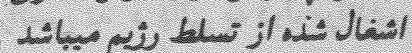

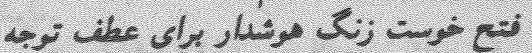

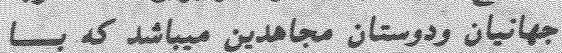

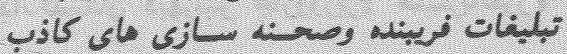




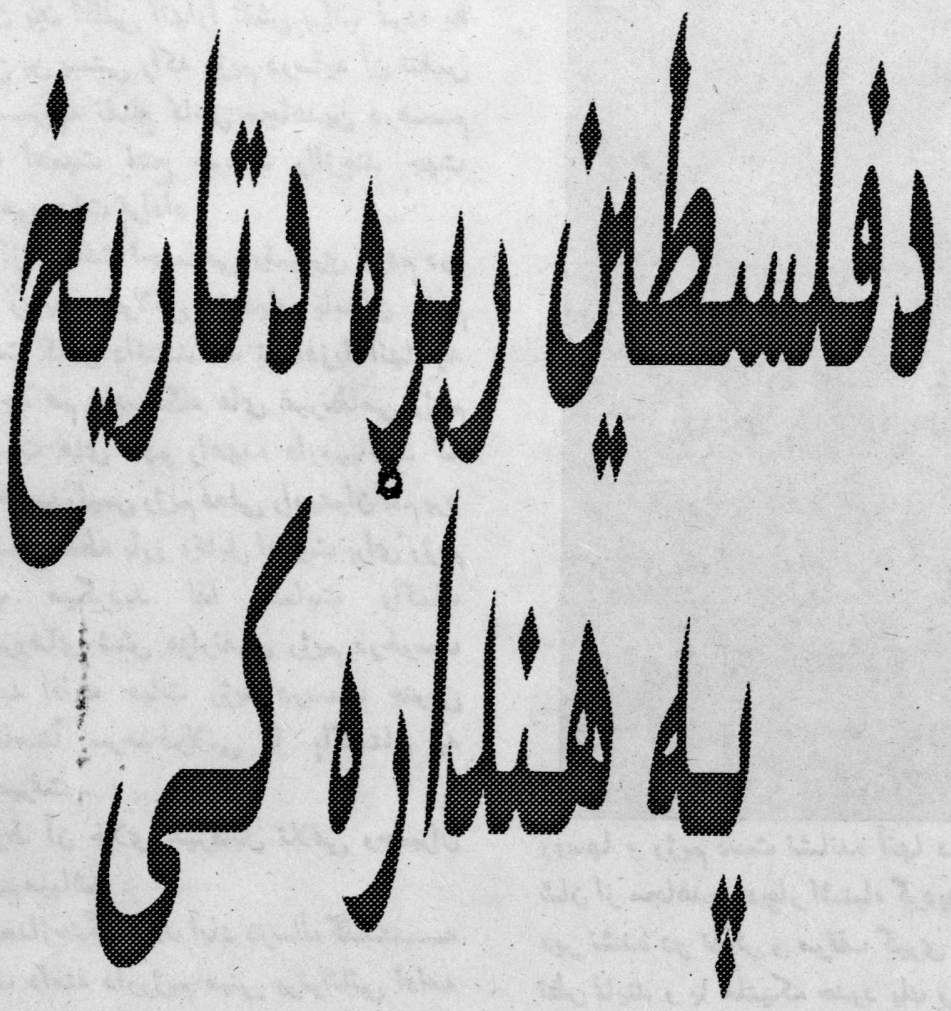

ميسنه سره تينكي وي.

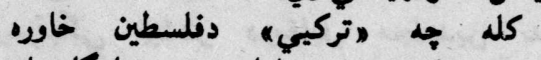

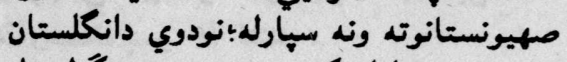

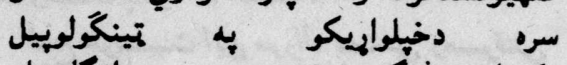

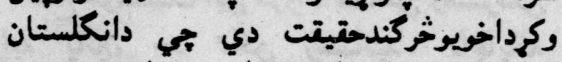
استعطاري عزايم اوديهودانويتي بيلاتونه ديوي

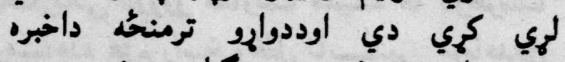

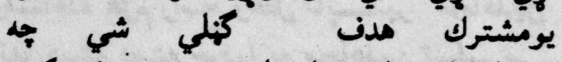

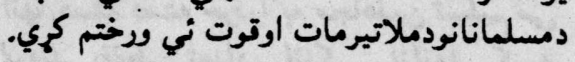

يهودانوخهل دولت، سياسي اوتكنالوجي

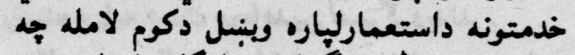

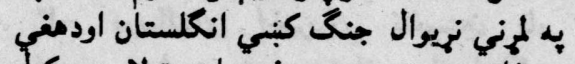

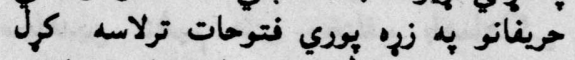

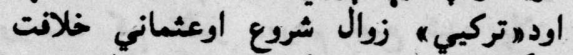

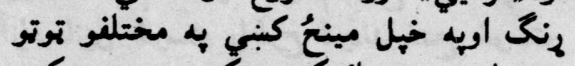

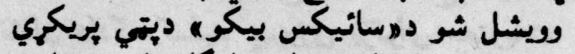

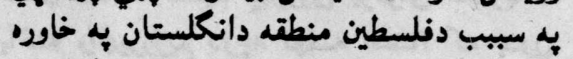

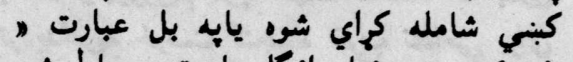

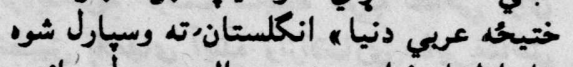

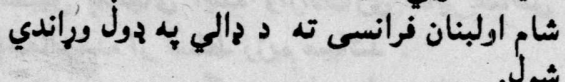

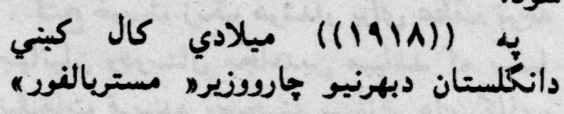

بوخت دي.

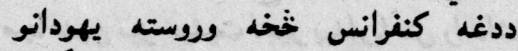

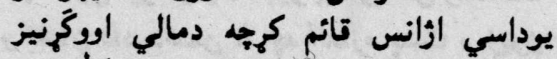

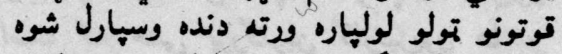

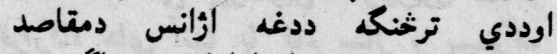
واواهذافودلاس ته راودئي

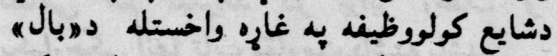

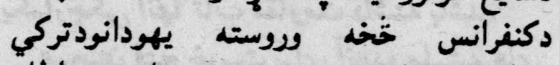

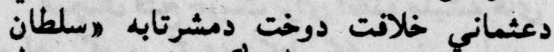

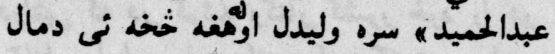

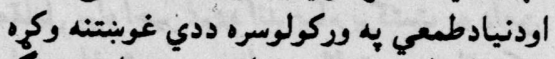

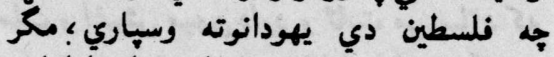

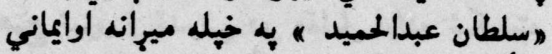

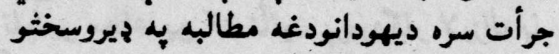

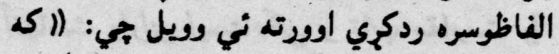

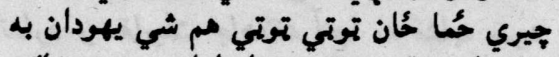

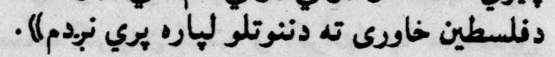

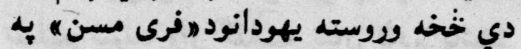

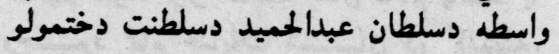

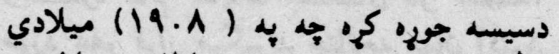

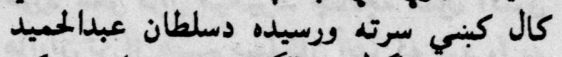

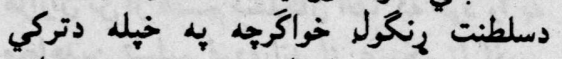

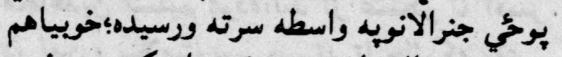

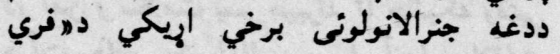

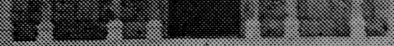

* زياهن : عبدالناصر " شفيق * ओ ओ ओ ओ ओ

د نلسطين مسئل جه د داسلامى اوعريب نزي

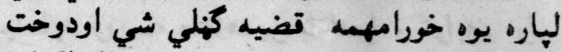

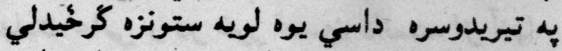

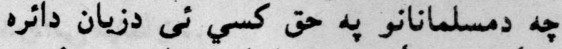

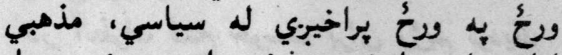

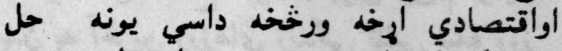

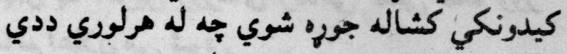

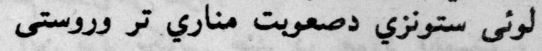

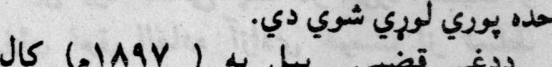

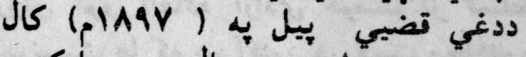

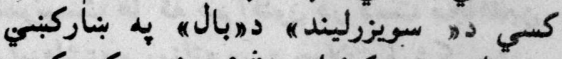

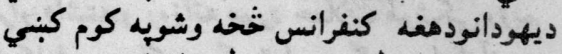

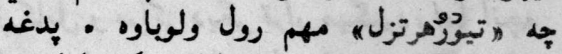

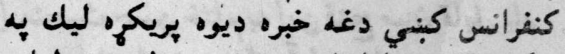

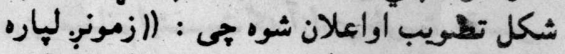

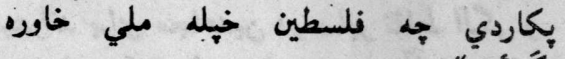

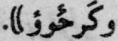

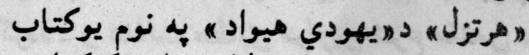

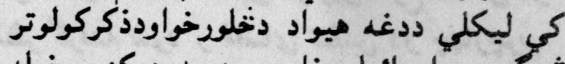

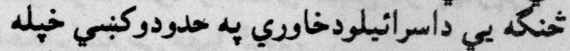

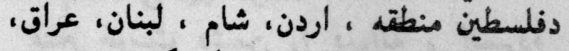

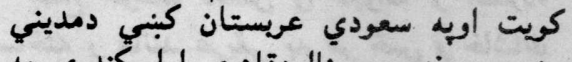

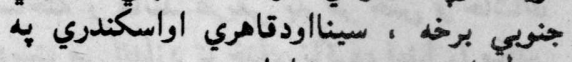

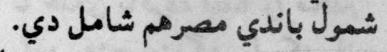

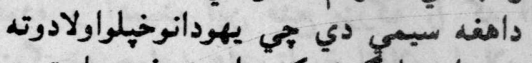

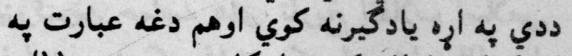

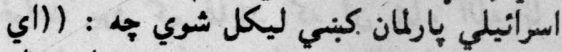

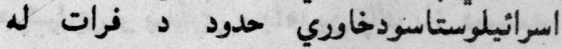

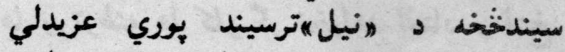

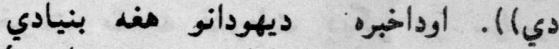

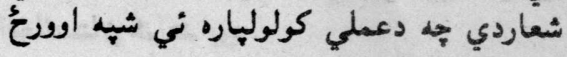




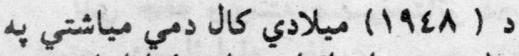

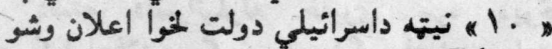

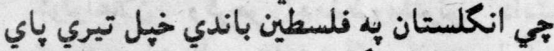

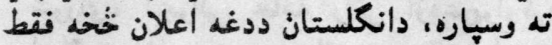
ينحة دتيقي وروسته دامريكي جمهيهورونيس

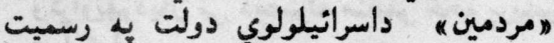

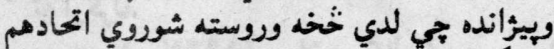

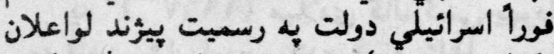

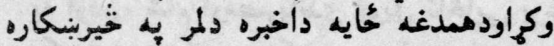

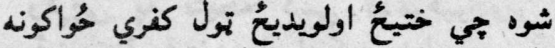

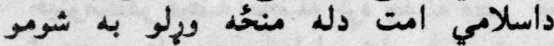

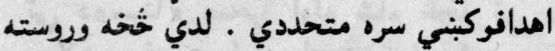

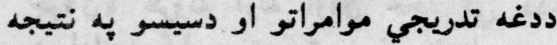
كبني به اسلامي خاوره كبني يوغيراسلامي دولت رامينحُته شو.

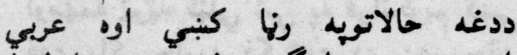

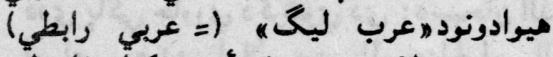

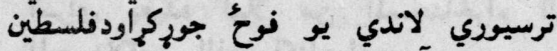

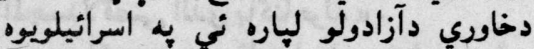

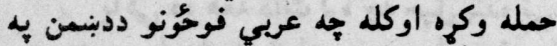

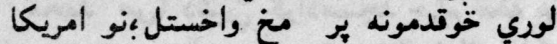

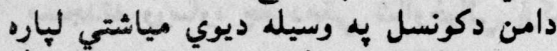

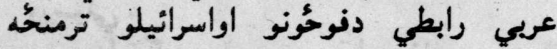

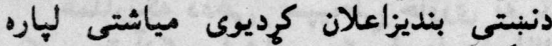

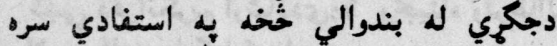

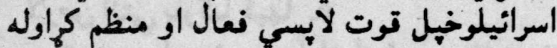

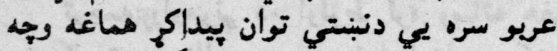

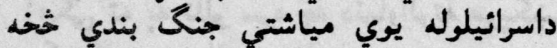

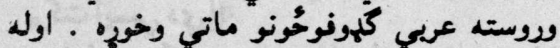

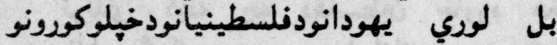

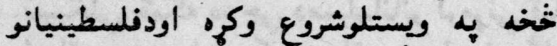

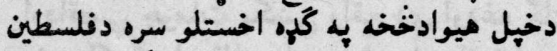

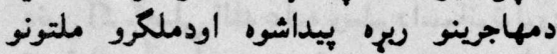

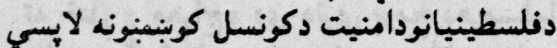

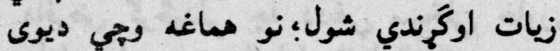

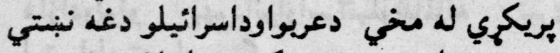

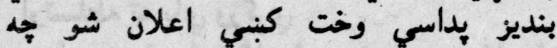

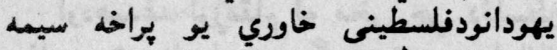

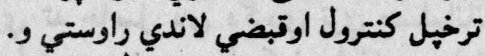

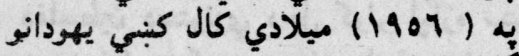

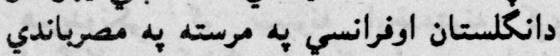

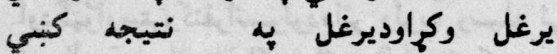

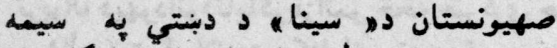

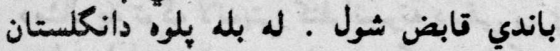

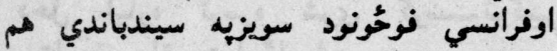

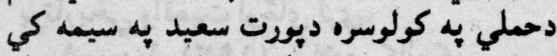

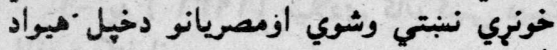

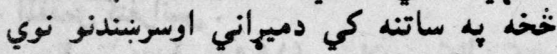

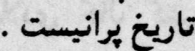

له ختيره أسياكبني اسرائيل

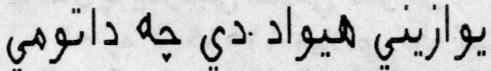

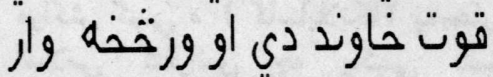

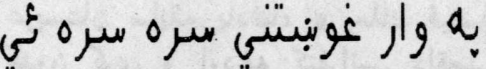

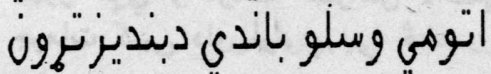

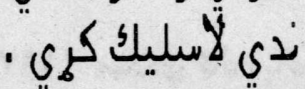

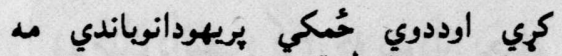

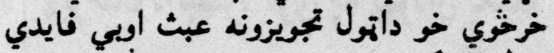

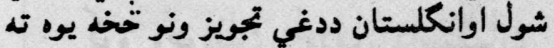
هم كومه توجه ونكهر. يه (19EY ) ميلادي كال كبنهي يهودانو

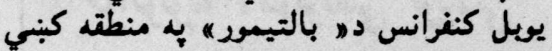

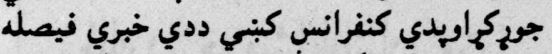

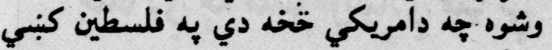

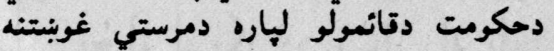

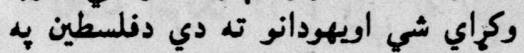

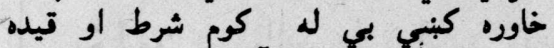

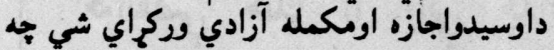

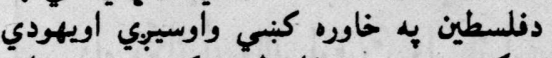

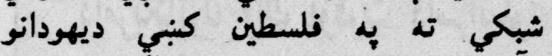

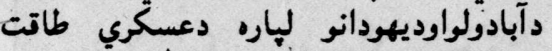

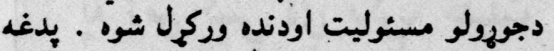

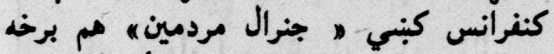

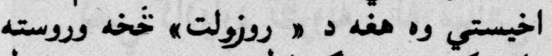

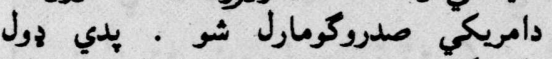

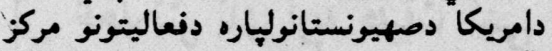

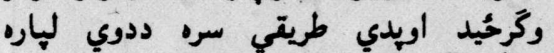

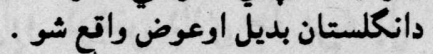

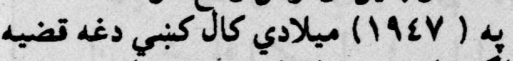

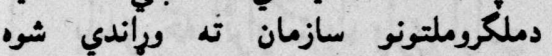

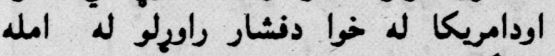

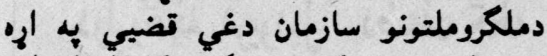

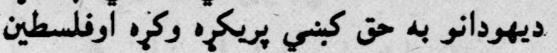

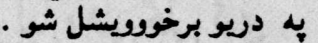

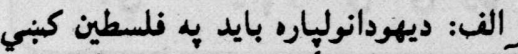

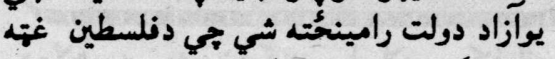

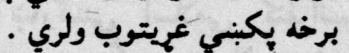

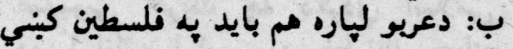

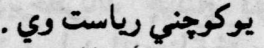

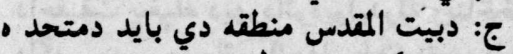

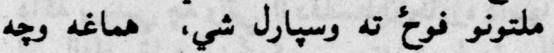

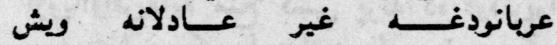

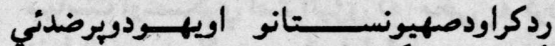

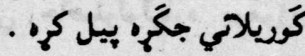

يوه اعلاميه كي وويل جي انكلستان

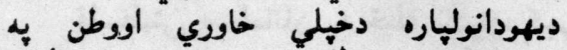

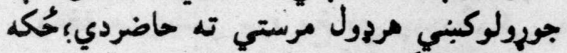

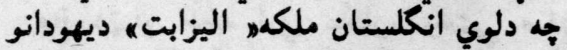

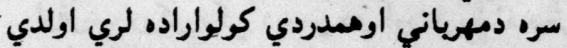

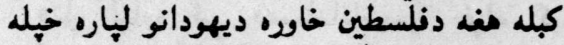
ملي خاوره كرخول غوائي دادين داداسي يوحيرانونكي

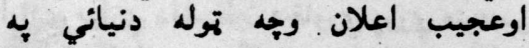

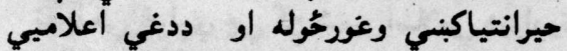
معني داوه جه يوغيرمستحق دورئ خآوند وكنلي

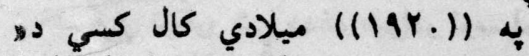

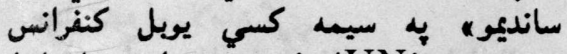
جوشوجي (UN) (دمتحده ملتونوسازمان)

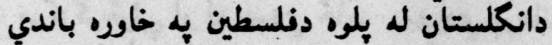

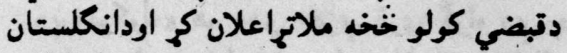

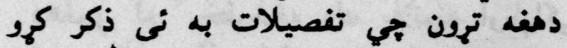

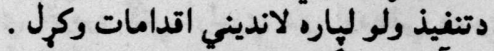

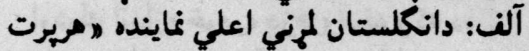

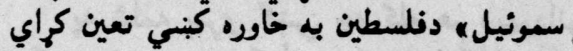

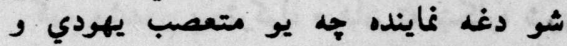

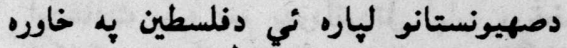
كينس لوي خدمات ترسرهُ كرل

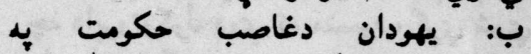
مهمواوحساسو خانكو كي متروكاي شول

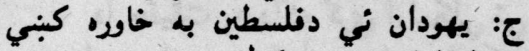

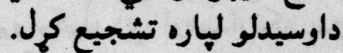

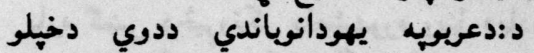

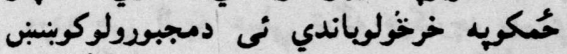

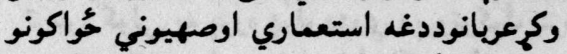

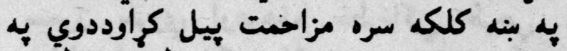

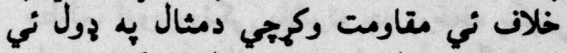

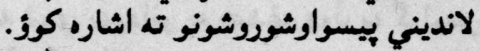

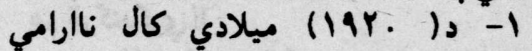

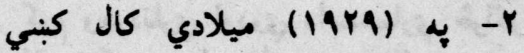

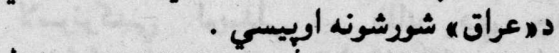

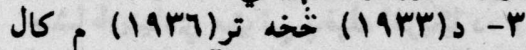

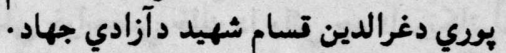

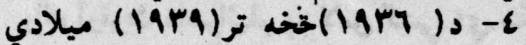
كال بودي به خردفلسطين كبني دمسلمانانويرلة

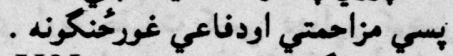

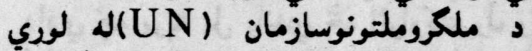
دفلسطين خاوري ته خُيني كميتي وليبردول شوي

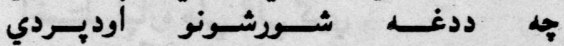

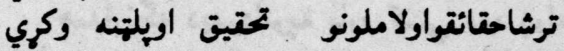

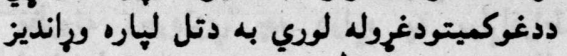

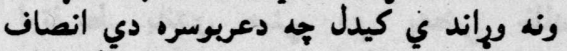
وكراي شي أويهودان ملته داوسيدلو تخخه منع ديد ونه 
- نقطه

نلسطيني مسلمانان به خهيله ستونزه كبني

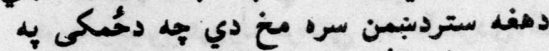

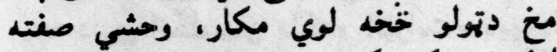

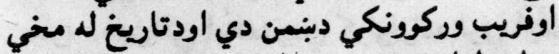

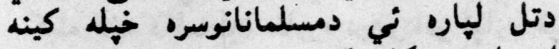

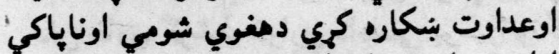

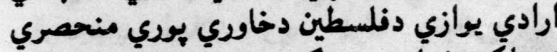

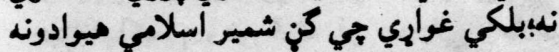

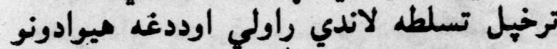

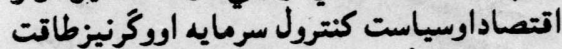

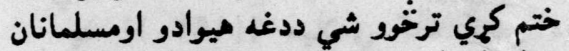

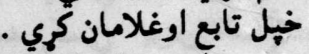

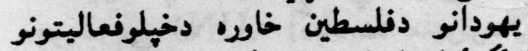

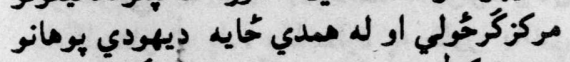

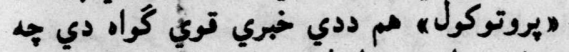

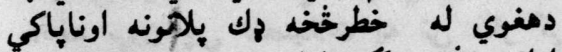

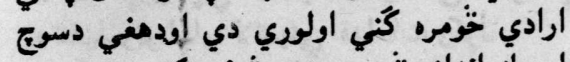

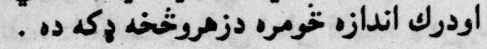

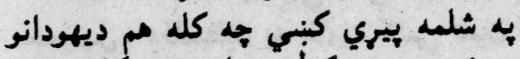

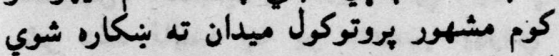

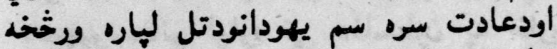

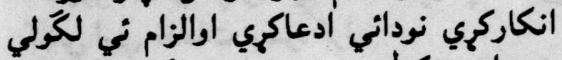

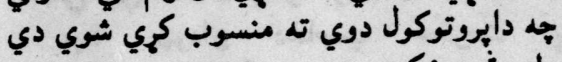
ولي خيه ونكو دا حقيقت به ماكئ كري اوليكلي ني دي

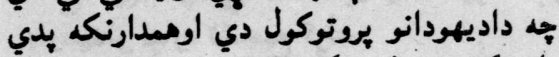

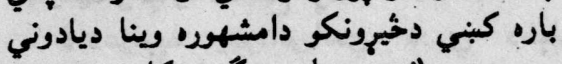

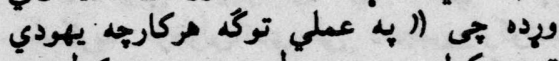

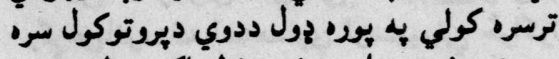

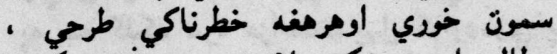

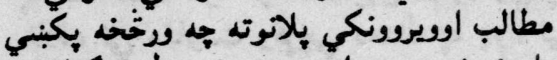

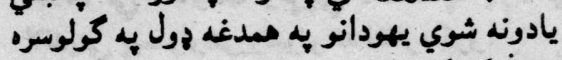
هم خركندكري)|.

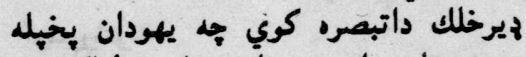

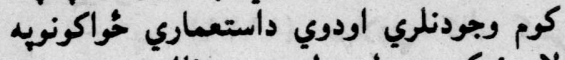

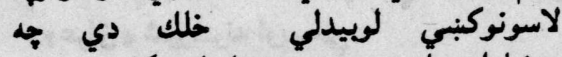

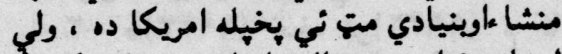

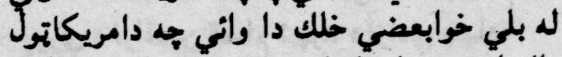

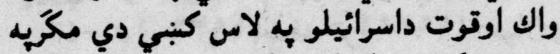

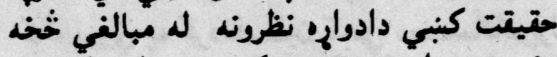

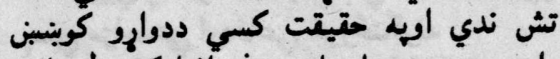

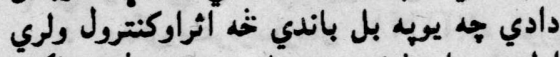

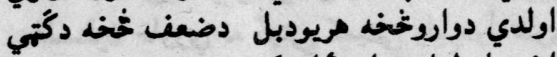

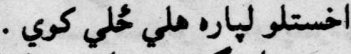

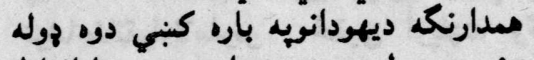

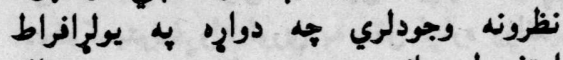

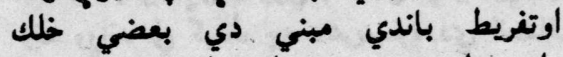
داتصورلري جى يهودان دأسي يوسترتوت بعضي
دكراجي به بناركبني اسلامى كنفرانس

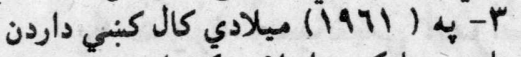

دعمان به بناركنبى اسلامي كُنفرانس ع- يه ( مراكش كبنهي د ( كاسابلاتكاً) ) به بناركبني

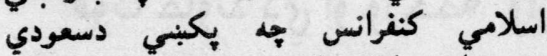

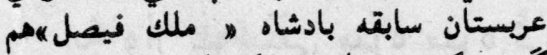

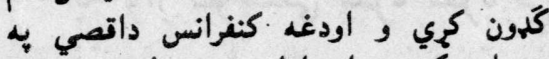

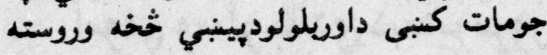
ترتيب شوي ؤ.

ت

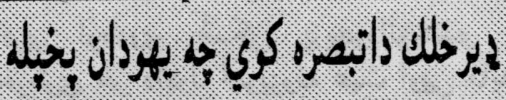

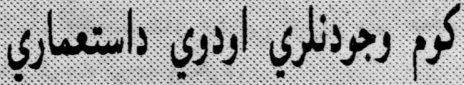

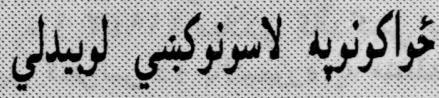

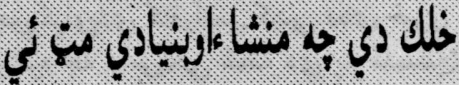

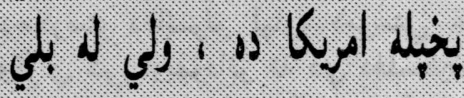

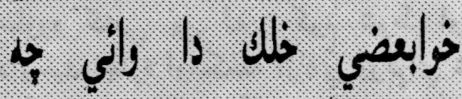

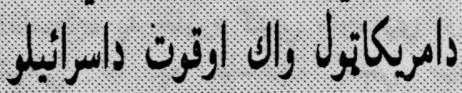

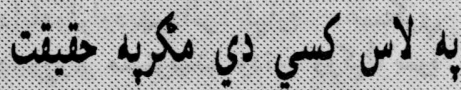

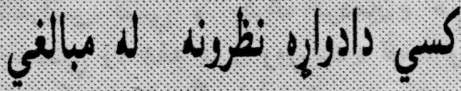

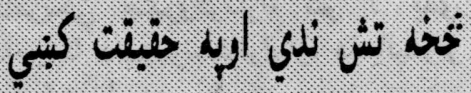

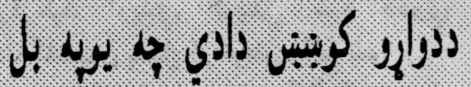

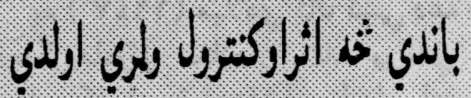

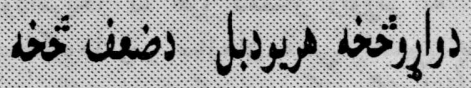

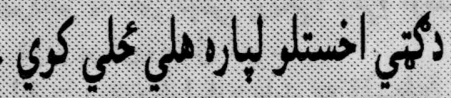
د"لامور ي به بناركبنى اسلامي كنفرانس

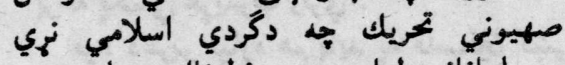

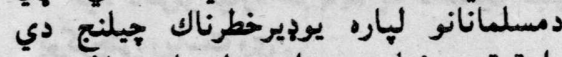

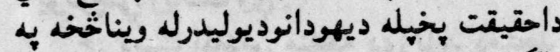

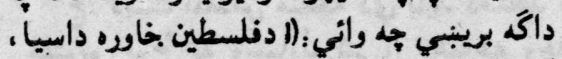

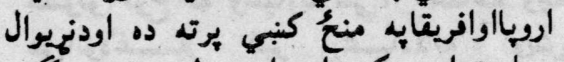

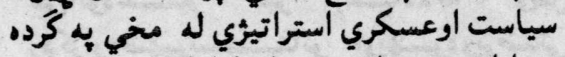

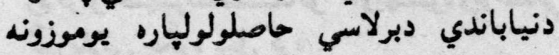

لدي تخخه وروسته صهيونستانو دلاسينا ،

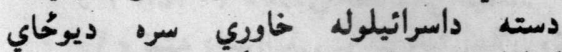

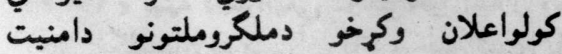

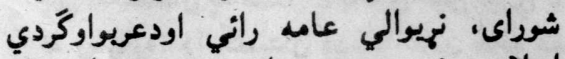

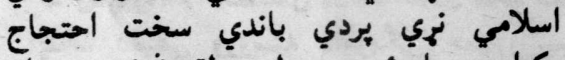

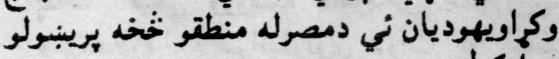
ته أركارل.

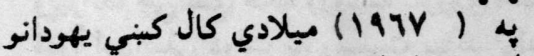

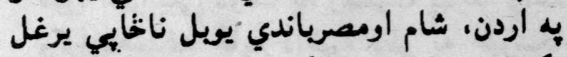

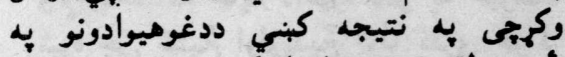

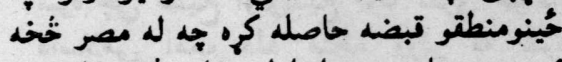

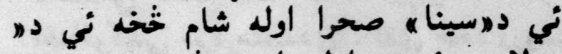

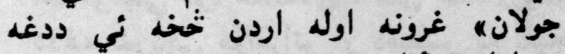

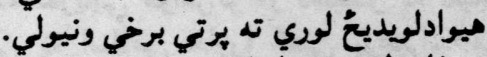

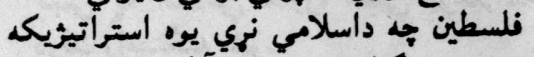

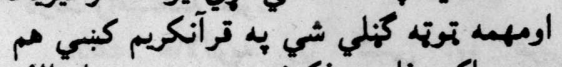

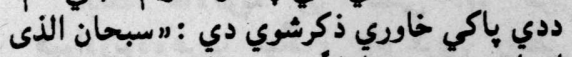

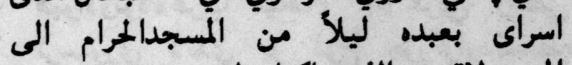

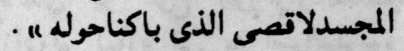

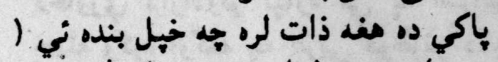

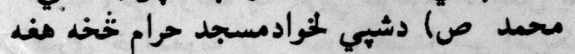

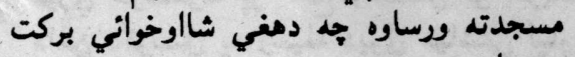

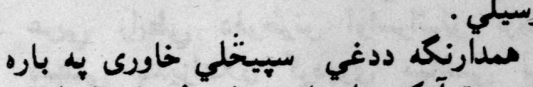

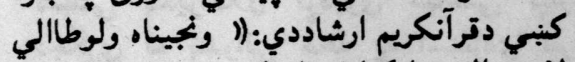

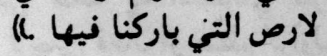

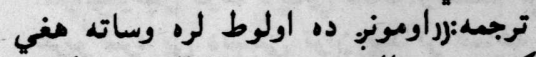

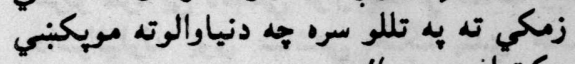

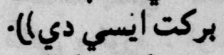

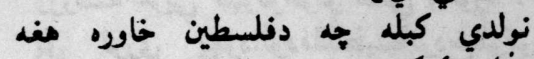

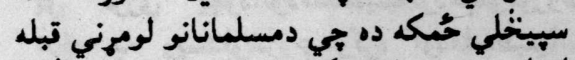

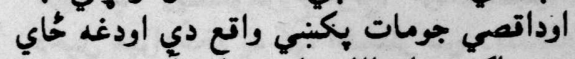

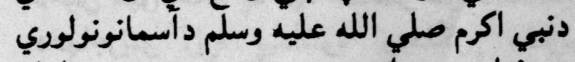

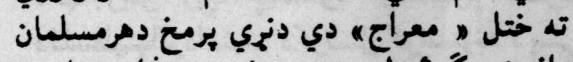

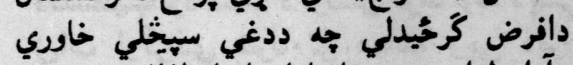

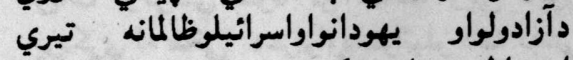

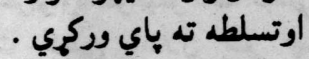

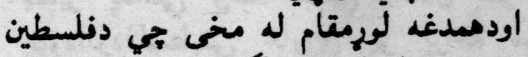

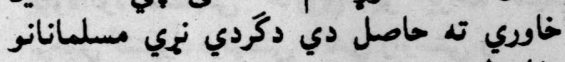

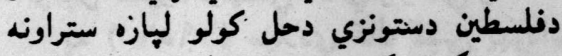

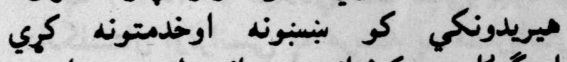

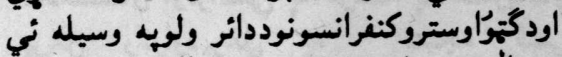

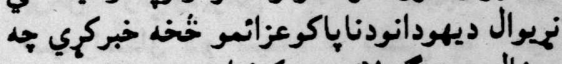

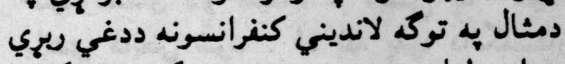

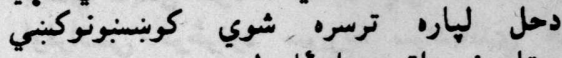
يوتاريخي واتعيت اوخاي لرئ

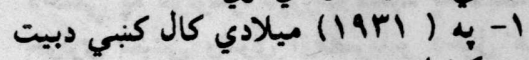
المتدس كنغرانس . r- به (1901) ميلادي كال كني 


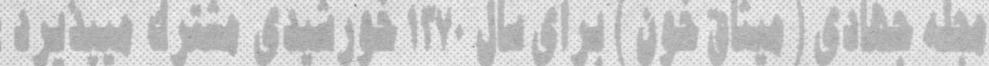

دذلسطين به خاورن كبني داسراتيلوموجود

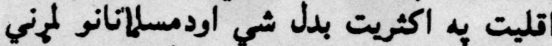

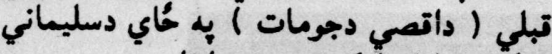

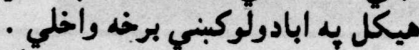
خداي تعالي فرمانيلي: (ر ومكرواوميكرالله

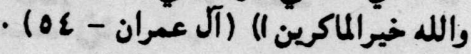

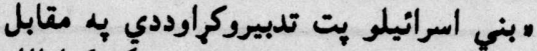

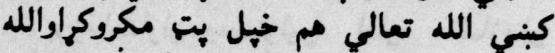

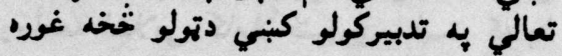

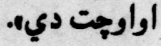

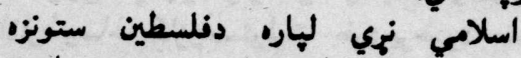

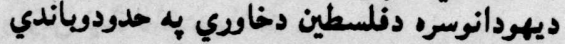

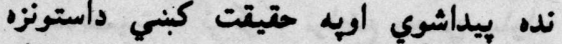

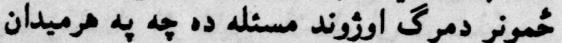

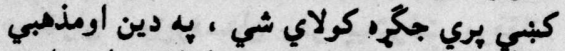

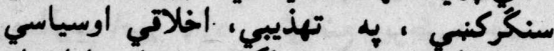

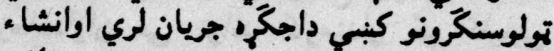

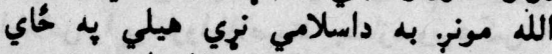

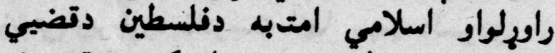

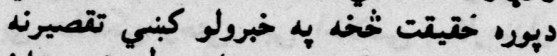

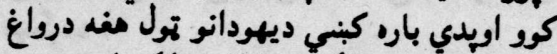

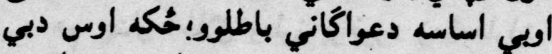

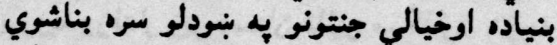

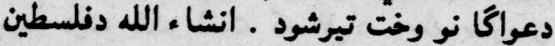
خاورن به ددي خاوري حتيقي وارثانو ته بـ به لاس

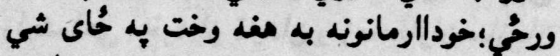

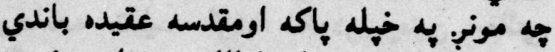

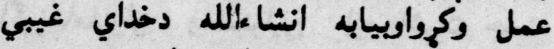

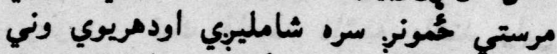

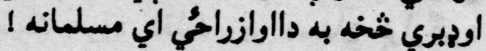

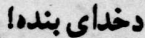

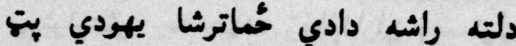
شويدي سرنى وريري كري.
بَّه وار غوبنتني سره سران ني اتومي وسلو

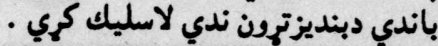

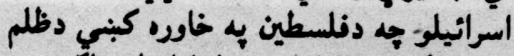

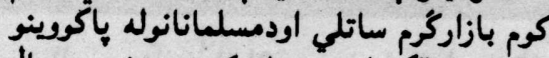

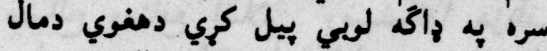

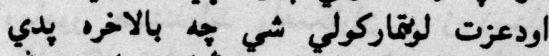

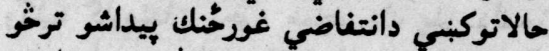

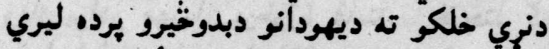

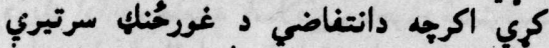

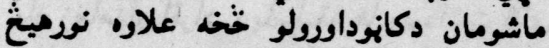

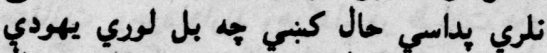

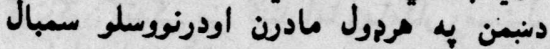

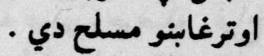

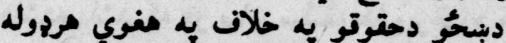

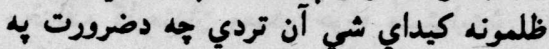

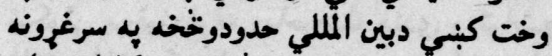

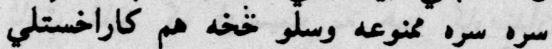

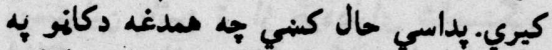
وسيلد متابلد كوونكي كوخينيان اومسلماني

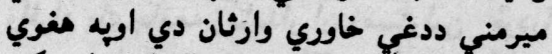

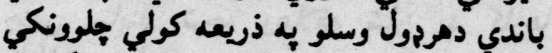

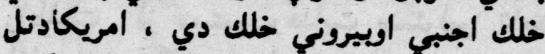

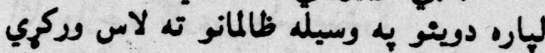

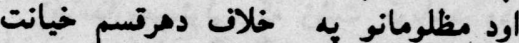

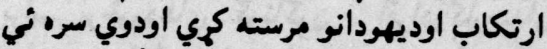

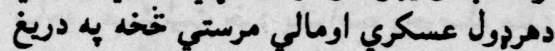

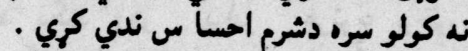

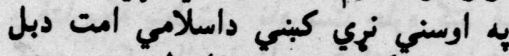

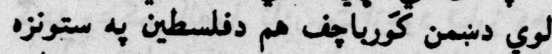

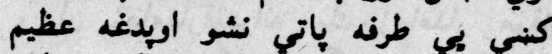

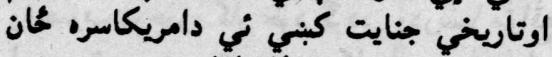

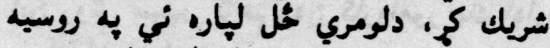

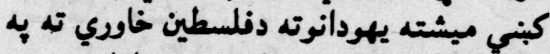

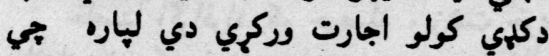

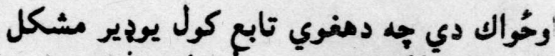

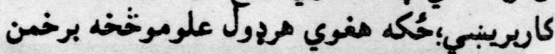
- $)^{2}$

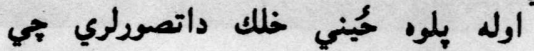

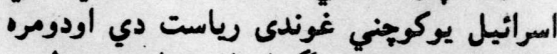
خطرورخخه نشتهب مكردادواره نظرونه سطحي أردي

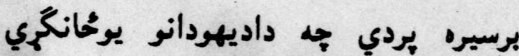

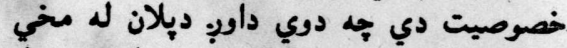

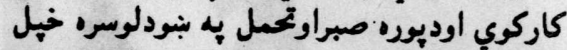

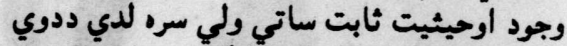

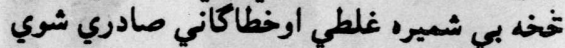

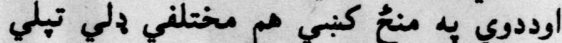

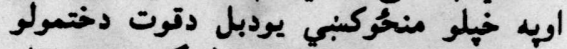

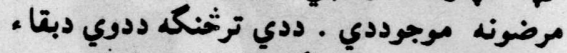

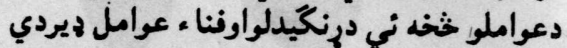

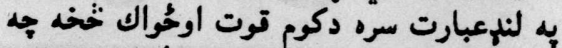

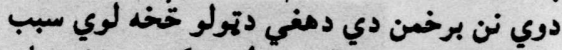

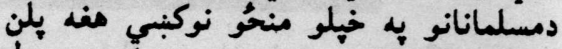

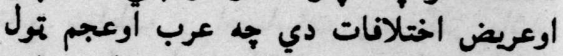

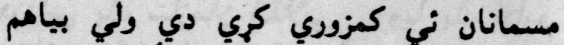

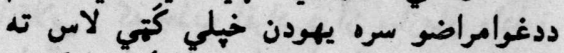

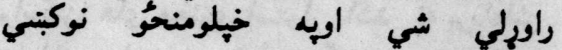

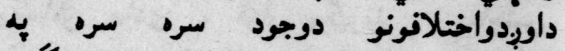

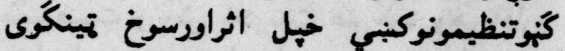

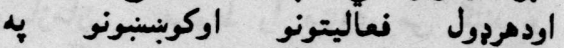

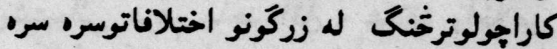

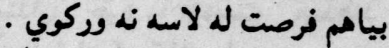

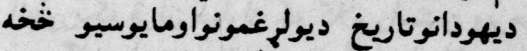

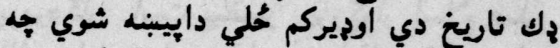

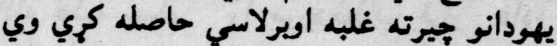

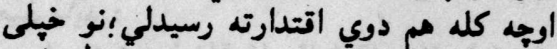

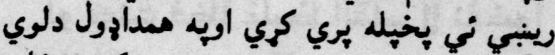

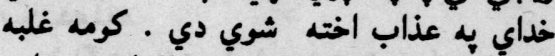

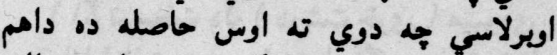

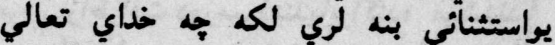
فرمائلم دي: (( بحبل من الله وحبل من الناس)

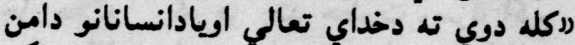

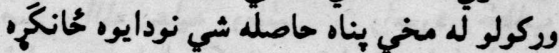
خبره دهردائر (I) ) ديهودانو سباست دتل لياره به دودي درواغو اوكركد ولاه دي اودوي ادعاكوي جه كه جيري

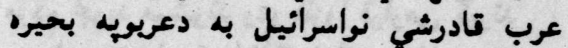

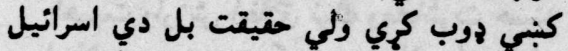

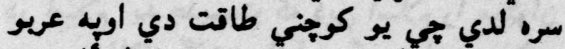

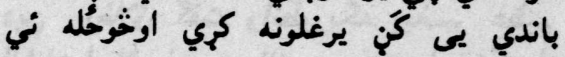

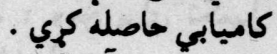
به ختيزه آسياكنبي اسرائيل يوازيني ميواد دي جه داتومي قوت خاوند دي او ورخخف واري 


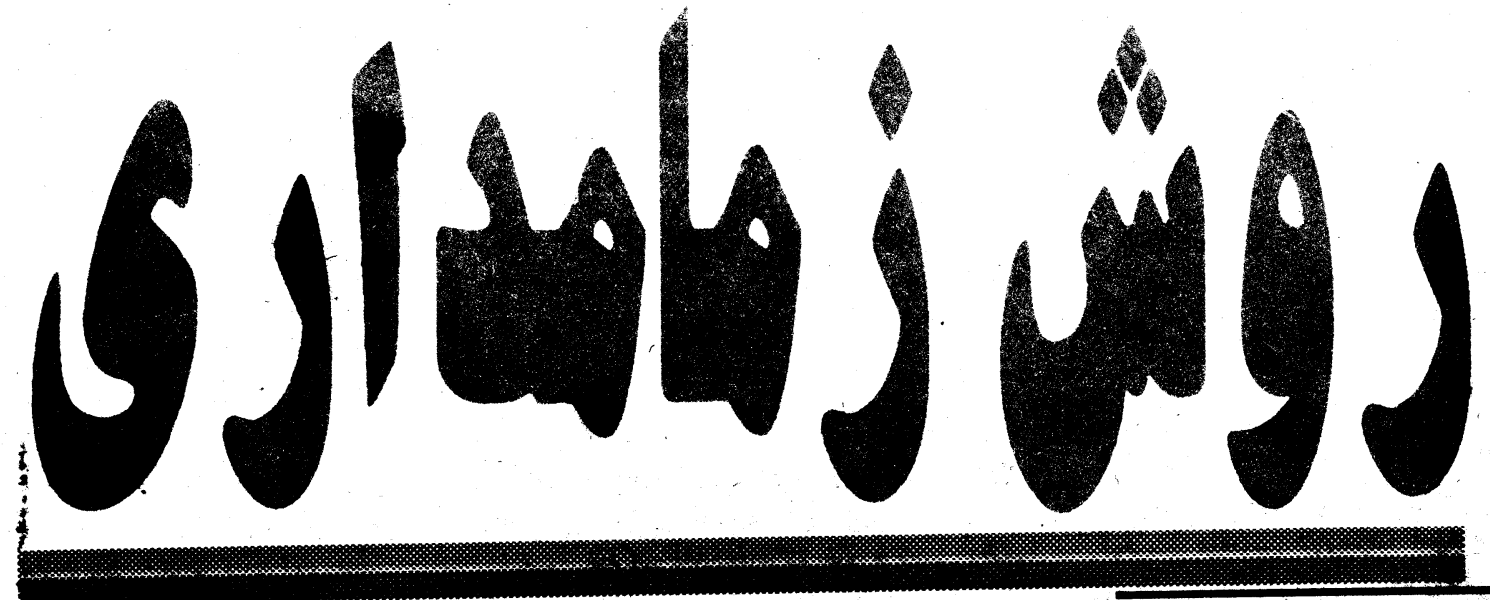

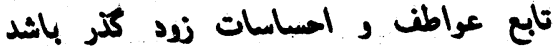

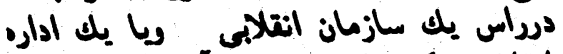

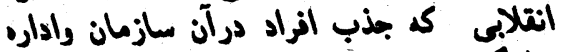

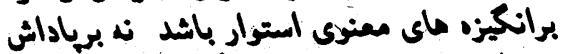

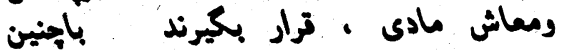

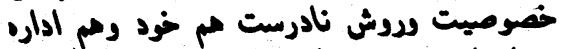

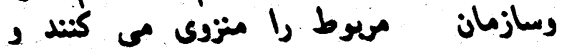

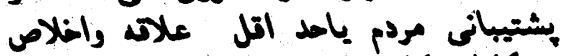

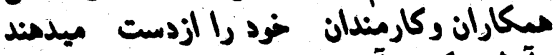

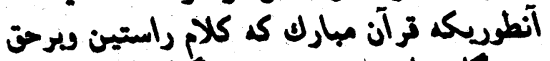

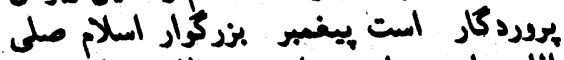

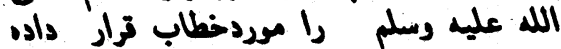
ميغرمايد :

لو كنت فظا عليظ التلب ل الغضوا من مولك الك

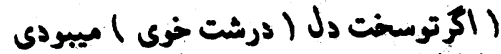

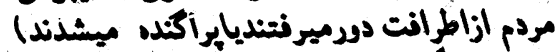

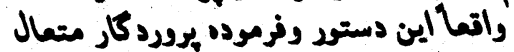

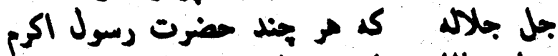

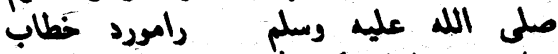

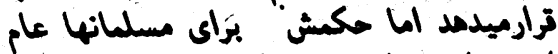

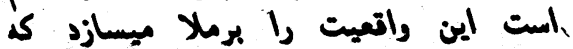

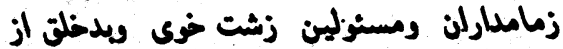

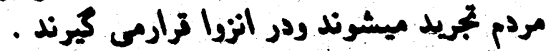

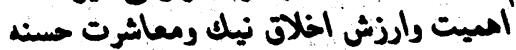

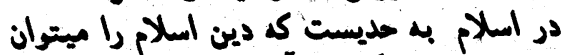

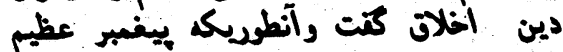

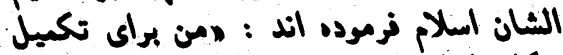

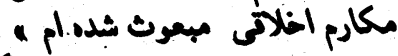

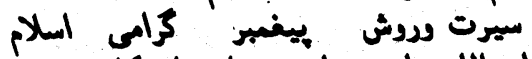
صلى الله عليه وسلم سراسر انعكاس دمينده
مالح ومنافع ابلام رمسلمانها مؤظف

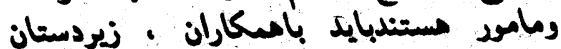

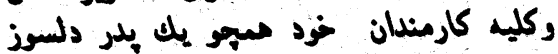

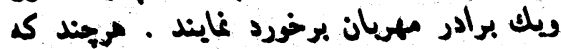

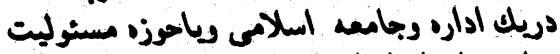

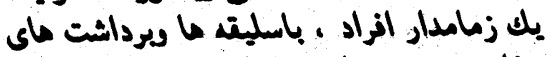

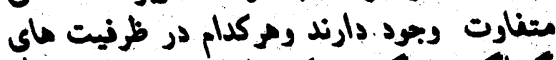

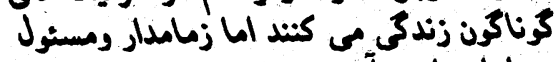

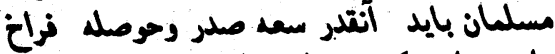

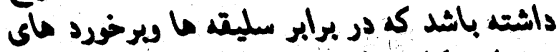

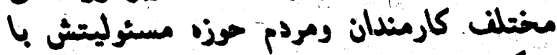

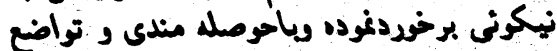

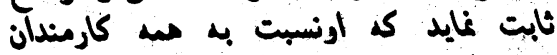

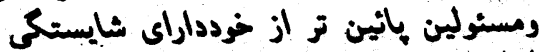

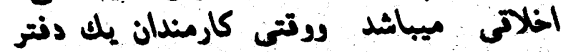

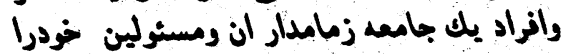

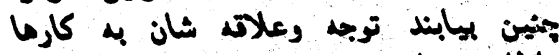

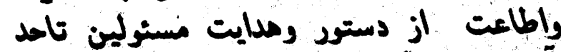

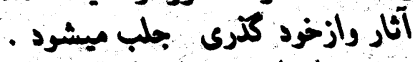

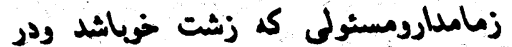

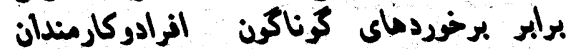

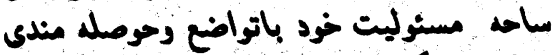

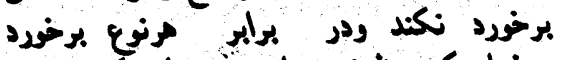

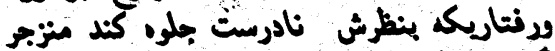

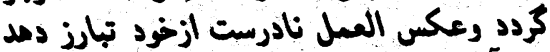

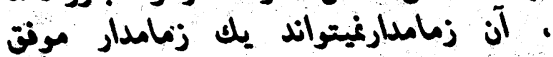

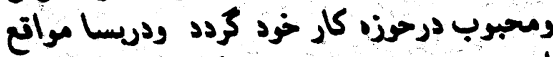

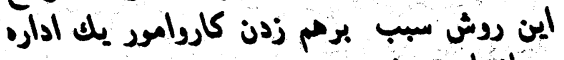

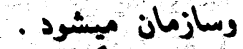

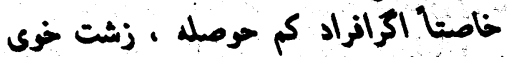

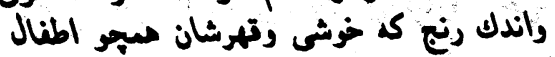

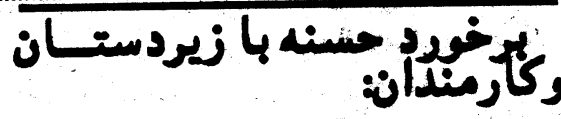

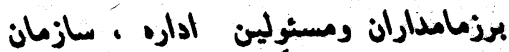

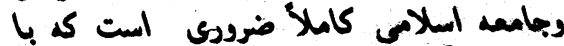

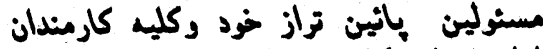

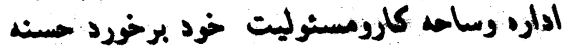

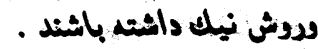

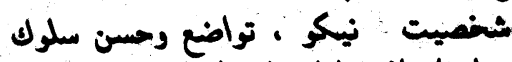

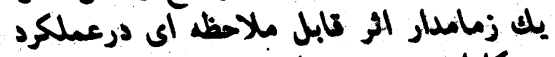

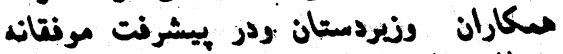

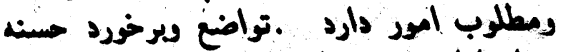

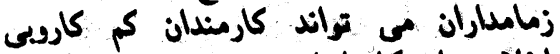

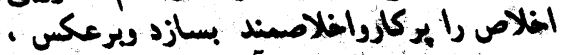

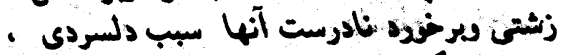

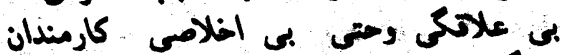

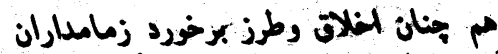

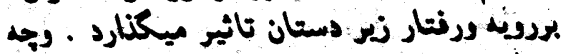

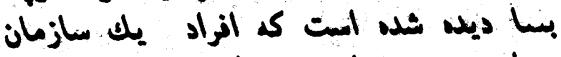

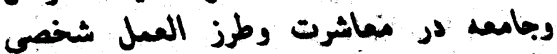

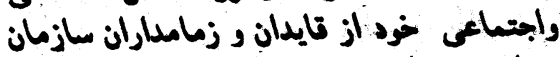

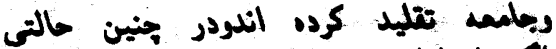

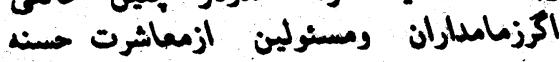

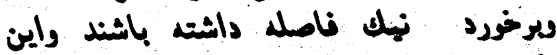

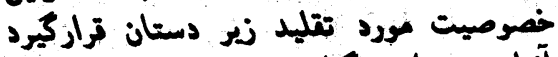

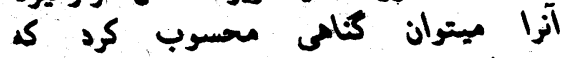

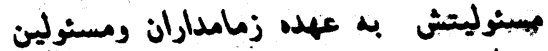

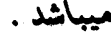
زمامداران ومسئولين مسلسانها كه براى

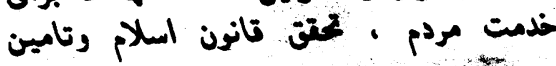




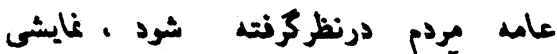

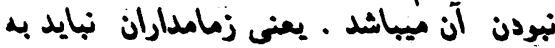

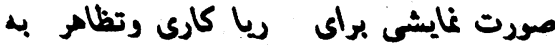
ملاكات ها ومذاكرات تلابه وخرمايشى باتعداد

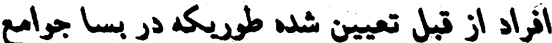

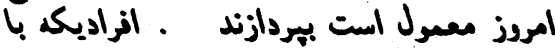

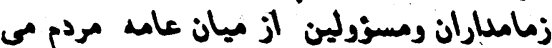

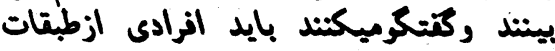

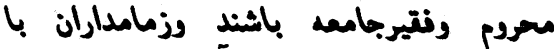

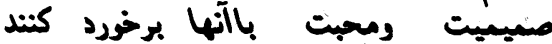

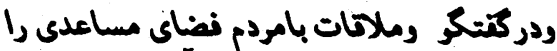

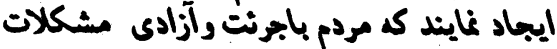
خود را باز كو كنتد ورنتار نادرست مسنولين وائين

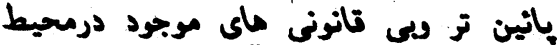

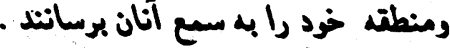

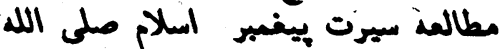

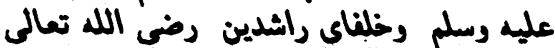

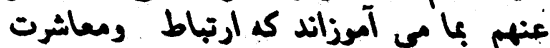

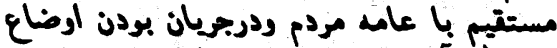

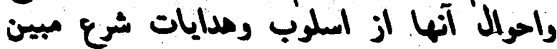

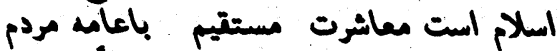

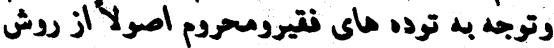

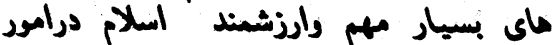

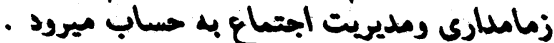

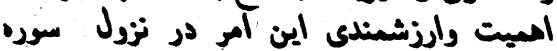

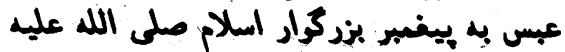

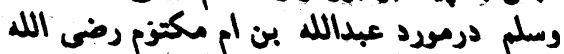

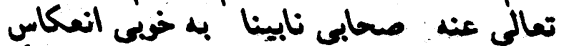

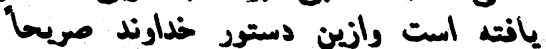

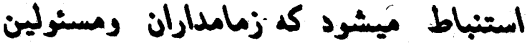

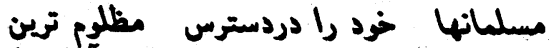

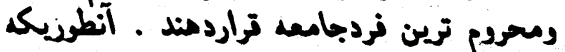

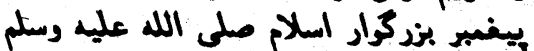

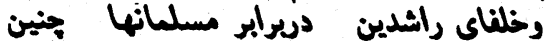

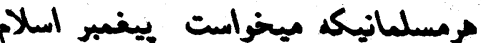

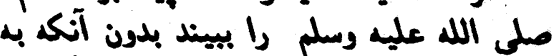

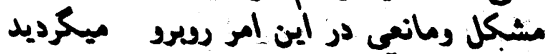

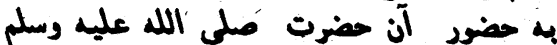

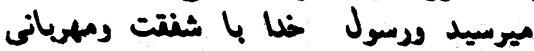

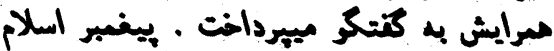

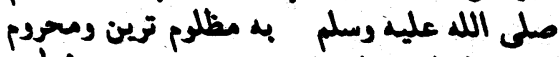

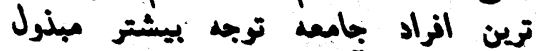

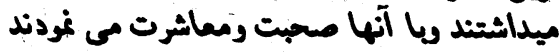

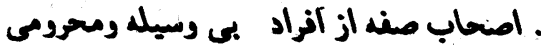

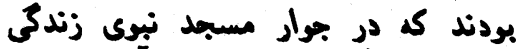

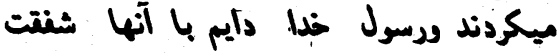
خلفاى راشدين نيز مطابت مبردئ باسيرت
معنى ومغهوم اين مطلب كه مردم زمامداران

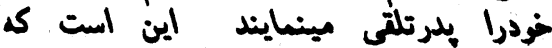

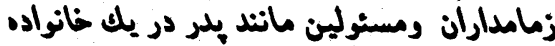

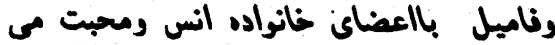

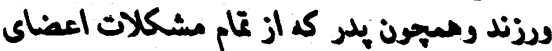

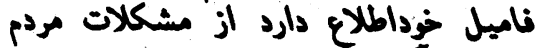

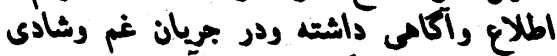

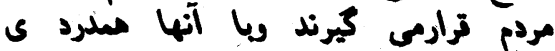

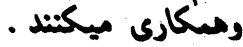

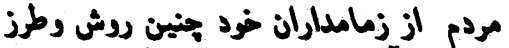

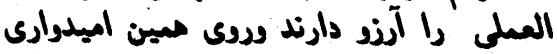

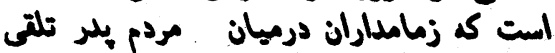

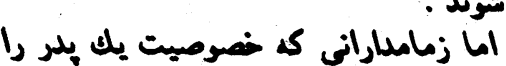

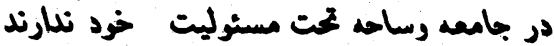

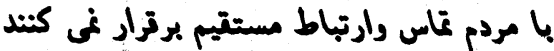

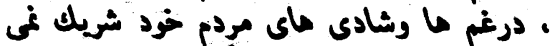

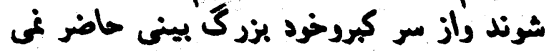

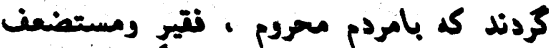

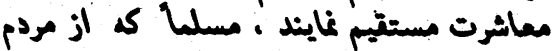

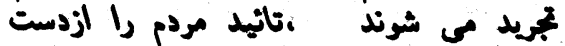

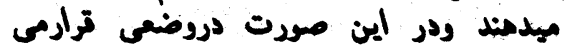

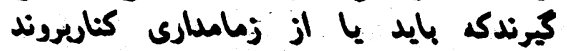

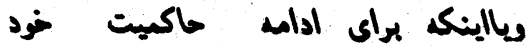

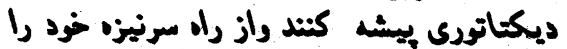

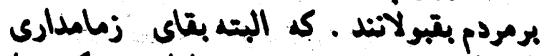

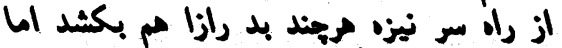

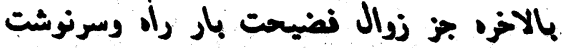
هريند برترارى ارتباط مبستقيم باعلها

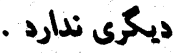

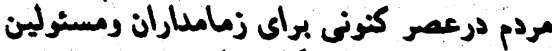

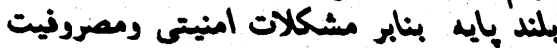

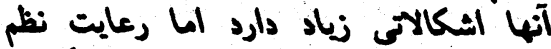

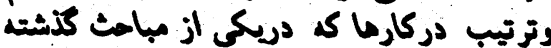

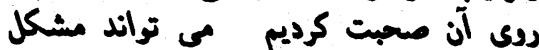

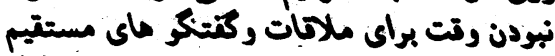

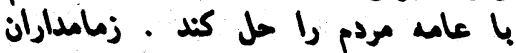

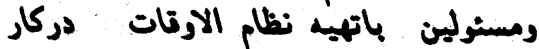

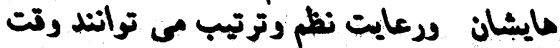

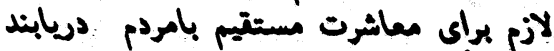
راصولا بايد براى اين امر مدتى رأ الختصاص

$$
\text { داصند }
$$

مشكل امنيتى نيز به اين شكل كماند

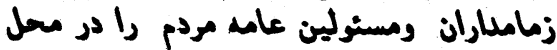

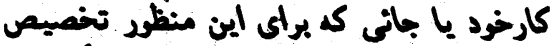

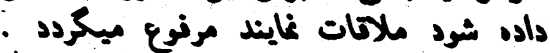

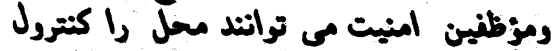

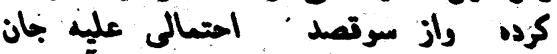

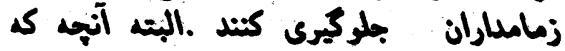

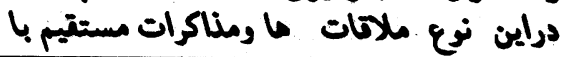

عالى ترين وعطيم ترين اخلاق نيكو وبرخورد

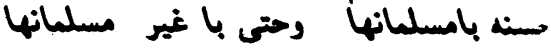

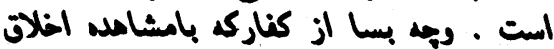

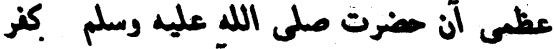

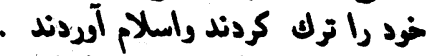

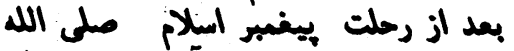

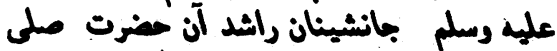

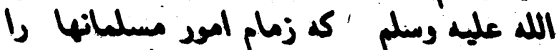

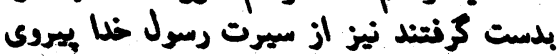

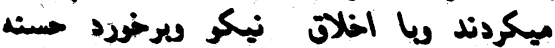

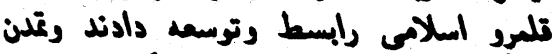

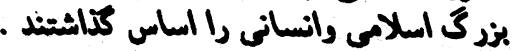

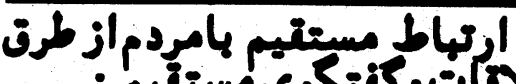

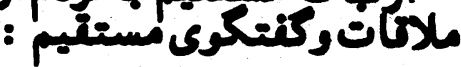

زماهداران ومستولين مسلمان بايد باعاهـ

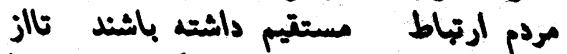

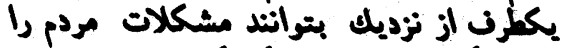

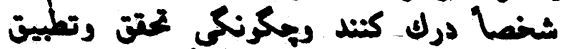

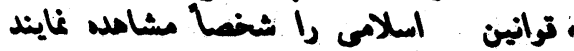

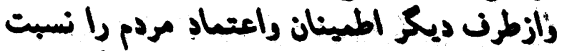

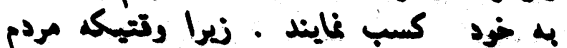

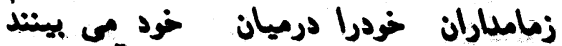

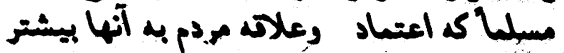
- as

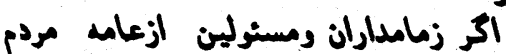

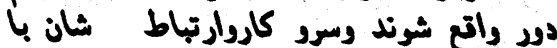

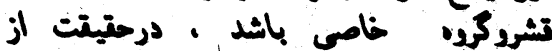

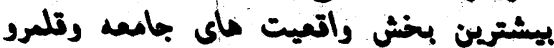

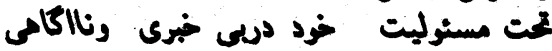

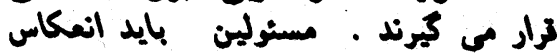

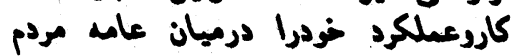

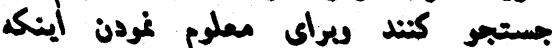

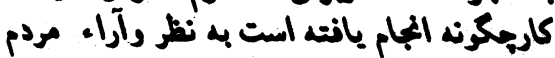

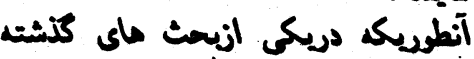

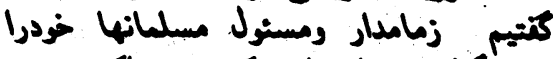

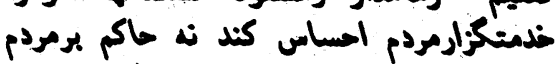

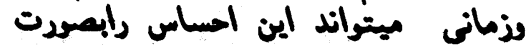

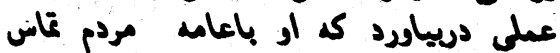

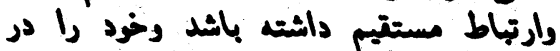

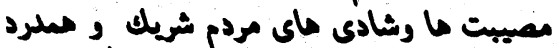

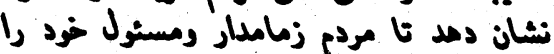

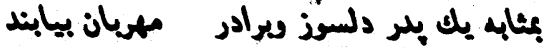

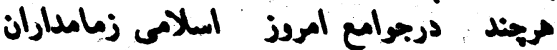

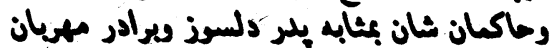

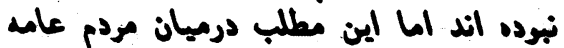

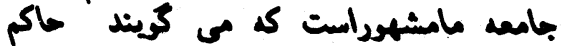

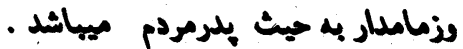


مسلمانها المتناده ناجايز ونامبثروع ميدارد

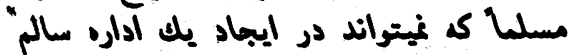

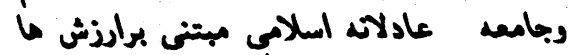

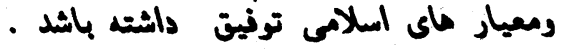

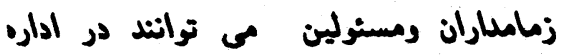

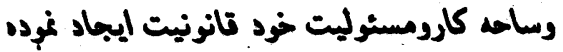

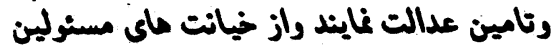

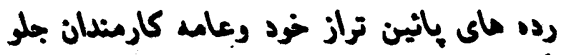

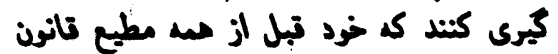

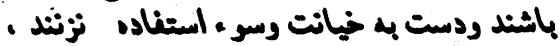

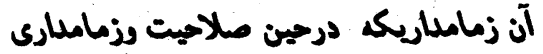

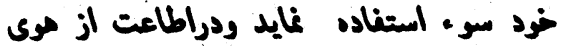

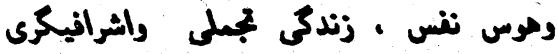

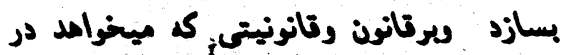

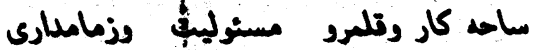

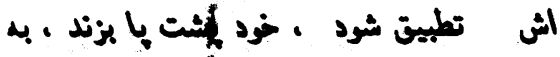

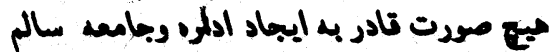

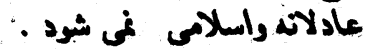

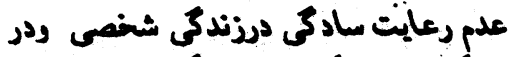

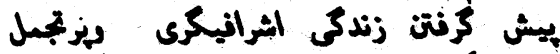

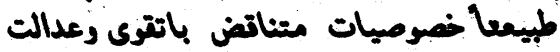

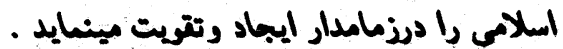

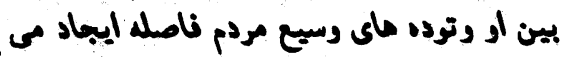

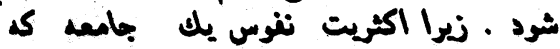

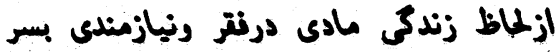

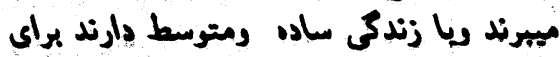

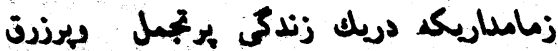

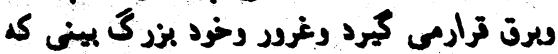

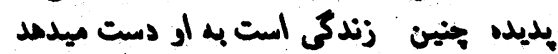

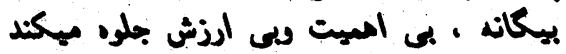

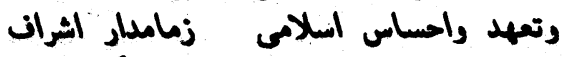

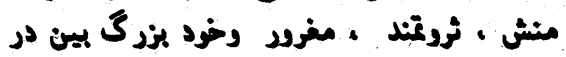

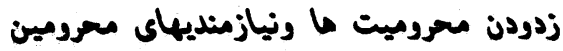

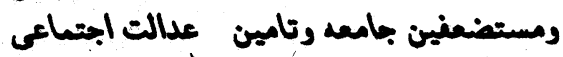

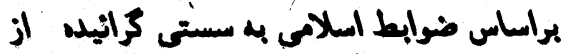

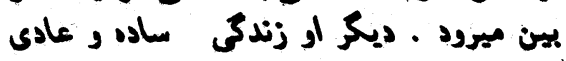

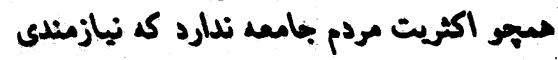

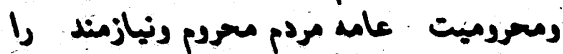

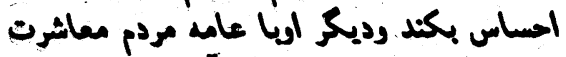

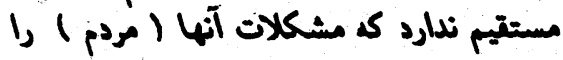

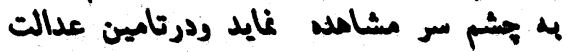

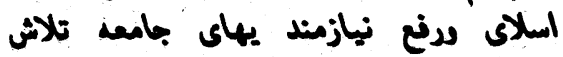

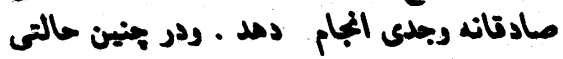

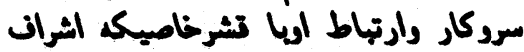

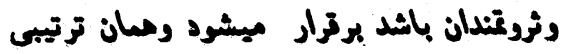

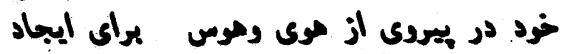

"بوده وازاين نقاط نظر نسبت به سايرافراد

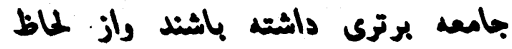

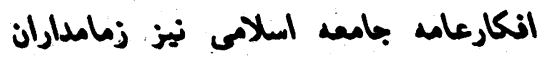

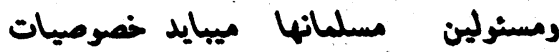

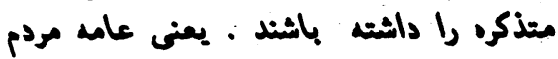

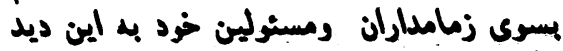

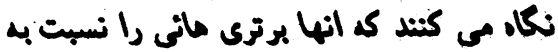

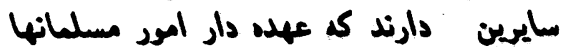

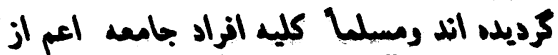

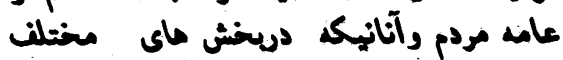

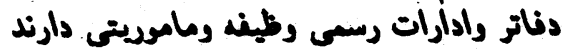

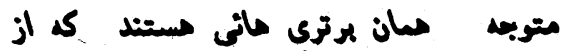

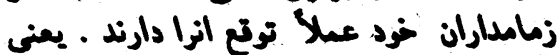

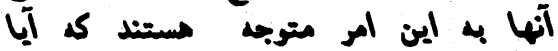

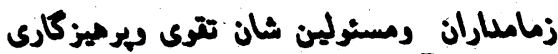

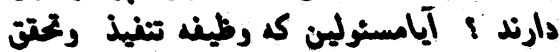

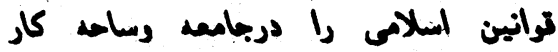

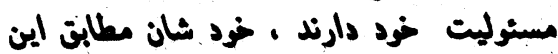

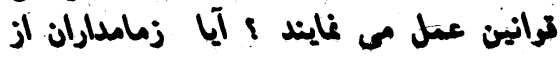

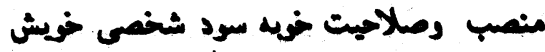

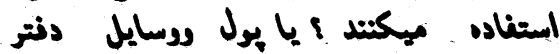

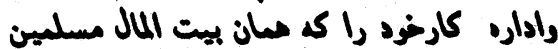

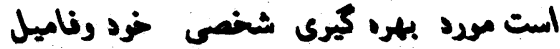

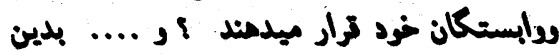

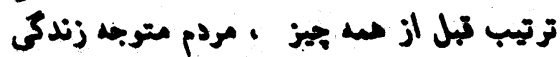

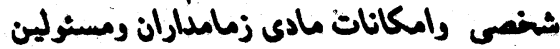

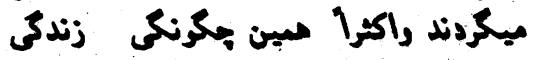

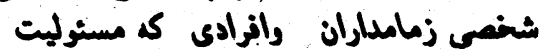

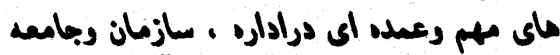

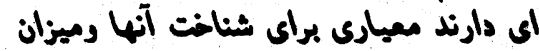

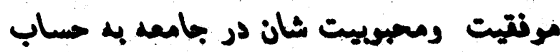

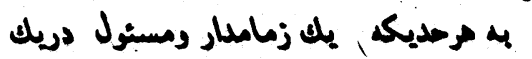

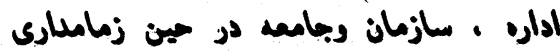

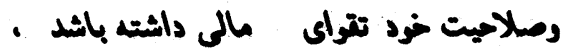

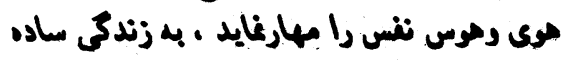

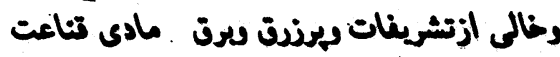

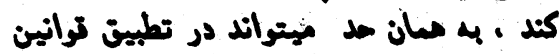

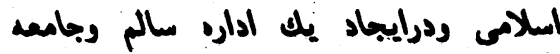

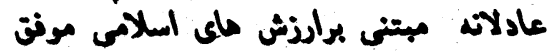
باندان

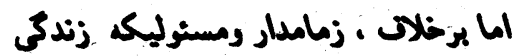

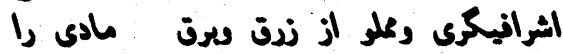

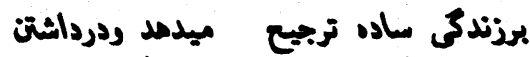

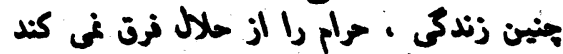

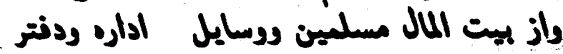

رورش بيغم اسلام صلى الله عليه وسلم.

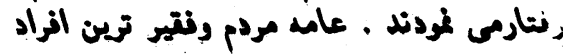

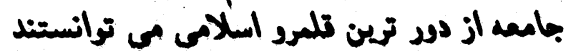

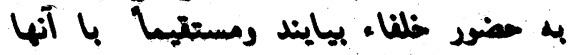

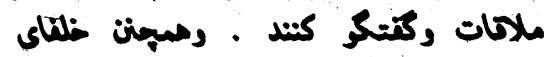

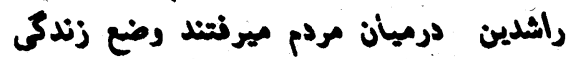

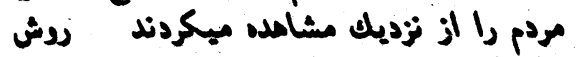

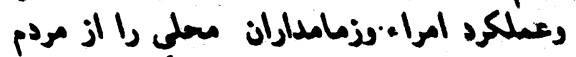

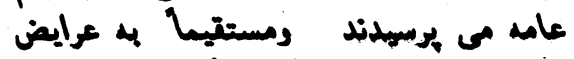

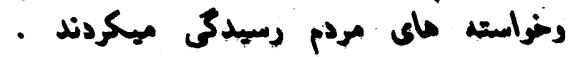

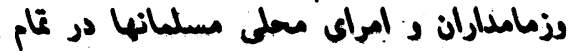

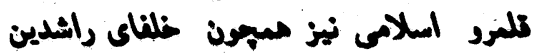

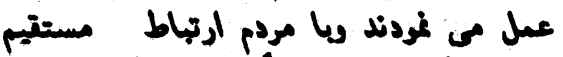

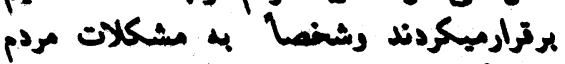

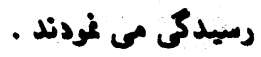

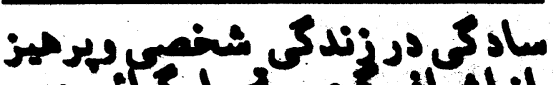

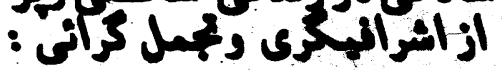

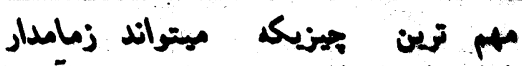

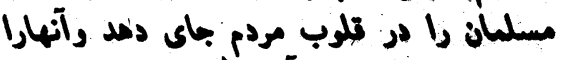

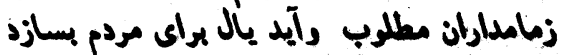

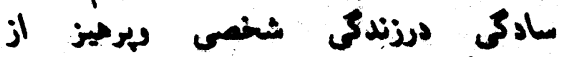

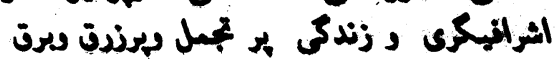
آنطوريك درميامث كذشته خاطرنشان

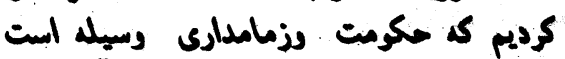

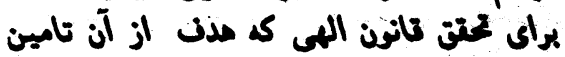

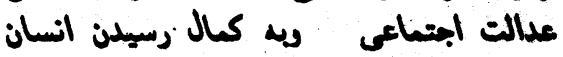

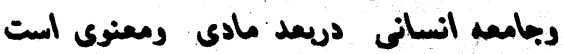

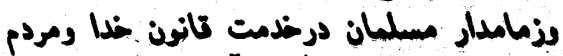

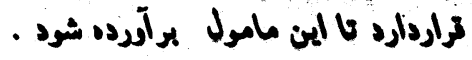

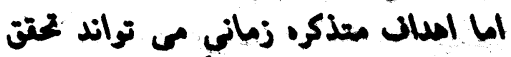

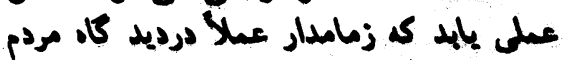

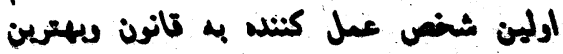

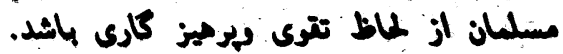

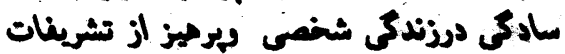

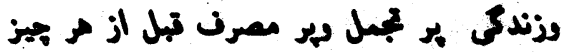

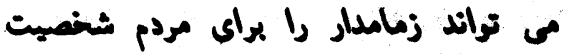

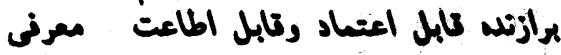
- دإن

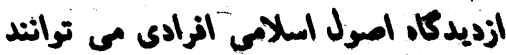

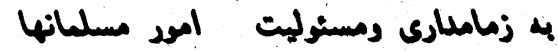

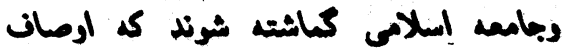

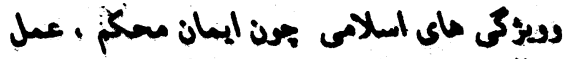

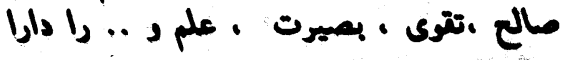


خود زندكى بسيار ساده داشته ودايم دردسترس

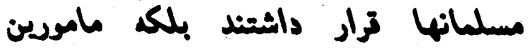

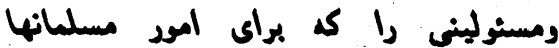

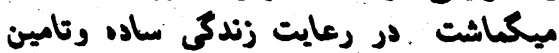

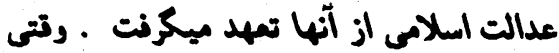

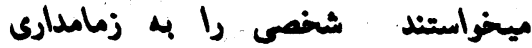

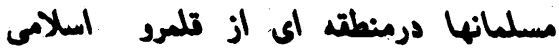

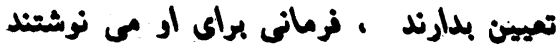

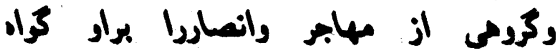

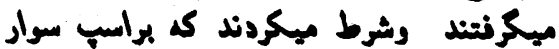

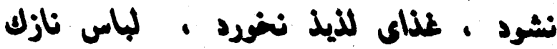

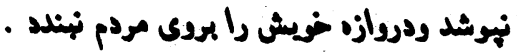

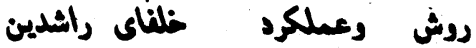

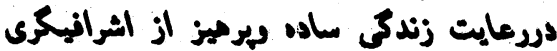

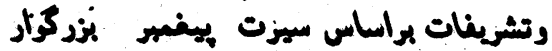

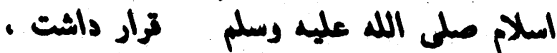

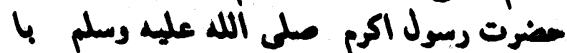

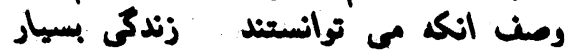

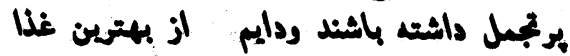

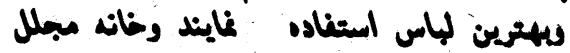

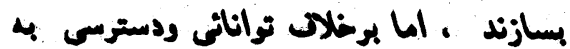

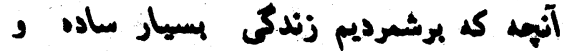

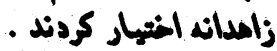

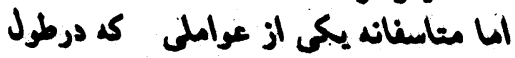

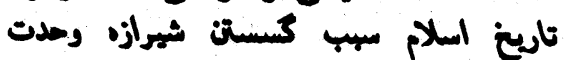

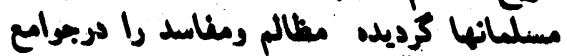

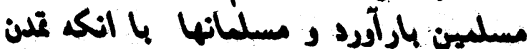

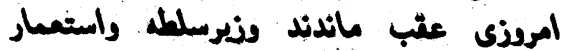

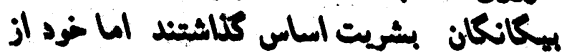

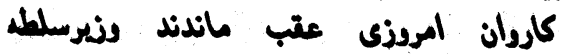

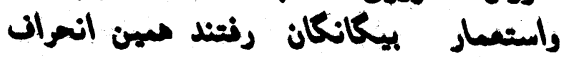

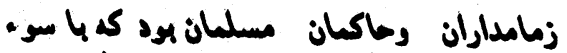

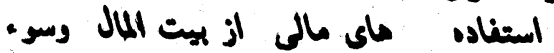

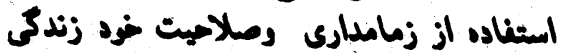

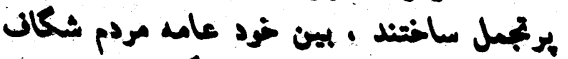

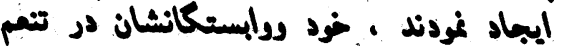

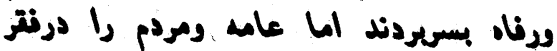

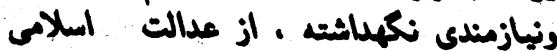

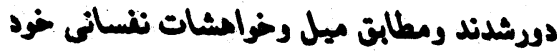

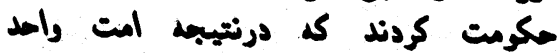

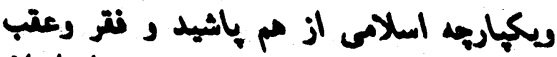

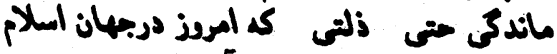

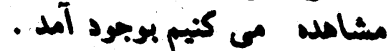

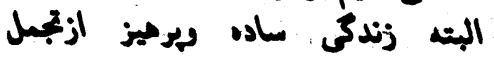

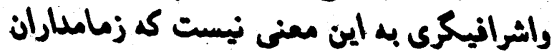

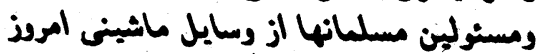

در بيش كرنتن زندكى ساده ودور ازيجمل

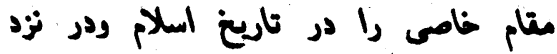

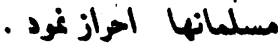

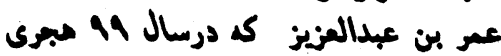

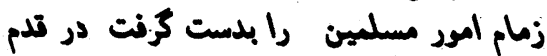

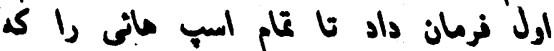

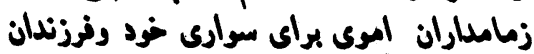

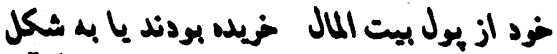

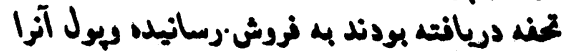

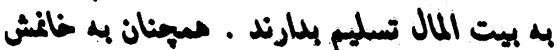

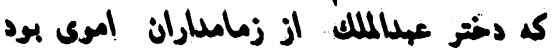

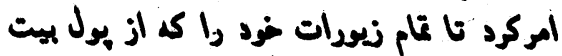

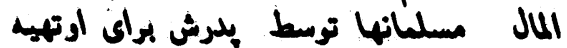

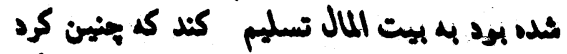

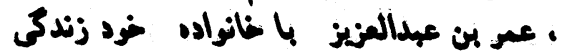

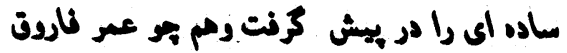

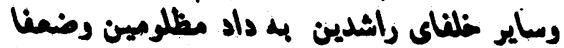

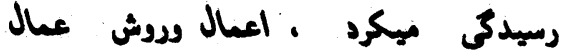

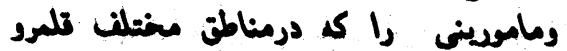

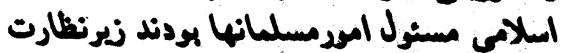

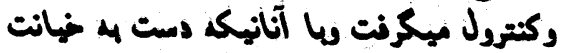

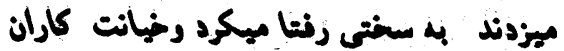

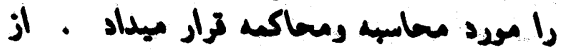

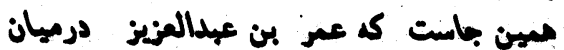

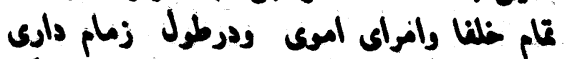

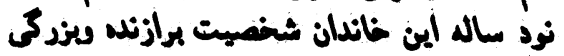

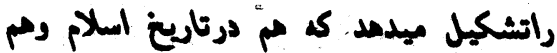

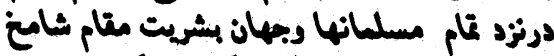

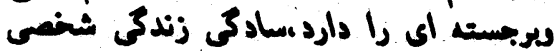

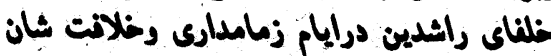

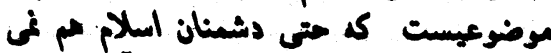

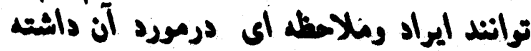

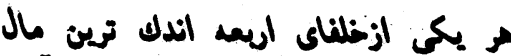

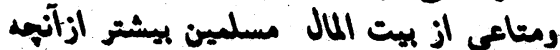

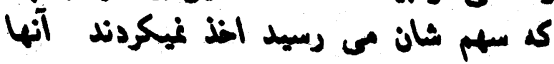

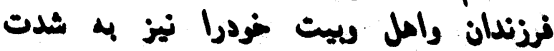

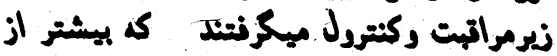

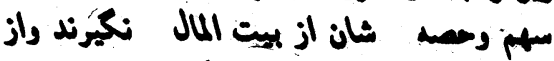

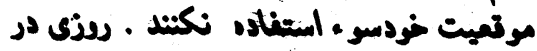

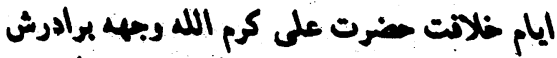

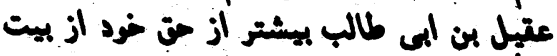

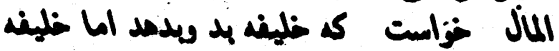

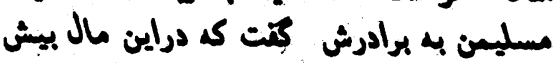

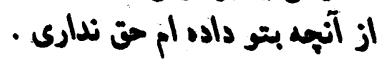
عمر نارون خليفه دوم مسلمين نه تنها كد
زند3ى برجبمل درفساد وخيانت غرت ميشود

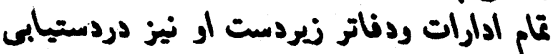

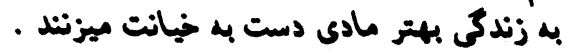

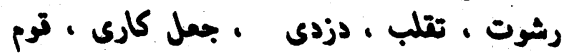

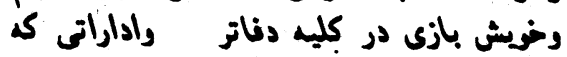

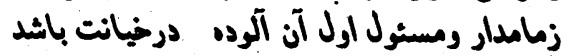

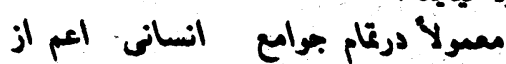
بوجود ميآيد

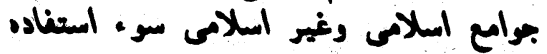

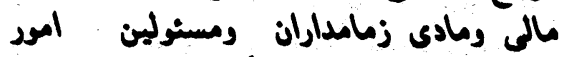

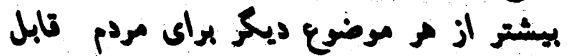

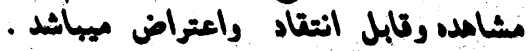

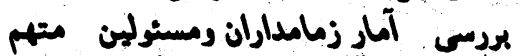

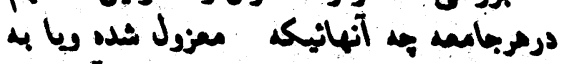

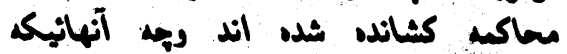

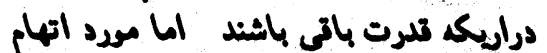

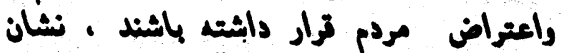

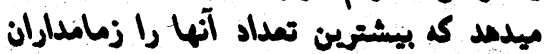

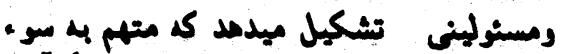

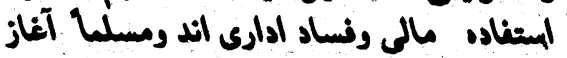

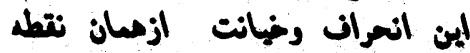

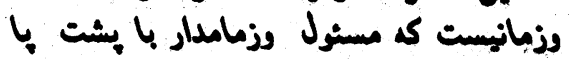

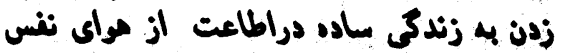

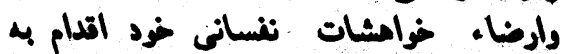

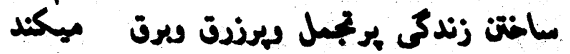

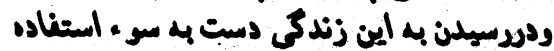

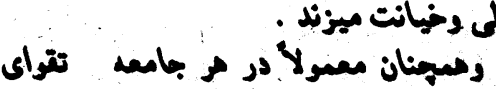

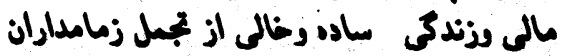

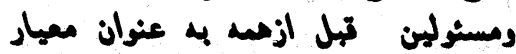

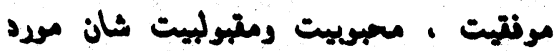

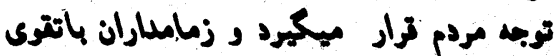

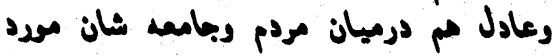

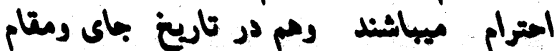

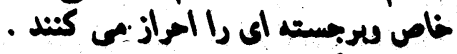

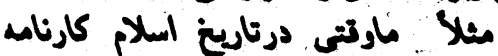

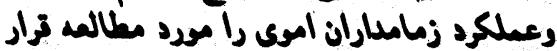

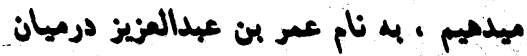

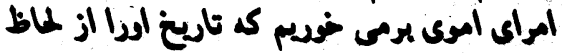

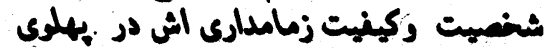

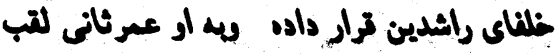

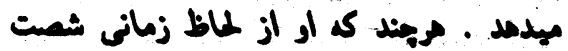

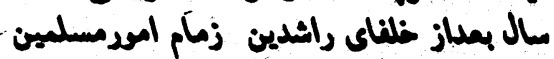

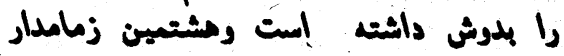

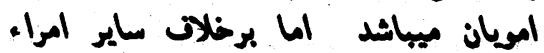

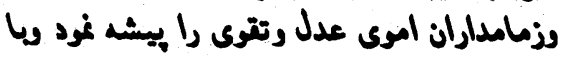


وبر تز بنداشته ودر تنغيذ وتطبيت قوانيى

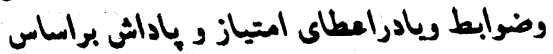

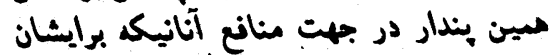

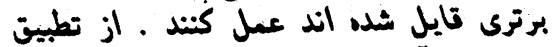

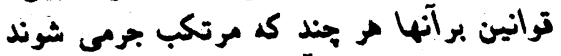

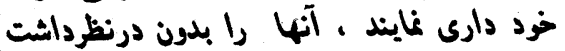

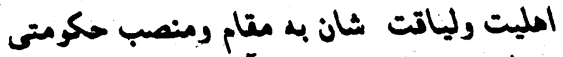

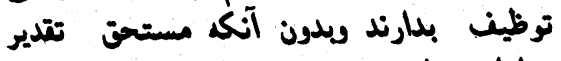

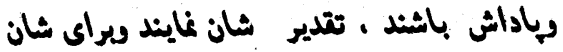

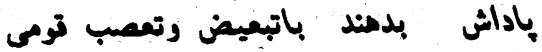

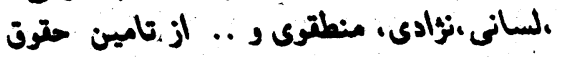

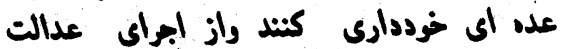

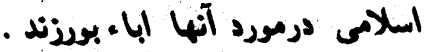

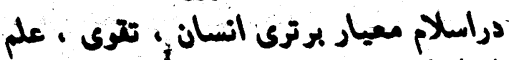

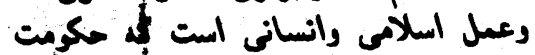

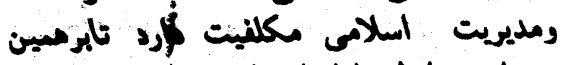

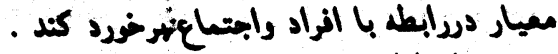

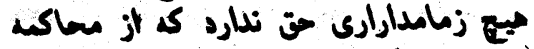

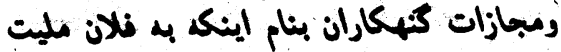

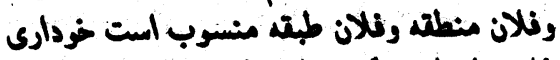

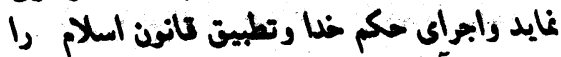

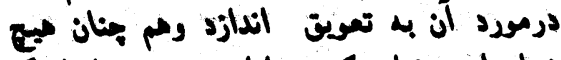

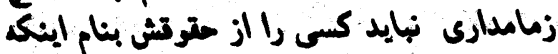

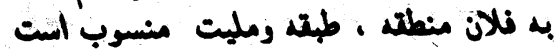

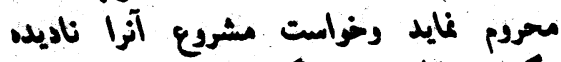

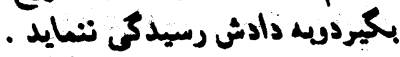

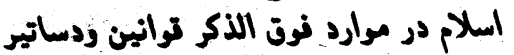

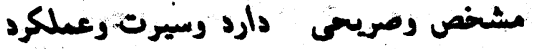

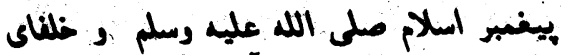

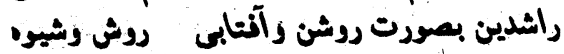

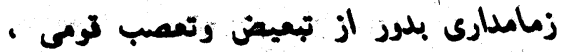

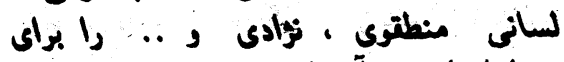

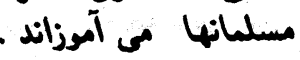

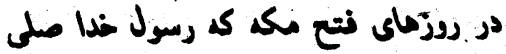

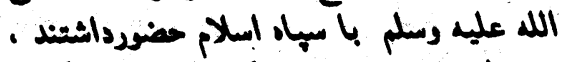

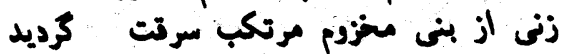

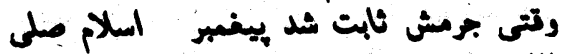

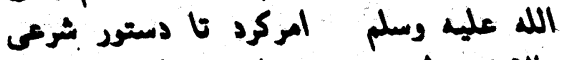

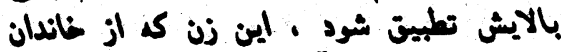

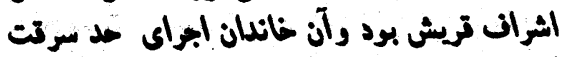

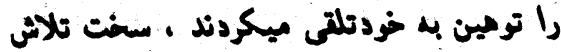

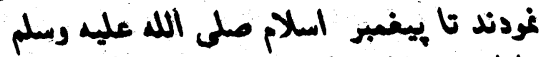

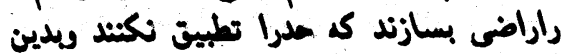

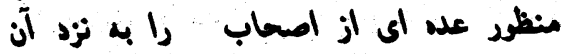

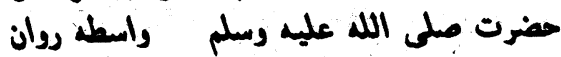

را با رنج ومشتت بدست بياورند وبراى زندكى

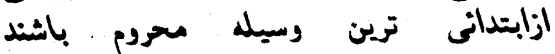

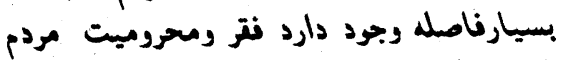

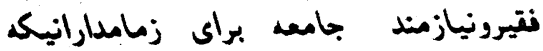

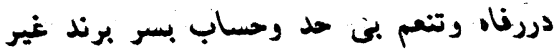

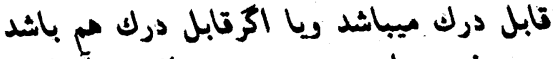

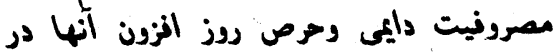

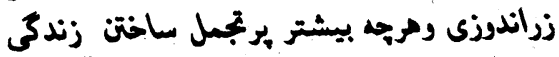

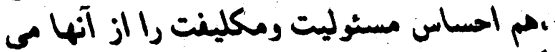

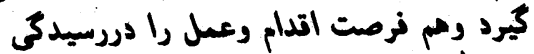

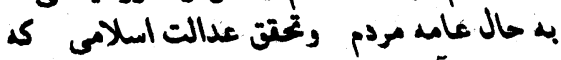

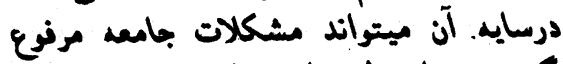

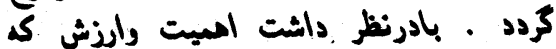

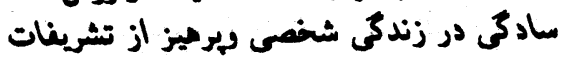

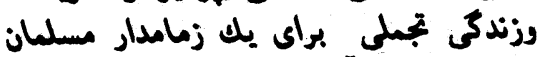

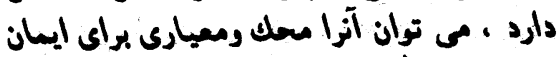

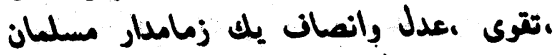

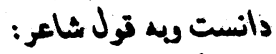

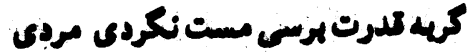

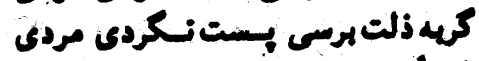

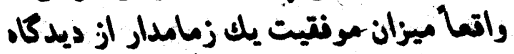

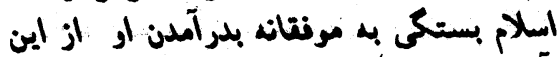

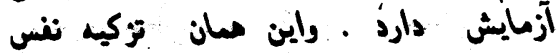

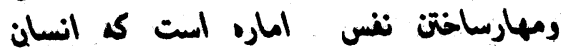

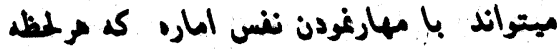

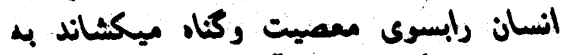

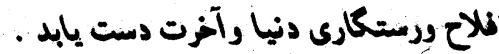

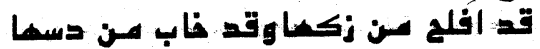

\section{هو هن از تهميض و تعصب :}

از آنجانيكه اسلام ،دين وآيتن خدارنديست

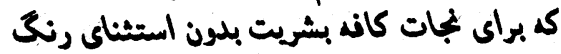

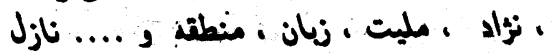

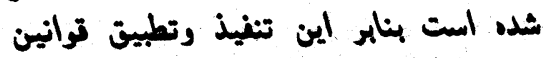

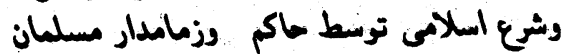

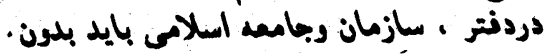

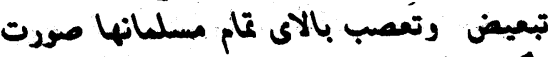

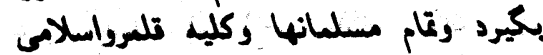

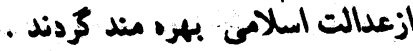

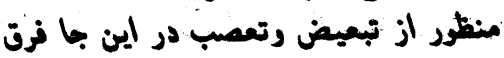

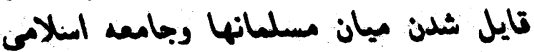

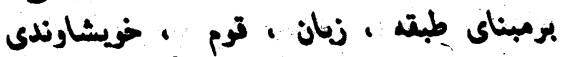

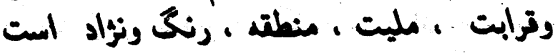

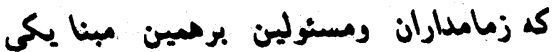

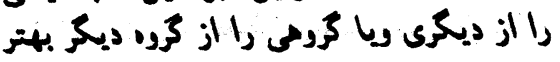

كم ضرودتى عمده دراجراويشبرد امور

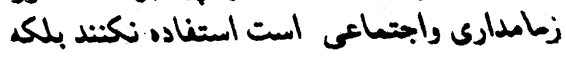

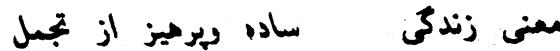

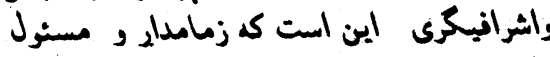

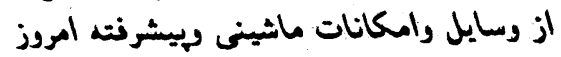

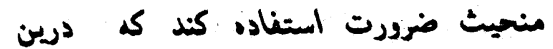

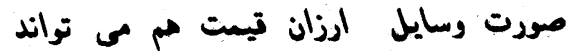

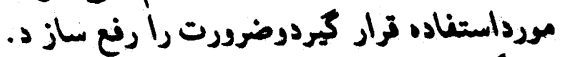

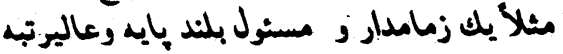

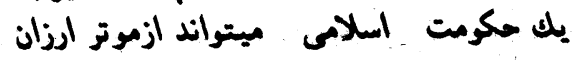

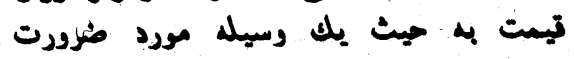

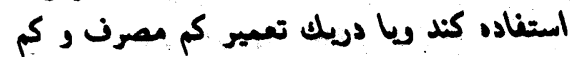

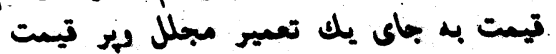

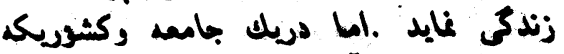

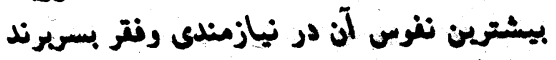

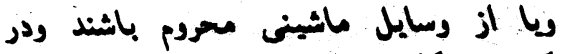

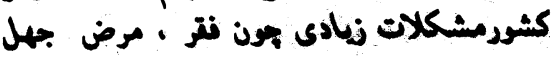

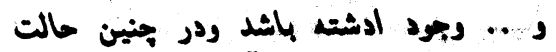

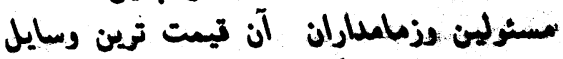

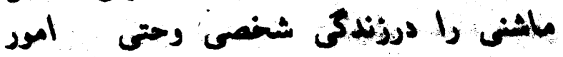

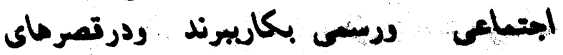

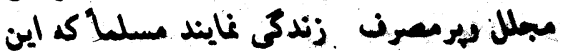

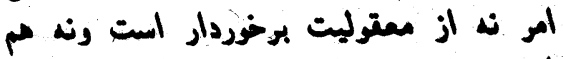

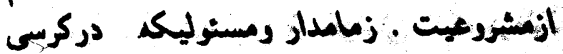

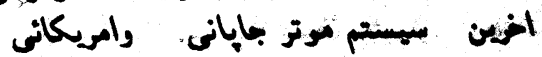

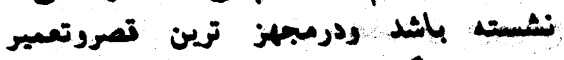

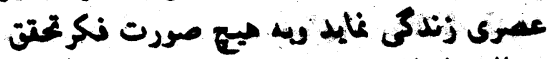

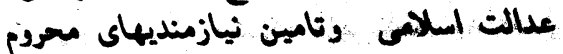

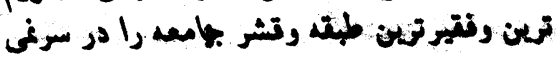

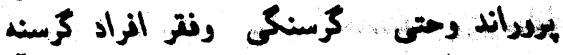

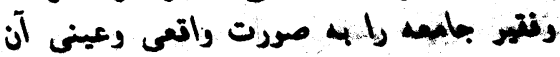

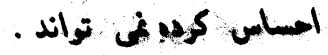

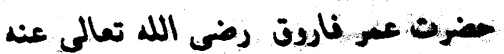

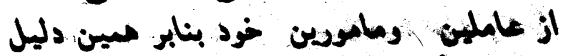

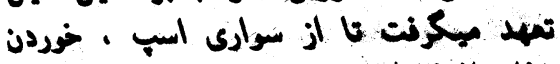

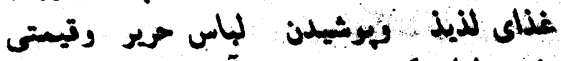

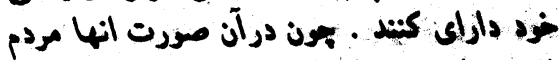

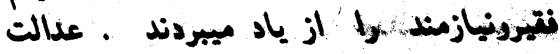

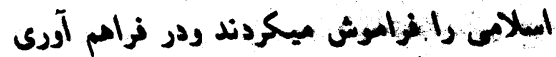

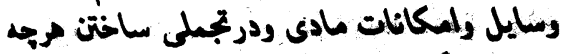

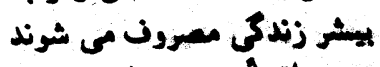

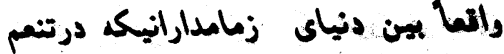

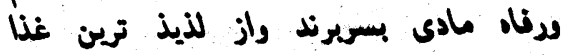

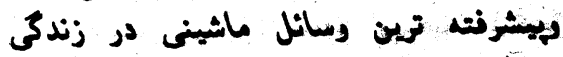

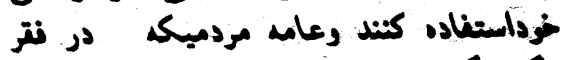

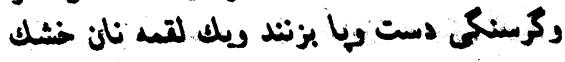


ايى رابوجود آرددند ،هرجند كه دسايس

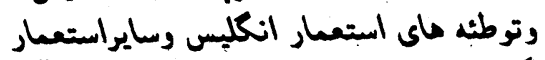

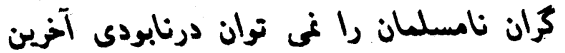

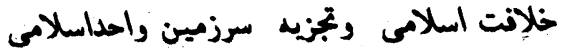

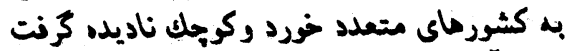

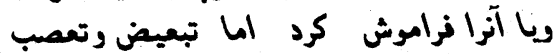

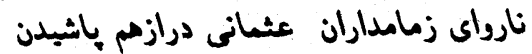

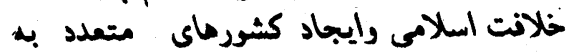

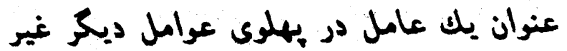

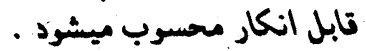

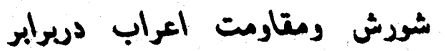

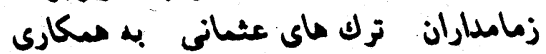

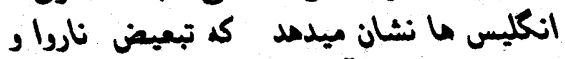

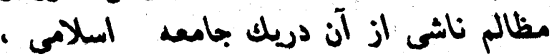

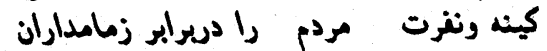

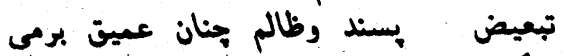

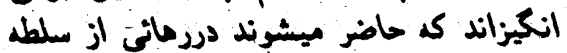

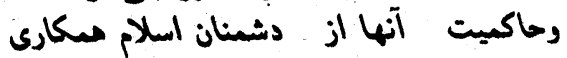

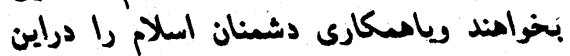

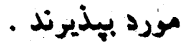
واتعا" دريك كثوراسلامى بدترين ومنغور

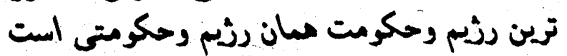

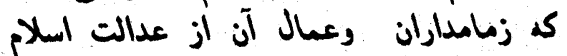

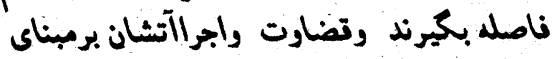

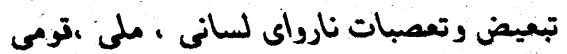

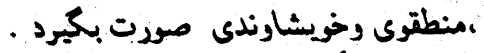

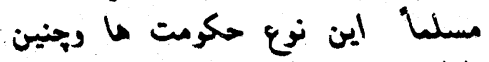

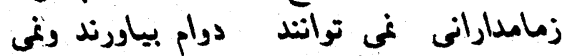

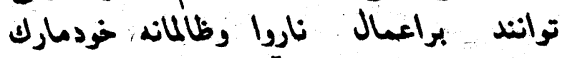

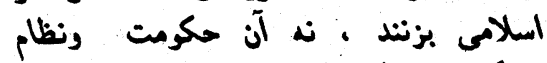

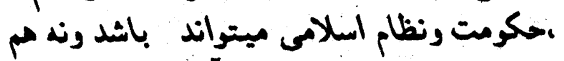

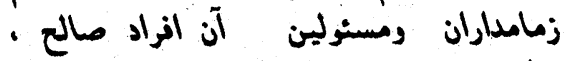

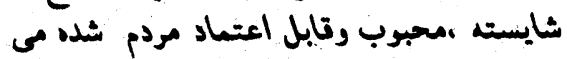

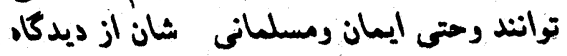

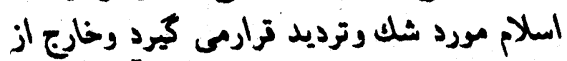

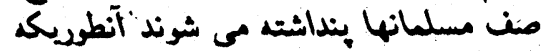

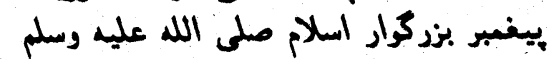

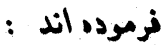

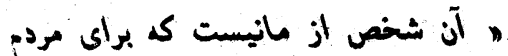

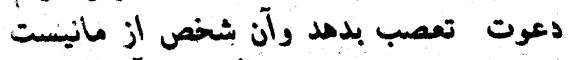

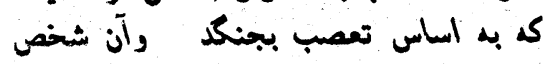

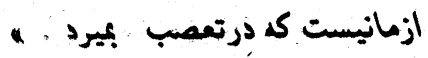

وهر الله التوفيق

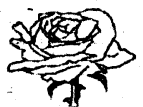

وبى تتوى از يكطرن در يـيشبرد امورادارن

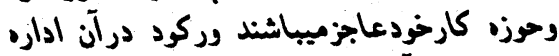

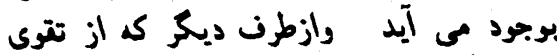

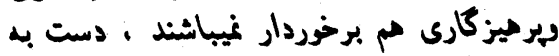

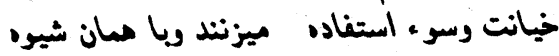

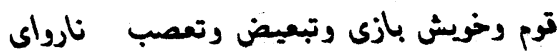

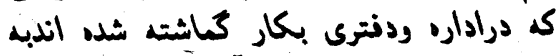

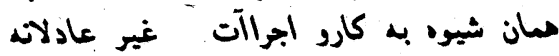

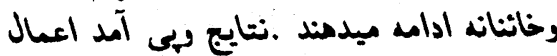

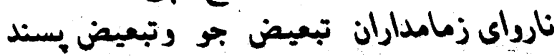

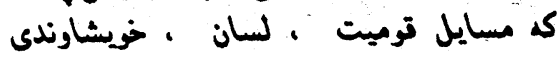

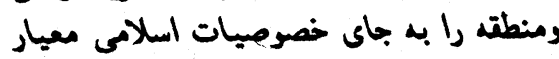

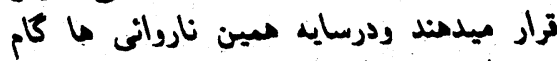

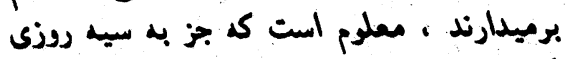

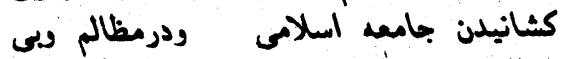

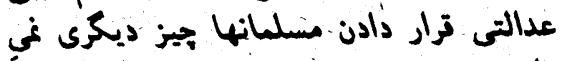
باشد .

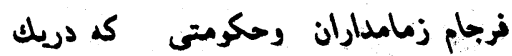

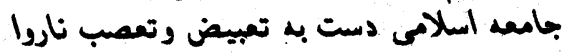

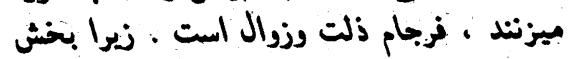

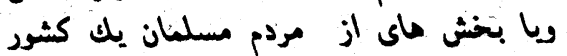

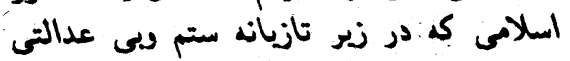

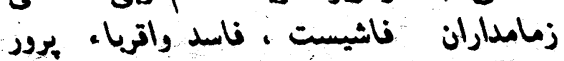

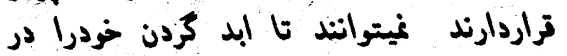

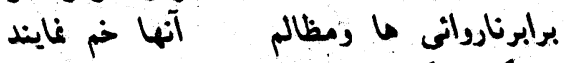

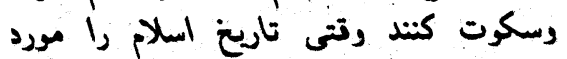

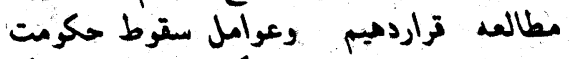

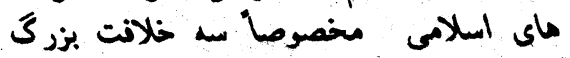

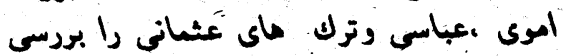

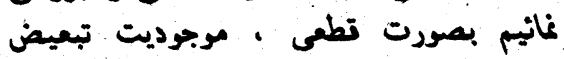

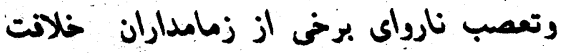

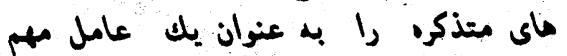

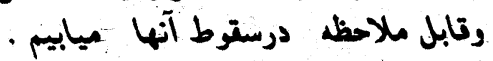

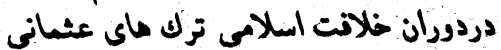

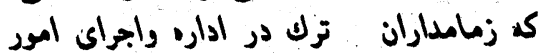

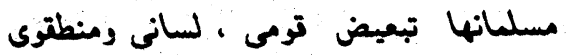

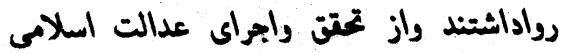

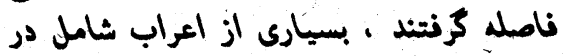

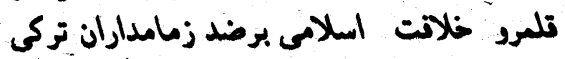

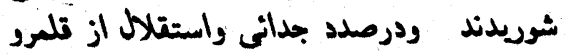

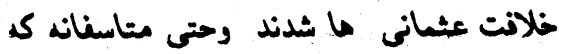

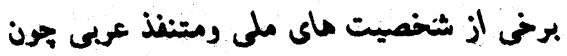

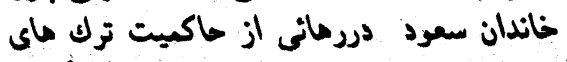

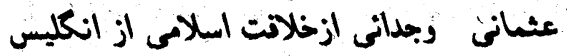

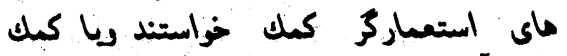
هاى آنهارا بذيرنتند وكثورمنتقل وجداكانه
بيغمبر اسلام صلى الله عليه وسلم

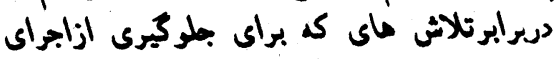

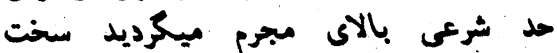

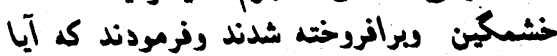

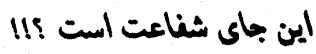

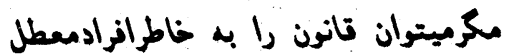

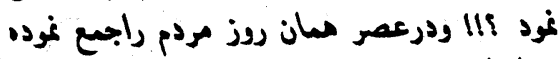

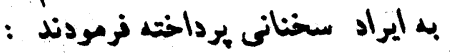

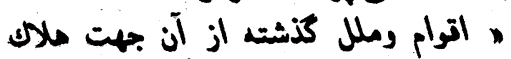

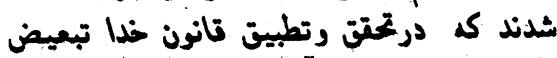

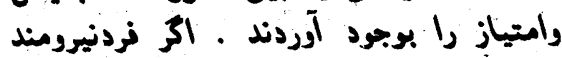

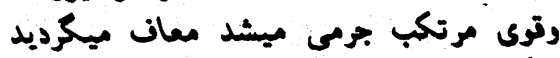

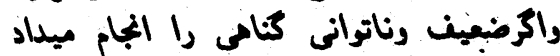

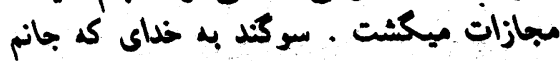

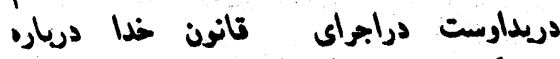

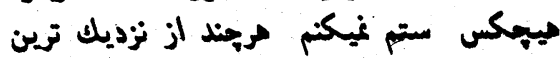

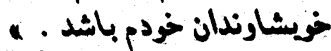

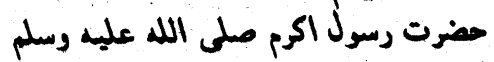

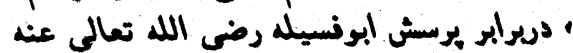

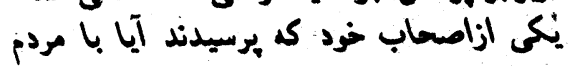

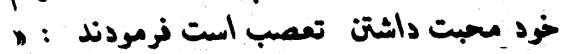

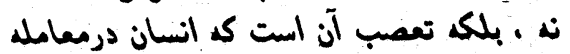

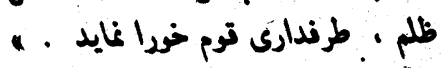

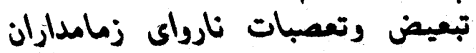

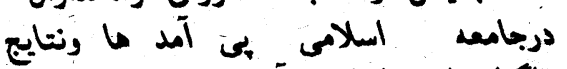
ناكوارزيادى رابارمى آزرد :

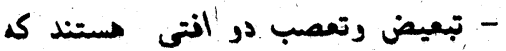

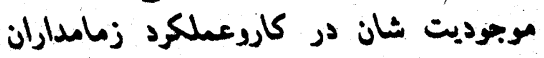

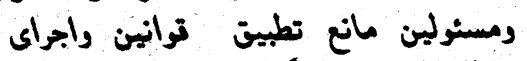

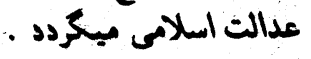

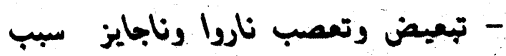

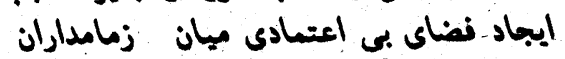

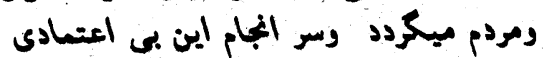

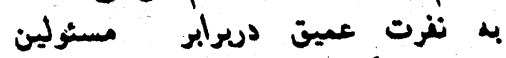

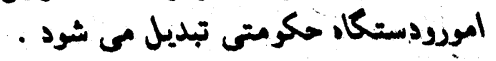

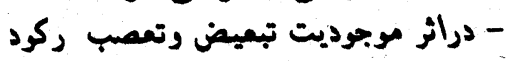

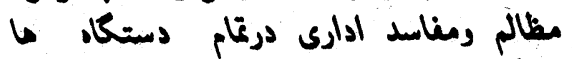

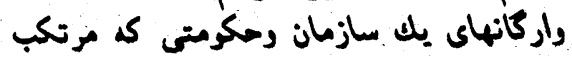

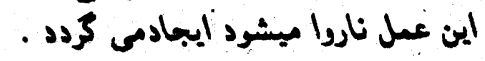

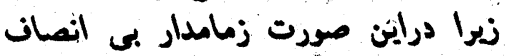

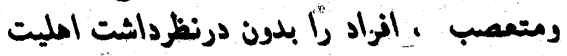

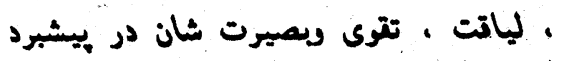

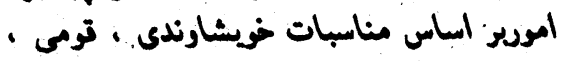

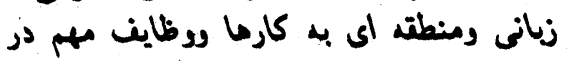

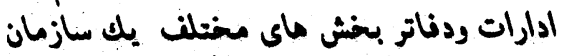
وحكومت ميكارد ومسلس مسنولين ناليل ماريل 
جإيلوس ها ها

معرون است كي وتتى معلم لونى جهاردهم براي ار كيميا

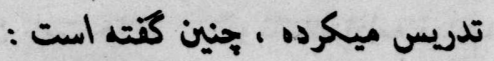

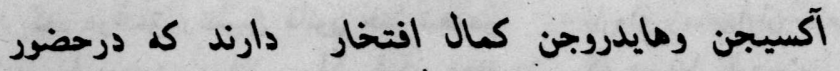

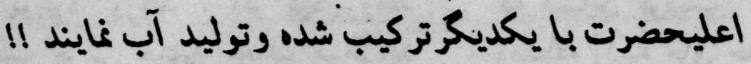

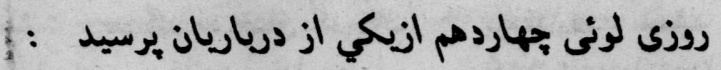

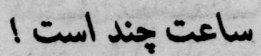

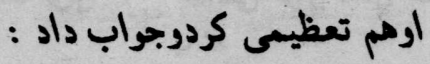

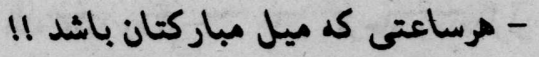

مز يت عالم برعابد

ماجدلى بم مدرس آتمد زخاتقا.

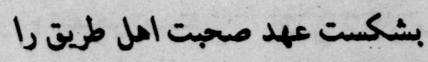

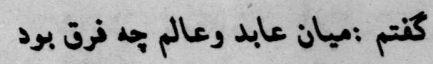

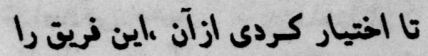

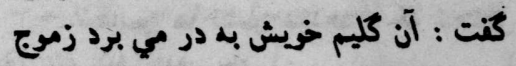

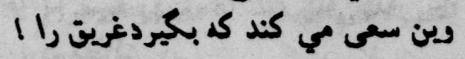
(1)

اشك جشّم

بروفيسور كيميا بجه كوجلك خودرا بواسطه اينكه به كتابهايش دست مي زد ، سخت سرزنش كرده

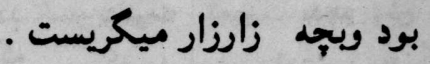

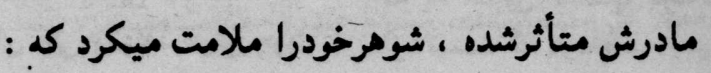

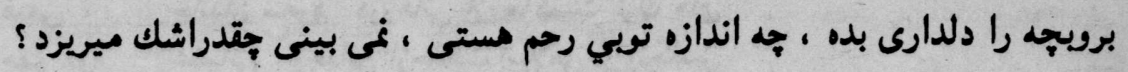

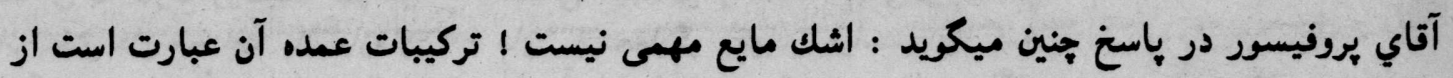

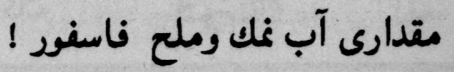




\section{مرف فكمبهاخه}

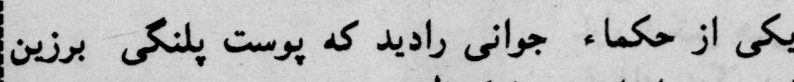

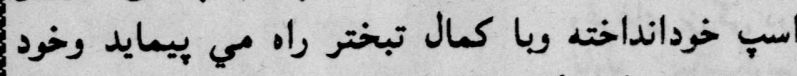

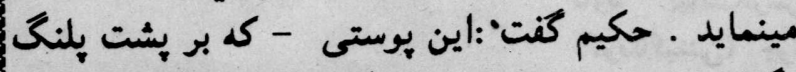

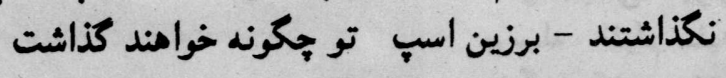

\section{مر گ طبيعى !}

يك نفر مسافر وارد شهر شد واز رمنعائى - كن ممرامش مريد

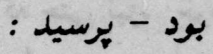

- منزل معروف ترين طبيب / مرين شهركجا است ؛

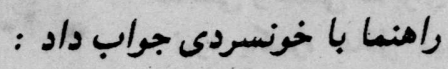

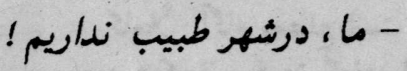

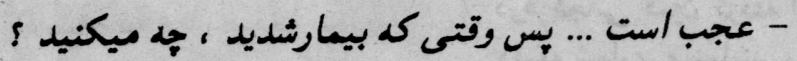

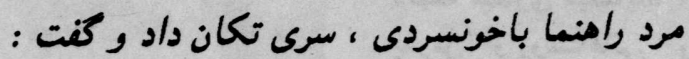
- ميع به مرگ طبيعى مي ميريم !...

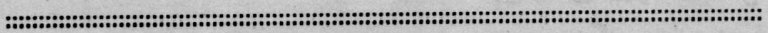

\section{بله ياد كمشده}

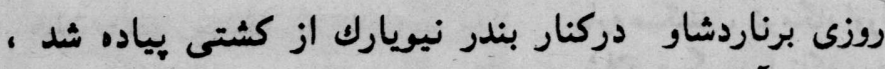

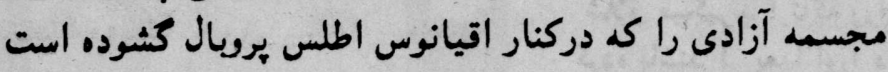

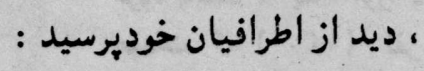

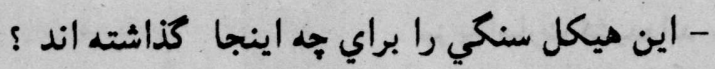

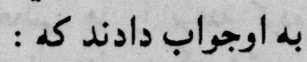

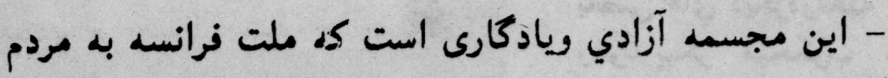

$$
\text { اتازونى هديه كرده است. }
$$

$$
\text { برنارد شاو با لبخند شاعرانه كفت : }
$$

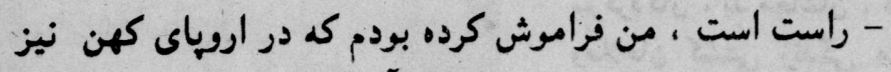

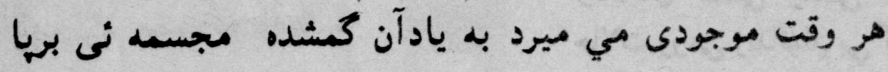

\section{US:}

تريستان يرناردنويسنده شوخ طبع فرانسوى

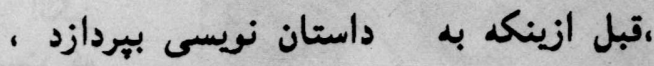

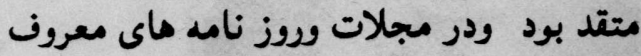

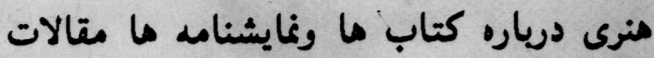

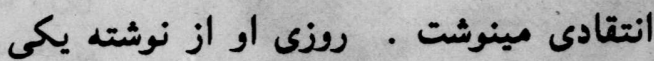

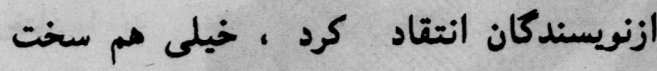

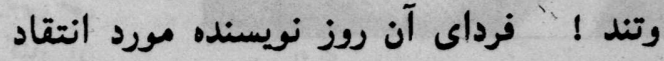

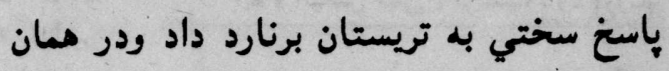

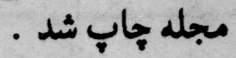

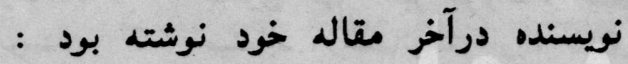
تعجب مي كنم كسى كد تاكنون يك داستان ويا

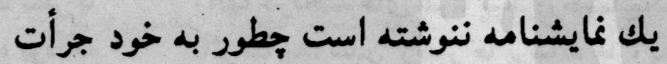
ميدمد ا از آثار نويسندكان معروف انتقاد كند ؟

اين خود نكته ثنى بود وشايد مدير وسردبير

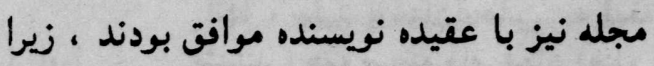

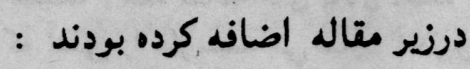
- ما منتظر هاسخ آقاى تريستان برنارد

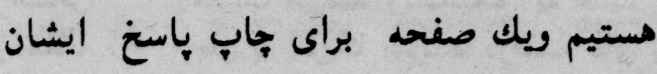
اختصاص داده ايم !

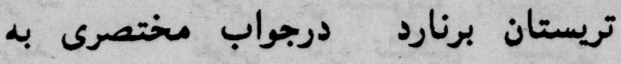

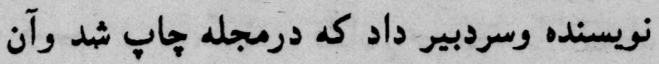

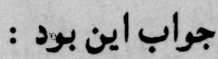

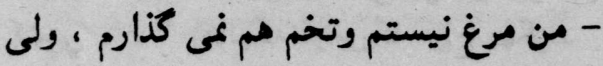

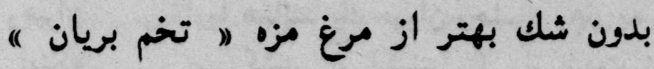

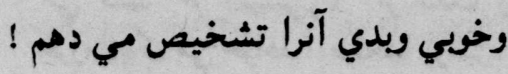




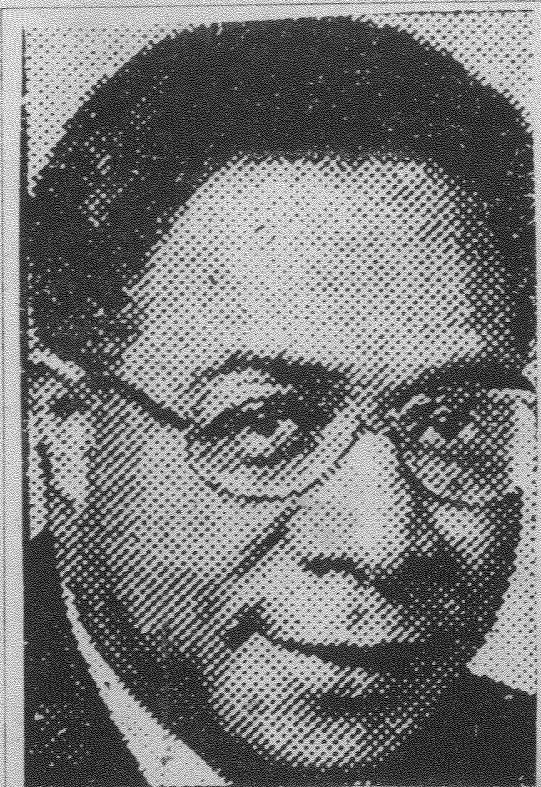

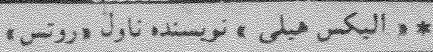

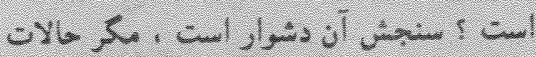

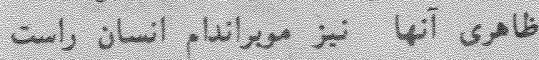

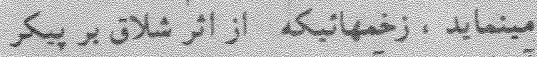

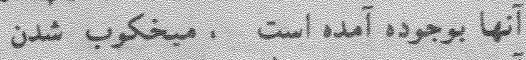

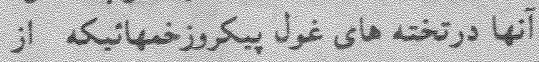

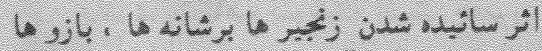

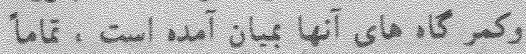

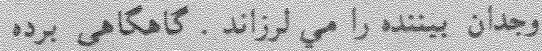

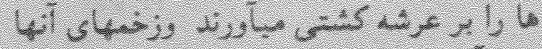

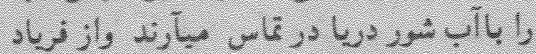

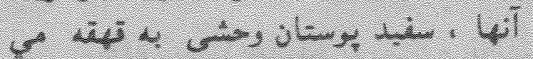

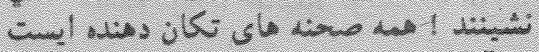

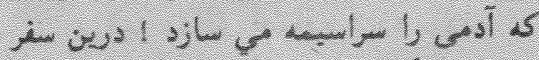

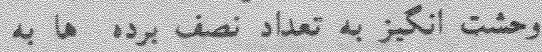

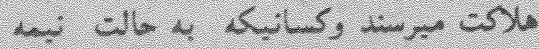

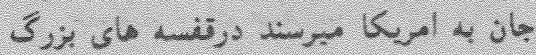
دئ

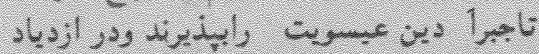

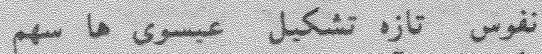

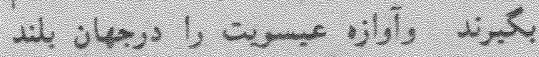
is

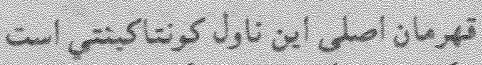

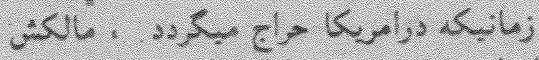

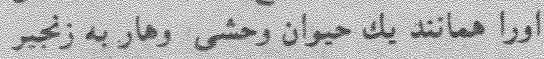

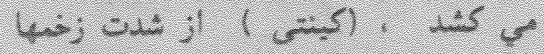

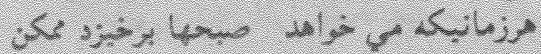

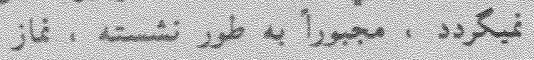

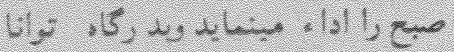

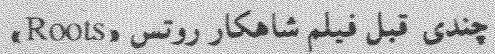

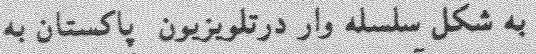

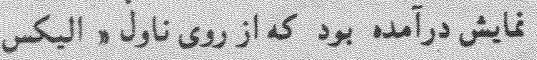

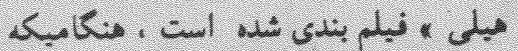

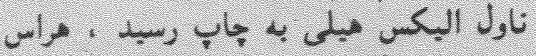

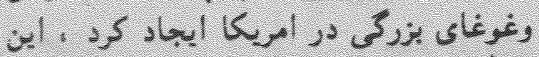

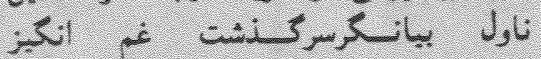

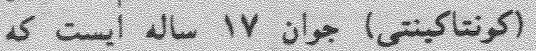

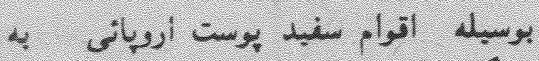

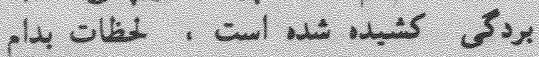

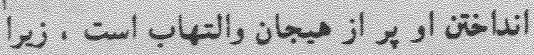

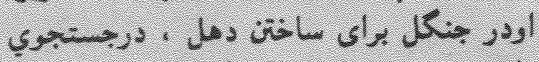

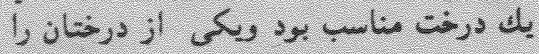

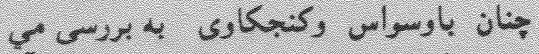
أن

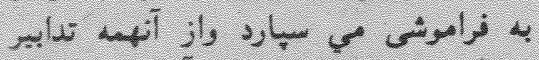

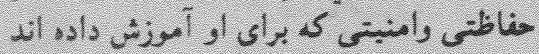

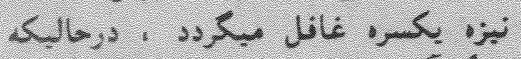

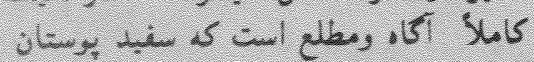

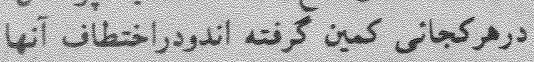

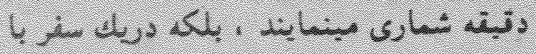

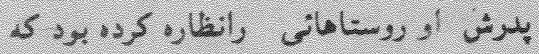
0 is a

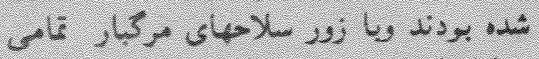

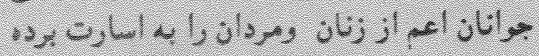

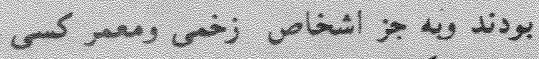

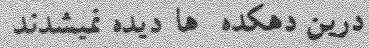

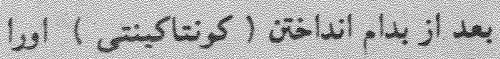

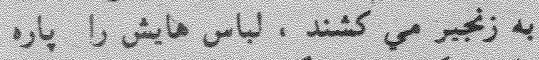

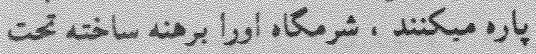

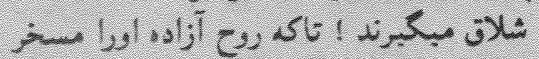

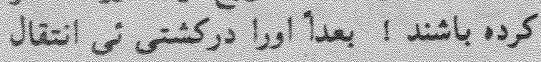

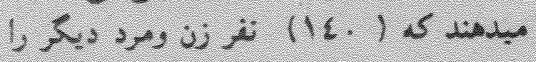

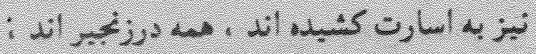

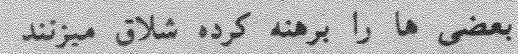

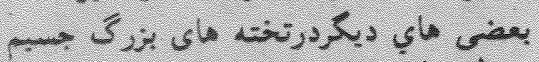

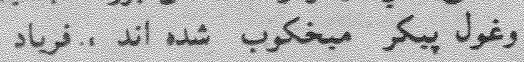

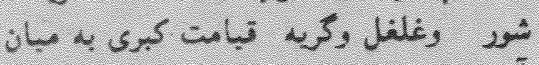
vis a

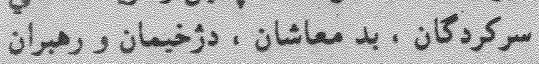

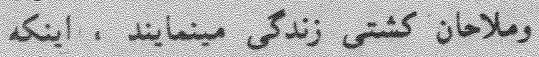

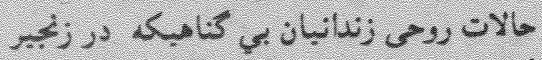

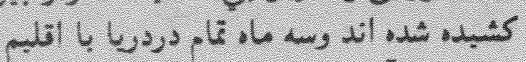

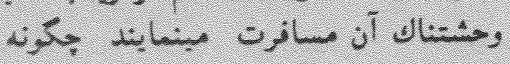




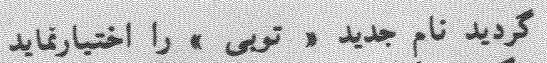

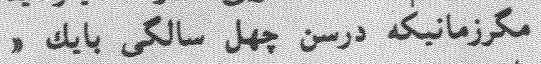

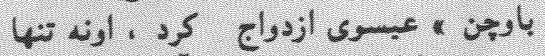

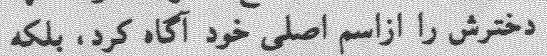

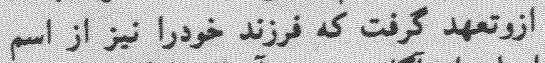

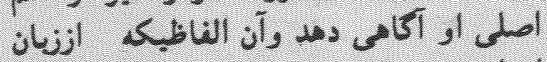

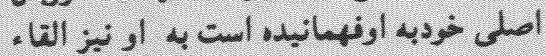

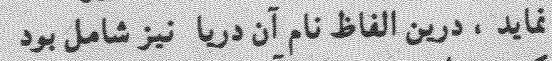
- S

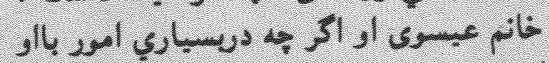
و ر

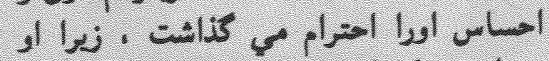

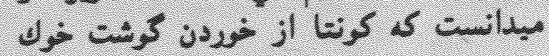
تانرت دار

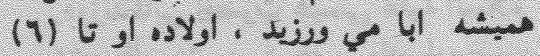

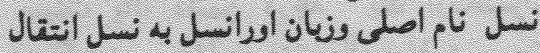

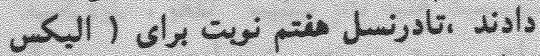

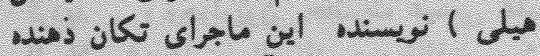

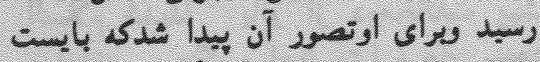

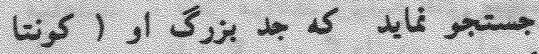

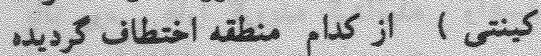

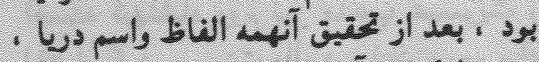

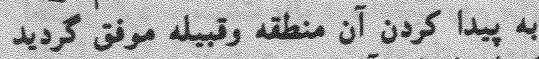

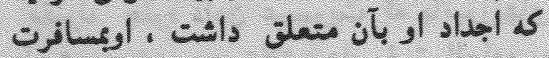

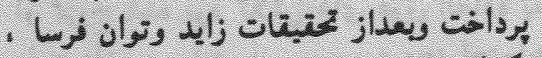

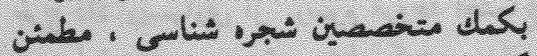

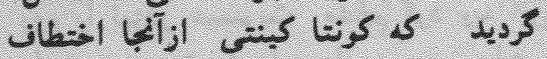

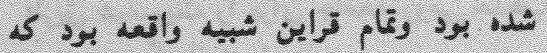

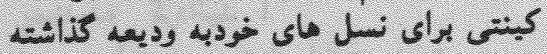

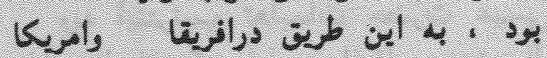

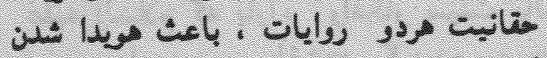

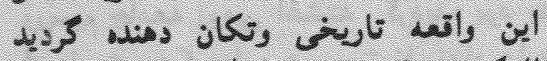

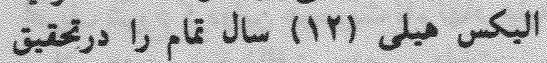

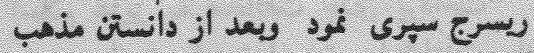

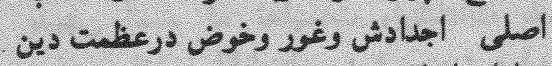
iguer

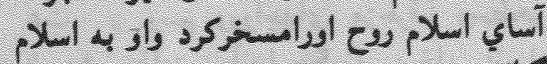
. +13

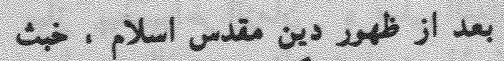

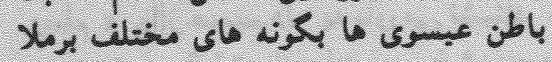

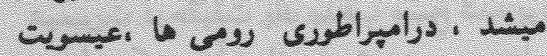
" Jl

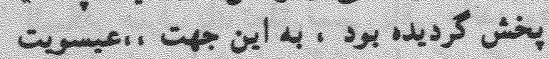

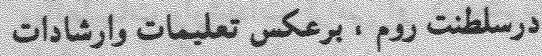
بن برتصورات وتفكرات سينت بال بور،

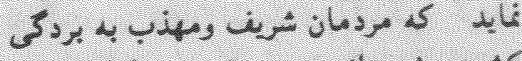

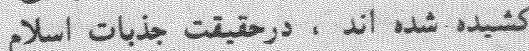

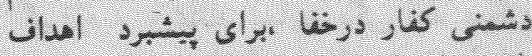

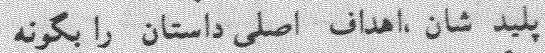

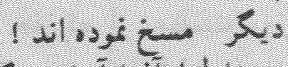

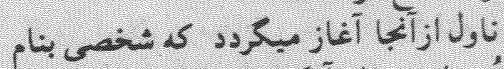

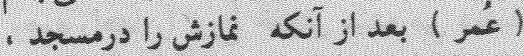

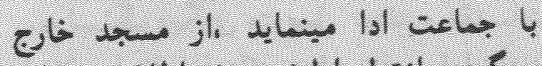
با s 5 أس

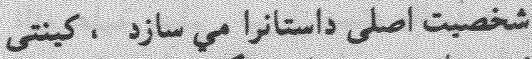

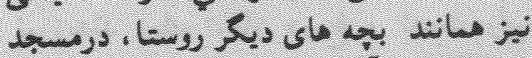

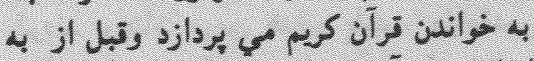

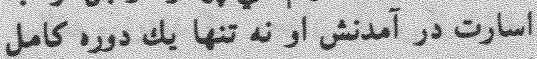

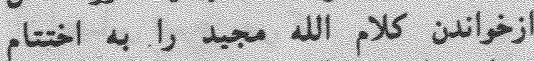
.

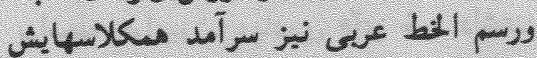

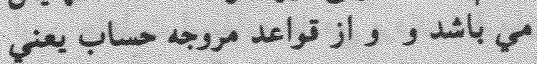

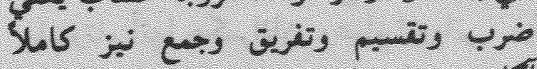

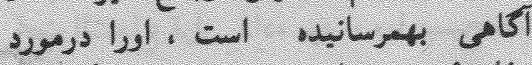

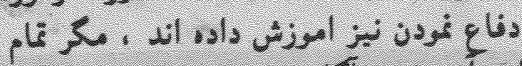

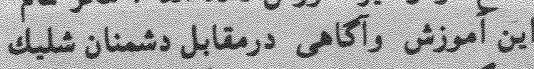

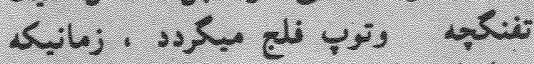

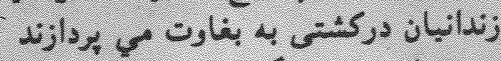

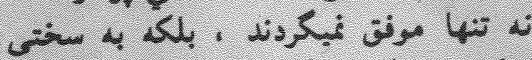

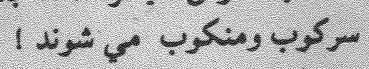

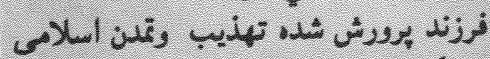

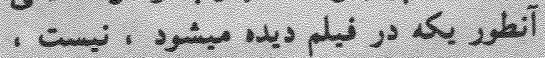

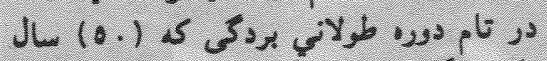

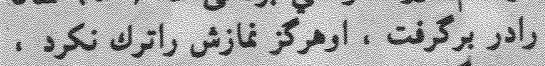

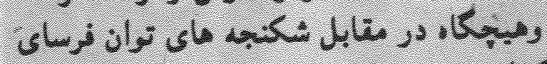

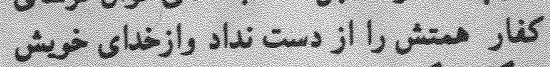

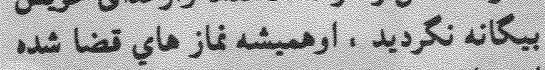

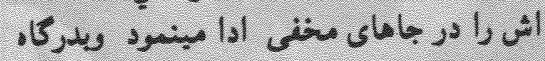

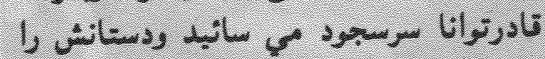

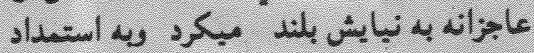

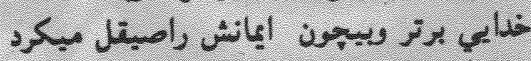

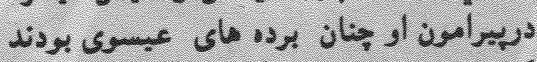

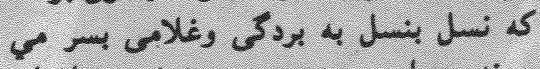

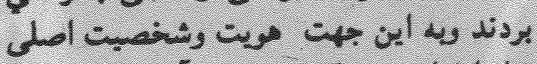

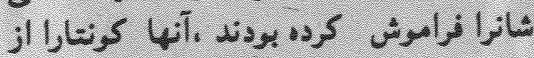

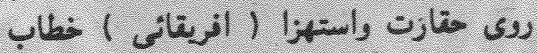

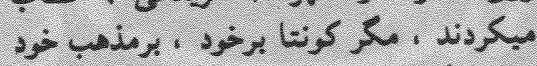

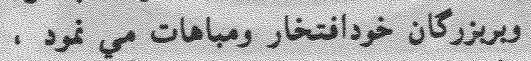

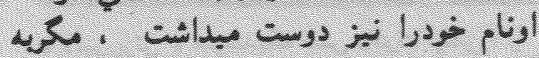

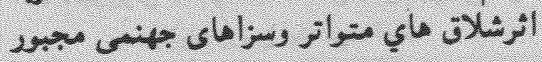

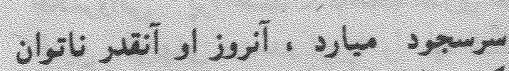

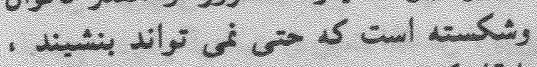
S.

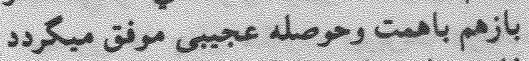

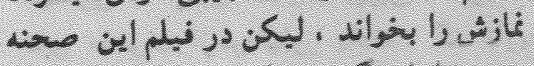

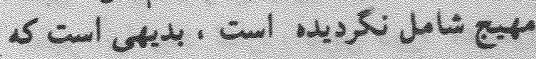

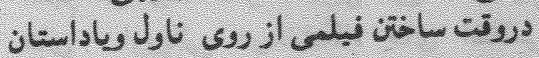
م

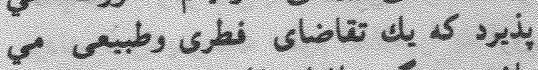

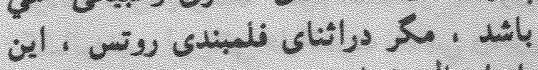

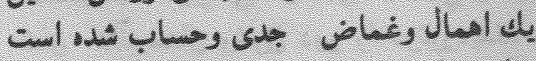

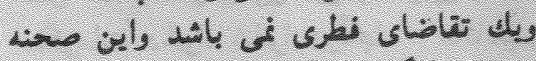

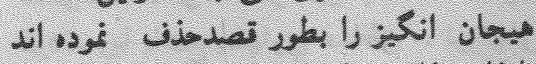

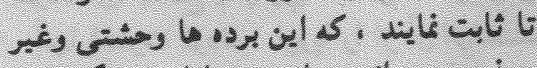

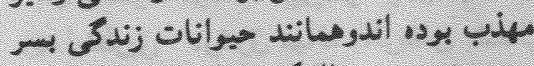

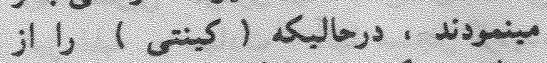

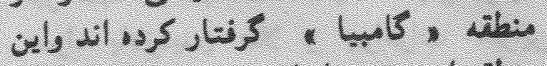

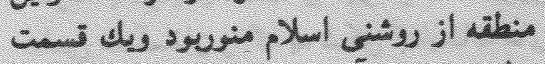

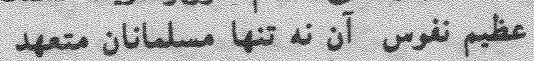

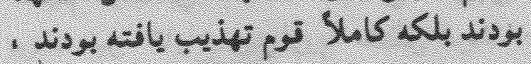

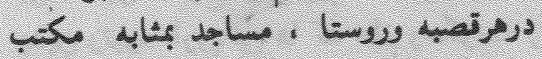

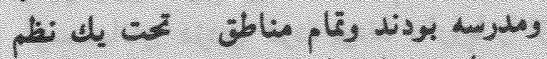

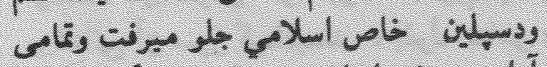

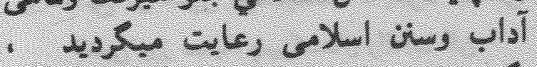
أن

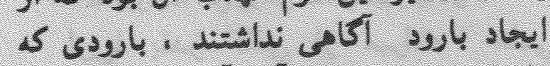

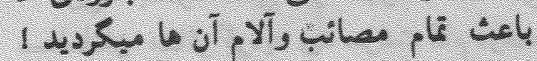

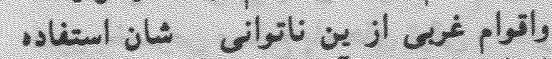

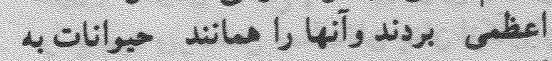

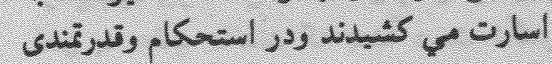

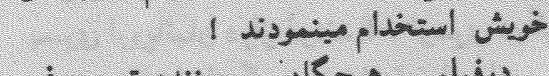

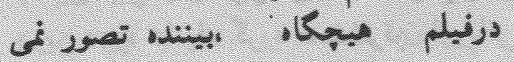


نيروها ، اولين اتدام رونين راعليه مسلمين درفلسطين آغاز كردند كه باعث بروزين

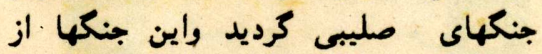
(1.9V)

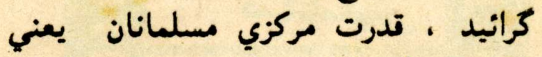

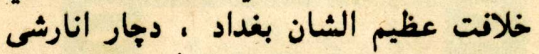

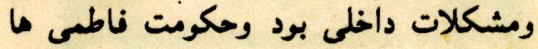

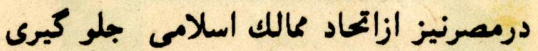

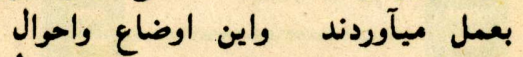

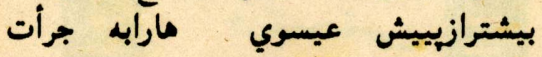

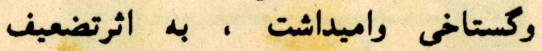

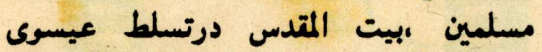

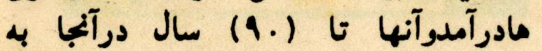

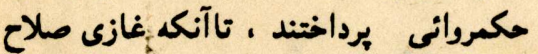

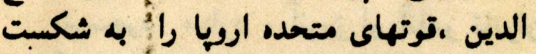

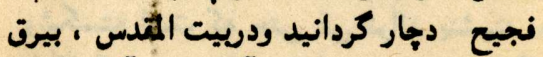

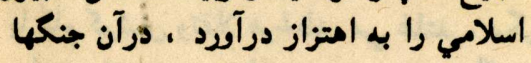

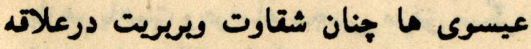

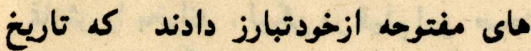

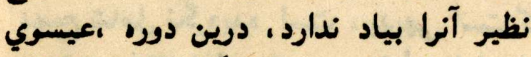

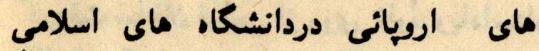

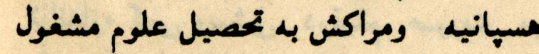
بودند ، وبدينوسيله علوم اسلاميرا به ارويا

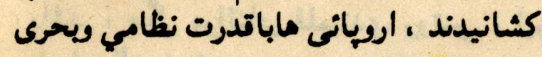

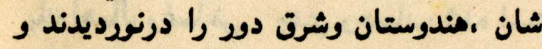

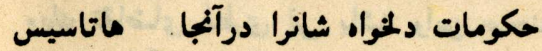

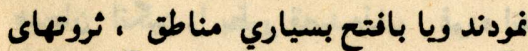

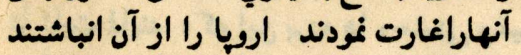

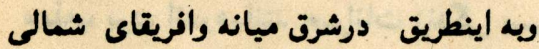

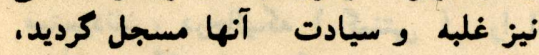

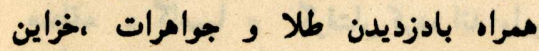

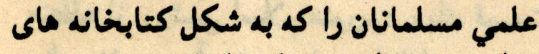

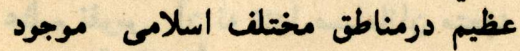

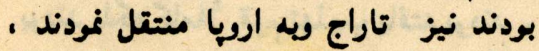

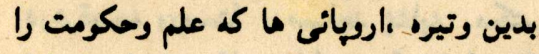

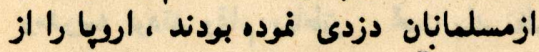

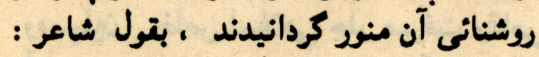

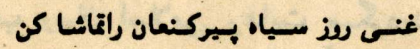

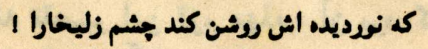

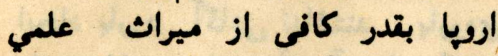

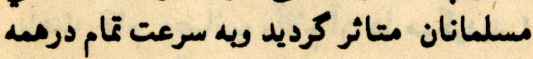

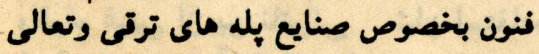

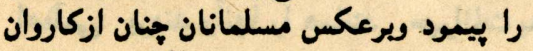

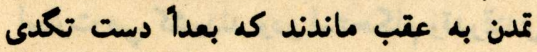

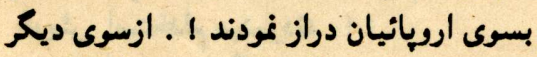

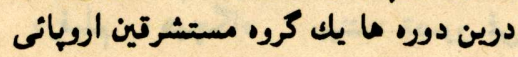

بزرخ روم دهار تشيتت وبراكندكى كرديد

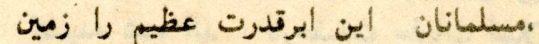

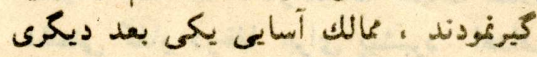
مفتوح شدند ولشكر أسلام به تسطنطنيه

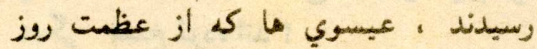

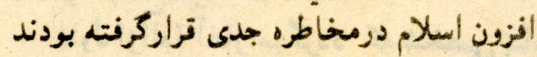

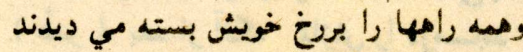

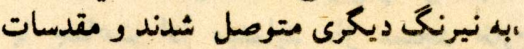

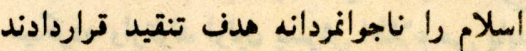

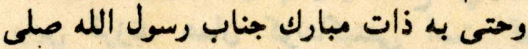

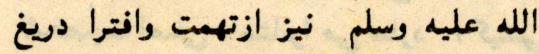

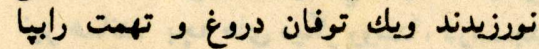

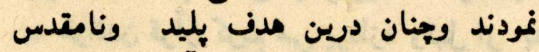

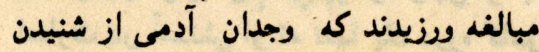

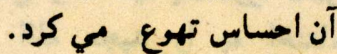

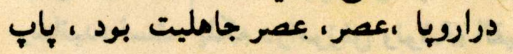

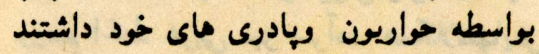

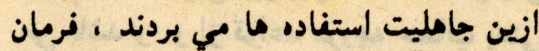

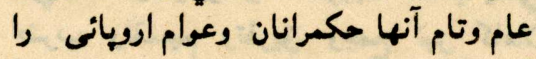

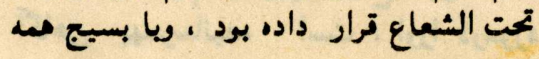

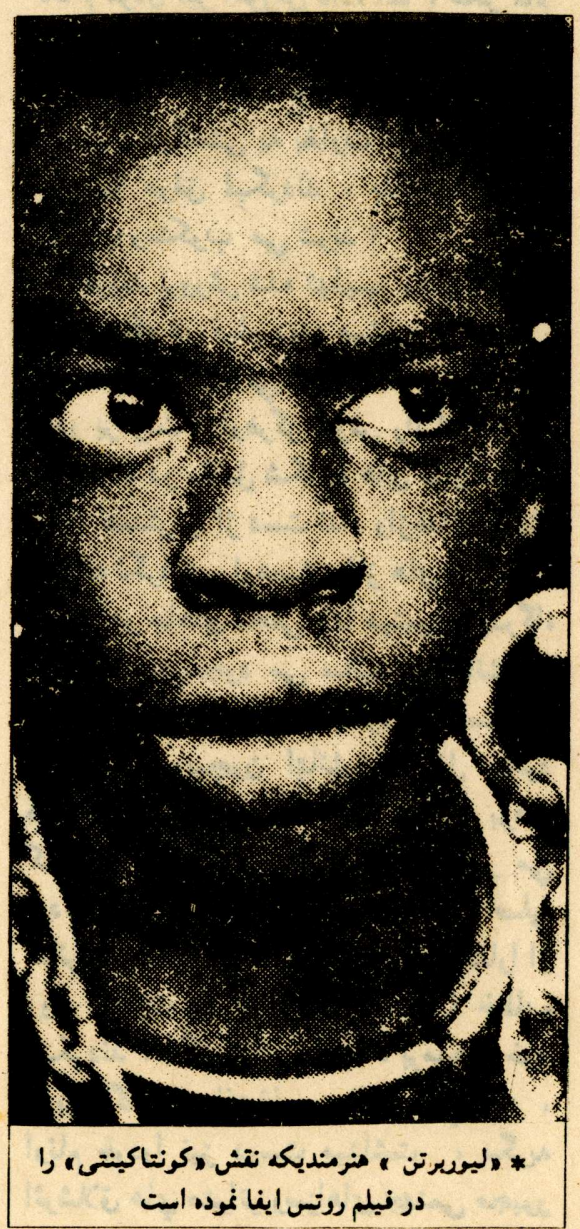

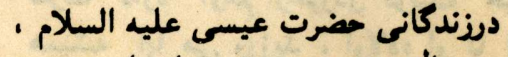

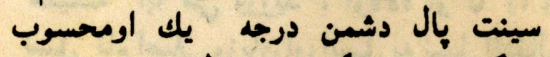

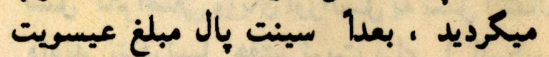

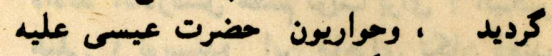

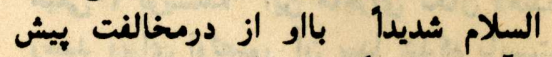

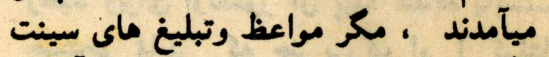

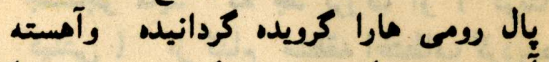

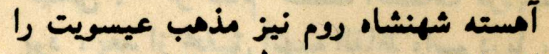

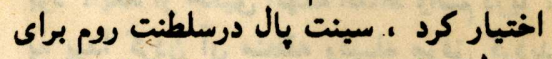

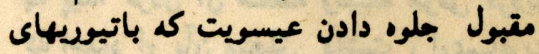

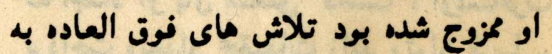

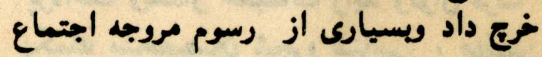

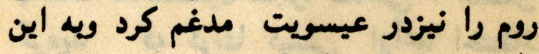

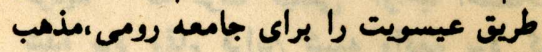
بسنديده كردانيد

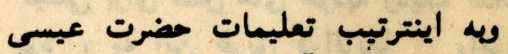

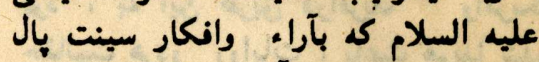

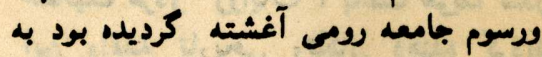
ححريف شروع كردواين عيسويت نام نهاد عليه

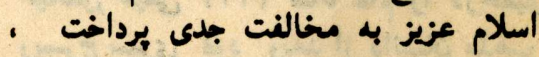

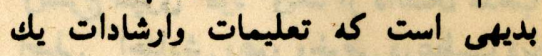

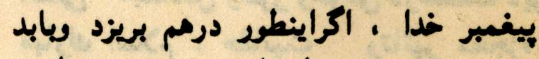

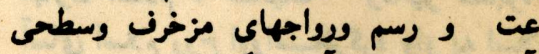

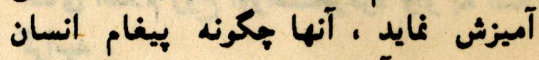

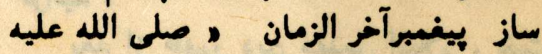

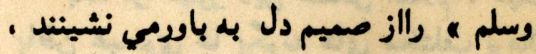

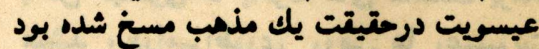

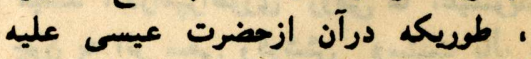

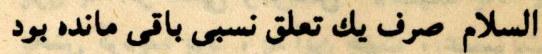

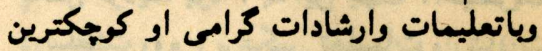

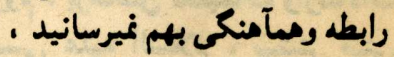
بعد از ظهود دين مبين اسلام امهراتورى 

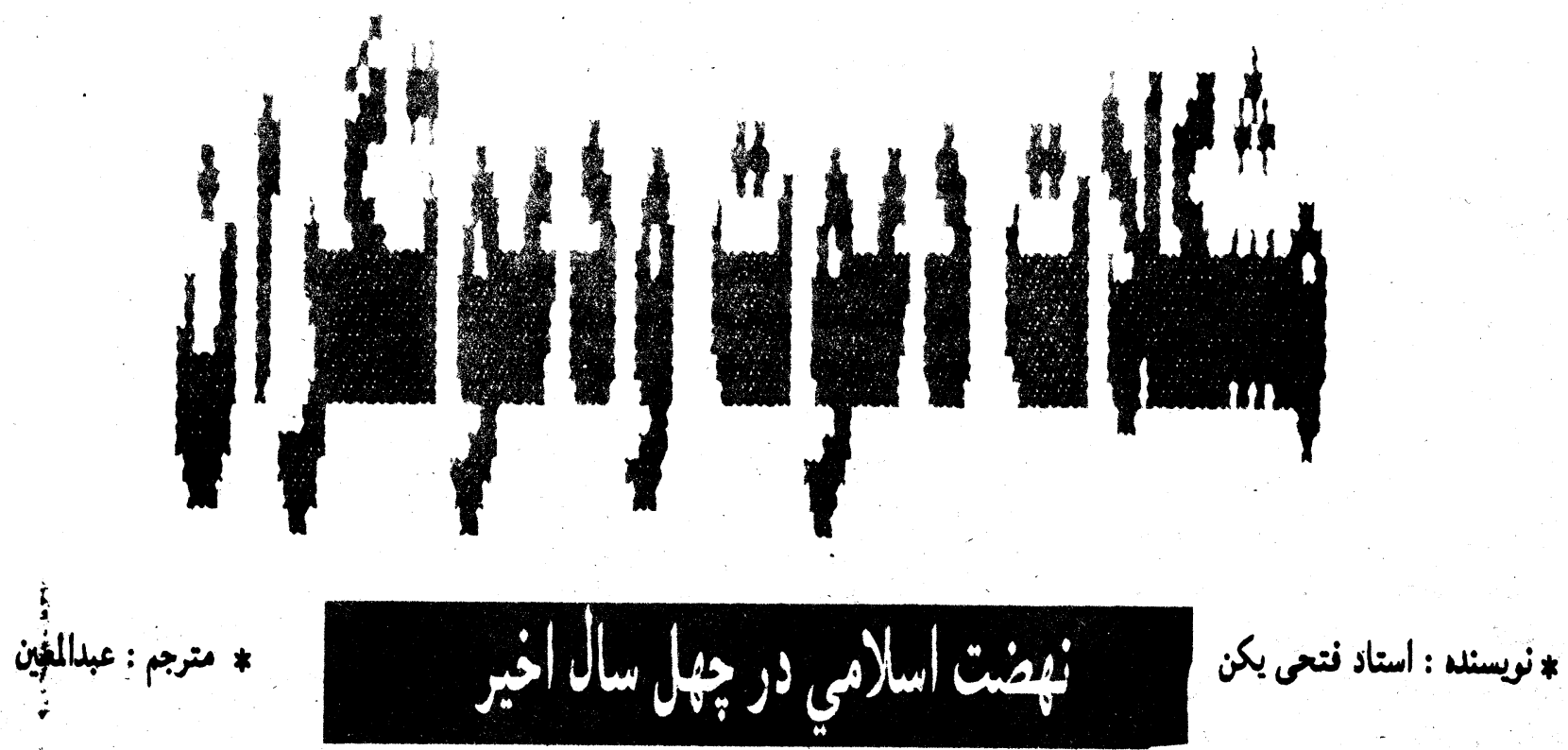

مدنها ووضع تصسيم ما وسنجش بهلوما

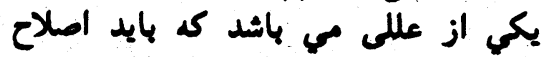

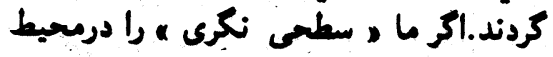

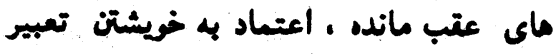

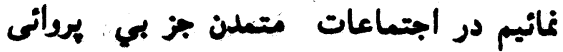

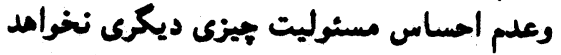

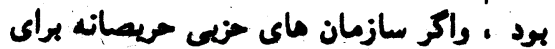

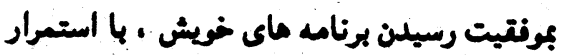

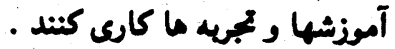

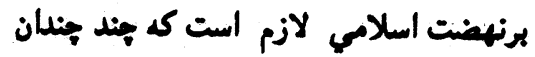

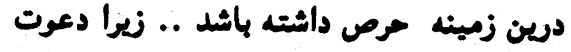

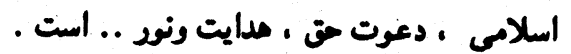

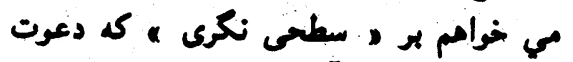

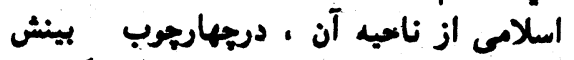

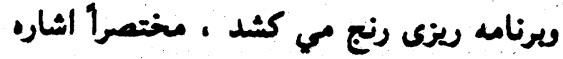

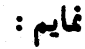
الآن دربرابر ما دو سوال ترار دارد كه جواب به

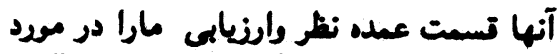

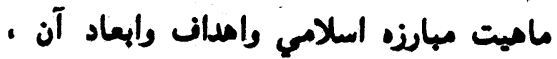
بيان مي دارد : سوال اول : آيا دعوت اسلامى يك عمليه ترميم

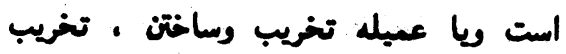

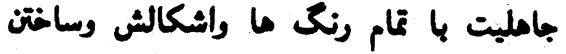

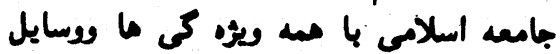

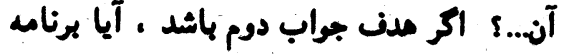

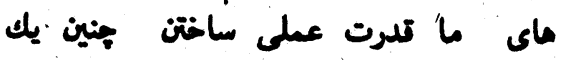

اجتماعات نيست ، وبرنامه وروشهاى معمول در

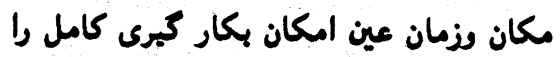
با تام جز نياتش در مسه زمانه ما ومكانها

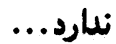

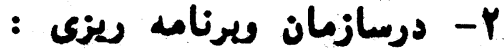

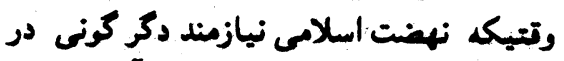

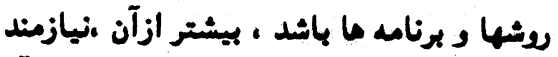

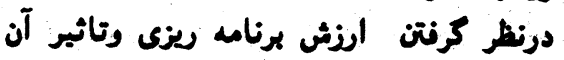

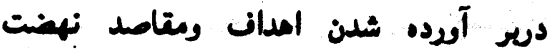

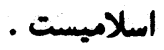

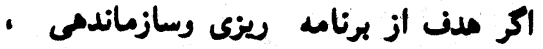

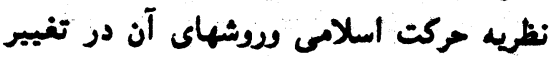

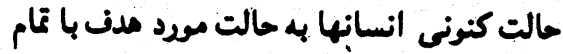

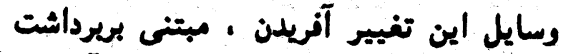

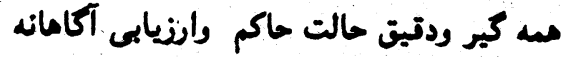

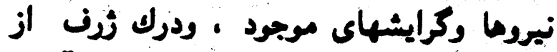

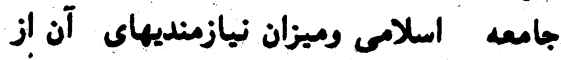

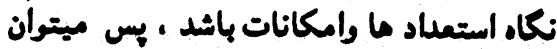

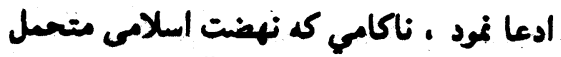

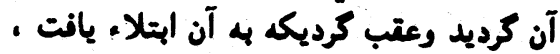

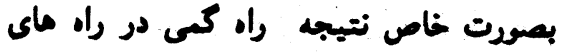

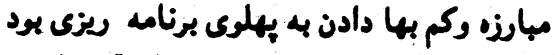

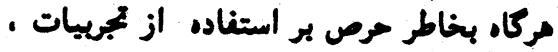

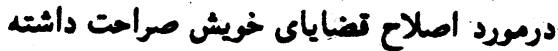

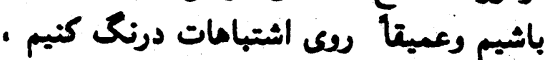
كتته مي توانيم كه رسطحى نكرى a درتعيين
* * دريرنامه وروش مازمان

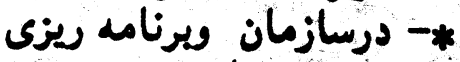
* * دربينش وانديشه

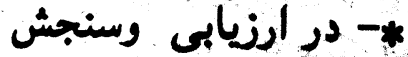

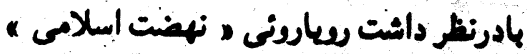

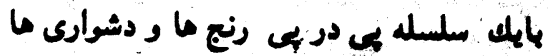

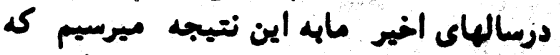

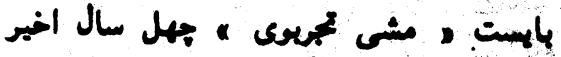

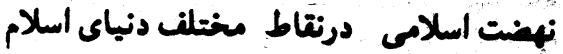
إز بانب دعونكران ، مودهجبديد نظر ترار عمينكونه هرمباران مسلسان لازمست تان

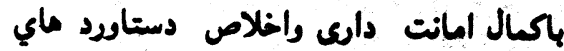

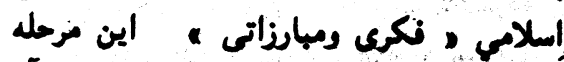

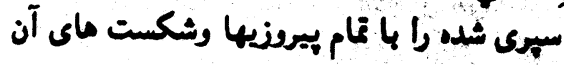
مبالعه منايند

1-

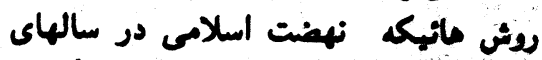

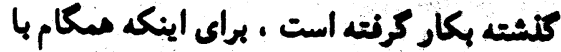

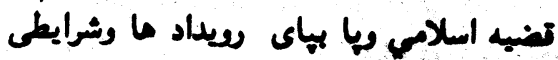

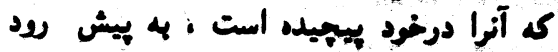
ماره نهازمند وضاحت ودمر كونى است ئ ...

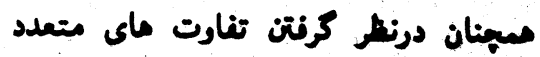

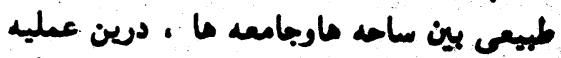

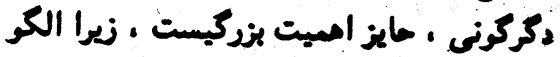

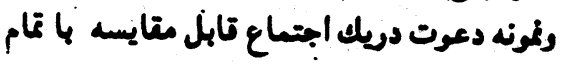


ومآهانگ سازى ، زمينه استغاده ازين نيروما

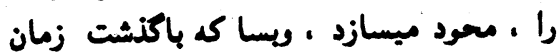
اين توانانى مارا نيز از دست خواهد داد داد ـ . ..

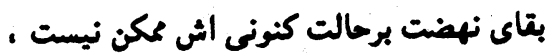

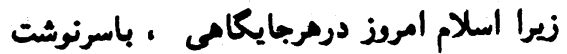

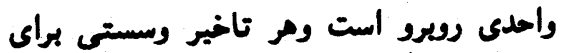

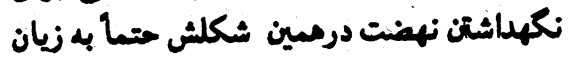

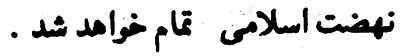

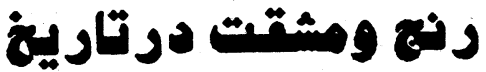

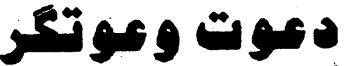
* آموزشكاه محنت ورنج

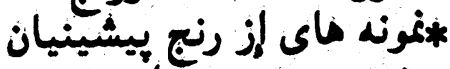

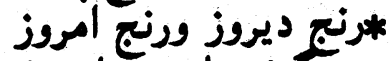
* *بكونه بارنج ماوستختيها مبارزه نمائيم ؟

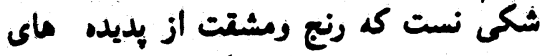
لازمى ركت اسلاهي در كنشته وحال بوده

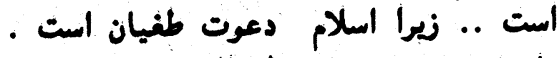

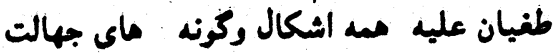

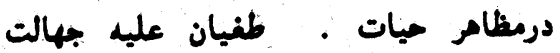

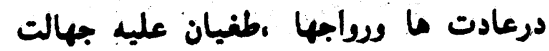

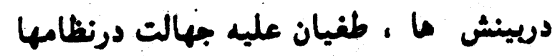

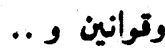
اين ويزه كمى كد اسلام با آن متعايز مي كردد

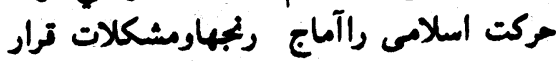

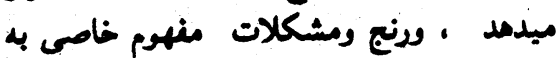

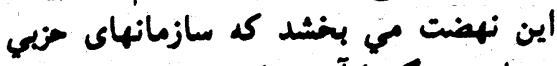

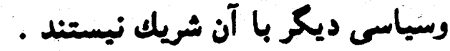

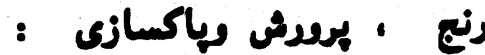

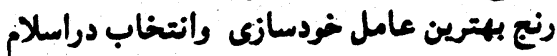
است وجه بسا كه خودسازى نظرى تازمانيكه

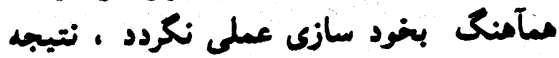

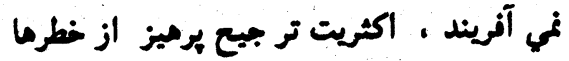

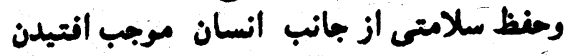

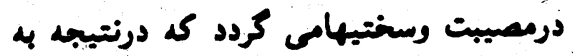

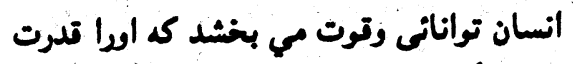

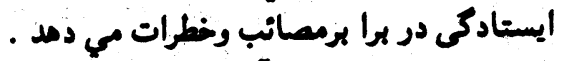

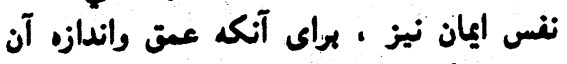

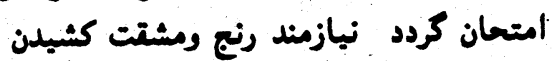

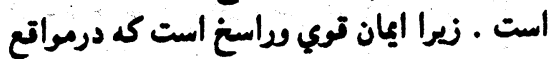
دشوار بابرجامي ماند ... اما ايمان ضعين
زمينه نهضت اسلامي ،يايه كذارى نهضت به

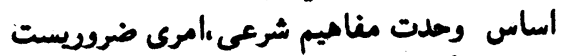

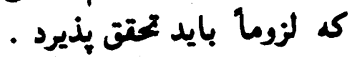
در بسيارى از تضايا واموريكه نهضئ اسيرد اسلامي

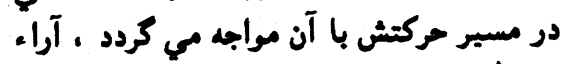

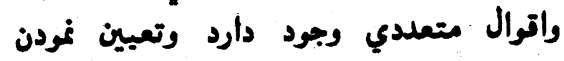

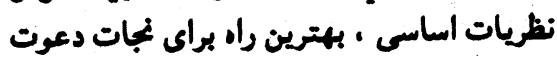

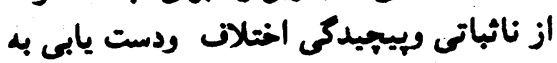

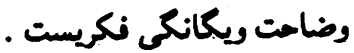

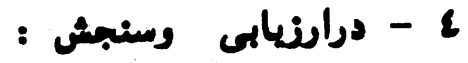

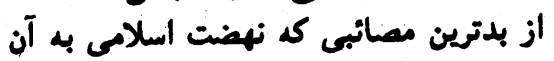

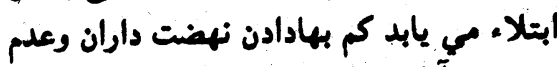

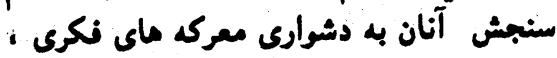

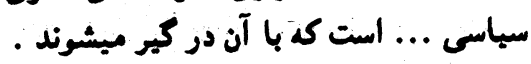
من براي اين بديده جز دوسبب أ عامل ديكرى ميثرن

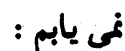
اول : برآورد زياد وخوش بينى بيش از حد

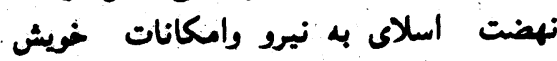

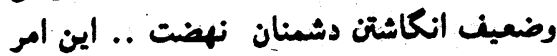

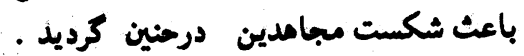

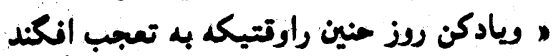

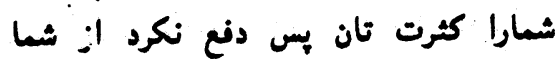

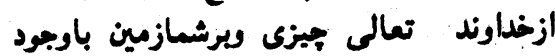

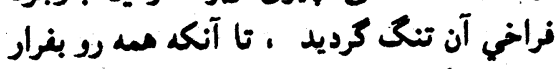
نهاديد بركثتيد ، ومشت كدانذد كاني،

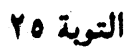

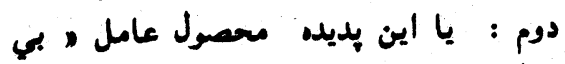

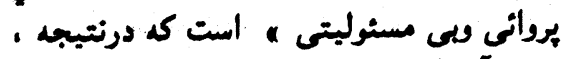

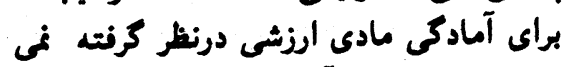

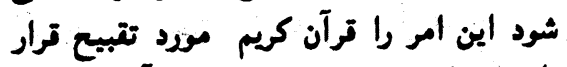

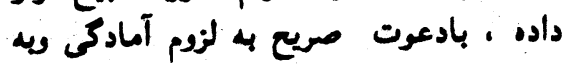

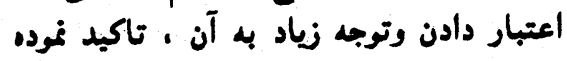
" وآماده كنيد براى ايشان مرجه توانيد از

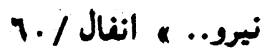

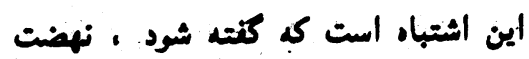

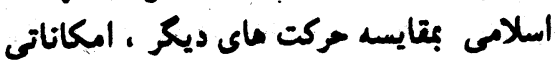

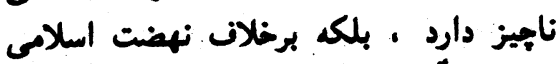

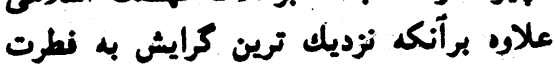

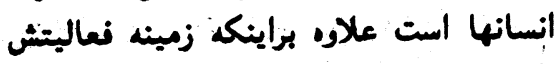

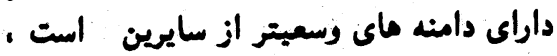

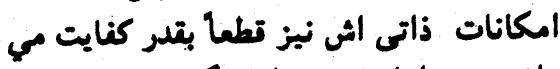
باشد .. اما نقرش از ناز نكاه برنامه ريزى

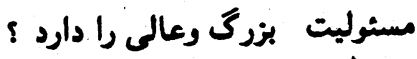

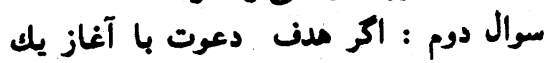

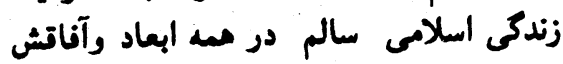

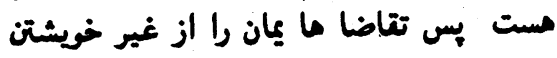

ازفرمان روايان ورئيم ما مان يان

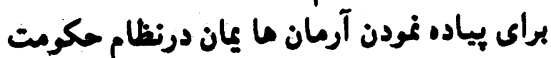

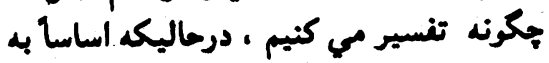

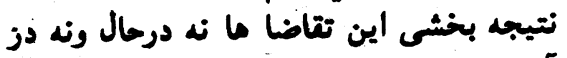

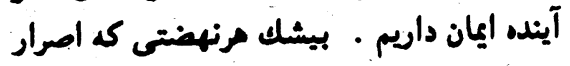

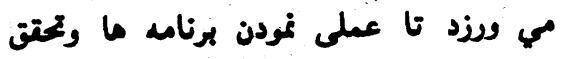

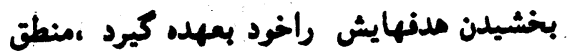
سالميست وبجاست كه نهضيت راخرد اسعلامى كيرد آنرا سياست وسرمشت خويش ترار دهد ... واجتناب آنراب

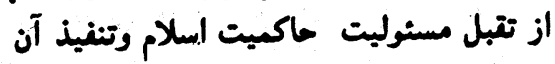

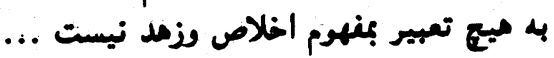

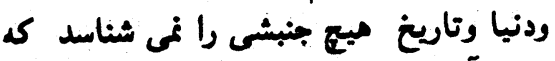

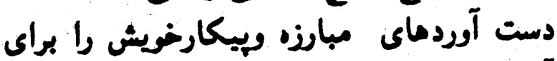

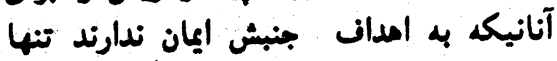

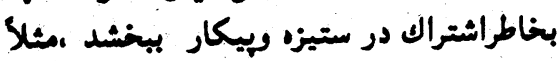

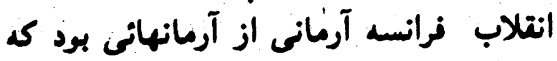

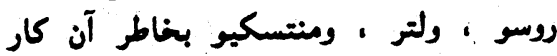

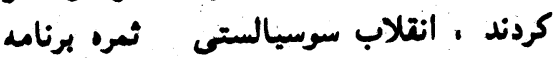

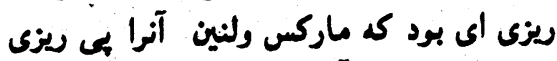

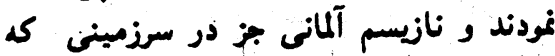

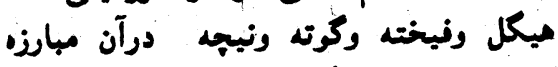

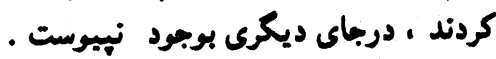

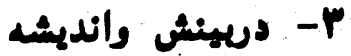

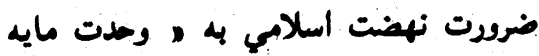

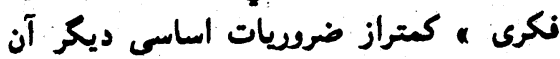

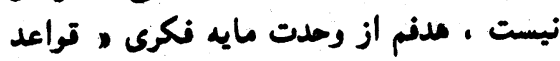

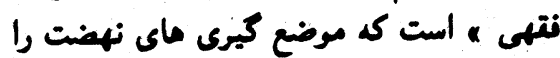

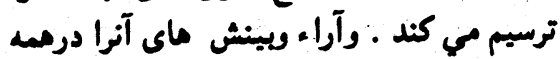

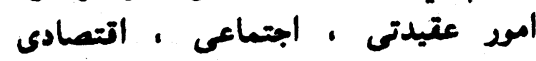
وسياسى ... تعيين مينمايد .

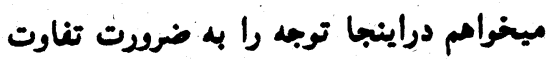

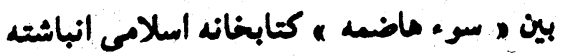

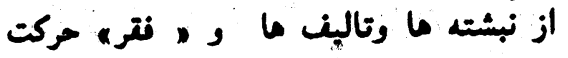

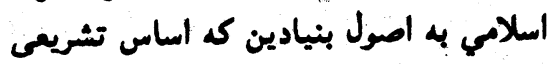

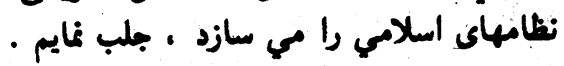

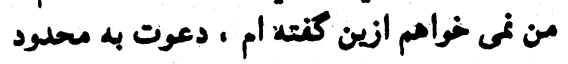

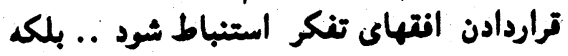

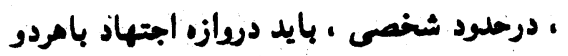

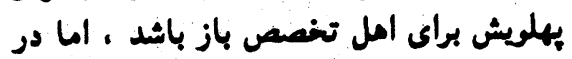


آنانرا خسران ديده كان ، ويجات داديم اورا

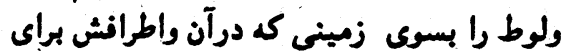

VI / إنهان داستان ريجه راكه بدر ييام آوران ، آنرا بديد

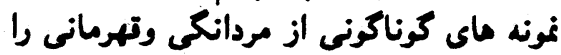

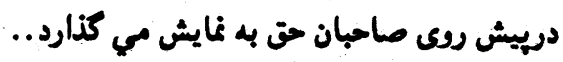

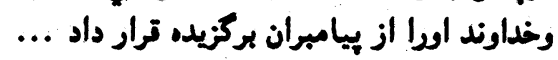

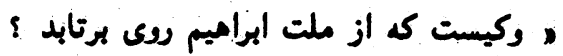

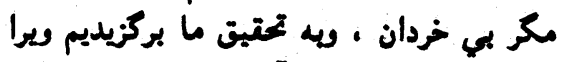

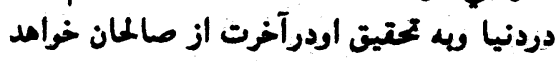

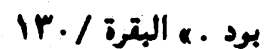

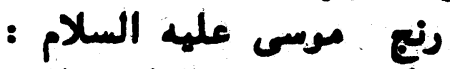
زندكَى موسى عليه السلام سرإِّتر ، سلسله

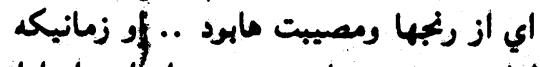

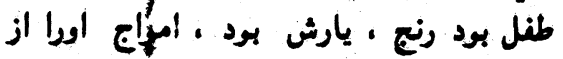

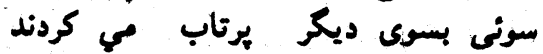

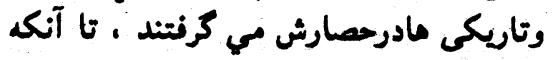

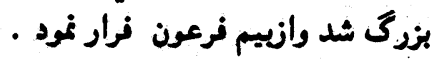

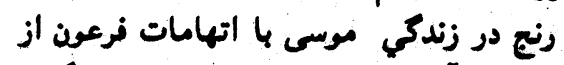

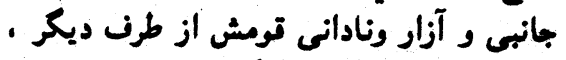

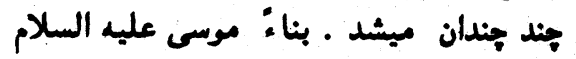

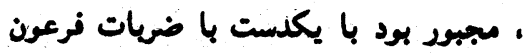

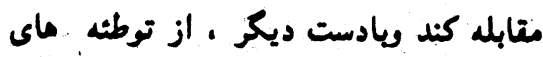

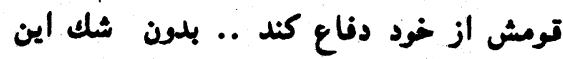

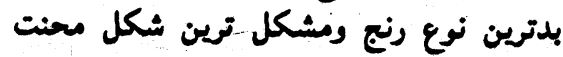

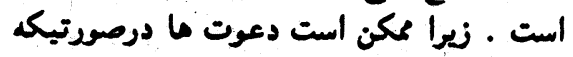

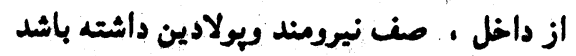
درمقابل خطر نال ترين مشكلات خارئ وائل

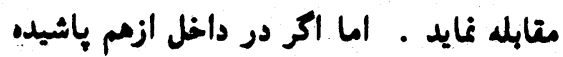

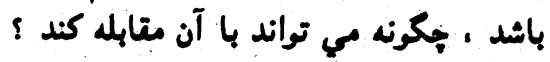

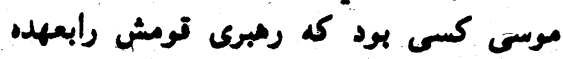

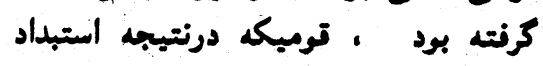

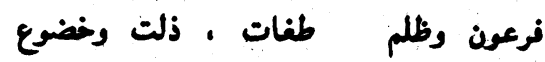

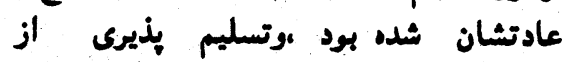

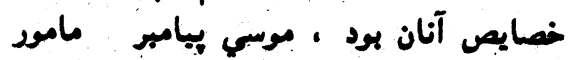

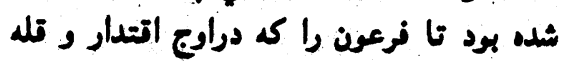

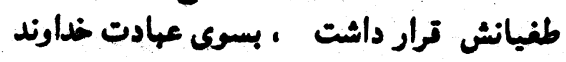

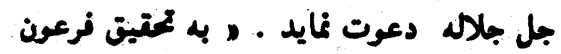

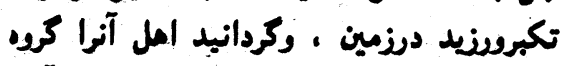
كروه . به بيباركى مي كشاند كرومى ازآنان

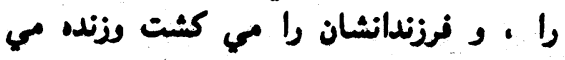

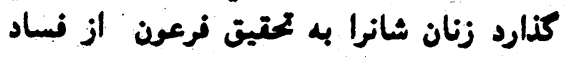

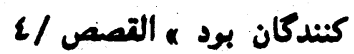

فرستاديم سبتت كرنته است كد البته آنها

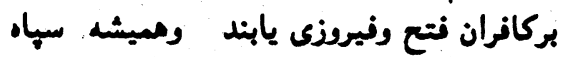

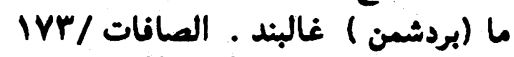

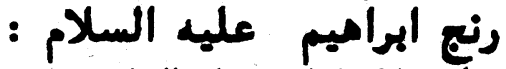
رئجي را كه ابراميم عليه السلام ديد ، ملقد

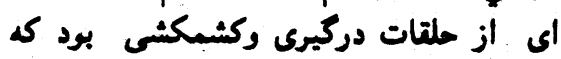

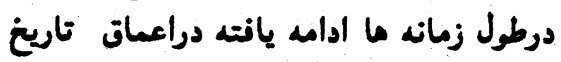

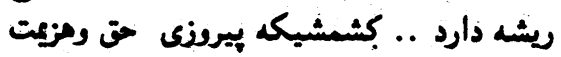

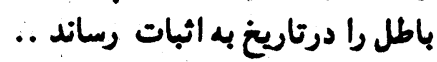

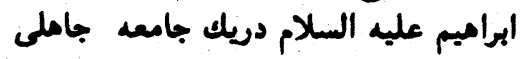

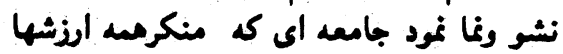

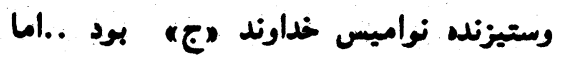

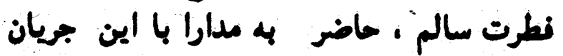

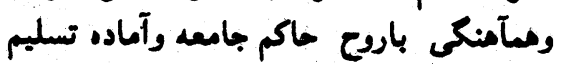

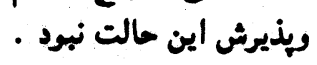

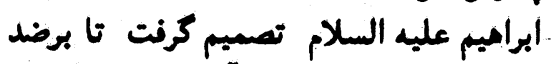

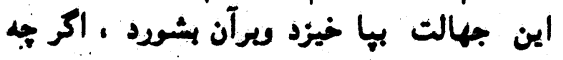

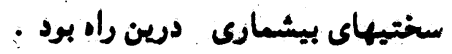

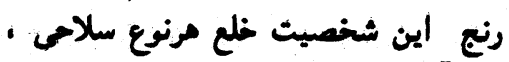

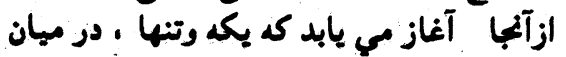

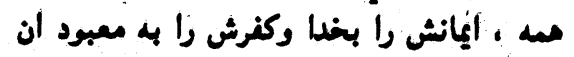

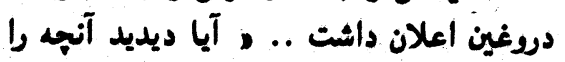

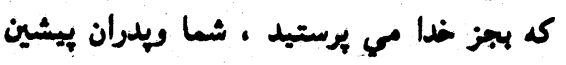

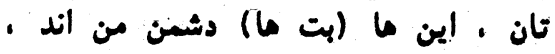

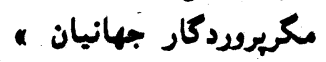
VV - V0 / الشعراء

برمر دعوتكر لازم است تا درين مسل زيل

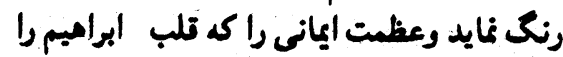

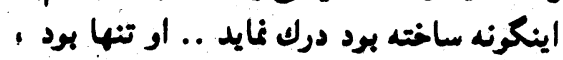

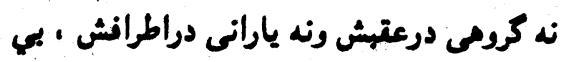

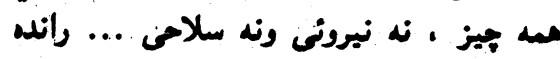

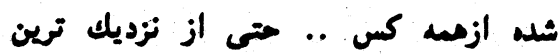

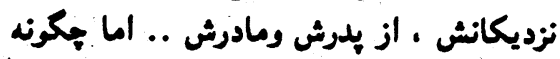

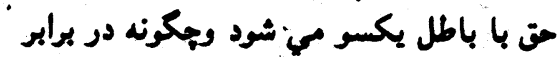

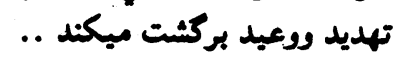

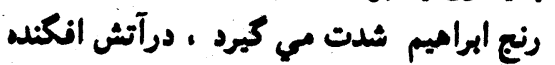

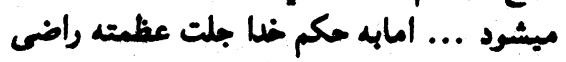

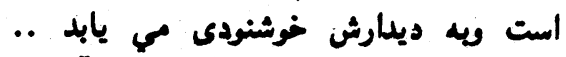

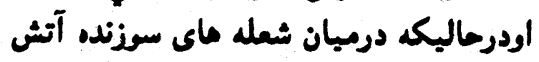

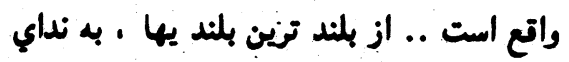
خدا بل جلاله كوش فرا مي نهد كه مي فرمايد

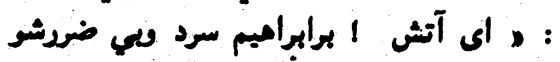

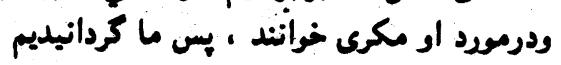

ينعدى در براير سنتيها دوجار شكست وازمم

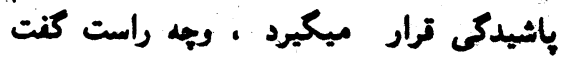

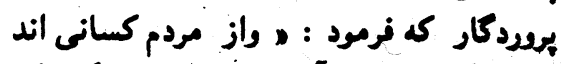

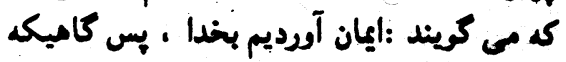

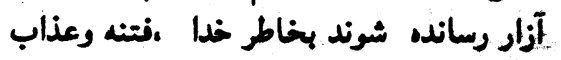

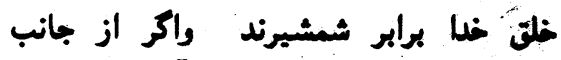

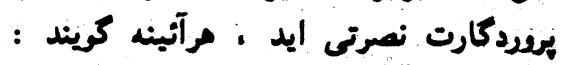
باثما بوديم آيا نيست خداوند ائد داناتر برأنجه درو

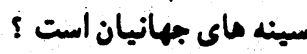

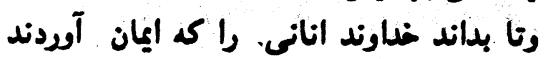

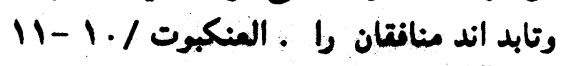

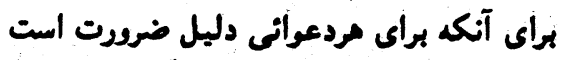

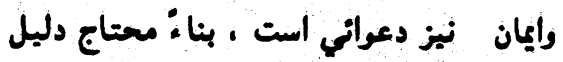

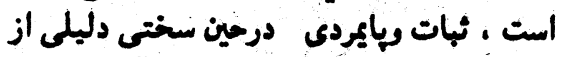
دايل ايان ومظهر ثبات ويايدارى آن ميباشد دئد

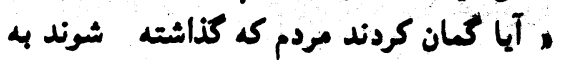

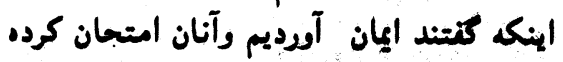

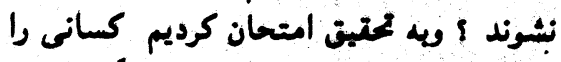

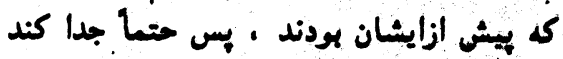

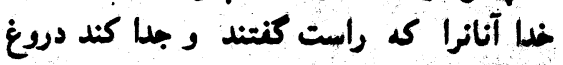

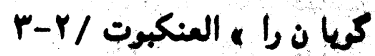

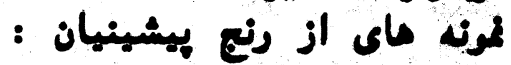

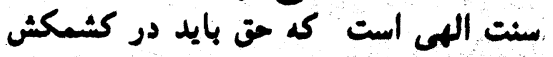

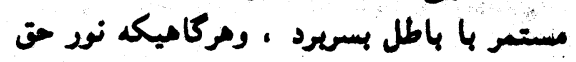

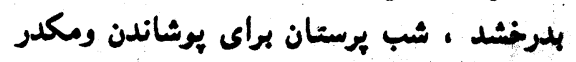

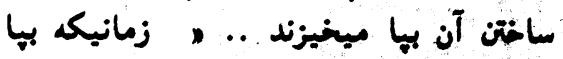

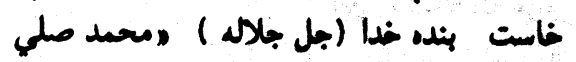

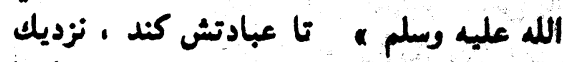

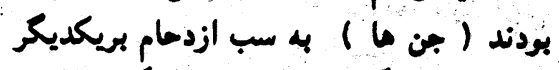

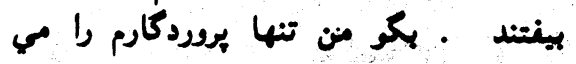

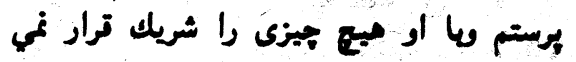
19 / 19

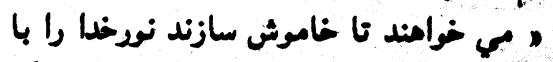

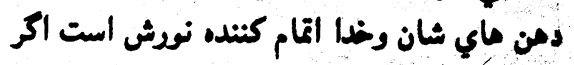

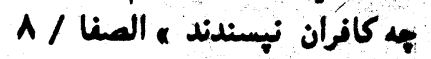
ازمنكام خلقت نغستين واولين ييامبر

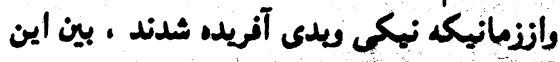

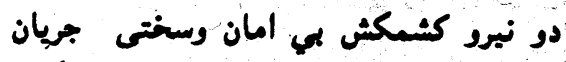

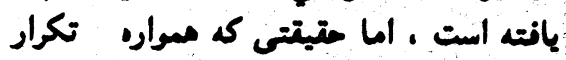

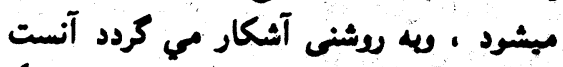

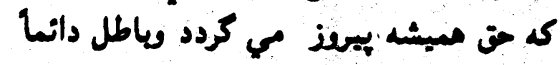

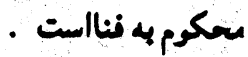
ومانا عهد بهابت درارو بندكانيكه برسالت 
يهوديان كوشيدند تا از تاثير كذارى دعوت

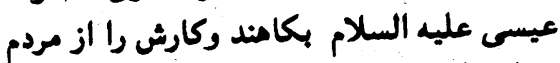

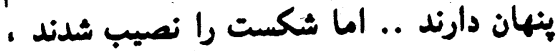

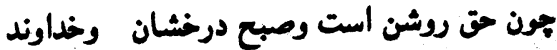

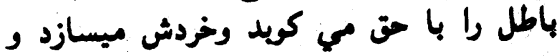

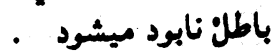

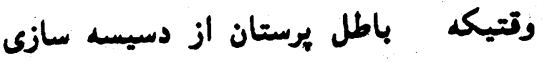

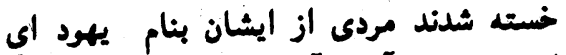

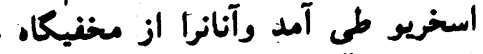

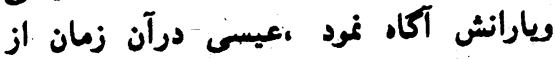

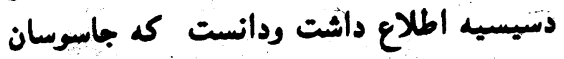

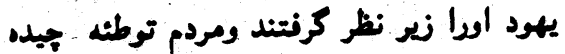

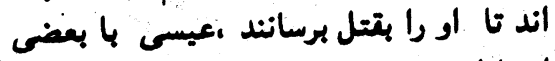

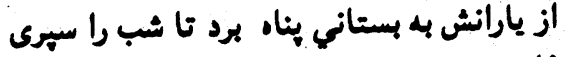

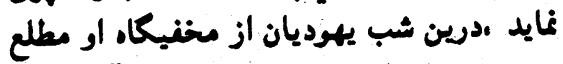
شدند ومحل را درمعاصره خويش درآرردند تا

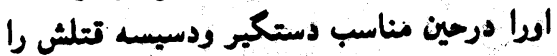

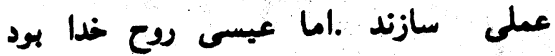

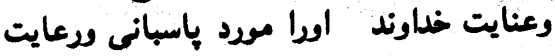

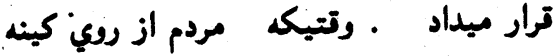

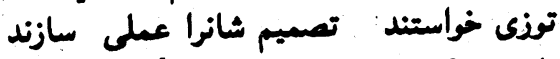

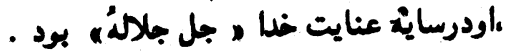

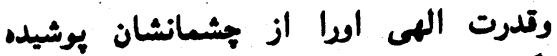

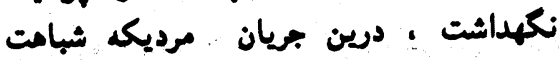

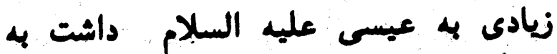

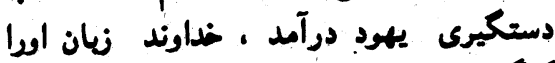

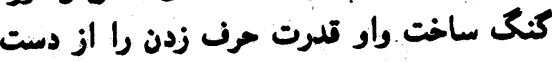

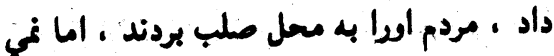

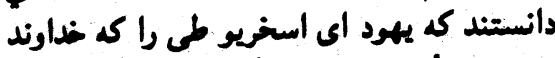

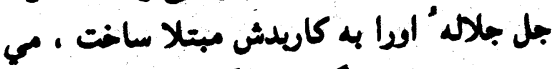

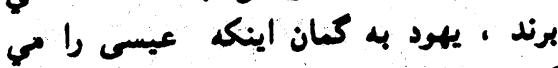

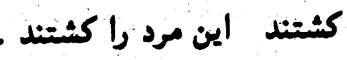

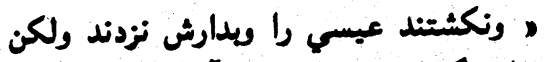

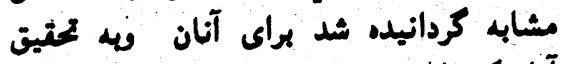

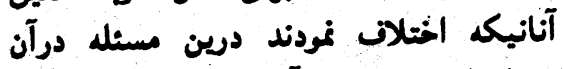

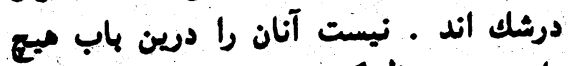

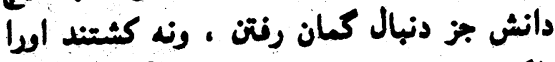

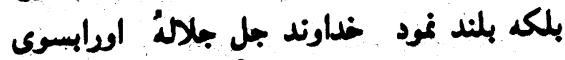

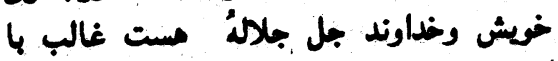
(1اصامه حارح ()
متابله كرد ، شخصيت عظيم عيسى بن مريم

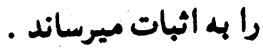

شكوك كوناكونى كه عيسم عليه السلام

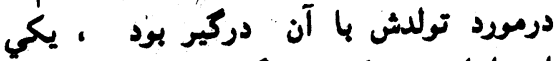

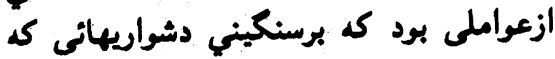

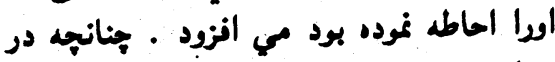

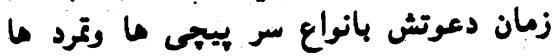

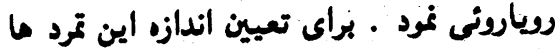

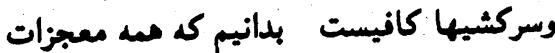

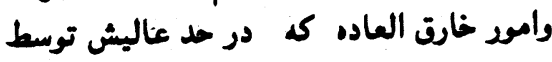

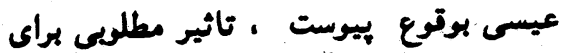
جلب انكار ويدست آوردن دلها نداشت .

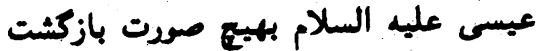

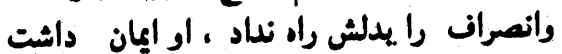

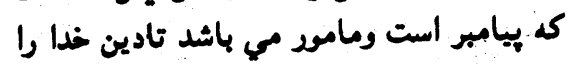

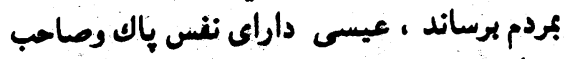

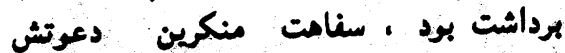

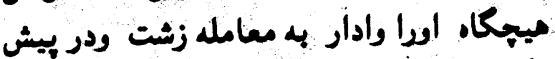

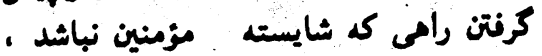

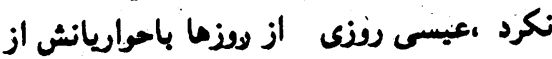

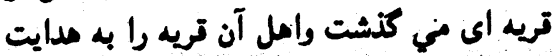

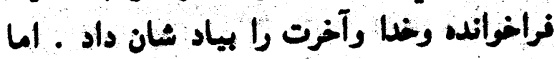

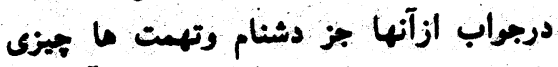

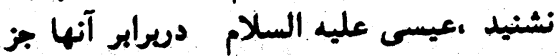

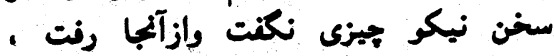

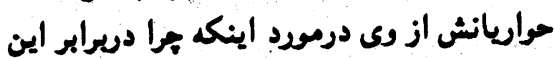

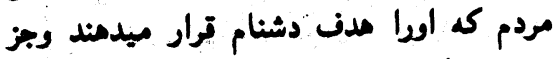

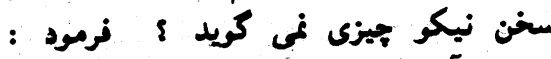

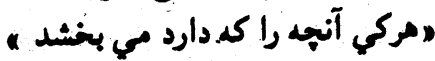
وقتيكه انسان تعليمات عيسى عليه السلام

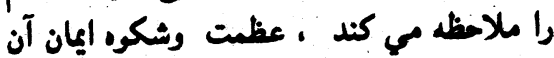

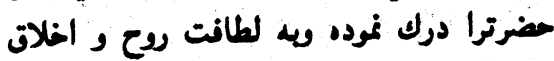

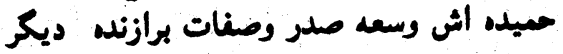

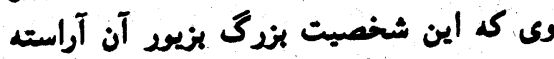

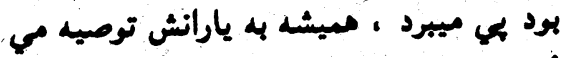

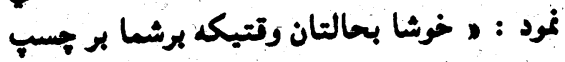

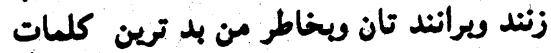

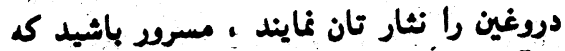

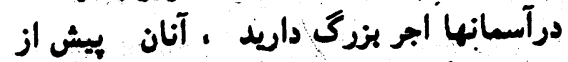

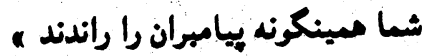

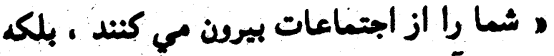

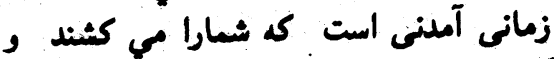

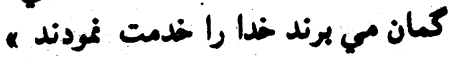

موسى عليه السلام رامش را ادامه داده

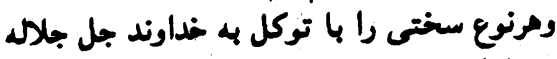

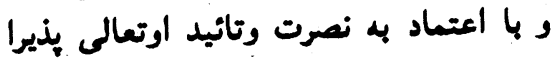

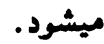

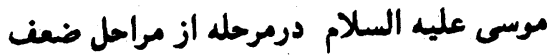

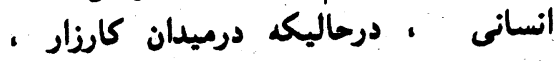

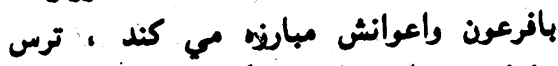

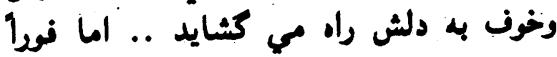

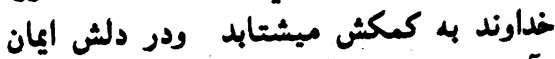

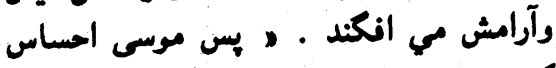

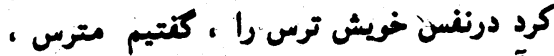

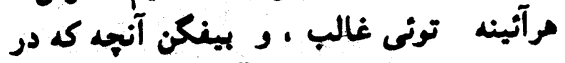

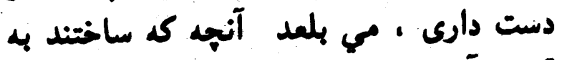

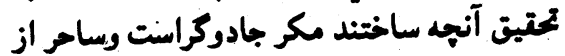

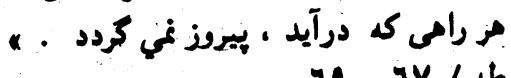

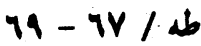

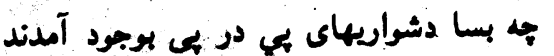

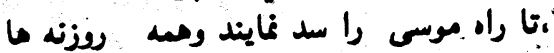

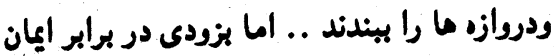

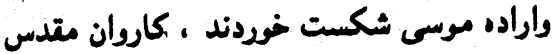

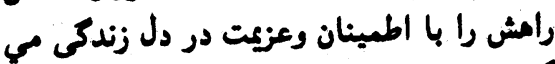

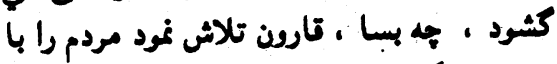

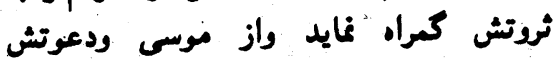

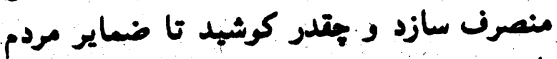

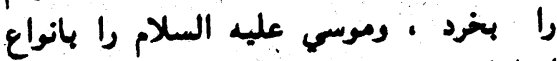

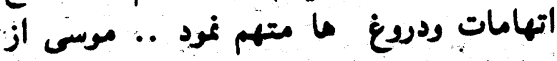

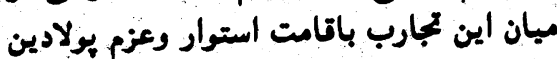
سرفراز بيرون مي آمد آياري

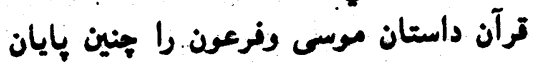
مي بخشد . مران داليكان

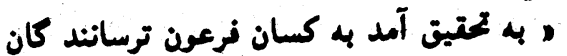

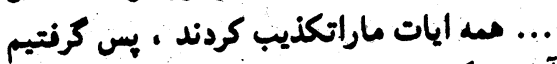

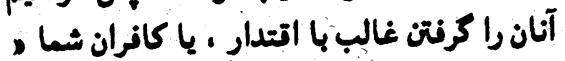

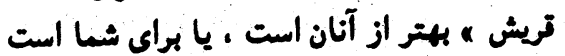

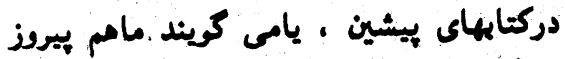

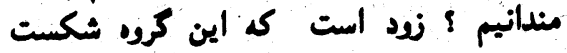

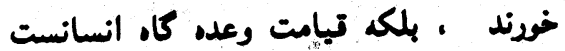
وتيامت بسيارملال كننده وتلخ است . . .

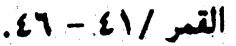

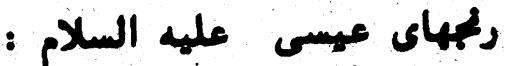

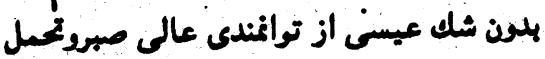

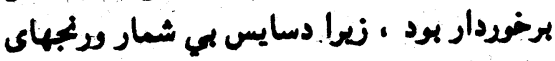
درشرايط دشوار بار وآنياي 

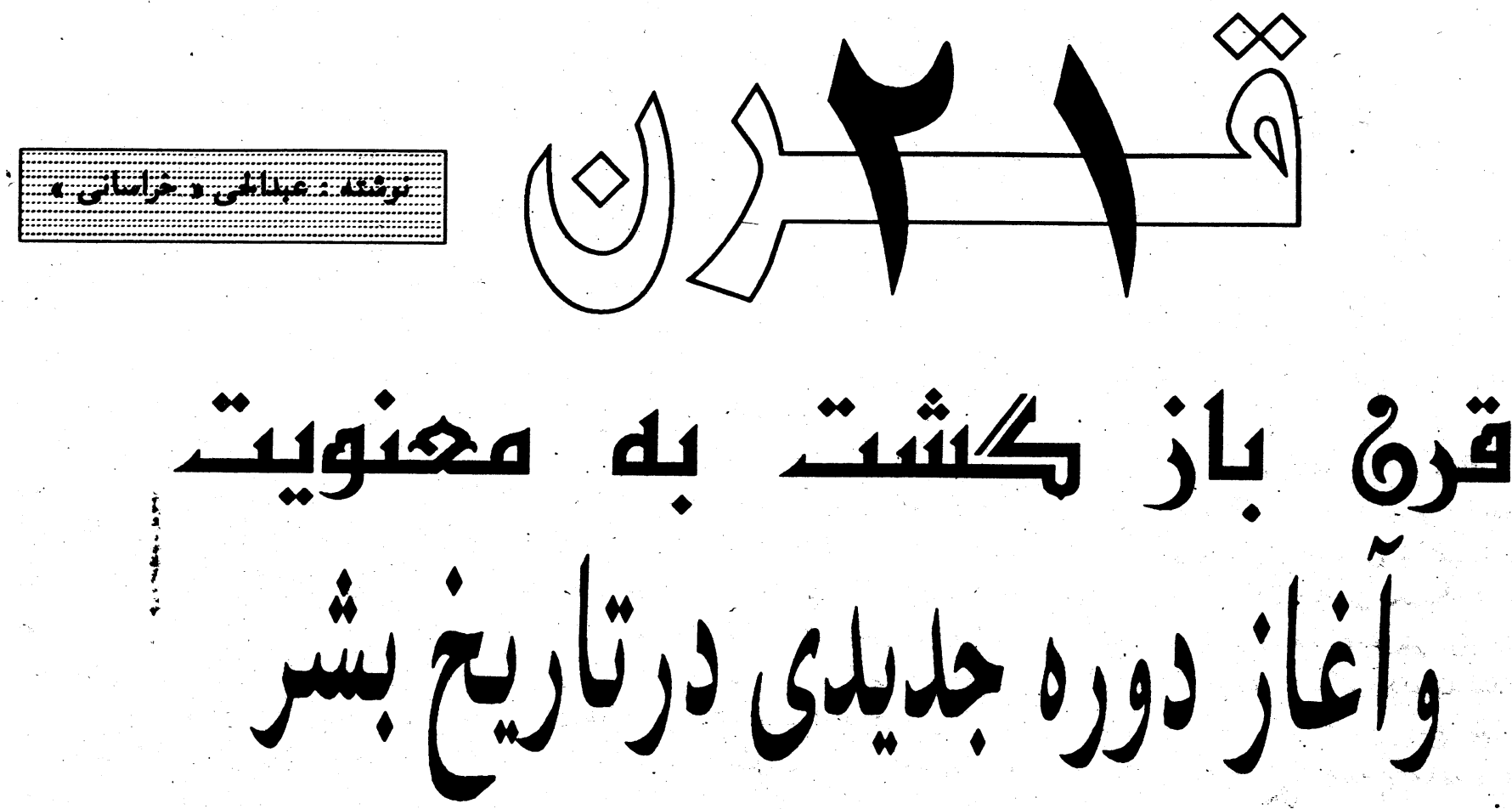

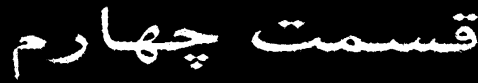

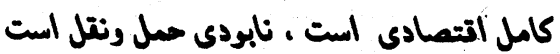

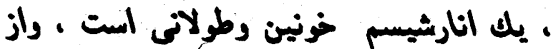

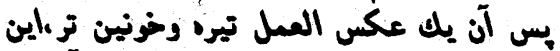

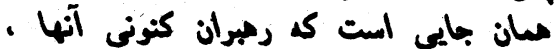

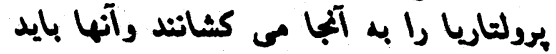

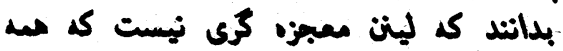

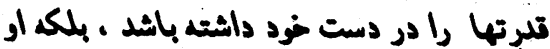

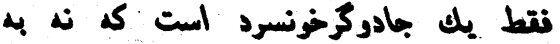

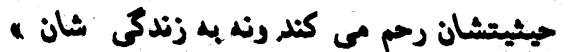

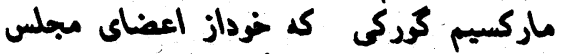

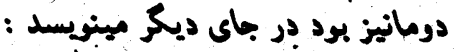

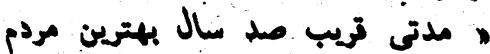

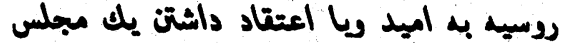

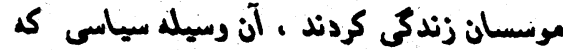

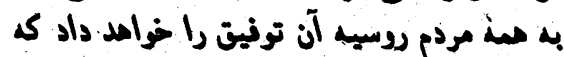

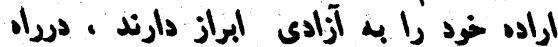

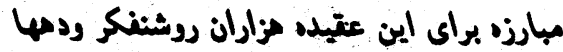

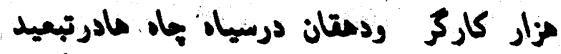

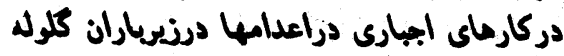

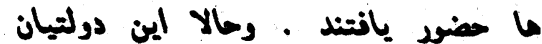

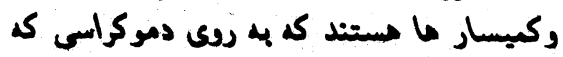

تكاندمنده كودكان بع سر بردت وسر رامى

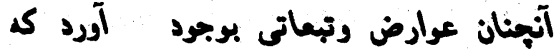

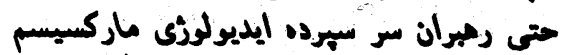

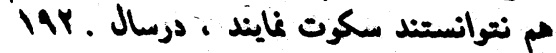

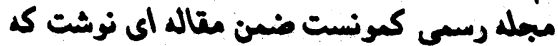

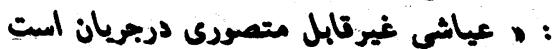

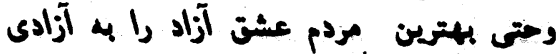

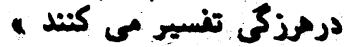

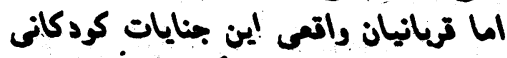

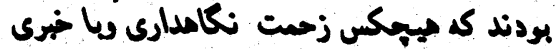

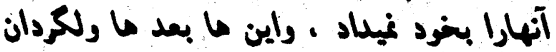

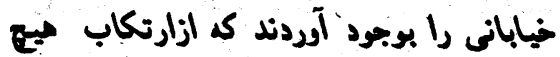

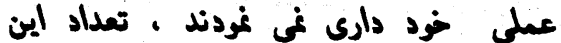

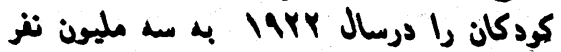

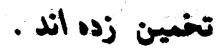
خشونت بباى رسبد كه حتى نويسندكان

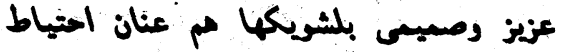

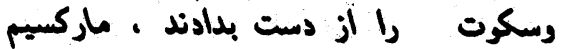

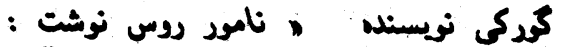

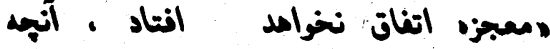

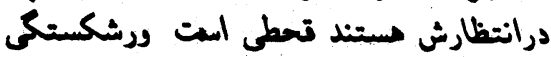

دوماه بعد از اين ماجرا بلثويكها رسطا

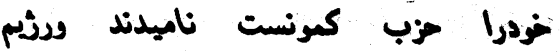

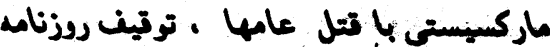

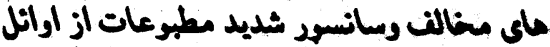

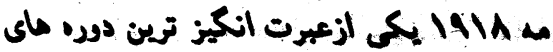

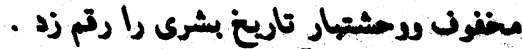
برطيت يله آمار منتشره تعداد كسانيكه

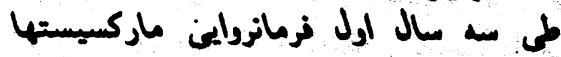

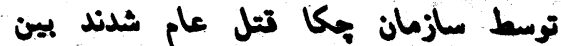

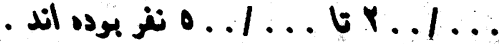

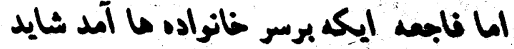

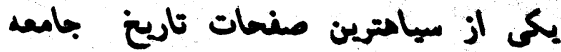

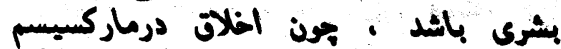

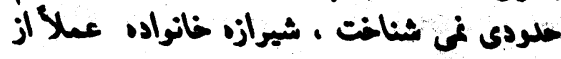

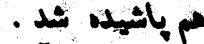
بوجود أمدن خيل عظيم بيساران روانى

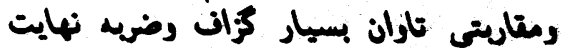

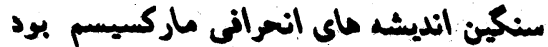

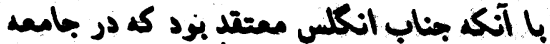

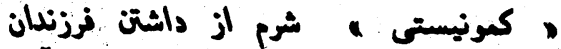

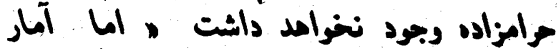




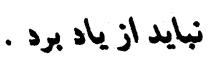

سرالجام بس از سالها جنايت ديكتاتور خون

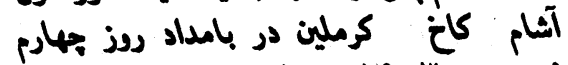

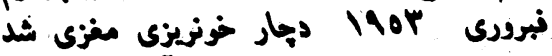

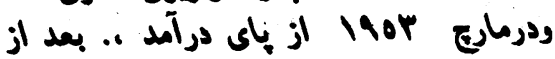

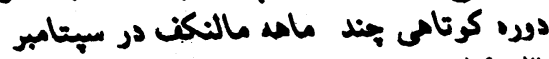

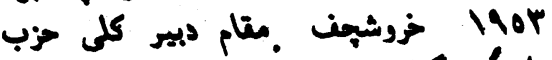

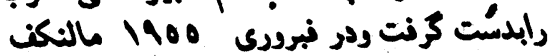

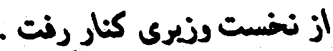

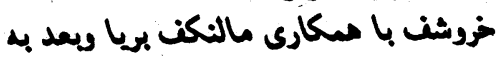

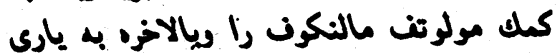

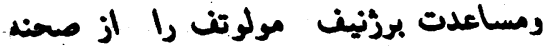

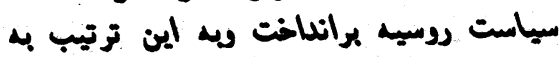

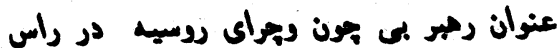

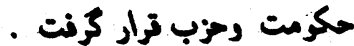

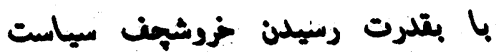

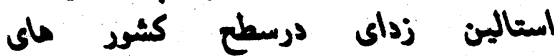

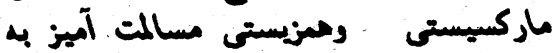
عنوان يل الهل مهم سياست غارجى انتفاب المين

شد . ش

الما تغيير عمده در مياست روميه بعدازي

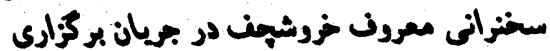

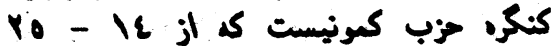

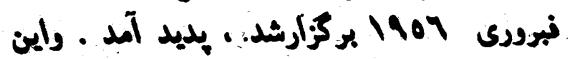

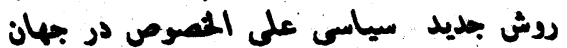

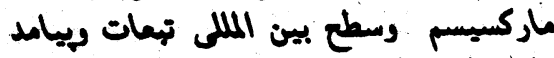

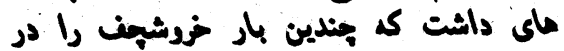

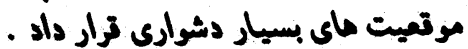
تا زمان مر

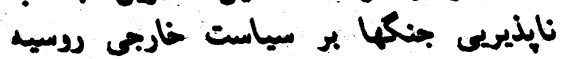

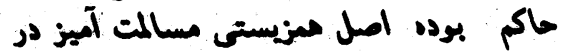

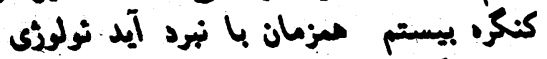

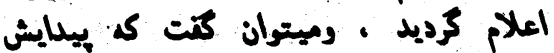

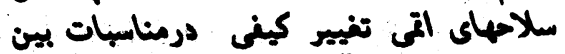

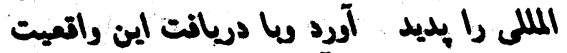

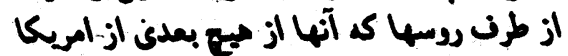

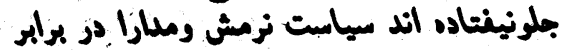

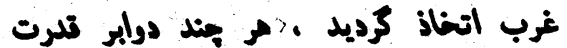

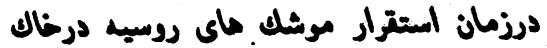

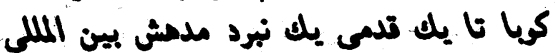
جلو آردند .

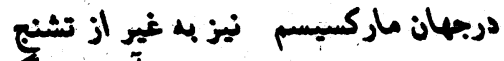

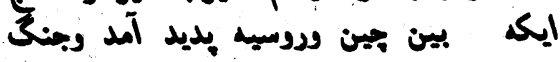

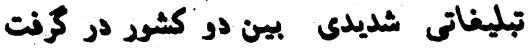

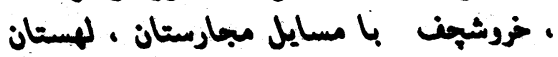
وكريا ردبروشد وراتع بينى ار در بعضى ازيل
خونى استالين مينويسد :

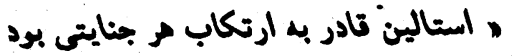

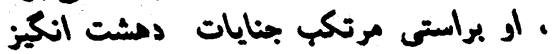

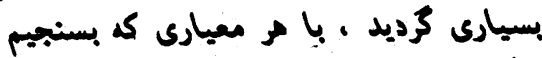

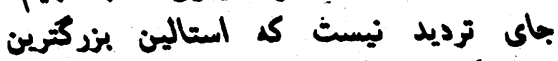

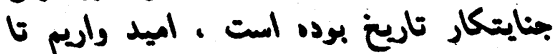

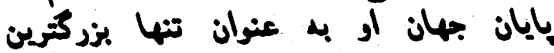

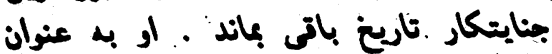

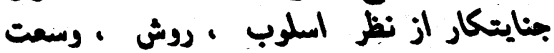

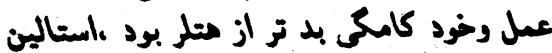

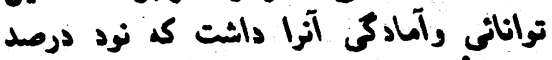

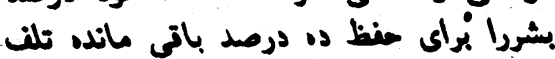

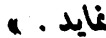

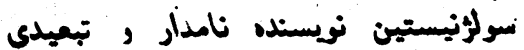

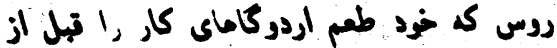

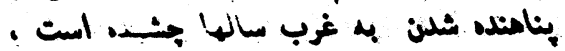

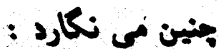

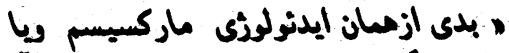

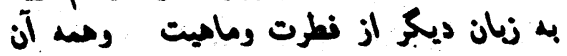

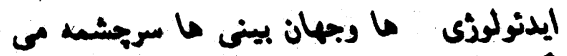

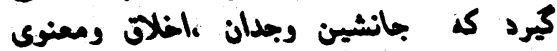

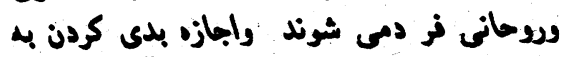

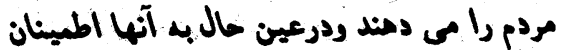

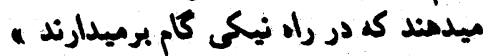

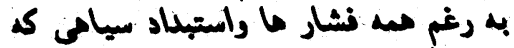

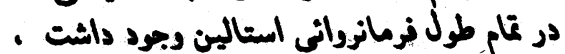

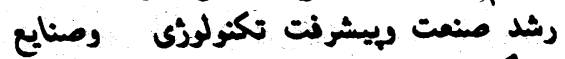

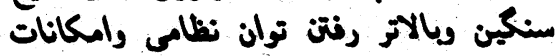
على روسيه رادر دوران ديككاتورى ابتالين والين

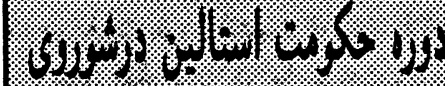

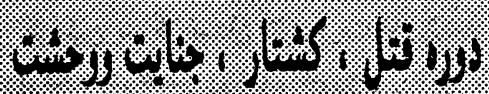
"IT) (2)

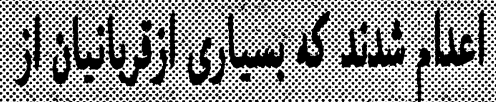
(4)

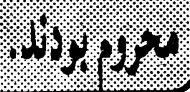

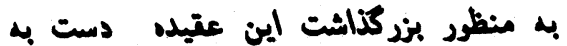

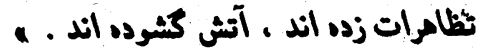

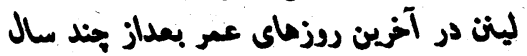

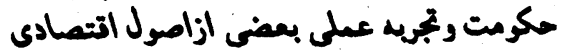

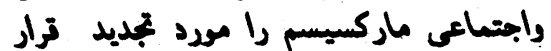

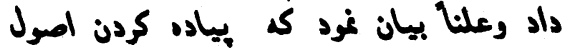

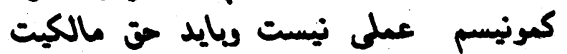

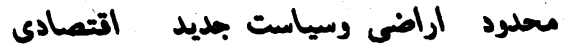

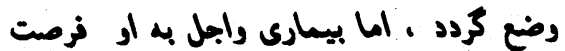

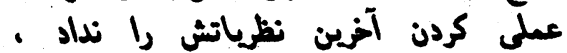

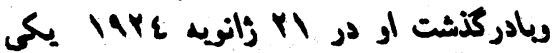

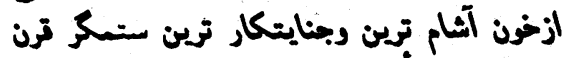

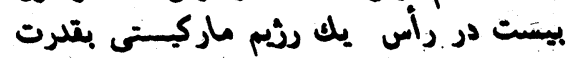

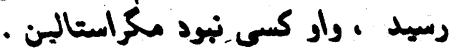

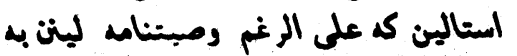

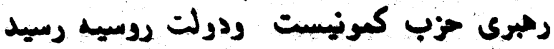

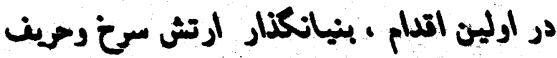

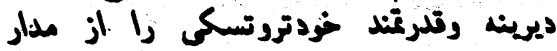

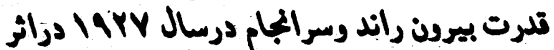

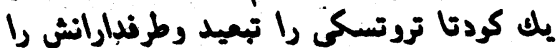

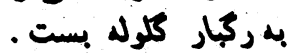

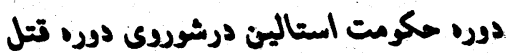

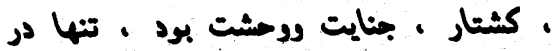

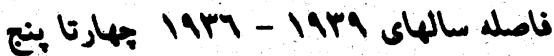
مليون نغ اعدام شدند كه بسيارى ازتريانيان ازئ

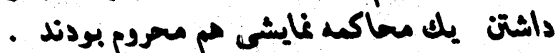

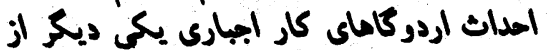

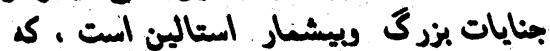

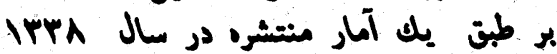
نزديك به هشت مليون نغر در آبها اسير بوده

اند اند اند

در باره اردوكا، ماي كار ابهارى زئريرنيال

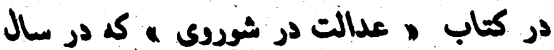
I 1980

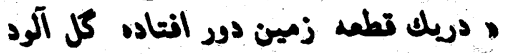

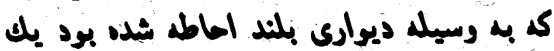

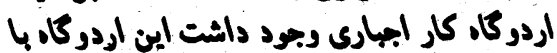

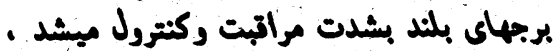

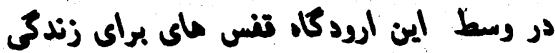

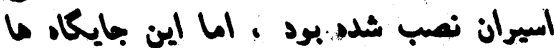

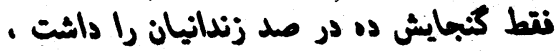

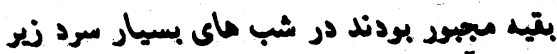

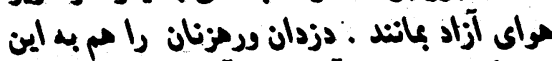

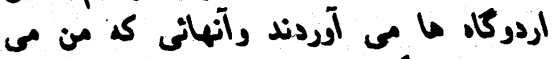

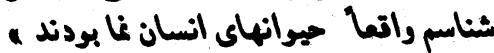

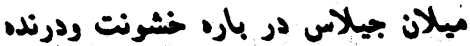




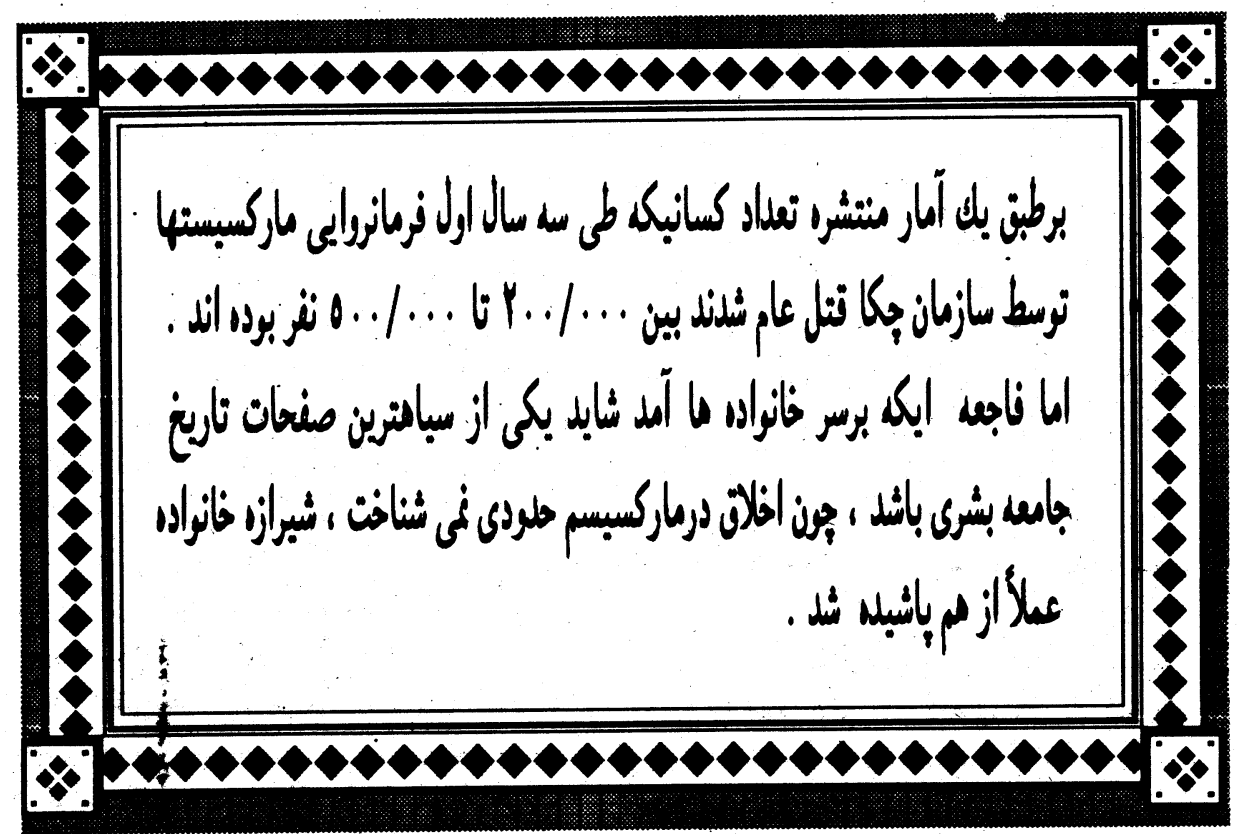

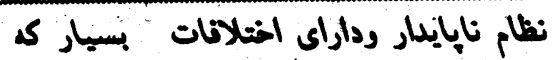

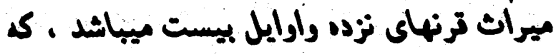

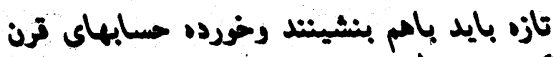

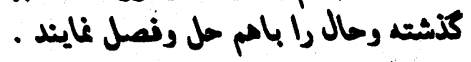

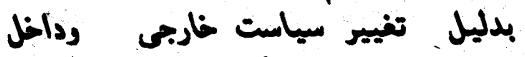

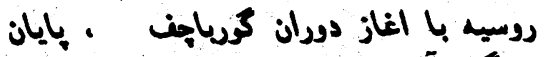

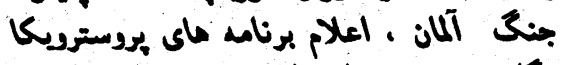

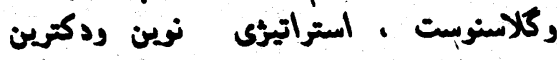

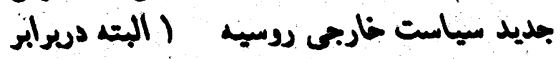

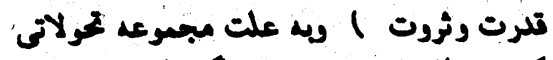

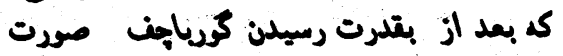

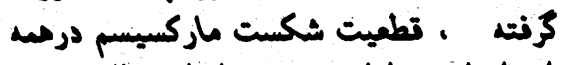

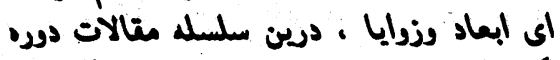

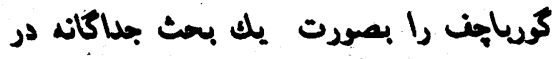

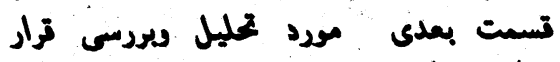

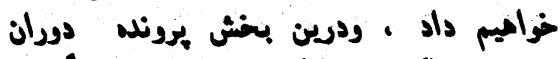

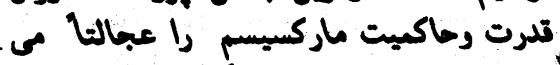

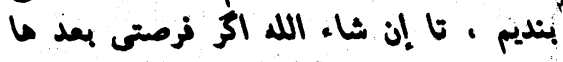

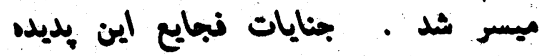

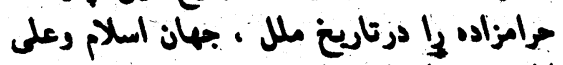

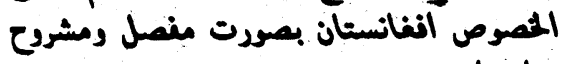

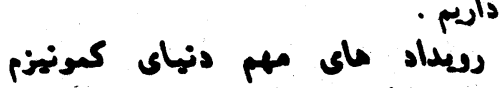
بيان داريم - بلموص أقنان

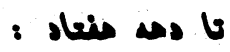

: : :

حزب كونيست جين برهبرى مانو بعد ازي

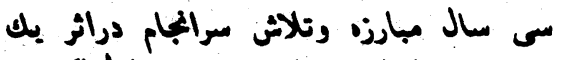

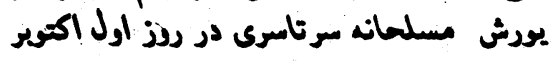

برخورد ماى بين المللى متدمات ستوط اثى

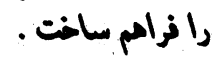

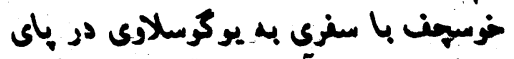

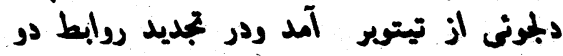

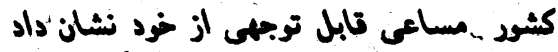

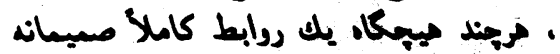

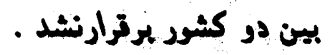

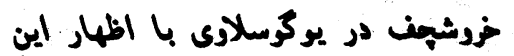

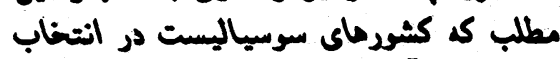

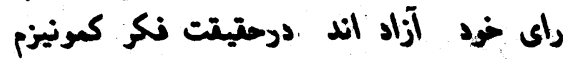

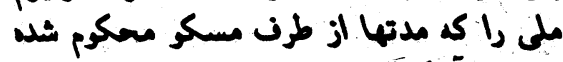

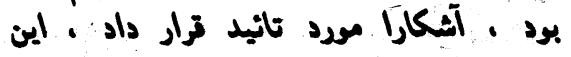

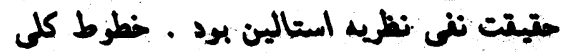

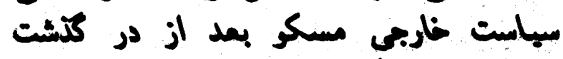

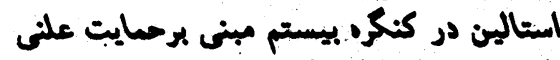

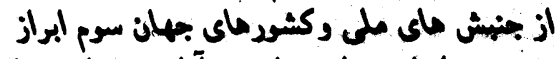

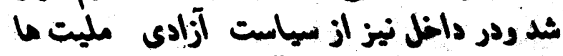

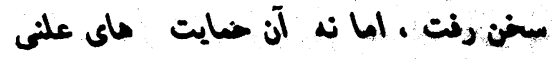

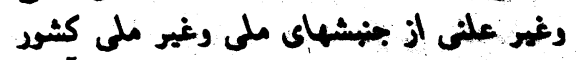

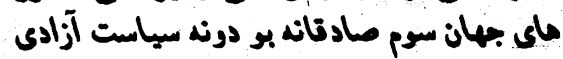

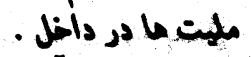

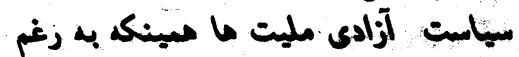

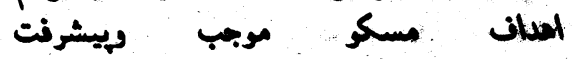

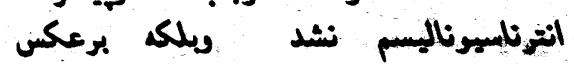

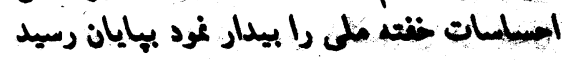

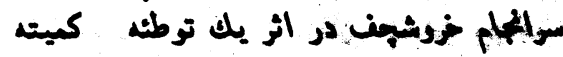

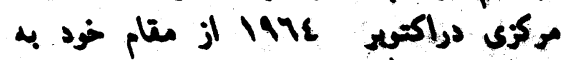

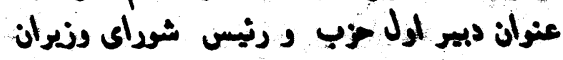

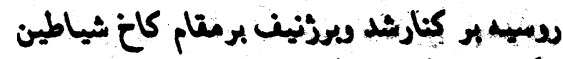

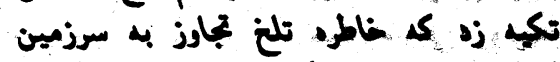

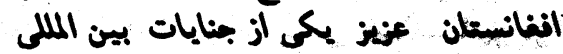

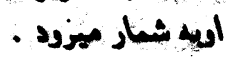

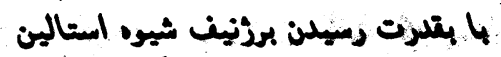

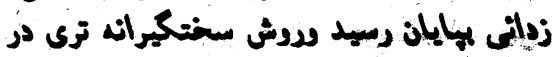

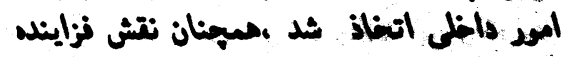

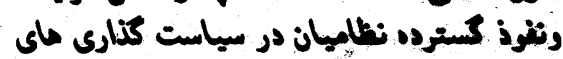
a

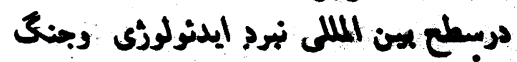

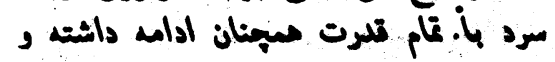

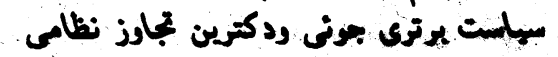

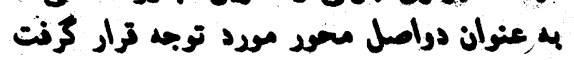

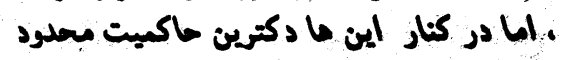

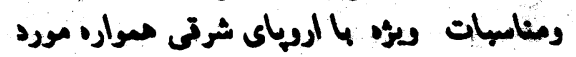

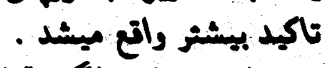

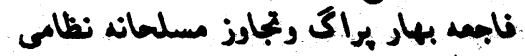
به انفلنستان از بنايات فراموش ناشدنى تاريخ 


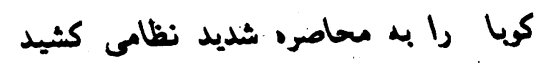

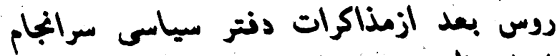

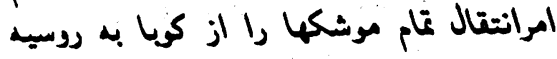

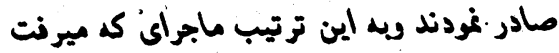

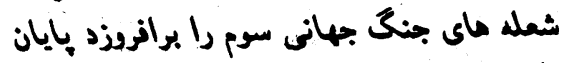

بانت.

\section{: 1971 ديوار هرلين}

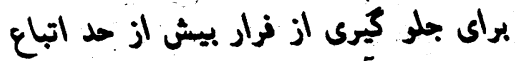

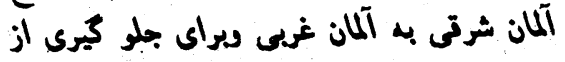

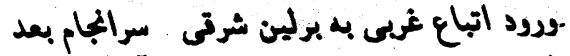

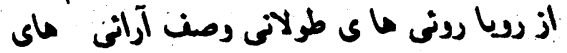

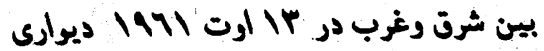

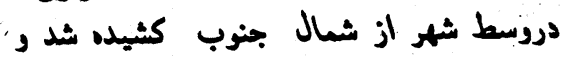

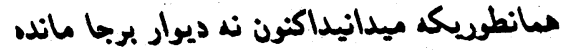

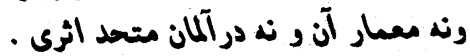

\section{:}

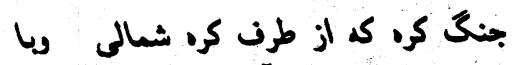

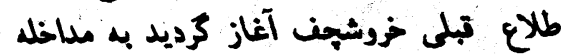

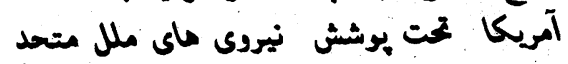

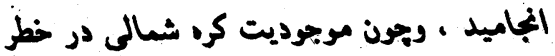

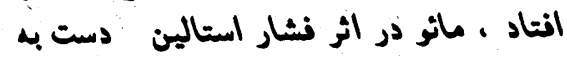

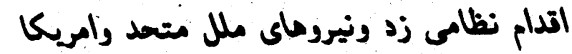

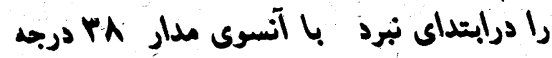

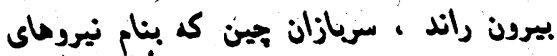

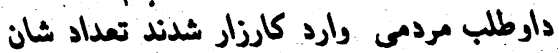

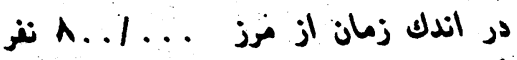

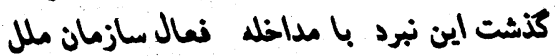

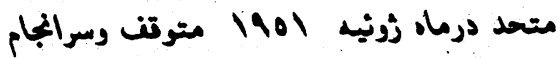

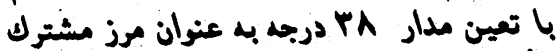

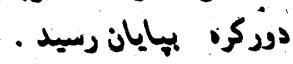

اينكه با نتل جند جمله از وديد كتاب تزاريسم

وانقلاب ا ا

و OLUTION

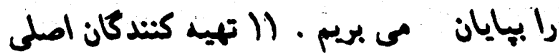

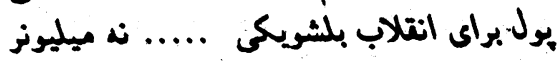

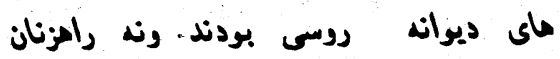

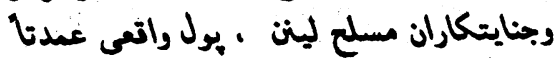

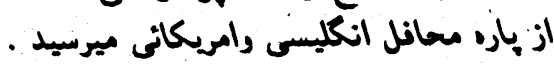

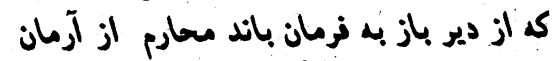

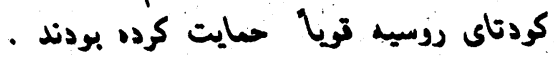

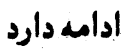

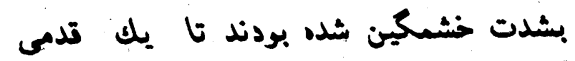

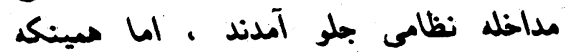

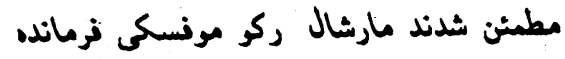

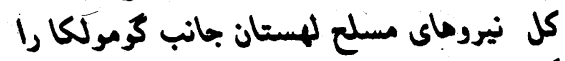

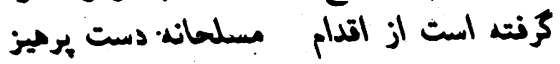
مزوند

\section{: مبارسمان}

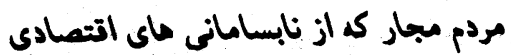

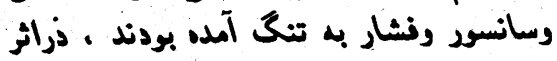

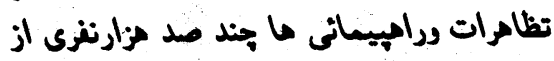

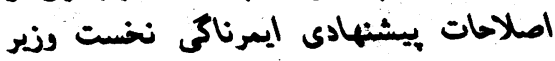
اصلاح طلب منار به شدات بشتيبانى ئوده

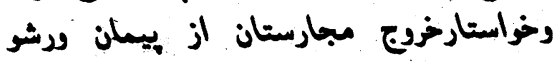

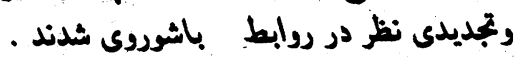
روس ها با توجه به بنحان كانال سوئز

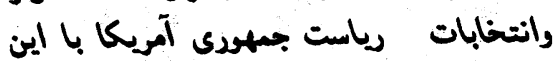

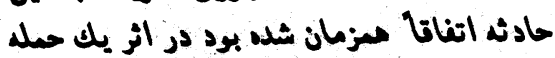

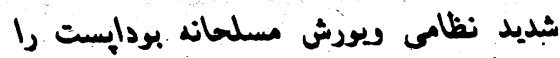

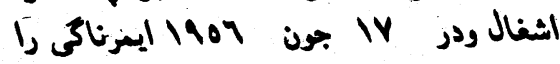

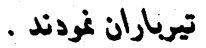

\section{بهاريراك - بكنلواكيا - بهاي :1974}

مونج اصلامات از بهار وتابستان

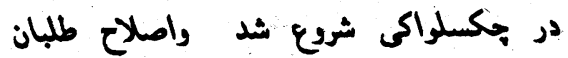

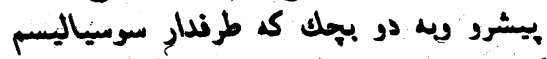

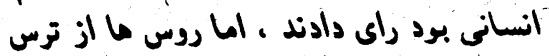

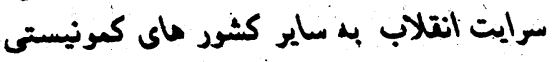

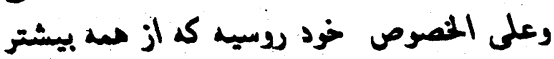

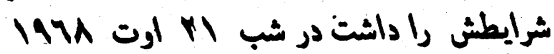

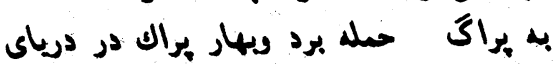

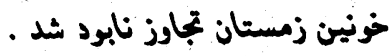

$$
\text { : } 15
$$

دريى يجيروزى فيدل كاسترو وحلد

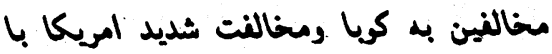

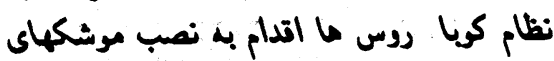

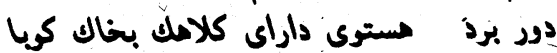

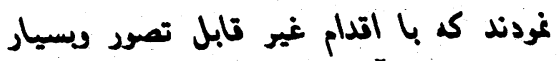

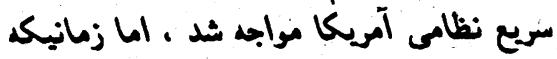

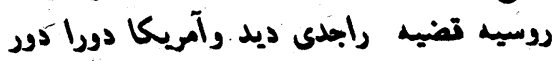

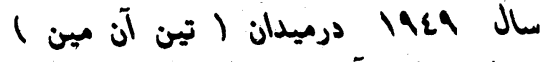

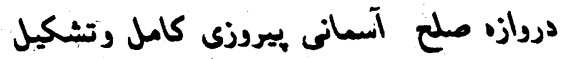

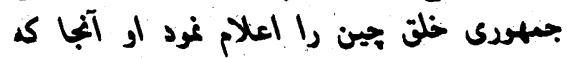

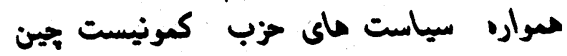

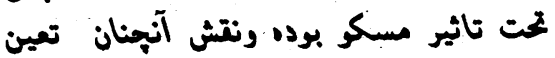

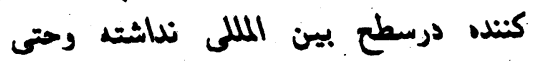

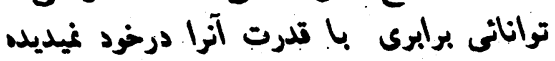

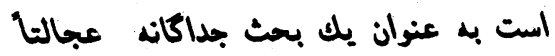

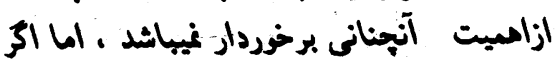

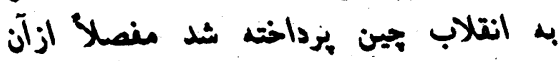

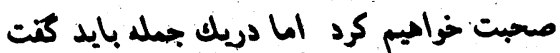

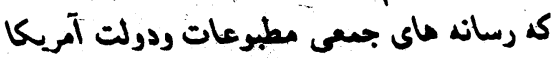

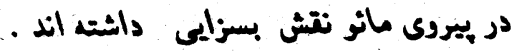

\section{: شودوى وهين}

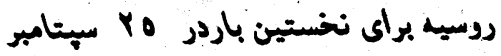
19L9

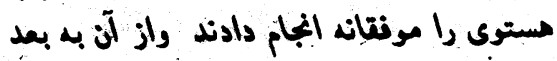

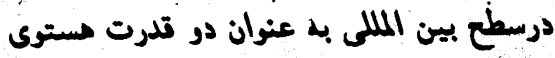

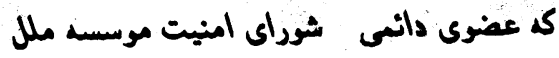

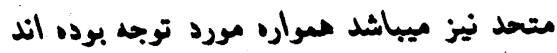

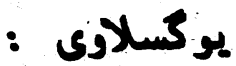

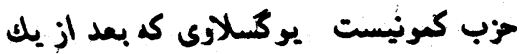

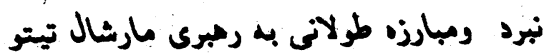

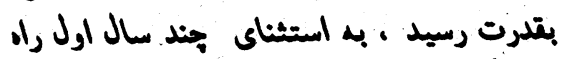

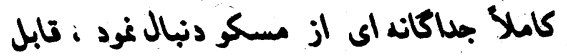

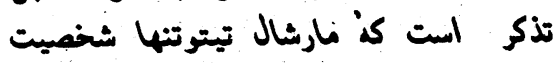
برجسته جهان ماركسيسم بو دكه علنا وريسا

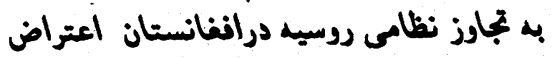
مز

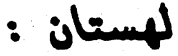

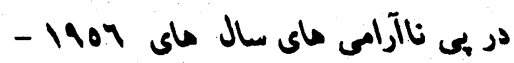

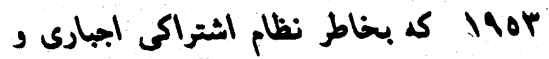

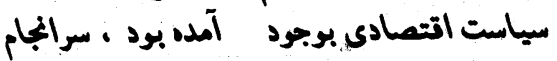

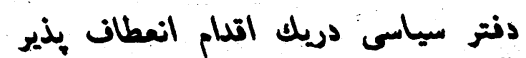

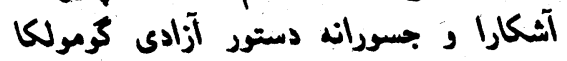

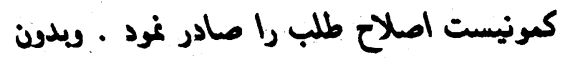

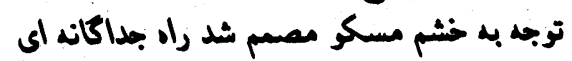

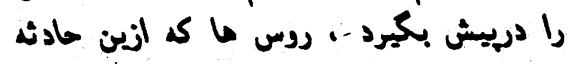



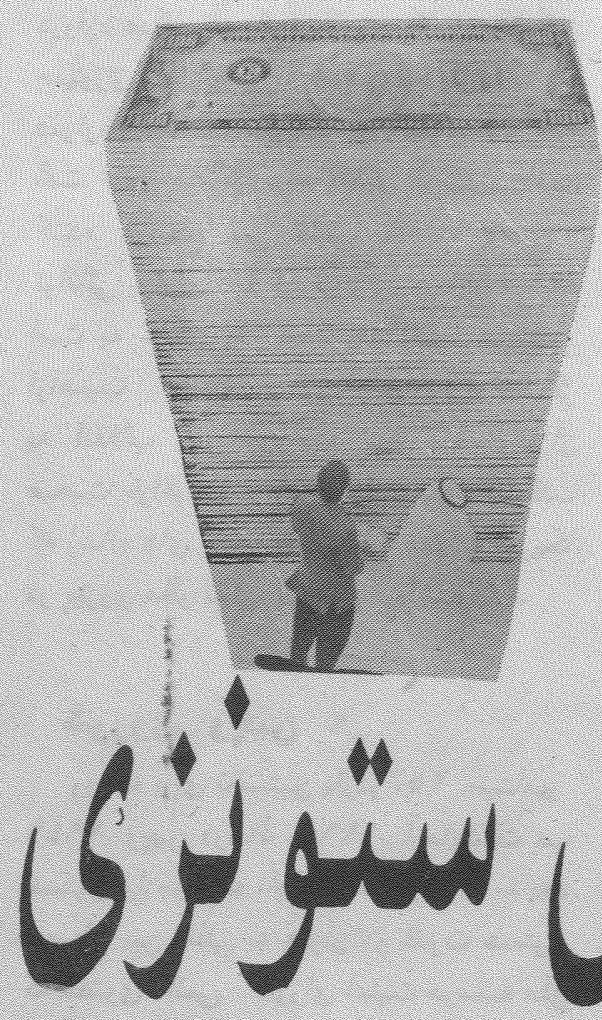

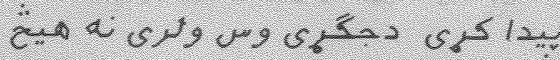

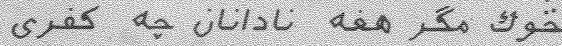

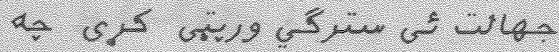

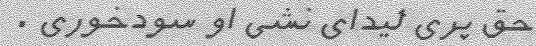

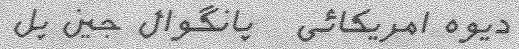

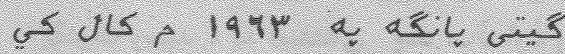

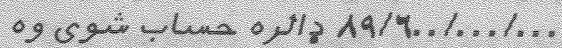
जै

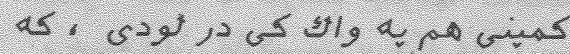

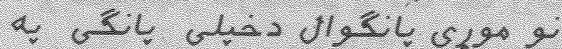

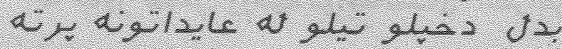

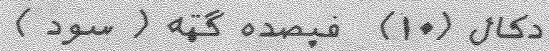

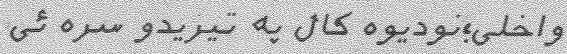

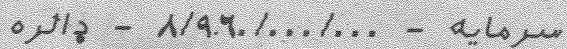

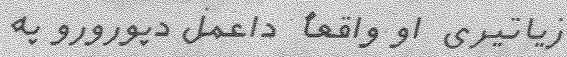

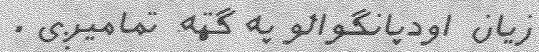

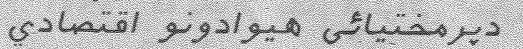

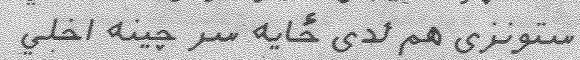

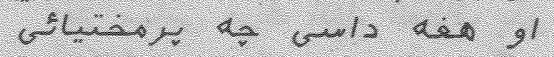

calaial glas de agston

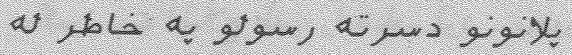

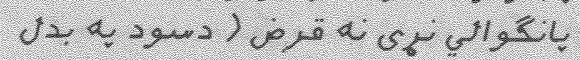

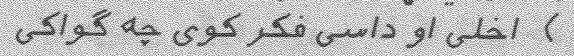
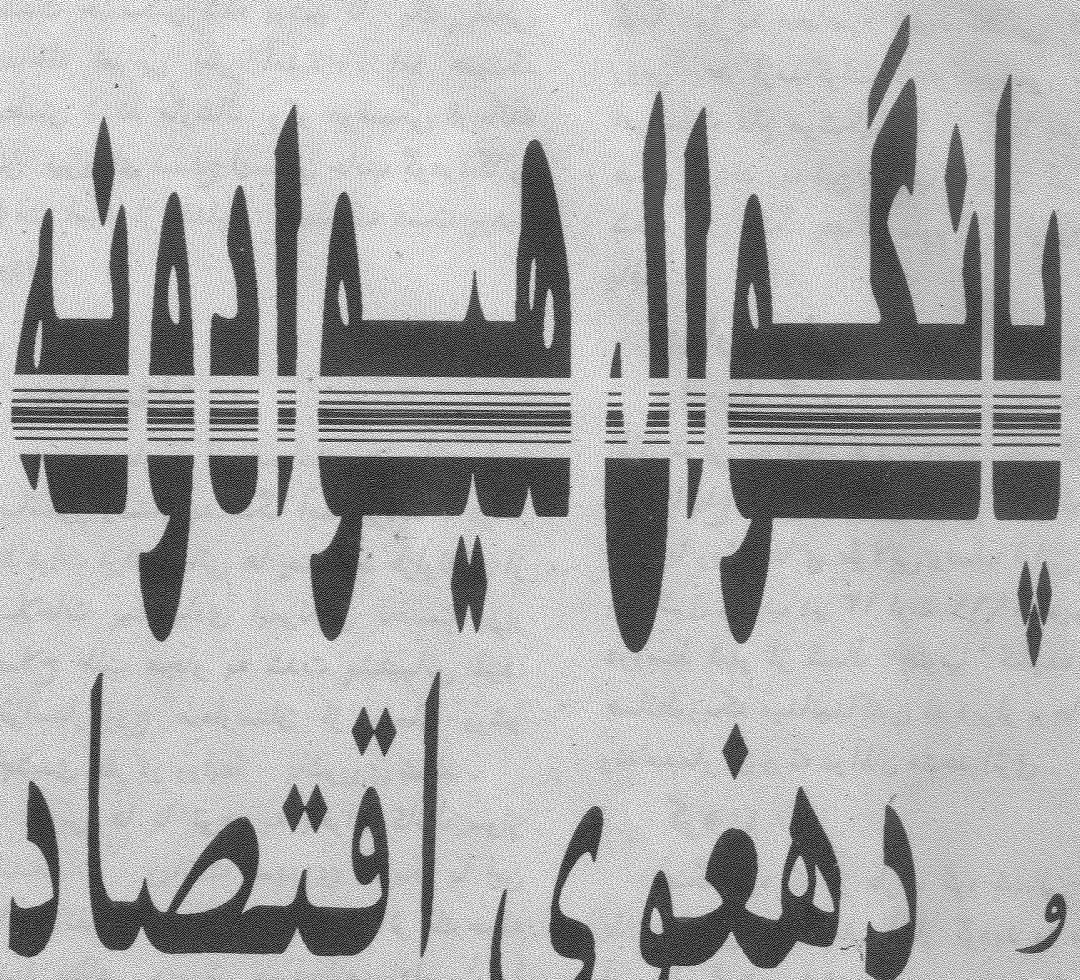

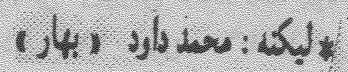

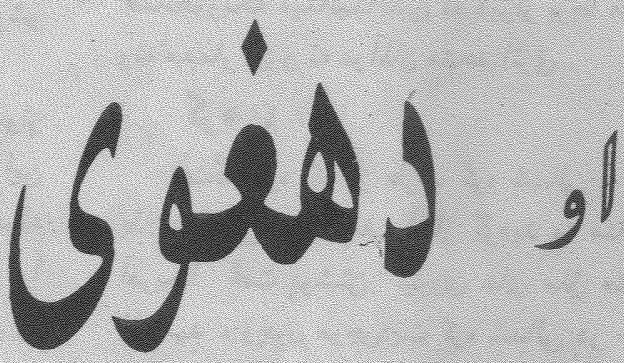

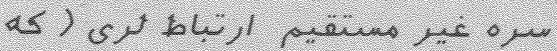

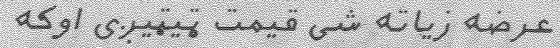

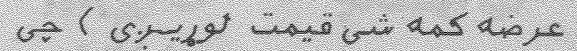

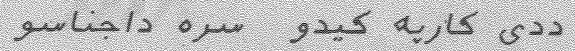

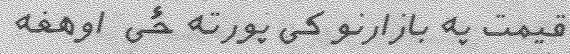

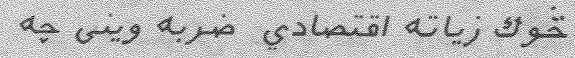

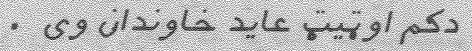
a) alg ului \& jkin la pa a g.

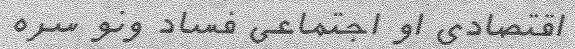

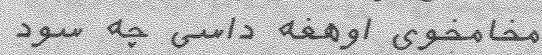

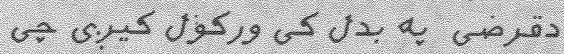

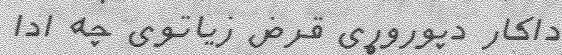

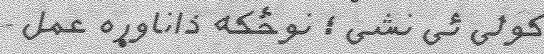
vilut gre a vilg a ( agu)

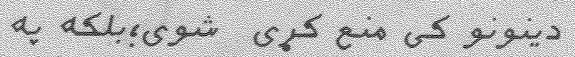

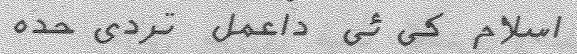

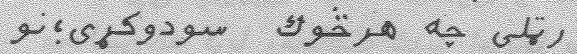

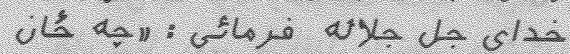

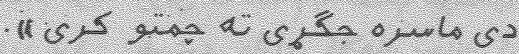

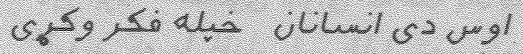

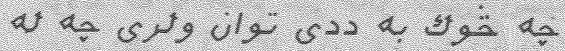

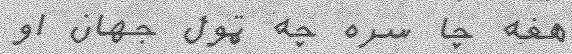

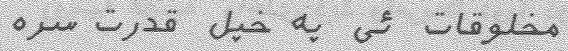

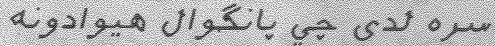

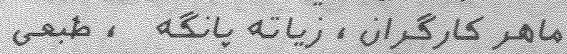
- Logr agutili vpe copj alj a ulinl \& 4 gl asgl an

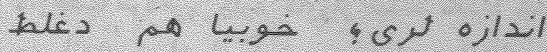

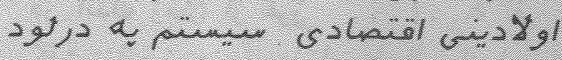

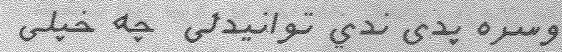

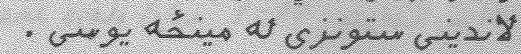

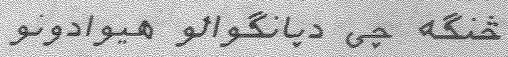

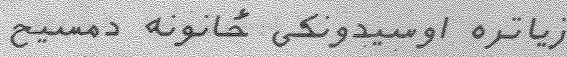

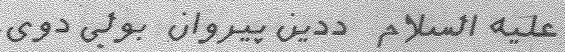

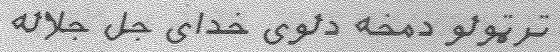

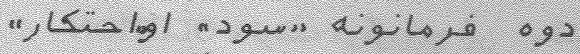

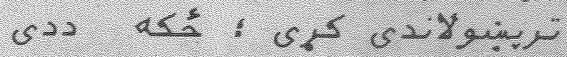

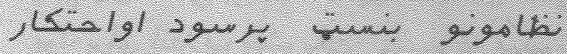

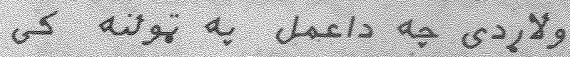

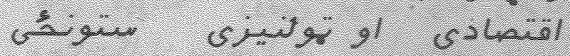

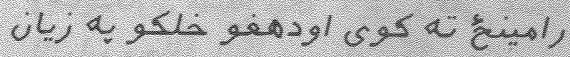

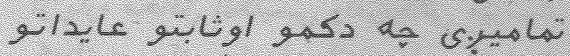

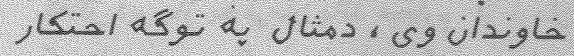
dac vas as ca dac ojgl vela

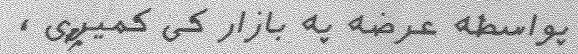

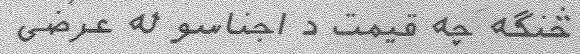




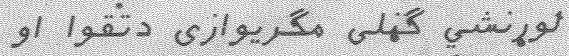

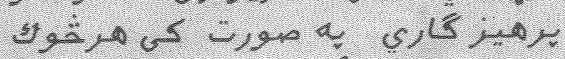

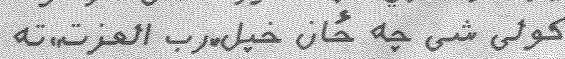

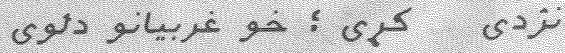

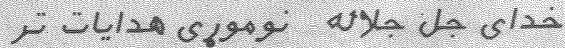

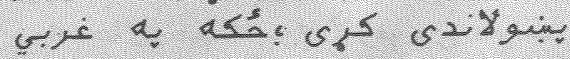

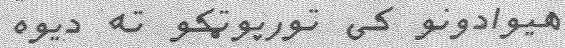
sys des as, w a vlga oning

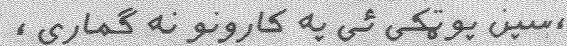

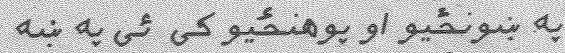

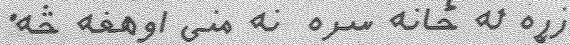

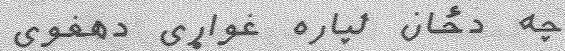

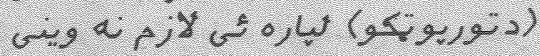

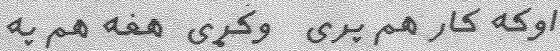

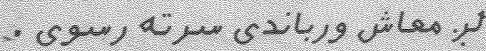

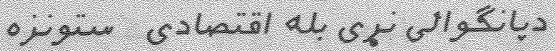

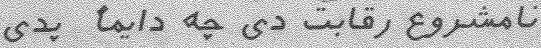

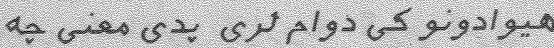

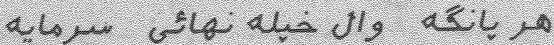

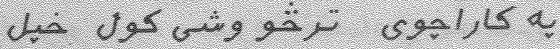

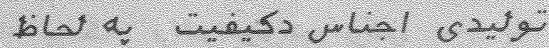

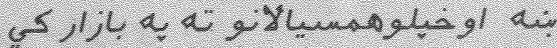

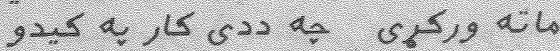

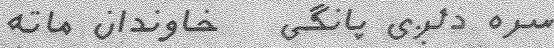
steg ch wgs wingl vigh a bla \&

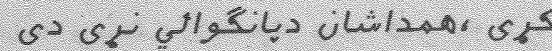

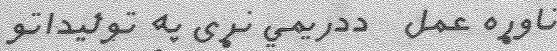

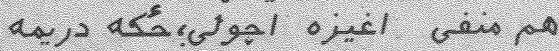

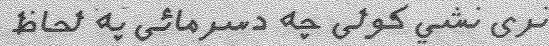

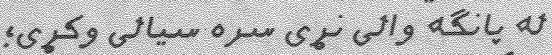

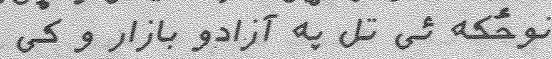

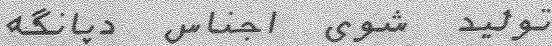

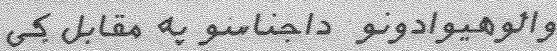

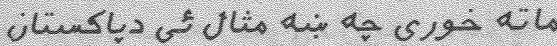

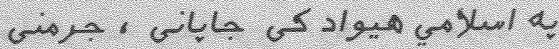

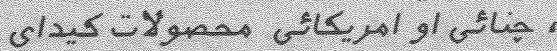

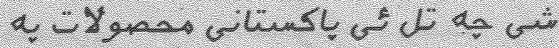

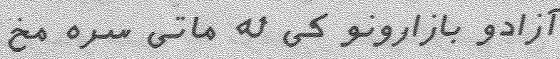

s,olhs gi a, inicl o, 5,15

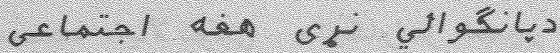

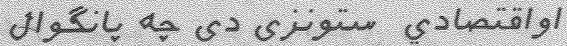

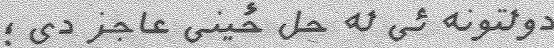

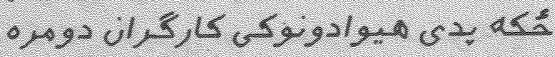

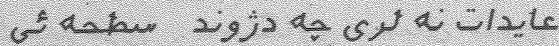

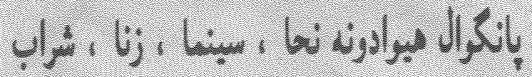

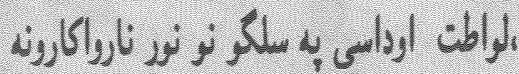

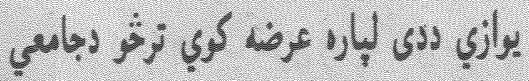

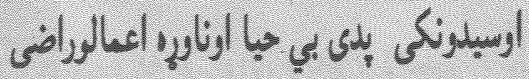

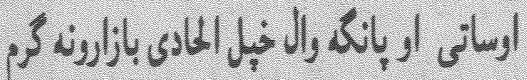

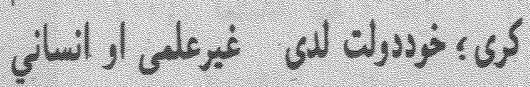

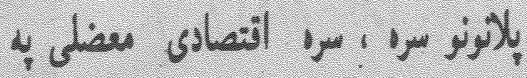

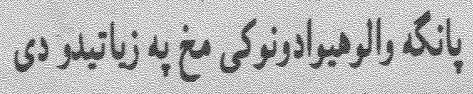

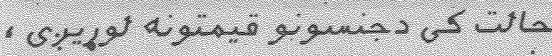

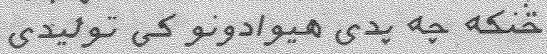
J

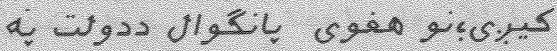

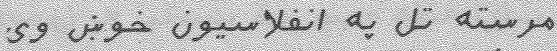
or vis a rili

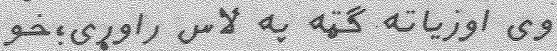

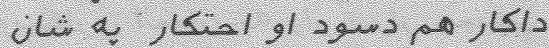

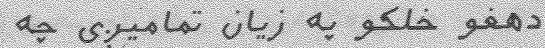

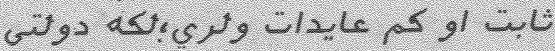

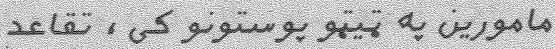

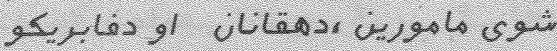

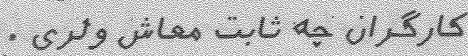

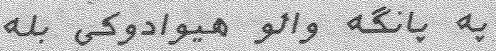
vcluigl a a ojgin colnisl

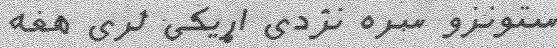

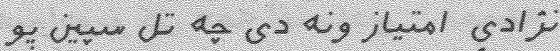

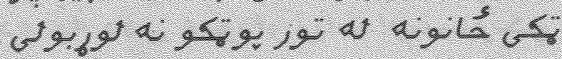

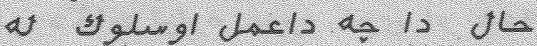

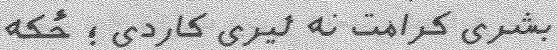

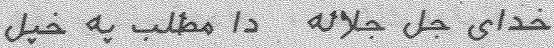

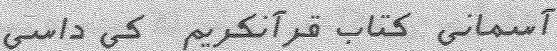
of aligs

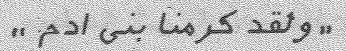

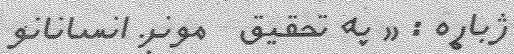

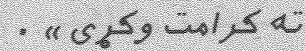

a vila

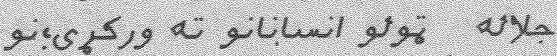

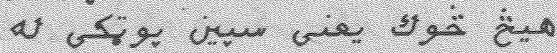

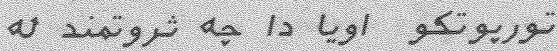

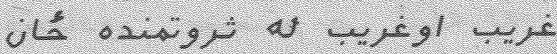

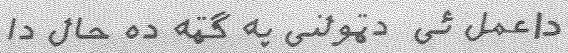

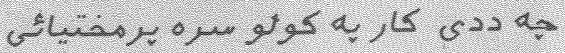

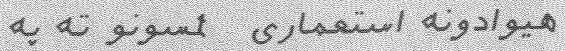

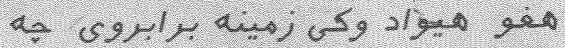

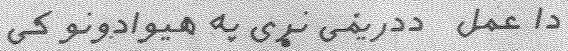

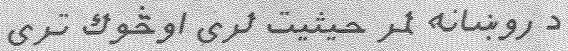
- co $0^{5}$ com , <il

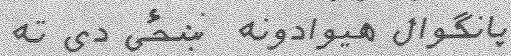

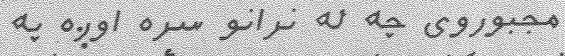

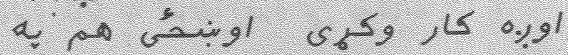

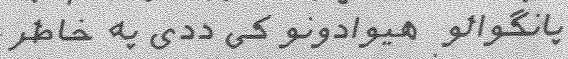

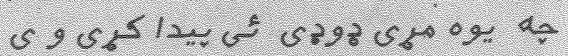

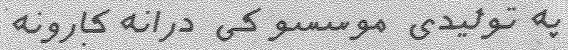

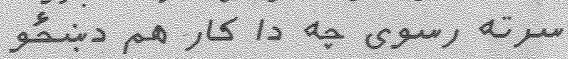

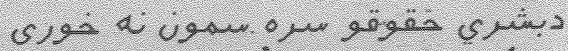
blat viloma a son ata :

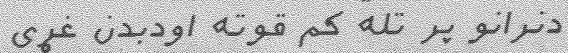

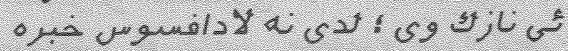

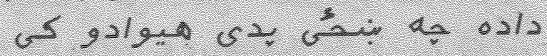
aug g्रLu vigetis glo KLs

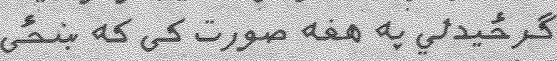

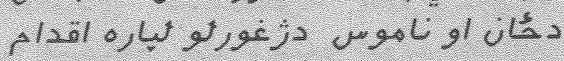

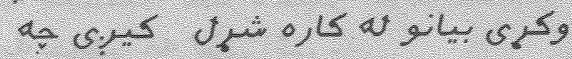

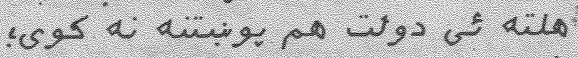

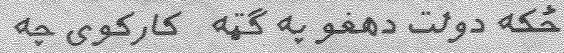
- cr) unimgl asL a L (204) visgito os grothis $v^{2}$

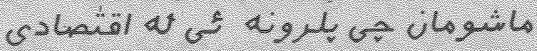

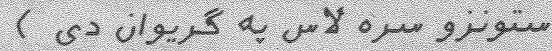

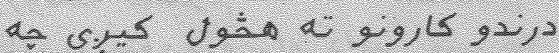

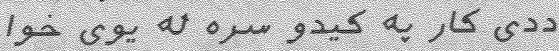

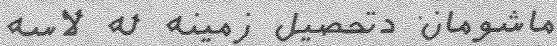

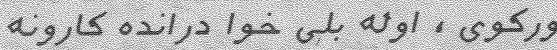
- vón

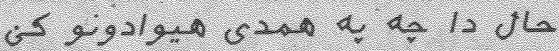

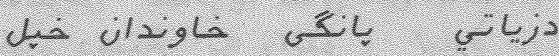

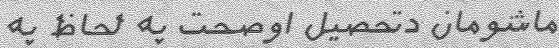

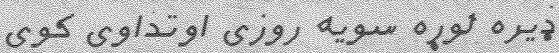

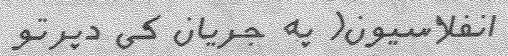

gri anje a wlgligur

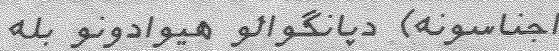

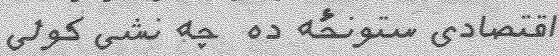

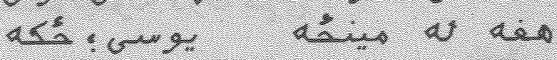

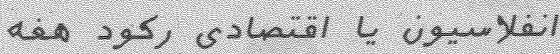

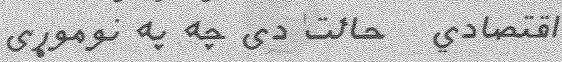




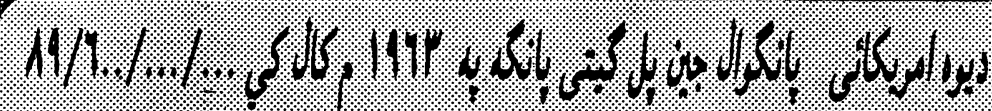

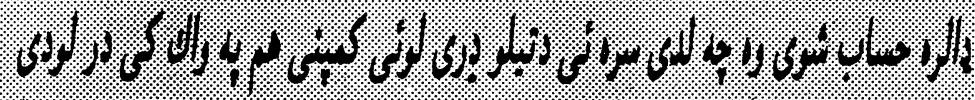

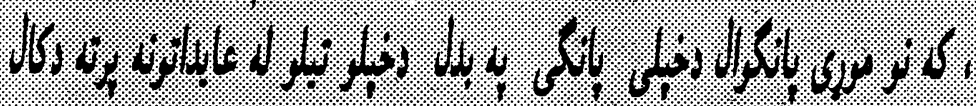

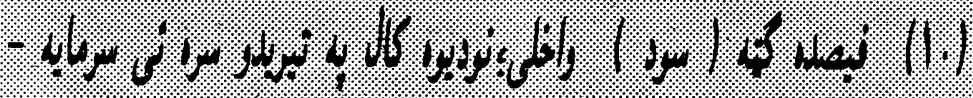
. i. .6.

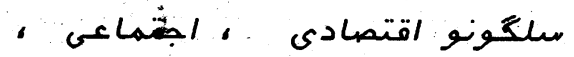

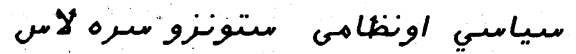

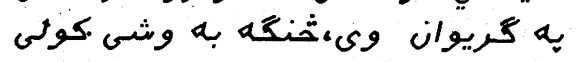

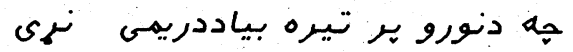

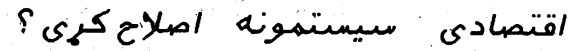

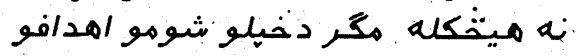

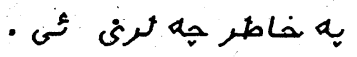

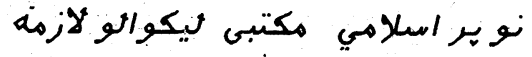

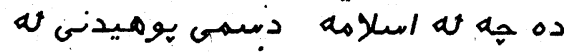

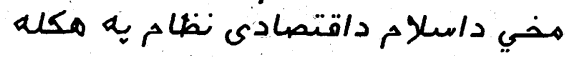

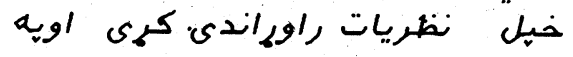

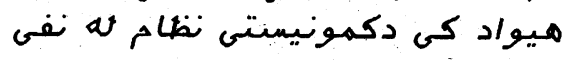

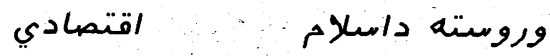

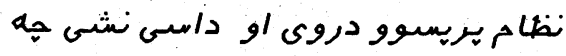

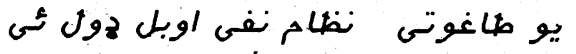

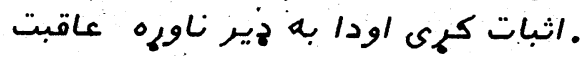

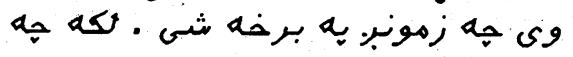

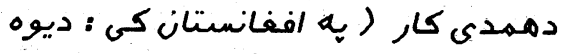

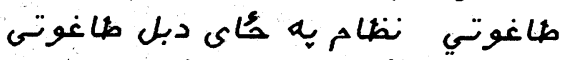

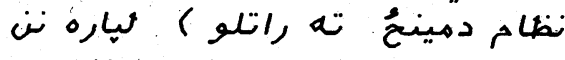
ذشرق اوغرب شازشونه روانه روانه دئه

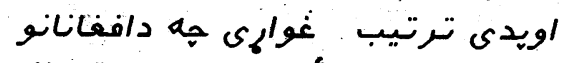

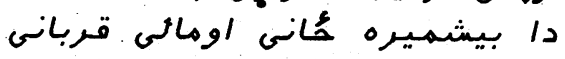

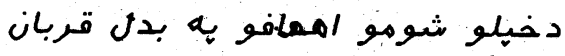

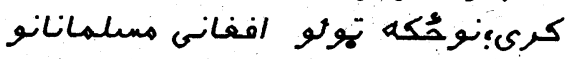

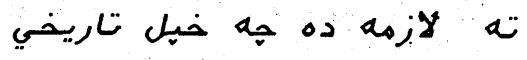
•

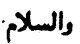

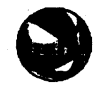

هه دى كاره هيخوا زيات يه نومورو

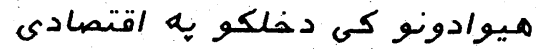

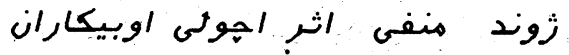

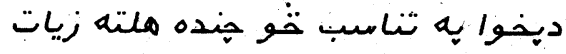

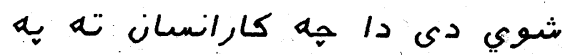

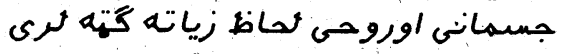

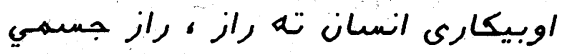

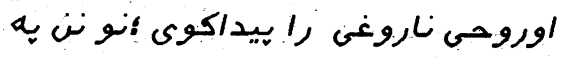

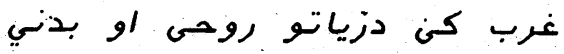

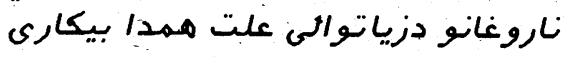

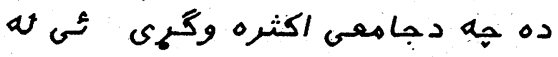

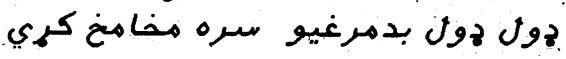

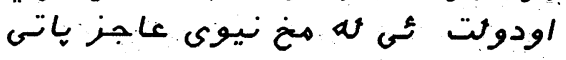
• شودى دونى

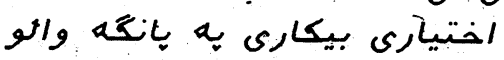

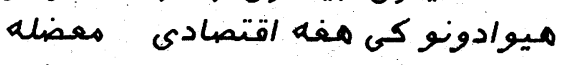

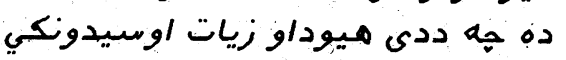

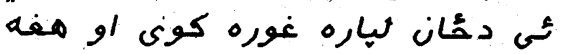

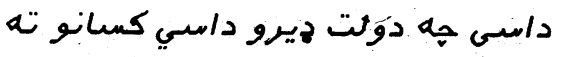

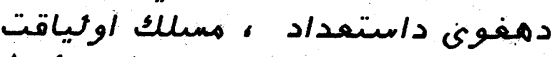

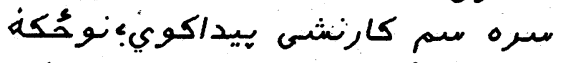

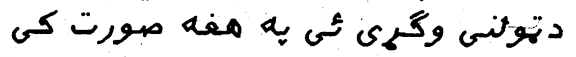

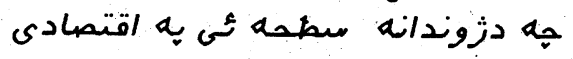

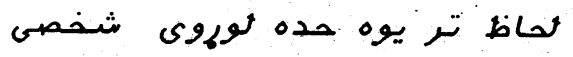

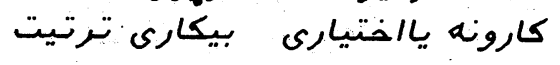

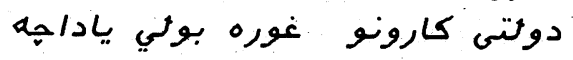

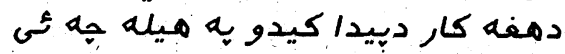

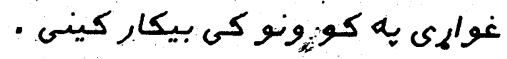

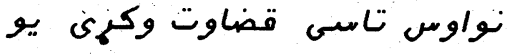

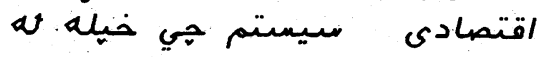

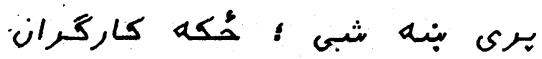

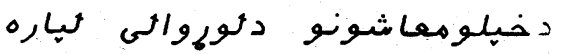

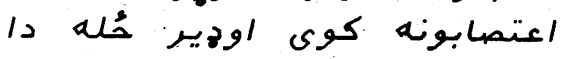

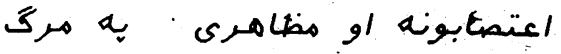

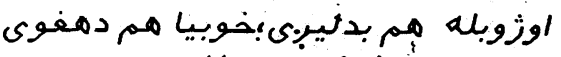

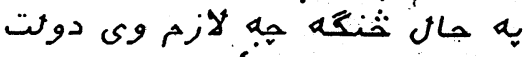

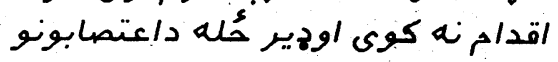

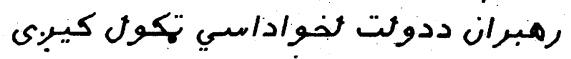

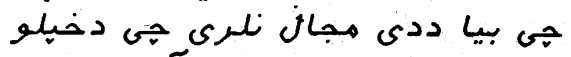

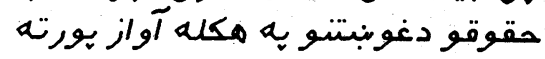

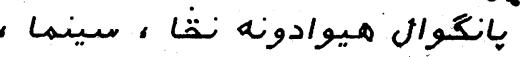
- كرقو

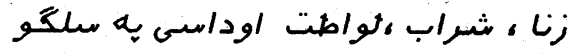

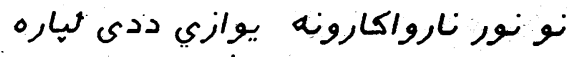

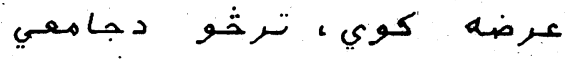

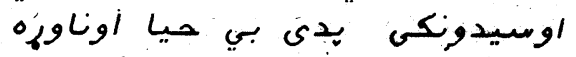

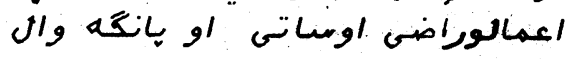

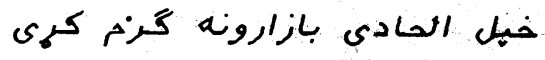

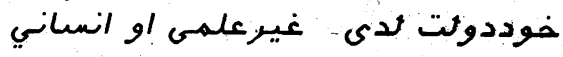

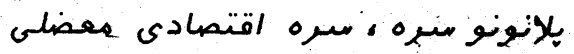

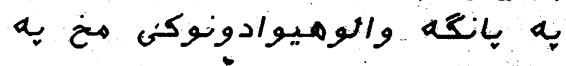
زياتيدودى ده ونه دميكانيزه ( ماشينى ) كارونو ئهو

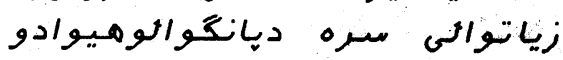

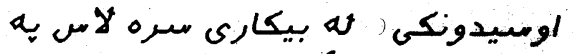

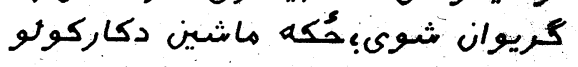

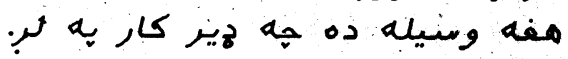

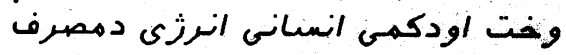

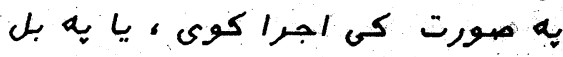

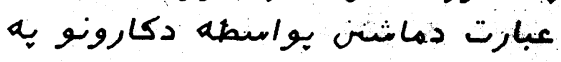

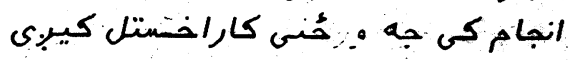

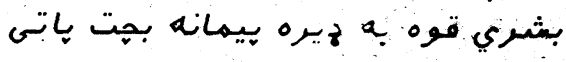

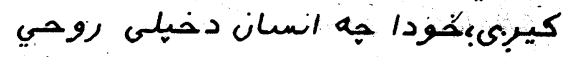

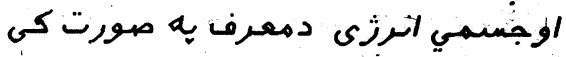

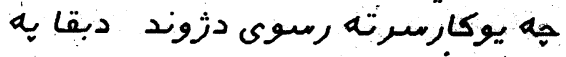

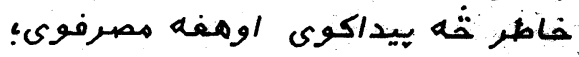

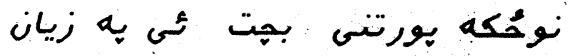

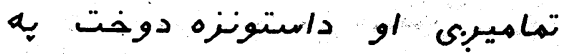

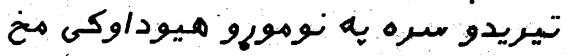

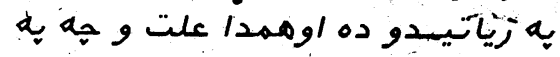

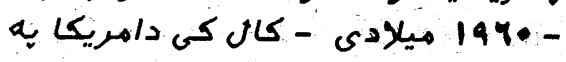

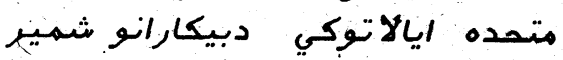
W مو -YY-

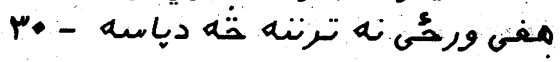

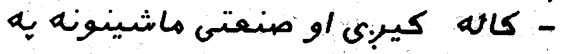

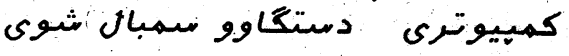




\section{4 at:}

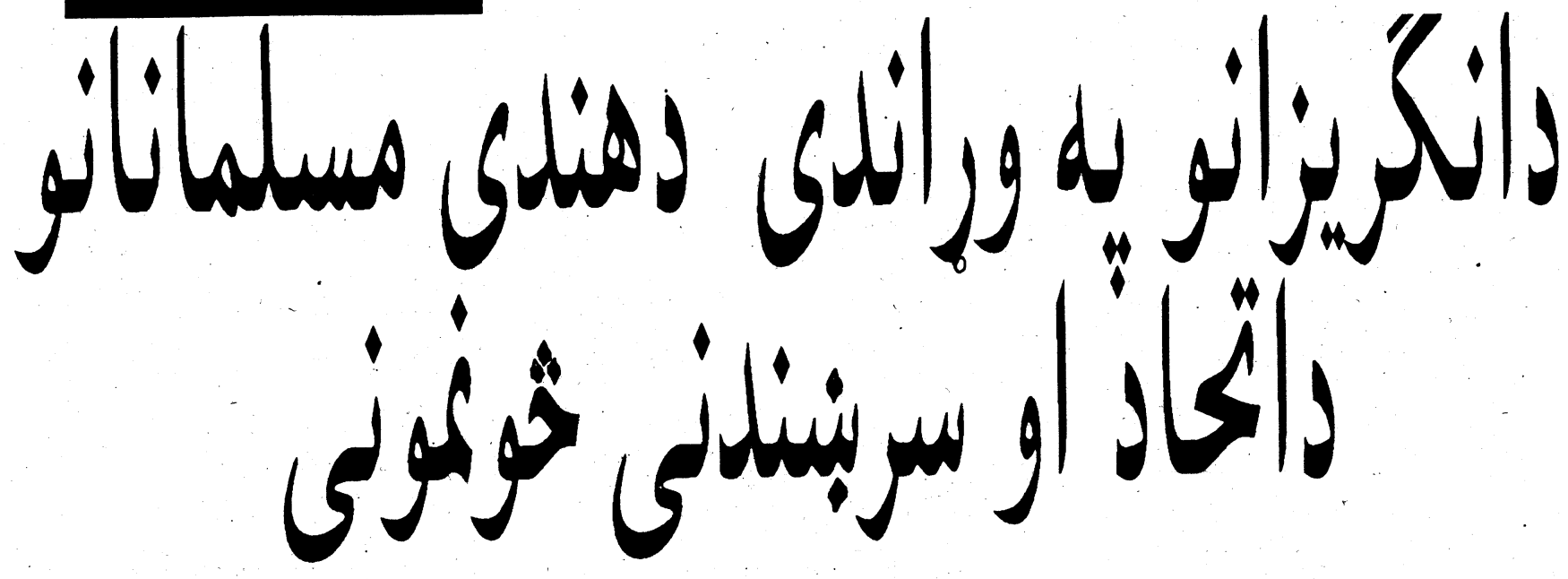

مندى طايفو بي وراندي له لويو

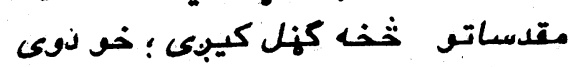

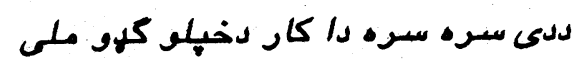

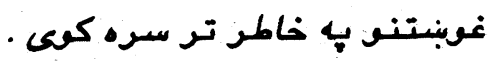

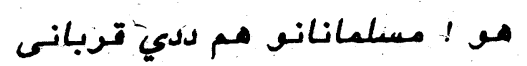

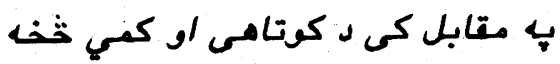

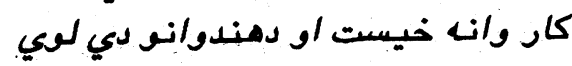

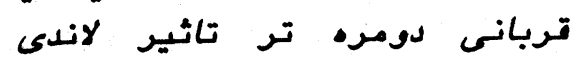

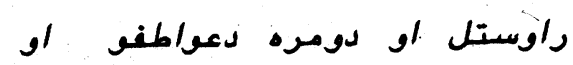

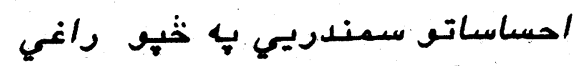

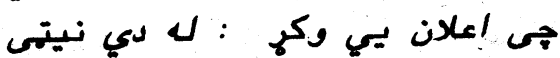
وروست بايد بـ تول مند كمي خوك له

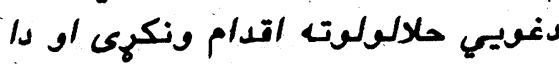

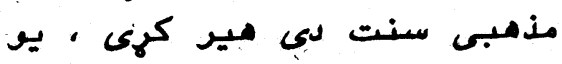

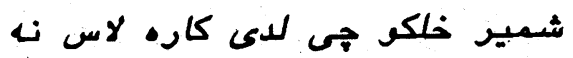

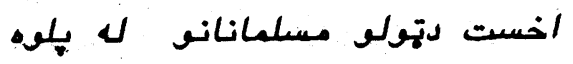

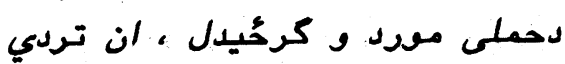

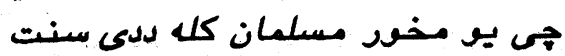

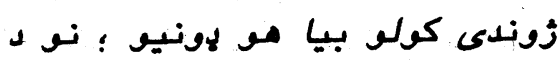

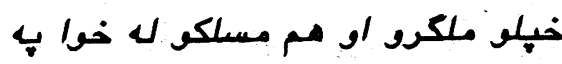

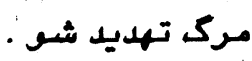

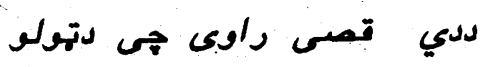

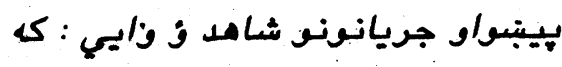

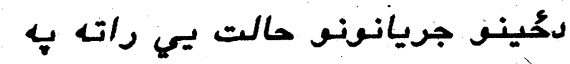

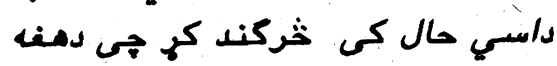

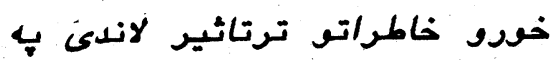

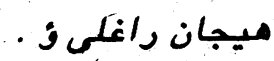

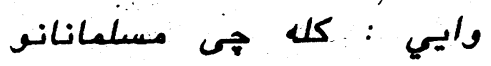

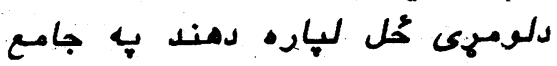

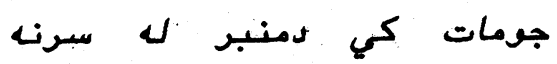

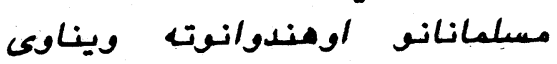

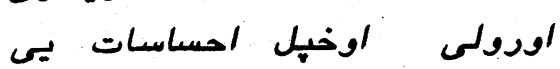
خركندول ؛ نو مسدارنكه مند وانو

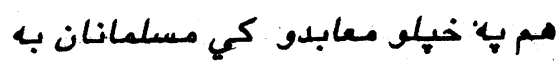

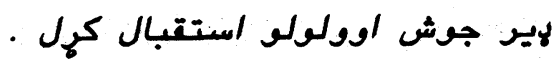

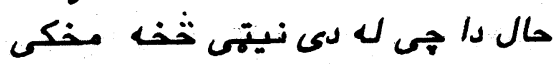

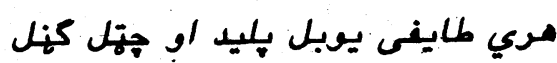

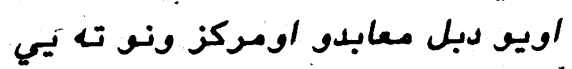
لدورتك اجازه نـ وركوله .

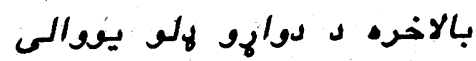

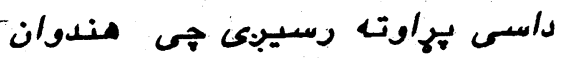

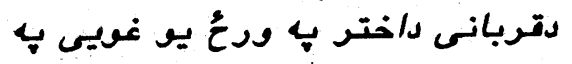

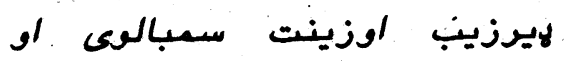

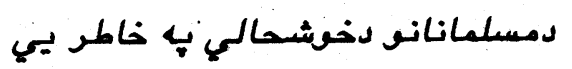

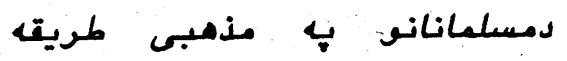
قربانس كوى حال دا هم غويمي دتهولو ملهون
لدعلى جناح او كاندى هب زمانه

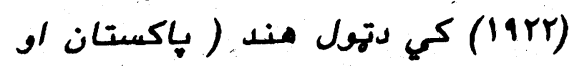

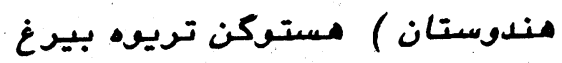

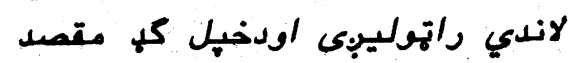

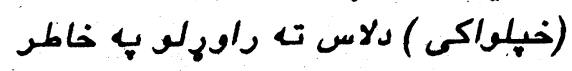

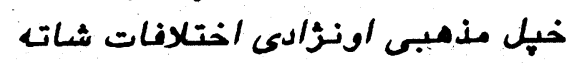

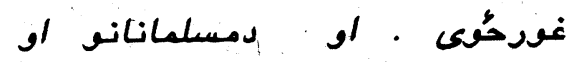
مندوانو ترمنع داسم دمحبت فضاكا

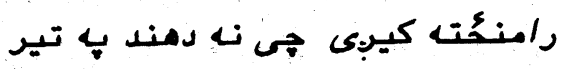

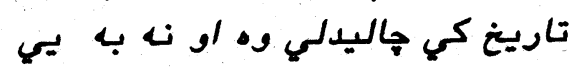
وروست خوك وليدلمي شسى ،

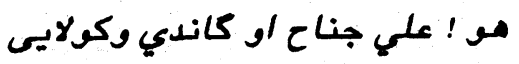
شول جم دمند تهول اوسيدونكى

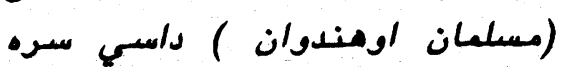
يوموتهي كري جم نزى ورتـ دحيرت

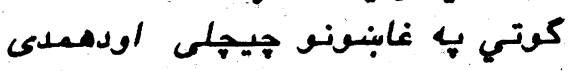

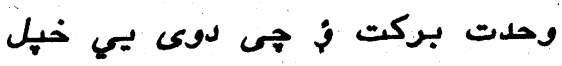

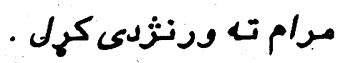
د" كفاح "المسلمسين في وركي تحرير الهند ، كتاب مؤلف عبدالمنعم النحر

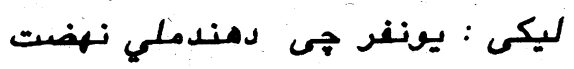
يمي له نزل ي ليدلي او بـ مبنغ كم يمي

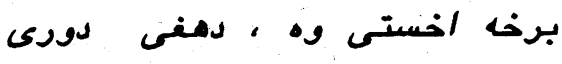


اوبيايي دانتلاب مركزتـ به هتب توكى

بالاخره قاضمى دتورن شهور كسانو

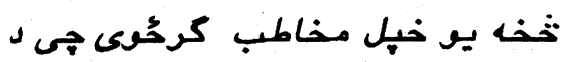

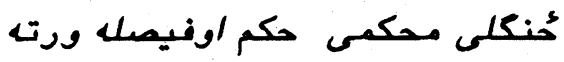

واوروي .

منه مخاطب يو نبكلن او توىى حوان و ، آرامس تخيرى يمي دا بـ كوتـ

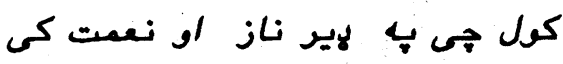

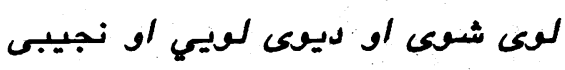

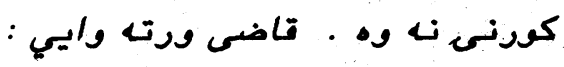

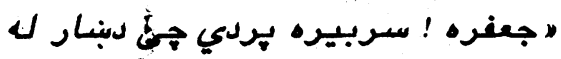

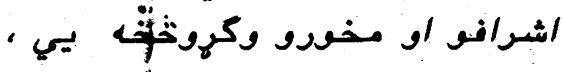
باسسواده: اوديومس خاوند نُّيمي اوله

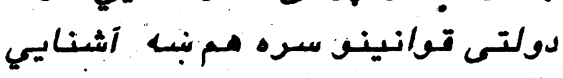

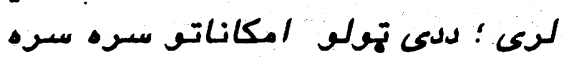

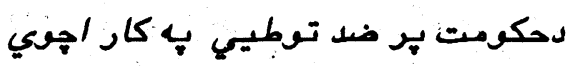

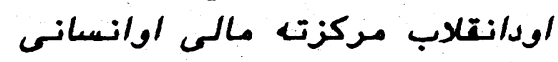

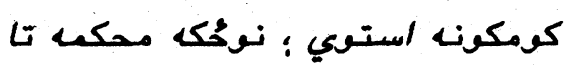

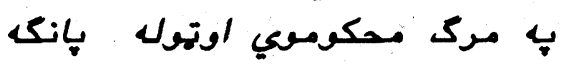

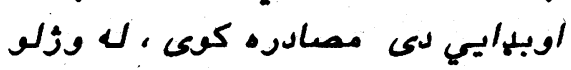

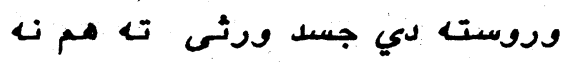
وركول كيربى او به لهيره خواريى او

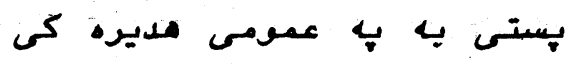
خاورته وسبارل شسم ... اودا زما لباره هيره

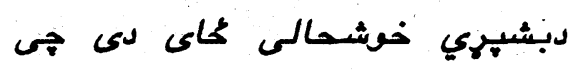
تادسولى هب لركى هانسفى ووينم " . دقاضى لل خبرو ثخذه وروست بانت

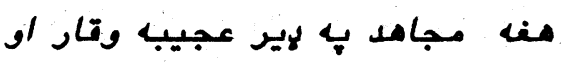
متانت ورتـ وايمي : دروحونف واك يك

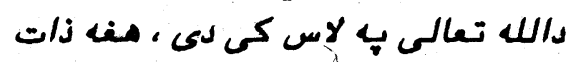

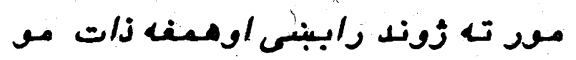

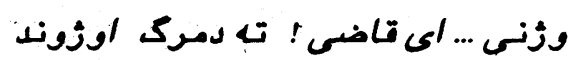

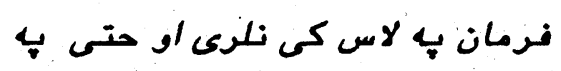

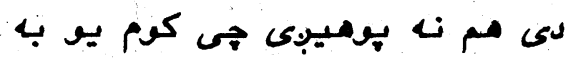

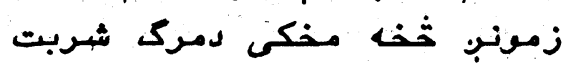

$$
\text { وخكمى }
$$

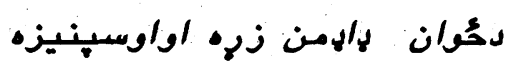

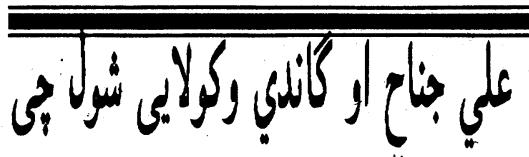
jhand | Sigland Jis lis

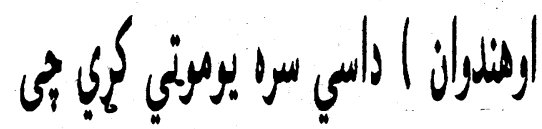

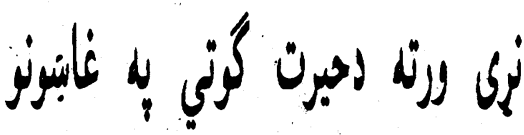

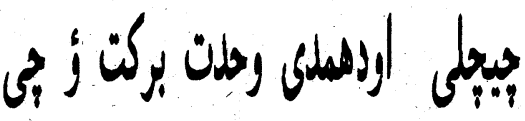

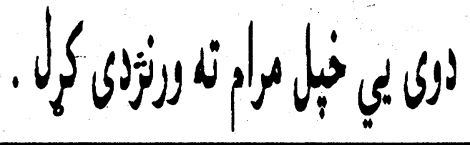

مبارزى او سرنيندنو بـ مكله هير

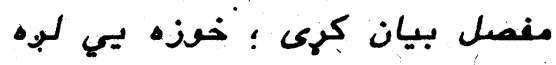
برخه دنمونس بـ توكه كرانو لوستونكو ته وراندى كمي :

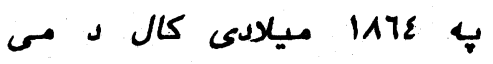

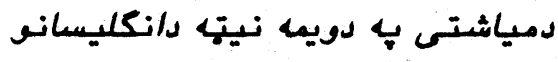

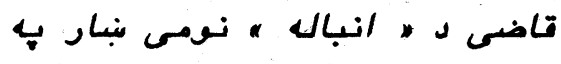

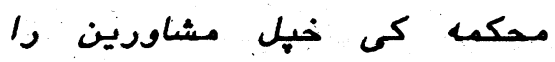

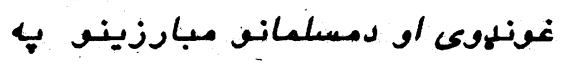

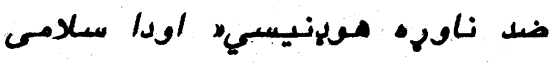

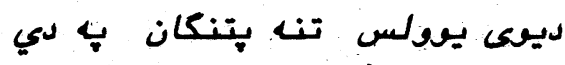

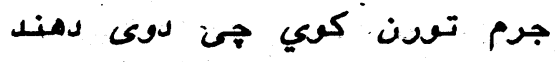

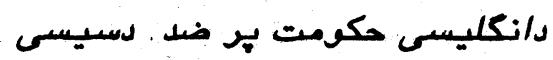

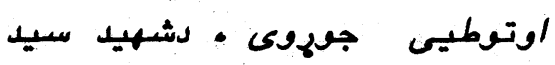

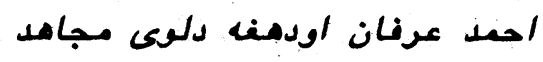

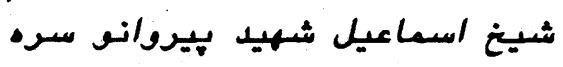

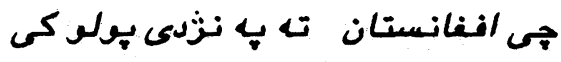

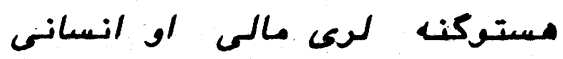

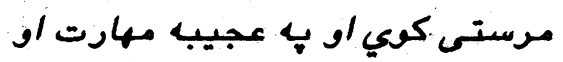

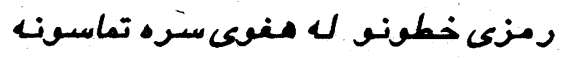

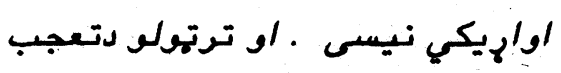

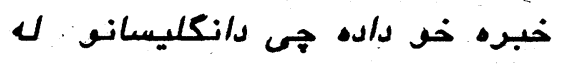

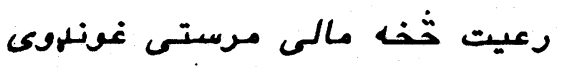

جيرتك نهضت او انتلاب بـ ممدي

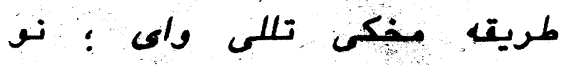
دبريتاينا حكومت بـ خوامخوا لهير

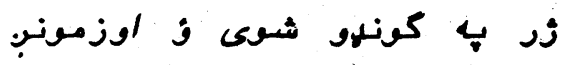

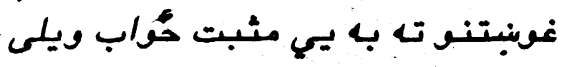

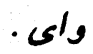
دكتاب مؤلف وايمي هم دا خركند

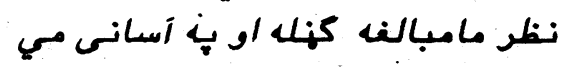

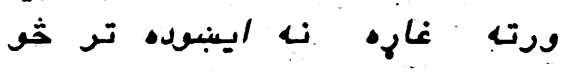

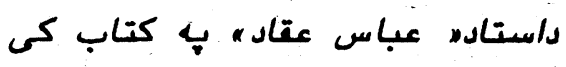

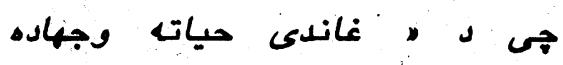

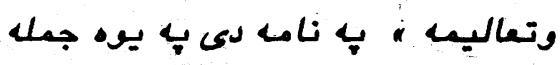

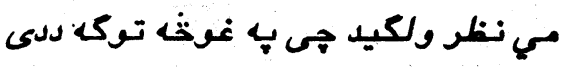

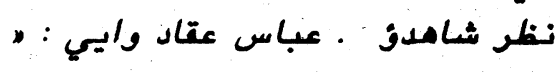

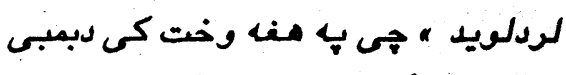

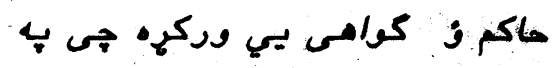

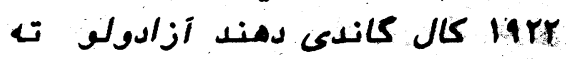
يعازى يو كام فاصله درلمده .

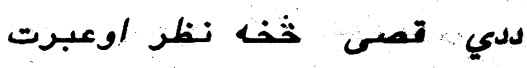
اغستل كرانو لوستونكو تع حواله

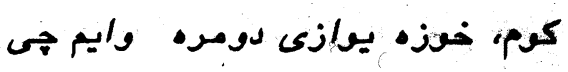

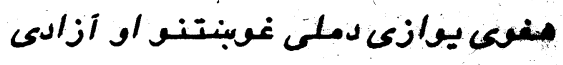

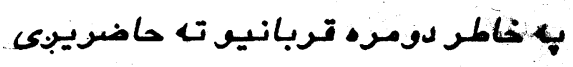

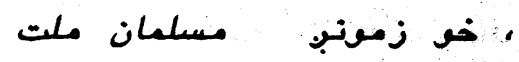

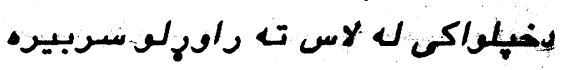

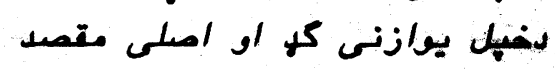

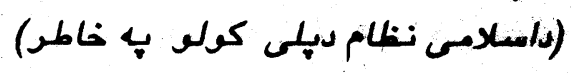

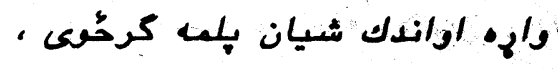

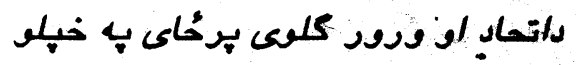

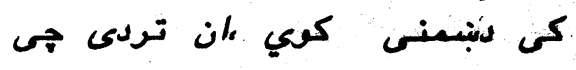

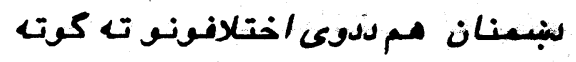
نيسم او مسيشه دنه اتحاد له كبل

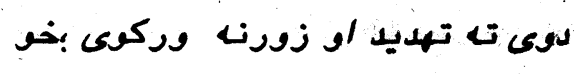

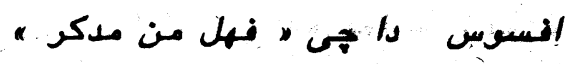

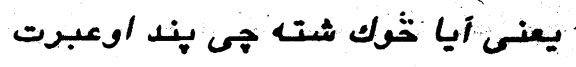

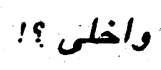

مسدارنك ابن الصسن " لندوى "

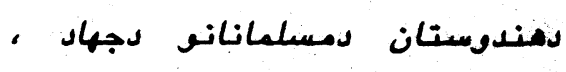


جعر يمي له

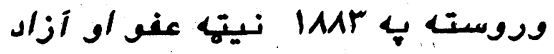
شسو - وروست

داوه دظالمانو او مستكبرانق بـ دوماني

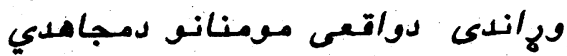

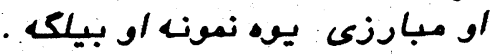

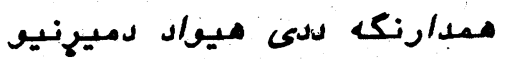

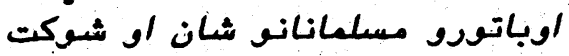

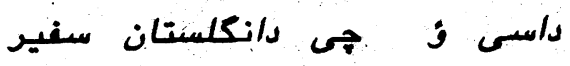

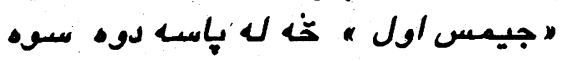

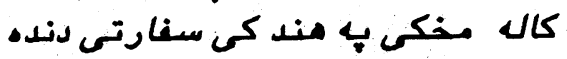

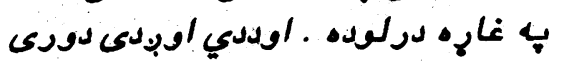

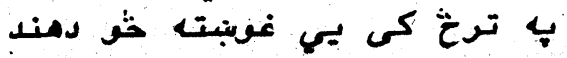

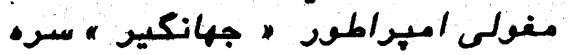

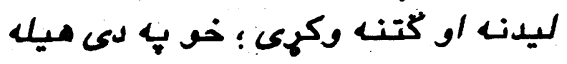

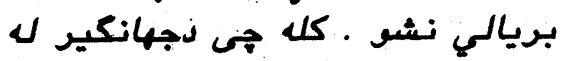

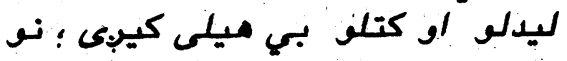

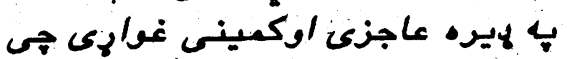
لجهانكير له درباره دانكلستان

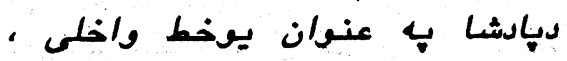

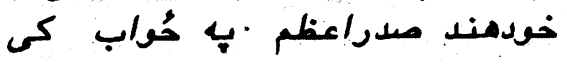

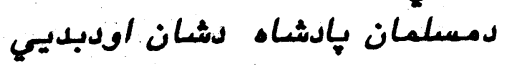

$$
\text { ورته وايمي : دمديلي }
$$

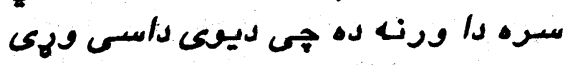

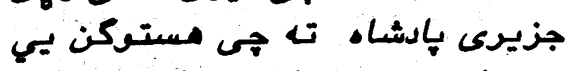

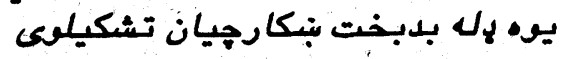

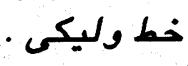
مو! دافسوس خبره داده همن هي

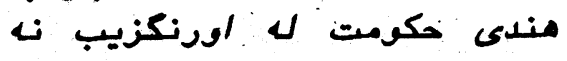

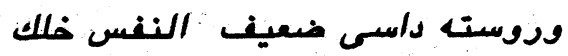

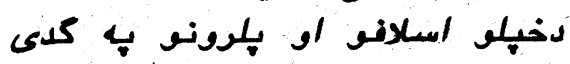
كيناستل هم بـ تدريع سره يمي مند وستوط اونابودى كندي تـ ور تيل تيك

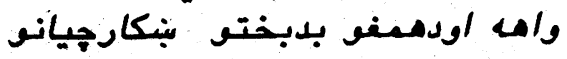

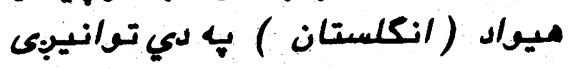

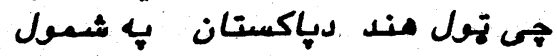

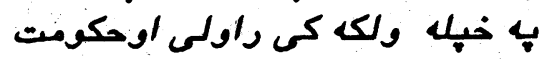
اوبالاخره هي اوسنمي عصر كم مندوان يب مسلمانانو دومره ناوهره تيرى كوي جم حتى د مقد ساتو

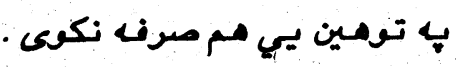

لاركي دشهادت مخه ونيسى ؛ نو خيل هكم تع تغنير وركوي او

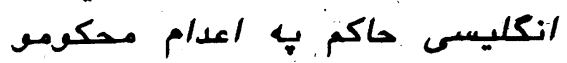
لدريو والهو مجامدينو تا به لدي لهول تغيير شسوى حكم او روى :

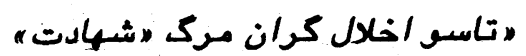

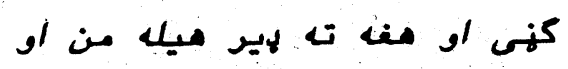

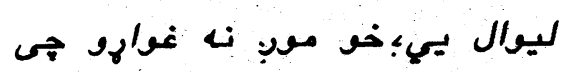

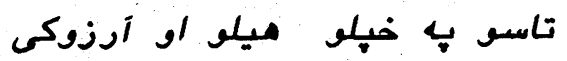

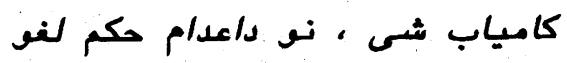

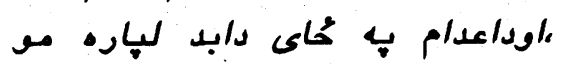
لسيلان بـ جزيرو كى بـ بند محكومسم . منس و هم هب لهيرو سختو اعمالو

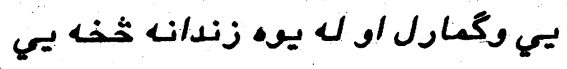

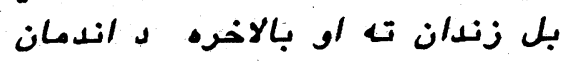

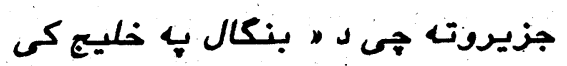

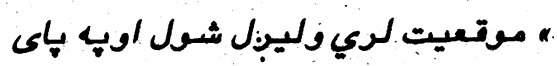

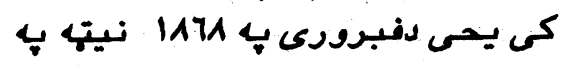
زندان كمى وفات او مبكرى شيخ

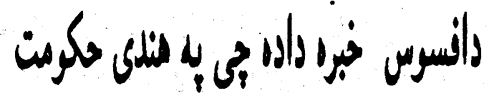

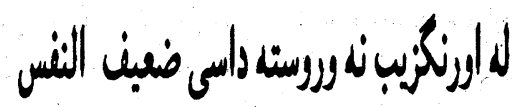

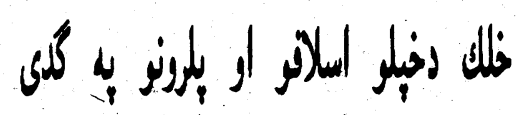

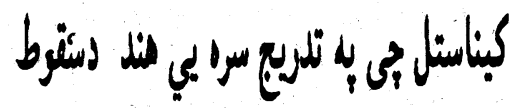

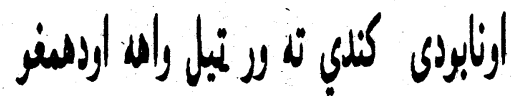

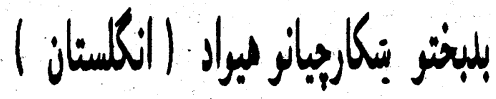

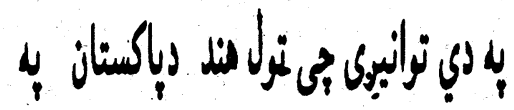

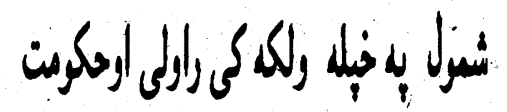
- $65 s p$
روحي دحاضرينو دتعجب اوحيرانس

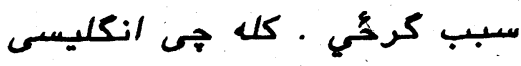

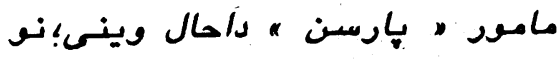

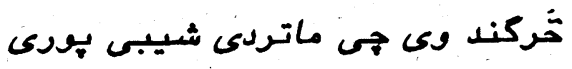

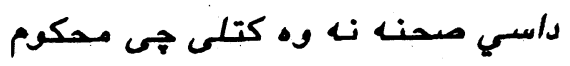

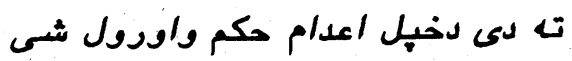

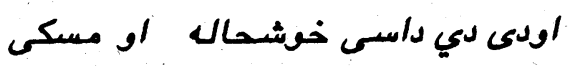
وى !! حمان بي حَواب كى ورته وايمي :

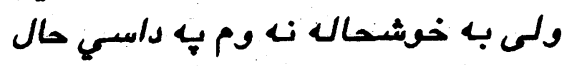

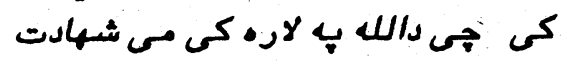

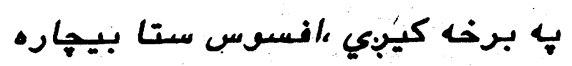

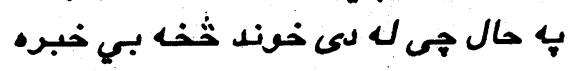
او محروم يمي .

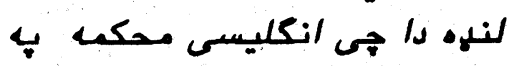

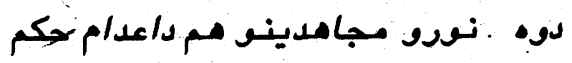
مادروى هم يو سبين بونيرى مولانا

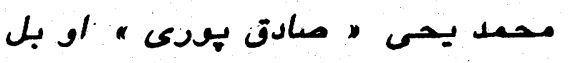

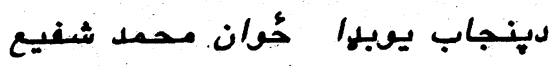
توميرى اواته نور نفر بـ دايمى بند

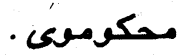

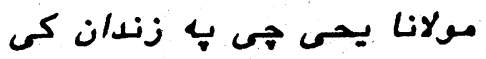

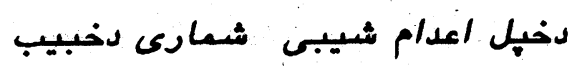

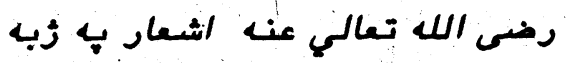
زمزمب كوي او وفيمي :

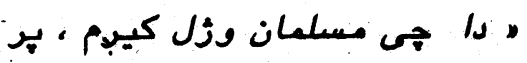

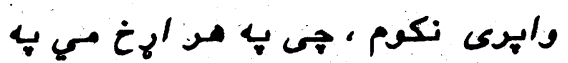

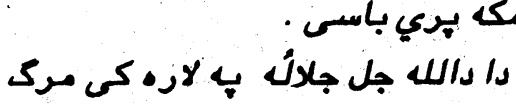

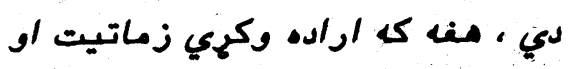

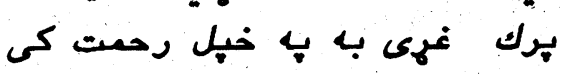

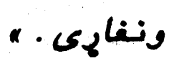

خو ! كله جم انكليسم هاكسانو دا حس كره همي مجامد اومبارزه بنديان به لهير شيسوق اوولولف داعدام

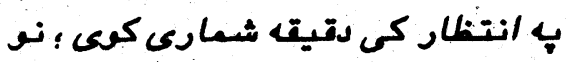
دلير تهر اوغضس نه دليونتوب حالت

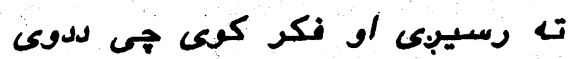

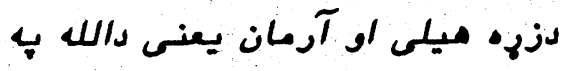


ستأسو بومو خلكو دلاسه خوزمونتبو

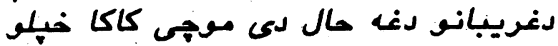

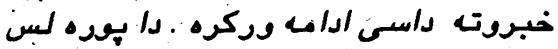

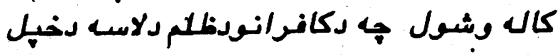

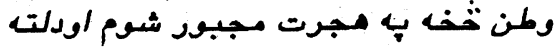

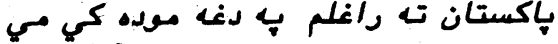

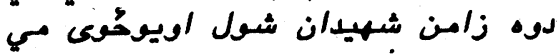

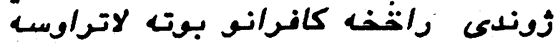

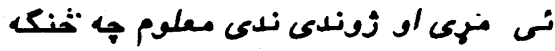

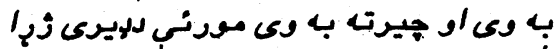

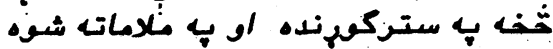

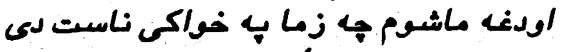

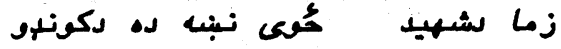

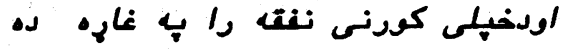

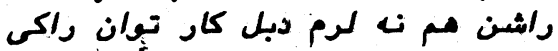

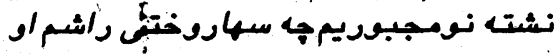

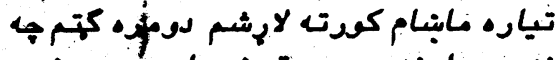

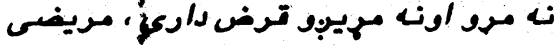

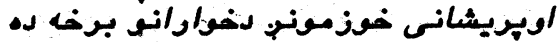

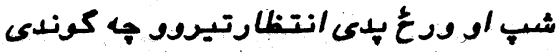

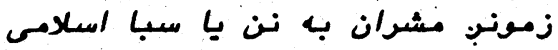

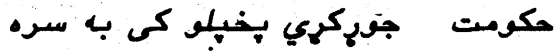

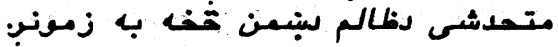

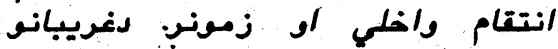

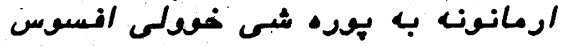

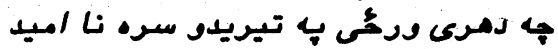

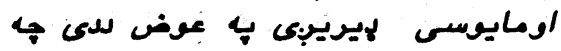

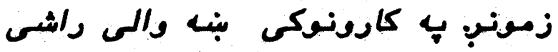

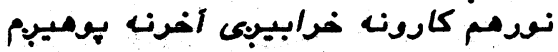

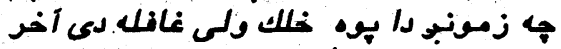

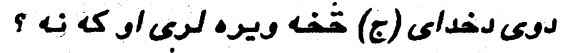

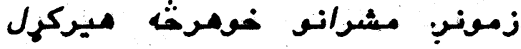

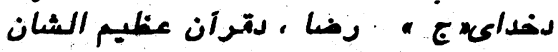

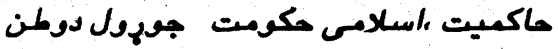

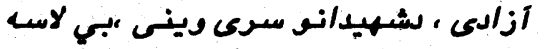

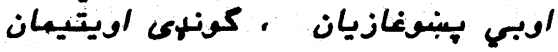

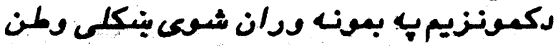

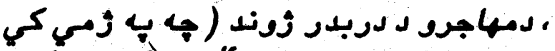

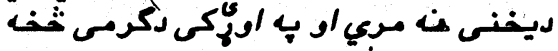

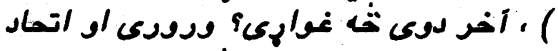

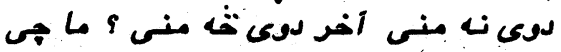

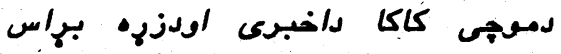

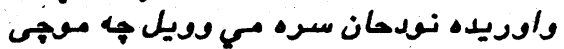
كاكا اوسياست !!!

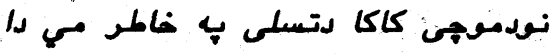

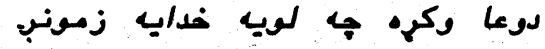

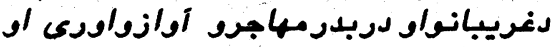

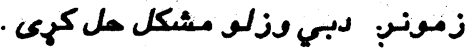
Pry

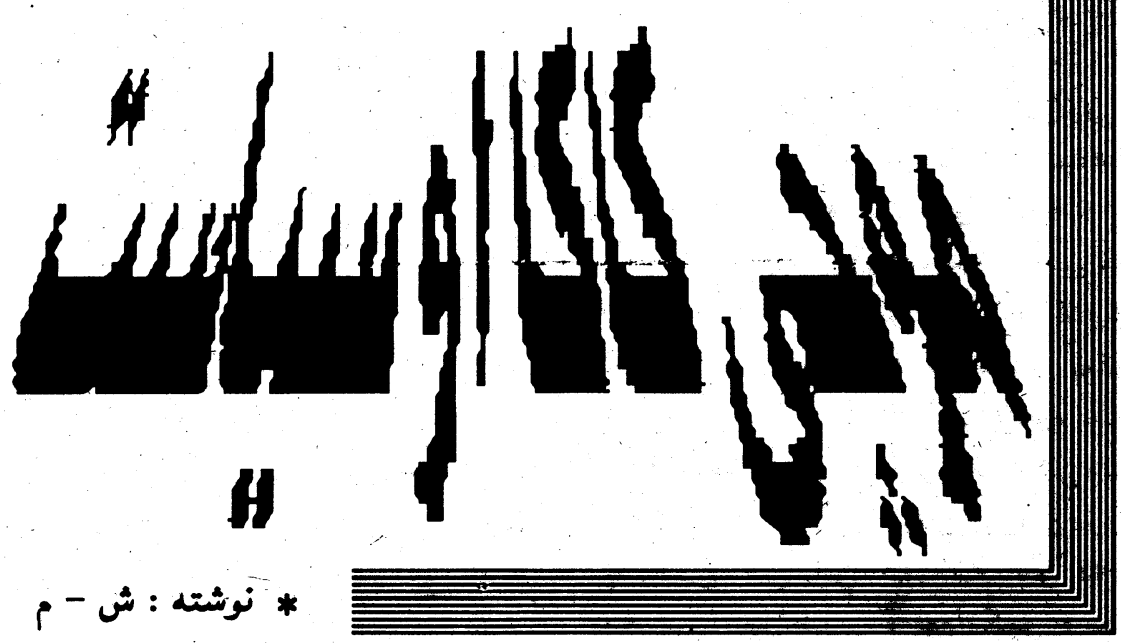

كاكا زما بـ بوتهونو كارشروع كيح او بيا

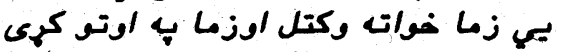

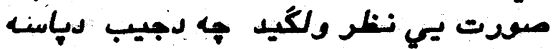

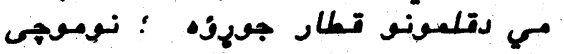

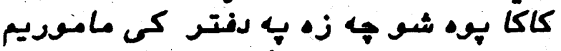

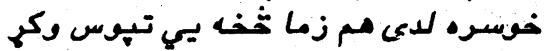

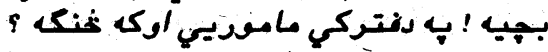

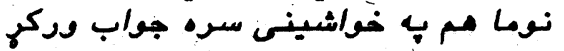

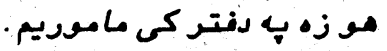

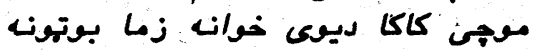

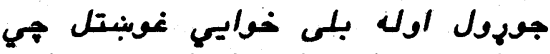
دخبل زهره بهاس راته راوباسم نه بياييي

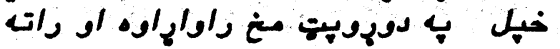

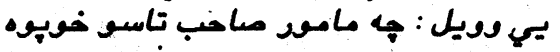

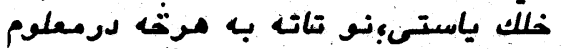

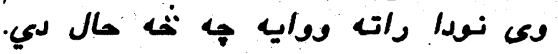

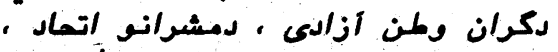

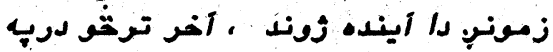

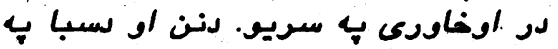

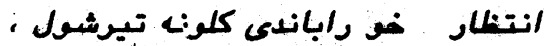

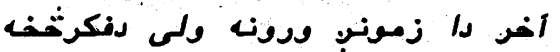

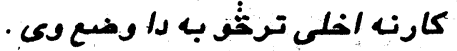

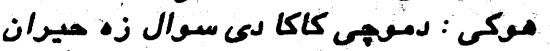

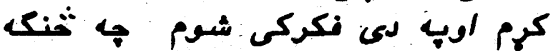

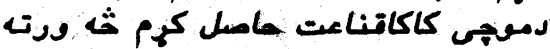

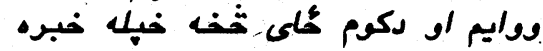

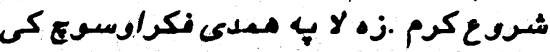

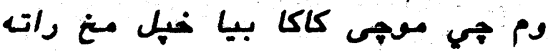
راواراوه جي دنعونو در دونهواونغربت

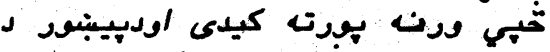

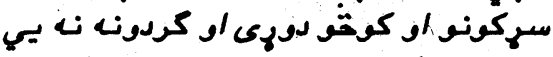

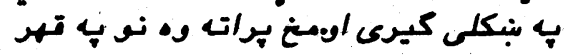

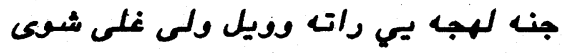

نبكوركي ميران ناست وم او لهمان

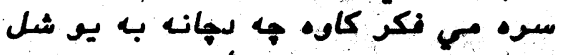

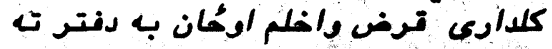

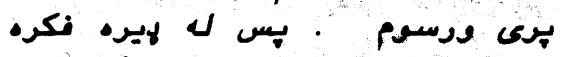

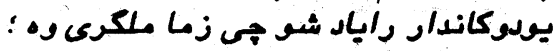

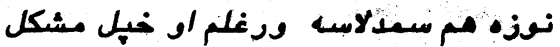

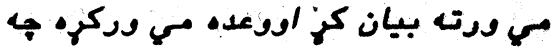

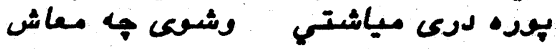

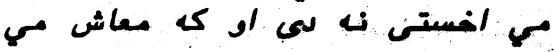

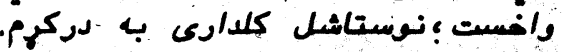

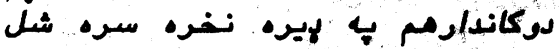

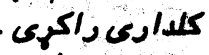

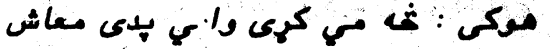

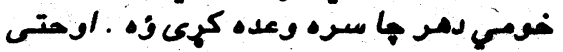

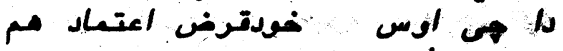

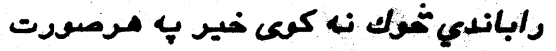

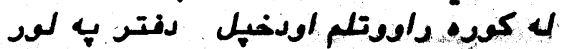

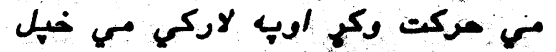

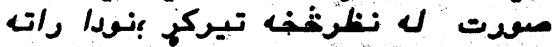

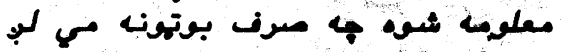

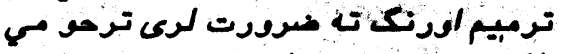

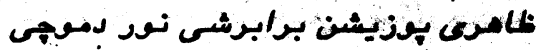

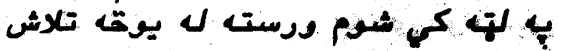

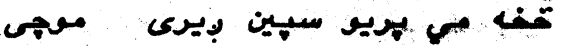

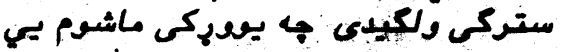

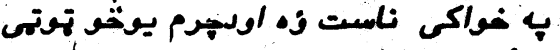

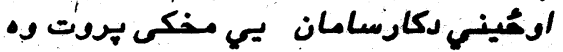

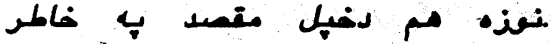

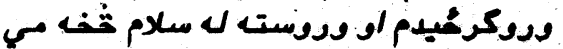

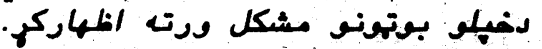

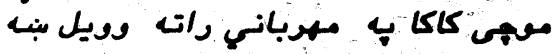

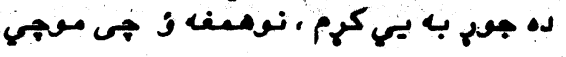




\section{أ}

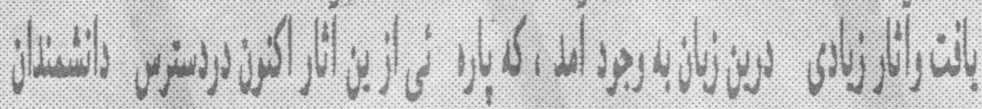

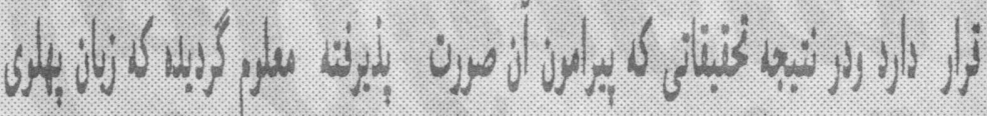

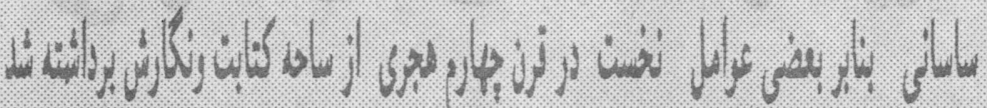

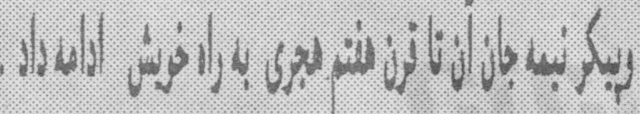

2

نارس كرديده

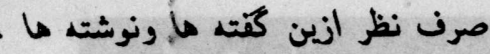

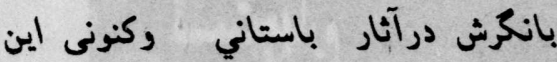

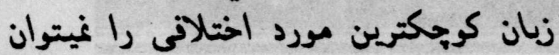

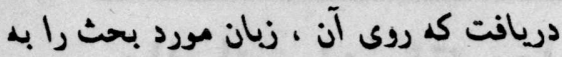

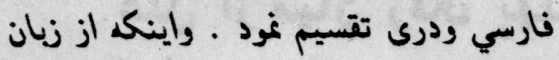
مذكور لهجات زياد ومتعددى شاخه كثيده

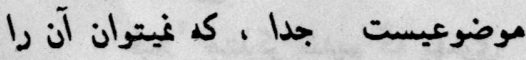

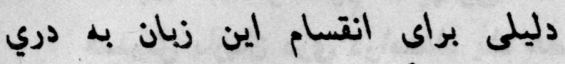
ونارسي انبكاشت .

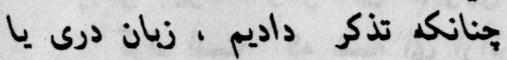

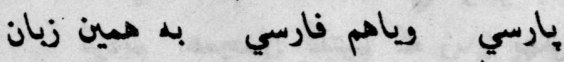

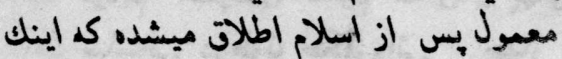

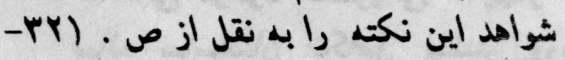

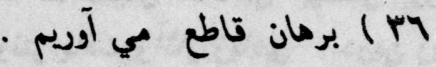

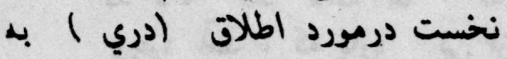
زبان مذكور : نحسي دورو

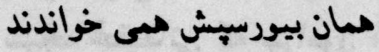

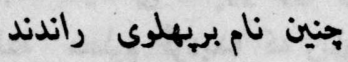

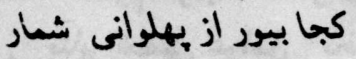
بود درزبان 2رى ده هزار يلواني

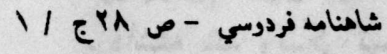
دل بدان يانتى ازمن كد نككوداني خواند

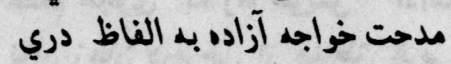

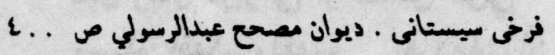

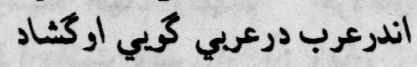
وارباز كرد بارسيان رادردري كري أندي
برشمارى از مس آنها سخن را به درازا

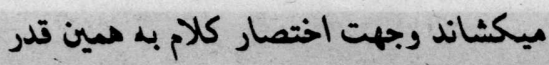
اكتفا مينطاييم نارسي يادري إينم إين

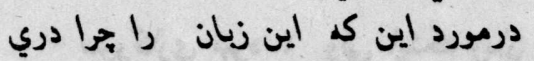

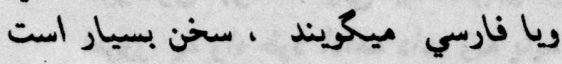

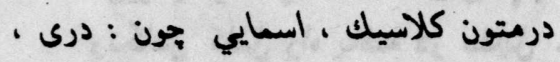

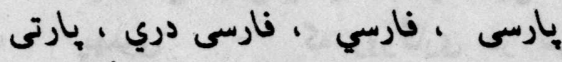

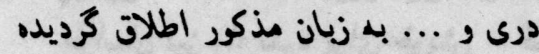

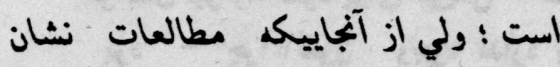

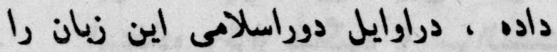

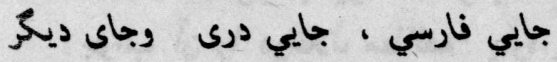

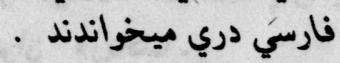

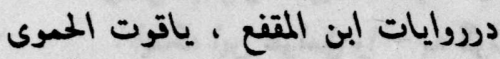

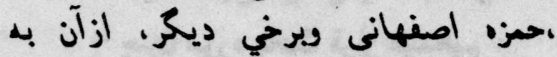

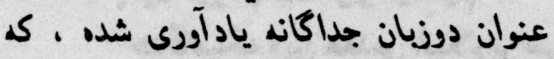

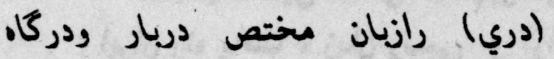

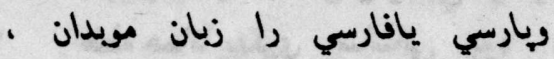
دانشمندان واهل فارس خوانده اند .

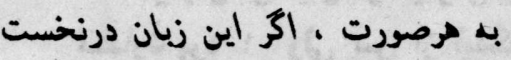

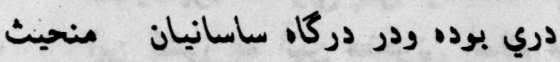

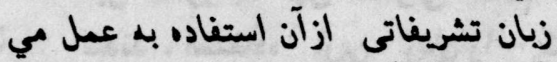

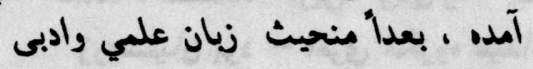

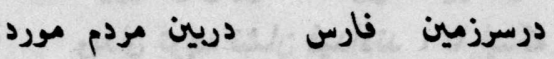

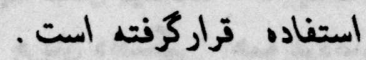

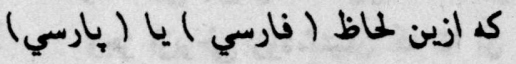
شده است ، جونكه زيان مردم سرزيِين
ترن ديكر يكسره بدست مغول نابود

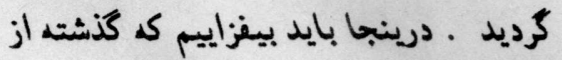
شكست ايران بدست تازيان كد به ناهار

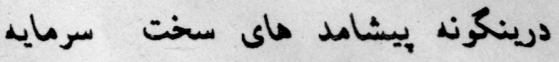

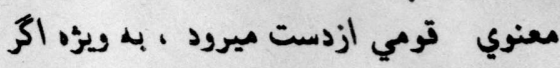

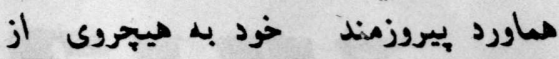
تدن بهره يي نداشته باشد وبه تعصب شورد بهديد

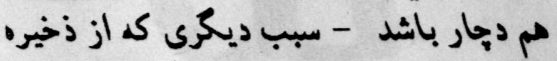
هنكفت كتب يهلوى روزكار ساسانيان بي

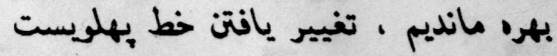

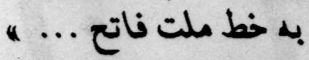

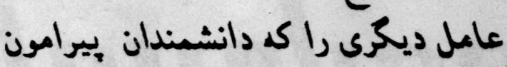

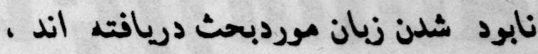

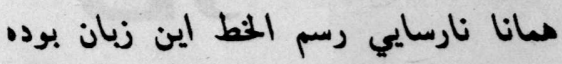

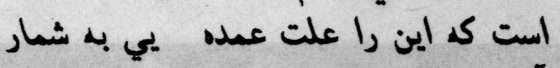
آورون آند الند

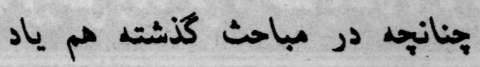

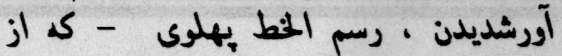

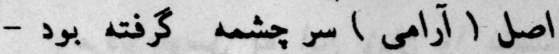

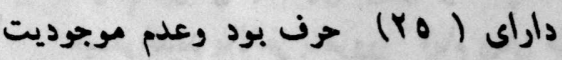

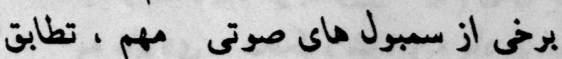

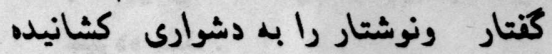

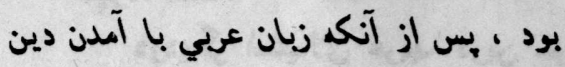

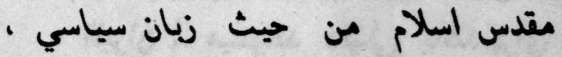

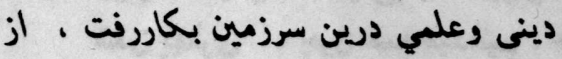

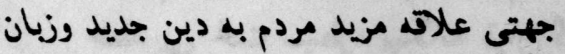

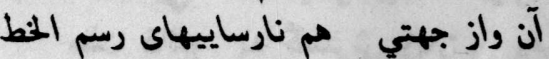

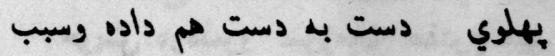

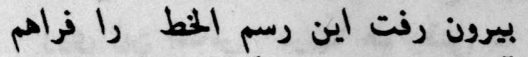

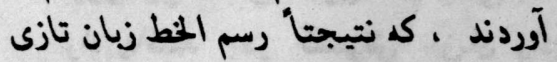

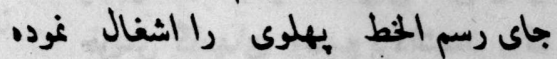

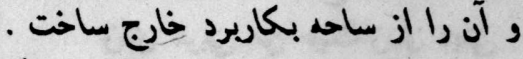

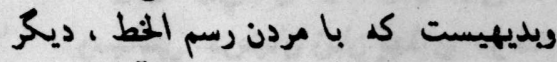

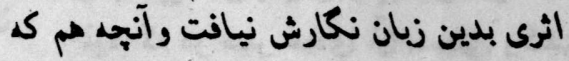

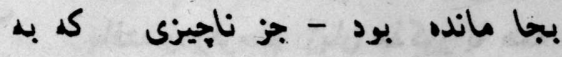

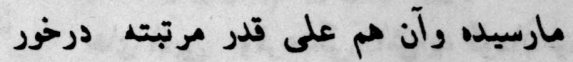

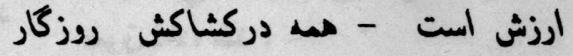

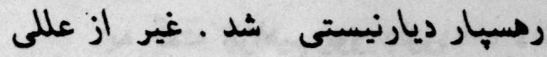

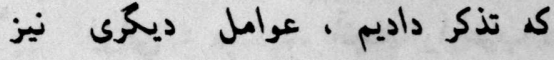

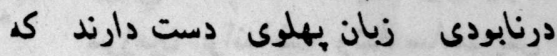


" مردمان بخارا باول اسلام درآغاز ترآن

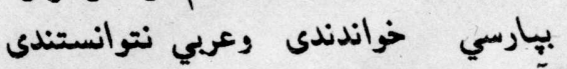
ov

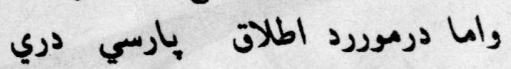

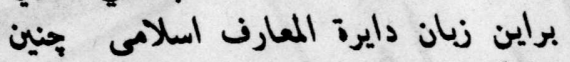
مينهارد : بران

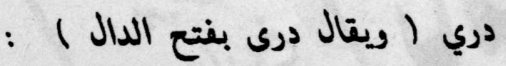

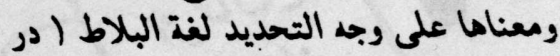

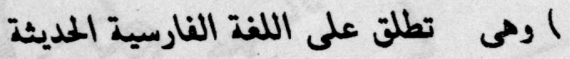

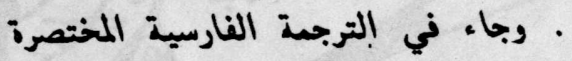

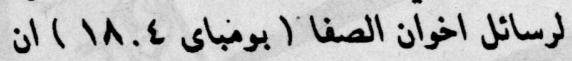

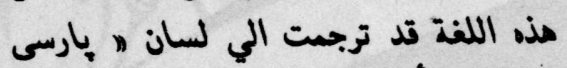

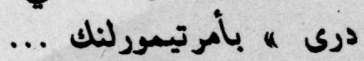

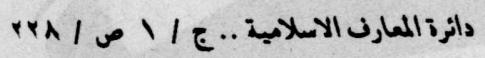

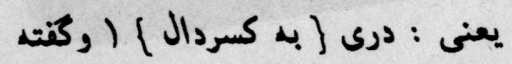

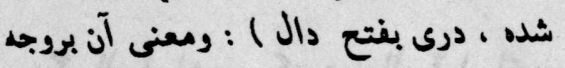

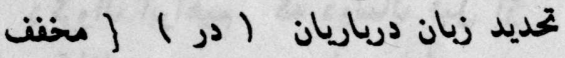

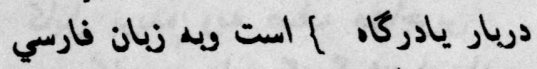

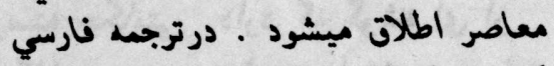

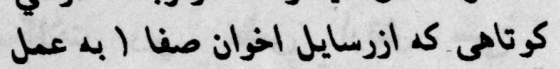

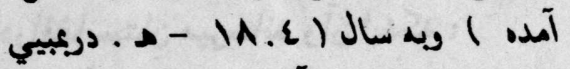

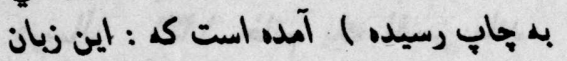

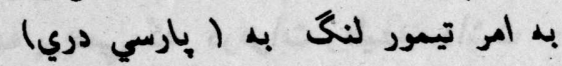

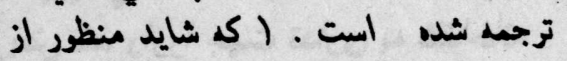

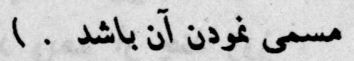

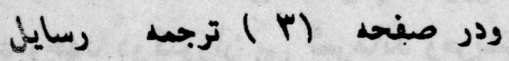

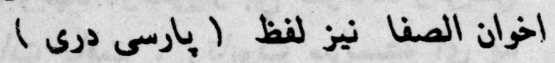

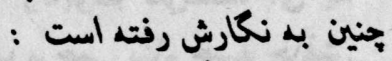

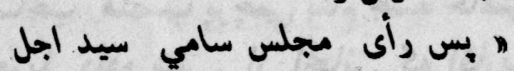

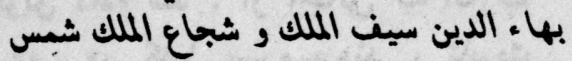

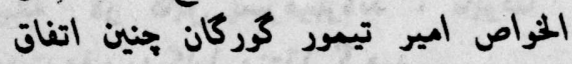

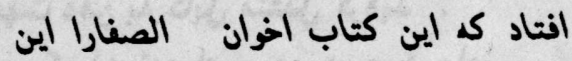

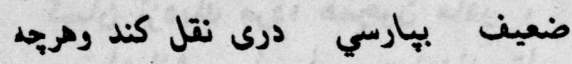

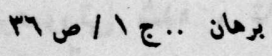

$$
\text { حشواست از و دوركند .... }
$$

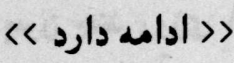

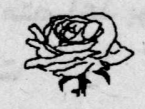

دوديحر درمورد الطلات (بارسي ) بـ بـ

$$
\text { زبان مورد بحث : دردور اطلاق }
$$

كس بدين منوال ييش ازمن جنين

شعرى نحفت بدين

مرزبان بارسي راهست بالين نوع بين

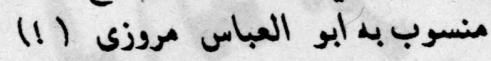

بسى رنج بردم درين سال سى العى مردي

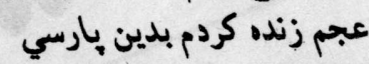

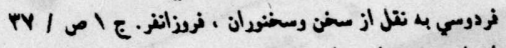

الها صحا بتازيست ومن مي لئي

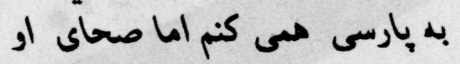

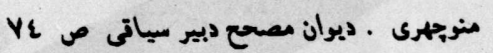
كر بارسازنى شنود شعيارسيش

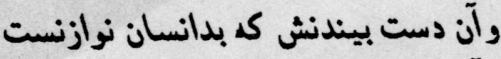

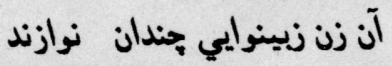
تا مركسيش كريد كاين بينواز نست نوازن

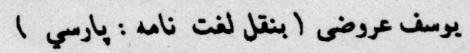

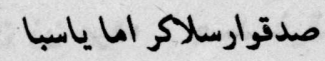

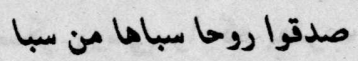

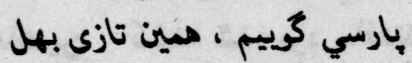
هندوى آن ترك باش ازيج هان ودين تازيل

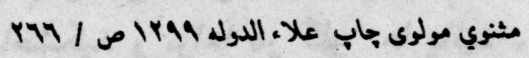

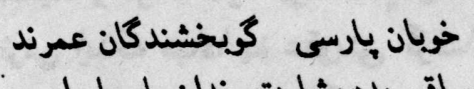

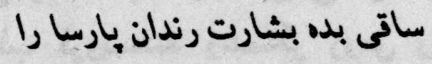

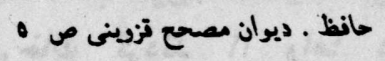

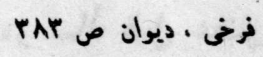

خاصه آن بنده كه ماننده من بنده بود دورد

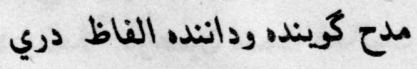

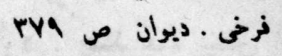
سع بحثايد زشرح لفظ ارجذراصم

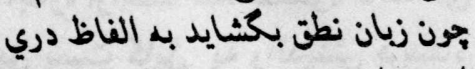

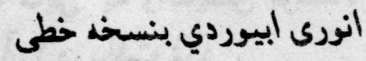
صفات روى وى آسان بود مرا كفيتن

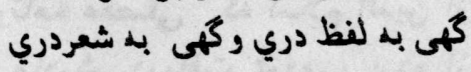

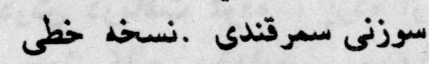
نظامي كه نظم درى كار اوست درى نظم كردن سزاوار اوست ديت ارست

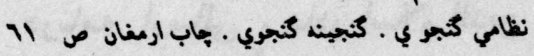

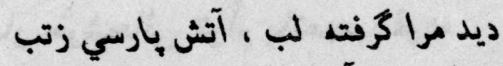

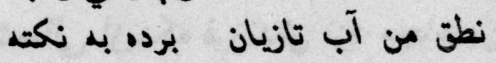

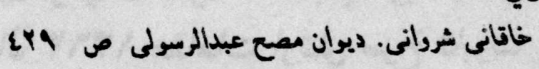

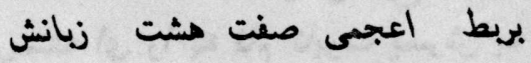
sردهان

ازسرزخه ترجمان كرده بد تازى ودري

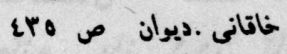

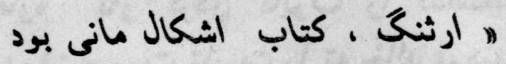

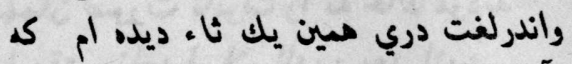

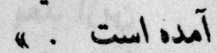

اسلى طوسى . لنت ذرس ص الن

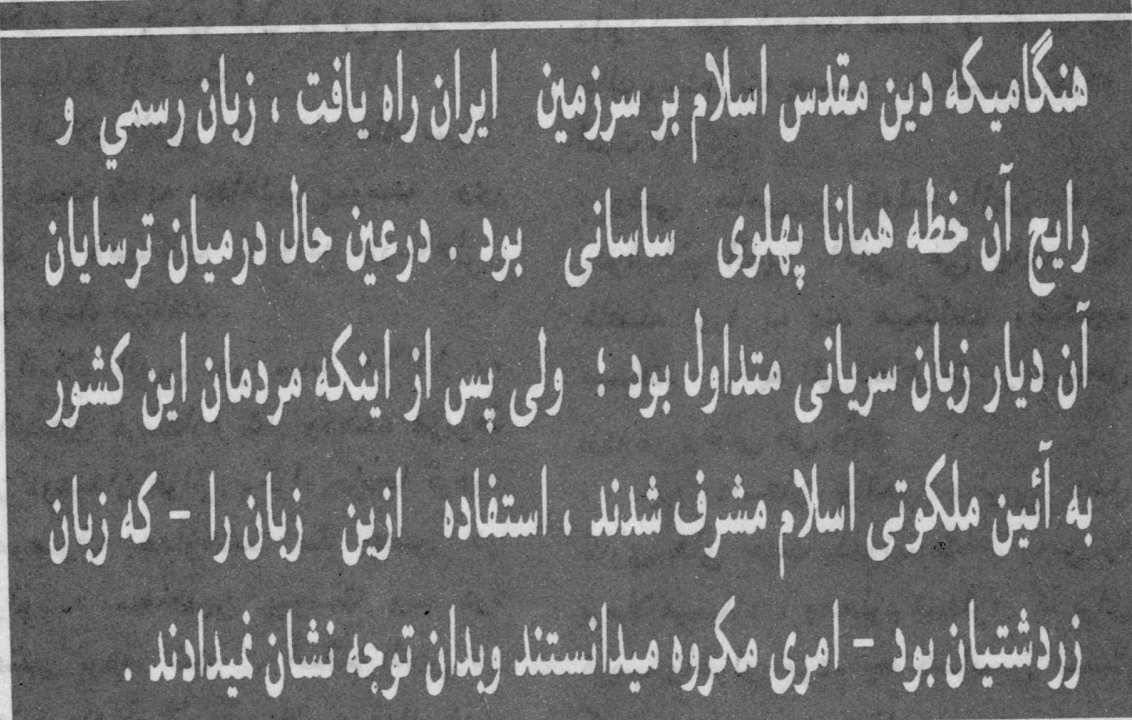

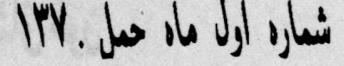


ودر" سال تبل عضويت تطعه كاندوى اردي

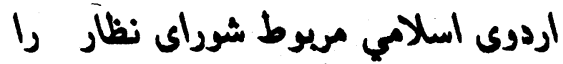

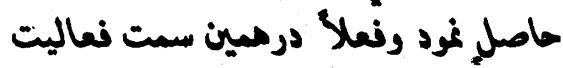

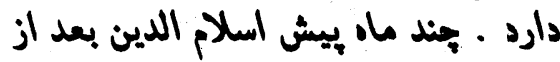

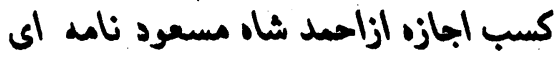

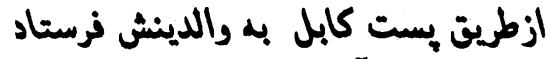

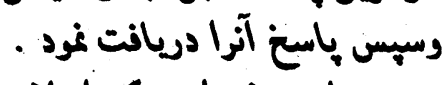

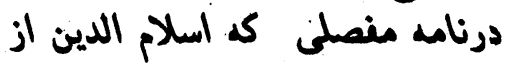

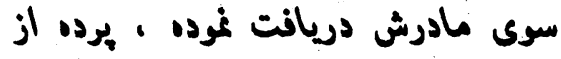

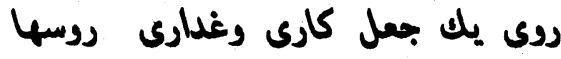

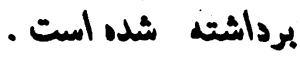
درنامه ارسالى ، مادر ابهلام الدين

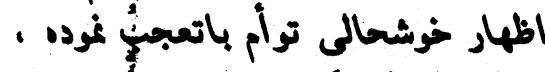

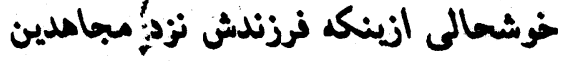

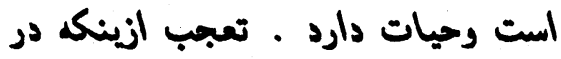

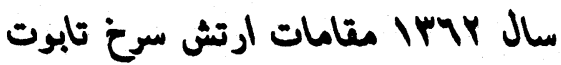

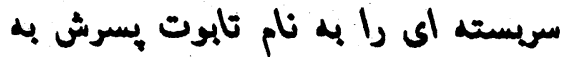

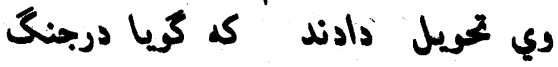

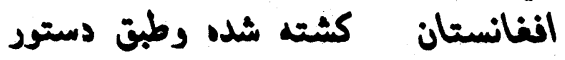

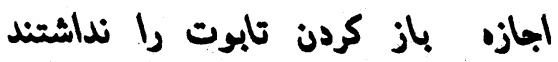

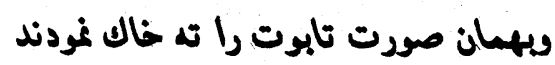

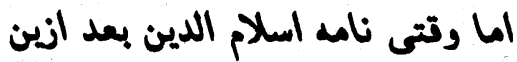

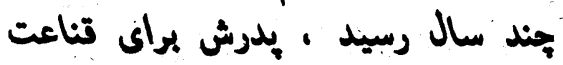

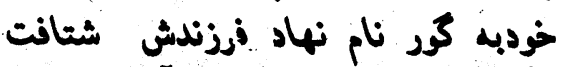

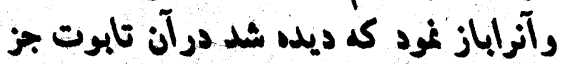

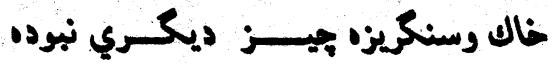
است 11

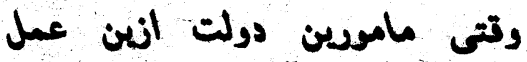

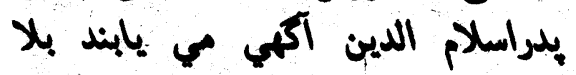

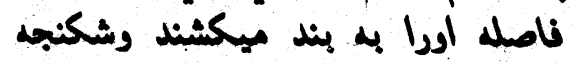

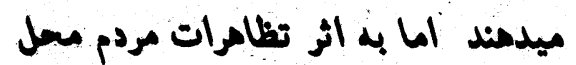
بزودى رمائى مي يابد.

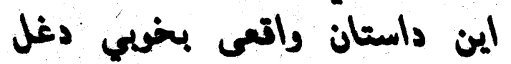

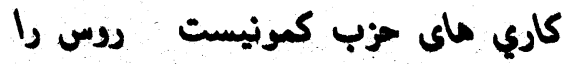

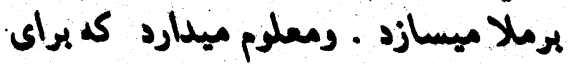

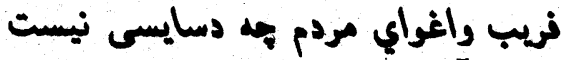

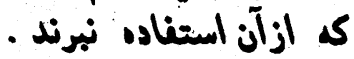

O

دكروال ابراهيم كه دوسال تبل از مئ

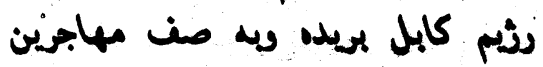

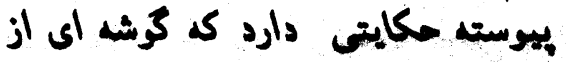

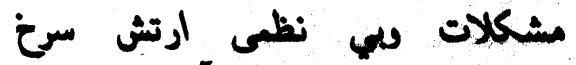

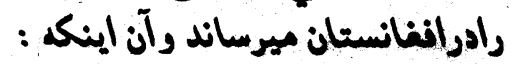

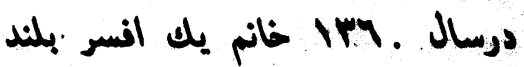

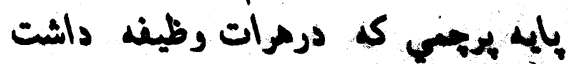
مريض شمد واردا جهت تداوى به شغاخانه

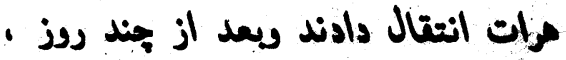

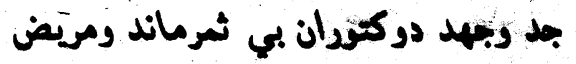

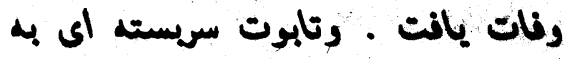

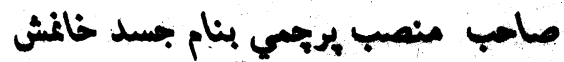

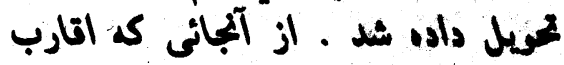

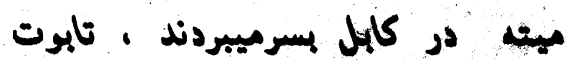

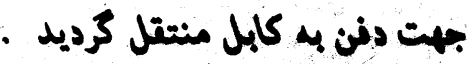

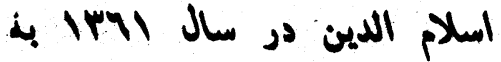

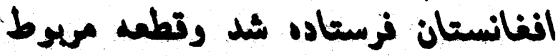

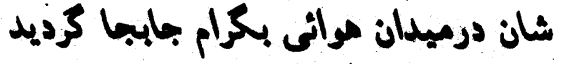

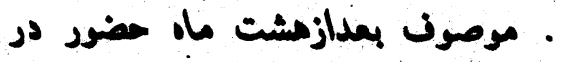

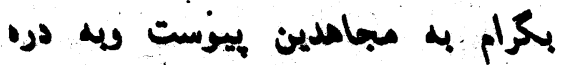

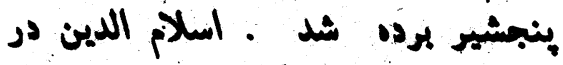

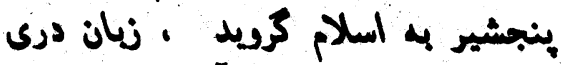
وتعليمات دينى را درآيجا فرا كرنت

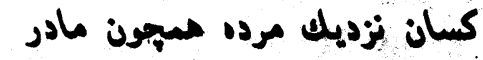

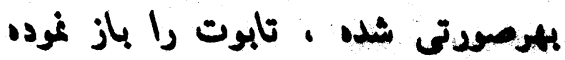

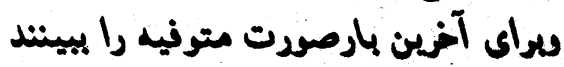

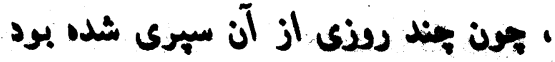

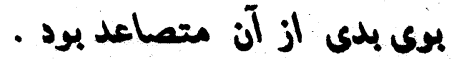

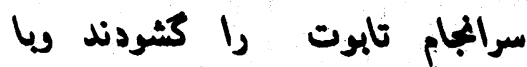

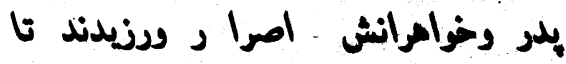




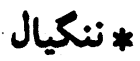

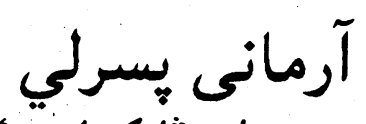

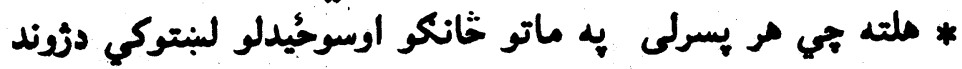

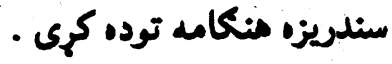

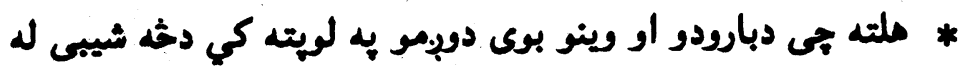

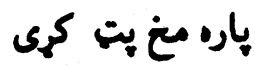

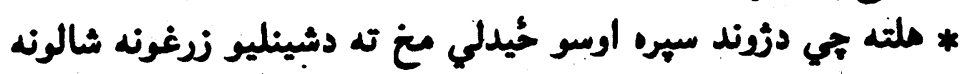

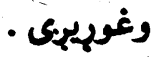

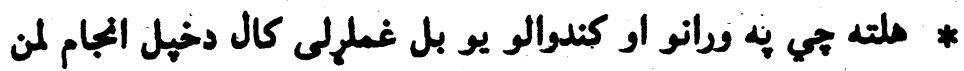
توله كزى . * ملته جي دبونو اودونو او جنكونوقيامت له زُوند اومستى سره لد

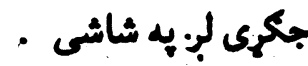

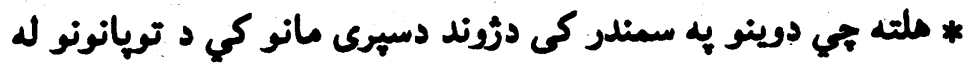

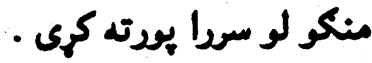

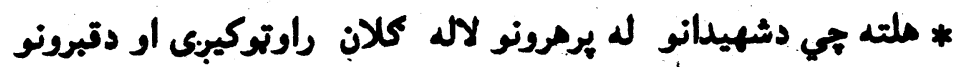

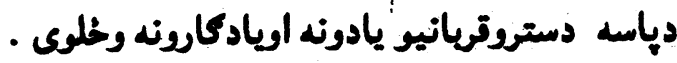

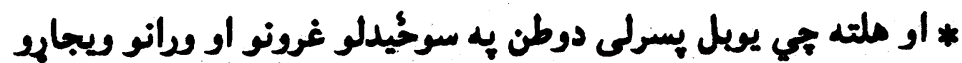

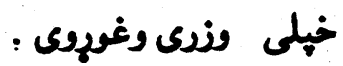

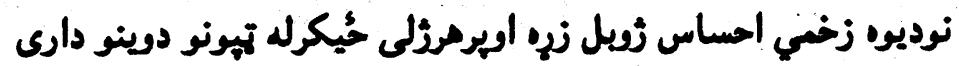

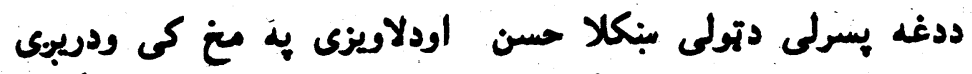

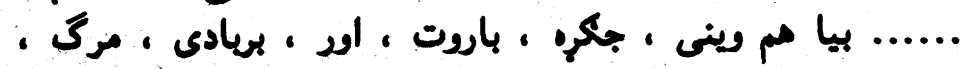
يرمرونه اوويرونه .

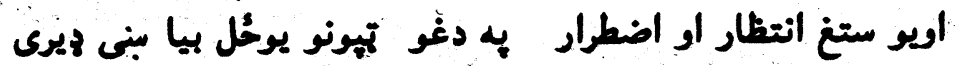

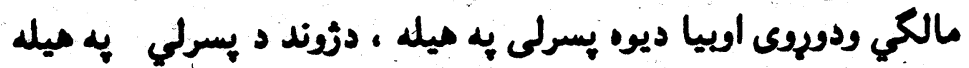

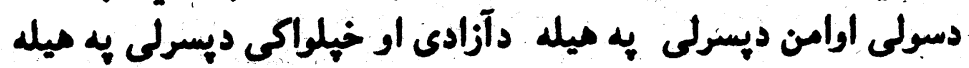

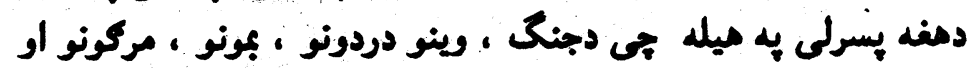

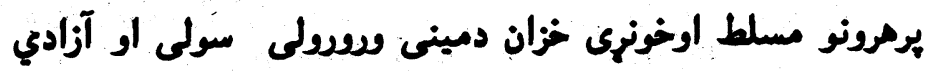

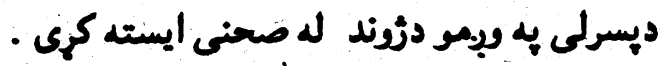

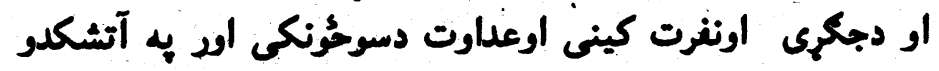

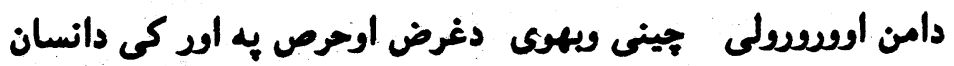

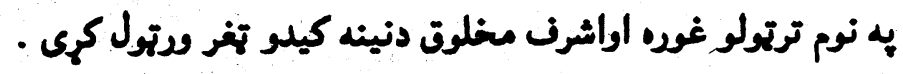
او

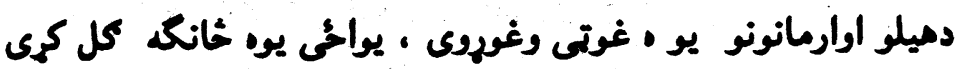

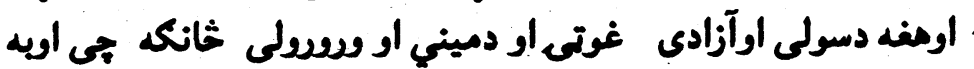

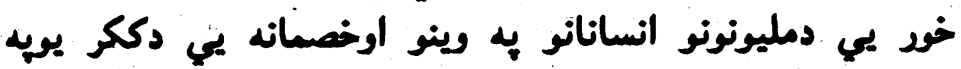
دواشويده .
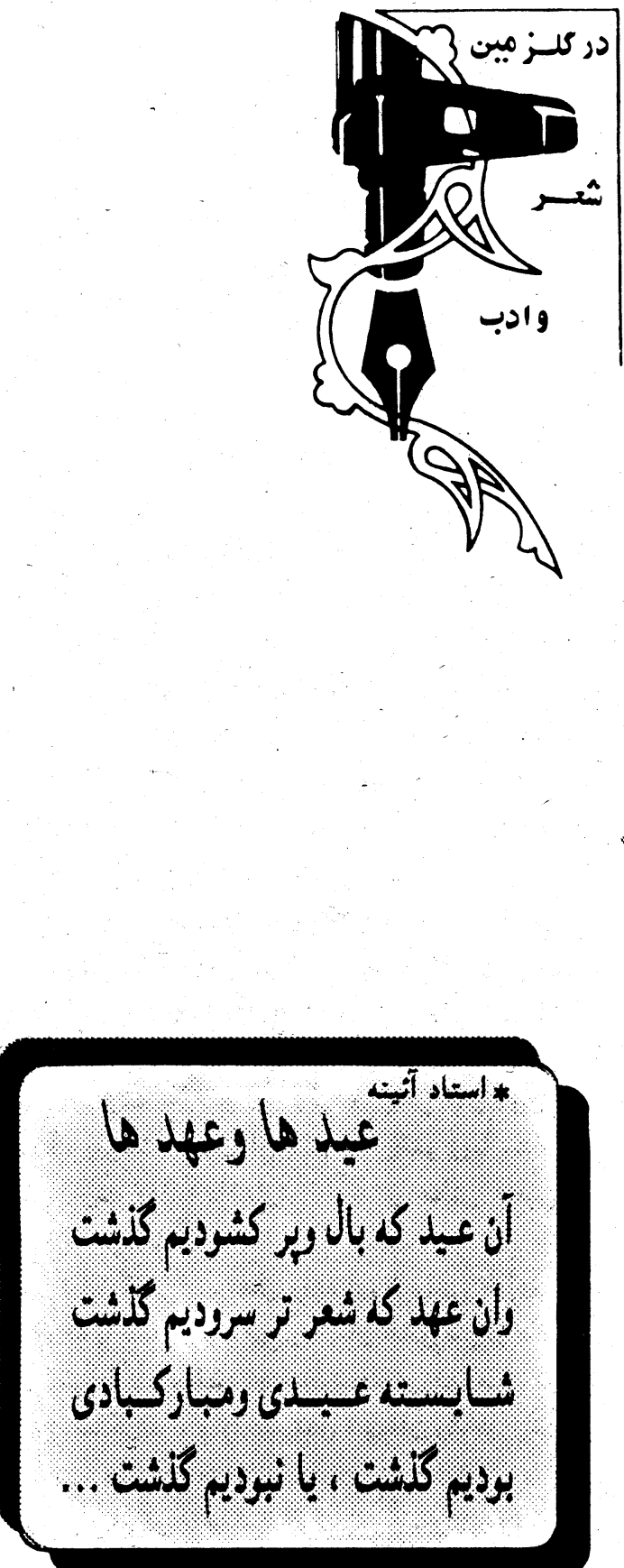


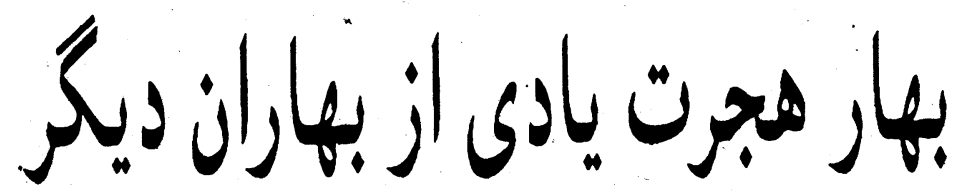

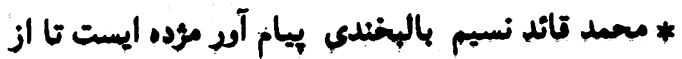

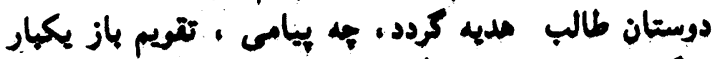

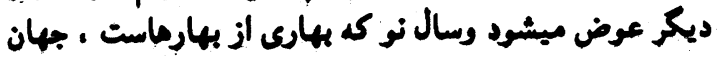

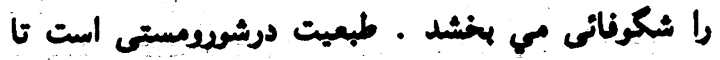

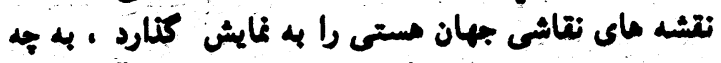

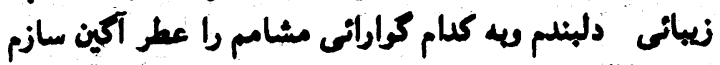

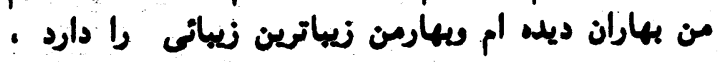

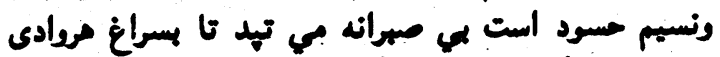

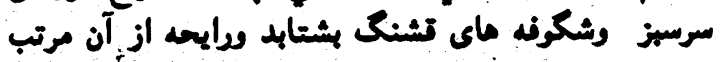

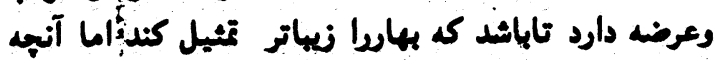

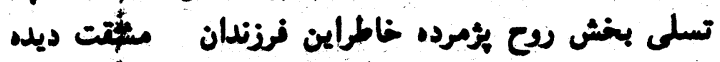

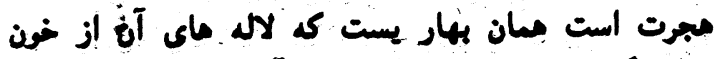

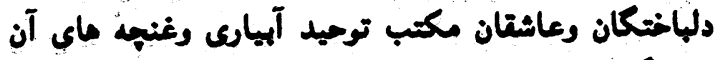

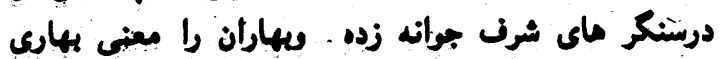

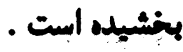

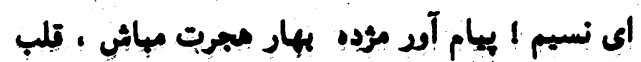

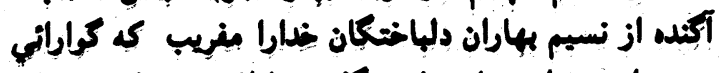

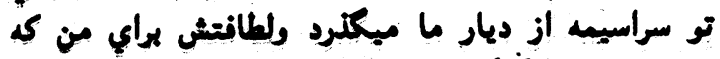

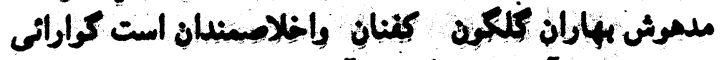

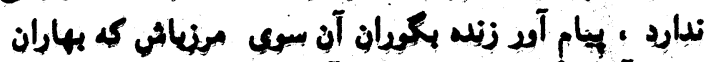

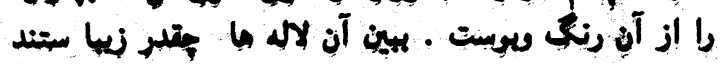

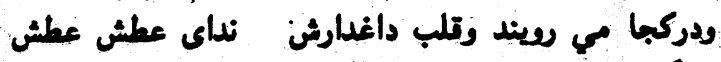

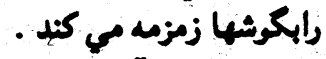

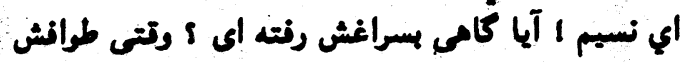

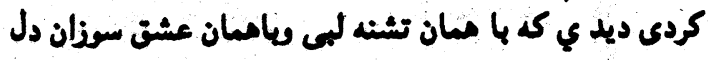

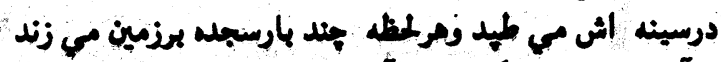

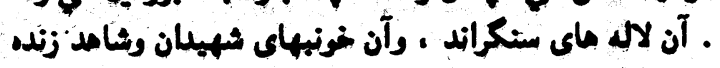

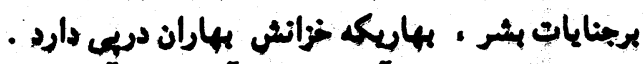

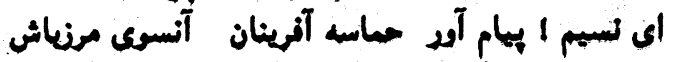

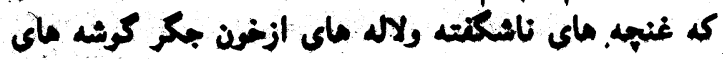

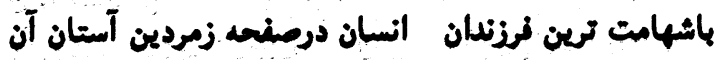

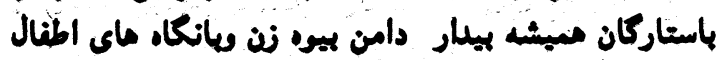

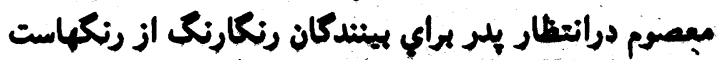

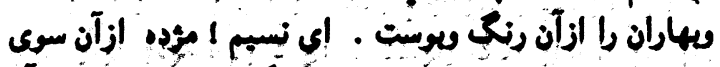

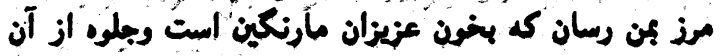

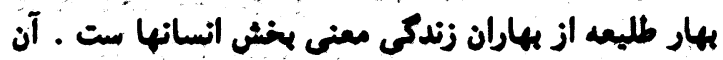

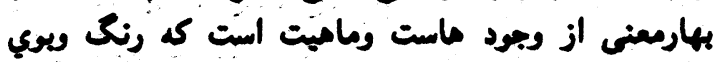

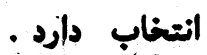
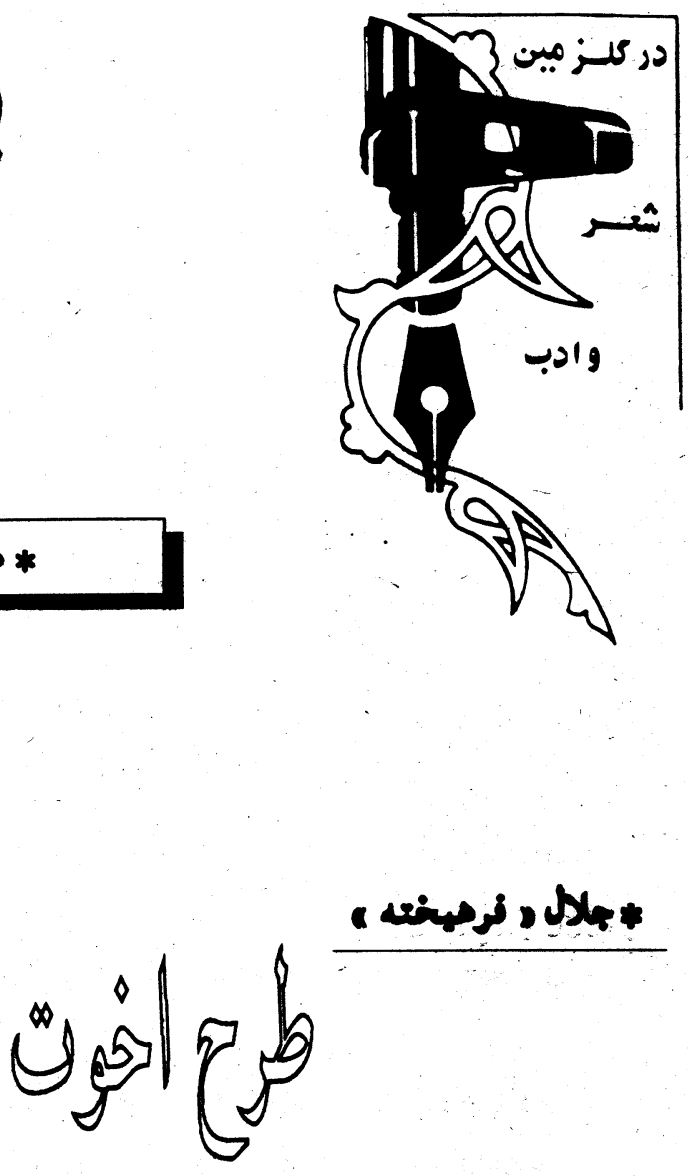

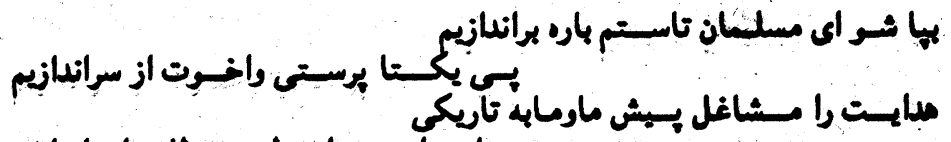

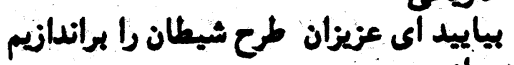

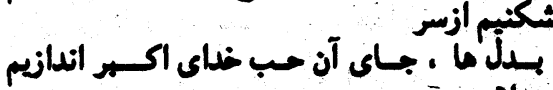

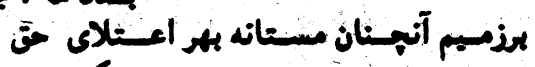
كد درسرتاسـر كيتي خروش مستشر اندازيم

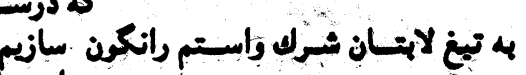

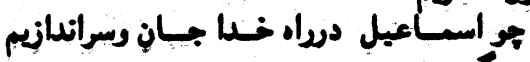

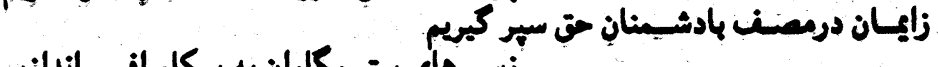
زهسرماي ستسـكاران يه بيكار افسر اندازيم

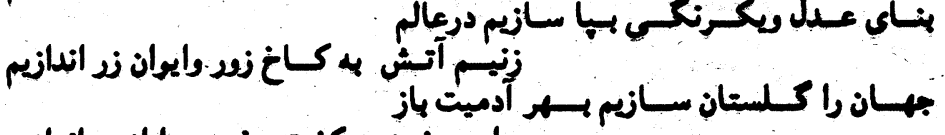
مواى دشمني وكثت وخون را الز سراندازيم

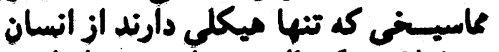
به فولادينه كويالى به بأى منري اندازيم 


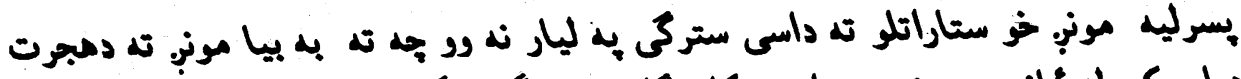

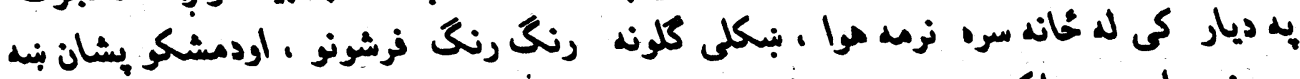

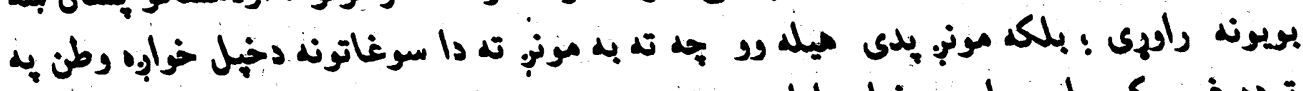

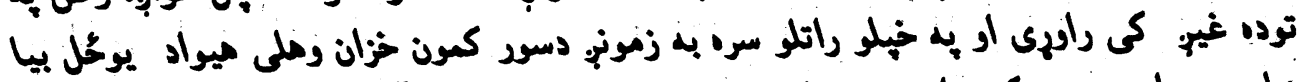

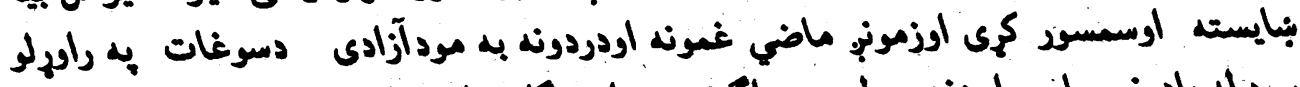

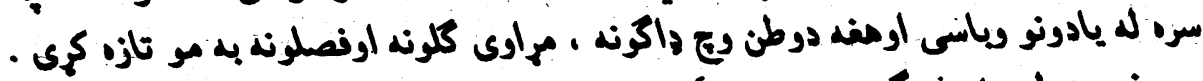

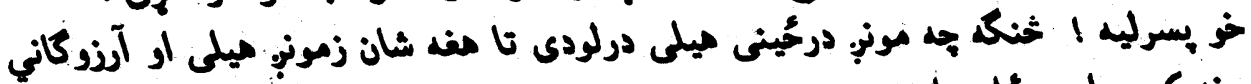

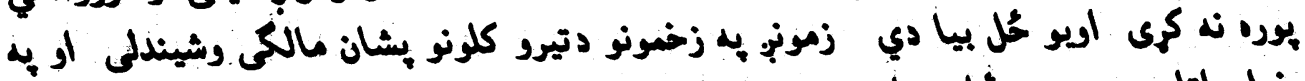

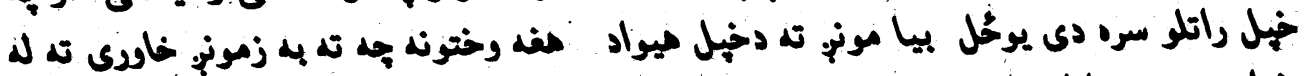

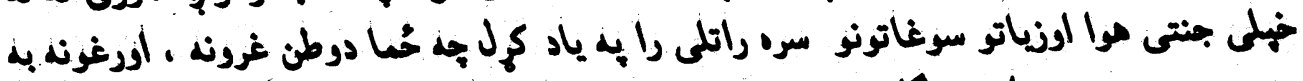

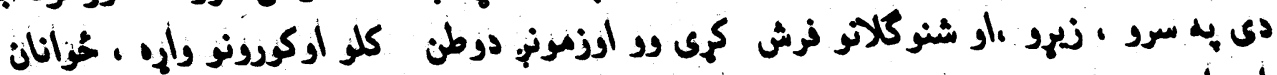

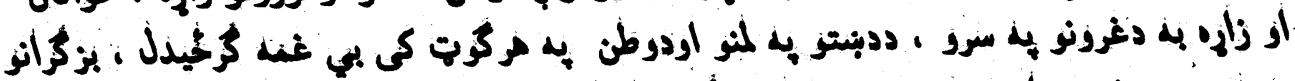

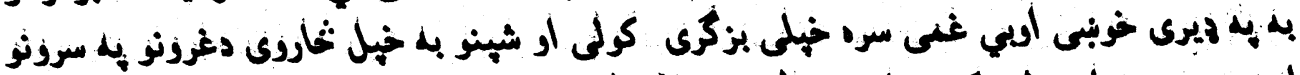

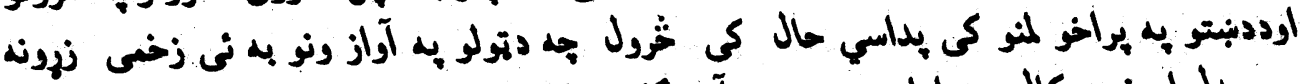

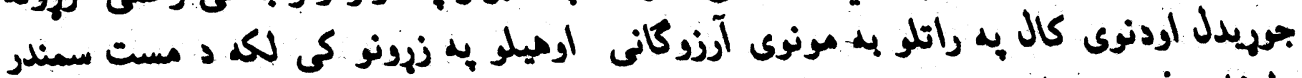

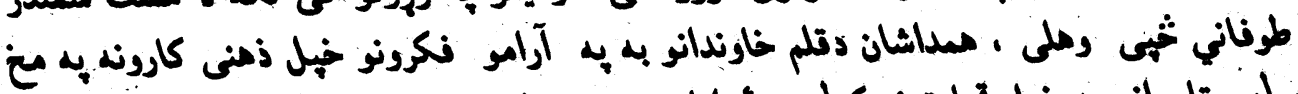

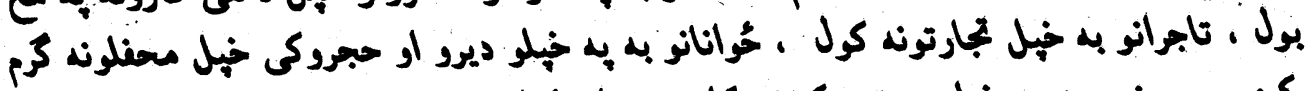

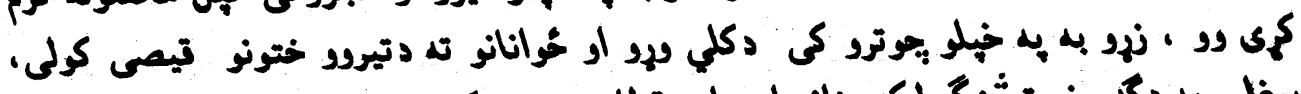

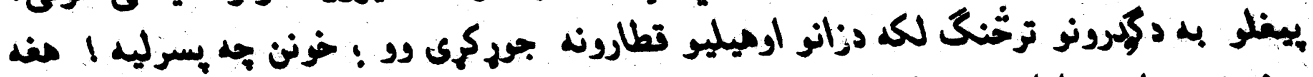

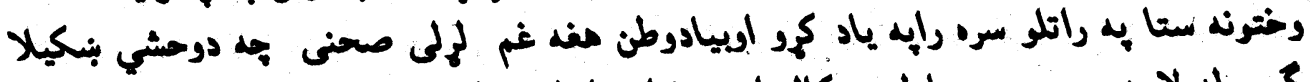

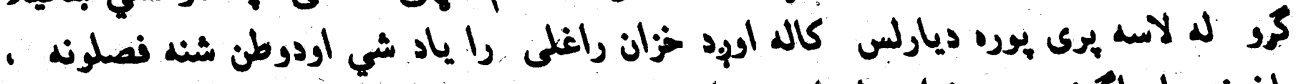

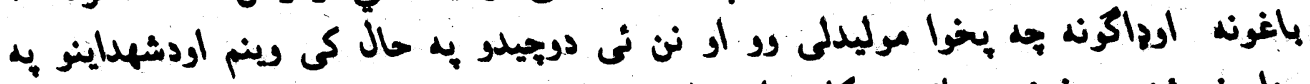

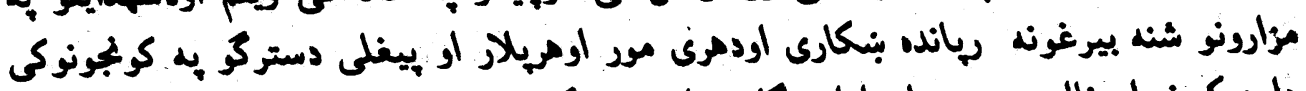

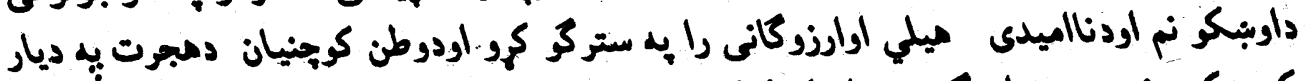

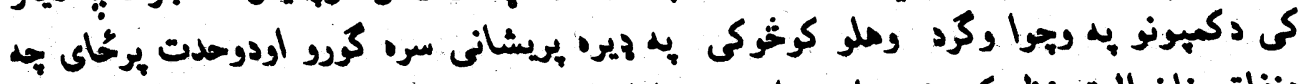

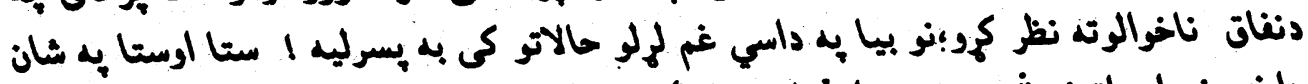

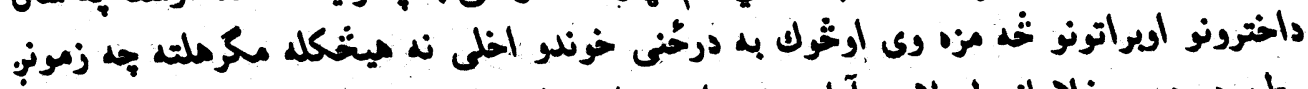

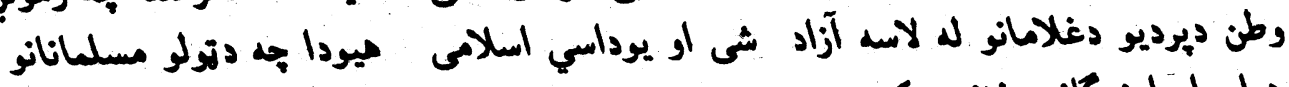

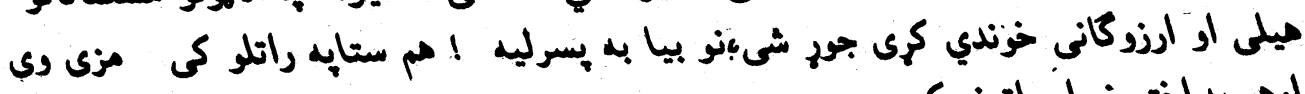

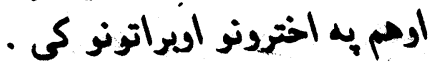
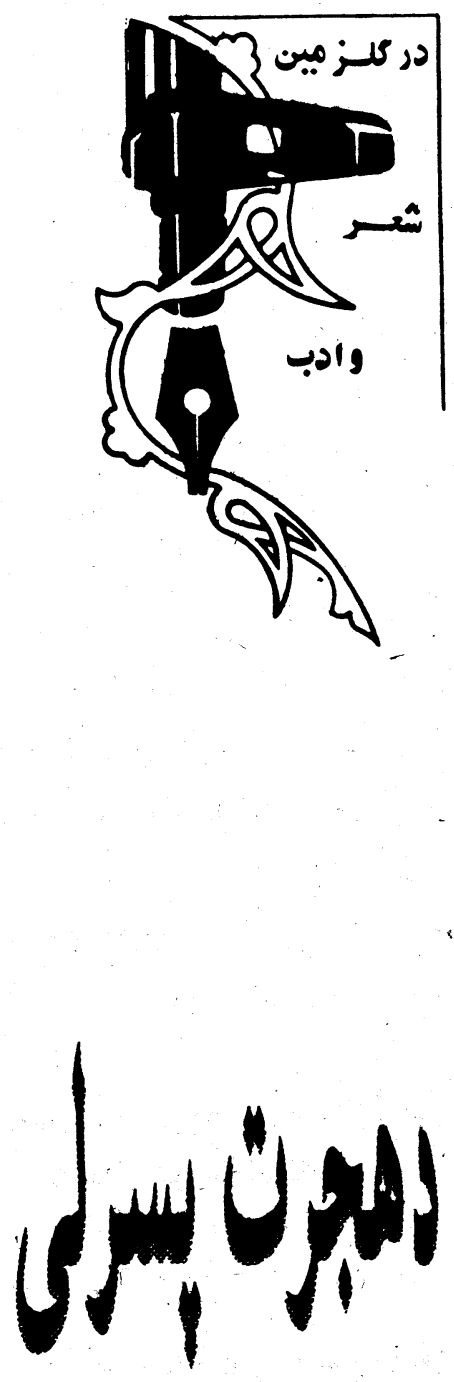

* محمد داود " بهار "

والسلاء 


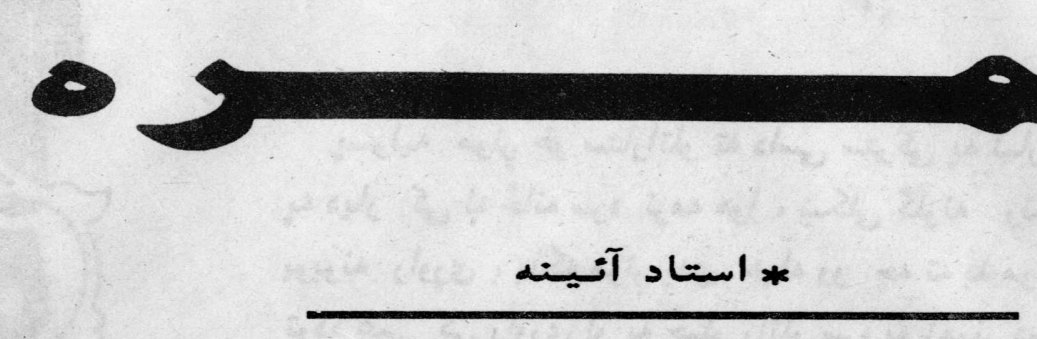

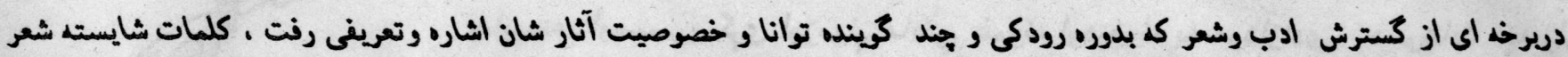

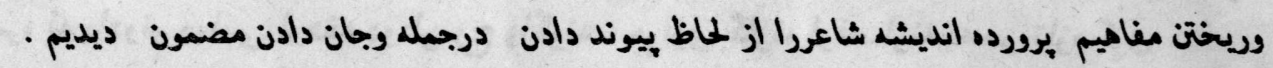

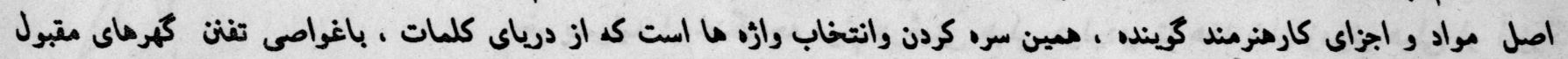

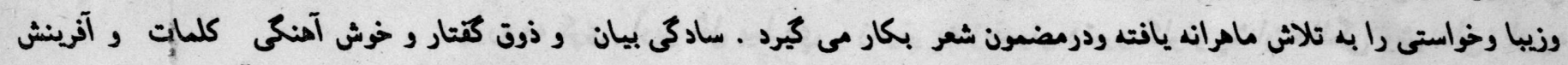

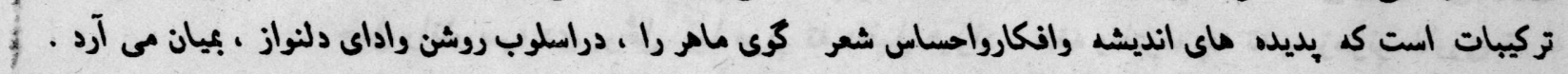

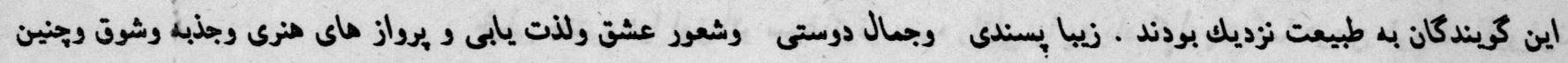

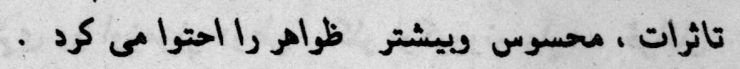

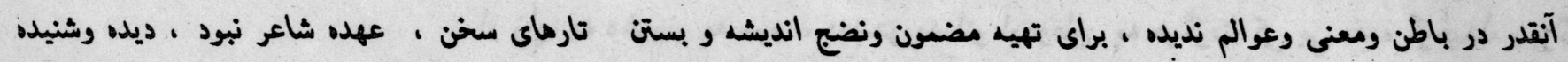

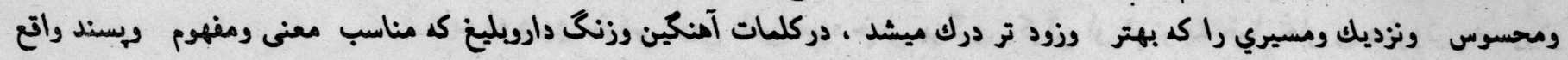

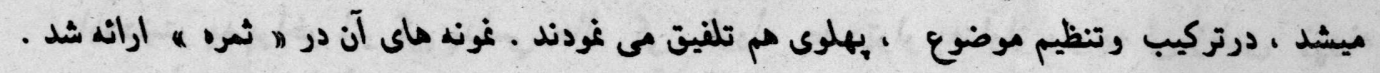

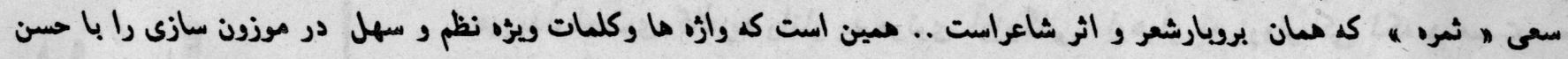

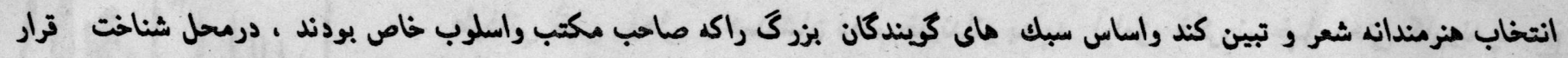
is

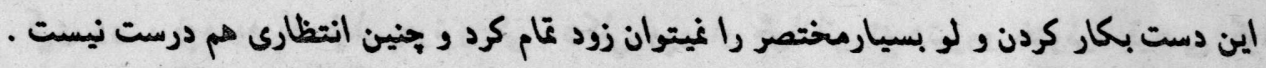

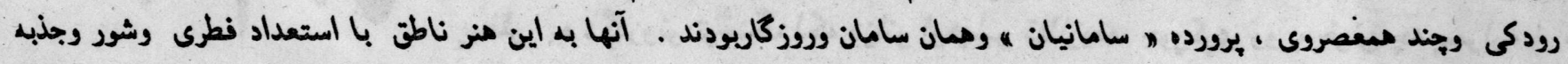

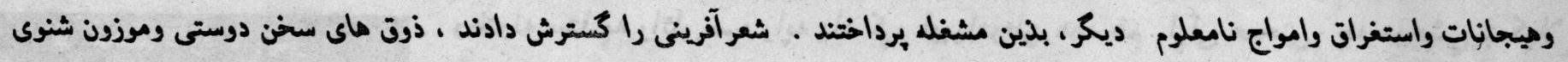
رازنده كردند .

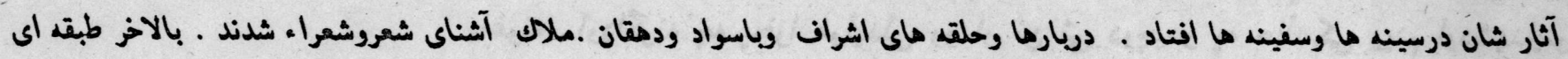

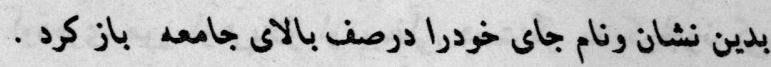

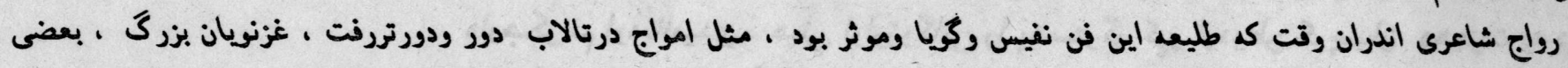

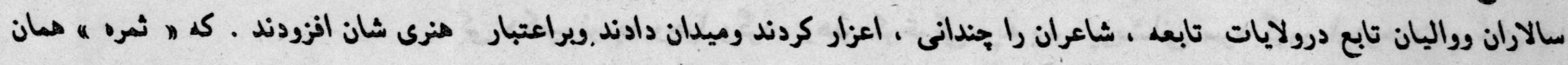

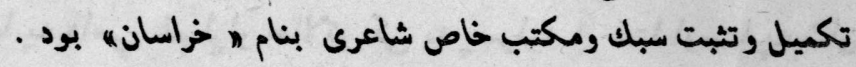

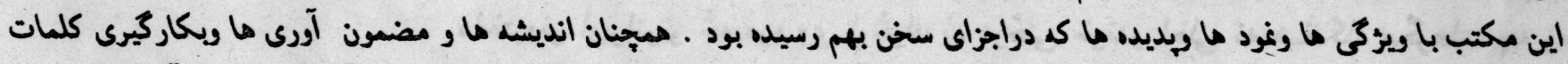

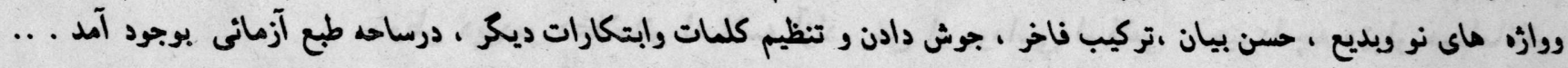

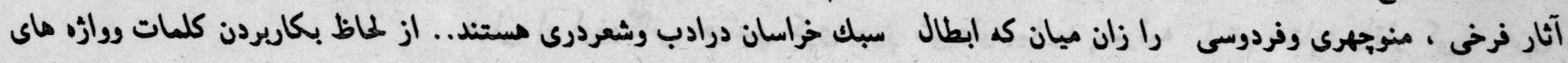

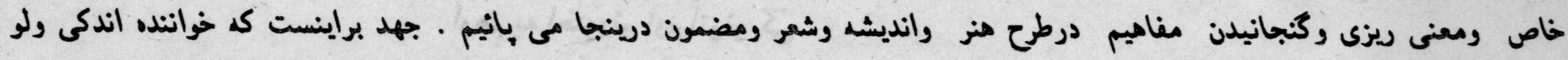

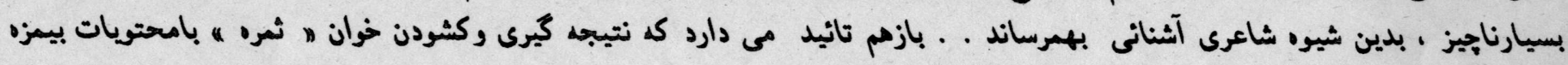
|دامع/رو

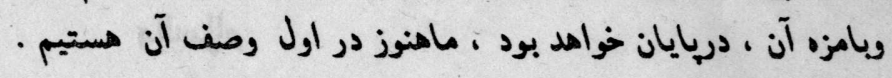




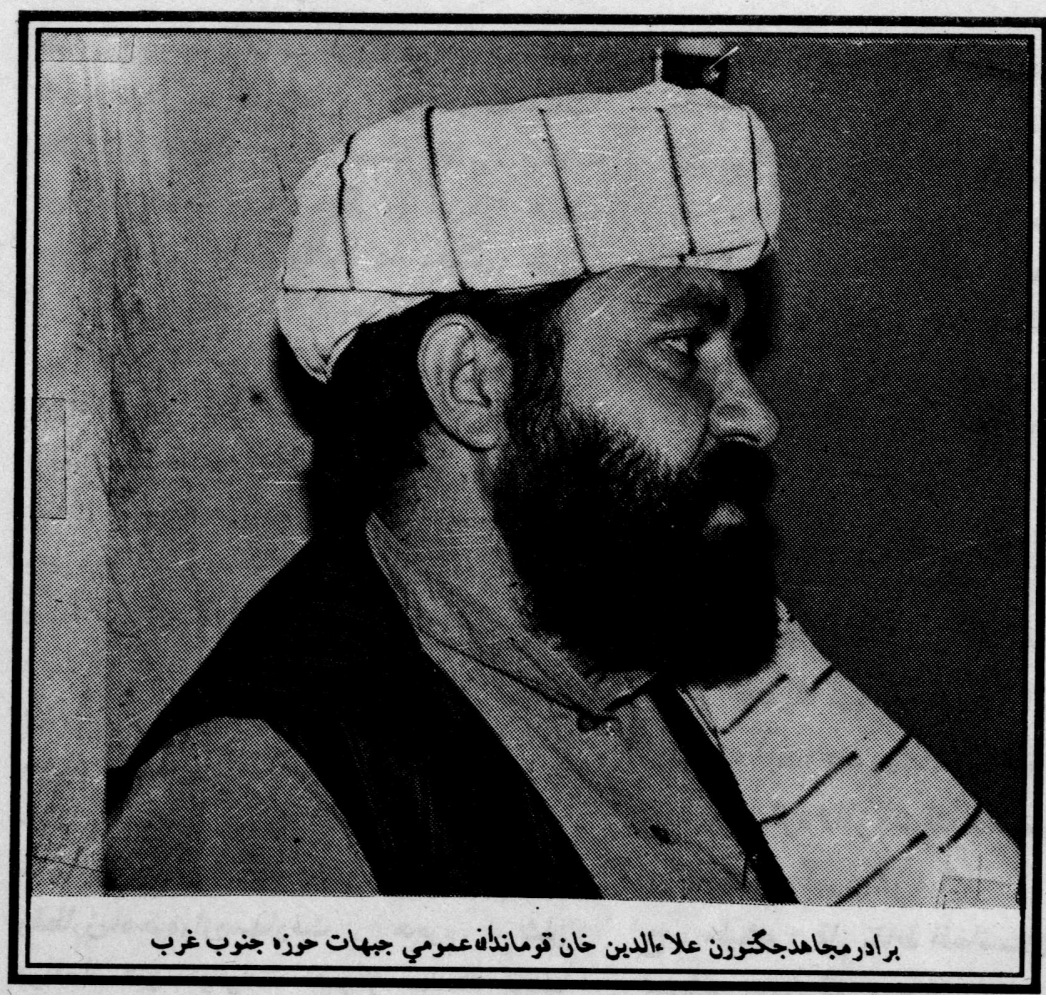

وانكيزه آن وخاطره إيكه ازاين جنبش

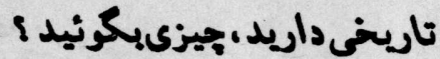

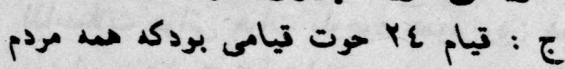

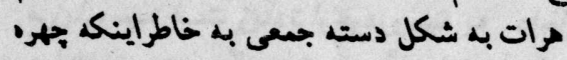

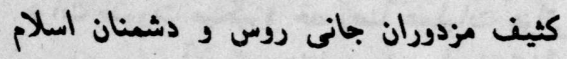

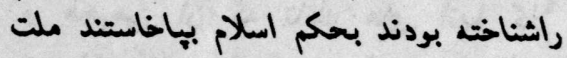

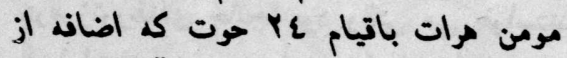
مير (Y0)

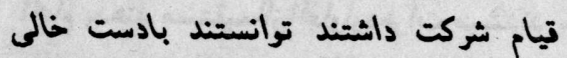

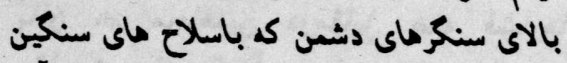

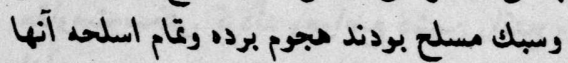

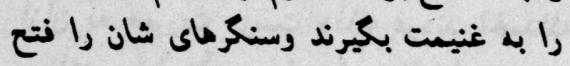

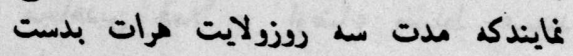

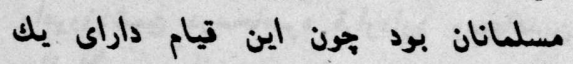

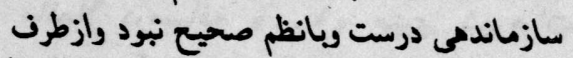

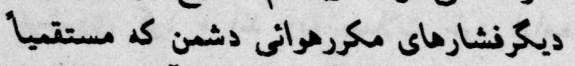

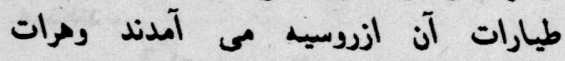

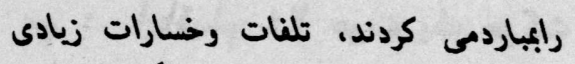

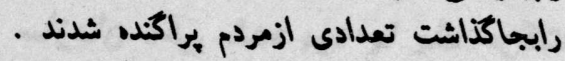

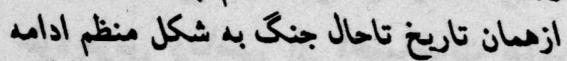

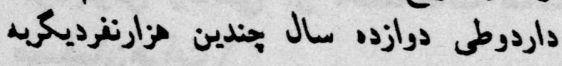

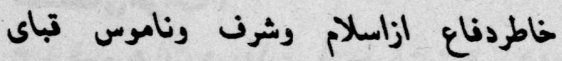

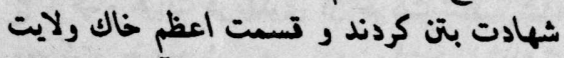
هرات را آزادساختند درديهلدوى ديت آن جون هرات رلات
به شكل متناوب جريان دارد علت عمده ايكه

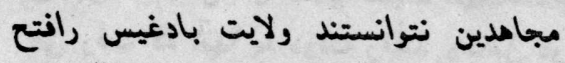

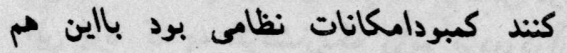

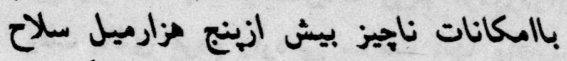

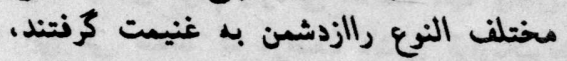

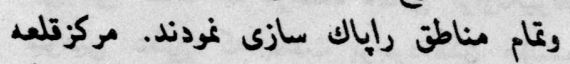

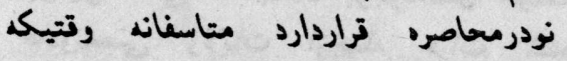

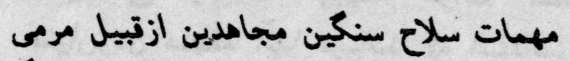

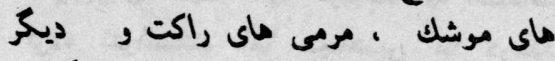

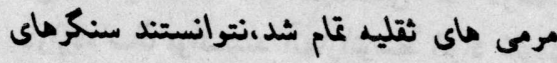

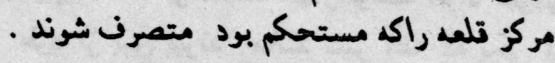

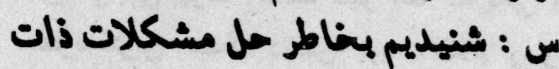

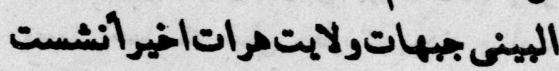

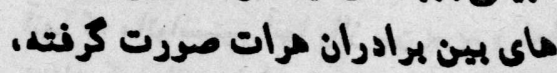

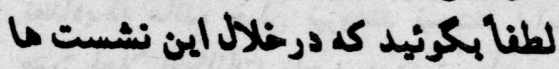

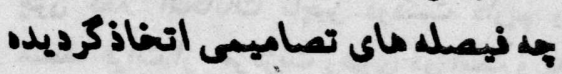

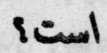

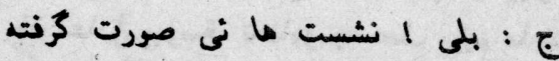

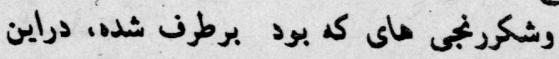

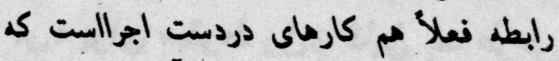

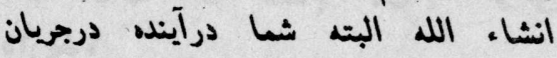
ترارخواهيد كرفت الته

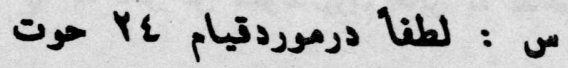

س :اميداست دربارن وضع جبهات

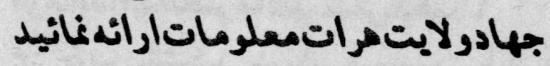

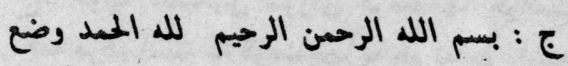

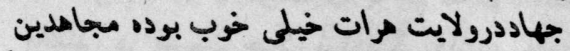

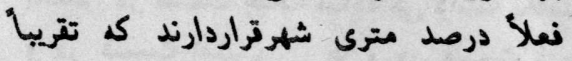

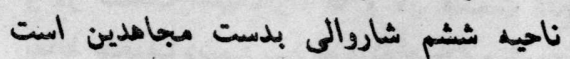

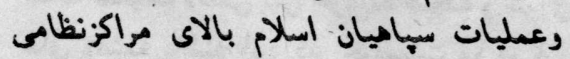

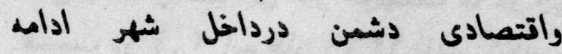
داردومجاهدين ماعمليات خودرا بالآى مراتيات

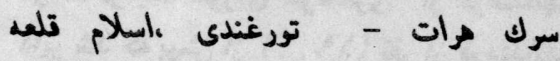

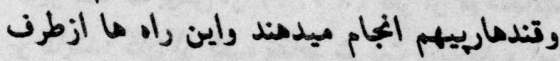

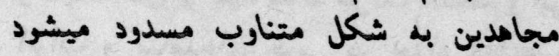

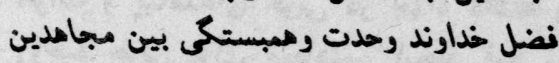

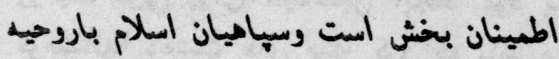

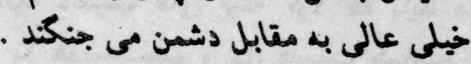

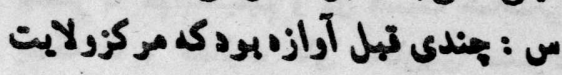

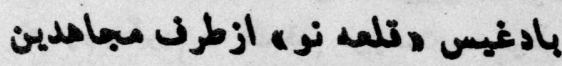

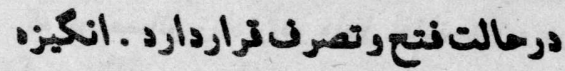

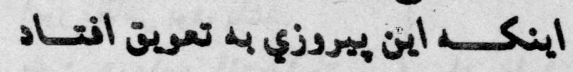
I > ب4 ج : طوريكه شمالمعلومات داريد مركز ولايت

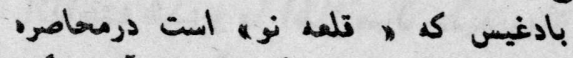

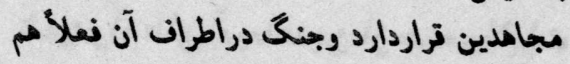




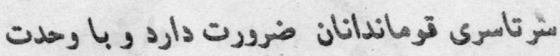

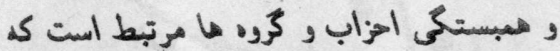

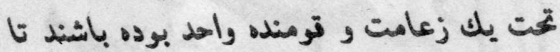

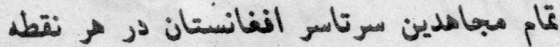

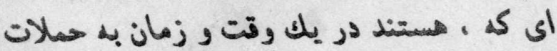

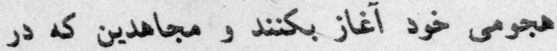

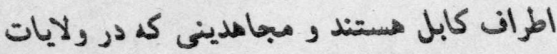

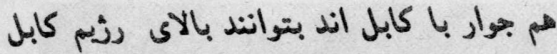

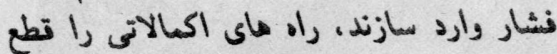

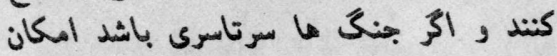

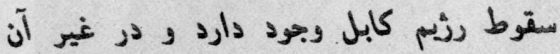

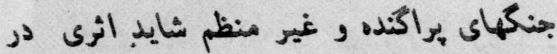

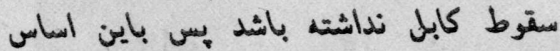

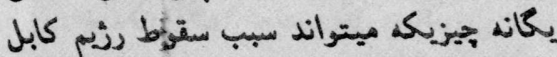
كرد

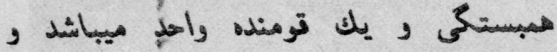

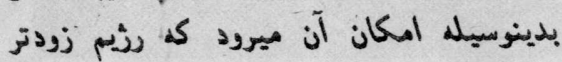
سقوط كند.

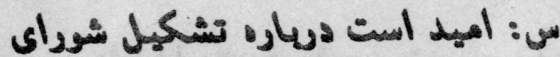

تو ج: خوب ،تشكيل شوراي قومندانها خواست

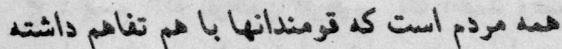

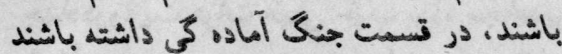

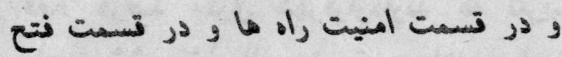

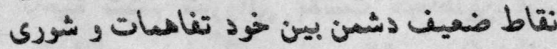

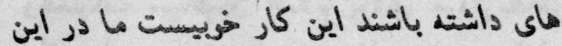

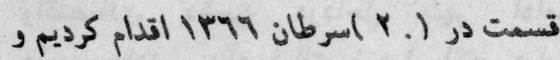
در ساغر يك شوراى سرتاسرى از تومندانها

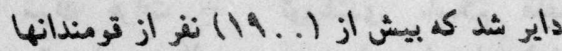

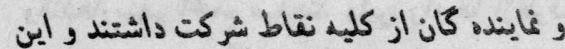

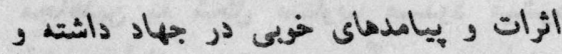

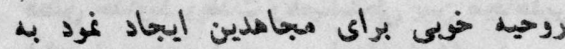

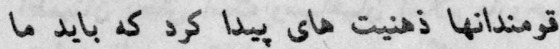

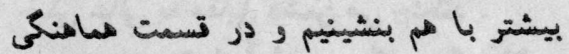

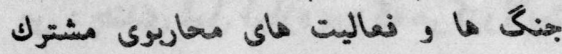

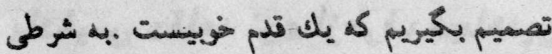

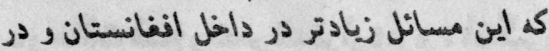

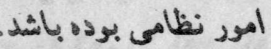

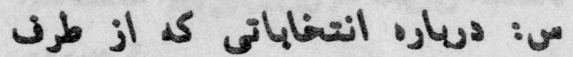

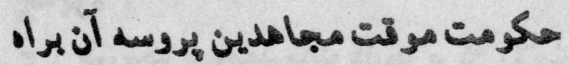
انداغته شده و وبا آغاز سال بلديد وباز شدن راه هاي مبعاهدين از مهد ولايات
الساسات بالك اسلامى ازخودتهر مانى بينظيرى

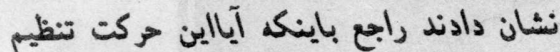

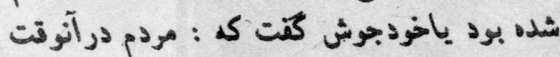

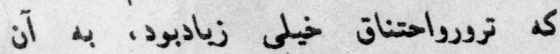

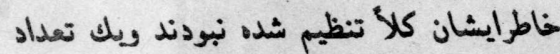

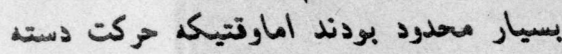

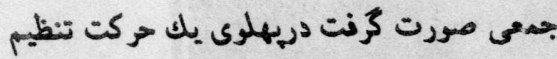

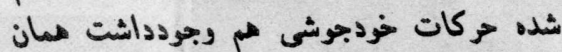

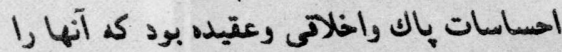

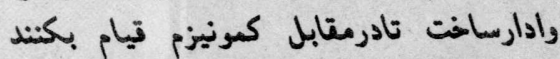

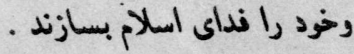

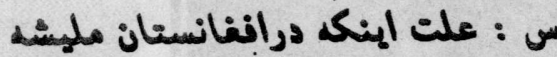

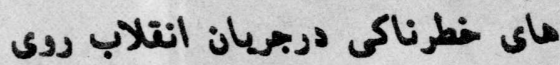

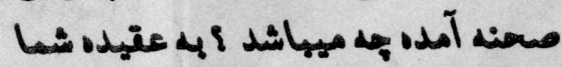

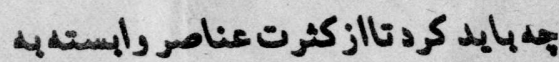

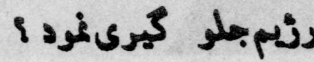
ج : مليشه درتمام نقاط انفانستان وبحوددارد .

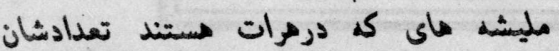

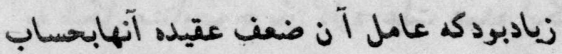

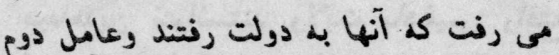

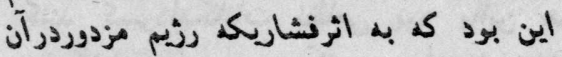

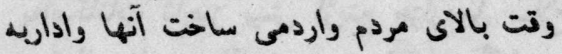

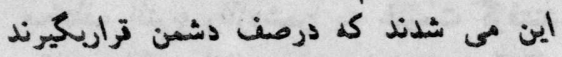

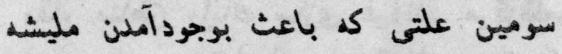

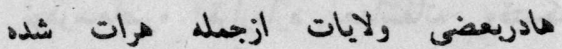

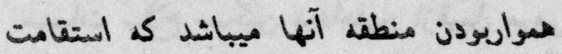

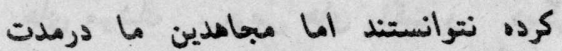

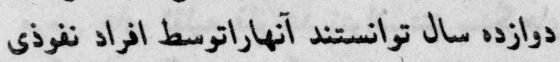

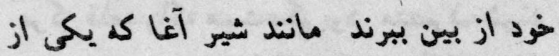

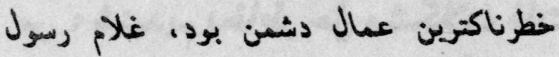

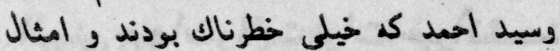

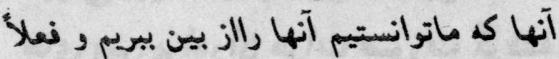

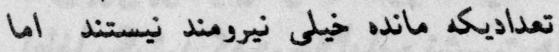

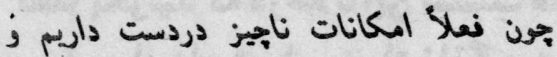

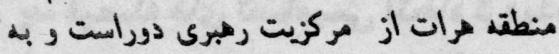

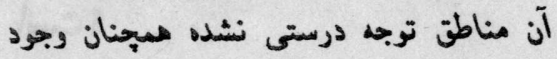

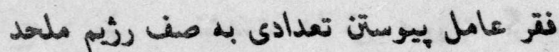

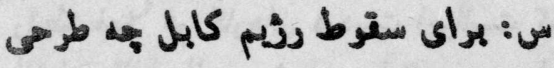
داريدأ براي ج: به نكر من سقوط رئم كابل به تفام

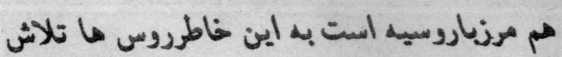

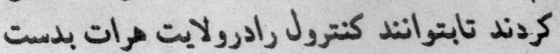

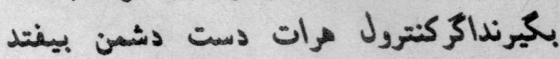

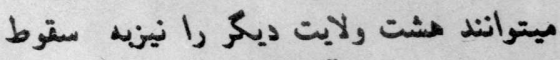

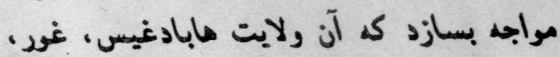

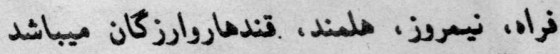

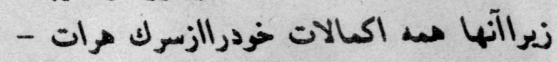

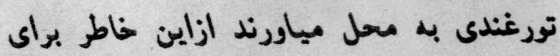

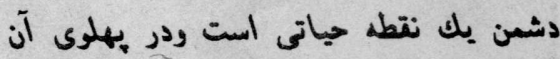

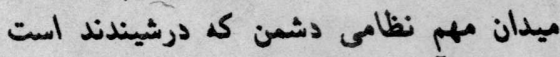

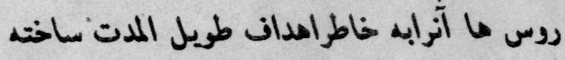

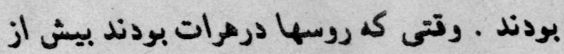

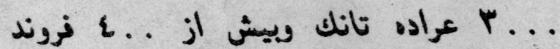

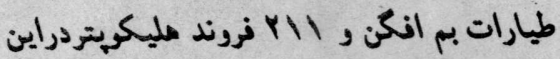

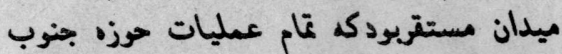

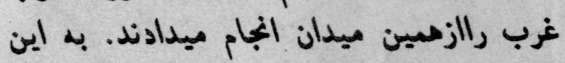

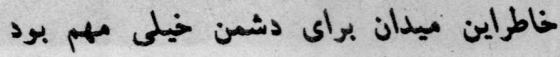

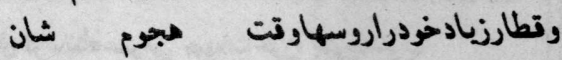

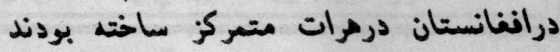

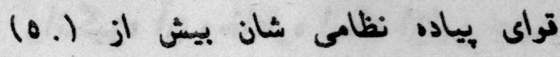

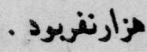

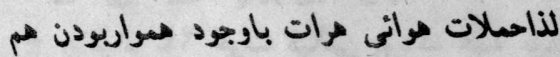

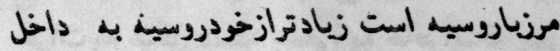

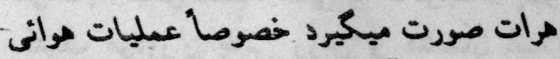

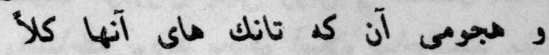

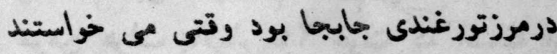

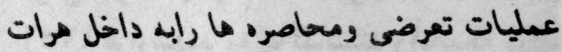

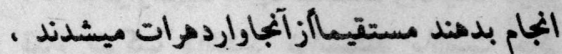

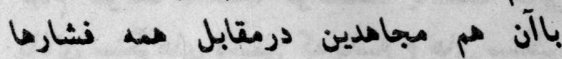

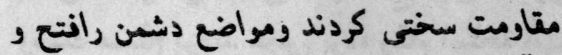

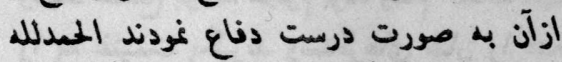

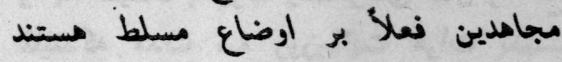

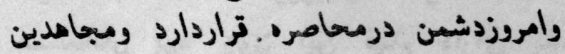

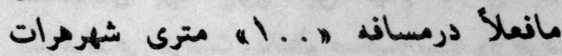

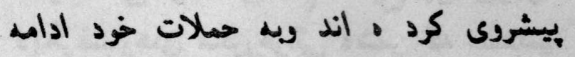

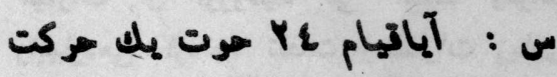

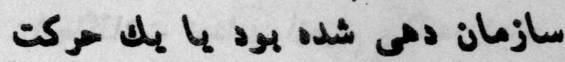

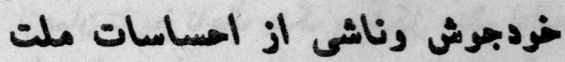
مسلمانهرات ج : تيام مرات دريهلوى آن حركت تنظيم شدهات

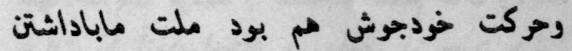




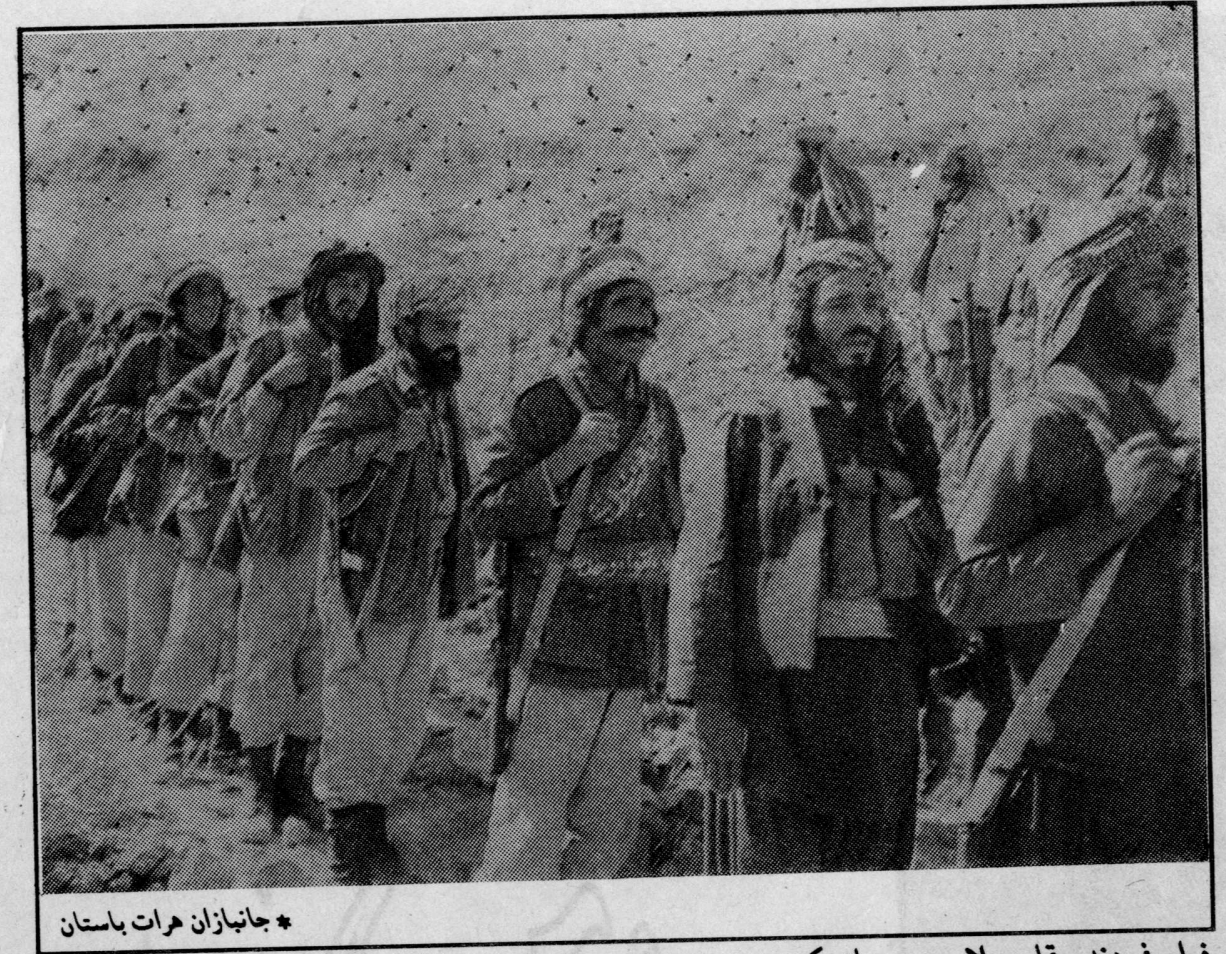

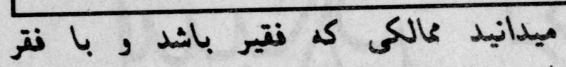

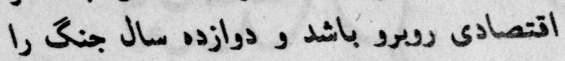

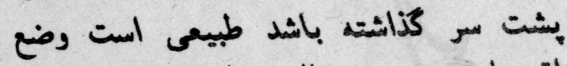

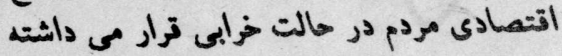

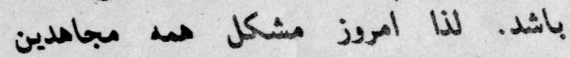

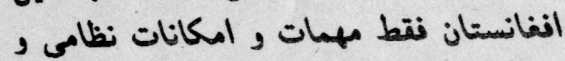

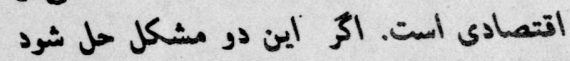

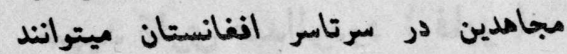

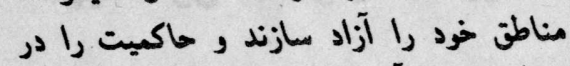
منطته بوجور آورند.

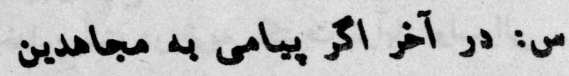

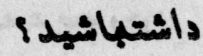
ج: بيام من به هده مباهدين انغانستان اين

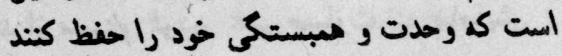

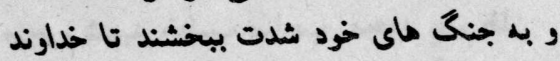

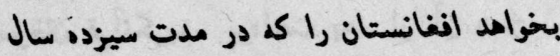

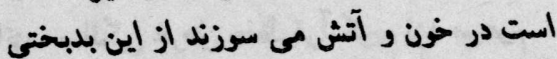

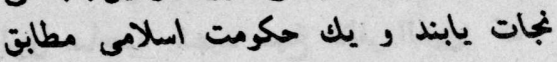

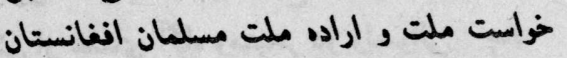

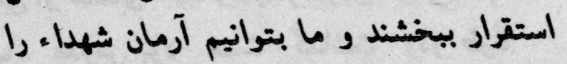

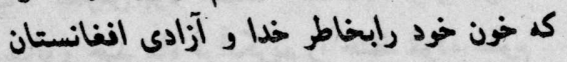

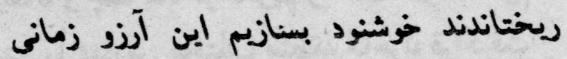

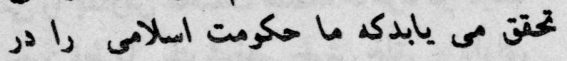
انغانستان مستر بسازيم.

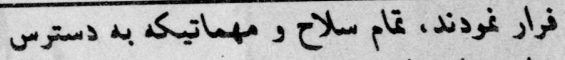

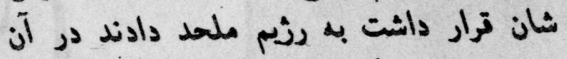

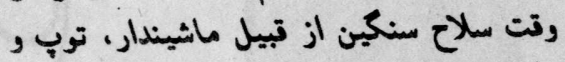

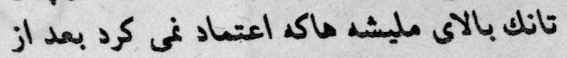

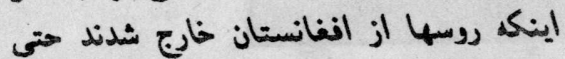

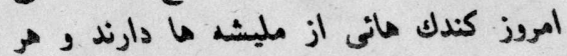

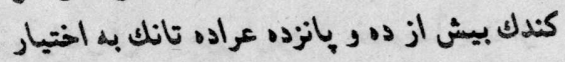

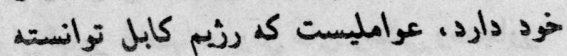

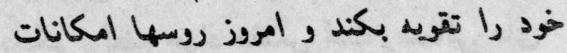

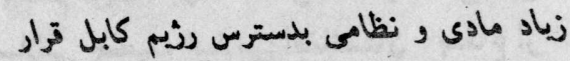

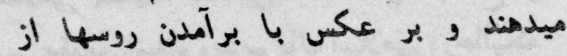

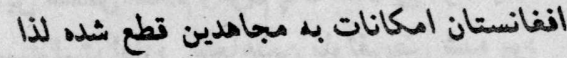

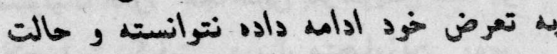

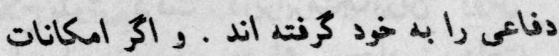

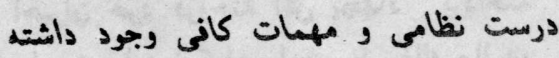

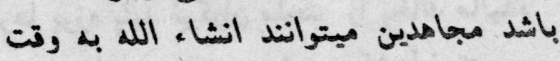

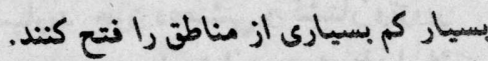

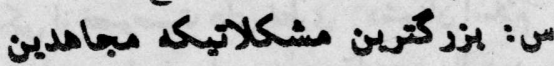

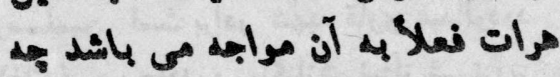

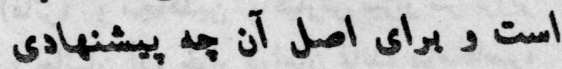
- Isylo ج: تنها مشككلات ،شيكلات مباهدين هرات

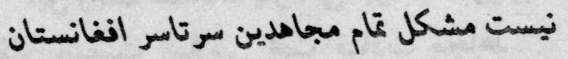

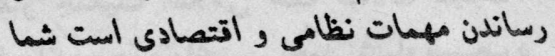

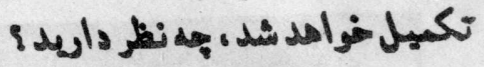

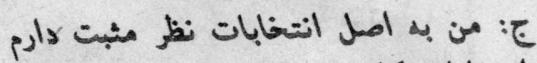

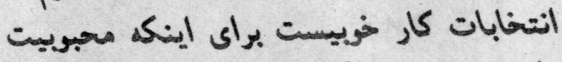

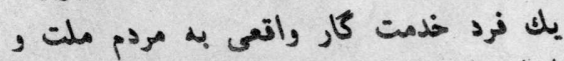

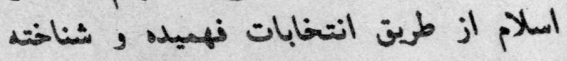

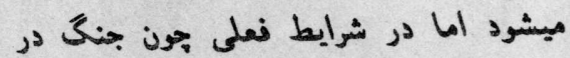

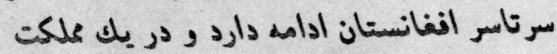

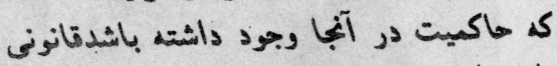

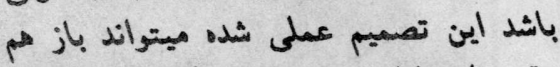

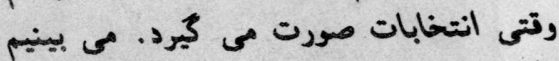

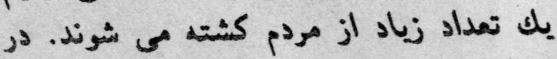

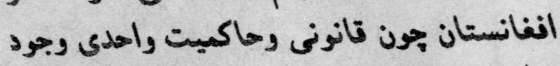

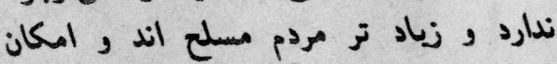

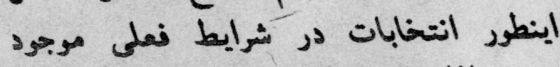

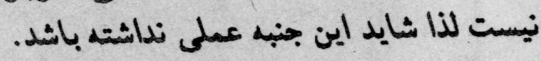

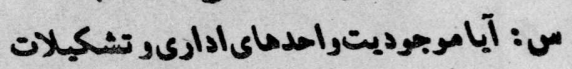

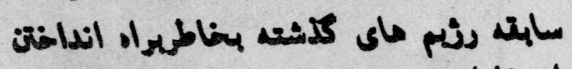

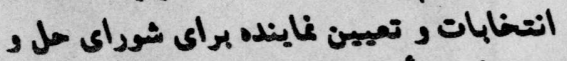

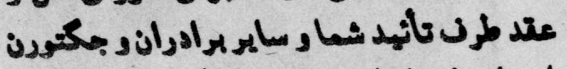

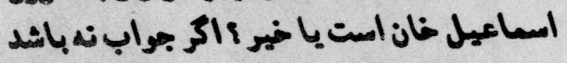

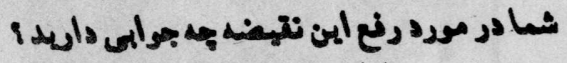

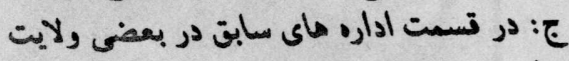

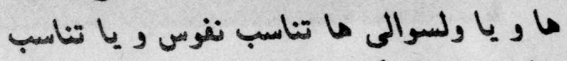

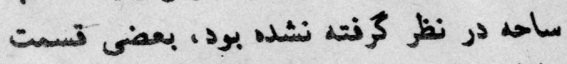

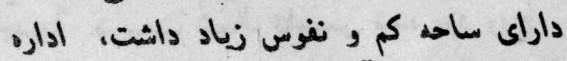

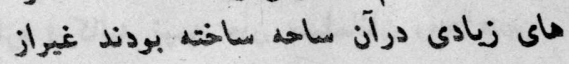

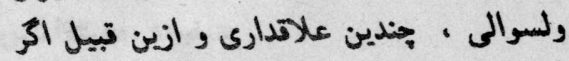

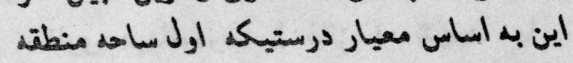

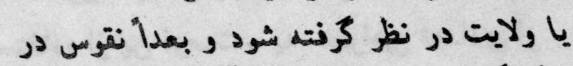

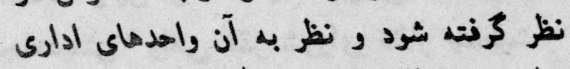

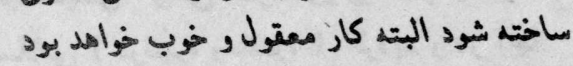
و عدالت رعايت خواهد كرديد..

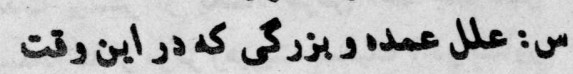

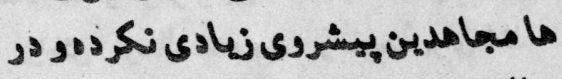

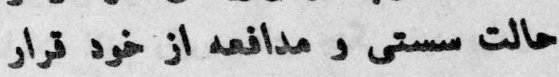
is

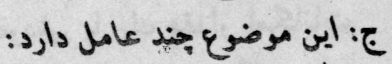

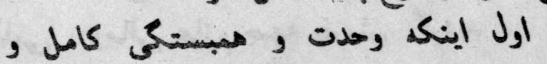

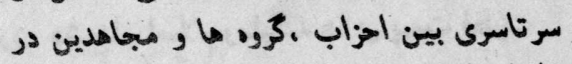

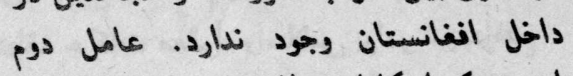

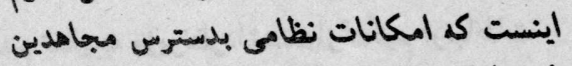

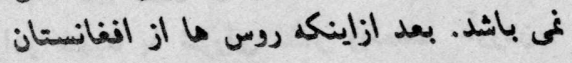



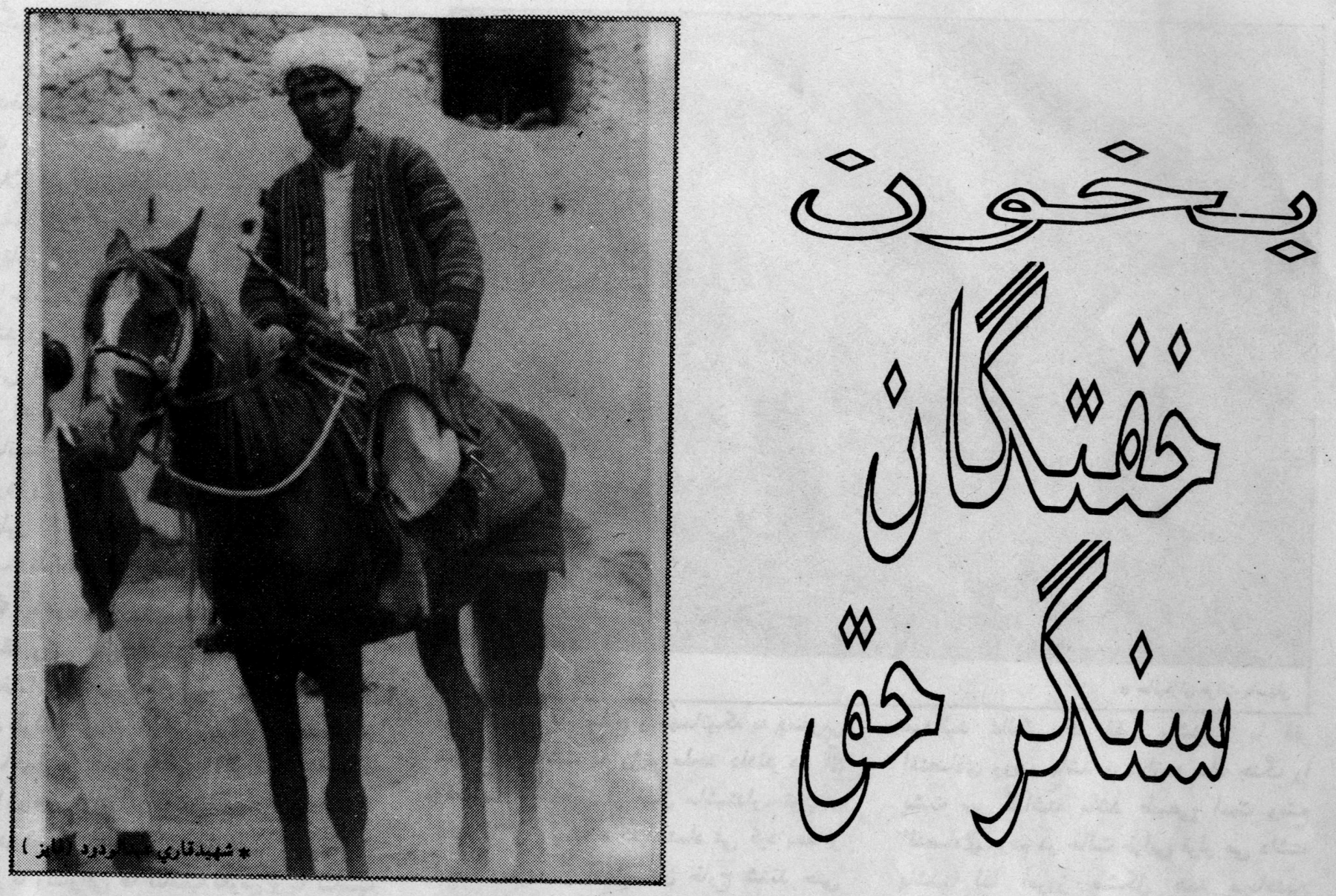

جديدا درسمت شمال تاسيس شده بود روح تازه دركالبد نيمه جان مسلمانان ومجاهدين شئدين

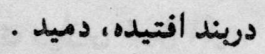

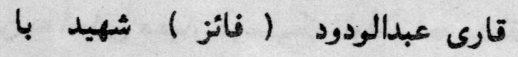

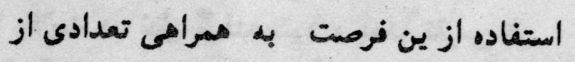

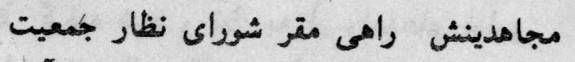

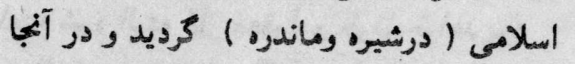

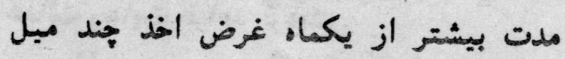

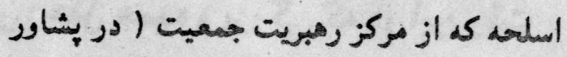

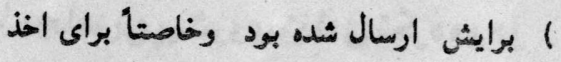

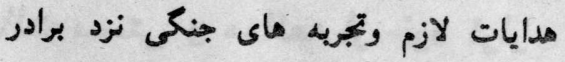

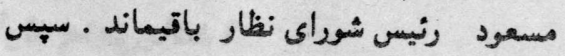
علاوه از سلاح خودش با يك مقدار امكانات

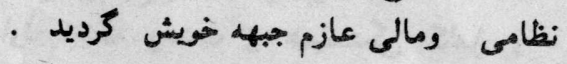

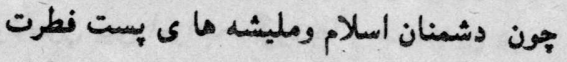
منطقه حركات معقول واسلامى برادر شهيداقدم بقدم تعتيب وزيرنظرداشتندوازتحكيم ارتباطات برادر شهيد با شوراى نظار وبدست آوردن

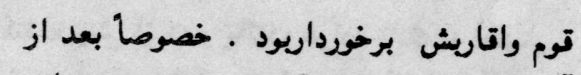

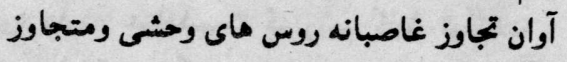

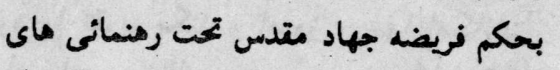

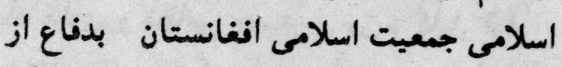

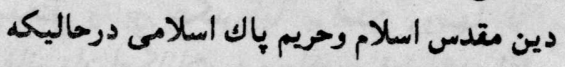

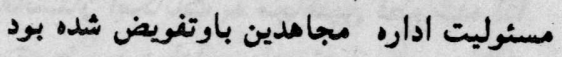

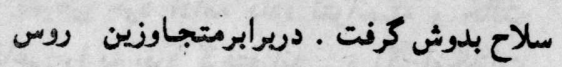

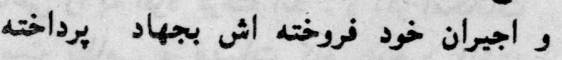

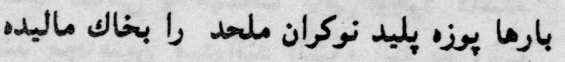

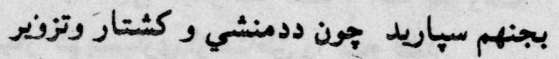

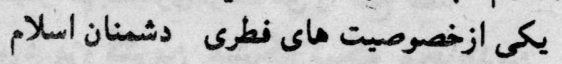

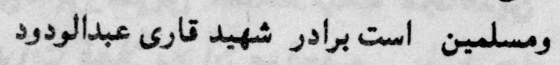

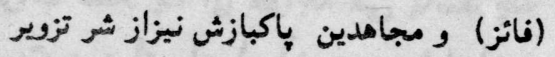

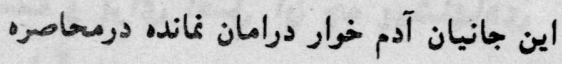

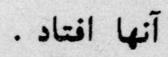
اين واتعه مصادف بازمانى بود كد شوراى

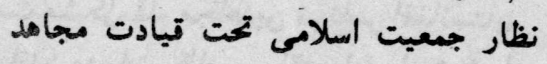

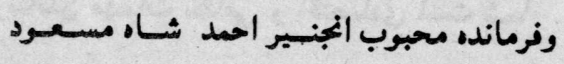

\section{شهيد قارى عبدالودود ( فايز )}

جهل وينج سال تبل در يك خانواده متدين

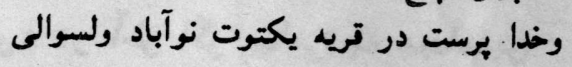

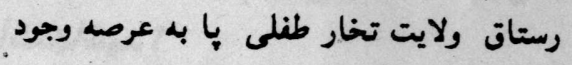
كذاشت ـ اسمش را عبدالودود مسمى نمودند

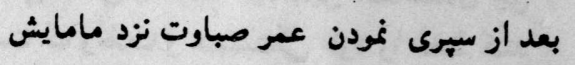

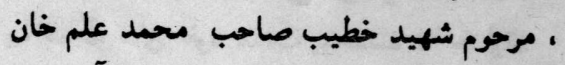

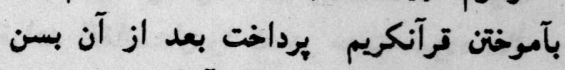

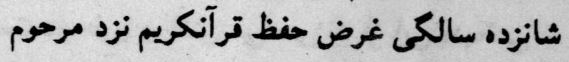

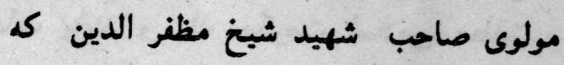

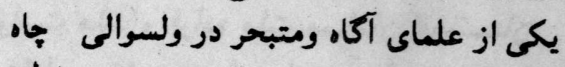

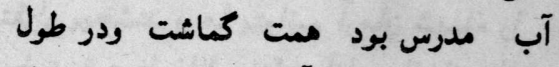

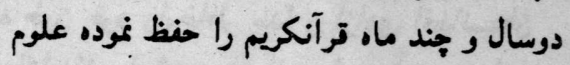

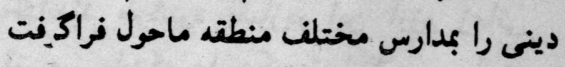

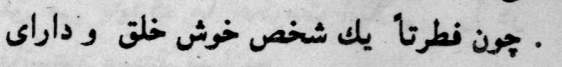
اوصاف حمبده بود واز محبويت خاصى دريبن خلى ودين 


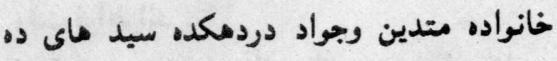

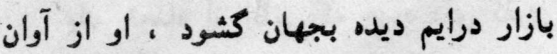

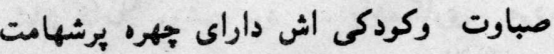

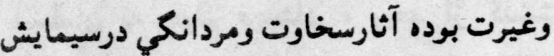

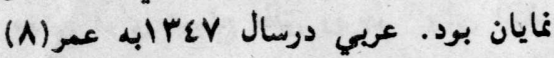

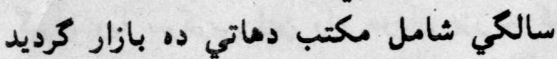

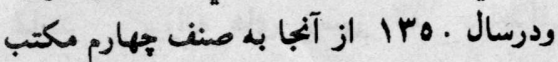

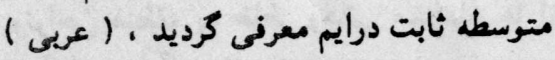

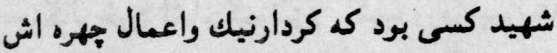

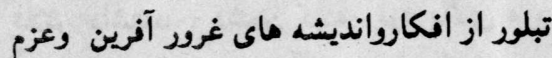

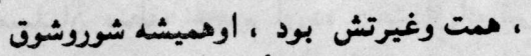

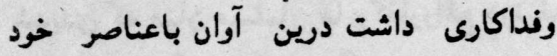

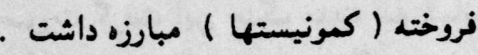

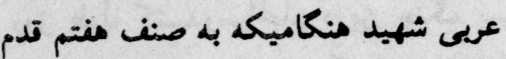

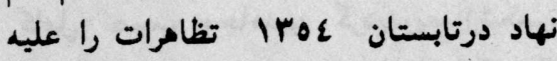

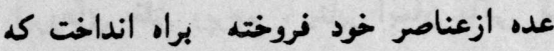

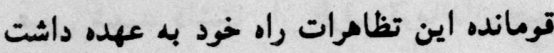

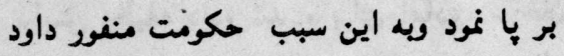

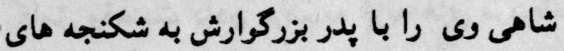

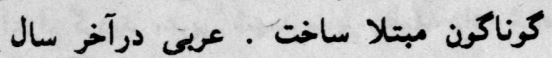
IYOO

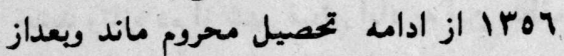
كذشت يك سال شامل ليسه كوكجه فيض آنساد آباد كرديد اودرليسه فيض آباد ، نه تنها مصروف دروس محوله اش بو بو د، بـ بلكه عليه كمونيست ماى فرومايه سخت دركير مبارزه

عريى شهيد جون به اساس ايمان وشوت

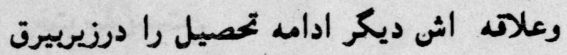

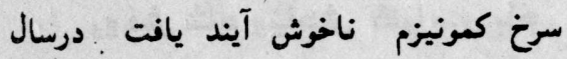

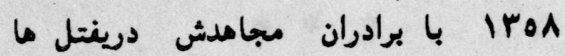

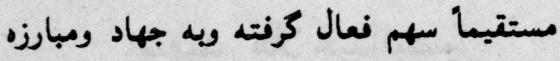

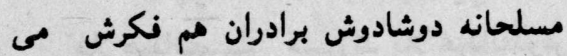

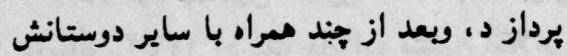

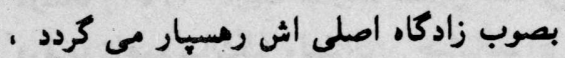

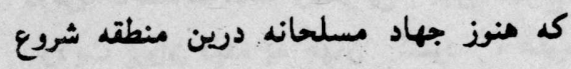

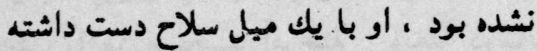

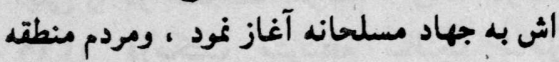
را براى آمادكى درمقابل حكومت مزدور
به امتزاز درآيد.

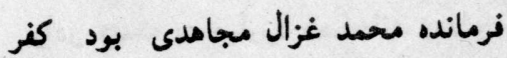

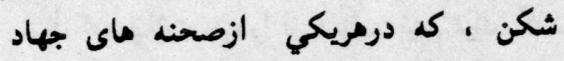

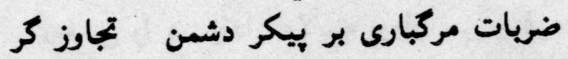

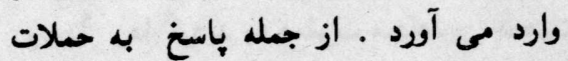

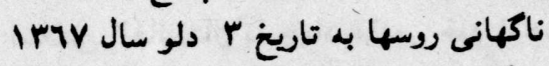

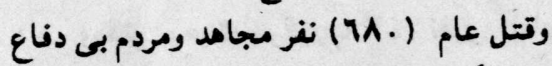

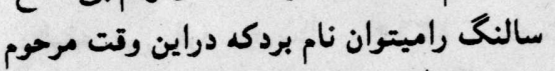

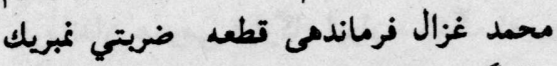

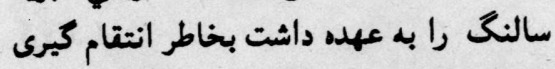

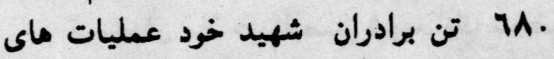

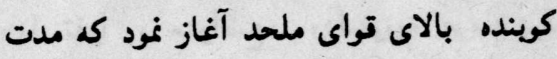

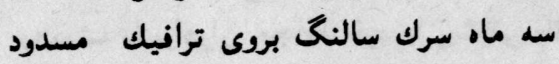

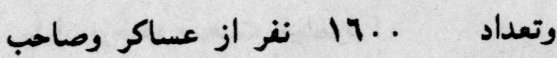

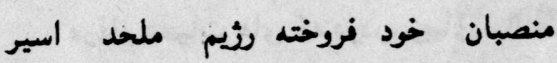

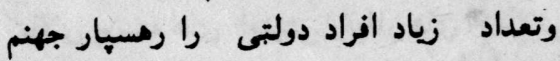
باخت.

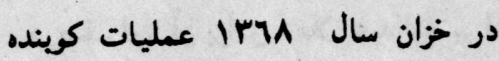

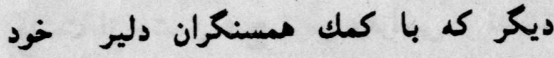

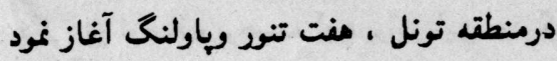

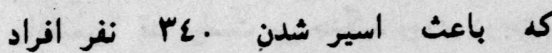

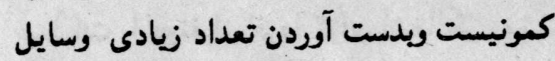

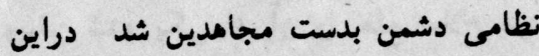

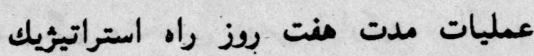

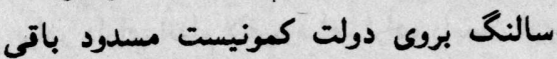

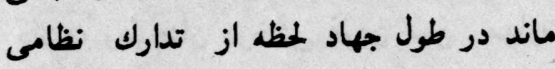

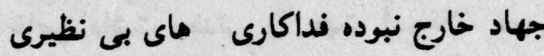

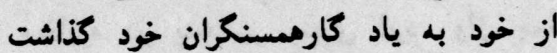

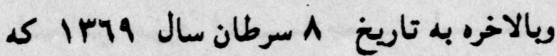

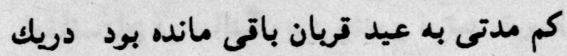

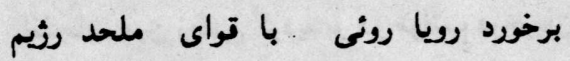

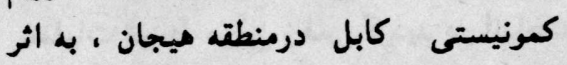

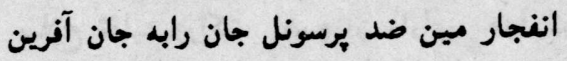

روش شثاد ويادش گروامى باد

\section{$* * *$}

شهيد سيد محمد داود ( عريى * * مرئ ) سيد محمد داود شهيد فرزند ايشان سيد عربي

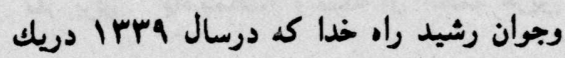

امكانات رزمى در مراس افتيده به نكر آن

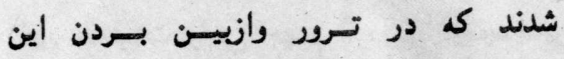

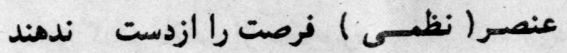

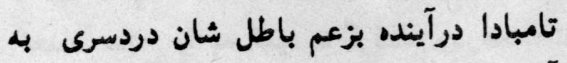

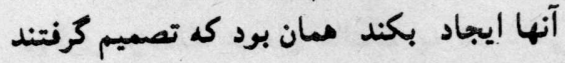

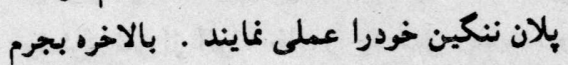

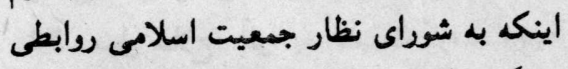

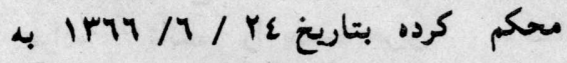

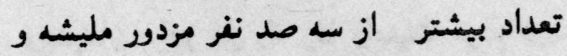

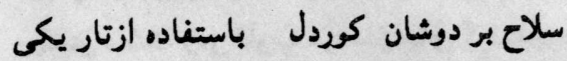

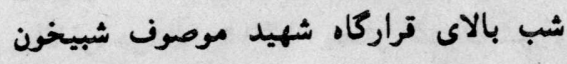

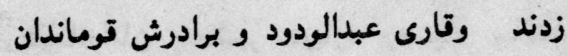

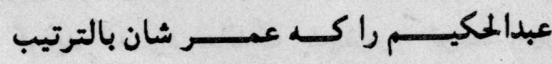

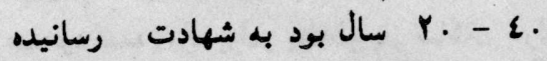

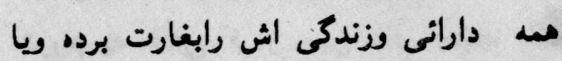

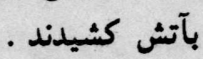

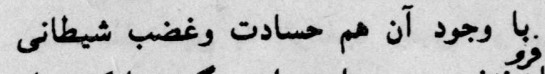

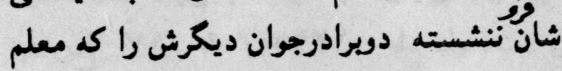

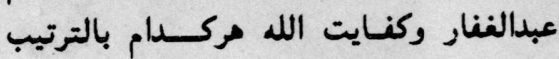

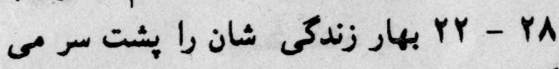

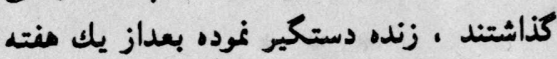

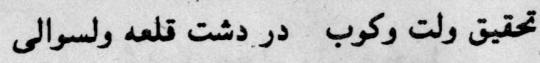

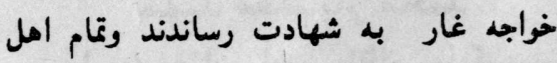

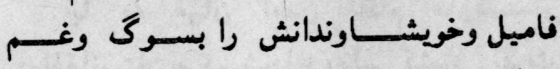

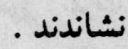
روهشان شثاد يادثنان گَرا عسي باد

$$
\text { شهيدمحمدغزال }
$$

تريه انامك جبهه سالنش جنوبى وفرمانده تولى

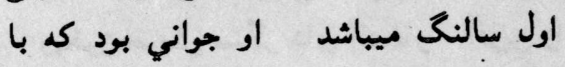
اطبينان به بيروزى انتلاب اسلامى افغانستان بردي

جهاد ميكرد وييروزى را منوط به ريختينت

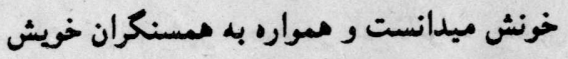

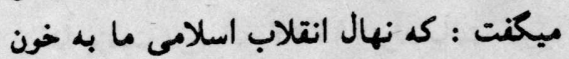

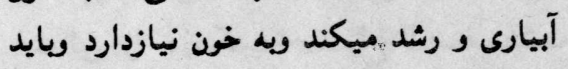

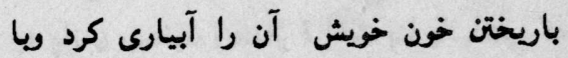

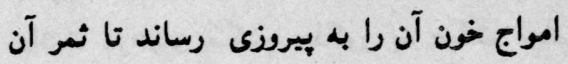

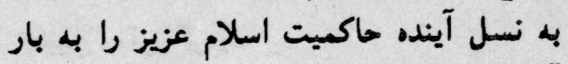

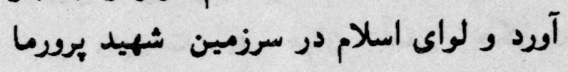




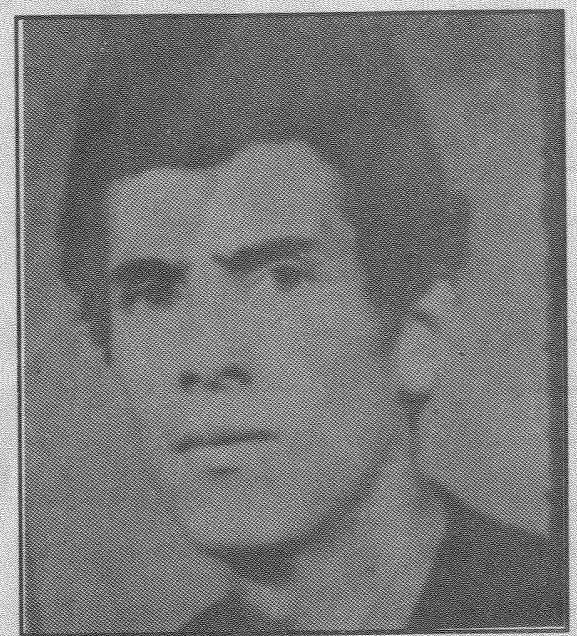

* شهيد ملا عبدالبصير

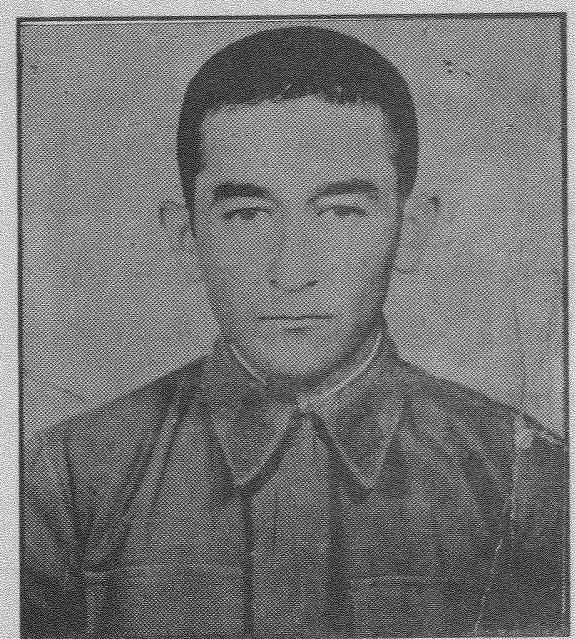

* *هيد عبدالمصور *

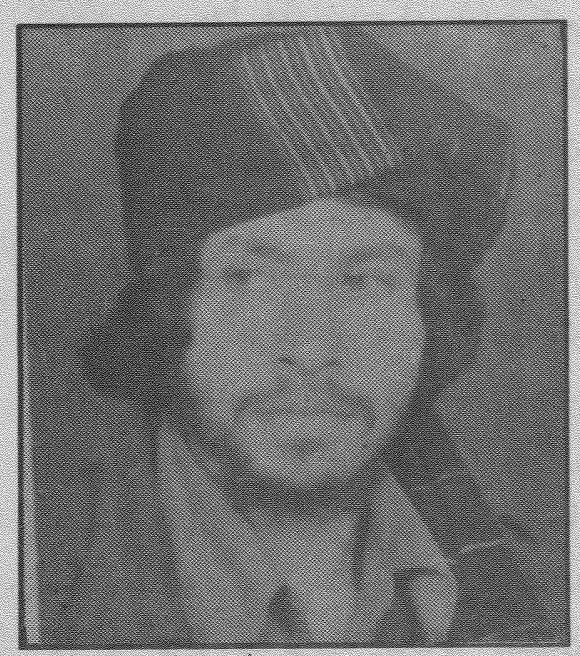

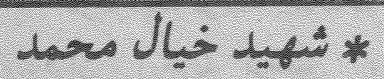

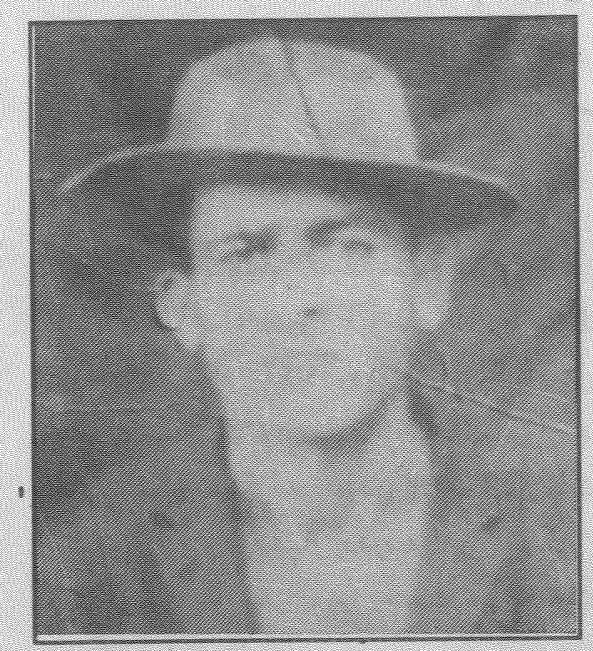

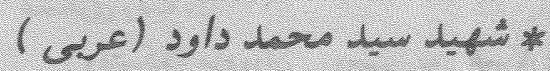
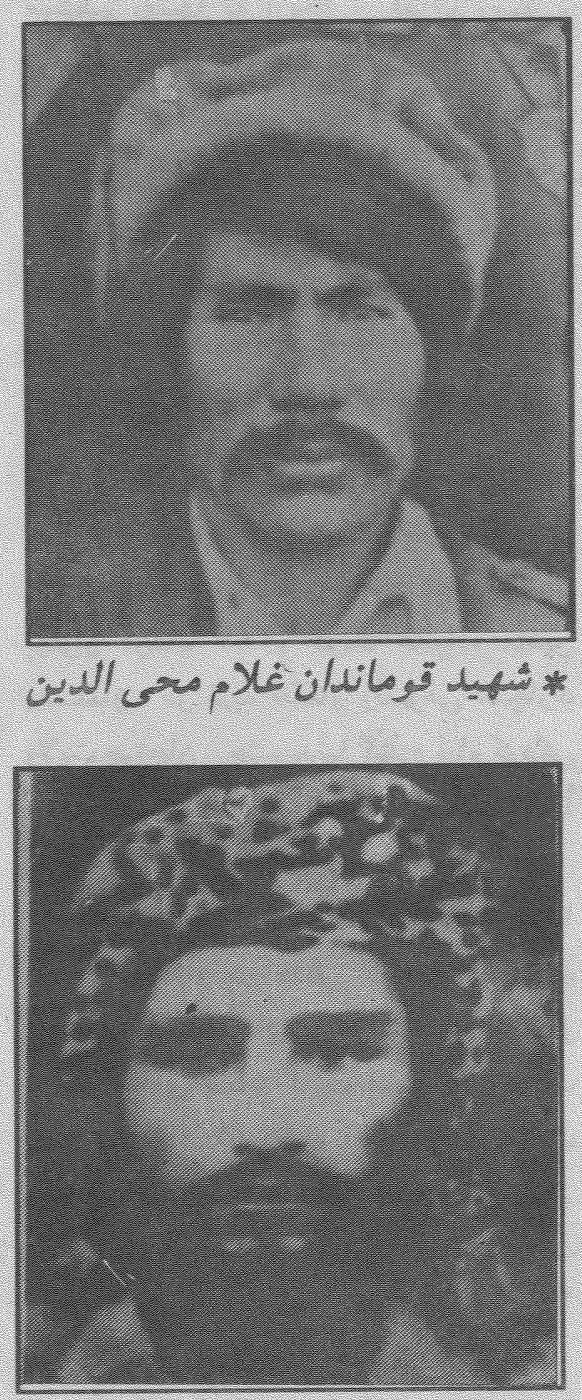

* 3هيد محمد موسى ( سربوى ) *

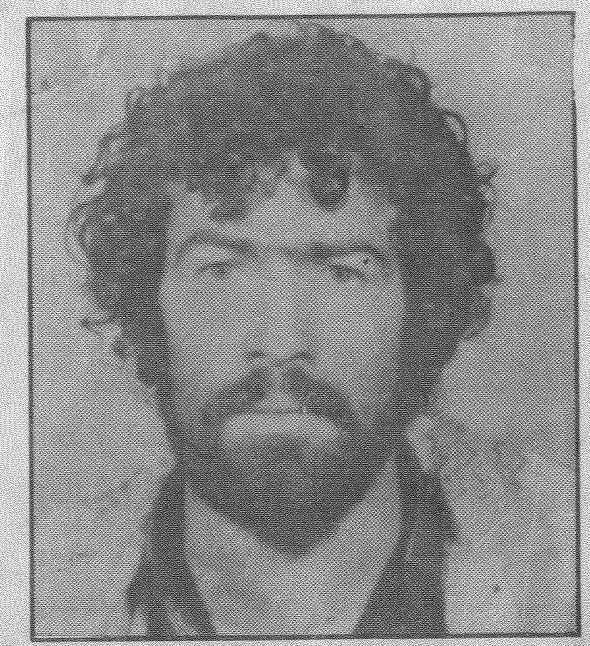

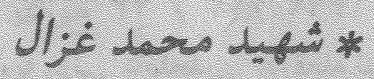

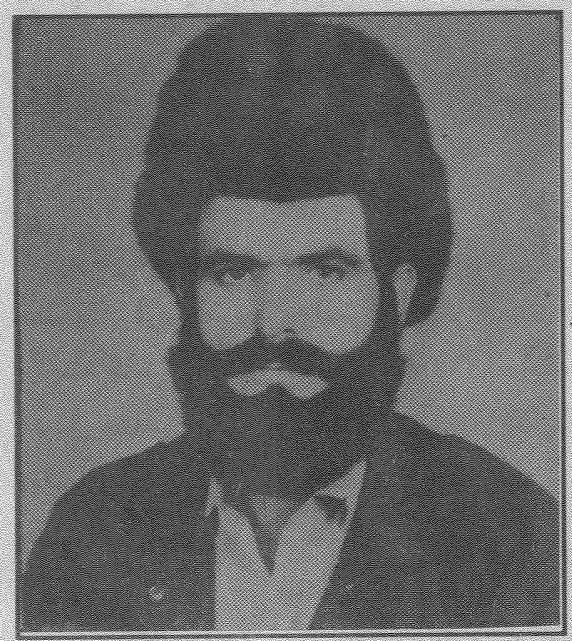

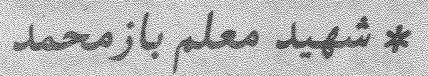

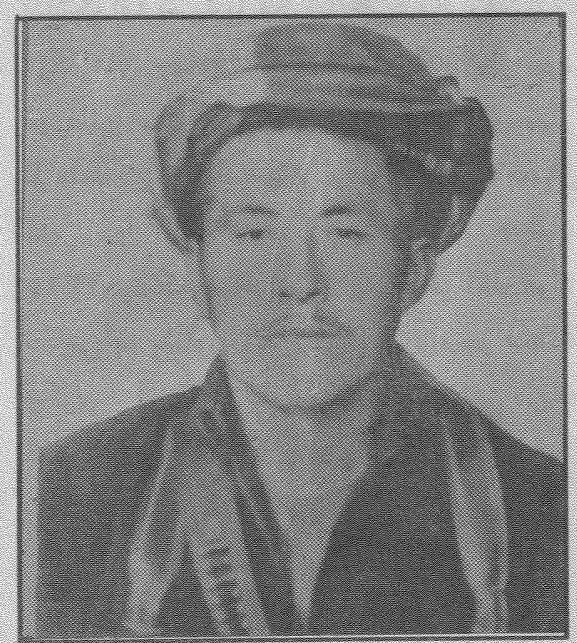

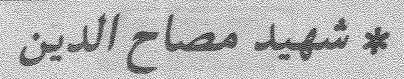




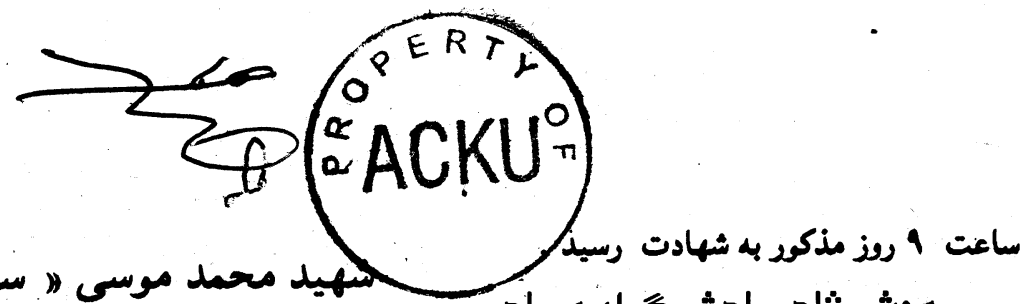

سهيل محمل موسى "( سرورى. " شهيد محمد موسى ״ سرورى " در قريه

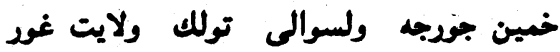
درسال |rE| بلدنيا كثود . بعداز سن منت سالكى شامل مكتب كرديد

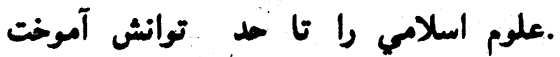

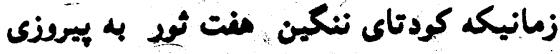
رسيد : اين هرادريل جبهه نرومندتشكيل داد ومدت A سال تام در براير تواى ملحد بنكيد

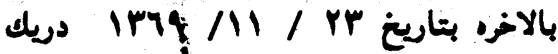

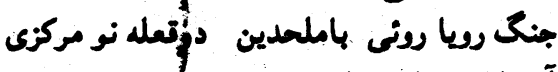

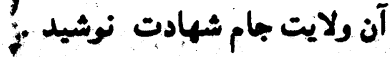

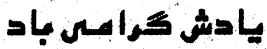
***

شيهيل خيال محسل

برادرشهيد خيال مسمد ولد عبدالرذاق مسكوند تريه موسهى ولسوالى تهار آسياب ولايت كابل بوده ، دربال IMPA

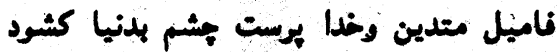
وبابيان آملن كودتاى منحوس منث ثمد به

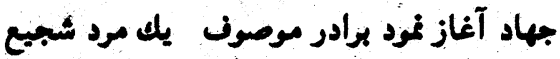
وقهرمان بود كه קندين عمليات در شهر

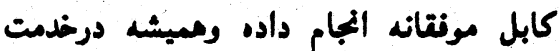

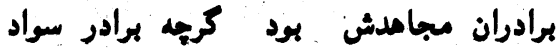

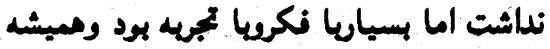
دركارماى بهادى فكر وغود ميكرد واز خود قهرمانى هاي رأ بيادكاركذاشته است ويسيار از ملحدين'در شاه شهيد وكارته نو وبالامصار

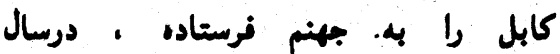

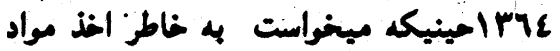
نظامى به يشأربيايد درعرض راه در منطتد جكرى از طرف كمونيست ماى ومشى دَريك

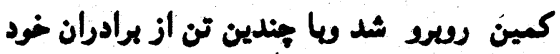
مام شعادت نوشيد .

راهب مهل بهرو باد

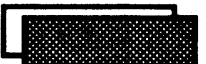

دوشش شناد يادش شراشيى باد

\section{شهيل عبل عالمور}

شهيد عبلالمصود فزند الماج مانط

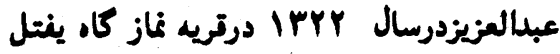
تشم به جهان كشود تعليمات ابتدائى ر را نزد امام مسجد فراكرفته غرض ادامه تعليمات

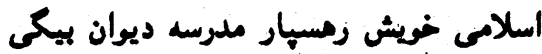

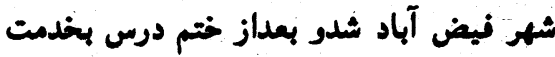

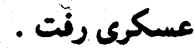
وتتيكه "مزدوان رومى رو به مسكارى

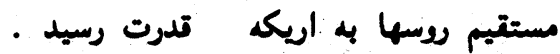
موصوف بهاد را عليه جاوزكان وجيه

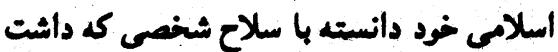

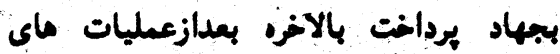
متداوم دريكى از زدو خدود ماى خونين ذيريعه

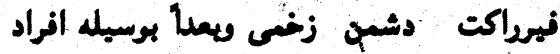

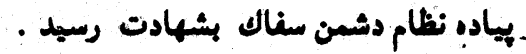

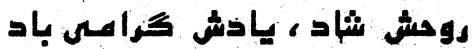

$$
\text { * * * }
$$

\section{شهيل مصاح اللهين}

شهين مصناح الدين ولد شهاب الدين

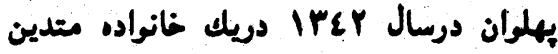
ومسلهان - در قريه غاسار ولسوالى سنهارك ولايت جمزبمان بشم بدنيا كشود ايام كودكى

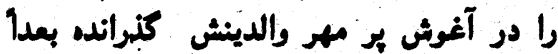

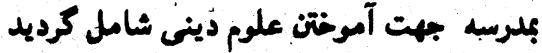
دوبال Irye سلاع بردوش كرنته دوشيا

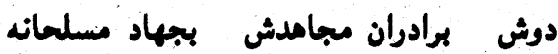

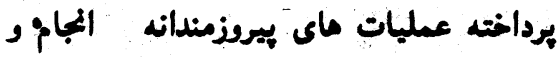
غناتيم زيادى بلست آترده است بنايهرثادت جهاد يكه داشت از طرف امارت جهاد ولايت

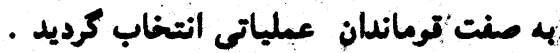
بالاخره دريله عمليات عرباروتى بالاي بوسته

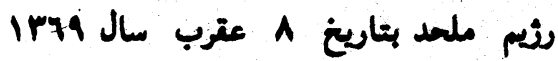

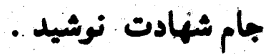

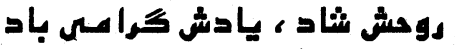

ماركستى باديكر برادرانش داخل يـكارشدند

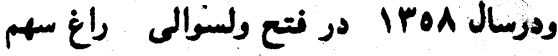

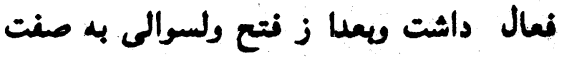

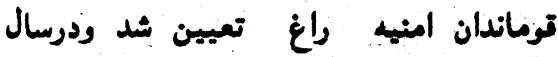

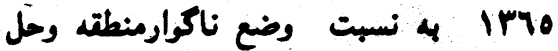
مشككلات بهه وارد كثرد اسلامى باكستان

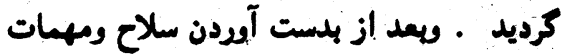

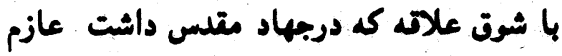

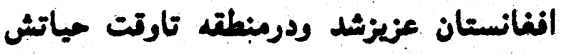

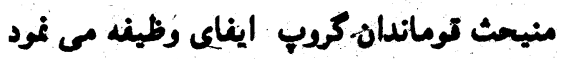

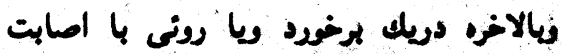

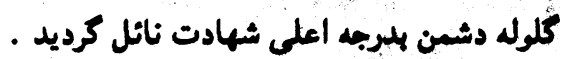

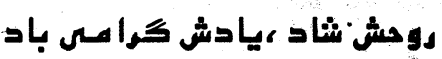

$$
\text { * * * }
$$

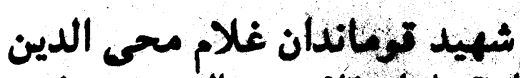
هادوتوماندان علام محى الدين شهيد فرزند

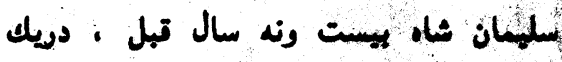
خانواده متدين وخنا هرست ذر قريه تلندر سرخ

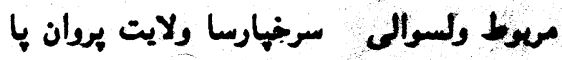

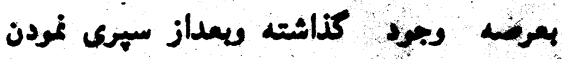
دود طنوليت درنزد المام مسجد محله بناطر فراكرنت علوم ديف مصروف شد وكتابهاى

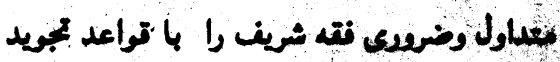

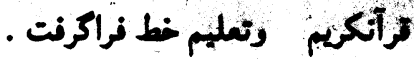

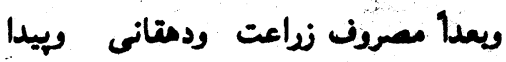

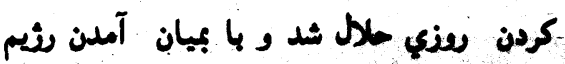

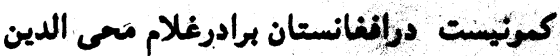
دالخل سنك ماى كُم بهادى كرديد ويا نشان

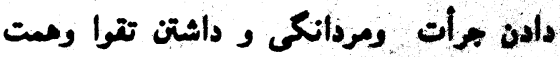

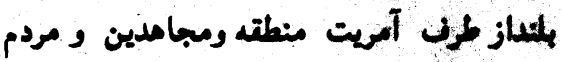
متلين ولهنت توماندان عمومى بمعيت اسللايى الثنانستان در قلندر مرخ تعيين كرديد ودر دوران بهاد از خود مردانكى ماى بسزاى تشان واد كه از بمله فتع ولسوالى سرخهارسا

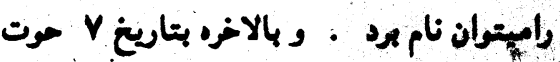

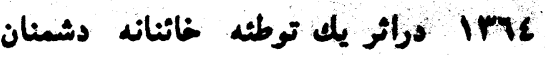

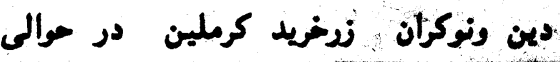




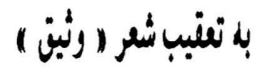

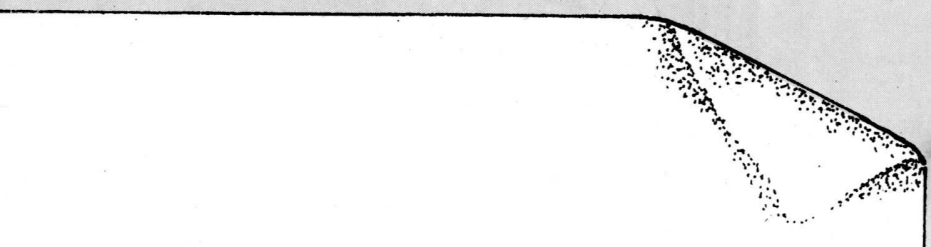

\section{ربس زيانه}

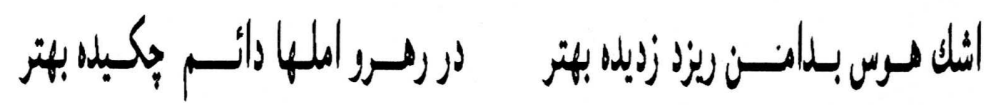

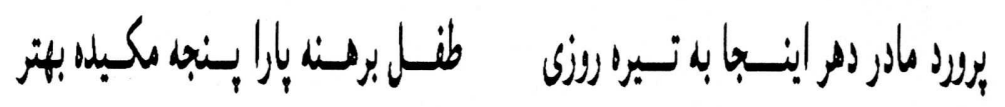

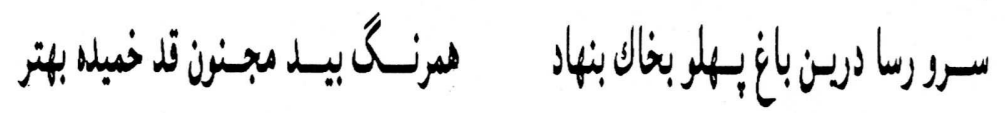

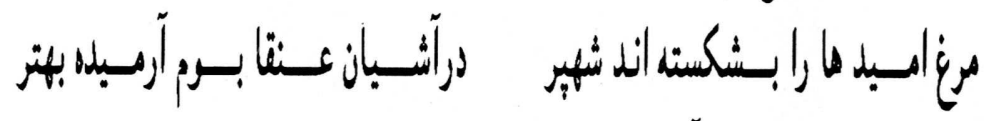

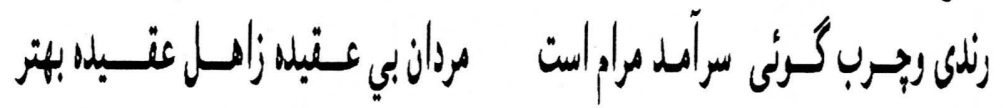

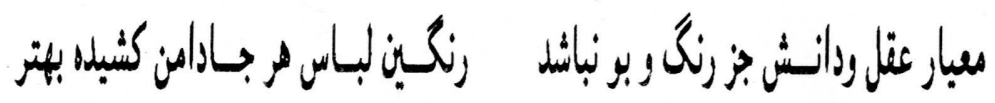

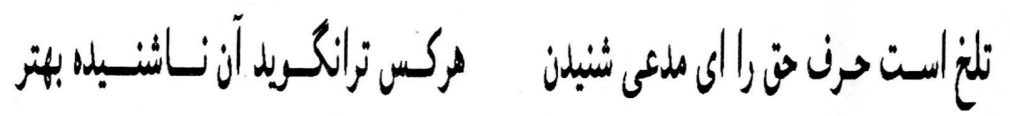

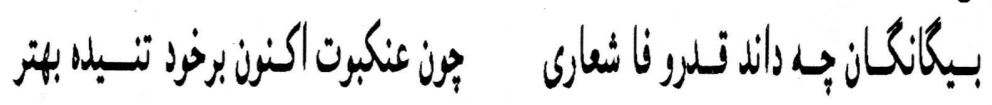

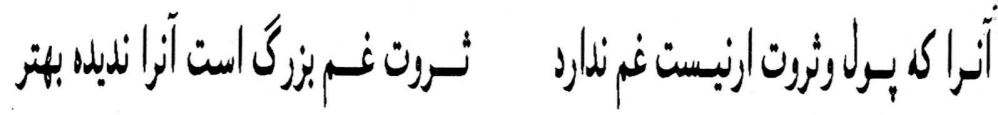

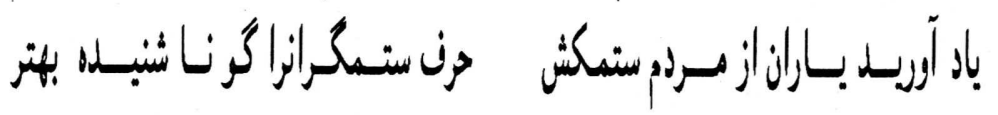

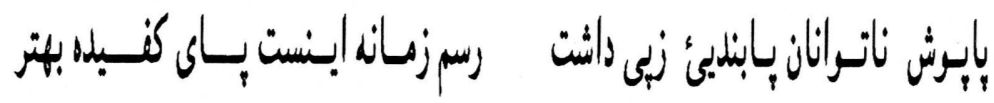

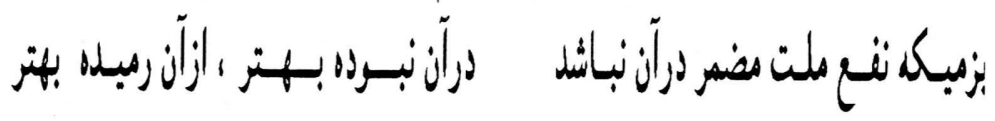

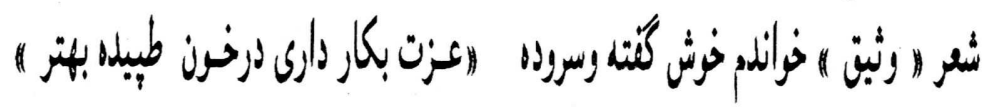

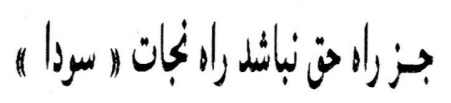

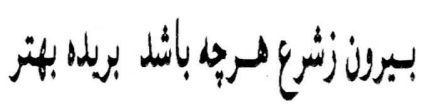

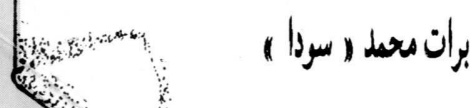

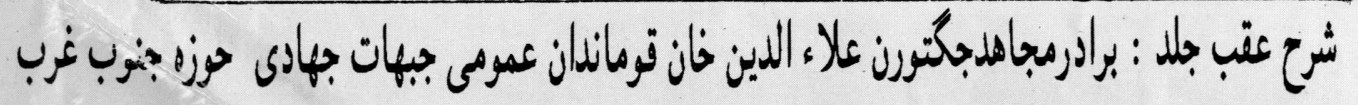


